(2.

40

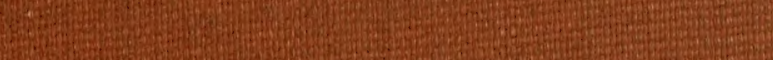

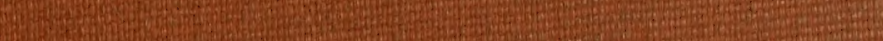

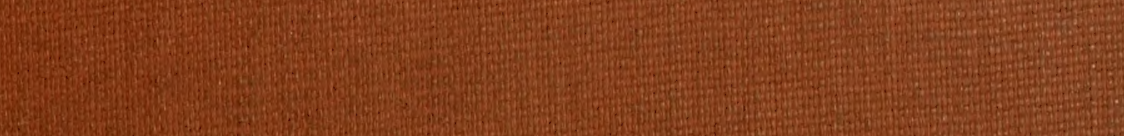

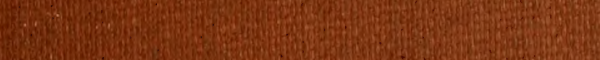

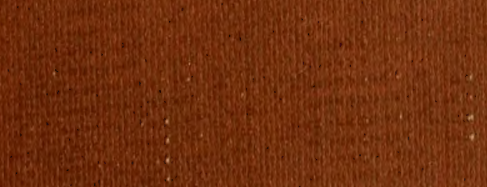

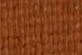

tis.

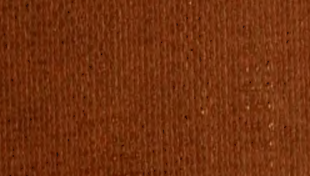
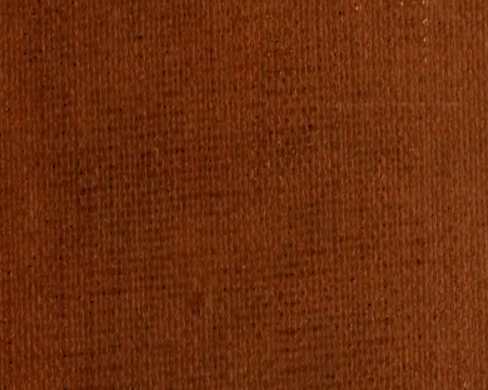

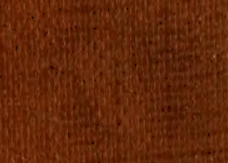

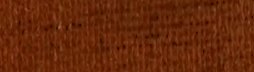

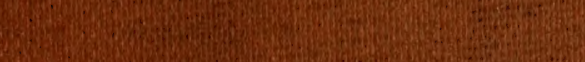

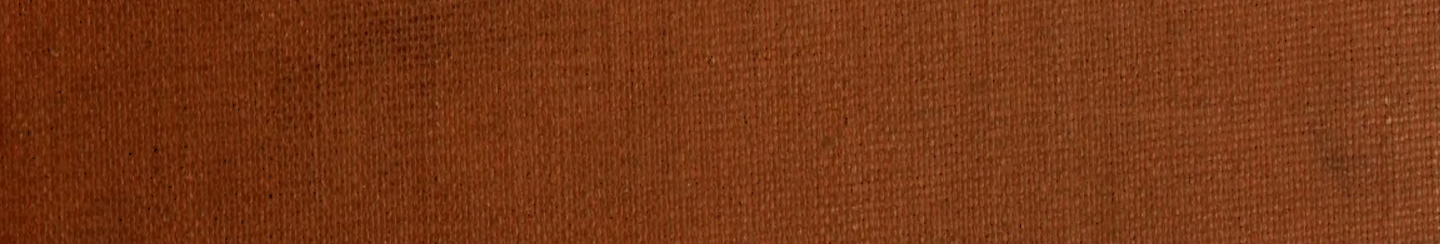
(2)

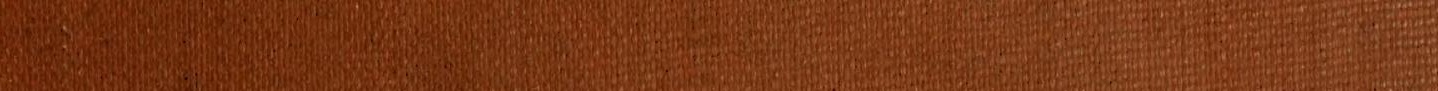

(2) 





 \\ FAUNA MOSQUENSIS.}

\section{ОIIЫT' \\ ОПИСАНІЯ

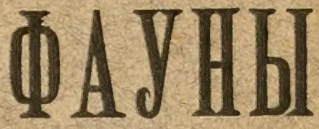

МОСКОВСКОЙ ГУБЕРНІИ.

\section{Tомт пе \\ МЛЕҚОЛИтнЮЩІя}

МОСКОВСКОЙ ГУБЕРНІИ.

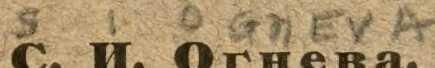

पАCTВ ПIЕРВAЯ.

CHIROPTERA, INSECTIVORA. RODENTIA.

\section{ИЗДАНIЕ}

Комиссіи для изсльдованія фауны Московской губерніи, СОСТОЯЩЕИ ПРИ ЗОоЛОГИЧЕСКОМъ ОТДЪЛЕНИ

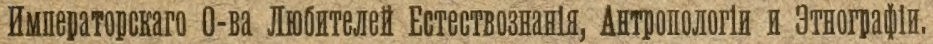

Подъ редакціеЙ профессора Московскаго Университета

Г. А. Кожевникова.

Ивдано на проценты съ неприкосновеннаго капитала, пожертвованнаго въ памнть

Нвофита Васильввича Калужскаго

ЕГО НАСЛВДНИКАМИ.

MOCKBA- 1913. 

FAUNA MOSQUENSIS.

Томъ I.

ЧАСТЬ ПЕРВАЯ. . 
I 


\section{FAUNA MOSQUENSIS.}

\section{ОПЫТЬ ОПИСАННЯ ФАУНЫ}

МОСКОВСКОЙ ГУБЕРНIИ.

Ton' пе p

\section{МЛЕКОЛИТАЮЩ І Я}

MOCКOBCКОЙ ГУБЕРНIИ.

\section{H. OrHe Ba.}

ЧАСТЬ ПЕРВАЯ.

CHIROPTERA. INSECTIVORA. RODENTIA.

\section{И 3 Л А H E}

Комиссіи для изсльдованія фауны Московской губерніи, СостоящЕЙ ПРІ ЗОолоГИЧЕСКОМъ ОтДЂЛЕНИ

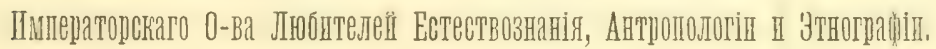

Подъ редакщіей профессора Московскаго Университета

Г. А. Кожевникова.

Нздано на проценты съ неприносновеннаго капитала, пожертвованнаго въ память

Неофйа Васильевича Калужскаго

Его НАСЛьдниками.

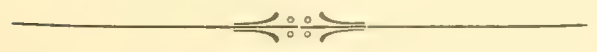


然

Типо-литографія Т-ва И. Н. КУШНЕРЕВЬ и К‥ Пименовская ул., с. дМосква-1913. 


\section{ПРЕДИСЛОВІЕ.}

Въ теченіе своеї двадцатильтней дћятетельности Компссія для пзсльдованія фауны Московской губерніп многократно печатала въ „Дневникъ Зоологическаго Отдъленія Императорскаго Общества Любптелей Естествознанія" дополненія пі поправкп къ спискамъ Московской фауны, а также болье пли менъе законченныя статы по отдыльнымъ группамъ этої фауны. За это время какъ въ Зоологпческомъ Музеђ Московскаго Универсптета, куда Компссія съ самаго начала своей дћятельності постановпла отдавать свои сборы, такъ ІІ у отдыльныхъ членовъ Комиссіп накопился по нъкоторымъ группамъ фауны достаточно богатый матеріалъ для того, чтобы пріступить къ обнародованію не отрывочныхъ данныхъ, а болье пли менбе законченныхъ фаунистическихъ трудовъ. Щедрое пожертвованіе, сдъланное Комиссіи насльдникамп покойнаго Неофпта Васильевича Калужск аго, открываетъ для Комиссіп полную возможность печатанія подобнаго рода трудовъ.

Bct эти соображенія заставили меня внести въ засьданіе Комиссіи 3-го декабря г9І г года предложеніе о желательности пзданія пттоговъ фаунпстическтхъ изсльдованій Московскої губ́ерніп подъ общпмъ названіемъ „F a u n a Mos qu ens is“. Компссія единогласно приняла это предложеніе, посль чего на особоль сов'щаніп, происходившемь I6 декабря І9г года при участіп предсьдателя Компссіп проф. Г. А. Кожевникова, секретаря Компссіп П. С. Гальцова и членовъ ея А. П. Золотарева, В. А. Линдгольма, С. Н. Огнева, Г. И. Полякова Іі Ф. С. Шербакова были выработаны основныя положенія, касаюшіяся этого пзданія, которыя II былп приняты Комиссіей въ засьданіп І9 мая І9г2 года.

Было постановлено, что „F a u n a Mos q u en s i s“ пздается Ко- 


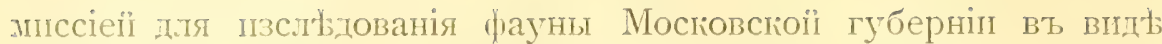
самостоятелыныт, не связанныхъ нпкапмт срокомъ появленія выпусковт обычнаго книжнаго формата in $8^{\circ}$ подъ заглавіемъ: „Fauna Mosquensis. Опыть оппсанія фауны Mосков-

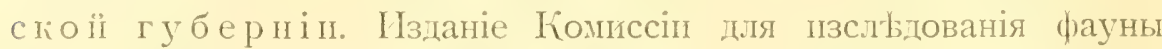
Московской губерніп, состоящеї прп Зоологическомь Отдъленіи Пмператорскаго Обцества Любителеї Естествознанія, Антропологіп іп Этнографіп“. Въ этомъ пзданіп помњщаются работы, посвященныя монографичесіому изученію жкивотнаго населенія Московскої губерніл съ точи зрънія систематпи, географицческаго распространенія и образа жизни, а также работы географическаго содержанія, шмьющі непосредственное отношеніе гъ фауны. Предметомь обработкі должна быть опредћленная систематическая группа жґвотнаго царства, каковою можеть быть классъ, отрядъ II дажке семейство, если это допускается характеромъ матеріала. Въ основу работь должно быть положено непремьнно непосредственное пзученіе собраннаго въ предьлахъ Московской губерніп матеріала, а не одна сводка пмьющихся въ литературь данныхъ. Fauna Mosquensis составляеть полную собственность Кописсіп Іі не входитъ въ серію изданій Общества Любптелей Естествознанія.

Въ засьданіп I9 мая І9г2 года Комиссія оказала мнь честь единогласныль избраніемъ меня редакторомъ этої серіг свопхъ пзданій, за что я прпношу ей свою глубоюую благодарность. Отгрывая эту серію солиднымъ трудомъ ассистента Зоологическаго Музея Московскаго Универсітета С. И. О г н в а, пропзведеннымъ въ лабораторіп Музея, я позволяю себ́ы высказать надежду, что за этой работой посльдуеть рядъ другіхъ не менъе интересныхъ работь, которыя сдълають „F a u na Mosquensis“ основої для ознапомленія съ жпвотнымъ населеніемъ Средней Россіп.

Редакторь „Faunae Mosquensis“ проф. Григорій Кожевниковъ.

Москва, 1 іюня 1913 года. 


\section{ОГЛАВЛЕНІЕ.}

Списокъ цитнруеной литературы. . . . . . . . . . . . . . я

Объясненіе сокращенныхъ названії журналовъ . . . . . . . . . . 17

Отрядъ Сhiroptera. Л етучія иыш

Селейство Vespertilionida e............. 19

Родъ Nyctalus Bowd. . . . . . . . . . . . . . . 19

Nyctalus noctula Schreb. Рыжая летучая мышь . . . . . . . . . . . . . ?01

Nyctalus leisleri Kuhl. Летучая щын Леĭcлера. . . . . . . . . . . . :30

Родъ Pipistrellus Kaup. . . . . . . . . . . . . . . . . . . . . . . .

Pipistrellus nathusii Keys. et Blas. Летучая мынь Натузіуса . . . . . . 37

Pipistrellus pipistrellus Schreb. Малая или малоголовая летучая мышь. . 37

Родъ Vespertilio L. .................... . . . . .

Vespertilio murinus L. Двуцвьтная летучая мышь илг кожань . . . . . 51

Родъ M у о і s Kaup. . . . . . . . . . . . . . . . . . 60

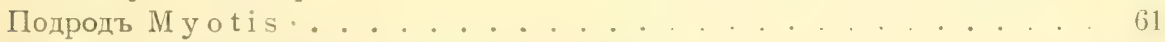

Myotis mystacinus (Kuhl.). Усатая ночнщца . . . . . . . . . . . 151

Подродъ L е и с опо е.................... 71

Leuconoe daubentonii (Kuhl.). Летучая мышь Добентона. . . . . . . . 71

Leuconoe dasycneme Boie. Прудовая ночница . . . . . . . . . . . . . Т

Родъ Plecotus Et. Gerffr. ................ st

Plecotus auritus (L.). Ушанъ . . . . . . . . . . . . . . it

Таблица для опредьленія впдовъ московскпхъ летучихъ мышеї . . . . ؛!:

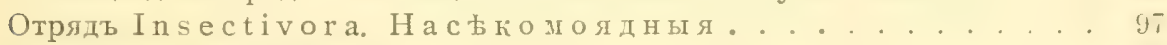

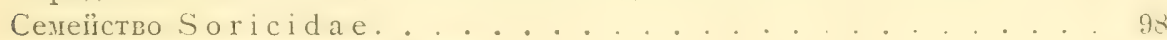

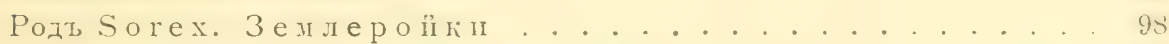

Sorex araneus L. Обыкновенная землеройка . . . . . . . . . . 99

Sorex minutus L. Землеройка крошка. . . . . . . . . . . . . . . . . 11:;

Родъ N e o mys Kaup. .................. 119

Neomys fodiens (Schreb.). Водяная кутора . . . . . . . . 119

Таблица для опредъленія московскихъ землероекъ (Soricidae) . . . 128

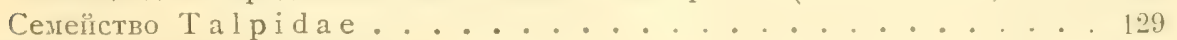

Родъ Та lра L. Кроты ................. . . 12!

Talpa europaea L. Кроть. . . . . . . . . . . . . . . 130

Родъ М уоgal е Cuvier. Выхухогі . . . . . . . . . . . . 138

Myogale moschata Pall. Bыхухоль . . . . . . . . . . . . . . 134

Cenen̈ствo Erinaceida e. Eжи . . . . . . . . . 140

Родъ Erinaceus L. . . . . . . . . . . . . . . 141

Erinaceus europaeus L. E年ъ обыкновенный . . . . . . . . . . 110 
Erinaceus curopaeus danubicus Matschie. Em röiнmíl . . . . . . . . 1.11

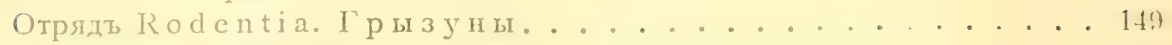

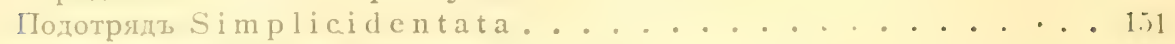

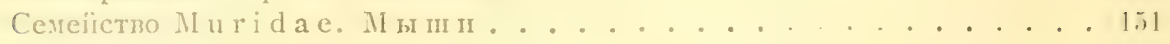

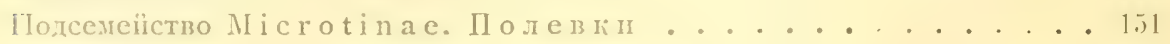

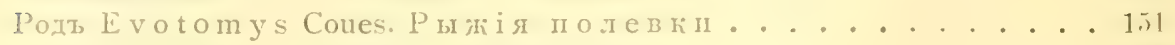

Evotomys glareolus Schreb. Рыңая полевка . . . . . . . . . . . 15-

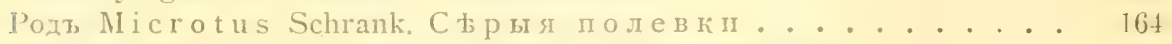

Microtus ratticeps Keys, et Blas. Полевка грысоголовая . . . . . . . . . 16il

Microtus agrestis neglectus Jenyns. Полевка темная . . . . . . . . . . . 171

Microtus arvalis Pall. Полевка об́кновеннная . . . . . . . . . . . . 179

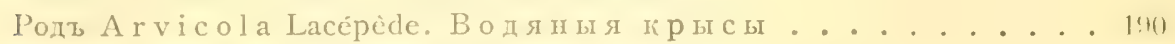

Arvicola amphibius L. Водяная זрыса . . . . . . . . . . . . . 1:1

Таблца для опредйленія видовъ лосковскпхъ полевокъ . . . . . . . 20"2

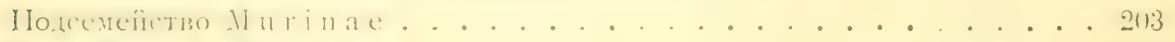

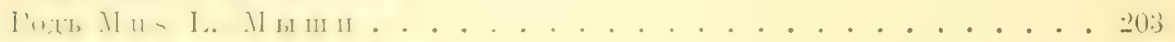

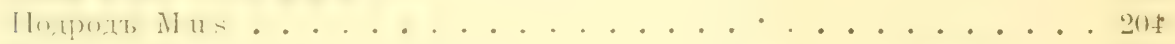

Mus sylvaticus mosquensis sbsp. nov. Средне-русская льсная мышь . . . 201

Mus musculus L. Мышь домашняя . . . . . . . . . . . . . . 219

Mius (Apodemus) agrarius Pall. Полевая мышь . . . . . . . . . . . . 22t

Mus (Micromys) minutus Pall. Мышь малютка . . . . . . . . . . . . . . 230

Родт E р і m у тrouessart. Кр ы сы . . . . . . . . . . . . . 2:34

Epimys norvegicus Erxl. Сłрая крыса, пасюкъ . . . . . . . . . . . 23t

Epimys rattus L. Черная крыса. . . . . . . . . . . . . . . . 2:3

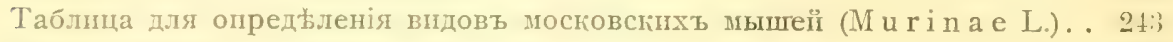

Подсенейство C ric etina . . . . . . . . . . . . 2 216

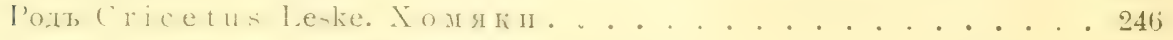

Cricetus cricetus L. Хомякъ обыкновенный . . . . . . . . . . . . . 241;

Семейство G 1 i res. С они . . . . . . . . . . . . . . . 25j

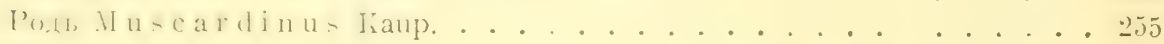

MI s c a rinus avellanarius L. Opьшковая соня . . . . . . . . 255

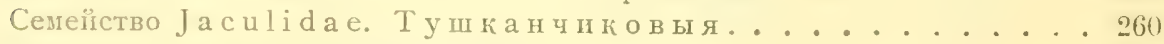

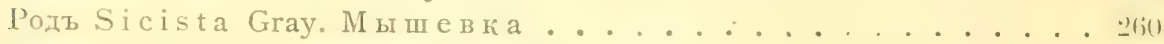

Sicista subtilis Pall. Mышевка полосатая... . . . . . . . . . . . 201

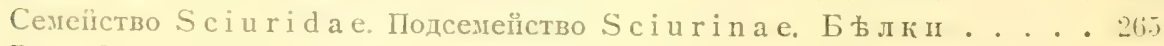

Родт Sciurus L.................... . . . . $26 j$

Sciurus vulgaris L. Etлria . . . . . . . . . . . . . . 265

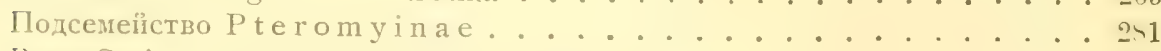

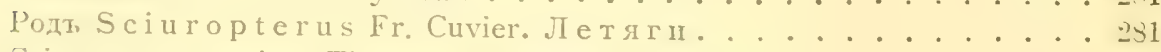

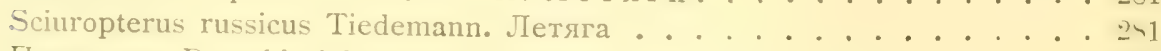

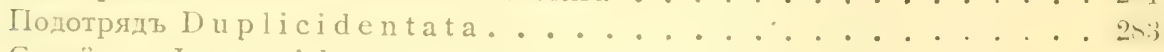

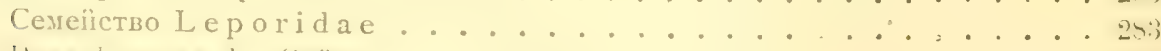

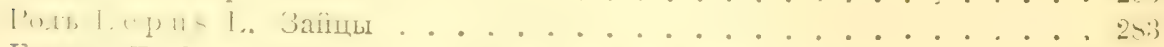

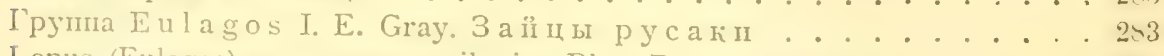

Lepus (Eulagos) europaeus aquilonius Blas. Русакъ средне-русскій. . . . 24:\}

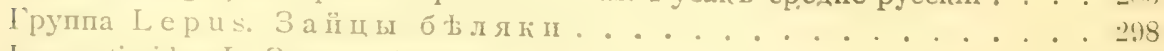

Lepus timidus L. Заяцъ б́ылякъ . . . . . . . . . . . . . . . . . . 294

Оо̆тясненіс рисуниовт . . . . . . . . . . . . . . . . . . 31 


\section{Введеніе.}

Страннымъ образомъ, систематика млекопитающихъ, ихъ географическое распространеніе и образъ жизни являются для Россіи одной изъ наименъе разработанныхъ областей зоологіи. Между тьмъ, этотъ классъ животнаго царства, стоящій на высоть генетической ступени развитія, казалось бы, заслуживаль бо́льшаго интереса. И дьйствительно, біологія этихъ животныхъ, гдь особенно ярко проявляется индивидуальность высоко организованнаго существа, географическое распространеніе, еще столь мало изученное,--все это представляетъ очень большой интересъ для зоолога.

Особенно знаменательнымъ является тотъ фактъ, что центральная часть Европейской Россіи изучена по отношенію фауны ея млекопитающихъ особенно мало. Поэтому я взялъ за центръ своихъ изсльдованій $\mathrm{M} \mathrm{осков} \mathrm{скую} \mathrm{губернію.} \mathrm{Къ} \mathrm{сожаль-}$ нію, здьсь мои работы носятъ довольно споралическій характеръ. Правда, при ловль млекопитающихъ необходимы стапіонарныя наблюденія и, по возможности, тщательное изученіе узкихъ районовъ. Только тогда можно составить себъ полное представленіе о фаунь' Mammalia какой-либо мьстности. В Бдь надо помнить, что въ ловль звђрей, болье чьмъ гдњь-либо, все зависить отъ случайности, отъ того, попадетъ ли какая-нибудь рбдкая форма мыши или полевки въ зарытое ведро или ловушку. Если принять во вниманіе громадную площадь, занимаемую даннымъ видомъ, его рьдкость и только ничтожное, сравнительно съ площадью изсльдованій, количество ловушекъ, то станетъ понятнымъ, какъ малы шансы, чтобы дыйствительно рьдкая форма попалась въ руки наблюдателя.

Свои работы по изученію московскихъ млекопитающихъ я началь въ 1907 году, продолжаю ихъ и теперь. Естественно, что за этотъ длинный періодъ времени въ моихъ рукахъ накопился богатый фактическій патеріаль. Особенно тщательно мной были 
изучены уғзды Можайскії и Звенигородскії. Я имью также довольно значительные сборы изъ Рузскаго, Московскаго, Клинckiro, lioroponcкаго, Серпуховскаго и Коломенскаго уу. Къ сожалtниiк, очень отрывочны мои матеріалы пзъ Дмитровскаго у. За время моихъ экскурсій я собралъ около гооо мелкихъ млетіопитаюцихъ, что вмђсть съ қоллекціями Зоологическаго музея Московскаго У ниверситета изъ Московской губ. составляетъ довольно богатый матеріалъ. Въ своей работь я не ограничился только Московской губ., гранищы которої въ смысль зоогеографиі совершенно пропзвольны, п только случайность заставпла неня взять эту губернію за центръ изученія. Поэтому я использовалъ весь имьвшіиіся у меня лично и въ коллекціяхъ Московскаго Зоологпческаго музея матеріаль по млекопитающимъ изъ Европейской и Азіатской Россіи, такъ что вся коллекція, на основаніи котороїі написана эта работа, превышаеть зооо экз. ІІзъ сказаннаго ясно, что своей цълью я поставиль не узкое изученіе фауны Мамmalin Московской губ., а по возможности,-выясненіе спстематической и географической связи обитающихъ въ ней звђрей съ тьми, которые живуть далеко за ея предьлами. Это повлекло за собою необходимость подробно разбирать географфическое распространеніе даннаго вида въ предьлахъ Россіӥской Имперіи Zалье, результатомъ систематической переработки большого матеріала явились дихотомическія таблицы, которыми заканчиваются описанія трудныхъ группъ. Въ заключеніеукажу, что особенное вниманіе я удьлялъ разбору возрастныхъ отличій пп половому диморфизму, изсл'ьдованіе котораго даетъ много св'ьжихъ и новыхъ свьдьній.

Что касается до литературныхъ источниковъ, спеціально по 中аунь млекопитающихъ Московской губ., то они очень небогаты. Въ І8о2 году вышло сочиненія проф. И. А. Двигубскаго, озаглавленное „Primitiae Faunae Mosquensis“, охватывающее собою всьхъ животныхъ Московской фауны. ІІзъ млекопитающихъ въ немъ перечислено 18 видовъ. Вотъ списокъ 1. А. Двигубскаго (съ сохраненіемъ правописанія автора): I) Vespertilio murinus, 2) Canis Lupus, 3) C. Vulpes, 4) Mustele Tulgaris, 5) M. Erminea. 6) M.putorius, 7) Ursus Arctos. 8) U.meles. 9) Talpa Europaea, Io) Einaceus Europaeus, II) Mus Rattus, I2) M. Musculus, I3) M. sylvaticus, I4) M. amphibins. I5) M.arvalis, 16) M. Cricetus, I7) Sciurus Vulgaris, I8) Lepus timidus.

Изъ этого списка можно видьть, что въ немъ перечислены, во-первыхъ, наиболье замьтныя и извьстныя формы, во-вторыхъ, изъ летучихъ мышей говорится только объ одной, причемъ очень трудно точно сказать, какой видъ разумьлъ авторъ. 
Въ І845 году вышла въ свћтъ небольшая работа проф. К. Ф. Рулье: „О животныхъ Московскоц̆ губерніи или о главныхъ перемьнахъ въ животныхъ первозданныхъ, историческихъ и нынь живущихъ, въ Московской губерніп замьчаемыхъ". Какъ видно уже изъ этого ньсколько длиннаго заглавія статьи К. Ф. Р улье, въ ней затронуты главнымъ образомъ палеонтологическіе вопросы; въ тьхъ случаяхъ, когда авторъ касается животныхъ современної фауны, онъ останавливается на разсмотрыніи тьхъ немногихъ, которыя исчезали подъ Москвою въ историческій періодъ, какъ, наприм'ьръ, кабаны и бобры.

Въ 1857 году въ журналь „Allgemeine Deutsche Naturhistorische Zeitung" появилась статья Ed. Assmus, въ которой имьются свьдьнія о распространеніи млекопитающихъ въ Московской губ́. и приводится списокъ, заключающій $3^{\mathrm{I}}$ видъ. Изъ этого общаго числа надо исключить, кромь домашнихъ животныхъ, еще 5 видовъ, явно ошибочно указанныхъ для изученной мбстности: Plecotus barbastellus, Vesperugo serotinus, Crocidura aranca и др. За вычетомъ ихъ, списокъ А с м уса содержить только 22 вида. Посль указанной работы очень долгій срокъ въ литературь не появлялось статеіі по распространенію млекопитающихъ въ Московской губ. Ньсколько мелкихъ указаній имьется только въ „Періодическихъ явленіяхъ подъ Москвою“ Л. П. Сабан bева (jliурналъ Импер. Общ. Охоты, годъ VII). Много фактическаго матеріала дала работа А. А. Тихоми рова и А. Н. Корчагина: „Списки и описаніе коллекціи млекопитающихъ Зоол. Муз. Моск. Ун.“, появившаяся въ І889 году.

Въ І892 году Зоологическим Отдыленіемъ Общ. Любителеї Естеств. подъ общей редакціей П. П. Мельгунова было выпущено второе, совершенно переработанное изданіе "Prim it i a. Faunae Mosquensis" Двигубскаго. Списокъ Mammalia для этого изданія былъ составленъ К. А. С атунины мъ и заключаеть +t вида. Въ г895 году появилась работа этого автора„Позвоночныя Московской губерніи, вып. І-ый. Млекопитаюпція" (Извьстія Общ. Люб. Ест., т. LXXXVI). Эта статья содерікитъ очень много цђнныхъ указаній географическаго распространенія и біологіи млекопитаюшихъ. Общій списокъ видовъ, въ ней приводимыхъ, равняется +5 . Если исключить изъ этого числа зайца "тумака“, котораго К. А. Сатунин в въ качествь отдьльнаго вида приводить подъ названіемъ Lepus hybridus Pall., то останется старое число найденныхъ формъ-44. Во введеніи къ своеї работь К. А. Сатунинъ говоритъ: „Несмотря на ограниченность района, гдь я производиль свои тщательныя изсльдованія, 
я не думаю, чтобы впосльдствіи къ моему списку можно было прибавить что-нибудь, громь нысколькихъ летучихъ мышей, которыя, по причинь трудности ихъ добыванія, изсльдованы мною недостаточно и, кромь того, обладая, сравнительно съ другими млекопитающими, лучшими средствами къ передвиженію, могуть вдругъ появиться въ мьстности, гды ихъ раньще не было".

Эти предположенія почтеннаго автора сбылись только отчасти. 悺ствительно, мнь удалось добавить списокъ летучихъ мышей однимъ видомъ Nyctalus leisteri Kuhl. Но неожиданно пополнились и другія группы. Такъ, быль найденъ южный ежъ Erinareus curopaeus dambicus Matsch., соня Muscardinus arellanarins L. Кромь того, за посльднее время въ работахъ систематиковъ. обрашается большое вниманіе на колебанія и отклоненія, которыя могуть быть констатированы въ иредьлахъ отдыльнаго вида. Изученіе этихъ колебаній влечетъ за собою установленіе мьстныхъ географическихъ формъ. Это новое теченіе ярко отразилось на разработк'ь систематики млекопитающихъ. Съ этой точки зрьнія на мою долю выпала новая переработка мелкихъ звьрей московской фауны и выясненіе таксономическаго значенія каждаго изъ нихъ въ рядь близкихъ къ нему подвидовъ. Выяснилось, напримьръ, что льсная мышь, помьченная K. А. Сатунины м ъ какъ Mus sylvaticus L., представляетъ совершенно новую форму, названную мною Mus sylvaticus mos. quensis sbsp. nov. Темная полевка является не типичной Hicrotus agrestis L., какъ она приведена въ работь С атунин а, а $M$. $a$. neglectus Jen. и пр.

Въ первой части своей работы я даю систематическіе и біологическіе очерки летучихъ мышей (Chiroptera). наськомоядныхъ (Insectivora) и грызуновъ (Roctentia) московской фауны; во второї-будуть помьщены другіе отряды (Carnivora, Ungulata) и заключительный общій зоогеографическій обзорь изсльдованної мьстности, а въ конць-возможныя дополненія къ первой части.

Отсрочка въ изданіи обработки хищниковъ Московской фауны въ значительной мырt зависитъ оть недостатка матеріала II трудности его сбора. Я былъ бы поэтому весьма признателенъ. лицамъ, которыя пожелали бы облегчить мны эту задачу доставкой матеріала. Очень часто черепа лисицъ, волковъ и другихъ. хищниковъ являются совершенно ненужными для тьхъ, у кого они въ рукахъ, а межпу тьмъ этоть матеріаль весьма цьненъ. въ научномъ отношеніи и получить его зоологу можно далеко. не всегда. Далье было бы очень желательно имыть шкурки и черепа хорьковыхъ: куницъ, ласокъ, горностаевъ, хорьковъ, но- 
рокъ. Я былъ бы очень радъ, если бы на эту просьбу откликнулись охотники и всь лица, интересующіяся еще столь мало изученной русской фауной.

Въ заключеніе считаю пріятнымъ долгомъ выразить свою пскреннюю благодарность всъмъ лицамъ, доставлявшимъ мнђ матеріалъ или содьйствовавшимъ такъ или иначе въ выполненіи моей трудной задачи: В. Б. Баньковскому (†), А. А. Бируль, А.А.Браунеру, В.Н. Вучетичу, П. С. Гальцову, Б. М. Житкову, Н. Ф. Иконникову, Г. Э. Іоганзену, В. В. К а р пову, проф. Г. А. Кожевникову, акад. Н. В. Насонову, М. И. Погодину, Г. И. Полякову, Д. И. Скороспьлову, проф. П. П. Сушкину, В. В. Т роицкому, В. А. Филатову, Д. П. Филатову, Ө. С. Щербакову, И. С. Щукину.

Выражаю также свою глубокую благодарность Комиссіи для изсльдованія фауны Московской губерніи, давшей средства для напечатанія этой работы.

Прежде чьмъ переходить къ указанію использованной литературы, мн'ь хотћлось остановиться еще на одномъ частномь вопросњ—на характер' измћреній, столь важныхъ въ систематической работь. Всь промъры сдьланы въ. миллиметрахъ, при чемъ мелкія млекопитающія пзмьрялись штангенциркулемъ, крупныя - лентой. Во всьхъ случаяхъ измьреній тьла приведены точныя указанія мьстъ, отъ коихъ они производятся. Однако, въ промьрахъ черепа кое-что требуеть объясненія. Всюду мноиі указаны:

r) „Наибольшая длина черепа"-отъ основанія переднихъ рьзцовъ или отъ конца носовыхъ костей (смотря по тому, какая часть выступаетъ болье впередъ) : оо наиболье выдающейся части въ заднемъ отдьль черепа.

2) „Основная длина“-оть передняго края foramen occipitale magnum до основанія (снизу) переднихъ ръзцовъ.

3) „Кондиллярная длина“-оть задняго края затылочнаго мыщелка до основанія переднихъ рызцовъ.

4) „Межглазничная ширина“-самое узкое мьсто между глазницами.

Всь остальныя измьренія оговорены въ тексть особо. 


\section{Списоқт цитируемой литературы.}

Этотъ списокъ приводится въ порядк' латинскаго алфавита. Для большаго удобства фамилія автора въ заглавіи статьи помьщается въ одномъ и томъ же мьсть даже тогда, когда работы напечатаны на различныхъ языкахъ, и по разниць транскриппіи первой буквы фамилія авторадолжна была бы стоять въ различныхъ мьстахъ алфавита.

I) Allen, Report on the Mammals collected in North. Siberia by Buxton. Bullet. Amer. Mus., vol. XIX, Igo3.

2) Alston and Danford, On the Mammals of Asia Minor. Proceed. Zool. S. Lond., I88o.

3) Аникинъ В. П., Отчетъ о командировк' въ Нарымскій край льтомъ I90о г. Извыст. Томскаго ун-та, кн. XXII, I9o2.

4) Arnbäck-Christie-Linde, Der Bau der Soriciden und ihre Beziehungen zu anderen Säugethieren. Morph. Jahrb., B. XXXY'I, Hif. 4,1907 .

5) Assmus Ed. Phil., Beobachtungen über die Mammiferen einiger Provinzen Russlands. Allgemeine Deutsche Naturhist. Zeitung, 1857 .

6) Bailey Vernon, Revision of the American Voles of the Genus Evotomys. Pr. Biol. Soc. of Wash., vol XI, I897, p. II3-I38.

7) Barret-Hamilton, On a Variation in the Pattern of the Teeth of a specimen of the Common Field Vole. Proceed. Zool. S. Lond., r896, p. 598.

8) Barret-Hamilton, On the Existence in Europe of two Geographical Races or subspecies of the Common Vole. Ibid., I896, p. 599 .

9) Barret-Hamilton, Some Specimens of Dormice (Muscardinus). Ibid., I90o, p. 85.

Io) Barret-Hamilton, Note on the European Dormice of the Genera Muscardimus and Glis. A. M. N. H., r898, p. 423.

II) Barret-Hamilton, Variable Hare (Lepus timidus). Proceed. Zool. S. Lond., I9oo, p. 87 (II crbд.).

12) Barret-Hamilton, Note on Variation in the Weasel and Hedgehog. A. M. N. H., rgoo, p. 243.

I3) Barret-Hamilton, Note on the Common Hedgehog and its Subspecies or local Variations. A. M. N. H., I9oo, p. 36o.

I4) Barret-Hamilton, Some specimens of European Squirelles. Proceed. Zool. S. Lond., I899, p. 3. 
I5) Barret-Hamilton, Further Note on the Harvest-Mouse (Mus mmutus Pall.) and its Geographical Variations. A. M. N. H., Igoo, p. 527 .

r6) Barret-Hamilton, A History of British Mammals. London, part. I-XII, I9IO-I9I2.

I7) Belke Gustav, Quelques mots sur le climat et la faune de Kamienec-Podolski. Bull. Soc. Imp. Nat. Mosc., I853, p. 4ro et suiv.

I8) Belke Gustav, Notice sur l'histoire naturelle du district de Radomysl (gouv. Kief). Bullet. Soc. Imp. Nat. Mosc., I866, p. 491 .

I9) Belke Gustav, Esquisse de.l'histoire naturelle de Kamienetz-Podolski. Bull. Soc. Imp. Nat. Mosc., ı858, № 4, p. 25.

2о) Бе рез о в ск ій М., Списокъ мелкихъ млекопитающихъ. Въ „Очеркахъ съверо-запад. Монголіи“ Г. Н. П о т н ин а. Вып. IIV, Спб., г88г-л883, I, стр. 348.

2т) Бихнеръ Е.; Научные результаты путешествій Н. М. Пр жевальск аго по Центральной Азіи, Отд. Зоол., Млекопитающія, вып. I-V. Спб., І888-І894.

22) Büchner Eug., Die Saügetiere der Ganssu-Expedition (ז884-87). Mél. Biol., TXIII.

23) Б іанки В. Л., Замьтки о млекопитающихъ, водящихся въ береговой полось Петергофскаго у., между деревнями Лебяжья и Черная Лахта. Ежегодн. Зоол. Муз., т. XIV, Igog.

24) Blanford W. T., The Fauna of British India, Mammalia, Lond., I888-I89I.

25) Blanford W. T., Scientific results of the second Jarkand Mission. Calcutta, I879.

26) B lanford W. T., Eastern Persia, vol. II. The Zoology and Geology. Lond., I8;6.

27) Blasi us J. H., Fauna der Wirbelthiere Deutschlands (Saügethiere). Brauschw., I857.

28) B lasius J., Amtlicher Bericht über die I9-te Versammlung deutscher Naturforscher und Aertzte zu Braunschweig. 1842, p. 89 (Über Lepus aquilomius).

29) Blasius, Archiv für Naturkunde von Wiegmann, I843, II, P. 57 .

3о) Богданов ъ М. Н., Птицы и звьри черноземной полосы Поволжья и долины средней и нижней Волги. Тр. Общ. Ест. Каз. унив., т. I, I87т.

3I) Bonhote, The Mammalian Fauna of China, part. I, Murinae. Proceed. Zool. S. Lond., I905, p. 384. 
32) Brandt Eduard, Untersuchungen über das Gebiss der Spitzmäuse (Sorex Cuv.). Bull. Soc. Imp. Nat. Mosc., I868.

33) Brandt J. F., Beiträge zur näheren Kenntniss der Säugethiere Russlands. St.-Petersb., ז855, Memoir. math. etc., T. VII, Lurn) .: „Die Handflügler de's Europäischen und Asiatisch. Russlands“.

34) Brandt J. F., Bemerkungen über die Wirbelth. des nördlichen europäischen Russlands, besonders des nördlichen Ural. In.: Hoff ma n n, "Der nördliche Ural und das Küstengebirge Pai-Choi“. St.-Petersb., I856, Bd. II.

35) Brandt J. F., Bemerkungen über die Verwandschaften der biologischen Haupt-Typen der Kerffresser (Mammalia Insectivora) und ihre Verbreitung in besonderer Beziehung auf die Fauna des Russischen Reiches, Mél. Biol., T. II, fasc. 6, I858, p. 581, $5^{87}$.

36) Браунерь А. А., Замбтка обь экскурсіи въ Бессарабін) юь 1907 г. Тр. Бесс. Общ. Ест., т. I, I904-I9o8.

37) Бр аун ер ъ А. А., Млекопитающія южной Россіи. Крысы, водящіяся въ Одессь. Зап. Нов. Общ. Ест., т. ХХХ, 1907.

38) Браунер ъ А. А., О летучихъ мышахъ Бессарабіи пा Подоліи. Тр. Бесс. Общ. Ест., т. II, вып. I.

39) Браунер ъ А. А., Летучія мыши Крыма. Зап. Кр. Общ. Ест., т. I, I912.

40) Булы чев ъ Н. П., Очеркъ флоры и фауны Крбитскаго у. Зап. Ур. Общ. Ест., т. IV, І878.

4I) Данил о в П. Н. Описаніе видовъ рукокрылыхъ и наськомоядныхъ, водящихся въ юго-восточ. части Орловскої губ. Москва, г 868.

42) Д в и г у б к ій, Опытъ естеств. исторіи всыхъ животныхъ Россійской Имперіи. Москва, т829.

43) Dwigubsky Johannes. Primitiae Faunae Mosquensis seu Enumeratio animalium, qae circa Mosquam vivunt. I802.

44) D w ig u b s ky, Prodromus Faunae Rossicae, I, Mammalia, I804.

45) Dobson G. E., Monograph. of the Asiatic Chiroptera and Catalogue of the Species of Bats in the Collection of the Indian Museum of Calcutta. London, I876.

46) Dobson G. E., A Synopsis of the Genera of the Family Soricidae. Proceed. Zool. S. Lond., I89o, p. 49-5I.

47) Dobson G. E., Catalogue of the Chiroptera. Lond., I878.

48) Dobson G. E., Monograph. of the Insectivora, part. I-III. Lond., I882-I89o.

49) Eversmann E., Vespertiliones in promontoriis uralensibus tractibusque confinibus observati. Bull. Soc. Imp. Nat. Mosc., T. XVIII, I845. 
50) Эверсманнъ Э., Естественная исторія Оренбургскаго края. Казань, г840, I85о, I868, ч. II, Звьри.

5I) Eversmann E., Reise von Orenburg nach Buchara. Berlin, I823.

52) Eversmann E., Einige Beiträge zur Mammologie und Ornithologie des Russischen Reichs. Bull. Soc. Imp. Nat. Mosc., т. XXI, I8 8.

53) Evers m a n $\mathrm{E}$., Mittheilungen über einige weniger bekannte Saügethiere Russlands. Ib. I840, № I.

54) Eversmann E., Addenda ad celeberrimi Pallasii Zoographiam Rosso-Asiaticam. У чен. Зап. Каз. ун., І835, кн. I-2, І84 I, І842.

55) Eversmann E., Noch ein kleiner Beitrag zur Mammologie und Ornithologie des Russischen Reichs. Bull. Soc. Imp. Nat. Mosc., I853.

56) Eichwald E. Fauna Caspio-Caucasica, nonnulis observationibus novis illustrata. I84I.

57) Eichwald E., Naturhistorische Skizze von Lithauen, Volhynien und Podolien. I830.

58) Э са уловъ В л., Списокъ позвоночныхъ животныхъ, водящихся и встрьчающихся въ Торопецкомъ и Холмскомь уу. Псковской губ. Тр. Спб. О. Ест., т. IX, 1878.

59) F a lk J. P., Beiträge zur topographischen Kenntniss des Russischen Reichs. Dritter Band, welcher Beiträge zur Thierkenntniss und Völkerbeschreibungen enthält. St.-Petersb., ${ }_{7} 786$.

6o) Fellman Jakob, Bidrag till Lappmarkens Fauna. Suomi, $13+7$

6I) Finsch O., Reise nach West-Sibirien im Jahre I876. Wissenschaftliche Ergebnisse. Wirbelthiere. Verh. Wien. Ac., I879, Bd. XIX.

62) Ge bler, Uebersicht d. Katunischen Gebirges. Mém. Ac. St.Petersb., III, 1837 .

63) Georgi J. G. Bemerkungen während einer Reise im Russischen Reich im Jahre I772. St.-Petersb., I775.

64) Georgi J. G. Geographisch-physikalische und naturhistorische Beschreibungen d. Russisch. Reichs. Könisb., I80o.

65) Гмелинъ Самуиль Ге оргъ, Путешествіе по Россіп для изсльдованія трехъ царствъ естества. Спб., І 77 I-1785.

66) Grevé Karl, Unsere Waldmaus. Igrı.

67) Grevé K., Saügethiere Kur-Liv-Estlands. Ein Beitrag zur Heimatskunde. Riga, 1909.

68) $Г$ румт $-\Gamma$ ж им айл западный Китай. Т. II, І899, стр. 409. Списокъ млекопитаюшихъ въ обработкь Е. А. Бихнера. 
69) Hilzheimer M ax, Die Europäischen Hasen. Zool. Anz., B. XXX, 1906, S. 510.

70) Hilzheimer Max, Die Hasenarten Europas. Jahr. Würt., 1008.

7x) Ж и тковъ Б. М., Матеріалы по фаунь' млекопитающихъ Симб. губ. Дн. Зоол. Отд., т. II, 쵸 8, г898.

72) Жи итовъ Б. М. и Бутурлин и С. А., По сьверу Россіи, Отчеть Нмпер. Общ. Любит. Ест. о пођздкђ въ Архангельскую губ. и на острова Колгуевъ и Новую Землю. „Землевьдънie", Igor.

73) ЖКитков ь Б. М., Новая Зем.тя. М., т9о3.

74) Shitkov B. M., Mus rattus L. im Europäischen Russland. Zool. Anz., I9oI, p. I7I.

75) Shitkov B. M., Über einige Fälle von Variabilität höherer Wirbelthiere. Zool. Jahrb., B. XXV, Hf. 2, I907.

76) 3 а бусовъ Н. П., Изсльдованіе иннерваціи летательной перепонки летучихъ мышей. Тр. Общ. Ест. Каз. унив,, т. XLII, I9Iо, стр. 58.

77) З а р удны ї Н. А., Зам ътки по фаун'ь млекопитающихъ Оренбургскаго края. Мат. позн. фауны Россійск. IIип., в. III, М., І897.

78) К а релинъ Г. С., Разборъ статьи г. А. Рябинина „Естественныя произведенія земель Јральскаго Казачьяо Войска". Тр. Спб. О. Ест., т. VI, I875, стр. І86.

79) Кащенко Н. Ө., О коллекции млекопитающихъ изъ Забайкалья. Ежегодн. Зоол. Муз., т. XV, гgго.

8о) $\mathrm{K}$ ашенко Н. Ө., Обзоръ млекопитаюшихъ Западной Сибири и Туркестана. В. I. Chiropter, Insectivora, съ 5-ю зоогеогр. табл. Томскъ, г905.

8г) К а ен ко Н. Ө., Результаты Алтайской Зоолог. экспедиціи. І898 г. Томскь, І899 г.

82) К ащенко Н. Ө., Опредьлитель млекопитающихъ животныхъ Томскаго края. Томскъ, г9оо.

83) К ащ е н к Н. Ө., Млекопитающія, собранныя Алтайской экспедиціей П. Г. Игнатова въ т9о г. Ежегодн. Зоол. Муз., т. VII, I902, стр. 289.

84) Кащенко Н. Ө., Stenocranius и Platycramins, два новыхъ рода водящихся въ Россіи полевокъ. Ежегодн. Зоол. Муз. Т. IV, I90I, стр. I65.

85) Kessler K., Einige Mammologische Notizen. Bull. Soc. Imp. Nat. Mosc., I858.

86) Кесслеръ К. Ө., Естественная исторія губерній Кіевскаго учебн. Округа. Зоологія. Кіевъ, 185 
87) Кесслеръ К. Ө., Матеріалы для познанія Онежскаго озера и Обонежскаго края. Спб., г 868.

88) Кесслеръ К. Ө., Замътка о распространеніи въ Европейской Россіи нбкоторыхъ летучихъ мышей. Тр. Спб. Общ. Eст., т. III, I872.

89) Keyserling und Blasius, Uebersicht der Gattung und Artcharaktere der Europäischen Fledermäuse. Arch. Naturg., I839, p. 293 .

90) Keyserling und Blasius, Die Wirbelthiere Europas. Braunschweig, I840.

9г) Кобельть В., Географическое распредьленіе животныхъ въ холодномъ і умьренномь поясахъ сьвернаго полушарія. Переводъ В. Л. Біанки. Спб., г9о3.

92) Kolenati, Die Gaumenfalten und Nebenzungen der Chiropteren, Sitzb. K. Acad. B. XXIX, № Io, 1858, p. 329.

93) К руликовскій Л., Замьтки о млекопитающихъ южныхъ уъздовъ Вятской губ. Зап. Ур. Общ. Ест., т. XXIII, I902, стр. го8-ті8.

94) К р у ли к о в с к і й. Л., Дополнительныя замьтки омлекопитаюшихъ Уржумск. у. Зап. Јр. Обш. Ест., т. ХXТІ, І907, стр. I86-І8-.

95) Laxmann Eric. Sorex Caecutiens. N. Act. Petr., T. III, I $788, \mathrm{p} .285$.

96) Lehmann A., Reise nach Buchara und Samarkand in den Jahren 18fI und 18+2. Beitr. z. Kenntn. d. Russ. Reichs. Brl. XVIII, $185^{2}$.

97) Л е п ехинъ И., Дневныя записки путешествія по разнымъ провинціямъ Россійск. Государства. 4 части. Спб., І77І-І8о5.

98) Linnaeus Carolus, Systema Naturae. X Edit., $175^{8}$.

99) Lönnberg Einar, On Hybrid Hares between Lepus timidus L. and Lepus europaeus Pall. from Southern Sweden. Proceed. Zool.S. Lond., I905, p. 278-287.

I0o) Lönnberg Einar, Note on the Individual Variations of the Common Hedgehog. A. M. N. H., I90o, p. 542.

гог) Ма акъ Р., Путешествіе въ долинь рьки Уссури. 2 тома. Спб., г86г.

102) М а а к ъ Р., Путешествіе на Амуръ. Спб., І859.

Io3) Matschie Paul, Rumänische Säugethiere. Sitzb. Ges. Berl., Igor.

I04) Mèhely, Monographia Chiropterorum Hungariae. Budapest, I900.

Io5) Mè h e ly L., Saügethiere. Dritte asiatische Forschungsreise des Grafen Eigen Zichy. Bd. II, Zoolog. Ergebnisse, Budap.-Leipz., IgoI. 
то6) М ен з бир ъ М. А., Бьлка (монографія), Пр. Ох., 1878.

I07) Middend orf A., Sibirische Reise. Bd. II, St.-Petersb.

Io8) Middend orf A., Bericht über einen Abstecher durch das Innere von Lappland während der Sommer-Expedition im Jahre. r840. Beitr. z. Kenntn. d. Russ. Reichs. Bd. XI, p. I39-183.

Iog) Middendorf A., Über die, als Bastarde angesprochenen Mittelformen zwischen Lepus europaeus Pall, und L. variabilis Pall. Mèl. Biol., т. I, I85I, p. 217 .

IIo) Millais J. G., The Mammals of Great Britain. Vol. I-III, 1904-1906. London.

III) Miller Gerrit, Four new European Squirreles. A. M. N. H., $190 \%, \mathrm{p},+26$.

II2) Miller G., Brief synopsis of the Waterrats of Europe. Proceed. Biol. S. Wash., v. XXIII, I9ro, p. I9-22.

II3) Miller G., Twelve new-European Mammals. A. M. N. H., I909, p. $4 \mathrm{I} 5$.

Ir4) Miller G., Some Voles from the Tian-shan Region. A. M. N. H., I906, p. 37I.

II5. Miller G., Preliminary Revision of the European Redbacked Mice. Proceed. Wash. Acad., vol. II, I9oo, p. 83-Iog.

II6) Miller G., The Families and Genera of bats. Smithson. Instit., U. S. National Mus., I907.

II 7) Milne-Edwards, Recherches pour servir à l'histoire naturelle des mammifères. Paris, I868-I874.

II8) Milne-Edwards, Observations sur quelques Mammifères du Nord de la Chine. Annal. Sc. Natur., I867, p. 375.

II9) Milne-Edwards, Coup d'oeil sur les Mammifères de la Chine et du Thibet oriental. Bull. Acclimat., 1872, pp. 239-252.

I20) Nehring A., Über Tundren und Steppen der Jetzt-und Vorzeit mit besonderer Berücksichtigung ihrer Fauna. Berlin, I8go.

I2r) Nehring A., Einige Varietäten des gemeinen Hamsters (Cricetus vulgaris Desm.). Sitzb. Ges. Berl., I899.

І22). Никкольскій А. М., Позвоночн. животныя Крыма. Прилож. къ LXVIII т. Зап. Ак. Н., № 4, I89г г.

І23) Никольскій А. М., Матеріалы къ познанію фауны позвоночныхъ животныхъ сьв.-вост. Персіи и Закасп. Обл. Тр. Спб. Общ. Ест., т. XVIII, І886.

т24) Никольскій А. М., Путешествіе въ Алтайскія горы льтомь 1882 г. Ib., т. XIV, I883.

I25) Nordmann, Observations sur la faune pontique. Voyage dans la Russie Méridionale et la Crimée par la Hongrie, la Valachie et la Moldavie de M. Anatole de Demidoff. T. III, Paris, I840. 
I26) Ogilby M. A., Memoir on the Mammalogie of the Himalayas. 1839 .

г27) Огневъ С. И., О коллекціи млекопитающихъ изъ Уссурійскаго края. Ежегод. Зоол. Муз., т. XVI, т9І2 г.

г28) Огневъ С. Н., Матеріалы для фауны звьрей, птицъ и гадовъ юго-вост. Орловск. губ. Дн. Зоол. Отд., т. ІІІ, в. 9, 1908.

І29) Огневъ С. И. и Горбач евъ С. Н., Млекопитающія юго-вост. Орловск. губ. Изв. Общ. Орл., т. II, - І9го.

I3o) Pallas Petro, Zoographia Rosso-Asiatica etc. Petropoli. Volumen I, I83i.

I3I) Pallas P., Reise durch rerschiedene Provinzen des Russischen Reichs. I773-I788.

I32) P a llas P., Novae species quadrupedum e glirium ordine. Erlangae, 1778 .

I33) Плеске Ө. Д., Критическій обзоръ млекопитающихъ и птицъ Кольскаго полуострова. Приложеніе къ LVI тому Зап. Aк. Н., № I, I887.

I34) Поляков ъ И. С., Письма и отчеты о путешествіи въ долину р. Оби. Прилож. къ ХХХ тому Зап. Ак. Н., № 2, I877.

І35) Поляков ъ Н. С., Систематическій обзоръ полевокъ, водящихся въ Сибири. Прилож. къ XXXIX тому Зап. Ак. Н., І88I.

І 36) Поляков ъ И. С., Отчеть объ Олекминско-Витимской экспедиціи 1866 г. Зоолог. наблюденія. Млекопитающія. Зап. Ак. H., т. III, 1873 .

I37) П о р ч и н с к і й $\mathrm{I}$. A., О фауньь позвоночныхъ Гдовскаго у., Петерб. губ. Тр. Спб. Общ. Ест., т. III, І872 г., стр. 37 г.

г38) Пржевальскій Н. М., Монголія и страна тангутовъ. Трехльтнее путешествіе въ вост. нагорной Азіи. Изданіе Импер. Русск. Геогр. Общ., т. I, э875, т. II, І876.

г39) Пр жевальскій Н. М., Путешествіе въ Уссурійскомъ крағь. Спб., І 870.

І40) Пржевальскій Н. М., Третье путешествіе въ центральной Азіи. Изъ Зайсана черезъ Хами въ Тибетъ и на верховья Желтой рьки. Изд. Русск. Геогр. Общ,, І883.

г4I) П ржевальскій Н. М., Четвертое путешествіе въ центральной Азіи. Оть Кяхты на истоки Желтой рьки, изсльдованіе Съверной окраины Тибета и путь черезъ Лобъ-Норъ до бассейна Тарима. Нзд. Русск. Геогр. Общ. І888 г.

І42) П в вцовъ М. В., Матеріалы для зоогеографіи Джунгаріи. Заг. Зап.-Сиб. Отд. Геогр. Об., кн. I, І879.

I43) Radde Gustav, Reisen in Süden von Ost-Sibirien in Jahren 1855-I859. St.Ptb. I862-I863 
144) Radde G. und Walter A., Die Säugethiere Transcaspiens. Zool. Jahrb., Systematik B., IV, I889, Hf. V, pp. 993-I094.

I 45) Rörig G., Die nördliche Wühlratte, Arvicola ratticep.s. Keys. et BI. in Deutschland und ihre Verwandschaft mit den russischen Arricolinen. Arb. Biol. Anst., B. VII, Hf. 4, Igog.

I46) Rörig G. und Börner C., Studien über das Gebiss mitteleuropäischen recenter Mäuse. Ib., B. V, Hf. 2, I905.

г47) Рулье К. Ф., О животныхъ Московской губ. или о главныхъ перемьнахъ въ животныхъ первозданныхъ, историческихъ и нынь живущихъ, въ Московской губ. замьчаемыхъ. Москва, 1845 г.

І48) Сабаньев Л. П., Каталогъ звьрей, птицъ, гадовъ и рыб́ Средняго Урала. Bull. Soc. Imp. Nat. Mosc., I87I, II, p. $270-278$.

I49) Сабаньевъ Л. П., Позвоночныя Средняго Урала и географическое распространеніе ихъ въ Пермскої іп Орено́ургской губ. Москва, І874.

І5о) Сабан вев ъ J. П., Матеріалы для фауны Ярославской губ́. Bullet. Soc. Imp. Nat. Mosc., I868- I869.

І5 І) Сабан ьев ъ Л. П., Измьненія въ фаунь позвоночныхъ жівотныхъ Средней Россіи. Изв. Общ. Люб. Ест., т. XIV, стр. $+5-47$.

г52) Сабанньев ъ Л. П., Періодическія явленія подъ Москвою. Жуурналь Имп. Общ. Охоты, VII г.

г53) Сатунин ъ К. А., О кротахъ южной Россіи и Кавказа. Ізв. Кавк. Муз., т. IV, в. I, I908.

І54) С а т унин ъ К. А., Матеріалы къ познанію млекопитаюшихъ Кавказскаго края и Закаспійской обл. XII-XIV, ib., г9Іо г.

І55) С а тунин ъ К. А., Матеріалы къ познанію млекопитающихъ Кавказскаго края и Закаспійской обл. VIII-X, ib. I908 г.

г 56) 'С а т у н и ъ К. А., Млекопитаюція сьв.-вост. ІІредкавказья по сбору экспед. Кавк. Музея льтомъ I906 г. Ib., т. III, I907 г.

г57) С атунинъ К. А., Млекопитающія Талыша и Мугани., ib., т. II, в. 2-4, I906.

г58) Сатунинъ К. А., Млекопитающія Европейской Россіи и Кавказа. Chiroptera, роды Rhinolophas, Barbastella и Plecotus. Прилож. къ „Прир. и Охоть", І905 г. и продолж. листы 3 и 4, I905 г.

І59) С атунин ъ К. А., О млекопитающихъ степей сьверо. вост. Кавказа съ 2 карт. Нзв. Кавк. Муз., т. I, в. 4, І9о.

І6о) С а тунин ъ К. А., Матеріалы къ познанію млекопитающихъ Кавказскаго края и Закасп. обл. I-VII. Изв. Кавк. Муз., T. III, 1907. 


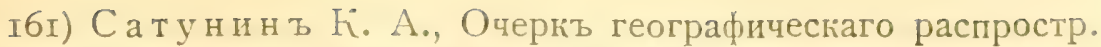
млекоптающихь Россійской Iмперіи. Прилож. къ журн. „Охотничій В Бстникъ“. Сборникъ „Наука и Охота“, подъ ред. проф. Г. А. Ко 毦е вникова. М. Igo8 г.

I62) С а т у н и ъ К. А., Обзоръ изсльдованія млекопитающихъ Кавказскаго края. Зап. Кавк. Отд. Геор. Общ., кн. XXIV, I9o3. I63) С атунин ъ К. А., Первое дополненіе къ списку млекопитающихъ Кавк. края. Ib. I908 г.

г64) Сатунинъ К. А., Объ ежагъ Россійск. Ммперіи. Тр. Общ. Ест. Каз. Унив., т. XXXIII, в. 6, І90о г.

I65) С атунинъ К. А., Позвоночныя Московск. губ́,, в. 1 Млекопитающія. Нзв. Общ. Люб. Ест., т. LXXXVI, I895.

I66) Сатунин ъ K. A., Mammalia, въ D wigubsky, „Primitiae Faunae Mosquensis, ed. II“, I892 г. (оттискъ изъ трудовъ II Международнаго Конгресса по Зоологіи въ Москвь) и „Согrigenda et Addenda“, I893.

г67) Сатунин ъ К. А., Млекопитающія Волжско-Уральской степи. Прилож. къ протокол. Засьд. Общ. Ест. Казанск. У-та, 슨 158,1896 г.

I68) S a t u n in K., Ueberneue und wenigbekanntelgeldes Zool. Mus. der Kaiserl. Acad. der Wissensch. Ежегодн. Зоол. Муз., т. XI, І9о7.

I69) S a tu n in K., Neue Nagethiere aus Centralasien. Ib. T. III, Igo2, стр. 547 .

I7o) Satunin K., On a new Hedgehog from Transcaucasia with Revision of the species of genus Erinaceus of the Russian Empire. Proceed. Zool. Soc. Lond., Igor.

I 7I) Schäff Ernst, Die wildlebenden Säugethiere Deutschlands. Neudamm, . Igr I.

r.72) Schreber J., Die Sägethiere in Abbildungen nach der Natur mit Beschreibungen. Fortgesetzt von A. Goldfuss und L. Wagner. 7 Theile und 5 Suppl.-Bände, Erlangen und Leipz., I825-I855.

I73) Schrenck L., Die Fauna des unteren Amur-Landes. Mél. phys. St.-Ptb., I854-1856.

I74) Schrenck L., Reisen und Forschungen im Amur-Lande. B. I, I860.

I75) Schrenck L., Zoologische Nachrichten rom Ussuri und der Südküste der Mantschurei, nach Sammlungen und brieflichen Mittheilungen d. Herrn Maximowicz. Bull. l'Ac. St. Petersb., T. IV.

I76) Scully, On the Mammals of Gilgit. Proceed. Zool. Soc. Lond., I88r, p. I97.

I77) Serertz off $N$., The Mammals of Turkestan. A. M. N. H., rol. XVIII, 1876 . 
I78) С вв в циов Н. А. Вертикальное и горизонтальное распредъленіе туркестанскихъ животныхъ. Нзв. Общ. Люб. Ест., T. VII, B. 2.

I79) С вв ерцов ъ Н. А., Періодическія явтенія изъ жизни птицъ, звьрей и гадъ Воронежской губ. Москв. I855.

180) С вве рц ов ъ Н. А., Замьтки о фаунь позвоночныхъ Памира. Зап. Турк. Геогр. Общ., № 3, г877.

І8г) С илантьевъ А., Фауна Падовъ, имьнія Нарышкина, Балашовск. у. Сарат. губ. СПБ. І894.

І82) С имаш ко Ю., Русская фауна, ч. II. Млекопитающія. Спо์., І85 г г.

І83) С ло вцовъ И., Позвоночныя Тюменскаго окр. и ихъ распространеніе въ Тобольск. губ. Мат. позн. фауны Росс. Имп., в. I, М. г892, стр. г8\%.

I84) С омов ъ Н., Орнитологическая фауна Харьковскої губ. (въ общ. части замытка о млекопитающихъ). Харьковъ, І897. 185) T a c zanowski, Catalogue des vertebrés du Royaume de Polngne. Bull. Zmil. Fr., 18--

I86) Thomas O Id., New Insectivores and Voles collected by Mr. Robert near Trebizond. A. M. N. H., I 906, p. 4I5.

I87) Thomas Old., A collection of Mammals from Northern and Central Mantshuria. A. M. N. H., I909, p. 500.

I88) Th o mas Old., On the Mammals from North. Persia, presented to the natural Museum by Bailward. A. M. N., I907, p. I96.

I89) Thom as Old., New Asiatic Muridae. A. M. N. H., v. VII, IgII, 205 .

Igo) Thomas Old., The Duke of Bedford's Zoolog. Exploration of Eastern Asia. XIII. On Mammals from the Province of Kan-Su and Szechwan, Western China. Proceed Zool Soc. Lond., I9II, p. I58.

I9I) Thomas Old., The Duke of Bedford's Zoolog. Exploration in Eastern Asia. XI. On Mammals from the prov. of Shan-Si and Shen-Si, North. China. Ib. I908, p. 963.

I92) Thomas Old, The Duke of Berdford's Zoolog. Exploration in Eastern Asia. On Mammals of Japan. Ib. I905.

193) Th o mas O ld., The Duke of Bedford's Zoolog. Exploration in Eastern Asia. IV. List Mammals from the Islands of Saghalien and Hokkaido. Ib., I907, p. 404

I94) Thomas Old., On Mammals from Central Asia, collected by Mr. Douglas Carruthers. A. M. N. H., IgrI, p. 39r.

195) Th o mas Old., New Mammals from Central. and Western Asia mostly collected by Mr. Douglas Carruthers. Ib., I9II, p. $75^{8}$. 
196) Thomas Old., On Mammals Collected in Turkestan by Mr. Douglas Carruthers. Ib. I909, p. 257.

197) Тихоми и ов ъ А. А., Коллекція позвоночныхъ животныхъ Пермской губ. Отъ Ө. А. Теплоухова. Дн. Зоол. Отд., т. II, № I-2, I894, стр. 27.

198) Тихоми ровъ А. А., Коллекція млекопитающихъ Закаспійской обл., доставленная П. А. Варенцовымъ. Дн. Зоол. Отд., т. II, І894, стр. 22.

I99) Тихомировъ А. А., и Корчагинъ А. Н., Списки и описаніе коллекцій млекопитающихъ Зоол. Муз. Моск. У-та. Изв. И. Общ. Люб. Ест., т. LVI, в. 4, № I, M. I889.

200) Trouessart E. L., Faune des Mammifères d'Europe (Conspectus Mammalium Europae). Berlin, I9ro.

20r) Trouessart E. L., Catalogus mammalium. Nova editio I898-I899. Supplementa, I904-905. Berlin.

202) Trouessart E. L., Sur les sous-espèces de l'Ecureuil d'Europe (Sciurus vulgaris). Bull. Mus. Ist. Nat. Paris, o 6, Igo6, p. 360 .

203) Чернай А., Фауна Харьковской губ. и прилежащихъ къ ней мьстъ, 2 вып., Харьковъ, 1852-1853.

\section{Объъяненіе сокращенныхъ названій журналовъ.}

Arb. Biol. Anst. Arbeiten aus der Kaiserlichen Biologischen Anstalt für Land-und Forstwirtschaft, Berlin.

A. $M . N . H$. Annals and Magazine of Natural History, London.

Ann. Sc. Natur. Annales des sciences naturelles.

Arch. Naturg. Archiv für Naturgeschichte von Dr. Wiegmann, Berlin.

Bull. NTus. Hist. Nat. Paris. Bulletin du Museum National d'Histoire Naturelle, Paris. in $8^{0}$.

Bull. Zool. Frr. Bulletin de la Société Zoologique de France, Paris, in 80.

Bull. l'Acad. St. Pétersb. Bulletin de l'Académie Impériale des Sciences de St-Pétersbourg.

Bull. Accl. Bulletin de la Société d'Acclimatation.

Bull. Soc. Imp. Nat. Mosc. Bulletin de la Société Impëriale des Naturalistes de Moscou.

Bull. Amer. Mus. Bulletin of the American Museum of Natural History, New-Jork. in $8^{0}$.

Дi. 30о. . Отд. Дневникъ Зоологическаго Отдьленія И. Общ. Јюбит. Естествознанія, Антропологіи и Этнографін, Москва, in $4^{0}$.

Ежелод. Зоол. Муз. Ежегодникъ Зоологическаго Музея Императорскої Академіг Наукъ въ Спб.

Зап. Кавћ. Omo. Геоц. Общ. Записки Кавказскаго Отдђла Императорскаго Русскаго Географическаго Общества, Тифлисъ.

3ап. Зап. Сиб. Отд. Геогр. Об. Записки Западно-Сибирскаго Отдъла Императорскаго Русскаго Географическаго Общества, Ожскъ. 


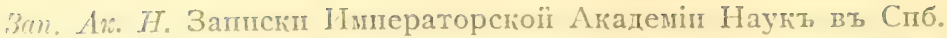

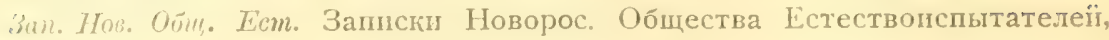
O Iесcа.

Зап. Тip. Oб. Есm. Записки Крымскаго Общества Естествонспытателей пा Любителеї Природы, Симферополь.

Зап. Ју. Общ. Есм. Записки Јральскаго Общества Любителей Естествознанія, Екатернно́ургъ.

Зап. Турк. Tеовр. Оüщ. Записки Туркестанскаго Отдьла Импер. Русскаго Географическаго Общества.

Iза. Павћ. Муз. Извђстія Кавказскаго Музея, Тифлисъ.

IГз. Оби. Люб. Ecm. Гзвђстія Иип. Общества Јюбителей Естествознапія, Антропологін и Этнографін, Москва.

IIзв. Общ. Орл. Извђстія Обцества для пзсльдованія Природы Орловскої губ., Орелъ--Кіевъ.

Iзв. Томск. У-ма. Извъстія Императорск. Томскаго Университета, 'Тмискъ.

Jahrr. Würt. Jahreshefte des Vereins für vaterliche Naturkunde in Württember...

Mam. nози. фауив Росс. Пми. Матеріалы къ познанію фауны пі флоры Росcin̈ckoï Имперіп. Отд. Зоологическії. Нзд. И. Обшества Испытателеї Прпроды въ Москвь.

Mém. Ac. St. Pétersur. Mémoires de l'Académie Impériale des Sciences de St.Pétersbourg, V-e Série.

Mrél. Biol. Mélanges biologiques, tirés du Bulletin de l'Académie Impériale des Sciences de St.-Pétersbourg. 80.

Mrél. plrqus. et chym. Mélanges physiques et chimiques, tirés du Bulletin de l'Académie Impéríale des Sciences de St.-Pétersbourg.

Mémoir. math. etc. Mémoires de l'Académie Impériale des Sciences de St.-Pétersbourg, VI Ser. Sciences mathématiques, physiques et naturelles.

N. Act. Petr. Nova Acta Academiae Scientiarum Imperialis Petropolitanae. 40, IV. Ser.

Proceed. Zool. S. Lond. Proceedings of the General Meetings for Scientific Business of the Zoological Society of London.

Proceed Biol. S. Wash. Proceedings of the biological Society of Washington, in $8^{\circ}$.

Proceed. Wash. Acad. Proceedings of the Washington Academy of Sciences Washingt. $8^{0}$

IIp. Оx. Природа п Охота, Москва.

Sit:b. Ges. Berl. Sitzungsberichte der Gesellschaft naturforschender Freunde zu Berlin, in $8^{0}$.

Sitzb. K. Acad. Sitzungsberichte der K. Academie der Wissensch. Wien.

Tи. Сиб. O. Ecm. Труды С.-Петерб́. Общ. Естествоиспытателеї.

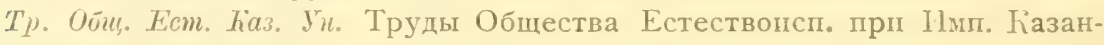
скомъ Университеть. Казань.

Tp. Бесс. Общ. Ecm. Труды Бессараб́скаго Общества Естеств. Кішеневъ.

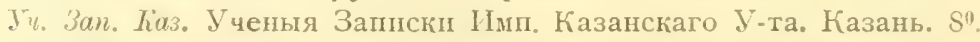

Verh. Wien. Acad. Verhandlungen der K. Wiener Academie. Wien.

Zor!. Jul,r\%. Zoologi-che Jahrbücher:

Zool. Anz. Zoologischer Anzeiger. 


\section{I. Отрядт, Chiroptera. Iетучія мини.}

\section{Семейство Vespertilionidae.}

Летучія мыши безъ кожныхъ прндатковъ на носу и около ноздрей; съ хорошо развитымъ козелкомъ; съ длиннымъ хвостомъ I широкой межбедерной перепонкой. Межчелюстныя кости не образуютъ processi palatini, всльдствіе чего костное нёбо спереди имьетъ широкую выемку, на краяхъ которой расположены рьзиы.

\section{1. Родъ Nyctalus Bowd.}

1825 r. Nycta7us, T. E. B ow d i h, Excursions in Madeira, p. 36.

1829 г. Pterygistes. J a c o b $\mathrm{K}$ a u p, System der Europäischen Thierwelt, I, 99.

1839 r. Vesperugo, A. Graf von Keyserling und J. Blasius, (89), p: 312.

1856 r. Panugo, F. A. K o le n a t i, Allgemeine deutsche Naturhist. Zeitung, Dresden, Neue Folge, p. 131 и 172. Также: (9 2), р. 335.

Къ этому роду относятся крупныя формы, легко характерпзуюшіяся цылымъ рядомъ признаковъ. Голова ихъ велика, съ очень сильно развитыми носовыми железами; уши широкі и коротки; будучи прижаты къ головь, далеко не доходятъ до конца носа. Внутренніиі контуръ уха выдается впередъ глубоко выпуклою дугою, полукруглый, загнутый внутрь край которой оканчпвается приблизительно на серединғ длины козелка. Постыдній очень коротокъ, сильно расширенъ кверху, что придаетъ ему булавовидную форму, а напбольшая ширина его лежить выше середины. Внутренній контуръ козелка вогнутый, что пропскодитъ отъ ръзкаго наклона внутрь его закругленной вершины. Крылья очень длинныя и тонкія. Основной членикъ пятаго пальца много короче такового третьяго. Крыловая перепонка снаружи прикрьпляется къ серединђ ступни. Нзъ хвостовой перепонки выступаеть наружуу только посльдній, рудиментарный хвостовой позвонокъ. Шпорный лоскутьь развитъ очень спльно. 
Объ особенностяхъ черепа я буду говорить при описаніи . отдьльныхъъ видовъ.

Зубная формула такова:

$$
\mathrm{i} \cdot \frac{2-2}{6}, \mathrm{c} \cdot \frac{\mathrm{I}-\mathrm{I}}{\mathrm{I}-\mathrm{I}}, \mathrm{pm} \cdot \frac{2-2}{2-2}, \mathrm{~m} \cdot \frac{3-3}{3-3}=34 \text {. }
$$

\section{Nyctalus noctula Schreb.}

\section{Рыжая летучая мышь или рано летающій кожанъ.}

Vespertilio noctula, Schreber (172) p. 166-167. Trouessart (200), p. 13. Pterygistes noctula Schreb. Trou es s a t (201), p. 80. Nyclalus noctula Schreb. Barret-Hamilton (16), 58. Pterygistes noctula Schreb., Mill a is (1 10$)$, p. 61, M é h e 1 y (1 04 4), p. 242-348. Vesperugo noctula Schreb., D o b s o n (4 7), p. 212. B lasius (27), р. 53. С ат унин ъ $(165)$, стр. 3. Сатунин ъ (1 66), стр. 3 .

\section{Систематическія особенности.}

Черепъ хараптеризуется сльдующими чертами строенія.Въ своей носовой области онъ сравнительно высокъ, но еще болье круто поднимается по направленію къ затылочной части, достигая наибольшей высоты около ламбдоидальнаго шва. Sutura sagittalis развита очень слабо и замьтна только у старыхъ самцовъ; скуловыя дуги широко разставлены и крђпки. Орбиты сравнительно плоски и широки, съ внутреннеї стороны онь сильно вздуты, въ особенности въ передней своей части. Выступы впередди орбитъ выдаются по сторонамъ замђтными углами. Въ межглазничной области frontalia сильно сжаты.

На стр. 2і помьщена таблица измьреній череповъ Nyctalus noctulu Schreb.

Насколько позволяеть судить имьющійся въ моемъ распоряженіи матеріалъ, черепа самокъ отличаются отъ череповъ самцовъ сльдующими особенностями: I) меньшимъ развитіемъ скуловыхъ дугъ и ламбдоидальнаго шва, 2) меньшей длиною, и 3) повидимому, болье короткимъ рядомъ зубовъ. Къ сожальнію, въ моей довольно большої поллекціи имьется много самокъ, но мало самповь Niyctulıs noctulu, и поэтому я не могу детально просльдить указанныя отличія на большемь матеріаль. Однако, и тотъ, которыї б́льъ мною изсльдованъ, является довольно убыдительнымъ.

Вь заключеніе замьчу, что мои измьренія довольно сильно отличаются отъ таковыхъ г. Барретъ-Гамильтона въ его новьйшеỉ монографіи о́ританскихъ млекопитающихъ. Такъ, напримјрь, этоть авторь приводить наибольшую длину черепа $=$ I9, тогда какъ у нашихъ экземпляровъ она достигаетъ до 20,2 и 


\begin{tabular}{|c|c|c|c|c|c|c|c|}
\hline 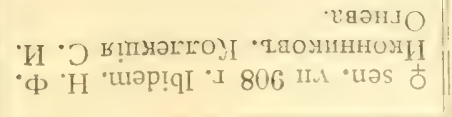 & $\stackrel{0}{2}$ & $\stackrel{0}{-1}$ & $\stackrel{\infty}{=}$ & is & $\begin{array}{l}1- \\
\infty\end{array}$ & $\therefore$ & \\
\hline 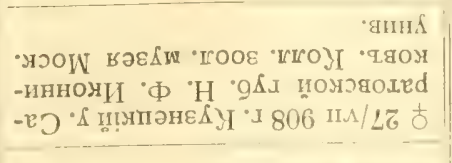 & $\begin{array}{l}\mathscr{D}^{\circ} \\
\infty_{-}^{-}\end{array}$ & $\stackrel{0}{\stackrel{0}{-1}}$ & $\stackrel{\breve{ٌ}}{\longleftarrow}$ & $\begin{array}{l}6 \\
20\end{array}$ & $\ddot{\infty}$ & 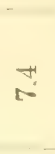 & \\
\hline 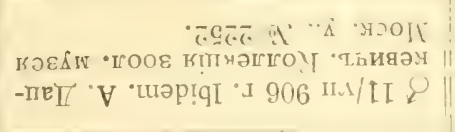 & $\stackrel{0}{\ddot{\theta}}$ & $\stackrel{-}{\cong}$ & $\stackrel{\infty}{=}$ & $\begin{array}{l}\infty \\
10\end{array}$ & $\begin{array}{l}20 \\
\infty\end{array}$ & $\begin{array}{l}c= \\
\alpha^{-1}\end{array}$ & \\
\hline 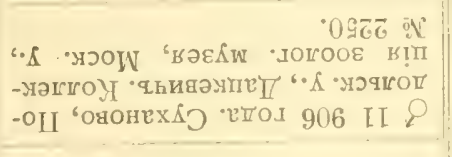 & $\stackrel{0}{\varrho}$ & $\vec{z}$ & $=$ & 0 & $\stackrel{\sigma}{\sigma}$ & $\begin{array}{l}\infty \\
\infty \\
\infty\end{array}$ & \\
\hline 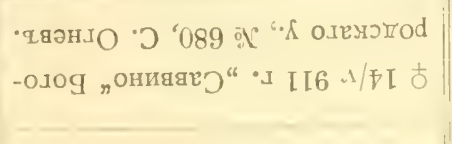 & $\stackrel{+}{2}$ & $\overrightarrow{0}$ & $\Rightarrow$ & is & $\begin{array}{r}e^{2} \\
\infty \\
0\end{array}$ & $\stackrel{0}{L}$ & \\
\hline 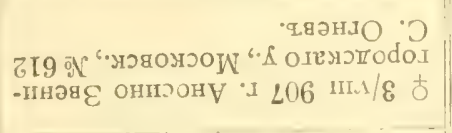 & 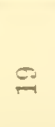 & $\stackrel{150}{\stackrel{10}{2}}$ & $\stackrel{10}{=}$ & ${ }_{105}$ & $\vec{\infty}$ & $\stackrel{12}{2}$ & \\
\hline 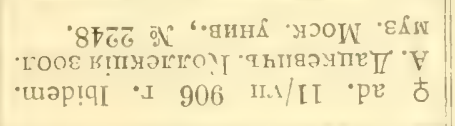 & $\stackrel{25}{=}$ & $\stackrel{10}{0}$ & $\stackrel{9}{=}$ & 5 & ${ }_{x}^{\infty}$ & ${ }_{i-1}^{\infty}$ & \\
\hline 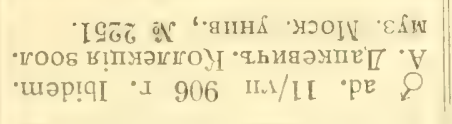 & สิ & $\stackrel{\vec{s}}{\mathscr{J}}$ & $\bar{z}$ & $\sqrt{15}$ & ${ }_{\infty}^{10}$ & $\stackrel{\infty}{=}$ & \\
\hline 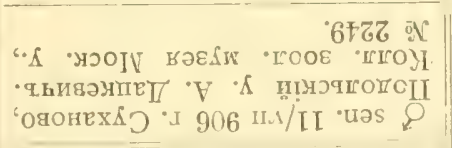 & 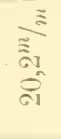 & $\underset{-1}{-10}$ & I & धै & $\vec{\sigma}$ & $\stackrel{81}{\infty}$ & \\
\hline 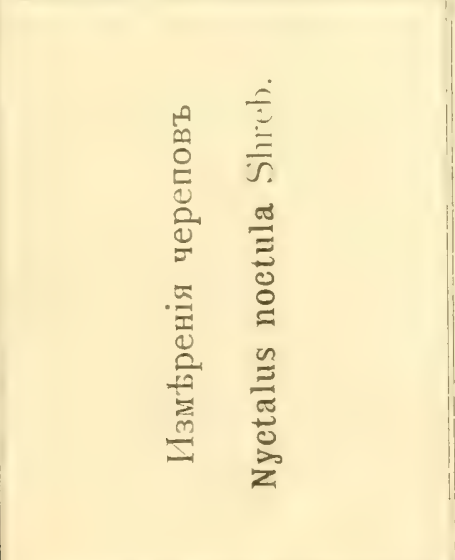 & 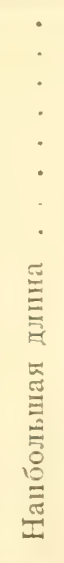 & 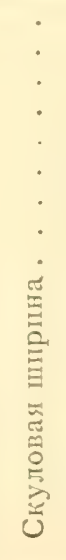 & 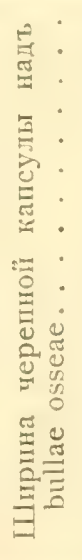 & 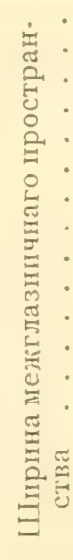 & 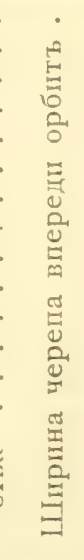 & 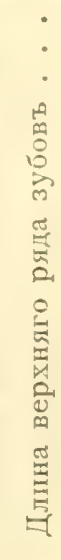 & 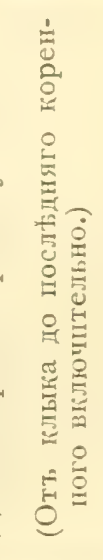 \\
\hline
\end{tabular}


равна 19 только въ одномъ случағ изъ девяти. Далье, наибольшая ширина скуловыхъ дугъ, по Ба р ретъ-Г а ил ь тону, $=12,75$, тогда какъ у приводимыхъ мною она достигаетъ I4,5. То же надо сказать и о прочихь измтреніяхъ ${ }^{1}$ ).

Зубъь характеризуются сльдующими признаками: 1) внутренніï верхній рызецъ обычно двувершинный, но у старыхъ особей вторая вершина его стирается, 2) выступающая наружу часть внышняго рызца верхней челюсти равна 1/2 длины внутренняго, но въ поперечномь сьченіи много толще посльдняго, 3) промєжуточный (praemol.) верхней челюсти находится въ глуо̆инь зубного ряда, позаді и внутрь оть клыка. Замьчу здьсь же, что это одинъ изъ хорошихъ признаковъ отличія родовъ Nyctalus и Pipistrellus. 4) Верхніе клыки вдвое или почти вдвое длиннье нижнихъ и, наконецъ, 5) нижніе рызцы сь рьдкимъ постоянствомь-qего мы не замьчаемъ у другихъ формъ-всегда параллельны другь другу.

Привожу ниже излтренія моихъ экземпляровъ. Сравнивая размьры самцовъ и самокъ, можно видьть, что они крайне близки другъ къ другу. Правда, въ моей коллекціи имьются двь самки o 680 и \: 730, размьры коихь превышаютъ всьхъ самцовъ, но большій матеріалъ, весьма вьроятно, гокажетъ, что и посльдніе достигаютъ такого же роста. Такимъ образомъ, я въ настоящее время не могу подтвердить словъ г. Барретъ-Гам ильтона, что самки Nyctalus noctula крупные самцовъ. Относительно черепа мои выводы были даже прямо противоположны. Обращаю вниманіе въ заключеніе на одно обстоятельство: какъ можно видьть изъ прилагаемой таблицы, ступня самцовъ въ общемъ ньсколько длиннье, чьмъ у самокъ, но это.отличіе еше требуеть окончательной провьрки на большемъ матеріаль.

Oкраска старыхъ самцовъ и самокъ такова: область между глазъ, затылокъ, плечи и спина покрыты шелковистыми охристорнжими волосами, которые всь приблизительно одинаковой динны. Спинная часть межбедряной перепонки отличается болье свђтлымъ и рьдкимъ волосянымъ покровомъ. Шерсть нижней стороны замьтно желтье и свьтлье, съ золотистымъ оттьнкомъ, особенно рьзко выраженнымъ на подбородкь. Уши, козелокъ и губы довольно свьтлаго рыжевато-сћраго цвыта, въ особенности по праямъ ина внышеіі части ушей. Летательная перепонка значительно темнье и сърње. Отъ этого нормальнаго типа окраски жы замбчаемъ цылый рядъ отклоненій. Такъ, въ нашей серіи

1) B a r ret-Hamilton (16), part, I, p. 63. 


\begin{tabular}{|c|c|c|c|c|c|c|c|c|c|}
\hline 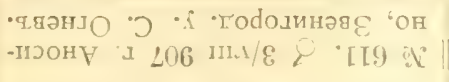 & 5 & $\stackrel{10}{0}$ & $\infty$ & $=$ & 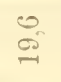 & ai & 20 & 유 & $\stackrel{\infty}{\infty}$ \\
\hline 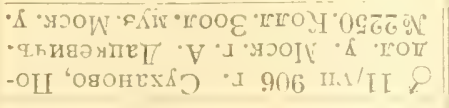 & だ & $\stackrel{20}{=}$ & to & $\stackrel{F}{F}$ & $\stackrel{\infty}{\tilde{\Xi}}$ & $\stackrel{\infty}{=}$ & $\ddot{*}$ & 占 & $\frac{91}{15}$ \\
\hline 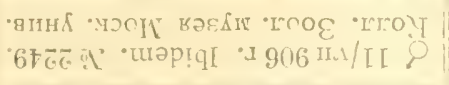 & $\stackrel{i}{i}$ & $\cong$ & to & L & छे & $\bar{z}$ & : & $\stackrel{\infty}{=}$ & 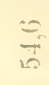 \\
\hline 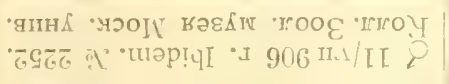 & $\bar{E}$ & $\stackrel{\infty}{\stackrel{\infty}{上}}$ & $r$ & 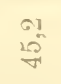 & 요 & $\stackrel{0}{\Leftrightarrow}$ & ain & $\stackrel{\infty}{\sim}$ & is \\
\hline 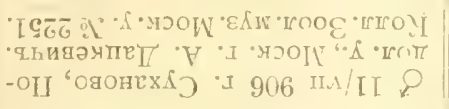 & మే & $\underline{L}$ & $i^{2}$ & in & $\tilde{\tilde{\tilde{\sigma}}}$ & $\stackrel{\infty}{=}$ & $\underset{10}{\stackrel{\infty}{n}}$ & $\subseteq 9$ & $\overrightarrow{\mathrm{L}}$ \\
\hline 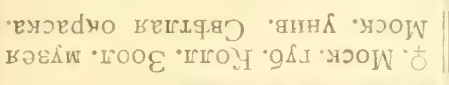 & 0 & $\triangleq$ & $\stackrel{\infty}{\infty}$ & $\begin{array}{l}0 \\
\text { 前 }\end{array}$ & $\stackrel{\infty}{\approx}$ & $\stackrel{g}{=}$ & in & 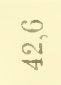 & $\overrightarrow{\text { ai }}$ \\
\hline 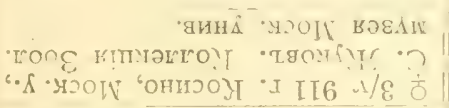 & $1=$ & $\stackrel{\infty}{=}$ & $\stackrel{\infty}{=}$ & $\frac{12}{30}$ & $\overline{\bar{a}}$ & $\stackrel{10}{=}$ & $\underset{\mathrm{in}}{\mathrm{N}}$ & $\begin{array}{l}\text { is } \\
\stackrel{\leftrightarrow}{\longrightarrow}\end{array}$ & is \\
\hline 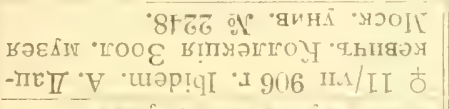 & $\stackrel{20}{E}$ & $\simeq$ & $\stackrel{0}{i}$ & $\stackrel{8}{20}$ & $\frac{\infty}{61}$ & $\stackrel{\infty}{e}$ & $\overbrace{0}^{5}$ & $\$$ & $\begin{array}{r}4 \\
53\end{array}$ \\
\hline 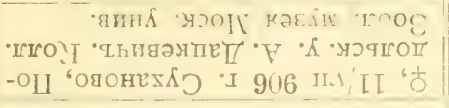 & $\stackrel{0}{5}$ & $\underline{s}$ & $\approx$ & $\stackrel{\infty}{T}$ & $\overrightarrow{\mathrm{s}}$ & $=$ & $\frac{a 1}{\ln }$ & $\stackrel{10}{7}$ & 19 \\
\hline 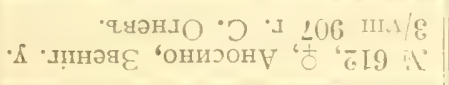 & $\vec{R}$ & $\ddot{0}$ & $\sigma$ & $\stackrel{5}{25}$ & $\stackrel{8}{s}$ & 10 & 요 & $\stackrel{\leftarrow}{55^{5}}$ & 19 \\
\hline 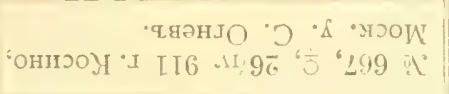 & $\stackrel{10}{E}$ & $\stackrel{20}{=}$ & $\infty_{n}$ & $\frac{01}{15}$ & $\stackrel{10}{\approx=}$ & $\stackrel{25}{2}$ & 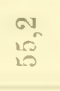 & $\stackrel{\infty}{a}$ & ז̊ำ \\
\hline 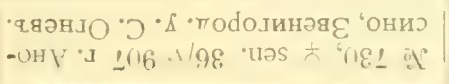 & $\frac{10}{10}$ & $\cong$ & $\varphi_{n}$ & 우 & हे & ${ }^{20}$ & $\underset{8}{20}$ & 120 & 15 \\
\hline เяวно & $\frac{10}{10}$ & $\ddot{E}$ & $l_{i}^{\infty}$ & 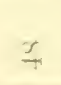 & $\ddot{\bar{\omega}}$ & 三. & 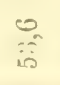 & $\stackrel{\curvearrowright}{\exists}$ & $\vec{b}$ \\
\hline 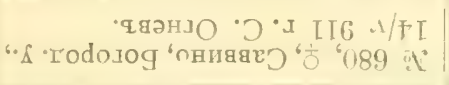 & 30 & $\stackrel{e^{\prime}}{=}$ & 10 & 온 & คి & 13 & \&i & $\mp$ & $\frac{81}{15}$ \\
\hline 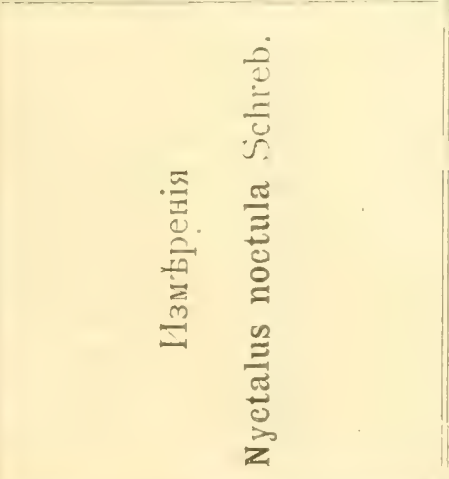 & 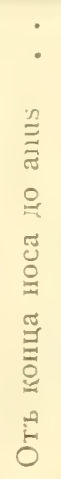 & 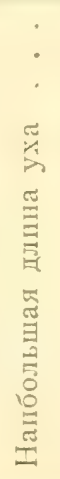 & 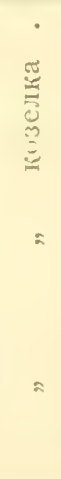 & 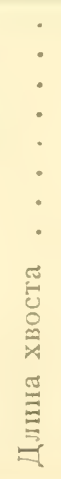 & $\begin{array}{l}: \\
: \\
\vdots \\
\vdots \\
\vdots \\
\frac{0}{0} \\
5 \\
0\end{array}$ & 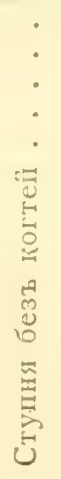 & 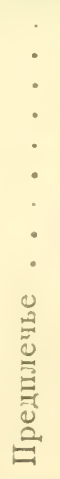 & 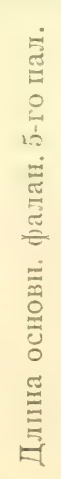 & $\begin{array}{l}= \\
\therefore \\
\therefore \\
\therefore\end{array}$ \\
\hline
\end{tabular}


нашелся экземпляръ, выдававшійся своей очень свђтлой желто ватой окраской и съро-желтоватыми ушами и летательной перепонкой.

Что касается до окраски молодыхъ самцовъ и самокъ, то они очень рђзко отличаются отъ стариков' Вся верхняя сторона ихъ тьла рыже-бураго цвыта съ рьзко выраженнымъ шоколаднымъ оттьнкомъ. Нижняя сторона свьтлье, болье рыневато-сьрая, но значительно темные, чьмъ у старыхъ. Уши, козелокъ и губы желто-съро-бураго тона; летательная перепонка еще темнье, болье чернаго оттьнка.

Относительно сезонныхъ измьненій мои свьдьнія еще скудны. Могу отмьтить только, что осенніе экземп.яры отличаются болье длинной шерстью, но общій ходъ линьки мнь пока просльдить не удалось. Отмьчу здћсь интересъ и желательность дальньйшихъ изльдованій въ этомъ направленіи, такъ какъ линька Nyctalus moctula Schreb. не изучена даже въ самыхъ общихъ чертахъ и западно-европейскими зоологами.

\section{Географическое распространеніе.}

Рыжая летучая мышь принадмежитъ къ одному изь самыхъ распространенныхъ видовъ не только въ предылахъ Московской губерніи, но и во всей Европейской Россіи. Однако, въ распространеніи ея замћчается нькоторая спорадичность, которая, замьчу, является хараґтерної чертої для географфпческаго распредьленія почти всьхъ Chiroptera. Въ предьлахъ Московской губерніи этотъ видъ найденъ мною въ большомъ количествђ въ ближайшихъ окрестностяхъ столицы, какъ, напримьръ, въ Петровско-Разумовскомъ, I Дарицынь, Кунцев ь, Нзмайловскомъ Зв ь-

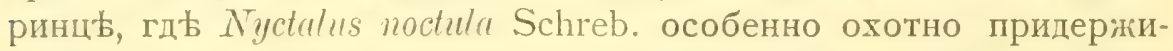
вается старыхъ липовыхъ насажденій. Далће, рыжая летучая мышь довольно обыкновенна въ разныхъ частяхъ Московскаго, Можайскаго, Рузскаго, Клинскаго, Звенигородскаго, Богородскаго уу,; гды наблюдалась мною преимущественно въ старыхъ липовыхъ паркахъ. Въ коллекціи Зоологическаго Музея Императорскаго Московскаго Јниверситета имұются экземпляы изъ Подольскаго у., собранные А. П. Дац к в и ч ем ъ. По словамъ К. А. Сатунина, это-наиболье обыкновенная летучая мышь въ Московскої губерніи и встрђчается даже въ самомъ городы Москвь. Выше я замьтиль, что въ распространеніп описываемаго вида замьчается спорадичность. Такъ, напримьръ, въ нькоторыхъ частяхь Можайскаго уғзда (Тесовскій удыльный льсъ) мны не приходилось видьть ни одного экземпляра $N$. noctula Schreb., 
но вмысто него встрьчался сравнительно часто близкій видъ $\Lambda$. leisleri Kuhl. Болье того, при моихъ изсльдованіяхъ мнь много разъ приходилось замьчать, что въ какомъ-либо ограниченномъ pai̊oнt, будь то старыї парюъ, пли неболышої высогоствольный льсной островъ, встрБчается опредьленный комплексъ видовъ съ нћсколькимп преоб́ладающими. Такимь образомь, при изученіи фауны летучихь мышей бываеть необходимо ознакомиться съ далеко отстоящими другъ оть друга мьстами, гды онь водятся.

Наши свьдынія о распространеніи этого вида въ предылахъ Средней Россіи не отличаются достаточною полнотой. Въ центральной части этой области рыжая летучая мышь найдена Э сау ло в ы м въ Псковской губ. (58, стр. 223), а по моимъ наблюденіямъ довольно обыкновенна въ Сычевскомъ и Гжатскомъ уу. Смоленской губ., Малоярославецкомь у. Калужской и въ съверной части Тульской губ. Я имью также матеріаль изъ Брянскаго у. Орловской губ., и наблюдаль ее въ восточныхъ у бздахъ той же губерніи, гдь, однако, Nyctalus noctula Schreb. значительно pьже. Далье на югъ рыжая летучая мышь найдена К. А. Сатунины мъ въ Черниговской губ. (см. Тихомировъ и Корчагинъ: І 99, стр. І 2), А. Чернаем в (2о3, стр. 8) и Н. Н. Сом о вым (I 84, стр. І 5 I) и въ разныхъ мьстахъ Харьковской губерніи. Встрьчена К ес ле р м ъ въ Кіевской и около Радомысла, Кіевской губ., G. B elke (г 8, p. 49г). Добыта въ Украйны Блаз іусом ь и около Каменецъ-Подольска-G. B elke (г 7, p. 4I7). Подвигаясь на востокъ, мы находимъ ее въ степяхъ между Волгою и Ураломъ, гды этотъ видъ не многочисленъ, по словамъ К. А. Сатунина (г67. стр. 5). По М. Н. Богданову (3о, стр. 159), наша летучая мышь встрьчается въ Казанской, Симбирской, Пензенской и съв. части Саратовской губ́. Въ посльдней, именно въ Кузнецкомъ у., она найдена въ значительномъ количествь Н. Ф. Нкон н и ко вы м ь, отъ котораго я имью ньсколько экземпляровъ, и указана А. А. С илантьевымъ ( 8 I, стр. 303). Для Симбирской губ. ее указываеть Б. М. Ж и тковъ, гды она обыкновенна въ долинь Алатыря и Ардатовскомъ

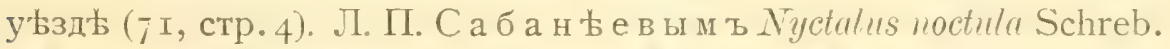
найдена въ Ярославской губ. на р. Которости, хотя этотъ авторъ не вполнь увыренъ въ своепъ опредьленіи, такъ какъ летучая мышь добыта не была. Такъ же неопрдьленно говорить онъ о нахожденіп ея въ городы Яроставль и Полушкиной Рощь ( 5 o, p. 250 и р. 5I7). По словамъ 3 а рудн а го, довольно обыкновенна подъ Оренбургомь (77, стр. 363). Въ той же губерніи, а 
также и Казанской, найдена Эверсманном т (49, р. 492). Па.tbe на юго-востокъ добыта около Гурьева (P a 11 a s, I 3 o, p. I22). Объ экземплярахъ изъ Гурьева отъ г. Карелина упоминаетъ проф. Н. Ө. К а щ ен ко (8 о, стр. 33). По берегамъ Чернаго моря наблюдалась Но рд м н н о м; въ Бендерскомъ у., Бессарабской губерніи, добыта Браунером в, а для Крыма указана ПІалласомъ (г 3 о, р. І23) и И. Двигубскимъ (42, стр. 57). Въ Крыму же добыта Н. М. Кулагиным (Тихомировъ и К арчагинъ, І 99, стр. І2). П оо словамъ А. А. Браунера, водится по всему Крыму (39, стр. 89). Что касается до распространенія этой летучей иыши въ сђверныхъ частяхъ Европейской Россіи, то, кромь указанія Эверсманна о нахожденіи ея въ Пермской губ. и свидьтельства Л. Кру ли ков скаго о распространеніи ея въ южныхъ уњздахъ Вятской губ. (93, стр. Іхо), мы ничего не знаемъ. Въ Петербургской губ. В. Л. Біанки Nyctulus noctula Schreb. не нашель, хотя и считаеть весьма выроятнымъ ея распространеніе въ этой мьстности, такь какъ она была найдена въ Финляндіи (23, стр. Іо8). Въ Прибалтійскомъ крађ она найдена въ Курляндской губ. (Лихтенштейномъ), въ Ригь и около Лисдена (Г реве, 67, р. 25).

Внь предьловъ Европейской Россіи она встрђчена въ степяхъ сьвернаго Предкавказья, около города Ставрополя К. А. Сатунинымъ, Динникомъ и В. А. З ейдлицемъ (см. С атунин ъ, І 5 9, стр. І2). Въ сьверо-восточномъ Предкавказьь ее нашель К.А. С а т ун ин ъ ( 156 , І908). По К е с л е ру, встрьчается на Кавказь, гдь найдена въ Кисловодскь (88, стр. III). Наконецъ, въ Закавказьь добыта въ Елизаветпольскомъ и Арешскомъ уу. (Сатунинъ, І 57, стр. го4). Далье на востокъ она распространена по побережью Каспійскаго моря (Пал ласъ) и въ Закаспійскомъ крағ ( $К$ ащенко, 8 о, стр. 33) и найдена въ восточной части киргизскихъ степей близъ бзера Норъ-Зайсана Э в е р с а н н о ъ $(49,492)$. На съверь въ Сибири добыта около Барнаула Томской губ. (Кащенко, 8 о, стр. 33). Экспедиціей проф. В. В. С а пожникова $N$. noctula Schreb. найдена въ Семирьчьь. Въ Туркестанћ рыжая летучая мышь добыта въ Самарканды, Кульджь (Н. А. С $\mathbf{b}$ в е рцо в ы м ъ), близъ В ьрнаго и озера Иссыкъ-Куль. Для Персіи указана Dr. B u h s e (Б р а н д ъ 33, р. 33). Кромь перечисленныхь мьсть, $N$. noctula Schreb. найдена въ Великобританіи, ПЈотландіп, Норвегіи, Даніи, съверной Германіи, откуда распространена по всей западной Европь до среднеї ІІталін, Сицили, Средизенноморскої области и по всеї Африкь. Кром'ь того, эта летучая мышь добыта въ Гималаяхъ 
(Dobson, 47, 213), на Цейлонь, Малайскомь Архипелагt, Суматрь, Явь, въ Японіи, Гитағ, Непаль, Сиккимь, Кандагарь, Cингапурt (см. Bla n f o d, 24, p. 3og, Mammalia). Въ этой области, однако, распространеніе Nyctulus noctula Schreb. требуетъ еще тщательнаго изученія, такъ какъ сталкивается съ близкимъ видомъ Nyctalus lasiopterus Schreb. (= molossus Temm.).

\section{Образъ жизни.}

Әта летучая мышь особенно любить старые липовые парюи, гды обычно цьлыми колоніями держится въ глубокихъ дуплахъ. Колоніи эти не смьшиваются съ близкими къ Nyctalus noctula Schreb. фориами; характерної чертої описываемой мыни яв.ляется ея неуживчивость, тогда какъ разные виды Myotis и Pipistrellus живутъ часто вмьсть. Если потревожить такую колонію, то обыкновенно на другой день въ дупль, гды держалось много летучихь мышей, не будеть уже ни одной. Кром' дупль деревьевъ, N. noctula Schreb. держится и подъ карнизами домовъ и нежилыхъ старыхъ построекъ.

Когда солнце начинаеть садиться, колонія рыжихъ летучихъ мышей приходитъ въ безпокойство. Тогда можно слышать пискъ и возню, которая выдаеть обитателеї дупла. Біологически этоть видъ отличается сравнительно очень раннимъ вылетомъ на охоту. Часто въ хорошіе вечера, въ йонь іюня, можно видьть, какъ N. noctula Schreb. кружатся высоко въ воздухь вмьсть со стрижами, когда солнце еще не сьло. Весною этотъ видъ вылетаетъ обычно ньсколько позднье,-по крайней мьры мнь не случалось видђть его такъ рано, когда еще совсђмъ свытло, что я часто замьчаль подъ осень. Въ этомъ отношеніи мои наблюденія совершенно сходятся съ таковыми г. О льдгама ${ }^{1}$ ), тщательно изучавшаго время вылета $N$. noctul Schreb. Полеть описываемаго вида необыкновенно стремителенъ и быстръ. Интересно наблюдать за нимъ въ теплые весенніе или льтніе вечера, когда во всьхъ направленіяхъ носятся майскіе жуки (Melolonthe hippocastani Fabr.) пли хрущи (Rlizotrogus solstitialis L.). Съ необыкновенной ловкостью на самомь разлеть хватають ихъ летучія мыши, и слышится только щелчокъ, съ которымъ схватывается зубами твердый и крупныї жукъ. Кому прнходилось наб́людать въ такое время этихъ мышей, тотъ, вьроятно, не разъ замьчаль одинъ своеобразныї и интересный маневрь во время полета. Об́ыкновенно съ большої высоты, сложивъ крылья, бросается кожанъ

1) O I d h a m, Zoologist, Igor, p. $5^{1-59}$. 
по отвћсу внизъ и часто, не долетьвъ до земли только на нtскольло метровъ, по откосу опять довольно быстро поднимается и на время скрывается изъ виду. Обычное объясненіе этого маневра таково: думають, что въ моментъ опусканія летучая мышь схиатила какое-лшбо большое наськомое, которое она поддерживаеть межбедряної перепонкої, и всльдствіе тяжести пойманної добычи спускается къ земль. Въ новьйшее время наблюденія Milla is, Oldham и др. показали, что мы имьемъ здысь передъ соб́о̊ явленіе, аналогичное ловль соколомъ своей добычп; подобно тому, какъ посльдній бросается на летящую ниже его птицу, такъ и $N$. noctula Schreb. кидается внизъ за своей жертвой. На основаніп личныхъ наблюденій я склоненъ придти къ подобному же заключенію. Это паденіе, „swoop“, какъ говорять англичане, бываеть такъ стремительно, что стрьлять въ данный моментъ летучую мышь совершенно невозможно. Зато охота за ними довольно легка, когда кожаны несутся, правда, съ большою быстротою, по прямому направленію. Съ наступленіемъ большихъ сумерекъ кожаны перестають летать высоко, а носятся между деревьями или даже надъ водой. Мн'ь ньсколько разъ приходилось наблюдать, какъ пьетъ воду описываемый видъ. Обыкновенно онъ дугою спускается къ водь, дотрогивается съ легкимъ всплескомъ до ея поверхности и повторяетъ этотъ маневръ по многу разъ.

Весною рыжая летучая мышь появляется обыкновенно $\mathrm{Hb}$ сколько раньше своихъ сородичеї. Въ Московской губерніи мнь приходилось видьть ее въ первой половинь апрђля на тягы вальдшнеповъ въ холодные ясные вечера, когда въ льсу еще много снбга, тяга только началась и отовсюду слышится бормотаніе тетеревей. Но вотъ весна вступаетъ въ свои права, и больше и чаще видно $\Lambda^{\top}$. noctula Schreb. Въ конць апрьля (24/rॅ 9 II) I первой половинь мая (3/个 и I4/ менныя самки. Интересно отмътить, что количество молодыхъ колеблется отъ одного до двухъ, при чемъ и тотъ, и другой случай одинаково часты. Это наблюденіе стоитъ въ полномъ согласіи съ данными Блазіуса и $К$ арла Фохта, изучавшими описываемый видъ на Европейскомъ материкь. Между тьмь, большинство англійскихъ пзсльдователей утверждаетъ, что у этой летучей мыпи бываетъ только одинъ молодой ${ }^{1}$ ). Быть можетъ, мы пиемъ передъ собої примьры біологическаго различія, обусловленнаго разнищей географическихь условій. Точно устано-

1) C.r., напр., G. D a n i e I1, Proc. Zool. Soc. 1834, p. 130. 
вить время рожденія молодыхъ мнь еще не удалось; выроятно, оно приходится на первую половину іюня, потому что уже зо іюня К. А. С а ту н и н нашелъ въ І89г году, въ Кзмайловскомъ Звьринць, въ дупль старой липы много самокъ съ соотвытствующимъ количествомъ молодыхъ, еще неспособныхъ летать ( 65 , стр. 3). Отмьчу здьсь интересное наблюденіе названнаго автора. Ему удалось замғтить, что въ этоть ранній періодъ жизни молодые $N$. noctulu Schreb. питаются наськомыми, которыхъ имъ ловятъ старики. Хорошо летающихъ молодыхъ мньь приходилось стрђлять во второй половинь іюля.

Перехожу теперь къ описанію очень интереснаго біологиче. скаго явленія, надъ которымъ, къ сожальнію, русскіе зоологи еще не дылали никакихь наблюденії. Я говорю о періодических странствіяхь Nyctalus noctula Schreb. Јьтомъ I907 г. я усердно коллектировалъ летучихъ мышей около Аносинскаго монастыря въ Звенигородскомъ уызды. Количество $N$. noctula Schreb. было очень мало: въ теченіе всего льта я видьль только 2-3 экземпляра, изъ коихъ одного добылъ. Совершенно неожиданно 2-го августа мой братъ, В. И. Огнев ъ, сообщилъ мнь, что замьтиль большую массу рыжихъ летучихъ мышей, летавшихъ по берегу Истры, около самаго Аносина, гдъ до этого времени не было замьтно ни одного экземпляра. На другой вечеръ (3 августа) я видыль и стрьляль описываелыхь мышей; онь держались здьсь очень большою стаей въ теченіе трехъ дней, а затьмъ совершенно неожиданно исчезли, хотя вечера продолжали стоять очень хорошіе. Мны думается, что мы имьемъ здьсь передъ собой явленіе перелета или кочевки $N$. noctula Schreb.

Просматривая извћстную мны литературу, я наше.л указанія на миграцію этого вида в’ работахъ западно-европейскихъ зоологовъ. Нькоторые авторы (Kolenati, Koch, Altum) утверждаютъ, что рыжая летучая мышь въ нькоторые годы покидаеть позднею осенью мьста своего пребыванія и большими стаями улетаеть на югъ. Кобельть (9 I, стр. 494) наблюдаль ньчто въ роды кочевки или перелета у этого вида. Méhely думаетъ, однако, что посльдній не покидаетъ мьстъ своего льтняго обитанія, но совершаеть кочевку изъ льсовь въ старые дома ( p. 349).

Что касается до литературныхъ указаній на перелеты другихъ видовъ летучихъ мышеї, то они довольно многочисленны. Я не буду здьсь останавливаться на деталяхь, а упомяну о нихь въ самыхъ общихъ чертахъ. Еще въ І828 г. Глогеръ наблюцаль въ Шлезіи вертикальныя кочевки Tespertitio mumus L. 
(= Tesperus discolor Natt.). Бла з іусь (2 7, p. 72) описываеть періодическіе перелеты Vespertilio borealis Nilss. въ предьлахъ сьверной Россіи. Бәръ наблюдаль появленіе летучихъ мышей позднимъ льтомъ въ Лапландіи. Особенно ярко выражены перелеты этихь млекопитающихъ въ неарктической области. Такъ, напримьръ, A thur Howel ${ }^{1}$ ) наблюдаль перелетъ летучихъ мышей около Вашингтона 27/xх 907 г. даже утромг и. днемг. Насколько можно было опредьлить въ бинокль, летьли главнымъ образомь Lasimus boreatis, Lasionycterus noctivagans п, по всеї вьроятности, какіе-то Myotis и Pipistrellus.

Осенью посльднихъ кожановъ мнь приходилось наблюдать около 7-го сентября.

Всь экземпляры коллекціи перечислены въ таблиць измыреній, помьщенной на стр. 23.

\section{Nyctalus leisleri Kuhl.}

\section{Летучая мышь Лейслера.}

Vespertilio leisleri, K u hl: Deutsche Fledermaüse, Ann. der Wetterauischen Gesellschaft für die gesammte Naturkunde, IV, p. 46. Vesperugo Leisleri, B lasius (2 i), p. 56. Dobson (47), p. 215. Nyctalus leisleri Kuhl Trouessart (200), p. 19. Pterygistes leisleri Kuhl Trouessart (201), p. 80. Méhely (1 04 ), p. 252, 349. Mill a is (110), p. 76. Nyctalus leisleri Kuhl B arret-Hamilton (16), p. 83 .

\section{Систематическія особенности.}

По строенію черепа (см. табл. I, р. 2) этоть видъ очень напоминаеть вышеописанныі. Здбсь, какъ у всћхь представителей рода syctalıs, мы пмьемъ предъ собою сравнптельно сильно поднятую носовую область, если смотрбть на нее въ профиль. Однако, отъ Nyctalus noctula Schreb. черепъ этой летучей мыши легко отличается большей сжатостью и меньшей поднятостью затылочной области. Crista lambdoidalis развитъ сравнительно много слабье, чьмъ у предыдушаго вида. Crista sagittalis едва намьченъ. Скуловыя дуги много тоньше и не такъ широко разставлены по отношенію къ общей длинь черепа, какъ у Nyctalus

1) Arthur Howel, Notes on diurnal migrations of bats (Proceedings of the biological Society of Washington, vol. XXI, p. 35-38, January 23, I908). C.. также: Hart M erria m, Trans. Royal Soc. Canada, V. sect. $\mathrm{IV}, \mathrm{p} .8,5,87$; G. S. Miller, jun. Science (N. S.), V, № II8, p. 45I-543, April 2, 1897; Dr. Edgar A. M e a rns, Bullet. Americ. Mus. Natur. History, X, I898, p. 345. 
moctulı Schreb. Bullae osseae. легко отличаются формою своихъ переднихъ и заднихъ ғонтуровъ. Мменно, у Nyctalus leisteri Kuhl онь гораздо болье округлы, чьмъ у $\Lambda$. noctula Schreb., у коего при общей вытянутости bullae замьчается угловатость очертаній сзади и острый выступъ, которымъ оны оканчиваются спереди. Къ перечисленнымъ признакамъ я могу прибавить еще одинъ: у Nyctalus noctula Schreb. сказывается болье рызкая перешну ровка черепа въ межглазничной области. Вьрность этого признака подтверждается приводимой таблицей изньреній.

\begin{tabular}{|c|c|c|c|c|c|}
\hline $\begin{array}{l}\text { Жзмьренія череповъ } \\
\text { Nyctalus leisleri Kuh! } \\
\text {. }\end{array}$ & 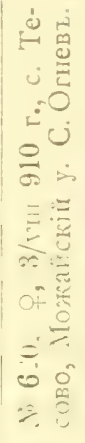 & 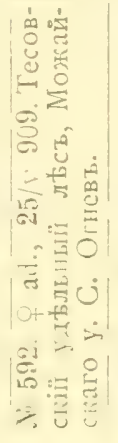 & 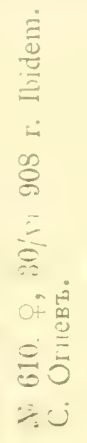 & 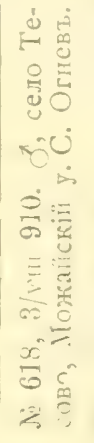 & 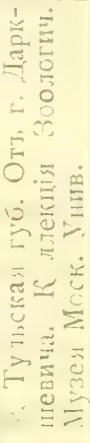 \\
\hline . & & & & & \\
\hline Напбольшая длина . . . . . . . & 16,2 & 16 & 15 & 16 & 16,3 \\
\hline Скуловая ширнна . . . . : . . . . . . & 16,8 & 11,2 & def. & 11,2 & def. \\
\hline 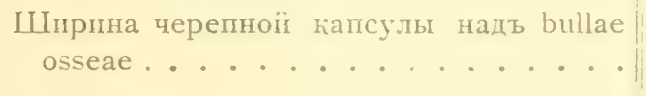 & 9,4 & 9,4 & 9,5 & 9,6 & 9,8 \\
\hline Ширпна межглазничнаго промежутка . . | & 5,3 & 5,4 & 5,3 & 5,4 & 5,6 \\
\hline Ширина черепа впереди орбитъ . . . . & 6.9 & 7,5 & 7 & 6.8 & 7 \\
\hline $\begin{array}{l}\text { Длина верхняго ряда зубовъ (отъ клыка } \\
\text { до посльдняго коренного) } . . . .\end{array}$ & 6,1 & 6 & 6,3 & 6,2 & 6,2 \\
\hline
\end{tabular}

Что касается до строенія зубовг, то они отличаются отъ $N$ ус falus noctula Schreb. нбсколькими особенностями: т) вньшній рђзецъ верхней челюсти достигаетъ $2 / 3$ внутренняго, но въ поперечномъ сьченіи почти равенъ ему, тогда какъ у $N$. noctulı Schreb. поперечное сьченіе вньшняго рłзца вдвое больше, чьмь внутренняго. Блазіусъ $(27$, р. 56) говоритъ, что внутренній рьзець одновершинный,-это не всегда вьрно. Просматривая экземпляры своей коллекціи я могъ убьдиться, что у всьхъ молодыхъ особей имьется вторая вершина, которая стирается только у старыхъ. 2) Верхніе клыки всегда вдвое длиннье ниж- 


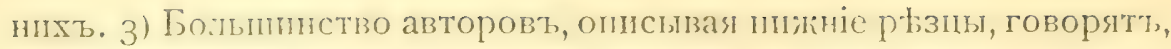
что они стоятъ по направленію челюсти и дотрогиваются другъ до друга, не будучи параллельны по своему расположенію. Méli el y ( с о 4, p. 349) впервые. понстатироваль тоть факть, что рłзцы у $N$. leislevi Kuhl иногда расположены параллельно другь другу. На своемъ матеріаль я могъ убыдиться, что относительное распредьленіе нижнихъ рьзцовъ у описываемаго вида подвержено значительнымъ колебаніямь, и одинаково часто встрычаются особи какъ съ параллельнымъ расположеніемъ нижнихъ ръзцовъ, такъ и съ направленнымъ по линіи челюстной кости. 4) Промежуточный зубъ верхней челюсти, какъ и у $N$. noctula Schreb., стоить далеко внутри зубного ряда.

Orрласа взрослыхь санцовь и самокь такова: верхь головы II спина покрыты длинными волосами съ темно-бурыми основаніями и палево-рыжими вершинами, что придаеть мьху рьзко двуцвђтный видъ при разсматриваніи волосъ въ отдьльности. Нижняя сторона замьтно свђтлtе, хотя основанія волось очень темнаго бураго тона, но прикрывающія ихъ свьтло-палево-сьрыя окончанія придаютъ этої части мtха очень яркій тонъ. Область летательной перепонки между предплечьемъ и бедромъ покрыта длинными, свьтлыми ржаво-палевыми волосами, съ болье темными основаніями. Уши, губы п летательныя перепонки сьробураго цвьта. Отъ этого типа окраски, въ общемъ гораздо болье свытлаго, чьмъ $N$. noctula Schreb., сушествуетъ много отклоненій. Во-первыхъ, мы имьемъ болье рыжіе экземпляры, близкіе по цвьту къ тону сіенны и схожіе съ $N$. noctula Schreb. Съ друтой стороны, нбкоторые очень старые экземпляры характеризуются необыкновенно свћтлымь оттыниомь персти, переходящимъ въ желтовато-палевый сверху и серебристо-палево-сђрый снизу. Что касается до цвьта ушей, губъ и перепонки таких летучихъ мышей, то съ возрастомъ эти части свћтлћють, особенно края ушей и губы, которыя совершенно депигментируются и дњлаются изъ бурыхъ свътло-желтоватыми. Наконецъ, встрычаются довольно часто красочныя отклоненія совершенно необычнаго типа. Такъ, въ моей коллекціи есть экземпляръ очень свьтлої окраски, на лбу котораго замџтно пятно, состоящее пзъ ćlро-сереи́ристыхъ волосъ.

По словамъ Alcock, самцы темнъе самокь; несмотря на всћ старанія, мнђ этой разницы наблюдать не удалось.

Окраска молодыхъ значительно темнъе и бур‡е, хотя много свьтлье Nyctulus noctula Schreb. соотвытствуюшаго возраста. Уши, губы и летательныя перепонки значительно темнђе, чћмь 
у старыхъ. Помимо р丸зкихъ цвътовыхъ отличій представителей рода Nyctalus, я особенно подчеркиваю разницу въ самомъ характерђ мыха: тогда какъ у Nyctalus noctula Schreb. онъ отличается весьма ровною длиной и короткостью волосъ, у Nyctalus leisleri Kuhl посльдніе сравнительно гораздо длиннье и волнистье. - Размьры самцовъ и самокъ, какъ показывають мои измьренія, шочти не отличаются другъ отъ друга.

\section{Географическое распространеніе.}

До настоящаго времени летучая мышь Лейслера въ предйлахьь Московской губ. никьмъ не была найдена. Мны удалось добыть этотъ видъ въ довольно большомъ количествђ въ Можайскомъ у. Московской губ., въ Тесовскомъ удьльномъ льсу и въ сель Тесовђ (въ 5 верстахъ отъ города Можайска). Просматривая коллекціи млекопитающихъ Зоологическаго Музея Iмиераторскаго Московскаго Университета, я нашель два экземплярd Nyctalus leisleri Kuhl изъ Коломенскаго у. (Кочкарево) отъ А. П. Дацкевича и одинъ экземплярь отъ В. Г. Дурова изъ Измайловскаго Зв'ьринца (ближ. окр. гор. Москвы). Кром' этихъ находокъ, упомяну еще объ одной. Совершенно засохшій экземпляръ N. leisleri Kuhl быль найденъ въ концы зимы въ 1908 г. между двумя рамами окна Зоологическаго Музея. Вьроятно, летучая мышь попала туда черезъ полуоткрытую форточку и не могла выбраться изъ своей тюрьмы. Къ этому же виду летучей мыши я склоненъ отнести одинъ экземпляръ, долго летавшій на университетскомъ дворь 7/XIl 907 г., около четырехъ часовъ дня, когда было уже довольно темно. Этотъ случай, самъ по себ́ довольно загадочный, становится еще страннђе, если принять во вниманіе пятиградусный морозъ, бывшій въ тотъ день. Посль этого я никогда не видалъ летучихъ мышей при такихъ необычныхъ условіяхъ. Кромь этихъ свьдыній о распространеніи лейслеровой мыши въ предьлахъ Московской губерніи, я пмыю еще нькоторыя данныя о нахожденіи ея въ другихъ губерніяхъ Европейской Россіи. Такъ, одинъ экземпляръ Nyctalus leisleri Kuhl былъ доставленъ мнь П. С. Г ал ь ц в в м ъ изъ Дорогобужскаго у ъзда, Смоленской гуо̆., изъ имънія Кайзеровки. Въ коллекціи Зоолог. Музея Импер. Моск. Университета нашлась одна мышь описываемаго вида изъ Тульской губ. отъ г. Д а ркшев и ч а и, наконецъ, ㅇ sen. Nyct. leisleri Kuhl добыта Н. Ф. Иконников ы ъ въ Кузнецкомъ у., Саратовской губ.

Литературныя указанія о распространеніи летучей мыши Леііслера въ предьлахъ Европейской Россіи отличаются исключитель- 


\begin{tabular}{|c|c|c|c|c|c|c|c|c|c|c|}
\hline 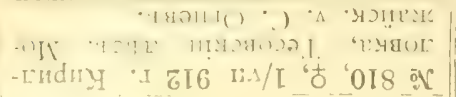 & 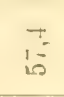 & 0 & 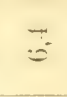 & $\exists$ & $1=$ & c. & $=$ & & लि & 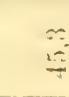 \\
\hline 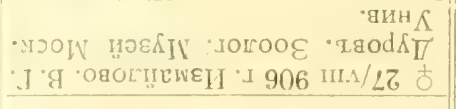 & in & 1 & 1 & 1 & $\stackrel{10}{=}$ & 1 & $\begin{array}{l}\stackrel{N}{⿰} \\
\text { sf }\end{array}$ & & $\overline{C D}$ & भ \\
\hline 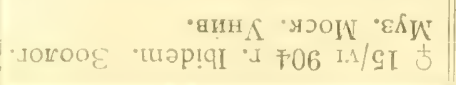 & $\hat{\sigma}_{0}^{-}$ & $\Xi$ & $=$ & $\begin{array}{l}\cos ^{2} \\
\cos ^{2}\end{array}$ & $\stackrel{10}{=}$ & $\infty_{\infty}^{\circ}$ & $\stackrel{\mathscr{P}}{\stackrel{9}{T}}$ & & कृ. & తి \\
\hline 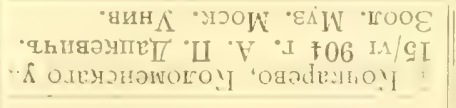 & $\underset{0}{\infty}$ & 0 & $\stackrel{91}{N}$ & $\stackrel{12}{9}$ & $\stackrel{0}{=}$ & 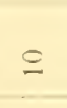 & $\stackrel{0}{\stackrel{0}{\longrightarrow}}$ & & $\because$ & $\begin{array}{l}0 \\
\stackrel{0}{c}\end{array}$ \\
\hline 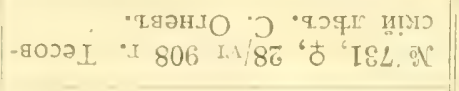 & $\frac{0}{6}$ & $\underset{I}{I}$ & $\sim$ & 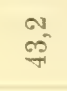 & $\stackrel{\infty}{\mathscr{D}}$ & $=$ & $\begin{array}{l}\infty \\
0 \\
\sigma\end{array}$ & & $\frac{1}{\infty}$ & 5 \\
\hline 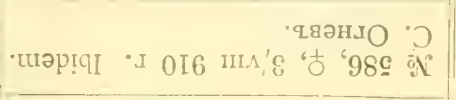 & is & $\stackrel{10}{2}$ & $\infty$ & $\stackrel{10}{5}$ & $\stackrel{\infty}{=}$ & $\begin{array}{l}61 \\
\infty \\
\infty\end{array}$ & $\stackrel{m}{\longrightarrow}$ & & $\frac{\omega}{\infty}$ & $\stackrel{0}{\sim}$ \\
\hline 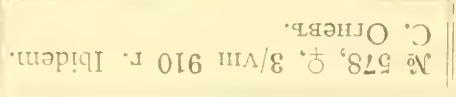 & $\underbrace{0}_{0}$ & $\stackrel{\infty}{\mathscr{2}}$ & 20 & $\stackrel{5}{F}$ & 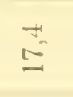 & $\infty^{\infty}$ & $\overrightarrow{5}$ & & co & $\stackrel{m}{\sim}$ \\
\hline 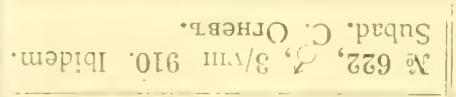 & $\frac{10}{15}$ & $\stackrel{\nexists}{I}$ & $0^{\infty}$ & ஜ & 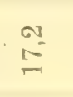 & $N$ & $\underset{\infty}{\infty}$. & & ڤ্ & $\stackrel{\infty}{-\infty}$ \\
\hline 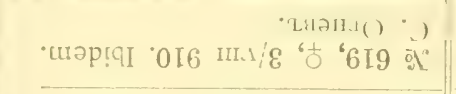 & $\underset{8}{8}$ & $\stackrel{20}{-1}$ & 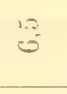 & 앙 & $\stackrel{10}{=}$ & $\because$ & $\begin{array}{l}x \\
\stackrel{x}{\leftarrow}\end{array}$ & & 12 & $\vec{T}$ \\
\hline 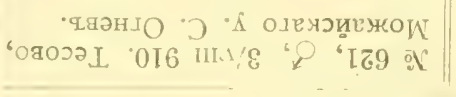 & $\overline{0}$ & 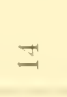 & $N$ & $\stackrel{9}{\rightarrow}$ & $\stackrel{2+1}{\Xi}$ & $\cong$ & $\bar{z}$ & & 5 & $\underline{7}$ \\
\hline 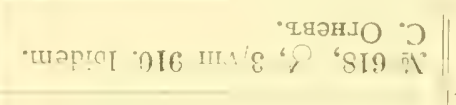 & $\tilde{g}_{-\infty}^{\infty}$ & $=$ & $\sqrt[20]{6}$ & $\stackrel{10}{\because}$ & $\stackrel{\Re}{\stackrel{N}{\Sigma}}$ & $\infty$ & $\frac{10}{1}$ & & $\because 20$ & $\bar{\square}$ \\
\hline 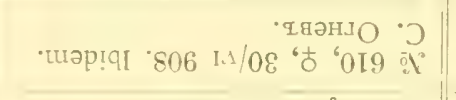 & తి & $\ddot{0}$ & S) & 와 & $\underset{\infty}{\infty}$ & $\stackrel{\infty}{\infty}$ & $\begin{array}{c}61 \\
21\end{array}$ & & $\begin{array}{l}\infty \\
\infty \\
\infty\end{array}$ & ஸू \\
\hline 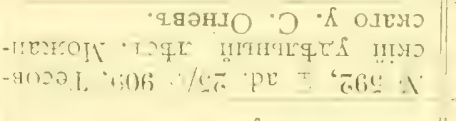 & $\stackrel{c}{x}$ & $\ddot{E}$ & $\tilde{s}$ & 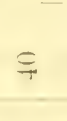 & $\underline{0}$ & $\stackrel{29}{=}$ & $\stackrel{\infty}{=}$ & & 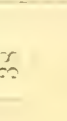 & \begin{tabular}{l}
9 \\
\hdashline
\end{tabular} \\
\hline 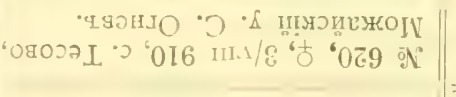 & $\stackrel{1}{\infty}$ & $\stackrel{2}{2}$ & $0^{20}$ & $\mathcal{F}$ & $\stackrel{120}{=2}$ & $\Leftrightarrow$ & $\underset{\overbrace{}}{\tilde{W}}$ & al & $\frac{a}{6}$ & $\stackrel{12}{7}$ \\
\hline 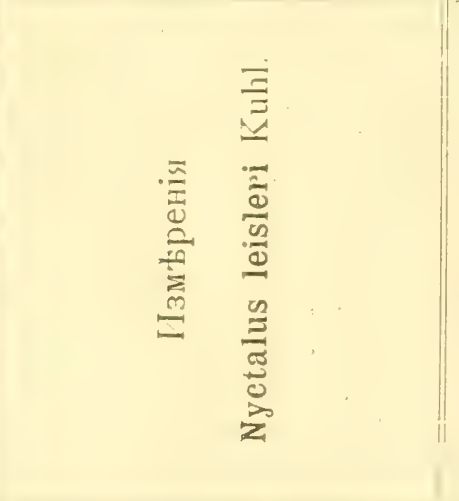 & 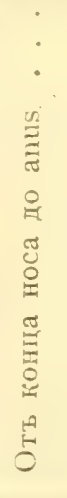 & 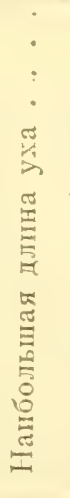 & 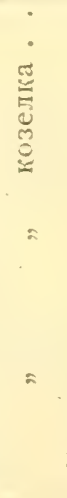 & 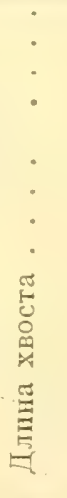 & $\begin{array}{l}: \\
: \\
: \\
\vdots \\
\vdots \\
\dot{\Xi} \\
\overline{0} \\
5 \\
0 \\
=\end{array}$ & 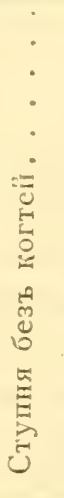 & 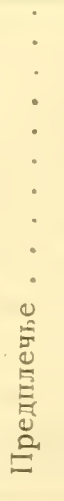 & 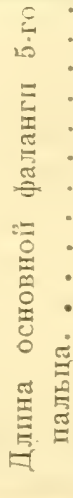 & 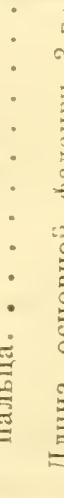 & 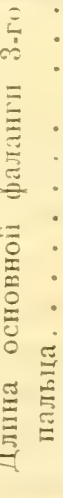 \\
\hline
\end{tabular}


ной бьдностью. Эта летучая мышь была найдена Эверсманом ъ между Волгою и Јраломъ (49, р. 495). По М. Н. Богдан о в у (3 о, стр. 159) найдена въ Саратовской и Астраханской губ. (В. Е. Яковлевымъ). К есслер ъ отмьчаеть этотъ видъ для Кіевской губ., а Л. П. Сабан в въ упоминаетъ объ экземплярь, добытомг въ I867 г. въ Лицейскомъ саду гор. Ярославля ( 5 о, стр. 5г7). А. А. Брауне р г говоритъ объ одномъ экземплярьь изъ Домузловъ, Евпаторійскаго у. (39, стр. 9о).

Въ Прибалтійскихъ губерніяхъ Nyctalus lessleri Kuhl найдена въ Курляндіи Лихтенш тейн о ъ (Bullet. Soc. Imp. Natur. de Moscou, I829, р. 289), въ Лифляндіи, около Риги (Grevé, 67 , p. 26) и, вьроятно, не рьдка въ Эстляндіи около Гапсаля (Grevé, 1. с.). Наконецъ, у Бл аз і у с а (2 7, р. 57) мы имъемъ общее указаніе на то, что $N$. leisleri Kuhl водится въ средней Россіи.

Внъ предъловъ изученнаго района эта мышь найдена въ Великобританіи, ІІрландіи, Польш (ок. Варшавы), среднеї и южної Германіи, Франціи, Альпахъ, гдђ распространеніе ея въ вертикальномъ направленіи достигаетъ, по Фатіо, 4500 ф. надъ уровнемъ моря. Далье, она извьстна изъ Венгріи, Италіи, съ Мадейры, Азорскихъ острововъ и Гиммалаевъ (см. D о b o n, 45 , p. 9г). По Барреть-Гамильтону (г 6, р. 84), встрычается въ Восточной области.

\section{Образъ жизни.}

По выбору свонхъ станцій Јейслерова летучая мышь сходна съ $\boldsymbol{N}$. noctula Schreb. Старые льсные участки, парки съ дуплистыми деревьями-вотъ любимыя мьста этого вида. Насколько я могь замьтить, Nyctalus teisleri Kuhl держится особнякомъ оть прочихъ формъ; у нея, какъ и у $N$. noctula Schreb., замьчается неуживчивость со своими сородичами. Большія общества этой мыши часто забираются въ старыя дупла деревьевъ, гдь проводять день. Одна такая колонія была обнаружена въ дупль старой липы, въ парк'́ около Тесова, Можайскаго у., 3-го августа гяло года. Весною этотъ видъ появляется позднъе $N$. иос. tula. Первые экземпляры были замьчены мною въ началь мая; вьроятно, отдыльныя особи появляются уже въ концђ апрыля. Погода не особенно вліяетъ на эту мышь, и мнћ приходилось вид бть ее въ холодные и довольно сумрачные, но тихіе вечера. Въ сильный вьтеръ $\Lambda$. leisleri Kuhl обычно не летаетъ. Полетъ описываемой формы необыкновенно быстрый, изящный и, по иоему мньнію, еще болье ловкій, чьмъ у $\mathbf{N}$. noctula Schreb. Нельзя безъ удовольствія смотрьть, какъ Лейслерова мышь на большой высот`ь несется по прямому направленію на фон'ь угасаюшеї 
зари и затьмъ вдругъ со страшной скоростью бросается внизъ за летаюцим въ вечернемъ сумракь наськомыми. Весною мны случалось видыть этихь мышей около 9 часовъ вечера (25/r 910), т.-е. почти сейчасъ посль захода солнца. Среди льта оны появляются обычно на $1 /$ часа позднье. Осенью посльдніе экземпляры я видылъ въ конць августа и въ первыхъ числахъ сентября.

Всь бывшіе въ моихь рукахъ экземпляры Лейслеровой лету чей мыши изъ Московскої губерніи перечислены въ таблиць измьреній.

\section{Родъ Pipistrell us Kaup.}

1829. Pipistrellus, J akob K a u , Skizzirte Entwickelungsgeschichte und Natürliches System der Europäischen Thierwelt, 1 Theil, p. 98. (Основанъ на Vespertilio pipistrellus Schreb.).

1839. Vesperugo, A. Graf von K e y s e $\mathrm{l}$ ing et $\mathrm{J}$. B l a sius (89), p. 312.

1856. Hypsugo, F. A. Kolen ati (92), p. 131, 167-169. (Основанъ на Vesperugo maurus Blas. II V. Krascheninnitiovi Evsm.).

1856. Nonnugo, F. A. Kolenati (92), р. 131, 169-172. (Основанъ на Vcspertilio Nathusii, Pipistrellus Kuhlii). См. также: Sitzungsb. der Akademie der Wissensch., 1858, p. 332-335.

Летучія мыши этого рода отличаются отъ предыдушаго гораздо меньшими размьрами и цблымь рядомъ какъ внбшнихъ, такь и внутреннихъ особенностей настолько постоянныхъ и дtйствительныхъ, что родовая дифференцировка не представ.леть какихъ-либо трудностей. Несмотря на это, большинствощъ прежнихъ зоологовъ, какъ, напримьръ, Б л аз іу с о ъ, Д о б с о н о ъ этоть и предыдущій родъ сливался въ одинъ-Теsperugo, къ коему относили, какъ увидимъ, и представителей такой далеко стоящей группы, какъ Vespertilio (прежде Vesperugo или Vesperus). Gerit Miller ${ }^{1}$ ) ясно показаль важность отдьленія рода Ріріstrellus оть Pterygistes (三Nyctalus) и хотя нбкоторые авторы, какь, напримьрь, Milla is ( I o, p. 6I), Old. Thom as ${ }^{2}$ ) склонялись къ соедшненію этихъ родовъ въ одинъ, Я считаю отличія между ними настолько яркии, что раздыленіе пхь яв.яется вполнь раціональнымъ. Јкажу вкратць главньйшія изъ нихъ. Помимо

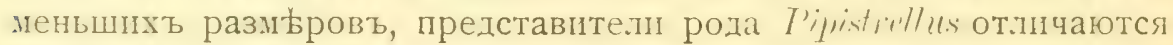
болье короткимь, широкпь крыломь, летательная перепонка котораго прикрьпляется къ основанію вньшняго пальца, а не къ серединь ступни, какь у предыдущаго рода. Основныя фаланги

1) The Nomenclature of some European Bats. Annals and Magazine of Natural History, vol. XX, 1897, p. 379-384.

2) Old. Thom as, Zoologist, 1898, p. 100. 
третьяго и пятаго пальцевъ почти равны, тогда какъ у Nyctalus, какъ мы уже видьли, фаланга третьяго гораздо длиннье пятаго. Козелокь достигаетьь своей напбольшей ширины ниже центра и ґъ вершинь суженъ, никогда не имья столь характерной для рода Nyctalus булавовидной формы.

На разсмотрьніи особенностей черепа II зубовъ, я остановлюсь при описаніи относящихся къ этому роду видовъ. Общая зубоая формула такова:

$$
\text { i. } \frac{2-2}{6} \text {, c. } \frac{I-I}{I-I}, p m \cdot \frac{2-2}{2-2}, \mathrm{~m}, \frac{3-3}{3-3}=34 \text {. }
$$

\section{Pipistrellus nathusii Keys. et Blas.}

\section{Летучая мышь Натузіуса.}

Vesperugo Nathusii Keyserling und Blasius (89), p. 320, Blasius (27), 58. Pipistrellus nathusii Keys, et Blas. Méh ely (104), 1900 p. 276. T'espenugo abramus Temm. Dobson (47) p. 226. Trouessart (201) p. 113. Сатунін ъ (165), стр. 4. п „Дополненія къ списку животныхъ Московской губ. “ Дневникъ Зоол. Отд. Общ. Любит. Естест., т. II, 1894, стр. 2. С а т у н пі н ъ (166), стр. 3. Pipistrellus abramus Temm. Trouess a t (201), 1904,p. 81. Pipistrellus nathusii Keys. et Blas. Trouessart (200), p. 16. Tesperugo Lathusii Ч е р н ầ (203), стр. 8.

\section{Pipistrellus pipistrellus Schreb.}

\section{Малая или малоголовая летучая мышь.}

Tespertilio pipistiellus Schreber (172), p. 167. Tesperugo pipistrellus Schreb. B lasius (27), p. 61. Dobson (47), p. 223. Сатунннт (165), стр. 3. A s sm us (5), Trouessart (201), p. 113, Pipistrellus pipistrellus Schreb. Tr o uessart (201), (Supplementum, 1904 r.) p. 200, 1910 г. p. 14.

Такъ какъ Pipistrellus pipistrellus Schreb. въ предьлахъ Московской губ. мной совершенно не найдень п включенъ въ списокъ только на основаніи очень опредьленнаго показанія K. А. С а тун и на, то я дьлаю параллельно съ подробным опюсаніемъ очень обыкновенной въ изученной мьстности Натузјевой летучей мыши обзоръ отличій оть нея малоголоваго кожана.

Это представляется мнь тьмъ болье необходимымъ, что до посльдняго времени многіе авторы затрудняются въ опредьленіп этихъ близкихь формъ, подробное сравненіе которыхъ поэтому особенно желательно.

\section{Систематическія особенности.}

Iерепо. (см. таб́л. I, рис. 5,6.). При сравненіи черепа Pipistrellus nathrisii Keys. et Blas. съ черепами N'yctalus, рьзко бросается въ 
глаза, что носовая область его очень уплошена и гораздо ниже лобног̆. Носовыя кости сильно вытянуты и, если смотрыть на нихъ сверху, замьтно вогнуты. Лобъ круто и высоко поднимается надъ носовой частью и, при разсматриваніи черепа описываемаго вида въ профиль, ньсколыко выше затылочной половнны. Отмьчу, что посльдній признакъ особенно характеренъ дли Pipistrellus nathusii Keys. et Blas. Скуловыя дуги очень тонки. Хорошимь признакомь отличія череповъ Pipistrellus и Nyctalus является еще сльдующее. У Nyctalus os occipitale, если сиотрьть на ея задній профиль, значительно уплощена, самое выдаюпееся и бсто этой кости надъ foramen occipitale magnum выступаетъ назадъ только едва болье, чжмъ condylus occipitalis. У Pipistrellus os occipitale сильнымъ вздутіемъ выдается назадъ, condyli occipitales отстоять гораздо болье впередъ, чьмъ самая выдаюшаяся часть затылочной кости надъ черепнымъ отверстіемъ. Какъ можно видыть изъ приводимыхъ таблицъ, измьренія череповъ самцовъ и самокь не отличаются другъ оть друга сколько-нибудь замьтно. Черепа молодыхъ разнятся отъ старыхъ меньшей перешнуровкой въ межглазничной области, ньсколько болье слабой вдавленностью сверху носовыхъ костей, не столь развитыми и менье широко разставленными скуловыми дугами. Какъ можно ясно видьть изъ приводимыхъ мною измьреній тьла и череповъ молодыхъ экземпляровъ, черепъ уже на раннемъ возрасть достигаеть своихъ окончательныхъ размьровъ, что дьлаеть легкимъ отличіе полувзрослыхъ $P$. nathusii Keys. et Blas. о'ъ менышаго $P$. pipistiellas Schreb. Помимо болье мелкихъ разиьровъ, черепь посльдняго, вида отличается сльдуюшими характерными особенностями: І) Носовыя қости относительно много короче, всльдствіе чего вся носовая область малоголової летучей мыши не такъ удлинена, какъ у P. nathusй Keys. et Blas. 2) Лобная часть черепа, хотя и замьтно выше носовой, надъ коей она довольно груто поднимается, но значительно ниже затылочной,-это служить самымъ точнымъ и легкимъ отличіемъ черепа названныхъ видовъ. 3). Далье, у Pip. nathusиi Keys. et Blas. въ нижней челюсти processus coronoideus круто, острымъ угломъ, выдается впередъ; также остро оканчивается и болье низкій pr. condyloideus. Совершенно иное строеніе видимъ мы у Pip. pipistrellus Schreb. Здьсь processus coronoideus далеко не такь замьтно поднимается, контурь его закругленный, что надо сказать и о processus condyloideus.

Зубъ. Относительно зубовъ какъ $P$. nathusi Keys. et Blas., такъ п Pip. pipistrellus Schreb. писалось уже довольно много и по- 
тому мнь хотьлось дать здћсь только критическій очеркъ различій ихь у этихь близкихъ формъ. У Pip. nathusii Keys. et Blas. внутренній двувершинный рьзецъ верхней челюсти менье чьмъ вдвое выше одновершиннаго наружнаго, посльдній, въ свою очередь, обыкновенно выше наружной (второіi) вершины внутренняго рьзца. Ілыки сравнительно велики. Внутреннії, двувершинный рызецъ Pipistr. pipistrellus Schreb. вдвое выше наружнаго, который обыкновенно ниже вньшней вершины перваго (внутренняго) рьзца. Посльдній признакъ болышинство авторовъ, какъ Блаз і у сь, Д о б сон ъ и многіе другіе считають наиболье важнымъ. Однако, я долженъ отмьтить, что очень часто у летучей мыши Натузіуса вышина второго (вньшняго) рьзца равняется второй вершинь внутренняго рьзца. Это строеніе встрьчается довольно часто и у малоголовой летучей мыши. Въ. такомь случа' необходимо смотрбть на относительные размьры самихъ рћзцовъ. Клыки сравнительно малы и не такъ остры, какъ у

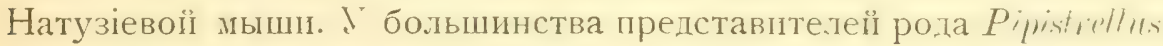
(за исключеніемъ только $P$. Fullii Natt.) первый ложнокоренной зубъ верхней челюсти никогда не бываетъ такъ далеко сдвинутъ въ глубину зубного ряда, какъ у Nyctalus, въ большинствь случаевъ ясно отдьляя второй ложнокоренной оть клыка.

Отъ описаннаго типа строенія зубовь довольно часто встрьчаются значительныя отклоненія. Такъ, напримьръ, В. Г. Дуровы м б быль добытъ 22. VII. 9оI г. въ саду богадьльни Гейеръ въ Москвь, экземпляръ (q), интересный тымъ, что у него ньть вн Бьшняго зубца на внутреннемъ рђзц (верхней челюсти)признакъ, приближающій его къ Pip. Kuhlii Natt. Bct прочія особенности типичнаго $P$. nathusii Keys. et Blas.

А. П. І а ц е ви ч ъ доставилъ изъ Суханова, Подольскаго у. Pip. nuthusii Keys. et Blas. (ㅇ); по вньшнимъ признакамъ этотъ экземпляръ вполнь типиченъ, но въ строеніи зубовъ замычается большое сходство съ малоголової летучей мышью. Такъ, вньшній верхній рђзецъ даже ниже второй вершины внутренняго.

Нёоиыя ск.ади. Кромь указанныхъ отличій, между описываемыми видами существуетъ еще одно. Нменно, характеръ нёбныхъ складокъ этихъ формъ значительно разнится другъ отъ друга. Это различіе сказывается особенно рђзко въ строеніи второй складки спереди. У Pip. nathusï Keys. et Blas. она обычно или прямая, или съ очень незначительной вогнутостью на переднемъ крағ. Совершенно иное видимъ мы у Pip. pipistrellus Schreb. Здьсь эта складка глубоко вогнута спереди, такъ что передъ нами ярко обозначенная двойная дуга. Отмћчу, что это отличіе, 
въ обшемъ очень хорошее, не всегда постоянно. Просматрпвая очень большія серіи Pip. nathusï Keys. et Blas. (около 200 экземпляровь), я могъ отмьтить, что у весьма немногихъ изъ нихъ форма второй нёбной складки приближалась къ типу ея строенія у малоголовой летучей мыши.

Уии и козелоко. По общему строенію и длинь ухо напоминаеть то строеніе, которое было описано для рода Nyctalus.

Однако, оно къ концу болье замьтно сужено, не такь глубоко вдается впередъ по линіи внутренняго контура и отличается очень рьзко по строенію козелка. Посльдній никогда не бываетъ булавовидної формы, обычно довольно коротокъ, округль на конць и вогнутъ по внутреннему краю. Ухо малоголовой летучей мыши отличается отъ Натузіевой довольно ясно дифференпированной двойной вырђзкой по вньшнему краю уха, придающей ея контуру волнистость въ видь трехъ болье или менtе замћтныхъ выступовъ. Далье, козелокъ Pip. pipisticllus Schreb. значительно короче и не такъ замьтно вогнуть по внутреннему краю, какъ у летучей мыши Натузіуса.

Orрacка. Разсматривая серіи старыхъ самцовъ и самокь $P$; pistrellus nathusii Keys. et Blas, я могъ выдьлить два типа окраскп: болье темный и болье свьтлый. Цвътъ мьха первыхъ буроватосьрый сверху, съ легкимъ палевым оттьнкомъ на концахъ волосъ, основанія коихъ, напротивъ, глубокаго бураго тона. Волосы нижней стороны значительно свьтлье и сьрђе, основанія ихъ темно-буры, но концы свђтлаго сьровато-бьлаго цвьта, съ

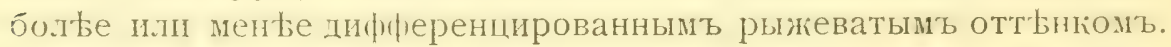
Летательная перепонка, уши и область губъ темнаго сыраго цвыта, съ примбсью рыжаго тона сіенны. Межбедряная перепонка сверху покрыта довольно длинными рыже-сьрыми волосами, с’ь болье темными основаніями.

Экземпляры второго типа окраски рьзго разнятся оть первыхъ. Вся область спины, верхняя часть головы и волосы спинной части межбедряной перепонки довольно свђтлаго палеворжаваго тона, съ болье темными бурыми основаніями волосъ; нижняя сторона сьро-палеваго цвьта, съ замьтными сьро-буроватыми основаніями волосъ. Такимъ образомъ, при первомъ взглядь эти экземпляры отличаются своей болье ржавой, яркой окраской. Летательная перепонка, уши, область губъ-свьтлоржаво-сьраго цвђта, особенно яркаго на спинной части межбедряної перепонки.

Въ окраск' жо.лодыхо самцовъ II самокъ мы встрбчаемъ тоже два рьзко отличныхь тппа: темныхъ и свьтлыхъ особей. Лету- 


\begin{tabular}{|c|c|c|c|c|c|c|c|}
\hline 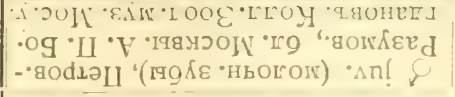 & $\stackrel{9 !}{2}$ & $\infty$ & & $\stackrel{\infty}{n}$ & $\underset{-}{*}$ & $\stackrel{\infty}{\rightarrow}$ & $\stackrel{\infty}{\sim}$ \\
\hline 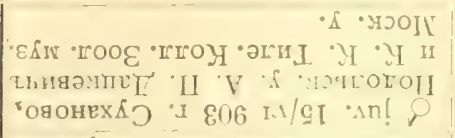 & $=$ & $\stackrel{\vec{\omega}}{=}$ & & $\stackrel{0}{i}$ & $\stackrel{10}{=}$ & $\stackrel{\theta}{-}$ & $=$ \\
\hline 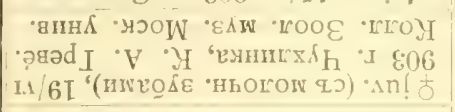 & $\begin{array}{l}\infty \\
\text { oi }\end{array}$ & $\bar{\infty}$ & & $\Omega_{n}$ & $\stackrel{0}{\forall}$ & $\stackrel{10}{\rightarrow}$ & 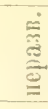 \\
\hline 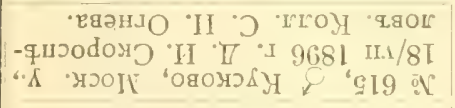 & 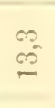 & $\vec{\infty}$ & & $\stackrel{\circ}{1}$ & $\stackrel{0}{*}$ & $\stackrel{\infty}{\sigma}$ & 5 \\
\hline 'p!qI 906 'IL. $/ 81 \cdot P$ & 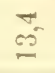 & $\dot{\infty}^{-}$ & & $\infty$ & $\stackrel{m}{-}$ & 10 & $\stackrel{\infty}{=}$ \\
\hline 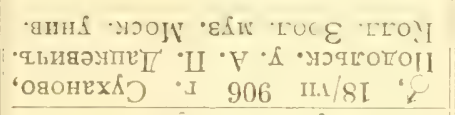 & 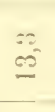 & $\begin{array}{l}\tilde{\sigma}^{\prime} \\
\infty^{\prime}\end{array}$ & & $\stackrel{0}{0}$ & $\underset{\sigma}{\sigma}$ & $\sigma_{-i}$ & 18 \\
\hline 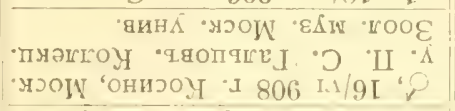 & $\overrightarrow{\vec{g}}$ & $\bar{\infty}$ & & $x_{5}^{x}$ & $\stackrel{\infty}{-\infty}$ & $\Rightarrow$ & 10 \\
\hline 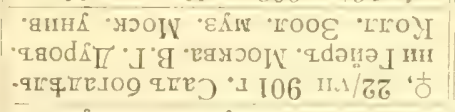 & $\cong$ & $\stackrel{\frac{3}{J}}{\frac{2}{2}}$ & & $\stackrel{\pi}{N}$ & $\stackrel{5}{\infty}$ & $\stackrel{g}{\rightarrow}$ & $\theta$ \\
\hline 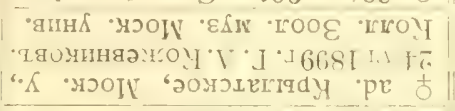 & 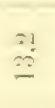 & $\begin{array}{l}x \\
x \\
x\end{array}$ & & $t_{i}^{\infty}$ & $\because$ & $\therefore$ & $=$ \\
\hline 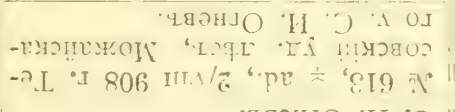 & $\hat{-}$ & $\hat{\prime}$ & & $=$ & $\because$ & LS & $\div$ \\
\hline 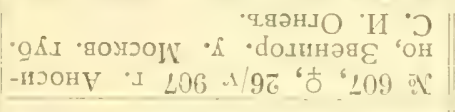 & $\stackrel{12}{9}$ & $\begin{array}{l}\infty \\
\infty\end{array}$ & & $\stackrel{0}{\circ}$ & $=$ & $\stackrel{F}{\sigma}$ & $\stackrel{\infty}{\sigma}$ \\
\hline 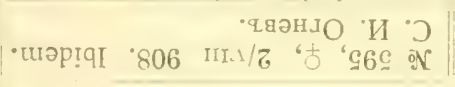 & $\begin{array}{l}\infty \\
\mathscr{D}^{-}\end{array}$ & $\dot{\infty}$ & & $\stackrel{\infty}{L}$ & $\approx$ & $\stackrel{\infty}{\longrightarrow}$ & $\approx$ \\
\hline 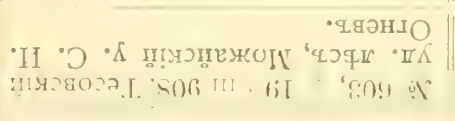 & $\cong$ & $\bar{\infty}$ & & $\stackrel{\infty}{\infty}$ & $\rightarrow$ & $\stackrel{\infty}{\infty}$ & 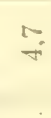 \\
\hline 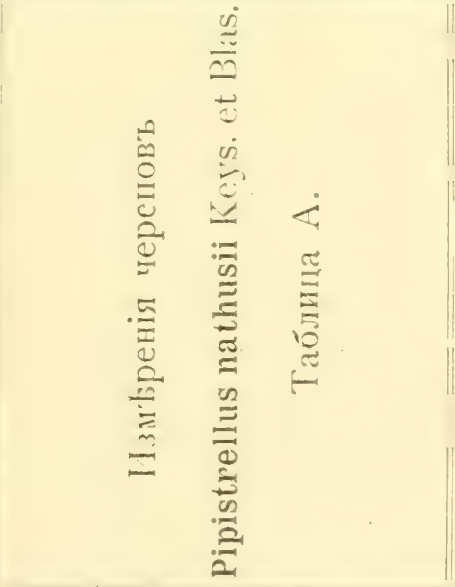 & 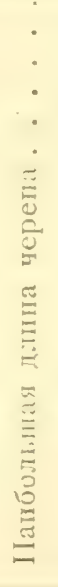 & 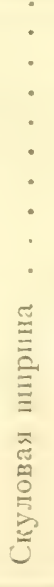 & 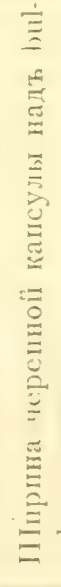 & 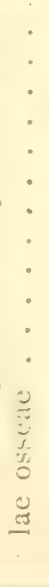 & 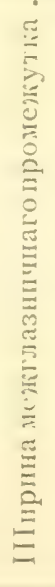 & 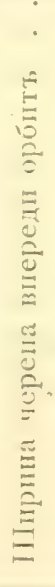 & 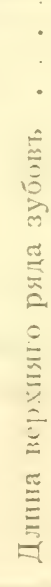 \\
\hline
\end{tabular}




\begin{tabular}{|c|c|c|c|c|c|}
\hline $\begin{array}{l}\text { Пзиьренія череповъ } \\
\text { Pipistrellus pipistrellus Schrch. } \\
\text { Таблица В. }\end{array}$ & 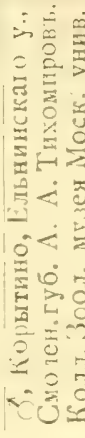 & 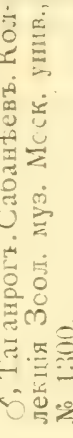 & 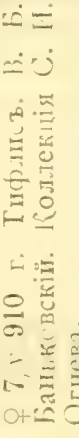 & 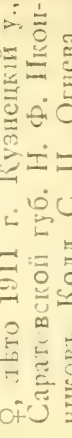 & 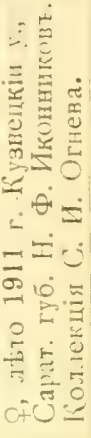 \\
\hline Напоольшая длина черепа . . . . . . & 11,6 & 11,6 & 12,1 & 11.5 & $11, \pi$ \\
\hline Скуловая ппцрина . . . . . . . . . & 7 & def. & 7,9 & $\tau, 4$ & 7,5 \\
\hline 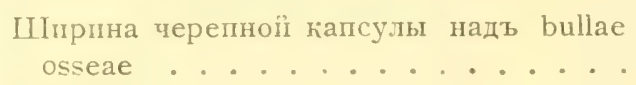 & 7 & 6,5 & 6,9 & $\$ 99$ & 6,8 \\
\hline Ширина межглазничнаго промежутка . . & 3,7 & 3,7 & 3,9 & & 3,5 \\
\hline Ширина черепа впереди орб́итъ . . . . & 4,3 & 4,2 & 4,5 & $f$ & 4,2 \\
\hline Длина верхняго ряда зубоовъ . . . . . . & & 4,6 & 4,7 & & 4, \\
\hline
\end{tabular}

чія мыши первой категоріи очень темны: верхняя часть головы, вся спина и покрытая волосами область межбедряной перепонки отличается довольно темнымъ, сьро-бурымъ тономъ мьха, еще болье темнымъ у основанія волосъ. Мьхъ нижней стороны двуцвътный: волосы у основанія глубокаго сћраго тона, съ легкой буроватої примьсью, тогда какъ концы ихъ болье свђтлаго сьровато-рыжеватаго оттьнка. Вообще этоть типъ окраски молодыхь Pip. nathusii Keys. et Blas. много темные соотвђтствующихъ старыхъ. Летательная перепонка, уши и губы довольно темнаго сьро-бураго цвђта, который значительно свђтльеть, дылаясь ярко-желтоватымъ в'ь области половыхъ органовъ, вдоль нижней части хвоста и бедеръ. На ряду съ такими темными экземплярами молодыхъ, которые, надо сказать, значительно преобладають, встрьчаются очень свьтлыя особн. Такъ, напримьръ, въ Петровско-Разумовскомъ (бл. Москвы) проф. А. П. Богдановы м ъ были добыты 3 молодыхь этого вида замьчательно свьтлой окраски. Голова Іі верхняя часть спины этихъ экземпляровъ отличается очень свьтлыми волосамн, основанія коихъ ржаво-бураго тона, а концы свьтло-желтовато-палевые. Верхняя часть межбедряной перепонки покрыта бьловато-желтым мьхом. Во- 
лосы нижней части тьла сьровато-буры въ своей основной части и свьтло-палево-сьры на концахъ. Уши, губы и болыьшая часть летательной перепонки очень свђтлаго сьро-желтоватаго тона, который переходить въ было-желтый на спинной части межбедрянсй перепонки, въ окружности половыхъ органовъ и по краю кожи, идущей отъ ногъ до пятаго пальца переднихъ конечностей.

Я не буду здъсь останавливаться на подробностяхъ окраски малой летучей мыши отчасти потому, что у меня не было матеріала изъ Московской губ., по которому я дылаль описаніе Pip. mathusii Keys. et Blas. отчасти же въ. виду очень большого вньшняго сходства этихъ формъ и возможности повторенія.

Въ заключеніе я даю таблицы измьреній описываемыхъ летучихъ мышей. Какъ можно видьть, самки этихъ видовъ немного крупнье самцовъ; насколько точно это отличіе-покажеть дальньйшій матеріаль (см. табл. С, $\mathrm{C}^{1}$ и D).

Географическое распространеніе Pip. muthusti. King. His.

Въ Московской губ. этотъ видъ долженъ быть отнесенъ къ очень обыкновеннымь представителямь ея фауны. Въ моихь рукахъ имьется довольно значительный матеріаль изъ Московскаго, Подольскаго, Богородскаго и Можайскаго у.у. Кромь того, эта летучая мышь наблюдалась мною въ Рузскомъ и Клинскомъ убздахъ. Даже въ самомъ городы Москв'ь она не рьдка въ садахъ; такъ, въ коллекціи Зоологическаго Музея Моск. Унив. имьются экземпляры отъ В. Г. Дурова (изъ сада богадьльни Гейеръ). К. А. С а ту ни н ъ и П. П. Мельгун о в ъ нашли этотъ видъ въ значительномъ колпчествь въ Џзмайловскомъ зв ьринць (бл. Москвы). Для окрестностеї Москвы ее указываеть также и проф. Ч е рнай (2о3, стр. 8).

Въ предьлахъ центральной Россіи она найдена мною въ Малоярославецкомь у., Калужской губ,. Гжатскомъ и Сычевскомъ у.у., Смоленской губ. Кромь того, она добыта въ Ельнинскомъ у. А. А. Тихомировымъ, а въ Дорогобужскомъ у.П. С. Гальц вымъ. Въ Тульской губ́. ее нашель Даркшев ІІ ъ, въ юго-восточной части Орловской-С. И. Огневъ и С. Н. Го рбачев ъ ( 2 9, стр. 7). Что касается до литературныхъ данныхъ по распространенію этого вида, то, съ одной стороны, они страдають нькоторой неполностью, съ другой - летучая мышь Натузісса несомнынно часто смьшивалась съ близкой къ ней мелкой формой, и потому не всегда возможно рьшить, къ какой изъ нихъ относятся литературныя свьдьнія. 


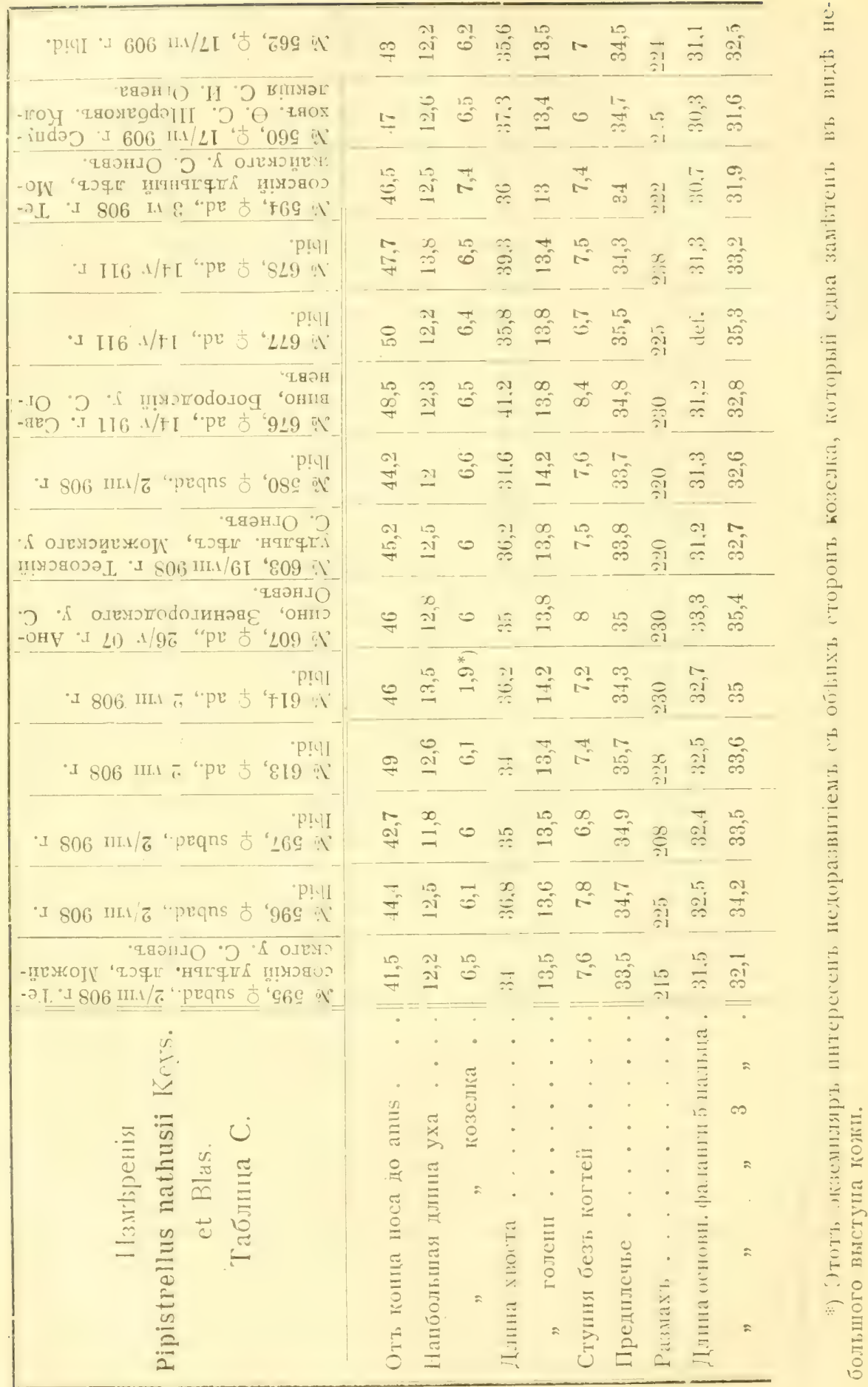




\begin{tabular}{|c|c|c|c|c|c|c|c|c|c|c|c|c|}
\hline 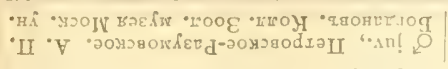 & & 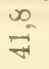 & & $\underline{12}$ & $\begin{array}{l}\infty \\
15\end{array}$ & $\begin{array}{l}0 \\
\infty \\
\text { On }\end{array}$ & $\stackrel{N}{ }$ & $\stackrel{2}{2}$ & $\stackrel{10}{0}$ & $\stackrel{\mathcal{Q}}{\mathscr{2}}$ & $\frac{10}{50}$ & 30 \\
\hline 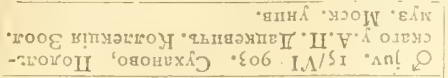 & & $\stackrel{10 .}{8}$ & & $\dot{\theta}_{-1}$ & $i_{\infty}^{\infty}$ & GI & $=$ & 8 & $\begin{array}{l}20 \\
\text { की }\end{array}$ & $\stackrel{10}{\infty}$ & $\frac{\pi}{21}$ & $\therefore$ \\
\hline 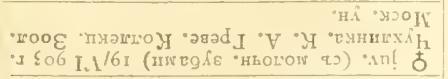 & & $\cos ^{20}$ & & $\varrho^{\infty}$ & 10 & $\overbrace{0}^{\circ}$ & $\sin ^{20}$ & $r$ & 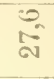 & $\stackrel{8}{\mathscr{E}}$ & 25 & $\overline{a i}$ \\
\hline 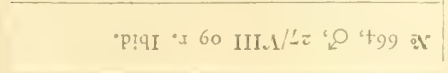 & & $\ddot{\nabla}$ & & $\stackrel{\infty}{=}$ & ज़ & $\stackrel{a}{a j}$ & $\stackrel{0 ?}{\pi}$ & $\infty$ & $\stackrel{5}{\Rightarrow}$ & 家 & $\sum_{n}^{\infty}$ & $\frac{6}{\infty}$ \\
\hline 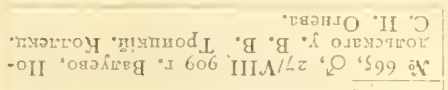 & & 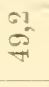 & & $\stackrel{N}{\sim}$ & $\stackrel{0}{0}$ & $\frac{a}{60}$ & $\stackrel{0}{\text { ô }}$ & $\infty$ & 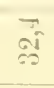 & $\begin{array}{ll}\text { â } \\
\text { aI }\end{array}$ & $\begin{array}{l}\text { ấ } \\
\text { ấ }\end{array}$ & $\underset{a i}{c i}$ \\
\hline 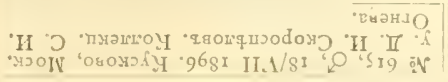 & & ज़ & & $\begin{array}{l}\infty \\
\text { oi } \\
-1\end{array}$ & $\infty$ & $\stackrel{\infty}{\infty}$ & $\stackrel{12}{2}$ & $\begin{array}{l}\infty \\
-\infty\end{array}$ & $\vec{D}$ & $\frac{D}{a}$ & $\frac{61}{60}$ & की \\
\hline 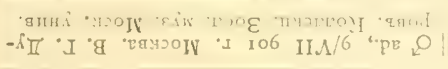 & & $\frac{15}{15}$ & & oi & $=?$ & $\frac{5}{50}$ & $\underline{6 !}$ & $\infty$ & ह5 & की & $\ddot{n}$ & $=$ \\
\hline 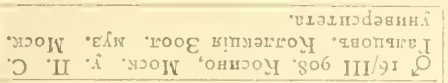 & & $\exists$ & & $=$ & 0 & 18 & 12 & 5 & $5_{0}^{91}$ & $\frac{0}{61}$ & $\ddot{8}$ & $\frac{a_{2}}{s i}$ \\
\hline P!qI I 906 II.I/SI "pe 0 & & $g$ & & 21 & $\infty^{\infty}$ & 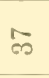 & $\ddot{0}$ & $\infty 0^{2}$ & का & ڤิ & बiं & $\frac{5}{\mathrm{~s}}$ \\
\hline 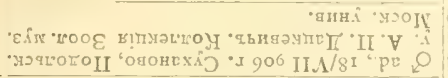 & & $\underset{\sigma}{\infty}$ & & oi & थू & $\omega$ & $\infty$ & $\begin{array}{l}6 \\
\infty\end{array}$ & $\frac{D_{j}}{m}$ & $\stackrel{91}{\mathrm{G}}$ & ตा & $\frac{\infty}{60}$ \\
\hline 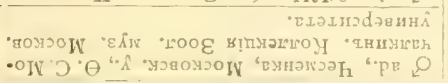 & & $\overrightarrow{e_{4}}$ & & $\stackrel{\infty}{\infty}$ & 10 & $\begin{array}{l}10 \\
\infty \\
\infty\end{array}$ & $\Xi$ & $\infty$ & हి & 象 & $\cong$ & हi \\
\hline 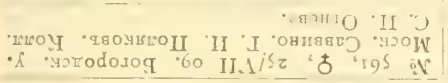 & & 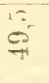 & & ơ & $\stackrel{0}{n}$ & $\stackrel{0}{=}$ & $\Xi$ & $\vec{E}$ & $\begin{array}{l}11 \\
150 \\
\text { is }\end{array}$ & $\frac{\infty}{\mathbb{N}}$ & ले & $\frac{\infty}{\infty}$ \\
\hline T!qI " & & $\begin{array}{l}0 \\
= \\
07\end{array}$ & & $\begin{array}{l}\infty \\
\text { oi }\end{array}$ & $N$ & so & $\begin{array}{l}0 \\
00 \\
-10\end{array}$ & $\begin{array}{l}1 \\
\infty\end{array}$ & is & त) & $\begin{array}{l}0 \\
\text { of } \\
\Leftrightarrow 2\end{array}$ & חల \\
\hline 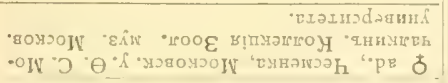 & & 9 & & $\begin{array}{l}\infty \\
05 \\
2\end{array}$ & 20 & 군 & ${ }_{12}^{\infty}$ & +5 & $\vec{m}$ & $\prod_{01}^{\infty}$ & $\frac{0}{\infty}$ & $\pi_{0}^{+0}$ \\
\hline 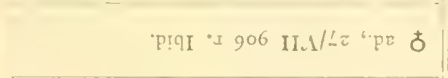 & & $\stackrel{a !}{\square}$ & & $\stackrel{\infty}{\infty}$ & $\infty$ & $\infty$ & $\overrightarrow{\sigma_{0}}$ & 1- & $\vec{m}$ & $\frac{19}{61}$ & $\overrightarrow{6}$ & $\tilde{E}$ \\
\hline 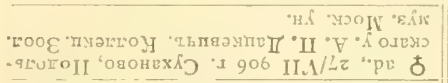 & & $\stackrel{\sigma}{\sigma}$ & & ô & $\omega^{\infty}$ & $\begin{array}{l}\infty \\
\infty \\
\infty\end{array}$ & 20 & $\infty$ & ตै & $\frac{10}{61}$ & ले & ల్ \\
\hline 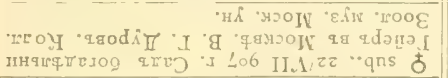 & & जै & & I & 5 & 69 & 120 & t= & $\frac{10}{50}$ & $\dot{j}$ & $\stackrel{11}{c 0}$ & ले \\
\hline 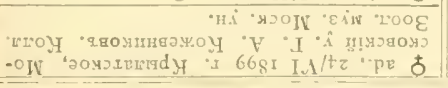 & & $\stackrel{\infty}{\infty}$ & & $\stackrel{2}{2}$ & $\omega$ & $\infty$ & $\underset{1}{ \pm}$ & $\sigma^{\circ}$ & 10 & $\begin{array}{l}0 \\
\text { 이 } \\
\text { an }\end{array}$ & $\frac{1}{5}$ & $\begin{array}{l}0 \\
20\end{array}$ \\
\hline 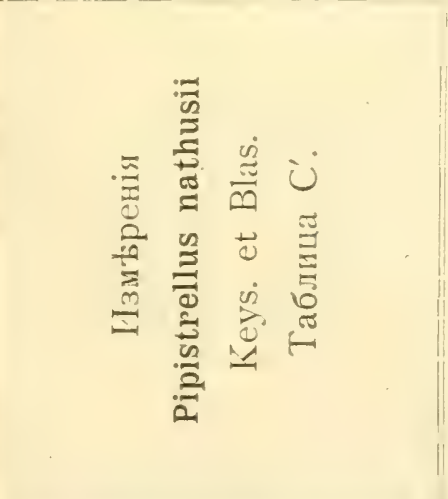 & 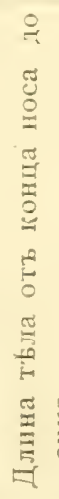 & 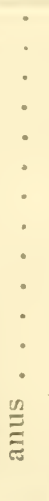 & 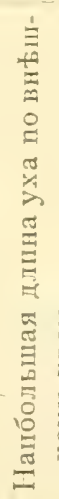 & 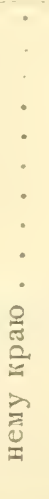 & 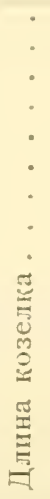 & 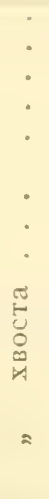 & 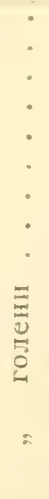 & 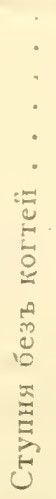 & 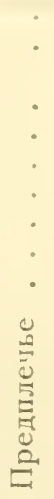 & 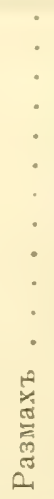 & 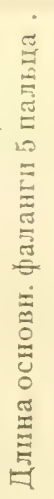 & $\infty$ \\
\hline
\end{tabular}




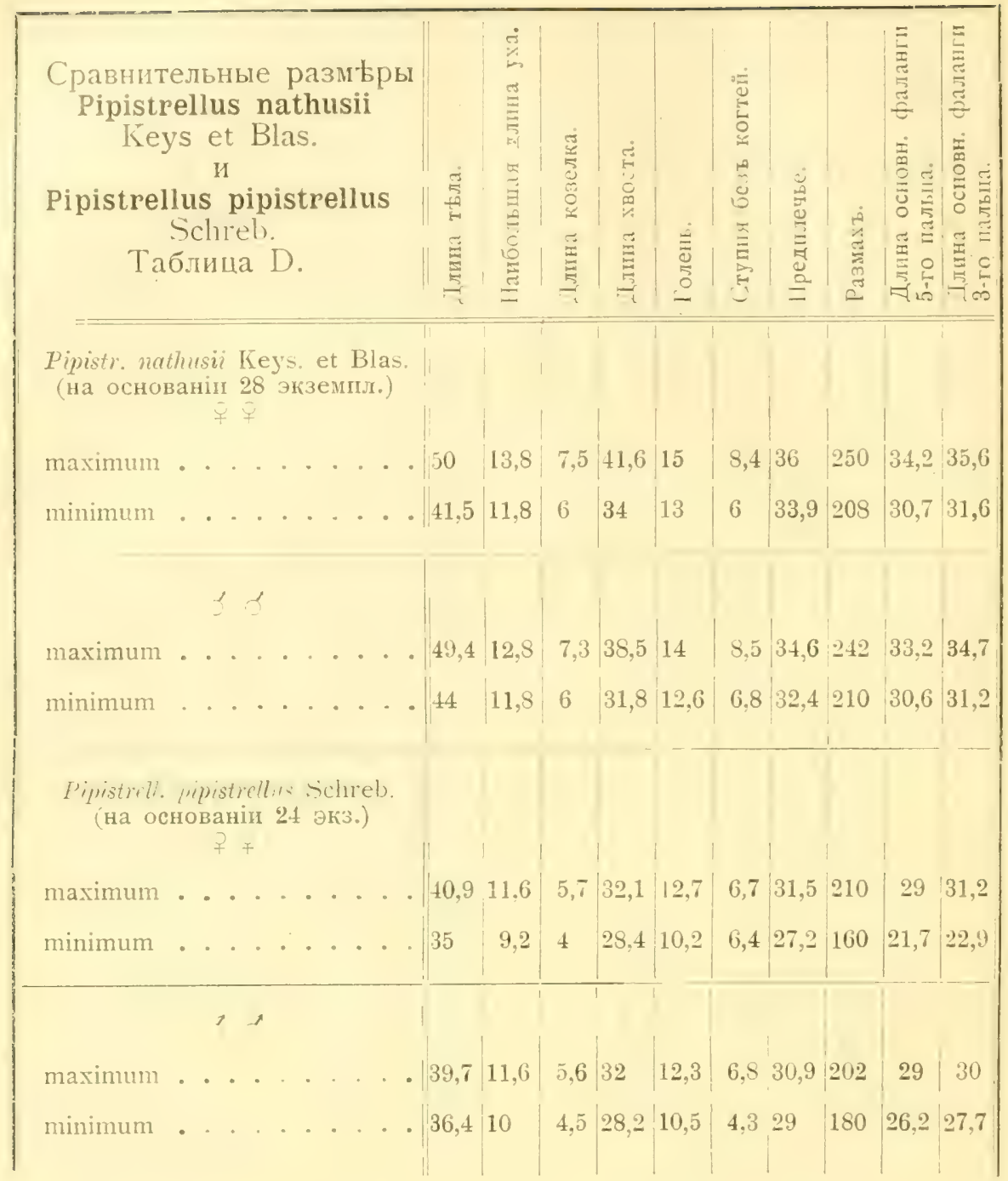

Въ предьлахъ южной части Европейской Россіи эта мышь найдена въ Харьковской губ. Н. Сомовым ъ (I 84 , стр. І5 г), Полтавской Чернаемъ (2 І 3, стр. 8), Кіевской губ. Кесслер о мь (86, стр. 3) и G. Belke въ окр. Радомысла (I 8, p. 49I). Въ Украйнь добыта Блазіусомъ, въ Бендерскомъ у. Бессарабской губ.-А. Браунеромъ (38, стр. 2), въ Саратовской губ. Н. Ф. Нконники о вы мъ, въ Самарской г. Эв е рсманн ом (4 9, р. 497), въ Оренбургской губ..и предгоріяхъ Урала Эверсманномъ и 3 аруднымъ. На Ураль этотъ видъ добытъ Л. П. Сабан вевым ( ( 48, p. 2І5) около Екатеринбурга, 
гдt встрьчается часто, а такяе въ Кушвннскомъ и Павдинскомь Ураль. Объ экземплярь изъ Малмыжскаго у., Вятской губ., упоминаетъ Л. К ру ли ко в скій (93, стр. пг). Далье, Pip. nathusii Keys. et Blas. найденъ въ Волжско-У ральскпхъ степяхь Б рандт о ъ $(34$, р. 33) и К. А. Сатуниным ъ ( 67 , стр. 7), въ Астраханской губ. Чернаемъ, (2 о3, стр. 8), и въ Уфимской губ.М. Д. Р узски м з (см. К а щенко, 8 о, стр. 39). Въ Прибалтійскихъ губерніяхъ отмђченъ для Курляндіи (Grevé, 67, p. 26); въ Эстляндіи (по Wasmuth) встрьчается очень рьдко. Далье на запады обыкновенень во всей Польшы (Taczanowski, I 85 , p. I26).

Внь предьловъ указанныхъ районовъ Pip. nathusii Keуs. et B las. найденъ на Кавказь K. A. С атунины м ъ (R a d d e, Die Samml. Kaukas. Mus. I, Zool., ı899, р. 85), гдь встрьчается также и въ западномъ Закавказьь (см. С атунин ъ, І 57 , стр. 235).

Въ Зап. Европь (по Блаз іу су) встрьчается отъ Реймса до южной части Европ. Россіи и отъ сьверной Германіи до Средиземноморской области. Nilsson отмьчаетъ этотъ вндъ для Швеціи, Тrouessart для Франціи, Doria для Италіи. По Kolenati, онъ распространенъ въ Австріи и Баваріи, Тріесть, Далмаціи и Греціи. По свидьтельству Méhely, встрьчается въ Венгріи. Кромь того, этоть видъ добытъ въ Нндостань, Южной Персіи, (Blanford, 26, р. 22) и Белючистань (Anderson and D e Winton, Mammals of Egypt).

Индо-малайскій Pipistrellus abramus Temm., коего Dobson (47, p. 227). считаль тождественнымъ сь Pip. nathusii Kejs. et Blas. является хорошо отличимої и рђзко дифференцированной формой (Mehely, г о 4, p. 36r).

Въ заключеніе остановлюсь на обзорь географическаго распространенія Pipistrellus pipistrellus Schreb. По словамь К. А. Сатунина, эта.летучая мышь очень обыкновенна вь Москов. губ. Просматрівая большую серію Pipistiellus изъ разныхъ у"ьздовъ Московской губ., я, къ своему удивленію, не нашелъ ни одного Pip. pipistrellus Schreb. Первоначально я думалъ, что это-случайная неудача, но теперь все болье и болье убьждаюсь, что этоть видъ вь предьлахъ среднихь губ́ерній Европейской Россіп всюду значительно рыже близкаго къ нему "nathusï“. Это невольно заставляеть меня очень сомньваться въ точности показанія К. А. Сатунина. Если малая летучая мышь и встрђчается въ изсльдованной мьстности, то во всякомъ случађ гор аздо р ь же $P$. nathusii Keys. et Blas. п должна быть отнесена къ р tдкимъ формамъ. Весьма возможно, что К. А. С а ту нин ъ отно- 
силъ ныкоторыхъ, въ особенности молодыхъ $P$. nathusiz къ болье мелкому виду, тьмъ болье, что смьшать этихъ мышей довольно легко, въ особенности начинающему зоологу, какимъ былъ К. А. С а т ун и ь к, когда писаль свою изв'ьстную работу о московскихъ млекопитающихъ. Что касается до бывшаго въ моихъ рукахъ матеріала по этому виду изъ среднихъ губерній Европейской Россіи, то онъ очень не великъ. Я видьль $P$. pipistiellus Schreb. изъ Ельнинскаго у., Смоленской губ. (А. А. Тихоми ровъ), пзъ Малоархангельскаго у., Орловской губ. (см. Огнев ъ, г28, стр. 28). По словамъ Л. П. С аб ан ьв в а ( 5 o, p. 5 14 ), встрбчается въ Ярославской губ. и, по Двигубскому,一въ Новгородской губ. (см. 42 , стр. 57 II 4 4, стр. 4). Въ южныхъ губерніяхъ Европейской Россіи этоть кожанъ найденъ въ Харьковской губ. Н. Сомовым ъ (І 84 , стр. І5I), въ Кіевской губ. К есслеромъ и B elke, въ Украйнь - Блаз іусомъ, въ Бессарабской губ. - Бр ауне ром ъ, около Каменецъ-Подольска-- В e $1 \mathrm{ke}$, въ Саратовской губ.-Н. Ф. Ико н н и ко в ы м. По словамъ П ал ласа (г зо, р. І23), встрьчается въ Оренбургскомъ крађ, въ Уральскихъ горахъ и на р. Бьлой, а по Двигубскому (42, стр. 57),-въ Казанской губ. и по Уралу. Однако, поздньйшіе изсльдователи этой мьстности - В ерсманн ъ и 3 а ру дны й-P. pipistrellus Schreb. здьсь не нашли.

Въ Крыму малая летучая мышь найдена Пал ласом ъ (г 3 о, p. I23), Нордманномъ ( 25 , р. II), Чернаемъ (2 і 3 , стр. 8) и Кесслером (см. Никольскій, т 22, стр. 37). За посльднее время ее отмьчаеть для Евпаторійскаго у. А. А. Браунер ъ (3 9, стр. 88). Въ Прибалтійскихъ провинціяхъ она найдена въ Курляндіи (Лихт енш те йн о ъ), въ Лифляндіи около Риги и въ Эстляндіи встрьчается также довольно часто (Grevé, 67, p. 27). Далье на западъ очень обыкновенна въ Польш'⺊ ( T a czanowski, I 8 5, p. г26). Найдена въ Галиціи и Буковинь (см. Brandt, 33, p. 3t).

Встрьчается часто на Кавказь, особенно въ Закавказьь, гды очень обыкновенна въ окрестностяхъ Тифлиса; однако, въ равнинної части Ленкоранскаго у. малая летучая мышь, по словамь K. А. Сатунина, уже сравнительно много рьже. Далье, Pip. f'pistrllus schreb. распространена въ южной части Закаспійсккої области, по южному берегу Каспія (Old. Thomas, I 88, p. I97), по всему Ирану, въ Южної Персіи и Белючистань. Уже въ Закаспійскої области типичнаго $P$. pipistrellus Schreb. смьняетъ близкая къ нему форма P.pipistrellus lacteus Temm. (= bactrianus sat.). Этоть болье свьт.лыї подвиды очень широко распространень 
въ Туркестань, гды найденъ въ Ташкенть, Ходженть', Самаркандь (Н. А. С Бв е р цо в м ъ, а въ посльднемь мьсть и D о иglas, O ld. Thom as, I 96, р. 258). Въ коллекціи Зоол. Музея Моск. Унив. пмьется хорошая серія $P$. pipistrellus lactens Temm. изъ гор. Ошъ, Ферганской обл., отъ Н. В. Богоя влен скаго. Вむроятно, къ этому подвиду надо отнести экземпляры, добытые $Э$ версманномъ въ Бухарь, и тьхх $P$. pipistrellus, которыхъ коллектировали Р адде п В альтеръ въ горахь Копетъ-Дага и на ст. Аму-Дарья (I 44, р. тоо4). Проф. Н. Ө. К ащенко (8о, стр. 35) говорить объ экземплярахъ $P$. pipistrellus Schreb. (нав ьрно $=$ lacteus Temm.) изъ восточнаго Туркестана (Яркендъ отъ г. Г ромб ч е в ка го, въ коллекціи Зоол. Музея Имп. Акад. Наукъ и оть проф. В. В. С а п жникова изъ Джаркенда). Еще далье на востокъ этотъ видъ встрьчается въ Гильгить, гды, по словамь Scully (г 76), и Blanford (24, p. 3І4) онъ очень обыкновененъ. Замьчу, что Палласъ (г зо, р. І23) говорить - распространеніи $P$. pipistrellus въ верхнемъ теченіи Енисея, но въ настоящее время я не могу опредьленно сказать, какой подвидъ тамъ можетъ встрђчаться.

\section{Образъ жизни.}

Распространеніе Pipistrellus nathusii Keys. et Blas. тьсно связано съ льсомъ. Тамъ, гдъ имыются старые парки или участки высокоствольнаго льса, можно искать и описываемый видъ. Однако, въ противоположность роду $N^{\top} y c t a l u s$, эти болье мелкіе представители очень охотно, цблыми обществами, скрываются подъ карнизами старыхъ построекь или подъ толстыми балками чердаковъ; лишь болье рыдко можно находить ихъ въ дуплахъ старыхъ деревьевъ. Въ большинствь случаевъ I'p). mith sï Kеуь et Blas. держатся соойествами, состояшим изъ представителей своихъ собратій, но все же я совершенно не могу согласиться съ мньніемъ Коха, утверждающаго, что два близкихъ вида рода Pipistrellus, о которыхъ мы говорили, никогда не держатся совмьстно ${ }^{1}$ ). Такъ, напримьръ, въ Саратовской губ. въ значительной серіи летучихъ мышеї, добытыхь Н. Ф. Иконников ы м ъ, среди г2о Pip. nathusii, найденныхъ подъ крышей стараго сарая, оказались 3 Pip. pipistrellus.

Натузіева летучая мышь появляется весною довольно рано;

1) Karl Koch, „Das Wesentliche der Chiroptera, mit Beschreibung der in Herzogtum Nassau und der angrenzenden Landstheilen vorkommenden Fledermäuse. Jahrbücher des Ver. für Naturkunde im Herg. Nassau, 17, 18 Heft, Wiesbaden, 1862-1863, p. 484. 
отдыльныхъ представителей ея я видьль въ холодные весенніс вечера (7.IV.gII), стоя на тягы вальдшнеповъ. Но въ это время описываемыхъ летучихь мышей видно сравнительно рьдко и въ. одиночку. Только въ концы апрыля или въ первыхъ числахъ мая, смотря по ходу весны, все болье и болье увеличивается количество этихъ летучихъ мышеї.

Онғы вылетаютъ на добычу очень поздно, съ наступленіемъ почти полної темноты. Полетъ ихъ быстрый и ровный; обычно можно видьть, какъ онь правильно облетаютъ домъ или цвьтникъ, иногда нькоторое время кружась на одномъ мьсть. Интересно наблюдать за описываемымъ видомъ, когда онъ съ удивительной точностью, по прямой линіи, летить вдоль старой широкої аллеи и, поворачивая, возвращается по прежнему пути, повторяя этотъ маневръ по многу разъ.

Время вывода молодыхъ приходится на средину іюня. Беременныхъ самокъ я находиль въ началь этого мьсяца (8.VI.09). Количество дытенышеї не превышаетъ двухъ.

Осенью посльднихъ особей этого вида я наблюдалъ въ первыхъ числахъ сентября. В Броятно, недостатокъ добычи, состоящей изъ мелкихь наськомыхъ, заставляеть тогда летучихъ мышей скрываться въ своихъ уббжищахъ.

Экзелилары иоллекиіи. Кромь 32 мышей, перечисленныхъ въ

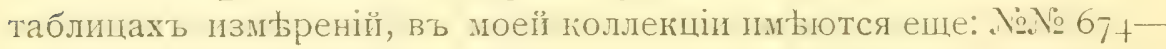
675 (зародыши), 8.VI.o9 г. Валуево, Подольскаго у., отъ В. В. Троицкаго. № 663. VI.og г. „ juv. Ibid. Въ коллекцій Зоологическаго Музея: 2 экз. Петровское - Разумовское (јuv. јuv.) оть A. ПI. Богданов а.

\section{Родъ Vespertilio L.}

1758. Tespertitio, Linna e us (98), p. 31-32. (Основанъ на Vespertilio murinus L. = discolor Natt. (не Vespertilio murimes Schreb., 1775.)

1839. Vesperugo, Key serling und B lasius (89), p. 312 (partim).

1839. Tesperus, K ey se $\mathrm{rl}$ ing und B lasius (89), p. 313 (part.).

1856. Meteorus, K o l e n a ti, Allgemeine Deutsche Naturch. Zeitung, Dresden, II, p. 131, 167-169.

Къ этому роду принадлежатъ летучія мыши среднихъ размьровъ, съ сравнительно большой головой и лоротким широкимь носомъ, съ сильно выступающими по бокамъ лицевыми железами. Jun, обычно замьтно пигментированныя и въ большинств' слу' чаевъ состоящія изъ толстой кожи, будучи прижаты къ головь, обыкновенно не доходятъ до конца носа. Внутренній контуръ ихъ выдается глубоко выпуклою дугой, загибаясь на высоть средины козелка и далеко не доходя до его основанія. Козе- 
локъ коротокъ, достигаетъ своей наибольшей ширины выше середины и едва замьтно суженъ ґъ вершинь, гды онъ оканчивается закругленіемъ. Внутренній контуръ его замњтно вогнутый. Крылья длинны и тонки. Основная фаланга третьяго пальца только немного длиннье пятаго. Јетательная перепонка доходитъ до основанія вньшняго грая ступни. Два посльднихъ хвостовыхъ позвонка не окружены перепонкої. Шпорный лоскутъ (эпиблема) развить слабо. Мьхъ обычно двуцвћтный: темный у основанія волосъ, окончанія коихъ много свьтлье. Зубная формула тагова:

$$
\mathrm{i} \frac{2-2}{6} \text {, c. } \frac{I-I}{I-I}, \mathrm{pm} \cdot \frac{\mathrm{I}-\mathrm{I}}{2-\mathrm{I}}, \text { m. } \frac{3-3}{3-3}=3^{2} \text {. }
$$

На характерныхъ чертахъ строенія черепа я остановлюсь при описаніи вила.

\section{Vespertilio murinus $L$.}

\section{Двуцвьтная летучая мышь или кожанъ.}

Vespertilio murinus, Lin n a us (9 8), p. 31. II é h ely (104), p. 229. T rouess art (20 l) (Supplementum 1904) et (200) 1910, p. 25. Tesperugo discolor Natt. B lasius (27), p. 73. Trouessart (201) (Catalogus 1897), p. 109. Dobson (4 7), p. 204. Vesperus discolor Natt. С а т ун ин т (16 5), p. 4.

Систематическія особенности.

Уерепг (см. табл. I, р. 7. 8, 9, Іо). Характеризуется сравнительно слабо приподнятой и широкой крышей. Затылочная область выше лобной. Носовая часть черепа сверху довольно замьтно вогнута и сиереди ясно выступають дв' впадины по бокамъ челюстныхъ костей. Глазницы широкія, съ довольно тонкими и далеко разставленными скуловыми дугами. Оть черепа Nyctalus по первому взгляду отличается болье уплощенной и опущенной носовой об́ластью. Возрастныя измьненія черепа этого вида очень велики. Я могу прежде всего отмбтить, что передняя часть черепа молодыхъ особей значительно сильные приподнята и напоминаетъ то строеніе, какое мы имњемъ у рода Nyctalus. Далье, носовая оо̆ласть крайне укорочена, скуловыя дуги разставлены далеко не такъ широко, а межглазничная ширина 20раздо больше по отношенію ко всьмъ прочимъ измьреніямъ, чьмъ у старыхъ особей.

Зубь. Характеризуются сльдующими признаками: т) въ верхней челюсти только одинъ ложнокоренной зубъ; 2) высота вньшняго рћзца верхней че.іюсти значптельно нине второй (вньшнеї) вершины внутренняго рьзца. Вь большинств' сл случаевъ второй рьзецъ только слабо замьтно выступаеть на линіи зубного ряда, 


\begin{tabular}{|c|c|c|c|c|c|c|c|c|}
\hline & \multicolumn{5}{|c|}{ Vespertilio murinus L. } & \multicolumn{3}{|c|}{$\begin{array}{c}\text { Vespertilio borealis } \\
\text { Nilss. }\end{array}$} \\
\hline $\begin{array}{c}\text { Сравнительные } \\
\text { промьры череповъ } \\
\text { Vespertilio muri- } \\
\text { nus L. } \\
\text { I } \\
\text { V. borealis Nilss. }\end{array}$ & 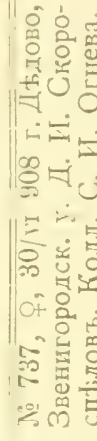 & 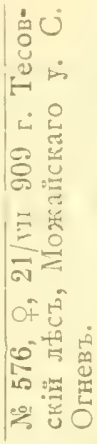 & 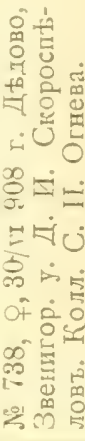 & 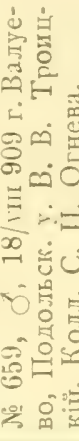 & 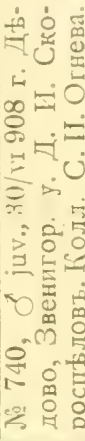 & 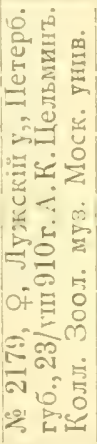 & 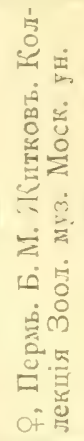 & 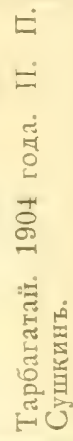 \\
\hline $\begin{array}{l}\text { Напбольшая длина че- } \\
\text { репа ...... }\end{array}$ & 16 & 14,8 & 15,5 & 15,2 & 14,6 & 15 & 15,8 & 15,4 \\
\hline Скуловая ширнна . . . & 11 & 10,3 & 10,8 & 10,6 & 9,4 & 9,8 & def. & 10,7 \\
\hline $\begin{array}{l}\text { Ширпна череп. капсу- } \\
\text { лы надъ bullae osseae. }\end{array}$ & 9,6 & 8,9 & 9,6 & 9,3 & 8,9 & 8,3 & 8,5 & 8,7 \\
\hline $\begin{array}{l}\text { Ширпна межглазнична- } \\
\text { го промежутка . . }\end{array}$ & 4,9 & 4,8 & 5 & 4.7 & 5,3 & 4,6 & 4,6 & 4,9 \\
\hline $\begin{array}{l}\text { Ширина черепа впере- } \\
\text { ди орбитъ . . . }\end{array}$ & 6,5 & 5,7 & 6,4 & 6,3 & 5,8 & 5,8 & 5,9 & 6,5 \\
\hline $\begin{array}{c}\text { Длина верхняго ряда } \\
\text { зуб́овт ...... }\end{array}$ & 6 & 5,2 & 5,6 & 5,7 & 5,3 & 5,3 & 5,7 & 5,8 \\
\hline
\end{tabular}

отличаясь свопми малыми размырами. Р Бзцы нижнеї телюсти чаше лежать по линіи нижнечелюстной кости, хотя параллельное расположеніе ихъ встрьчается далеко нерьдко, что приближаеть этотъ видъ къ Vespertilio borealis Nilss. Однақо, отъ посльдней формы T. mитіми L. легко можеть быть отличенъ, помимо вньшнихъ особенностей, и по строенію черепа и зубовъ. При первомъ взгляды на черепъ Vesp. borealis Nilss. бросается въ глаза большее вздутіе лобныхъ костей, что обусловливаеть замьтно выпуклую форму крыши черепа и болье приподнятый профиль, такъ какъ носовыя пі челюстныя кости не такъ сплющены, какъ у V. muimus L. По форм' зубовъ сьверный видъ отличается оть цвуцвьтнаго кожана гораздо болье длиннымъ вньшнимъ рьзцомь верхней челюсти, который только немного короче второй вершины внутренняго. Замьчу далье, что Méhely говоритъ объ экземплярахъ $V$. Zorealis Nilss, у коихъ нижніе рьзцы 
расположены по линіп челюстної кости. О такихъ экземплярахъ писаль и К. А. С атунинъ, отмбчая ихъ, какъ Vesperts bore. alis var. Проглядывая Vesp. borealis Nilss., я обратилъ особое вниманіе на один экземпяръ пзъ Таро́агатая, переданныї ми для опредьленія проф. П. П. Суш кины ъ. Кромь расположенія нижнихъ рьзцовъ по направленію челюстної кости, у этой мыши можно было обнаружить сравнительно малое развитіе вньшняго рьзца верхней челюсти. Крыша черепа гораздо пенье вздуга, чьмь у $Y$. borealis. По этимь признакамъ онъ приближается къ $V$. mиліиц L., отъ коего, однако, рьзко отличается строеніемъ уха и козелка, которые очень напоминають таковое у типичныхъ $V$. borealis Nilss., но ухо ньсколько длинные и јँе. Окраска тоже отличается отъ типичныхъ borcalis. Верхняя сторона тьла покрыта замьчательно длиннымъ мьхомъ, основанія волосъ котораго темнаго сьро-коричневаго тона, а окончанія свьтлаго палеваго цвьта, съ слабымъ сьроватымъ оттьнкомъ. Волосы нижней стороны тьла темно-съры у основанія, тогда каюъ концы ихъ сереб́ристо-бъ.лы, что прпдаетъ, въ общелъ, всеї нижней сторонь этой летучей мыши очень свьтлую окраску, рьзко отличающуюся оть верха спины. Јетательная перепонка, область губъ и уши темнаго буровато-сьраго цв'та. Нёб́ныя складки какь у I' , Loreulis Nilss. Iтакъ, можно видьть, что окраска нашего экземпяра свьтлье, чьмъ у V. borealis; это особ́енно рьзко сказывается въ ясной двуивитности, которой у borealis, кажется, не наблюдали, и въ очень свьтломъ оттьнкь мьха верхнеї стороны. Къ сожальнію, имьется только одинъ экземпляръ этой интересной мыши, и потому я не считаю возможнымъ давать ей особое названіе, отмьчая здысь только ея особенности.

Нёо̄ıья складки. Форма и расположеніе ихъ у типичныхъ $V$. mиніия: L. довольно изиьнчнвы. Первая складка представ.ляется ини почти прямої, пли со слабої двойної выгнутостью впередъ; вторая складка болье или менье сильно вогнута спереди. Ilaлtе идуть обычно пять дугообразныхь, раздьленныхъ посрединь складокъ. Въ исключительныхъ случаяхъ количество посльднихъ нёбныхъ складокъ достигаеть 6, т.-е. общее число, считая съ двумя передними, равно 8. Подобныя отклоненія наблюдаль М hely. Въ моей коллекціи имьется только одинъ такой экземпляръ, любезно переданный мны проф. П. П. С ушкиным ъ (къ сожальнію, мьсто нахожденія этої мыши въ точности нензвьстно). Tespertilin lorerelis Nilss. ptзко отличается формой второї нёбної складки, которая представ.летъ два замытныхъ углова- 
тыхъ выступа и отъ задняго грая которой идутъ перпендикулярные отростки, остро оканчивающіеся кзади.

Уии и козе.июг. Уши окрашены обычно темно и состоятъ изъ толстой кожи. Передній край уха далеко выдается впередъ и оканчивается глубокимъ загибомъ на половинь высоты короткаго, широкаго козелка. I $V$. borealis передняя часть уха далеко не такъ выпукла, внутренніі загибь его къ козелку идеть гораздо ниже. Само ухо много у́же и. относительно длиннье. Козелокъ не такъ расциренъ кверку.

Oкраска представляеть три рьзкодифференцированныхъ типа. Наиболье распространенъ сльдующій.

I) Cmaрьє салщь и салки. Вся верхняя часть спины, область между глазъ и затылокъ покрыты густыми волосами, съ глубоко черно-бурыми основаніями и очень свьтлыми серебристо-сћрыми вершинами, придающими общему тону иьха яркій серебристый оттьнокъ. Волосы нижней стороны сьры у своихъ основаній, съ б ьлесоватыми вершинами, что создаеть болье свьтлый цвьть брюшной стороны тظлла описываемаго вида. Однако, окраска нижней стороны подвержена очень широкимъ измьненіямъ. Иногда общій тонъ ея палево-серебристый, болье сьрый на нижней части груди и бокахъ и съ выступающимъ палевымь оттынкомь на шеь и подбородкь. Просматривая довольно значительныя серіи этого вида, я пришелъ къ положительному заключенію, что различія эти не имбють характера половой измьнчивости. Цвытъ губъ и ушей обычно очень темно-сьрый. Сверху летательная перепонка по интенсивности своеї окраски прибликается къ тону ушей, но снизу, въ особенности въ боковой области и на брюшной сторонь хвоста, она замьтно свьтльеть, дылаясь быловато-сьрої.

Ко второму типу окраски относятся экземпляры съ болье тусклымь мбхомъ, при чемъ цвьть варіируетъ оть темно-коричневаго съ сьроватыми окончаніями волосъ до почти чернаго. Әти однотонные экземпляры нькоторые изсльдователи считаютъ молодыми особями, но тщательный просмотръ большихъ серій ясно показаль мнь несостоятельность подобнаго рода утвержденій.

Наконецъ, къ посльднему типу окраски принадлежать очень свьтлые экземпляры. Верхняя гасть головы и спина тағихъ особей покрыта ржаво-бурыми волосами съ замьтными палевыми окончанілм. Ннжняя сторона значительно свьтлье: волосы здысь двуцвьтны. Основанія ихъ свьтло-палево-сьрыя, а окончанія бьлесовато-палевыя, особенно свьтлыя въ области горла и груди. Јии, губ́ы и летательная перепонка яркаго цвыта сіннны, который 
переходить въ свћтло-сћровато-желтый на нижней сторонь хвостовой перепонки и по краямъ ея. Такимъ образомъ, при первомъ взглядь на подобную летучую мышь бросается въ глаза ея очень свђтлая, ржавая окраска. Әкземпляры этого типа я пмыль изь Пермской и Нижегородской гуо̆ерній, гды встрбчаются бокъ-о-бокъ съ этщъ п тппичныя формы. Грпнппая во вниманіе посльднее, я скионень думать, что мы имьель здысь передъ собой просто красочное отклоненіе двуцвьтнаго кожана. Мнь кажется далье, что Vespertilio discolor luteus Kastsch. изъ Забайкалья, описанныі проф. Н. Ө. Ка ще н ко первоначально въ его "Оо́зорь млекопитаюицх западной Сибири и Тургестана", г9о5 (стр. го2 d.), а затьиъ въ работь „О млекопитающихъ Забайкалья", тяло (стр. 269), представляеть собою подобное же красочное отклоненіе, которое врядъ ли можно выдьлять въ „subspecies".

2) Oкраска молодьхог салиово и салокіо (см. табл. II, р. 35, 36, $37,38)$, у коихь появилась шерсть какъ на верхней, такъ и на нижней сторонь, такова. Верхняя часть спины и голова покрыты довольно короткими черно-бурыми волосами, съ замғтными серео́ристыми окончаніям. Волосы нижней стороны гораздо свћтлье, основанія ихъ палево-сыры, а концы быловаты. Черезъ сравнительно короткую и рьдкую шерсть нижней стороны подобныхъ экземплюровъ ярко сквозить свьтло-де.лтоватая кожа. Цвьть губъ желто-сьрый, уши черно-буры, кромь самыхъ основаній, окраска которыхь желтовата. Летательная перепонка сверху сьробуроватая, снизу много свътлье, въ особенности въ области боковъ и нижней части хвоста, которые бьловато-желтые. Словомъ, мы видимъ, что уже въ раннемъ возрасть дифференцируется окраска нижней и верхней стороны, и всђ предположенія о болье однообразной и темной окраск' молодыхъ ${ }^{1}$ ) надо считать нев'ьрными.

Въ заключеніе, я остановлюсь на описаніи молодыхъ, еше лишенныхъ волосъ, чтобы закончить ими очеркъ возрастної пзиьнчивости этого вида, цикль которой, кстати сказать, быль совершенно неизвьстенъ. Итакъ, окраска еще голыхъ молодыхъ такова: кожа верхней стороны, включая сюда верхь головы и спи-

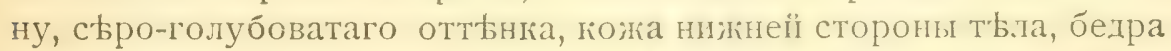
и предплечье (снизу) окрашены въ св ьтло-желтовато-бы.лый цвьтъ. Уши черно-буры, кром' пхъ основаній, которыя б́қ.іовато-сьры. Летательная перепонка сверху свьтло-сьраго тона, которыї на

1) Cм., напр., B lasius (2 7), p. 74 . 


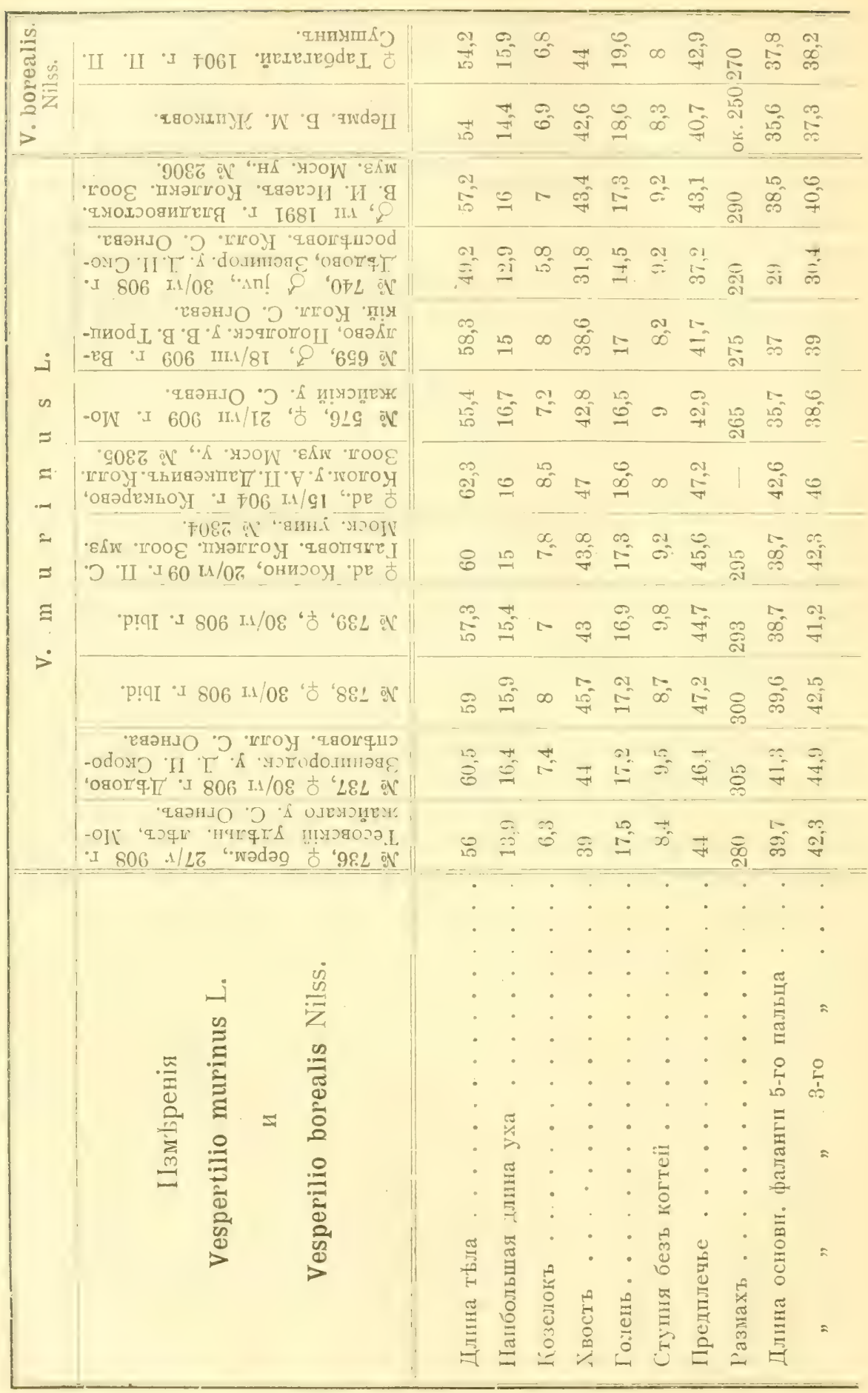


спинної сторонь плечевыхъ костей и заднихъ конечностей переходить въ темно-буро-коричневыї. Вся нижняя поверхность летательной перепонки б́ьлесовато-сьраго пвыта, особенно свьтлаго въ области боковъ тьла и нижней части хвостовой перепонки. Ступня черновато-сьрая сверху и св́t.ло-же.товатая снизу. На основаніи подбородка замьчается крупная сьрая бородавка. Для полноты этого очерка привожу разифры посковскихъ экзелпляровъ $V$. mитіпиs L. и для сравненія одного изъ Владивостока, а также бывшихъ у меня $V$. borealis Nilss. (см. табл. на стр. 56).

\section{Географическое распространеніе.}

Этоть видъ, повидимому, широко распространенъ въ предьлахъ Московской губ., такъ какъ я имью его представителей пзъ Московскаго, Звенигородскаго (д. Дьдово), Можайскаго (с. Тесово), Подольскаго (с. Валуево) и Коломенскаго уу. Одинъ экземпляь быль поймань даже въ самой Mосквь, на чердак стараго зданія Зоологическаго Музея (см. работу Сатунина, I 6 5, стр. 4). Что касается до распространенія описываемой иыши въ Средней Россіи, то она не рбдка въ Тульской губ. (откуда имьются экземпляры въ колл. Зоолог. Муз. Москов. Унив. отъ г. Даркшевича, см. также: С а тунин ь, I 65 , р. 4). Найдена C. Н. Го рбачевымъ въ Орловскомъ у. (in litt.). Н. Н. С oм о в отмњчаеть ее для Харьковской губ. Далье, встрьчается въ Кіевской губ. (К есле р ъ), въ Украйнь (Blasius), близъ Аккермана (А. А. Б р а у н е р ъ, 38, стр. 2). Э в е р с м н н ъ (49, р. 502 и 53, р. 24) находиль эту мышь очень часто въ сьвверной части У ральскаго края п южныхъ предгоріяхъ. Јала, по рыкамъ Сакмар Ику и пр. (см. также: Двигуб скій, 42, стр. 58). Брандт $(33$, p. 36$)$ упоминеть о полученін экземп.яровъ оть проф. Эв е р см анна изъ предгорій Iральскаго хребта, укрьпленія Спасскъ. Л. П. С абан в е в ъ ( 4 8, р. І6о) говорить, что эта мышь встрьчается въ огромномъ количествь какъ въ самомъ Ураль, такъ и въ черноземной полось. Н. А. 3 а р удн ы й $(77$, стр. 363) сообщаеть, что она обыкновенна между Орскомъ и Уральскомъ, встрьчается также въ Верхнеуральскь. По с.іовамь проф). Н. Ө. К а щенко (8 о, стр. 43), ему былъ присланъ одинъ экземпляръ изъ Белебеевскаго у., Уфимской губ., М. Д. Р у з с и и ъ. Далье, эта летучая мышь встрьчается въ Нижегородской п Симбирской губ., гдь найдена Б. М. ЖК и к о в м ъ (экз. въ колл. Зоол. Муз. Моск. Унив.) (см. также Богданов ъ, 3 о, стр. г6о). Нђсколько экземпляровъ этого вида привезены изъ Кузнецкаго у., Саратовской губ., Н. Ф. Иконн и ко вы м ъ, а А. А. С·и лан тьев ъ отмь- 
чаеть ее для окрестностей Падовъ (Саратовской губ.) (см. I 8 I, стр. 305). Въ Пермской губ. ее добыль $\Theta$. А. Т еплоухов ъ (см. А. А. Тихоми ровъ, І 97). Въ моей коллекций имьется экземплярь изъ Елабужскаго у., Вятской губ. По Словцову, двуцвьтнй гожанъ распространенъ въ Кокчетавскомъ у. и найпенъ въ окрестностяхъ Тюмени (см. также: К а щ е н о, 8о, стр. 4I).

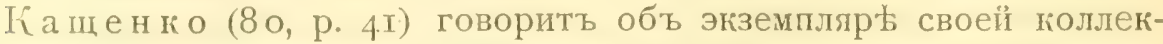
ціи, добытомъ въ устьы р. Иргизъ. К. А. С а т ун и н ъ (г 67, стр. 7) добылъ эту. мышь въ Волжско-Уральской степи. Въ Башкиріи найдена П. С. Наза ро вы м (экз. в’ь колл. Зоол. Муз. Моск. Унив.) и добыта ок. Казанки въ Киргизской степи А. Н. Х а р узины ъ (см. Тихомировъи Корчагинъ, І 99, стр. І2).

Что касается до распространенія этого вида въ Крыму, то для этой мьстности онъ указанъ $К$ ей ерлингом и Блазі сомъ (9о, р. XV), а также Симашко (г 8 I, стр. 3о). А. М. Н и к о л ь с к і й ( 122, стр. 38) говоритъ объ экземпляр ь, добытомъ К есслеромъ около Тотакоя въ І878 году. Наконецъ, А. А. Браунеръ упоминаеть объ одномь экземшлярь изъ Ялты (39, стр. 9I).

Въ Остзейскихъ провинціяхъ $V . m$, повидимому, обыкновененъ въ Курляндіи и, по Wasmuth, не распространенъ въ Эстляндіи, что, в броятно, объясняется случайнымъ недосмотромъ. На Кавказь найденъ К. А. С а туниным в в окр. Тифлиса ( 62 , стр. 5I и I 63 , стр. I7). Что касается до распространенія описываемой мыши въ Сибири, то она является, по словамъ проф. H. Ө. К ашенко (8о, стр. 4I), самой обыкновенной. формой въ предьлахъ Томскаго края. D obson (47, p. 205) говорить о нахожденіи этого вида бл. Барнаула. Кіромь того, $V$. m. найденъ въ Барабинской степи на р. Иртышь ок. г. Семипалатинска (А. С. Х а хлов м ъ). Въ коллекціи Зоол. Муз. Моск. Унив. имьется экземплярь съ западнаго берега Аральскаго моря пзъ урочища Тасъ-булакъ, добытый Л. С. Бе ргомъ (І г/х 902 г.). Восточнье встрьчается между Кашгаромъ и Яркендомь (Blanford) и въ Гильгить (по Scully). ЛI и т ен т ё н ъ при описаніи голлекцій, собранныхъ проф. Эверсман ном в во врея путешествія въ Бухару, говоритъ, что $V \cdot m$. встрьчается часто въ Средней Азіи, къ сожальнію, безъ болье точныхъ данныхъ. По словамъ проф. Н. Ө. К а щ н ко (79, стр. 269), встрьчается въ Нерчинскомъ у., Забайкальской обл. Впрочемъ, эти экземпляры проф. К ашенхо относитъ кь новой географической формы Tesperlilio discolor lacteus. Въ систематической части нашего очерка были уже приведены основанія моихъ сомныній относительно са- 
мостоятельности этого subspecies. По свидьтельству D obson (47, р. 205. и 45, р. 1о7), встрьчается въ Гималаяхъ. Thomas нашель эту мышь въ Манчжуріи (г 87, р. 500). Въ коллекціи Зоол. Муз. Моск. Унив. имьется экземплярь изъ Владивостока (оть д-ра В.И.Исаева), который я отношу къ типичной формь (см. табл. измьренії).

\section{Оорразь жизни.}

Мои свьдьнія относительно образа жизни этого интереснаго вида, къ сожальнію, еще очень не полны. Всь находки показывають, что двуцвьтный кожанъ особенно охотно прячется днемъ на чердакахъ старыхъ домовъ, подъ карнизами крышъ. Въ дуплахъ деревьевъ мны не случалось его находить; если это наблюденіе подтвердится, то здьсь можно видьть общую черту съ родомъ Pipistrellus. Я не рышаюсь вполнь опредьленно высказываться относительно времени вылета $V$. muinus L. на добычу, но многое говоритъ за то, что этотъ видъ показывается только съ настуиленіем темноты, значительно позднье представптелей рода Nyctalus. Такъ, мнь ни разу не приходилось стрблять двуцвьтныхъ кожановъ, когда было еше свьтло, и мои наблюденія надъ этой мышью въ неволь говорять за то же. Полеть описываемаго вида нысколько напоминаеть Nyctalus leisleri Kuhl, но менье изященъ и быстръ. Мнь приходилось видьть, какъ. . minus L. съ большою быстротой, часто по прямой линіи, несется высоко въ воздухь надъ рыкою и лугомъ, мелькая на фонь потухающаго заката. Время беременности и вывода молодыхъ приходится на май и іюнь. Такъ, беременныхъ самокъ я находилъ въ конць мая (25/•• 908 г.), а очень интересная серія молодыхъ, частью голыхъ и сльпыхъ, частью уже покрытыхь шерстью, была любезно передана мнь, Д. И. С к о р о с п ь л о в ы м ъ, добывиимъ ихъ 3о/v 908 г. въ Звенигородскомъ у. Количество зародышей не превышаетъ двухъ.

25 мая I9о8 г. мной былъ пойманъ старый экземпляръ (q) въ Тесовскомъ льсу, Можайскаго у. Кожанъ забрался подъ карнизъ окна и устроился около гнызда горихвостки (Ruticilla phoenicurus L.). Птички пытались, повидимому, всячески прогнать непрошеннаго гостя, но онъ издавалъ только злобное шипьніе и цыканье, не думая уползать. Когда эту летучую мышь удалось поймать, я посадиль ее въ большую стеклянную банку и пробоваль кормить-наськомыми и маленькими кусками сырого мяса, но она рьшительно ничего не желала ьсть и лишь злобно цыкала, если еї что-нибудь предлагали. Передъ вечеромъ, когда уже начинало совсьмь темньть, она выражала бөльшое безпо- 
койство: ползала по куску коры, положенному въ цилиндрь, и чистилась, принимаясь лизать низъ своихъ крыльевъ и мьхъ на брюхь. Черезъ нысколько дней нашъ экземплярь погибъ, вьроятно, всльдствіе упорнаго отказа что-нибудь ьсть.

Oиземляры коллекиіи. Кромь переqисленныхъ въ таблиць из-

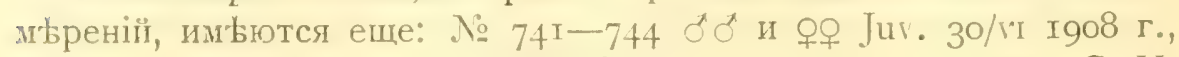
Дьдово, Звенигород. у. Д. Н. Скоросп вловъ, колл. С. И. Огнева.

\section{Родъ Myotis Kaup.}

1829. Iryotis Ir a u p, Skizzirte Entwiklungsgeschichte und Natürliche System der Europáischen Thierwelt, 1 Teil, p. 106. Основанъ на Vespertilio murinus Shreb. (не $V$. mirimus L!).

1830. Leuconoë Boie, „Isis“ (Jena), p. 256-7 (основанъ на Leuc. duubentonii).

1839. Vespertilio Keyserling und Blasius (89), p. 307 (не Vespertilio L. 1758).

1856. Brachyotus. (subgenus). Kolenati, Allgemeine deutsche Naturhist. Zeitung (Dresden), II, p. 131, 174-177, (основано на mystacinus, daubentonii in dasycnemus).

1856. Isotus (subgenus) Kolenati, l. c. II, p. 131, 177 (основано на nattereri in ciliatus).

1856. Iryotus Kolenati, 1. c. II, p. 131, 179-181 (основано на bechsteini II murinus).

Къ этому роду относятся летучія мыши отъ мелкихь до крупныхь размьровъ, характеризуюшіяся цћлымъ рядомъ признаковъ. Носовая область сравнительно очень узкая и удлиненная; уши достигаютъ длины головы, или еще длиннье. Форма ихъ болье вытянутая, чьмъ у предыдушихъ родовъ, внутренній край не выдается впередъ выпуклою дугою, но болье прямо срьзанъ и доходить до основанія козелка. Поспьдній очень длиненъ, рьзко суженъ къ концу, отклоненъ вершиною въ вньшнему краю, или же прямъ (лишь въ сравнительно рьдкихъ случаяхъ слабо наклоненъ внутрь: Myotis (Lenconoe) dasycneme Boie.). Внутренній контуръ козелка въ большей или меньшей степени выпуклый. Крылья сравнительно много шире, чьмъ у предыдущихъ родовъ. Основная фаланга третьяго пальца почти равна таковой пятаго. Посльдній (зачаточный) и часть предшествующаго ему хвостового позвонка выступаютъ наружу, не будучи окружены хвостової перепонкой. Эпио́лема не развита. Зуб́ная 中ормула, характеризуюшаяся присутствіемь трехь ложно-коренныхъ зубовь, такова:

$$
\mathrm{i} \frac{2-2}{6} \text { c. } \frac{\mathrm{I}-\mathrm{I}}{\mathrm{I}-\mathrm{I}} \mathrm{pm} \cdot \frac{3-3}{3-3} \mathrm{~m} \cdot \frac{3-3}{3-3}=3^{8}
$$


Этоть родъ можеть быть раздылень на двь группы, жоторыя по ихъ таксономическому значенію носять характеръ подродовыхъ:

A. Подродъ Myotis. Ступня короткая; крыловая перепонка доходитъ до основанія пальца; межбедренная перепонка образуетъ сзади у конца хвоста тупой уголъ.

B. П о дрод ъ Leисопое. Ступня длинная; крыловая перепонка доходитъ до основанія стун ни; межбедренная перепонка образуетъ сзади у конца хвоста острый уголъ.

\section{A. Подродъ Myotis. \\ 6. Myotis mystacinus (Kuhl). \\ Усатая ночница.}

T'espertilio mysiacinus K u h l, Deutsche Fledermäuse, Ann, der TVetterauischen Gesellsch. für die Naturkunde, 1819, p. 202. Vespertilio Brandtii Eversm an n (49), 505. Iyotis mystacinus Leisl. B a r e t-H a milt on (16), p. 158. Milla is $(110)$, p. 99. Trouessart, Supplementum, 1904, p.91. Trouessart ( 200 ), p. 33. Vespertitio mystacimus Leisl. B lasius (27), p. 96. K. A. C a tyнин ъ (165), стр. 4 пा, „дополненія къъ спискамъ жнвотныхъ Московской губерніп" Дневн. Зоологическаго Отд. Общества Любптелеї Естеств. т. II, 1894 , стр. 2.

\section{Систематическія особенности.}

Черелг отличается иьлымъ рядомъ признаковъ, свойственныхъ одновременно и всему роду Myotis. Прежде всего я могу отмьтить значительную вогнутость носовой обасти, типичной чертой строенія которої яв.яется ея дуговпдная приподнятость и п е p e $\lambda$ и, особенно замьтная въ профиль. Эта вогнутость носовыхъ костей выражена гораздо сильнье, чьмъ въ черепахъ Pipistrellus и Tespertilio, не говоря уже о Nyctalus, у коихь, какъ это указывалось, вся носовая область значительно прпподнята. Поналуй, canoil характерної чертої строенія послtzнеî y Myotis яв.ияется также ея суженность съ боковъ. У всьхь описанныхъ мною родовъ, всльдъ за межглазничным перехватомъ, идетъ замьтное расширеніе, ясно подчеркивающее собою ръзкое суженіе межглазничної части черепа. Разсматривая черепъ Nyotis mystacims Kuhl, мы видимь иное. Здысь можно ясно замьтить, смотря на черепъ сверху, какъ онъ постепенно становится все у́же и пріобрьтаеть наиболье сжатое съ боковь строеніе на своемь переднемъ конць, въ области praemaxillae и nasalia, которыя заканчиваются довольно острымъ угломъ, а не тупо и плоско срьзаны, какъ у предыдуцихт родовь. Далье, область затылка за- 
мытно выше лобной и, наконецъ, что особенно характерно, глазницы гораздо болье сужены кпереди, всльдствіе менье широкой разстановки скуловыхъ дугъ ${ }^{1}$ ) (см. табл. измьреній).

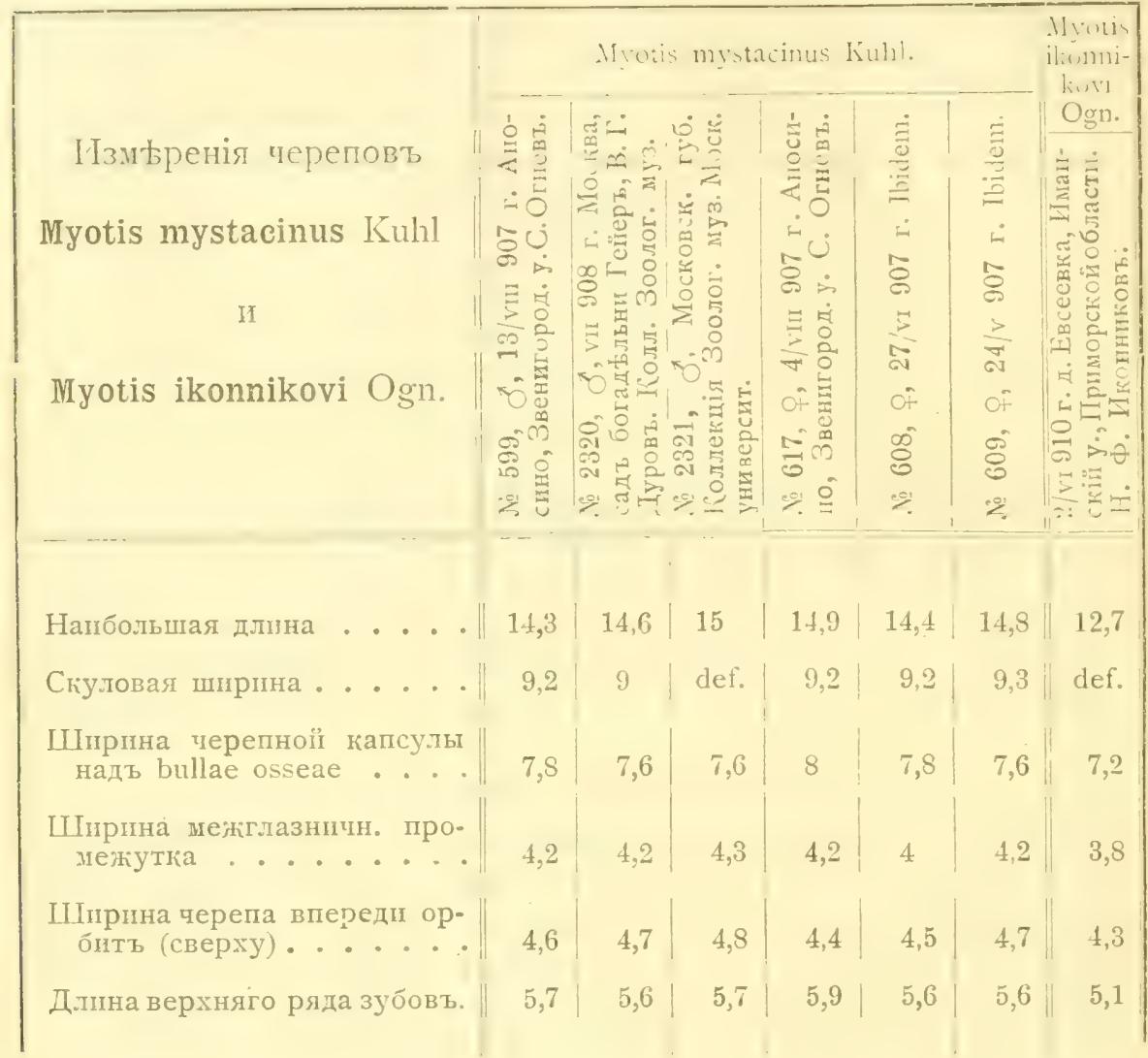

Зубы. Блазіусъ (27, р. 96) очень точно описываеть ихъ конфигурацію, а потому ограничсь пишь ныкоторыми дополненіями къ его описанію. По словамъ этого автора, нижніе рьзцы расположены по линіи челюстной пости. Дьйствительно, въ большинствђ случаевъ это совершенно в ьрно, но попадаются экземпляры, у коихъ замытно болье или менђе рызко выраженное параллельное по отношенію другъ къ другу расположеніе этихъ зубовъ. Барреть-Гамильтонъ въ своеї „History of British Mam-

1) Черепъ близкаго къ $M$. mystacinus Kuhl уссуріïcкаго $I$. ikonnikov Ogn. отличается, помимо свопхъ общихъ меньшихъ размђровъ, болье короткими nasalia In болье круто поднимающимися лобными костями, которыя въ

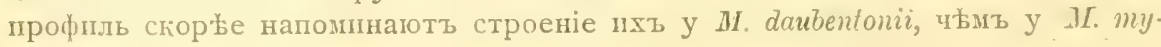
stucintu. 
mals", part III, 9ıо, р. гє3, даетъ рисунокь такого расположенія pьзцовъ. Далье,Блазі усъ говоритъ, что третій (крайній) płзецъ нижней челюсти оваленъ въ поперечноль сьченіи, въ вертикальнол направленіи немного длинные діаметра своей пирины

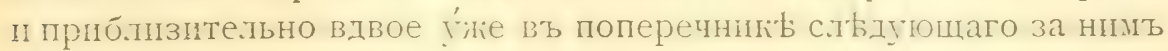
клыка. Посльдній признакъ не вполнь подходить къ моимъ экзелплярамъ, у коихъ описываемый рђзецъ въ поперечникь шире половины клыка. Наконецъ, второй коренной нижней челюсти только немного ниже и ньсколько тоньше перваго. Это служитъ хорошимь отличіемъ даннаго вида отъ Lenc. daubentonii Kuhl, о чемъ я буду говорить при описаніи посльдней формы.

Уии и козе.люг. По отношенію къ общимь размьрамъ тьла этого вида уши сравнительно длинны и, будучи прижаты къ голов или заходятъ за него. Вырьзка на внышней сторонь уха очень рьзка. Козелокъ немного длиннье половины уха и къ конщу весьма сильно суженъ.

Нёбия складки. Всьхъ складокъ 7, изъ которыхъ первая цћльная и выдается впередъ слабо выпуклою дугою. Вторая въ подав.ляюшещъ о́ольшнствł с.лучаевъ съ сравните.тьно с.ıабымъ вдавленіемъ въ центрь и спереди. Далье идутт четыре раздыленныхъ складки въ виды полудугъ, а посльдняя имьетъ видъ тупого угла, своей верщиної обращеннаго къ затылочной части черепа. Нёбныя складки восточнаго вида Myotis iliomikovi Ogn. отличаются формою второї спереди. У этого вида она глубоко вдавлена и имьетъ видъ двоїной, но нераздьленной дуги. Просматривая очень богатый матеріаль по MIyotis mystacims Kuhl (ок. 40 экземпляровъ), я только въ одномъ случаь могъ констатировать строеніе складокъ, напоминающее таковое у M. itiomiliovi Ogn.

Orраска подвержена довольно сильнымъ варіаціямъ, которыя могутъ быть сведены къ тремъ типамъ. Къ первому я отношу очень темныхъ усатыхъ ночницъ. Общій тонъ этихъ особей интенсивно бураго цвьта, особенно у основанія волосъ, понцы которыхъ нелного болье св ьтлаго сьро-бураго оттынкі. Oкраска волось нижней стороны темно-сьрая, у основанія съ ньсколько болье свђтлыми сьрыми, слегка рыжеватыми окончаніян. Окраска ушей, козелка и летательной перепонки необыкновенно темна, цвьтъ этихъ частей интенсивно черно-сырыі̆, только низъ межбедряной перепонки окрашенъ въ болье свьтлый сьрый цвьтъ, который особенно ярокъ у основанія и вдоль нижней части хвоста. Въ литератур' мны удалось найти указанія на 
тапую темную окраску Myots mystacimıs Kuhl. Экземпляры, по-

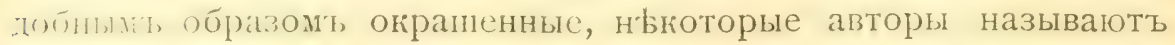
„2ur. migricans" $\left.{ }^{1}\right)$. Кох ъ и Фатіо ${ }^{2}$ ) говорятъ, что эта темно

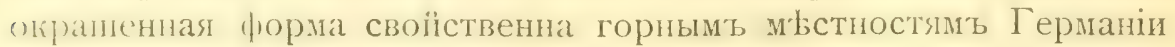
и IUвейцаріи. Однако, Б а р р е т ъ- Г а м и ль т о н ъ ( с 6, III, р. І63) находилъ ее по всей Великобританіи. Ко второму типу окраски я отношу такъ называемыхъ M. mystacims rufo-fuscum Koch, общіiі тонъ спины которыхъ значительно свьтлье. Здысь основанія волосъ также довольно интенсивно сьро-бураго цвьта съ сравнителыно очень сььтлыми палево-рыжими концами. Нижняя сторона окрашена много свђтлье: основанія волосъ ея сьры, а концы палево-бъловаты, съ болье или менье выраженнымъ сьрымъ оттьнкомъ. Уши и летательная перепонка тона сіенны, особенно свьтлаго на нижней части хвостовой области и значительно болье темнаго сверху. Наконецъ, къ третьему типу относятся очень свьтлыя особи „var. aureum Koch.“, которыя бросаются въ глаза палевымъ оттьнкомъ мьха верхней стороны и былесовато-желтымь нижней части тьла. Летательная перепониа болье или менье свьтлаго палево-бьловатаго цвыта, особенно яркаго въ хвостовой области.

Къ сожальнію, тотъ матеріалъ, который быль мною использовань, не даеть мнь надежнаго основанія для тощнаго разграниченія возрастної измьниивости отъ индивидуальныхъ особенностеї. Мнь думается, однако, что я не ошибусь, указавъ здысь на |лактъ обычно болье темної окраски молодыхъ. Дьйствительно, мнь не удалось пока видыть ни одного очень молодого экземпляра окраски типа "var. aитеиm" или даже „vиfo-fuscum"一всь пзученные мною молодые $\boldsymbol{M}$. mystacims Kuhl были очень темны. Первое время мнь казалось даже, что это общее правило возрастной измьнчивости, но болье тщательное коллектированіе заставило признать существованіе очень темно окрашенныхъ старыхъ индивидуумовъ.

Въ заключеніе остановлюсь на обзорь общихъ размћровъ нашихъ экземпляровъ (см. таблищу). Проф. Н. Ө. К ащен ко (8о, стр. 25), говорить, что, быть монеть, сиоирскіе экземпляры M. mystacinus Kuhl. надо выдьлить въ особый subspecies, характерной особенностью котораго являются ньсколько большіе общіе размыры, а также и тоть факть, что второй членикъ

1) Carl Koch, Jahrbücher des Vereins für Naturkunde im Herzogthum Nassau, 1862, X VIII, p. 440-448.

2) Victor F a tio, Vertébrés de la Suisse, 1869, I, p. 92. 


\begin{tabular}{|c|c|c|c|c|c|c|c|c|c|c|c|c|}
\hline 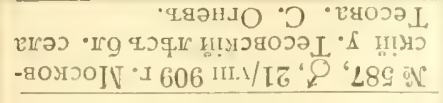 & 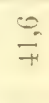 & & $\stackrel{y}{\sigma}$ & $\because$ & $e_{0}^{m}$ & $\infty_{\infty}^{-}$ & 23 & สิ & : & $\frac{\infty}{\infty}$ & $\stackrel{+}{=}$ & \\
\hline 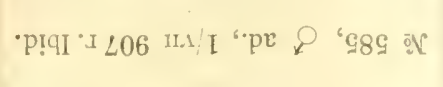 & $\stackrel{-1}{\div}$ & $\exists$ & $\stackrel{\infty}{\infty}$ & $\ddot{\omega}$ & $\begin{array}{l}\infty \\
0 \\
=\end{array}$ & $\infty$ & 12 & ผి & $\frac{n}{c}$ & कै & $\stackrel{109}{\Rightarrow}$ & 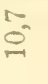 \\
\hline 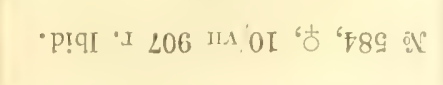 & $\begin{array}{ll}1.2 \\
\operatorname{lin}_{7}\end{array}$ & $\stackrel{\mathscr{m}^{\prime}}{\Xi}$ & $\stackrel{g}{L}$ & $\begin{array}{l}\infty \\
\infty^{-}\end{array}$ & 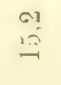 & in & $\begin{array}{l}\text { ब1 } \\
\text { की }\end{array}$ & कి & $\stackrel{=}{\therefore}$ & ले & 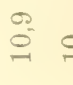 & $\stackrel{ }{\circ}$ \\
\hline 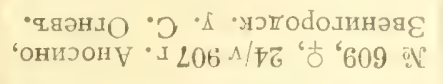 & 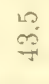 & $\stackrel{\infty}{\ddagger}$ & $\stackrel{\circ}{N}$ & $\stackrel{\infty}{\infty}$ & 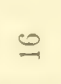 & $\stackrel{\infty}{\infty}$ & 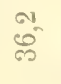 & ลี & $\overbrace{\substack{n \\
i}}$ & $\begin{array}{l}\text { is } \\
\text { in } \\
\text { is }\end{array}$ & $\stackrel{\cong}{\Rightarrow}$ & 里 \\
\hline 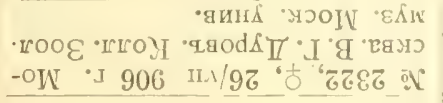 & $\stackrel{9}{9}$ & 20 & 10 & $\begin{array}{ll}e j \\
x \\
c\end{array}$ & $1=$ & ${ }_{\infty}^{20}$ & 20 & ลี่ & $a a^{a}$ & $\stackrel{\mathrm{c}}{\mathrm{c}}$ & $\stackrel{9 !}{=} 9$ & ڤn- \\
\hline 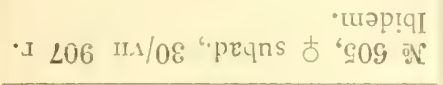 & $\equiv$ & $\stackrel{10}{0}$ & 10 & $\cong$ & $\stackrel{P}{=}$ & is & 5 & ลี & $\bar{m}$ & $\begin{array}{l}\infty \\
\text { aे } \\
\text { के }\end{array}$ & $\stackrel{\infty}{9}$ & की \\
\hline 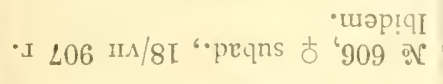 & F & $\exists$ & $\stackrel{\leftrightarrow}{\sim}$ & the & $\stackrel{2}{20}$ & - & 饮 & $\frac{0}{\mathrm{GI}}$ & \begin{tabular}{l}
01 \\
0 \\
\hdashline
\end{tabular} & $\stackrel{\leftrightarrow}{m}$ & $\stackrel{\infty}{0}$ & $\infty$ \\
\hline 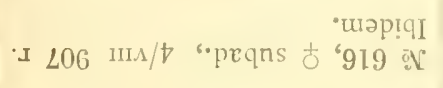 & $\exists$ & $\overbrace{0}^{\infty}$ & $\ddot{\sigma}$ & $\begin{array}{l}\infty \\
10 \\
\infty\end{array}$ & $\stackrel{\leftrightarrow}{0}$ & $\stackrel{5}{5}$ & $\overbrace{}^{20}$ & ลิ & $\ddot{\vec{v}}$ & फ्ञ & $\mathscr{\sigma}^{\infty}$ & 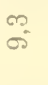 \\
\hline 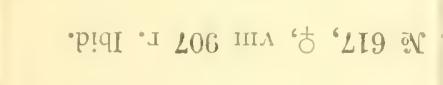 & $\stackrel{9}{7}$ & $\stackrel{\infty}{\infty}$ & $i 0$ & $\overrightarrow{\sigma o}$ & $\vec{E}$ & $\infty^{\infty}$ & $\frac{\pi}{\infty}$ & 옥 & $\frac{1}{11}$ & बेi & $\Rightarrow$ & $\stackrel{\sigma-1}{2}$ \\
\hline 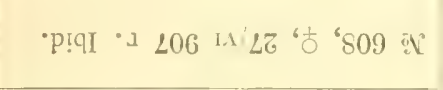 & $\stackrel{P}{ \pm}$ & $\underset{\Xi}{g}$ & $\stackrel{5}{5}$ & $\begin{array}{l}150 \\
50\end{array}$ & 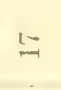 & $\vec{\infty}$ & 焗 & $\underset{\infty}{\infty}$ & $\frac{\sigma}{m}$ & मे & $\begin{array}{l}0 \\
0 \\
0\end{array}$ & $\begin{array}{l}\mathscr{y} \\
0\end{array}$ \\
\hline 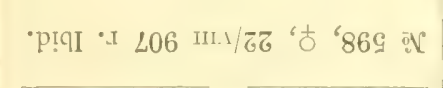 & $\stackrel{1}{\oplus}$ & $\stackrel{\ddot{\Xi}}{ٍ}$ & $\underset{\infty}{\infty}$ & $\begin{array}{l}\infty \\
\infty \\
\infty\end{array}$ & $\underset{10}{10}$ & $\stackrel{\infty}{\infty}$ & m & ลี & $\begin{array}{l}\mathscr{2} \\
\stackrel{8}{8}\end{array}$ & ๓ & $\stackrel{a}{\Rightarrow} 0$ & $\infty$ \\
\hline 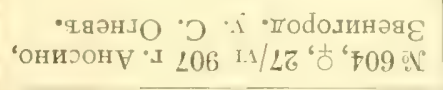 & $\stackrel{\overrightarrow{0}}{\overrightarrow{10}}$ & $\stackrel{0}{=}$ & $\stackrel{\infty}{\infty}$ & $\begin{array}{l}\infty \\
10^{\circ} \\
60\end{array}$ & $\stackrel{\infty}{\infty}$ & $\infty_{\infty}^{\infty}$ & ले & สิ & $\overrightarrow{0}$ & $\overrightarrow{60}$ & $\stackrel{10}{0}$ & $\begin{array}{l}\infty \\
\infty\end{array}$ \\
\hline 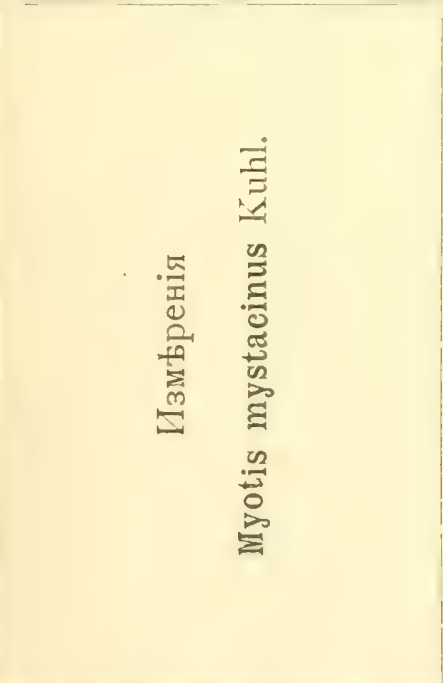 & 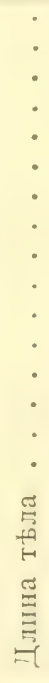 & 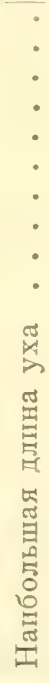 & $\begin{array}{l} \\
\vdots \\
\vdots \\
\vdots \\
\vdots \\
\vdots \\
\vdots \\
\vdots \\
\vdots \\
\vdots \\
0 \\
0 \\
0 \\
0 \\
0 \\
0 \\
0 \\
\end{array}$ & 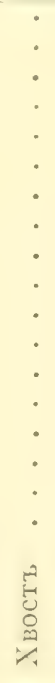 & 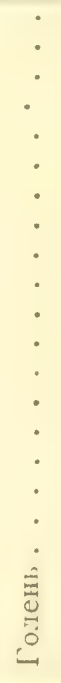 & 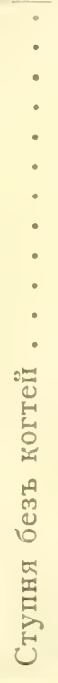 & 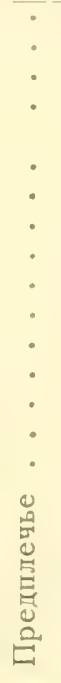 & $\begin{array}{l}\vdots \\
\vdots \\
\vdots \\
\vdots \\
\vdots \\
\vdots \\
\vdots \\
\vdots \\
\vdots \\
\vdots \\
0 \\
0 \\
0 \\
0 \\
0\end{array}$ & 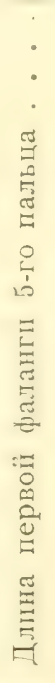 & 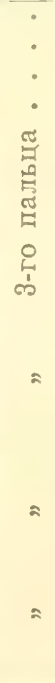 & 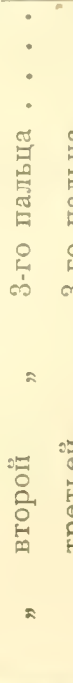 & 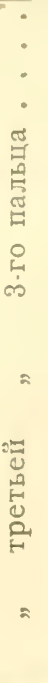 \\
\hline
\end{tabular}




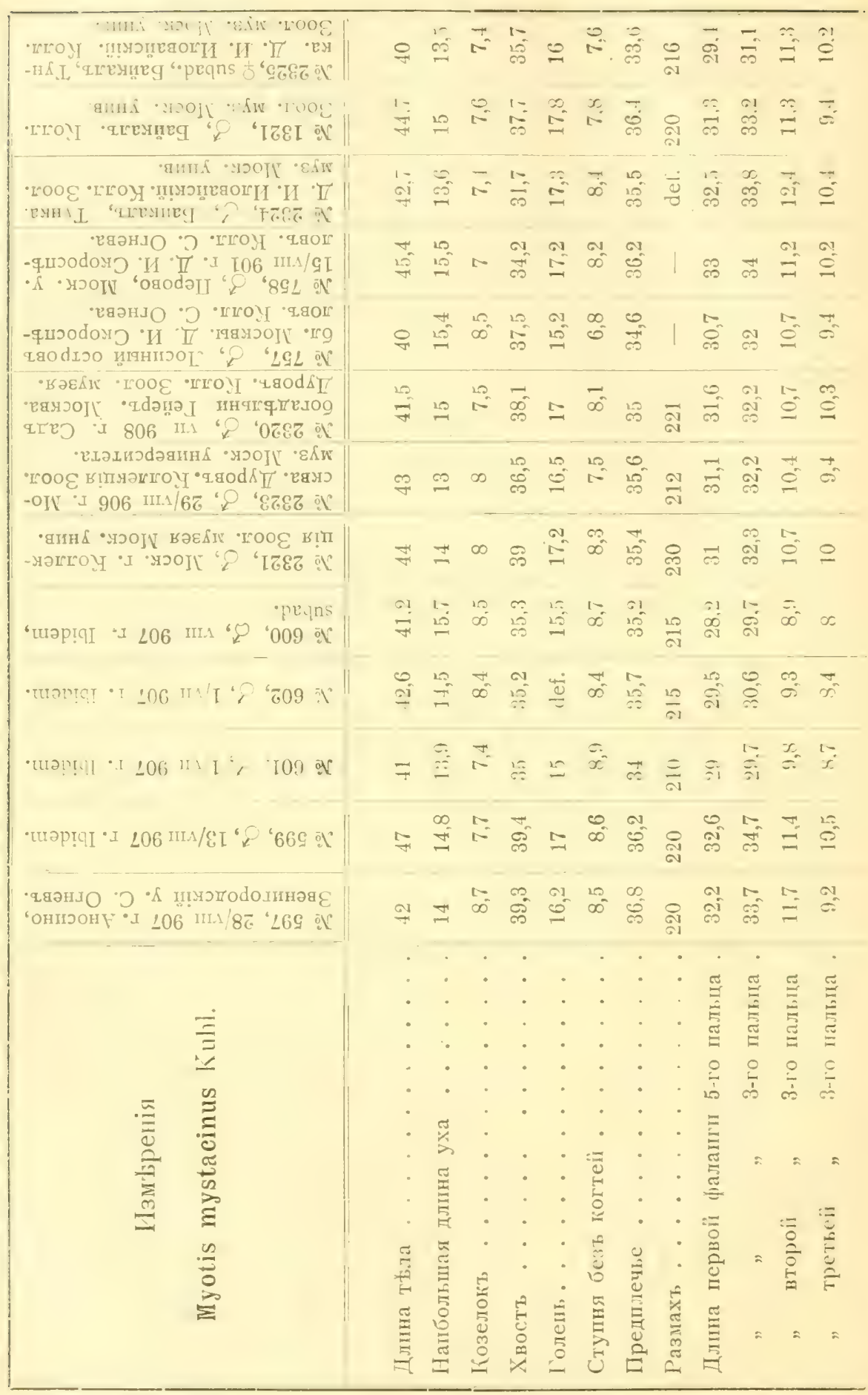


третьяго пальца больше третьяго членика того же пальца. Между тьиљ, у европейскихъ особей, по мнынію проф. Н. $\Theta$. K ашенко, эти соотношенія обратны, или же членики равны. На основаніи этихъ различій онъ въ болье поздней работь (79, стр. 268) называеть усатыхъ ночниць восточної Сибири $M$. mystacinus sibivicus Kastsch. Тщательное изсльдованіе моего матеріала, а также и небольшого сибирскаго, хранящагося въ Зоологичскомъ Музеь I Мп. Моск. Мниверситета, привело иеня къ заключенію, что эти прнзнаки въ дыйствительности совергє'нно не существуютъ. Достаточно посмотрђть на таблицы моихъ измьреній и промьровъ, приводимыхъ въ работь Н. $Ө$. К ащ ено, чтобы убъдиться въ ихъ полномъ совпаденіи ${ }^{1}$ ). Что касается до второго признака (относите.лные разиьры члениковъ 3-го пальца), то онъ основанъ явно на какомъ-то недоразумьніи. Какъ можно видыть изъ таблицы моихъ измьреній, только у одного изъ 2І московскихъ экземпляровъ (№ 6г6) моей коллекціи эти членики равны, у всьхъ прочихъ соотношенія ихъ совершенно таковы, какъ у сибирскихъ ${ }^{2}$ ).

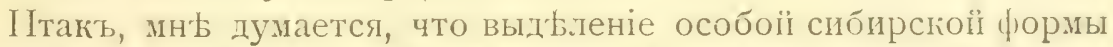
усатої ночницы врядъ ли возможно. Тшцательно слпчая о́айка.льскіе экземпляры съ моими $M$. mystacinus изъ Европейской Россіи, я могъ замьтить одно мелкое различіе, правильность коего можно подтвердить только на большихь серіяхъ. Кменно, ухо байкальскихь особей не имьеть такой ptзкой выемки на внышнемъ кра́⿱十口, какъ у типичныхъ, и, кронь того, у двухъ изъ трехъ M. mystacims оно относительно короче, чьмъ у московскихъ. По всему эта форма уха ньсколько напоминаеть таковую у $M$. iliomiliovi Ogn., но оно длиннье и не такъ выпукло по линіи внутренняго края, какъ у посльдняго вида ${ }^{3}$ ). Кромь того, че-

1) а) Томскъ, льто 1898 (отъ С. М. Ч у г у н о в а), самка: длин. тьлла: 48; дл. хвоста: 40; предпл.: 37; размахъ: 225; дл. 2-го чл. 3-го пальца: 111/2; дл. 3-го чл. того же пальца: 10. b) С. Нижній Уймонъ (на Алтаь) Љ, дл. тьла: 45, дл. хв.: 36; предпл.: 34; размахъ: 212; 2-го чл. 3-го пальца: 101/2; 3-го чл.: 10.

2) Blasius $(27$, p. 81,97$)$ говоритъ, что второй и третії членикі 3-го пальца у II. mystacimus равны, что, по его словаґъ, является характерної чертої этого вида. Служитъ ли это дыйствительнымъ различіемъ западно-европеїскихъ II нашихъ усатыхъ ночницъ, предоставляю рђшить дальньйшим изсльдователямь.

3) Относительно одного изъ байкальскихъ экзеипляровъ (ঐo 1321) Т ихоми иов ъ и Корч а г н ъ (199, стр. 13) пшшутъ сльдующее: онъ „подходитъ очень блізко къ $V$. mystacinus, но только уши и крыловая перепонка у него свђтлье, нежели у европейских экземпляровъ; въ то же время онъ не представляетъ того признака, который Бл аз іусъ (Fauna Deutschlands, 
репь байалискихь экземпляровъ схонь съ европейскими, тогда какъ у . .I. iliomikovi Ogn. онъ грайне оригиналенъ.

Экземпляь изъ Хань-Паула съ Сосьвы оть Д. И. Ило в айскаго (коллекція Зоол. Музея. Моск. Унив. № 2326) ничьмъ не отличается оть средне-русскихъ.

\section{Географическое распространеніе.}

Въ предьлахъ Московской губ. усатая летучая мышь найдена мною въ Московскомъ, Можайскомъ (село Тесово) и Звенигородскомъ (село Аносино) уу. Въ коллекціи Зоологическаго Музея имыются экземпляры изъ Московскаго у. и даже изъ самаго гор. Мосівы. По словамъ К. А. С а тун и на ( 65 , стр. 4), одинъ экземпляр этого вида быль доставленъ ему Г. А. Ко жевниковымъ, добывшимъ его въ первой половинғ августа т890 г.

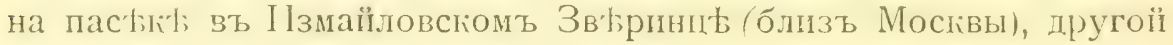
былъ пойманъ тамъ же П. П. М е л ь г н о в ы м ъ лћтомъ І893 года.

Въ распространеніи Myotis mystacims Kuhl сказывается изв'ьстная спорадичность. Такъ, я могу отмьтить, что въ нькоторыхъ мьстахъ она относительно рћдка, въ другихъ, какъ, напримъръ, въ Звенигородскомъ у., около с. Аносина является господствуюшей формої. Вюроятно, болье детальное изученіе распредыленія Myotis mystacinus Leisl. въ границахъ изученной губерніи покажеть ея широкое распространеніе. Что касается до указаній, имьющихся въ литератур' о нахожденіи $M$. mystacinus „въ средней Россіи, то они страдаютъ какой-то исключительной скудостью. Усатая летучая мышь, вьроятно, встрбчается въ Орловской губ. (Данил ов ъ, 4 I, стр. 23), но ни мной, ни С. Н. Го рбачевым в въ этой мьстности не найдена. Въ Калужской губ. добыта въ Перемышловскомъ у. В. А. Фил а товым ъ (экземплярь въ моей коллекціи). Для Харыковской губ. она не указана Че р н а е м и С о м о в мъ. Далье на югъ найдена Е. В. П ы л н о вы м в в области Воїска Донского, а Блаз іу со м ъ указана для Украйны. По А. А. Бр а у н е у, этоть видъ многочисленъ близъ Аккермана (38, стр. 2); восточнње встрђчается въ Симбирской губ. (Сызранскій у., Б. М. Жи тжов в); добыта въ Кузнецкомъ у. Саратовской губ. Н. Ф. Иконнико вы мъ; въ

р. 97) считаетъ самымъ характернымъ для даннаго внда, нменно: у байкальскаго экземляра третій членикъ (2-ая фал.) третьяго пальца короче 2-го членика (1-ой фалангі)“. Что касается до перваго признақа, т.-е. окраски, то онъ совершенно не существенъ, т. к. сходно окрашенные экзелпляры мнь прнходшлос- видыть изъ разныхъ губерніи Европейской Россін; относительно полної несостоятельности второго различія я говориль уже раньше. 
Оренбургскої губ. М. Д. Рузскимъ (хр. Авалянъ) и на границ этой губерніи и Уфимской-Я ко б с о н ом ъ и Шмид т о ъ (см. К ащенко 8о, стр. 26). Ш ренкъ ( 74 , p. II 4) упоминаеть объ экземпляр‡ изъ Казанской губ. По Эв ерсманну Vesperlilio Zrandtii (= mystacimus Kuhl) встрগчается въ южныхъ предгоріяхъ Урала и въ сьверной части Оренбургскої и Казанской губ., въ посльдней найденъ также и Богдановым ъ (3о, стр. І6о). Что касается до двухъ эгземпляровъ, добытыхъ въ Верхнеуральскь Н. А. З а рудны м ъ и опредћленныхъ М. Н. Богдановым в какъ Vespertilio Lrandtii Evers., то, какь правильно замьчаетъ проф. Н. Ө. К аще н ко, это, повидимому, были тоже M. mystacims Kuhl. Чтобы погончить съ распространеніемъ усатой ночницы на Ураль', отмъчу, что Л. П. С а бан водитъ ее для Каслинскихъ отроговъ этого хребта (г 4 8, стр. 2І6).

Въ Пермскіої губ. усатая мышь найдена Т е пл о ухо в ы м и С ерг ғевым (экземплярь въ голлекціи Зоол. Муз. Моск. Унив.). И. С. Поляков ъ отмьчаеть ее для огр. озера Водло (сьв. часть Пудожскаго у., Олонецкой губ., см. К есслеръ (88, стр. III). Подвигаясь теперь на западъ, мы находимъ усатую ночницу въ Петербурской губ. (С и м а ш о, І 8 I, стр. 37; Бі а н ки, 23 , стр. Іо8) и въ Остзейскихъ провинціяхъ (Г ре ве́, 67, р. 32; Бі ан ки, 1. с. р. го8). Въ Крыму $\boldsymbol{M}$. mystacimus найдена К. $Ө$. Кесслеромъ въ г88о году въ Тотаго' (см. Никольскі ї, I 22 , стр. 42). Въ коллекціи А. А. Б рауне ра имбются экземпляры изъ Евпаторійскаго и Перекопскаго уу. На Кавказ у усатая летучая мышь была добыта впервые Kolenati (см. Brandt, 33, p. 39). Сатунинъ ( 62 , стр. 54) отмьчаеть ее для Сьв.

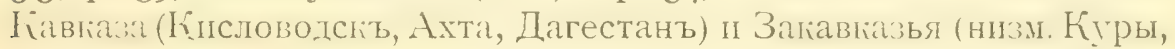
Арагса, Баку, Нуха, Аралыхъ). По словамъ того же автора, эта летучая мышь встрбчается въ южной части Закаспійскіой обл., въ южної Персіи и Белючистаньै (г 57, стр. 235, 242). Для Закаспійской обл. ее указывають Р адде и Вальтеръ (г 4 4, р. гооб). Въ предьлахъ Томскаго края усатая ночница добыта Н. Ө. Кащ е н ко, гдь попадалась неоднократно, хотя не часто (8о, стр. 25). На Алтађ она добыта проф. Кащенко въ Уймонской долинъ и Игнатовым ъ-около Телецкаго озера (см. 8 о, стр. 25 и 8 I, стр. г2). Въ Саянахъ найдена проф. П. П. С ушкиным ъ. Въ Тобольской губ. добыта И. Я. С ло вцов ы ъ ${ }^{1}$ ). Самымъ сы.

1) $\mathrm{Bъ}$ работь Словцова экземпляры названы Vespertilio murinus (183, стр. 25), (отд. отт). Опредьленіе псправлено профессоромъ К а енко (см. S0, стр. 26). 
вернымъ нахоженіемъ этого вига въ Сибири является ХаньПауль на Сосьвн (Д. И. Илов айскій, экземпляръ въ коллепціи Зоол. Музея Москов. Унив.) Далџе усатая летучая мышь встрђчается въ Семипалатинской обл. (Нарынсіая вол., Зайсанскаго у. экземпл. въ коллекціи Зоол. Муз. Моск. Унив. отъ Е. Н. З орина). По словамъ К а ш н к, въ коллекции Зоол. Муз. Имп. Академіи Наукъ имћется экземпляръ, добытый Ю. Н. В агн е ромъ на р. Енисељ, въ ста верстахъ отъ г. Красноярска. Еце талье на востокь $M$. mystacims найдена $\mathrm{P}$ адле ( 143 , p. т29) на сłверномъ Байкаль и на Яблоновомъ хребть, близъ Тунки (также на Байкаль) добыта Д. И. Иловай си и ъ (колл. Зоол. Муз. Моск. Унив.). Schenck ( 7 4, p. I з3) нашель усатую летучую мышь оголо Николаевска на Амурџ, близъ Бай-Хаджи и Борби (изъ посльдняго мыста экземпляры этого вила привезены М а акомъ). Кашен ко (79, стр. 268) говорить о нахожденіи описываемаго вила въ сыверної Монголіи и оноло Троициосавска, $\mathrm{P}$ а д де (I 7 4, p. I 29)--объ экземпляр है изъ Камчатки оть г. В о знесенскаго, а Dobson (45, p. г 34)-изъ Гималаевъ (Непаль) ${ }^{1}$ ). Кромь того, она найдена въ Пекинt (Dobson, 47, p. 3i5) и на Сахалин's (Old. Thomas, I 93, p. 407).

Въ Западной Европt описываемый видъ распространенъ очень

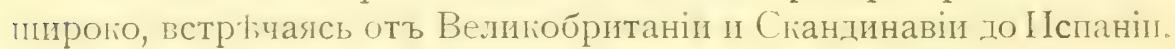
Въ Альпахъ, по свидытельству Фатіо, усатая летучая мышь достигаетъ въ своемъ распространеніи 5500 ф. надъ уровнемъ моря.

Кз сожальнію, мои біололиескія наб.лоденія надъ этимъ видомъ летучей мыши сводятся гъ весьма немногому. Мнъ часто приходилось находить усатыхъ ночницъ подъ большими балками чердаковъ, гды онь прячутся или въ одиночку, или цьлыми сообществами. Вечеромъ онь вылетають на добычу съ наступленіемъ почти полной темноты. Погода довольно сильно вліяетъ на нихъ, и въ холодные дожливые, а особенно въेтреные вечера, Myotis mystacimus Kuhl обычно совсћмъ не видно. Усатыя ночницы придерживаются обычно опушекъ льсовъ или аллей старыхъ парҺовъ, гдћ̆ иногда довольно низіо проносятся между деревьями, или, что чаще бываеть въ тихіе вечера, почти по прямой линіи облетаютъ, на уровн古 вершинъ старыхъ деревьевъ, свой охотничій районъ. Полетъ ихъ значительно уступаетъ въ бы-

1) Распространенный въ Непалњ и Спкким (см. Horsfield, Annals and Magazine of Natural History, 1853, p. 102), быть можетъ, представляетъ особыі subspecies. 
строть описаннымъ выше видамъ, что стоитъ въ связи съ Ко-

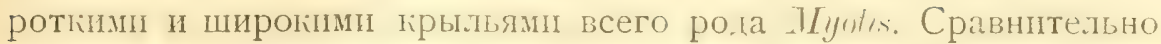
p tдко мнћ приходилось видыть усатыхь ночницъ летающими натъ поверхностью воды. Осенью посльднихъ особей я наблюдалъ въ концћ августа.

Әкзелияяы коллекии перечислены въ таблиц изы иреній. (стр. 65 и 66).

В. Подродъ Lеucon’ö.

\section{Leuconoë daubentonii (Kuhl).}

Летучая мышь Добентона.

Tespertilio daubentonii, Hein $\mathrm{rich} \mathrm{Kuh}$, Ann. der Wetterauschen Gesellschaft für die gesamte Naturkunde, 1819, p. 195, pl. XXV, fig. 2 (описанъ по экземпл. Л ей с ле ра). Myotis daubentonii Leisl. Tr o u es s r t, Supplementum, 1904, p. 90 et. $(200)$, p. 27. M éhely (104) p. 330. Milla is (110) p. 86. Myotis daubentonii Kuhl. B a r et-Hamilton (16), p. 143. Tespertilio daubentomii Leisl. Dobson (47), p. 297, Blasius (27), p.98. F. A. Caт ун ин ъ (165) стр. 4 ॥ (166) стр. 3.

\section{Систематическія особенности.}

Черепо отличается характерными чертами строенія для всего po_la IIyotis, которыя были указаны при описаніп үсатой ночницы. Однако, отъ черепа посльдней разнится по сл'вдующимъ признакамъ.-Лобныя кости болће круто поднимаются надъ носовой областью и, что особенно характерно, вышина ихъ почти всегда превышаетъ болће низкую затылочную область,-признакъ обшій съ Pipistrellus nathusï Keys. et Blas. Далье, носовая область значительно гіроче, чьмъ у Myotis mystacims Kuhl. и, наконецъ, черепная коробка много шире тақовой у предыдущаго вида (см. таблицу измьреній).

Зубъ. Строеніе ихъ очень напоминаеть то, что мы видыли у II. mystacinus Kuhl, но существуетъ н'Бсколько очень постоянныхъ признаковъ, къ разсмотрынію которыхъ мы переходимъ. Прежде скажу только нъсколько словъ относительно ръзцовъ нижней челюсти. Блазіусъ $(27$, р. 98) описываетъ ихъ расположеніе по линіи нижнечелюстной кости. II, дђйствительно, это расположеніе ихъ является наиболье частымъ и характернымъ. Просматривая очень большой матеріаль по этому виду, я только въ немногихъ случаяхъ могъ констатировать приближеніе къ параллельному по отношенію другъ къ другу распредыленія опи-

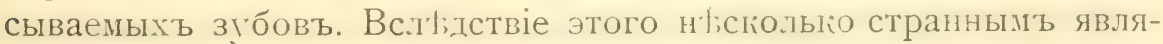
ется тоть фагть, что Барреть-Гамильтонъ (г 6, р. I47) 


\begin{tabular}{|c|c|c|c|c|c|c|c|c|}
\hline $\begin{array}{l}\text { Кзмбренія череповъ } \\
\text { Leuconoë daubento- } \\
\text { nii Kuhl. }\end{array}$ & 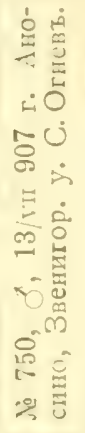 & 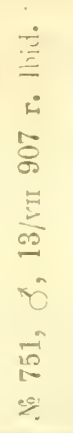 & 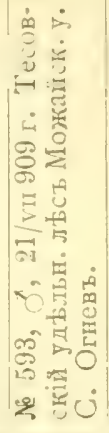 & 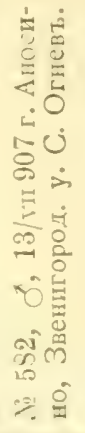 & 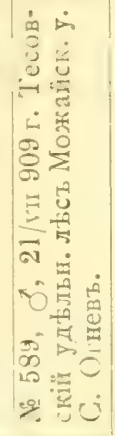 & 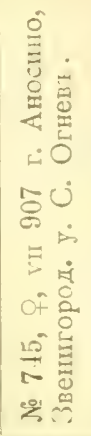 & 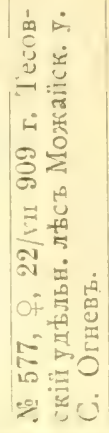 & 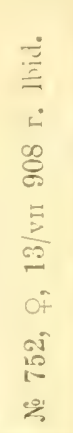 \\
\hline Напбольшая длина . • & 15,9 & 15,1 & 14,9 & 15,1 & 14,8 & 14,8 & 15,1 & 15 \\
\hline Скуловая ширшна . . & 9,8 & 9,8 & 9,2 & 8,8 & 9,2 & 9,3 & 9,4 & 9,3 \\
\hline $\begin{array}{l}\text { Ширина черепної кап- } \\
\text { сулы надт bullae } \\
\text { osseae } . . .\end{array}$ & 8,3 & 8,3 & 7,8 & 8,2 & 8 & 7,9 & 8,2 & 8,1 \\
\hline $\begin{array}{l}\text { Ширина межглазніч - } \\
\text { наго промежутка . }\end{array}$ & 4,4 & 4,4 & 4,2 & 4,4 & 4,4 & 4,4 & 4,3 & 4,5 \\
\hline $\begin{array}{c}\text { Ширнна впереди ор- } \\
\text { битъ ........ }\end{array}$ & 5,2 & 5,1 & 4,8 & 5 & 4,9 & 4,9 & 5 & 4,9 \\
\hline $\begin{array}{c}\text { Длина верхняго ряда } \\
\text { коренныхъ зубовъ }\end{array}$ & 5,7 & 5,6 & $5, \overline{5}$ & 5,6 & $5,6\}$ & 5,4 & 5,6 & 5,6 \\
\hline
\end{tabular}

даеть рисунокь зубовъ Myotis daubentomï, гды ясно выражено параллельное ихъ распредғленіе, безъ всякихъ указаній на случаи иной ихъ разстановки. Блазіусъ (27, р. 99), описывая форму третьихъ (крайнихъ) рђзцовъ нижней челюсти, говоритъ, что они овальны въ поперечномь сьченіи, что, однако, не вполнь точно. - Эти зубы легко отличаются отъ дыйствительно рђзко овальныхъ въ поперечник бу зубовъ усатой ночницы своей вытянутой формої.

Самымъ лучшимъ и очень постояннымъ признакомъ отличія близкихъ другъ къ другу формъ является строеніе второго ложнопоренного зуба нижней челюсти. Тогда капь у Myotis mystacims. Kuhl этотъ зубъ лишь немногимъ отличается оть предшествующаго перваго,-у добентоновой ночницы онъ әораздо ниже и болtе qьиъ впвое поние. Указанный признакь мны удалось констатировать у очень большого матеріала и всегда онъ выступаль съ обычною ясностью.

$y_{x o}$ будучи прижато къ голов٪, достигаетъ понца носа или едва заходить за него. Оть конфигураціи уха усатой ночницы 
отличается менъе рђзко выраженною выр‡зкой на внбшнемъ крағ и большей укороченностью относительно общихъ размьровъ тыла. Козелокъ почти достигаеть средины длины уха и не такъ суженъ къ своему юонцу, какъ это видно у Myotis mystacims Kuhl.

Нёбныя складии по своему строенію крайне напоминаютъ строеніе ихъ у M. mystacims. Общее число складоюъ равно семи. Различіе межлу описываемыми б.лизили ви. цами сlазывается только въ строеніи второї склапки. Въ огромномъ большинств чаевъ она болье или менье вдавлена спереди, напоминая строенie ея y Myotis iliomiliovi Ogn.

Oкраска. У этого вида не встрғчается столь рьзкихъ ея отклоненій, какъ у Myotis mystacims Kuhl. Здысь можно отличить только два типа, изъ коихъ одинъ преобладаетъ, тругої является сравнительно рыдкимъ. Къ первому, обычному, типу окраски относятся экземпляры, вся верхняя часть тбла которыхъ покрыта бурыми волосами, болье или менће интенсивнаго темнаго отт ънка у ихъ концовъ, иногда съ примьсью сыраго тона, тогда какъ основанія волосъ темно-бураго цвћта. Окраска нижнеї стороны очень постоянна: здьсь волосы у основанія темно-сыры, а цвьть ихъ окончаній пріобр втаеть б ғлесоватыї оттьнокь. Летательная

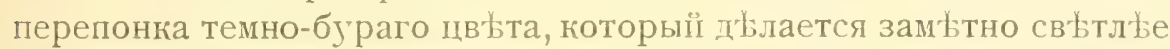
на нижней сторонь межбетряної области. Уши обычно свътлье, въ особенности по краямъ ихъ. Ко второму типу окраски относятся гораздо болье рбдкіе свьтлые экземпляры, очень напоминающіе свьтлыхъ усатыхъ ночницъ. Основанія волосъ спинної стороны этихъ особеї сћро-бураго цвьта большеї или меньшеї интенсивности, окончанія много свьтлье, обычно сыровато-ржавыя. Вся нижняя сторона покрыта густыми сұрыми волосами, съ интенсивно выраженными свђтлыми сьровато-палевыми концами. Цвьть летательной перепонки значительно свьтлье, тонъ ея окраски ярко-рыжій, переходящій въ бьловато-желтый на нижнеї сторон告 межбедряної области. Уши свћтлыя съ интенсивным оттьннком сіенны. Окраска молодыхъ отличается большимъ однообразіемъ верхней и нижней стороны и въ общемъ значительно темнте.

Въ заключеніе привожу измьренія экземпляровъ моей коллекціи (см. таблицу на стр. 74 и 75 ).

\section{Географическое распространеніе.}

К. А. Сатунинъ въ своей работь упоминаетъ только объ одномъ экземпляр 


\begin{tabular}{|c|c|c|c|c|c|c|c|c|c|c|}
\hline 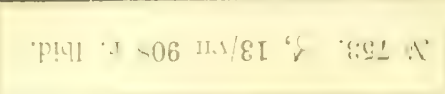 & $\stackrel{-1}{\longrightarrow}$ & $=$ & $x^{2}=$ & $\stackrel{x}{\because}$ & $\begin{array}{l}21 \\
21 \\
\ddot{2}\end{array}$ & $\Leftrightarrow$ & $=$ & $\sum_{i}^{\infty}$ & $\stackrel{\infty}{a}$ & $\stackrel{2 !}{20}$ \\
\hline 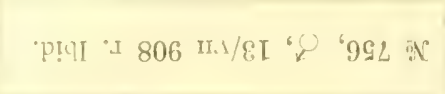 & $\stackrel{3}{\varrho}$ & $x$ & $\vec{s}$ & $\stackrel{x}{0}$ & $x$ & $\stackrel{1}{\equiv}$ & $\therefore$ & $\sum_{\bar{c}}$ & $\frac{1}{\square}$ & $\infty$ \\
\hline 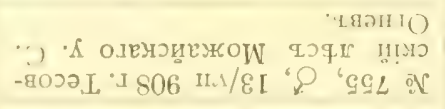 & $\because$ & 5 & i & 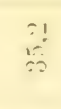 & $\cong$ & $\ddot{0}$ & 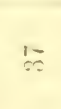 & $\overbrace{\substack{1 \\
: 1}}$ & $\stackrel{q !}{\dddot{\hat{\beta}}}$ & 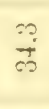 \\
\hline 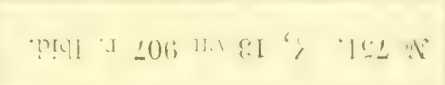 & 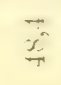 & 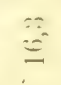 & 5 & 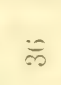 & $\ddot{\Xi}$ & $\cong$ & 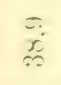 & $\stackrel{10}{7}$ & $\Leftrightarrow$ & $\approx$ \\
\hline •ptqI 'I $206 \mathrm{Ir.1} / 8 \mathrm{~L}$ ' & $\because$ & $\varrho$ & $\underline{s}$ & 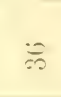 & $\underline{\alpha}$ & $=$ & $\stackrel{x}{\subseteq}$ & 产 & 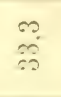 & 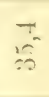 \\
\hline 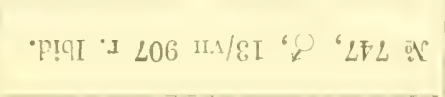 & $\stackrel{9}{=}$ & 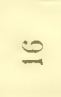 & $\therefore$ & E્ & $\underline{x}$ & $\stackrel{n}{\varrho}$ & $\begin{array}{l}\infty \\
:-5\end{array}$ & 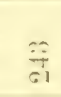 & $\stackrel{x}{\vdots} \vdots$ & $\stackrel{100}{=0}$ \\
\hline 'pIqI I I L06 IIs/EI ' $P$ '6FL & $\stackrel{5}{\rightarrow}$ & $=$ & $\infty$ & 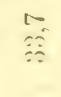 & $\overrightarrow{\ddot{x}}$ & $\equiv$ & क & 量 & $\underset{i}{i}$ & $\overrightarrow{\tilde{C}^{\circ}}$ \\
\hline •ptqI •I L06 IIL/EI 'Q ‘9FL & $\stackrel{\leftrightarrow}{9}$ & $\rightleftarrows$ & T: & 10 & $\stackrel{s}{a}$ & $\ddot{\ddot{g}}$ & $\begin{array}{l}\dot{v} \\
\dot{f} \\
\dot{v}\end{array}$ & $\frac{10}{31}$ & $\frac{\infty}{\infty}$ & $\begin{array}{ll}\infty \\
\infty \\
\infty\end{array}$ \\
\hline 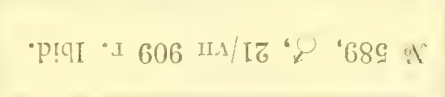 & 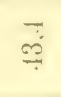 & $\overline{ \pm}$ & 10 & $\underset{1}{\infty}$ & $\because$ & $\stackrel{3}{\varrho}$ & 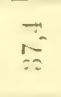 & $\overrightarrow{\hat{i}}$ & $\stackrel{3 !}{-0}$ & $\begin{array}{l}16 \\
10 \\
68\end{array}$ \\
\hline 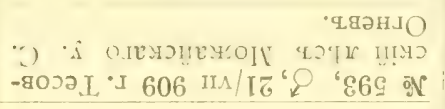 & 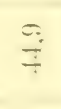 & $\because$ & $\Leftrightarrow$ & 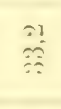 & $1=$ & $\ddot{\Leftrightarrow}$ & $\frac{1}{5}$ & $\stackrel{\circ}{: i}$ & $\underset{c}{a}$ & 竞 \\
\hline •ptqI "I L06 II.s/eI 'P '8tL & $\stackrel{\leftrightarrow}{\mathscr{T}}$ & 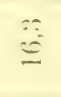 & $\because=$ & $\frac{11}{30}$ & $\stackrel{1}{\Xi}$ & $\stackrel{31}{9}$ & $\vec{t}$ & $\underset{20}{2}$ & $\frac{1}{30}$ & $\ddot{~}$ \\
\hline 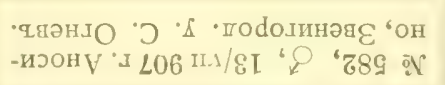 & $\stackrel{0}{+}$ & $\ddot{1}$ & $r$ & 2 & $\overrightarrow{\underline{x}}$ & $\stackrel{91}{\varrho}$ & $\underset{5}{3}$ & 资 & $\frac{9}{\infty}$ & 10 \\
\hline 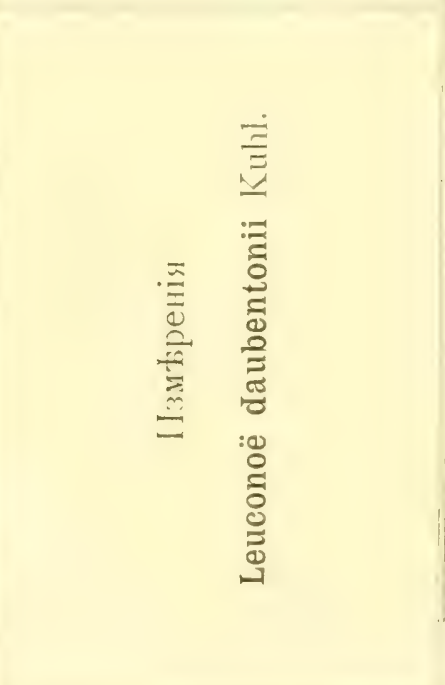 & 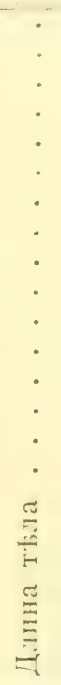 & 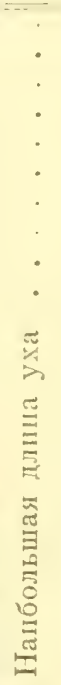 & 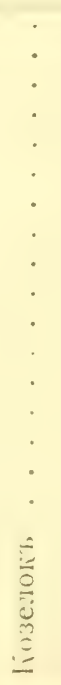 & 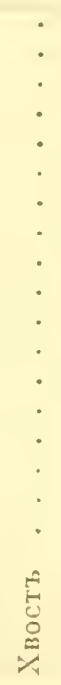 & 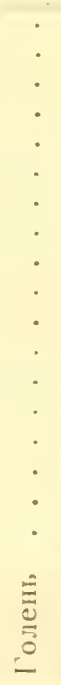 & 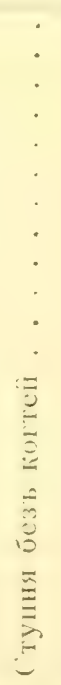 & 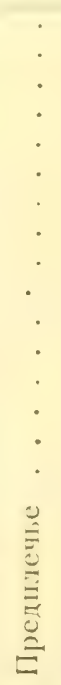 & $\begin{array}{l}\dot{ } \\
\dot{ } \\
\vdots \\
\vdots \\
\vdots \\
\vdots\end{array}$ & 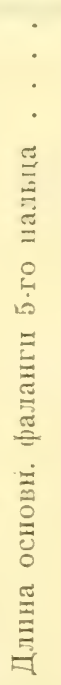 & 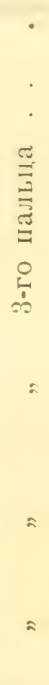 \\
\hline
\end{tabular}




\begin{tabular}{|c|c|c|c|c|c|c|c|c|c|c|}
\hline 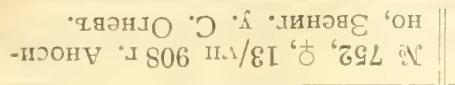 & $\underset{101}{12}$ & $\Xi$ & is & $\underbrace{\infty}_{-\infty}$ & $\stackrel{1}{\infty}$ & $\stackrel{0}{0}$ & $\begin{array}{l}\infty \\
\infty \\
\infty \\
\infty\end{array}$ & $\frac{10}{91}$ & $\frac{\mathrm{Q}}{\mathrm{m}}$ & $\underbrace{\infty}_{0}$ \\
\hline 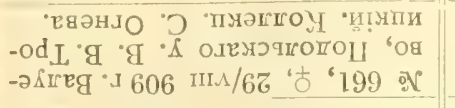 & 调 & 0 & $\stackrel{0}{0}$ & 芯 & $\stackrel{\varrho}{=}$ & 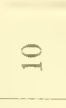 & $\stackrel{0}{\mathscr{0}}$ & ลั & Hi & ڤै \\
\hline 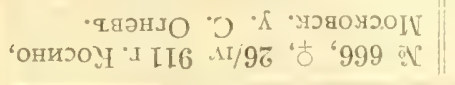 & $\overrightarrow{50}$ & $\stackrel{20}{=}$ & $\infty$ & की & $\stackrel{-1}{\Xi}$ & $\stackrel{2}{2}$ & $\int_{\infty}^{3}$ & ๑ิ & ఝ & $\bar{m}$ \\
\hline 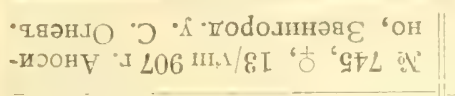 & $\underset{7}{7}$ & $\nexists$ & 10 & $\ddot{0}$ & $\widehat{E}$ & $\ddot{0}$ & $\sum^{\infty}$ & ㄱำ & $\underset{\infty}{\infty}$ & $\frac{G}{5}$ \\
\hline 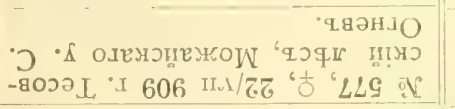 & $\stackrel{0}{\dot{T}}$ & $\stackrel{\sim}{\beth}$ & $\stackrel{+}{\sim}$ & हి & $\stackrel{\sim}{\infty}$ & 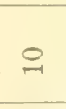 & $\begin{array}{l}\infty \\
\infty \\
\infty\end{array}$ & $\stackrel{\infty}{\text { जี }}$ & $\begin{array}{l}\infty \\
10 \\
10\end{array}$ & $\begin{array}{l}\infty \\
\hat{n} \\
\hat{n}\end{array}$ \\
\hline 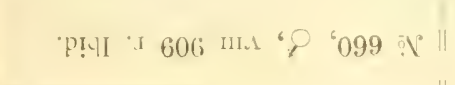 & $\stackrel{0}{\frac{1}{T}}$ & 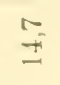 & $\infty$ & $\stackrel{28}{5}$ & $\stackrel{1}{1}$ & $\infty$ & $\frac{10}{50}$ & $\stackrel{\dot{\Theta}}{=}$ & $\approx$ & $\stackrel{3}{\because} \cong$ \\
\hline 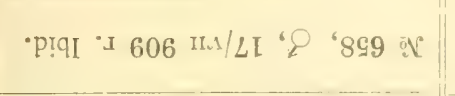 & $\begin{array}{l}\infty \\
\stackrel{\infty}{+} \\
\stackrel{+}{+}\end{array}$ & $\overrightarrow{10}$ & $\stackrel{\infty}{\infty}$ & $\underset{0}{\infty}$ & $\simeq$ & $\stackrel{0}{\circ}$ & की & స̆ & $\begin{array}{l}19 \\
\text { बi }\end{array}$ & की \\
\hline 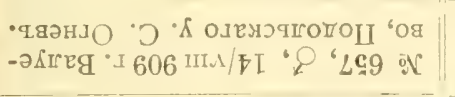 & $\stackrel{80}{9}$ & 10 & $\stackrel{\infty}{\infty}$ & 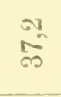 & $\simeq$ & $\stackrel{\infty}{\infty}$ & $\begin{array}{l}\infty \\
\infty \\
\infty \\
\infty\end{array}$ & $\begin{array}{l}19 \\
19 \\
61\end{array}$ & $\hat{\infty}$ & लै \\
\hline 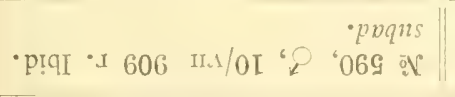 & $\vec{\nabla}$ & $\stackrel{6}{2}$ & $\stackrel{\infty}{\infty}$ & 10 & 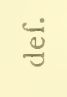 & 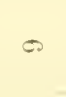 & $\stackrel{m}{s}$ & ज्ञ & $\stackrel{\text { ले }}{\mathfrak{m}^{-}}$ & में \\
\hline 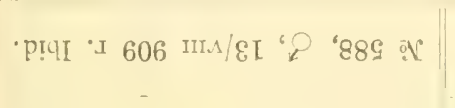 & $\stackrel{20}{\rightarrow}$ & $\stackrel{0}{ \pm}$ & 5 & $\underset{c 0}{\infty}$ & $\simeq$ & $\cong$ & $\tilde{\infty}$ & 吕 & $\stackrel{\infty}{\overbrace{}^{2}}$ & m \\
\hline 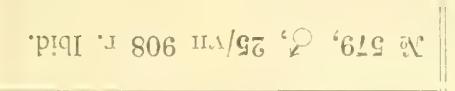 & $\stackrel{109}{7}$ & 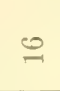 & 8 & 우 & $\vec{\infty}$ & $\stackrel{\circ}{0}$ & $\stackrel{\infty}{\infty}$ & 융 & al & c5 \\
\hline 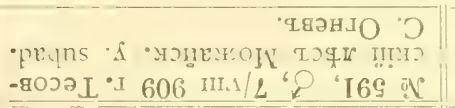 & $\stackrel{\rightarrow-1}{i=1}$ & 2 & ? & $\hat{\mathrm{O}}$ & $\stackrel{10}{10}$ & $\stackrel{\oplus}{\triangleq}$ & $\underset{\infty}{\infty}$ & $\stackrel{10}{\circ}$ & $\frac{12}{40}$ & $\begin{array}{ll}a ! \\
\text { in } \\
\text { on }\end{array}$ \\
\hline 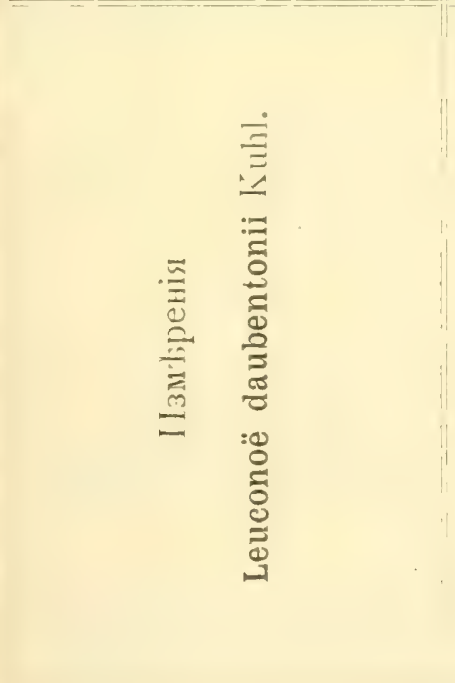 & 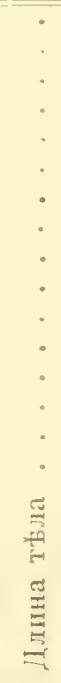 & $\begin{array}{l}: \\
\vdots \\
\dot{0} \\
\dot{0}\end{array}$ & 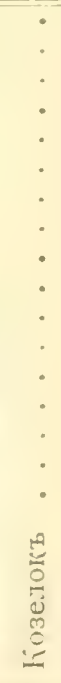 & 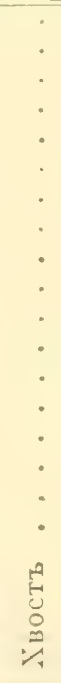 & $\begin{array}{l}: \\
\vdots \\
: \\
: \\
: \\
\vdots \\
\vdots \\
\vdots\end{array}$ & 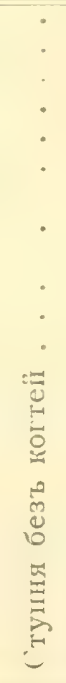 & 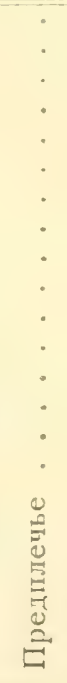 & 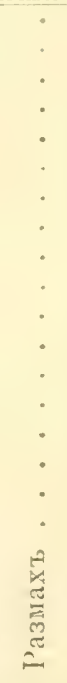 & 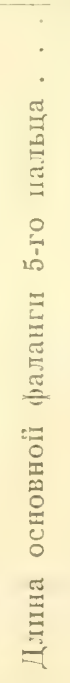 & 音 \\
\hline
\end{tabular}


нія "Фролово“, близт ст. Люберцы (Моск. у.). Между тұмъ, ночница Добентона должна по справедливости считаться одной изъ самыхъ обычныхъ формъ не только въ претьлахъ Московской губ., но и во всеиі средней области Европейскоц̊ Россіи. Въ частности, въ Московской губ. она іраїне обыкновенна въ Московскомь у. (близъ Косина), въ Звенигородскомт (亡. Дергаїково, им. Спасское, с. Аносино), Рузскомъ, Клинскомъ (с. Демьяново), Диитровскомъ (Никола-Угрџша, экземпляры отъ А. Н. Х а р узина), Можайскомь (Тесовскій льсь, с. Тесово, д. Дурнево, д. Митьково), Подольскомъ у. (с. Валуево). Что касается до частностей ея распространенія въ предълахъ среднеї и южної Россіи, то, хотя наши свьдънія далеки еще оть обстоятельной полноты, но все же ньсколью богаче, чьмь о близкой еї усатої ночниц'.

Такь, летучая мышь Добентона наїдена въ Ярославской губ. Л. П1. Сабан вевы м ( 5 о, р. 250) и, по моимъ наблюденіямъ, очень обыкновенна въ восточної части Орловскої губ., въ разныхъ уу. Смоленскої г. и Малоярославецкомъ у. Калужскої губ. Н. Н. С омовым ъ ( 84 , стр. I5I, I52) добыта въ Харьковскої губ., Кесслеромъ въ Кіевской губ., Нордманомъ близь Измаила на Дунаъ, Блазіусомъ - въ Украйнь. А. М. Никольскіï не указываеть этоть видъ для Крыма, но, по общему распространенію, Lenc. danbentonii Kuhl должна тамъ встрьчаться и отсутствіе показаній объ ея находкахь, вьроятно, относятся ґъ случаїному недосмотру. Далье на востокъ эта летучая мышь найдена въ rgor году В. И. И са вым т около Ханскої Ставки (Астраханскої губ.), а подымаясь выше по Волгы, мы находимь ее въ большомъ количествь по всему теченію рьки, гдђ она особенно многочисленна въ Симбирскої, Казанской, Саратовскої гг. (см. Богдановъ, зо, стр. г6о; Б. М. Жи итов ь, 7 I, р. 4; Эв е р сманн ь, 42, р. 5 I ; 3 а б у совъ 76, стр. 58). Эвер с анн ъ отмьчаеть ее также для сьверныхъ частеї Оренбургскіо̆ губ. и предгорій Урала, а Л. П. С аб ан ье в ъ ( 4 8, р. 2І6) для Каслинскаго Урала. Далье она наїдена Б. Д. К и рпи ч н и ко вы м ъ въ Варнавинскомъ и Ветлужскомъ уу., Костромской губ., а Л. К руликов с и и ъ въ Вятскої губ. (бл. Нжевскаго завода Сарапульскаго у., въ Малмыжскомъ и Ужумскомь уу., 93 . стр. I го и 94, стр. І86). Западнье встрьчается въ Петербурскої губ. и Финляндіи (Біанки).

Въ прибалтійсскомъ крађ она, по Греве́, очень обыкновенна вт. Лифляндіи и Эстляндіи и, вћроятно, встрьчается въ Курляндіи, хотя въ посльднеї мбстности прямыхъ указаніiі на ея нахожде- 
ніе еше не имьется. По Тачановскому она обыйновенна въ Польшь. Что касается го распространенія этої формы внь предьловъ Европейской Россіи, то относительно Кавказа мы не имьемъ объ ней никакихь свьдыній (см. Сатунин ь, г 63 ). То же надо сказать и о Туркестань, гля фауны котораго эта мышь не указывается, какъ въ старыхъ, такъ и новыхъ работахъ. Однако, во многихъ мьстахъ Сибири она не представляеть рьдкости. Такь, напримьрь, по Кащенко (8о, стр. 23) она не рьдка въ Томскь. Эверсманнъ и Брандтъ 33, р. 39) указывають ее для Алтая. Тамъ же она найдена проф. Н. $\Theta$. К ащенко (8 I, стр. І2) около с. Черги. Кромь того, нахожденія ея констатированы вь Барнауль⿱ (А. П. В ели жанины и ъ), бл. Чистозерской, юго-запад. Томск. губ. (Г. Э. І о г а з ен о ъ ъ), бл. Минусинска (А. рі ановы ъ). Проф. Н. Ө. К ашенко (8o, р. 23) говоритъ объ экземплярђ изъ Падуни (Байкаль), находящемся въ коллекціи Зоолог. Муз. Имп. Акад. Наукъ. Р адде ( 443 р. І28) привезь ньсколько мышей этого вида изъ Забайкалья. По словамь М а а а (т о 2, стр. 95), этоть видь обыкновененъ въ окрестностяхъ Кркутска и въ поймt рбки Ангары. Чренкъ нашель ее на Амурь (I 74, p. II5). Въ коллекціи Зоологическаго Музея Моск. Универ. имьется экзем-

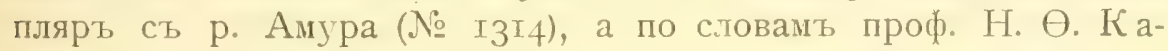
щ е ко, въ коллекціи Томскаго Унив. изъ Амурской обл. оть академика С. И. Коржинскаго. Наконецъ, Брандтъ (33, p. 39) говорить о нахожденіи $L$. daubentomii В о з есен ски м т на Камчатк'b.

Въ Западної Европь эта летучая мышь распространена отъ Швеціи, Норвегіи (Collet) и Англіи до Сардиніи и Сициліи, будучи всюду довольно обыкновенної. Въ горахъ Гарца (по Блазіусу) ночница Добентона поднимается до 2000 ф. надь уровнемъ моря, а въ Альпахъ до 4000 ф.

\section{Біологическія особенности.}

Въ тихіе льтніе и весенніе вечера, когда заря уже потухаетъ и становится довольно темно, можно наблюдать очень большое количество летучихъ мышей Добентона, носящихся во всьхъ направленіяхъ надъ самой поверхностью воды большого пруда или рьки. Полеть ихъ довольно быстрый, но крайне неправильный: мышь то и дыло мьняеть свое первоначальное направленіе, кружится надъ однимъ мьстомъ, затьмъ круто поворачиваетъ и скрывается въ темноть, иногда поднимаясь довольно высоко въ воздухь. 
Вь большинств' случаевъ, однако, $L$. đaubentomii предпочитаеть летать очень низко, пресльдуя мелкихь наськомыхъ. Особенно много приходилось мнђ видьть этихъ мышей когда массами показываются поденки (Ephemeridae), за поторыми начинается усиленная охота. Большее или меньшее появленіе L. daubentomiі стоить въ тысной связи съ погодої, къ измьненіямъ которої этоть видъ очень чувствителенъ, такъ что онъ совершенно не вылетаеть въ хотодные и вытреные вечера. Беременныхъ самоюъ мнь приходитось находить, начиная съ лінца апрьля (24. IV. 9II); число зародышей не превышало двухъ. Кь сожальнію, мны не удалось сдылать непосредственныхъ наблюденій натъ временемъ рожденія молодыхъ.

По 3 абусову (76, стр. 58) самки въ неволь родили в'ь висячемъ положеніи, принимая плодъ въ чашеобразно поднятую рулевую часть; посльдъ не выходиль очень долго и также долго не перегрызалась пуповина. Новорожденныі тотчась гір ппіо прицьплялся ґъ груди матери.

Посльдніе экземпляры видны осенью въ ґонц августа и первыхъ числахь сентября.

Экземлляры колюекиіи. Кромь перечисленныхъ 24 въ таблиць измьреній, въ моей коллекціи имьются еще: 추 655 (sex?) льто о9 г. Валуево, Подольск. у. отъ В.В.Т р о иц ка о; 추 654, I4. VIII. о9г. Ibidem. o 7 I2 24. Vll. gII г. Тесовскій льсь Можайскаго у. № 687 \& I7. VII. 9I I г. Ibidem. № 662 \& I6. VII. o9 г. Валуево Подольск. у. 추 759 \& 29. VI. 07 г. Аносино Звенигор. у.

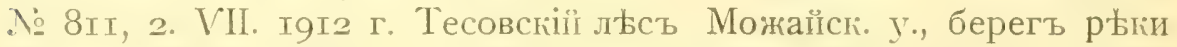

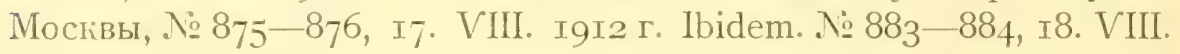
IgI2 г. Ibidem.

Въ коллекціи Зоологическаго Музея Моск. Унив.: 추 IзІ5, Угрьша Ґмитровск. У., А. Н. Х а р у з и н ъ, № 2328, ibidem, ㄱo 2329, ibidem, 츨 2330, льто т905 г. Спасское Звенигородск. у., С. Н. Огневъ.

\section{Leuconoë dasycneme Boie.}

\section{Прудовая ночница.}

Tespertilio dasycneme Boie. Isis, 1825, p. 1200, Blasius (27), p. 103. Dobson $( \pm 7)$, p. 295. Trouessart $(201)$, p. 125. С атунин $(165)$, стр. 4 иा (16 6), стр. 3. Ifyotis (Leuconoë) dasycneme Boie. Tr o u e s s a t (201), Supplementum, 1904, p. 90, $(200)$, p. 27.

\section{Систематическія особенности.}

Перелг, помимо своихъ общихъ большихъ размьровъ сравнительно съ Lеис. dribentomi Kuhl, отличается характерной конфигу- 
parieî. Прежде всего я могу отм むтить г о ра з д о большую утолщенность лобныхъ и теменныхъ костей, что обусловливаетъ собою менбе рђзкій подъемъ ихъ по сравненію съ носовыми. Посльднія тоже отличаются отъ того строенія, поторое мы видұли у добентовой и усатой ночницы: здъсь онға гораздо менґе вдавлены и болье приподняты. Наконецъ, у L. dasycneme затылочная область выше лобной, тогда какь у L. daubentonii Kuhl мы видыли обратныя соотношенія. Крому указанныхъ признаковъ, могу отмћтить еще, что межглазничная ширина черепа этого вида больше, чъмъ у близкихъ къ нему; bullae tympani болье удлинены и въ нижнеї челюсти processus coronoideus круче поднимается вверхъ, чьмъ у добентоновой летучей мыши. Я остановился на этихъ подробностяхъ строенія черепа потому, что въ большинствђ монографіï, какъ, напримъръ, у Méhely, Millais, Barret-Hamilton pбшительно нбтъ никакихъ указаній на эти детали. Къ сожалЖнію, въ моемъ распоряженіи былъ лишь незначительный матеріалъ. Ниже я даю измьренія имъю. цихся въ моемъ распоряженіи череповъ $L$. dasycneme Boie.

\begin{tabular}{|c|c|c|}
\hline $\begin{array}{c}\text { Черепъ } \\
\text { Leuconoë dasycneme Boie. }\end{array}$ & 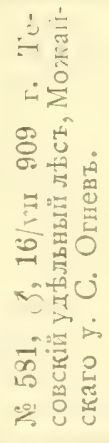 & 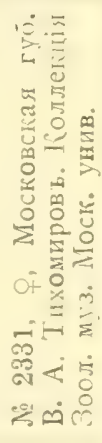 \\
\hline Наибольшая длпна . . . . . . . . . & 18,1 & 17.9 \\
\hline Скуловая ширнна . . . . . . . . . . . . & 12 & 12 \\
\hline 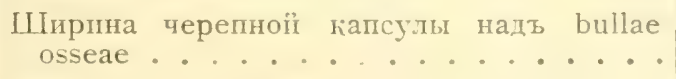 & 10 & 10 \\
\hline Ширина межглазничнаго промежутка . . . & 5,7 & 5,5 \\
\hline ШІпрнна черепа впереди оро́ить . . . . . & 6,8 & 6,5 \\
\hline Длина верхняго ряда зуобовъ . . . . . . & 6,6 & 6,7 \\
\hline
\end{tabular}


Зуби. Тпцательный пересмотръ моихь экземпляровъ показаль мн\% нЖкоторыя различія строенія зубовъ сравнительно съ описаніемъ ихъ въ книгы Блазіуса (27, p. Iо3-го4). По этому автору второй (внышніï) рђзецъ верхнеї челюсти равенъ выши-

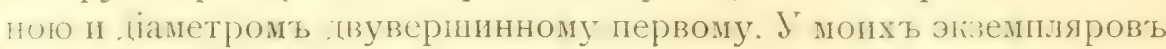
второї рћзець замьтно ниже перваго, но діаметрь его замьтно больше, чћмъ у сосьдняго рьзца. Изъ двухъ переднихъ одновершинныхъ ложнокоренныхъ зубовъ верхней челюсти второй не достигаеть половины длины перваго, много тоньше его и далеко оттьсненъ въ глубину зубного ряда.

По Блаз іу су, вершина этого зуба доходить толыю до передняго края коронки сльдующаго за нимь третьяго ложнолоренного. Указанный признакъ врядъ ли точенъ, такъ какъ у одного изъ моихъ экземпляровъ вершина второго ложнокоренного зуба замьтн выше коронки сльдующаго за нимъ третьяго.

Наконецъ, по Блазіусу, второй ложнокоренної нижней челюсти только немного ниже перваго, - у моихъ экземпляровъ разница въ ихъ вышинь была очень рызка, тогда какъ діаметры мало отличались другъ отъ друга.

По характеру 7-ми нёо́ихо складоко̃ L. dasycneme Boie очень напоминаетъ предыдушій видъ. Различіе скрывается только въ строеніи второй складки (спереди) $\left.{ }^{1}\right)$. У $\boldsymbol{l}_{\text {. }}$ dasycneme на ней не замғтно передняго дугообразнаго вдавленія и форма ея напоминаетъ скор Łе таковую у Myotis mystacimus Kuhl.

$У_{x 0}$, будучи перегнуто впередъ, въ большинств сл случаевъ не доходить до конца носа. Вершина козелка наклонена виятрь, такъ что его обиая форма приб́лижается къ серпообразной. Эта јориа является исключительной особенностью среди представителей рода Myotis.

Oкраска. Къ сожальнію, въ моемъ распоряженіи былъ очень незначительный матеріаль, но п ть нћсколько экземпляровь, которые я впгьћль, доказывають присутствіе обширныхъ варіацій въ

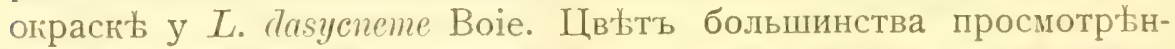
ныхъ особеї изъ Московской, Орловскої и Костромскої губерній быль таковъ: верхняя часть головы и вся спина покрыты довольно длинными волосами, темно-бурыми у основаній и съ коричнево-сћрыми окончаніями. У нбкоторыхъ особей концы волось замғтно свътлье, при чемъ ясно замьтенъ ихъ болье палево-сьрый оттьнокь. Волосы всей нижнеї стороны глуобокаго

1) Первої я называю ту, которая лежитъ между клыками, не считая обычно мало развитую, расположенную за передними рбзцамп. 


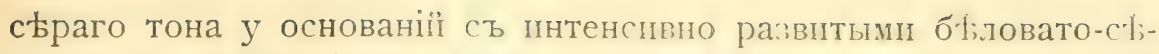
роватыми окончаніям. Цвыть летательой перепоки темно-сы-

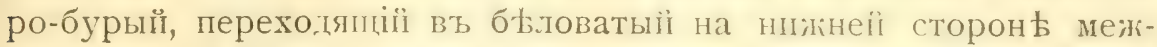
бедряної области. Уши обычно буровато-сьры, болtе свытлый оттынокъ заиьчается только у пхъ основаній. Описанная наиболье частая окраска напоминаеть 1. daubentonii Kuhl. Одинь московскій экземплярь, добытый. проф. В. А. Тих о и ровым ъ, рьзко отличается отъ цругихь своей свђтлой шерстью. Вся верхняя часть тьла этой мыши покрыта длинными двуцв屯тными волосами, которые у основанія темно-рыжіе, а у концовъ палевожелтые, съ болtе или менье развитымь сьроватым оттініомь. Волосы нижнеї стороны сьровато-буры у основаніиі и съ очень сильно развитыми б́ыловатыми концами. Уши, окружность губъ и подбородокъ свьтло-желтовато-палевые. Летательная перепонка палево-сђрая, сравнительно очень св бтлая. Въ межб́едряной области окраска дьлается еше свђтлье, переходя въ жіелтовато-бьлый оттынокъ. Ноги палево-желтыя. Этоть свытлый типъ окраски напоминаетъ таловой у M!jotis mystacimls Kuhl. Бы.то бы очень интересно выяснить на большемъ матеріаль, насколько часто онъ встрьчается у прудовой ночницы ').

Въ заключеніе приво жут таблицу изиьреній моихъ московскихъ экземпляровъ (см. сльд. стр.).

\section{Географическое распространеніе.}

До настоящаго времени наши свьдынія о распространеніи этого интереснаго вида еще очень далеки оть желанной полноты. Въ коллекции Зоологическаго Музея Моск. Јнив. имьются три экземпляра: одинъ изъ нихъ быль поїманъ въ Москв в во :дорь Павловской больницы проф. В. А. Тихоми ровы м, другойЕ. П. С окол о в м ъ на опытної паськь I. Р. Обц. Акклиматизаціи въ Нзмайловскомъ звьринць (бл. Москвы), наконецъ, третіiі :10быть въ Косины (бл. Москвы) въ іюнts г9г г. П. С. Г а ль ц о в м ъ и Н. Л. Чугуновым ъ. Мнь удалось застрьлить только два экземпляра въ Можайскомъ у. на р. Москвь, бл. Тесовскаго удъльнаго льса. Что касается до распространенія L. dasycneme Boie въ центральныхъ губерніяхъ Европейcroй Poсcin, то она добыта мною въ восточної часті Орловскої губ́, г.t нерt.ца въ Малоархангельскомъ у. Въ Харьковской гуо́. найдена $Н$. $\mathrm{H}$.

1) Проф. Н. Ө. К а ще н ко $(80$, стр. 21$)$ говоритъ, что „молодые окрашены свътлье старыхъ: спинная сторона у нихъ свђгло-бурая, брюшнаягрязно-бълая". Мої экземпляъ доказываетъ, что и среди старыхъ попадаются столь же свбтлыя особи. 


\begin{tabular}{|c|c|c|c|c|c|}
\hline $\begin{array}{c}\text { I:м lренія } \\
\text { Leuconoë dasycneme } \\
\text { Boie. }\end{array}$ & 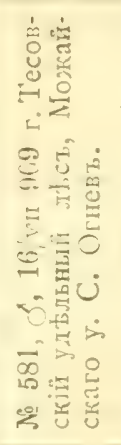 & 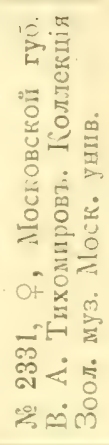 & 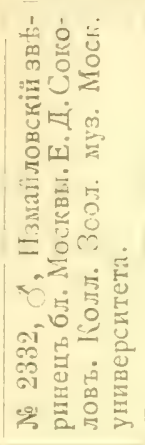 & 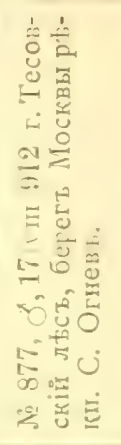 & 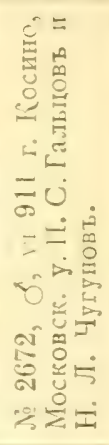 \\
\hline Длина тьла . . . . & 58,2 & 56,8 & 57,6 & 56,5 & 55 \\
\hline Наноохьшая длина уха • & 16,1 & 17,4 & 17.4 & 16,8 & 18,7 \\
\hline Козелокъ . . . . . & 7,4 & 8 & 8,2 & 7,6 & 7,3 \\
\hline Хвостъ $\ldots \ldots . . .$. & 43,9 & 50,2 & 49 & 48,2 & 46 \\
\hline Голень. . . . . . . & 20,6 & 22,1 & 21 & 21,8 & 21,4 \\
\hline Ступня безъ когтеї . . . & 11,7 & 12,5 & 12,7 & 11,9 & 11,7 \\
\hline Предплечье . . . . . . & 46,4 & 47,6 & 46 & 46,2 & 45,3 \\
\hline Размахъ ........ & 300 & 330 & or. 300 & 275 & 298 \\
\hline $\begin{array}{c}\text { Длпна основной фалангп } \\
\text { 5-го пальца } . . .\end{array}$ & 41,5 & 42,6 & 41,4 & 40,5 & 39,6 \\
\hline $\begin{array}{c}\text { Длина основної фаланги } \\
\text { 3-го пальца . . . }\end{array}$ & 44,9 & 45,5 & 43,6 & 41,9 & 43,3 \\
\hline
\end{tabular}

Сомовым ъ ( 84 , стр. I5 I, І52). Одинъ экземпляръ быль присланъ М. Д. Рузскимъ проф. Кашенко изъ Бугульминскаго у ьзда, Самарской губ. (8о, стр. 22). По словамь М. Н. Бо г дан о ва ( 3 о, стр. І6о), очень обыкновенна въ Казанскомъ и Лаишевскомь уу. Эверсманнъ находиль эту летучую мышь въ окрестностяхь Оренбурга и въ южныхъ предгорьяхъ У рала (49, p. 494). По С абан bеву ( I 48, стр. 2І6) встрьчается въ Каслинскомъ Ураль. Въ коллекціи Б. Д. Кирпичникова я видыль 4 экземпляра, добытые въ Ветлужскомъ и въ Варнавинскомь уу., Костромской губ. По словамъ В. Л. Біании (23, (тр. 208) встрьчается въ Петергофскомь у. Въ Прибалтійскихъ провинціяхъ, по свидьтельству Греве, добыта въ Лифляндіи (Grevé, 6 7, р. 32). По Т а а но в скому встрьчается Польшь. Кесслеръ говоритъ (88, стр. III), что прудовая ночница была 
имъ найдена въ большомъ количеств Б въ одної изъ крымскихъ пещеръ, именно въ Кизылъ-Кобь. А. М. Никольскій, провьрившій впосльдствіи опредьленіе проф. К е с сл е р а, нашель, что этотъ изсльдователь ошибочно опредьлиль за Lenc. dasycneme Boie типичныхъ Myotis myotis Bechst. (Tespertilio muinus Schreb. (nес Lin.!) въ работь Никольскаго) и описалъ ихъ даже подь новымъ именемъ - "Vespertilio submminus" ( 22 , стр. $40-4 \mathrm{I}$ ).

Свьдьнія о распространеніи $L$. dasycneme Boie въ Сибири еще очень скудны. По Н. $\Theta$. К а ц е н о (8о, р. 2І) два экземпляра этого вида добыты въ Toмckt, а Г. Э. І ог ан з е н нашель прудовую ночницу въ Кулундинской степи, Томск. губ., бл. дер. Чистозерской. По Брандту (3 3, р. 39) этотъ видъ быль добыть Геблеромъ на Алта'). Маакомъ ( со 2, стр. 95) найдены въ Енисейскомъ округь на рькахъ: Енашимо, Вангашь и Пить.

Что касается до распространенія описываемой формы въ Западной Европь, то она найдена, по Блазіусу, въ Даніи, близъ Ольценбурга, въ Ницерландахъ, въ Щвегін, б́л. Брауншвейга II въ Италіи. Dobson, (47, p. 296) отмбчаетъ L. dasycneme Boie для Пруссіи, Франціи, Венгріи и южной Англіи. Относительно нахожденія ея въ посльднихъ мьстностяхъ поздньйшіе авторы высказываются съ сомньніемъ. Такъ, M e h ely ( о о 4, p. 329), съ необыкновенной тшательностью изучившій 中ауну Chiroptra Венгріи, совершенно не нашелъ тамъ этой мыши. Если этоть видъ и встрђчается, то, повидимому, очень рьдко, и показаніе Мой си сович $\mathrm{a}^{1}$ ) о распространеніи прудової ночницы въ полось средняго теченія Дуная подлежитъ еще тщательної провьркь. Въ южної Англіп, каюъ показываютъ новыя наблюденія Бар рет в-Гамильтона, Leиc. dasycneme не встрьчается и указаніе Buckton ${ }^{2}$ ) надо считать ошибочнымъ.

Всльдствіе рьдкости этого вида, мнь не удалось сдылать надъ

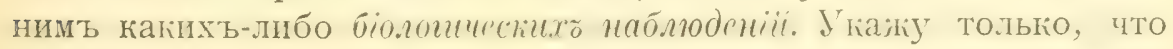
по образу жизни прудовая ночница очень напоминаетъ L. daиbentomii, подобно посльдней она вылетаеть на добычу съ наступленіемъ. темноты и обычно быстрымъ и неправильнымъ полетомъ носится надъ самой поверхностью воды.

Экземлляры коллекиі перечислены въ таблиць измьреній.

1) Mojsis ovics, Die Tierwelt der Österr-Ungar. Tiefebenen. Wien, 1897, p. 152,148 .

2) Proceedings Linnean Society of London, 1853, p. 260. 


\section{Родъ Plecotus Et. Geoffr.}

1816. Mracvotus, W. E. L e a ch, Systematic Catalogue of the Specimens of the Indigenous Manmalia and Birds that are preserved in the British Museum, I. (Основань на: Mracrotus europaens $\mathrm{L}$ e a $\mathrm{c} \mathrm{h}$-nomen nudum).

1818. Plecotus, Etienne Geoffroy, „Description des Mammiferes qui se trouvent en Egypte, II, p. 112, 118-119, pl. II, .oㅡ 3.

Этоть родъ настолько рҺзко отличается отъ всьхъ описанныхъ, что :ля харалтеристики его достаточно очень пороткаго описанія.-Огромныя уши, срощенныя на лбу, по :линь своей только немного уступаетъ длины предплечья. Козелокъ очень цлинный и широкій, суживается къ концу и близъ своего основанія, снаружи снабженъ зубовихнымъ отросткомъ. Нозтри открываются наружу на концы носа, а на верхней его части замьтны углубленія, соегиняюшіяся съ наружными отверстіями ноздреї, что придаетъ посль:нимъ удлиненную, слегка бисівитообразную форму. Крылья очень широкія, крыловая перепонка снаружи доходить до основанія пальцевъ. Эпиблема не развита. Зубная формула такова:

$$
\text { i } \frac{2-2}{3-3}, \text { c. } \frac{I-I}{I-I}, \mathrm{pm} \cdot \frac{2-2}{3-3} \mathrm{~m} \frac{3-3}{3-3}=36 .
$$

\section{Plecotus auritus (L.).}

\section{Ушанъ.}

Vespertitio auritus, C a rolus Linna e $\mathrm{s}$ (98), p. 32. Plecotus auritus L. Blasius (27), p. 39, Dobson (47), p. 178. Trouessart (201), p. 104 II Supplementum, 1904, p. 75. (200), p. 12, M éh ely (104), p. 138. Mill a is (110). Barret-Hamilton (16), p. 194. Сатунин (165), стр. 3 и (166), гтр. 3.

\section{Систематическія особенности.}

Череио ушана (Таб. 1, рис. 3, 4) по общеї нонфигураціи пре:ставляетъ очень много интересныхъ и своеобразныхъ чертъ, на-

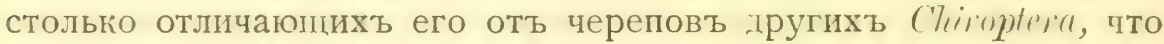
. іагнозъ скелета дьлается крайне легокъ при самомъ общемь знакомствь съ краніологіей этой интересной летучей мыши. Прежге всего я могу отмьтить необычайное развитіе bullae osseae, что, вмьсть⿱⺊口灬 съ сильної приполнятостью теменныхъ и затылочныхъ костсї, обусловливаетъ собою очень рызкій контрастъ въ развитіи

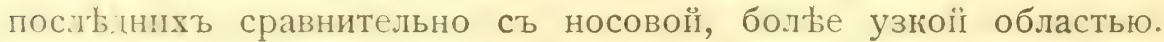
Далье, тf же bullae посажены очень далеко впередъ, т. ч. затылочная кость, если смотр‡ть на нее въ профиль, выдвигается 
своимъ залнимъ контуромъ далеко назаль по сравненію съ тыльными закругленіями bullae osseae. Своеобразна также большая приподнятость frontalia и parietalia по сравненію сь затылочной областью. Что касается до носовыхъ костей, то, какъ было уже сказано, онь значительно ниже сльдующихъ за ними лобныхъ, но згьсь необходимо отмђтпть сльгующую особенность.- У большинства описанныхъ формъ лобныя кости довольно ціруто по:нимались надъ областью nasalia, здћсь мы видимъ иное: уголь подъема болье пологіи, а самыя nasalia y носового отверстія образують замтный вь профпль гребень, за lопм слћіуеть вогнутость, говольно постепенно переходящая въ прпподнятость frontalia. Въ заключеніе два слова о формь скуловыхь дугъ. У этого вида онь тоже рђзко отличаются отъ всьхъ описанныхъ, приближаясь кь тому, что мы вицимь у рода likim/ophıs. Іменно, можно констатировать замьтный отростокь, сцвинутый

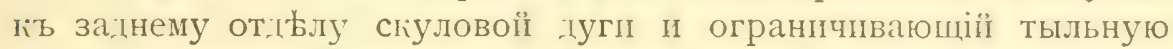
часть глазницы. Шнтересно отмытить очень рђзіую разницу по-

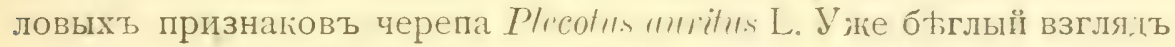
на серіи череповъ показываетъ, что черепъ самии заньтно длиннье такового у самца. Особенно удлинена у самии теменная и затылочная область, которая у самцовъ, напротивъ, много короче. Lалье, ossa frontalia самцовь болье высољо полнимаетя наль носової областью. Межглазничная ширина самоюь въ ныґоторыхъ случаяхь болье сужена, тогда какъ область черепа впереди орбитъ шире, чьиъ у самцовъ. Нанонецъ, цина верхняго зубного ряда у самки замьтно больше ${ }^{1}$ ).

Зубъ. Что касается ихъ строенія у Plecotus auritus L., то описанія Блазіуса и Добсона весьма точны и самый тщательный обзоръ лишь немного можетъ прибавить къ уже извюстному. По Блаз іу су (2 7, p. 39-40) нижніе рьзцы расположены по линіи челюстної кости. Просматривая свої : овольно значительный матеріаль, я могъ констатировать въ большинствь случаевъ рьзкое, параллельное по отношенію другъ ћъ чругу расположеніе этихъ зубовъ. Во всемъ остальномь указанные Блазіусомъ признаки совершенно подходили гі моимъ экземплярамъ.

Нёбиия скиади съ большою тшательностью изображены въ прекрасной монографіи Méhely. Въ строеніи ихъ особенно

1) Считаю нужнымъ отмьтить, что ть промьры череповъ венгерскихъ экземплровъ, которые даетъ въ своей монографіи $\mathrm{M}$ é h ely, заиьнно иенвие полученныхъ мною на московскомъ матеріаль: длина черепа $=15,5 \mathrm{~m} / \mathrm{m}$, напб. ширпна $=8,5$, жежглазничный промежутокъ $=3,5(104$, р. 327). 


\begin{tabular}{|c|c|c|c|c|c|c|}
\hline 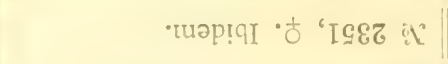 & $\stackrel{9}{5}$ & $\vec{\theta}$ & $\vec{a}$ & के & $\overrightarrow{15}$ & $\begin{array}{l}\infty \\
\text { in }\end{array}$ \\
\hline 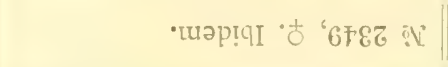 & $\stackrel{ \pm}{ \pm}$ & $\infty$ & an & サ & 150 & $\infty$ \\
\hline 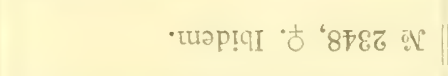 & $\vec{E}$ & co & $\stackrel{\infty}{\infty}$ & $\stackrel{01}{7}$ & $\equiv$ & $=$ \\
\hline 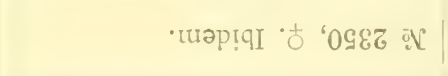 & $\stackrel{0}{=}$ & $\stackrel{\ddot{g}}{\ddot{g}}$ & 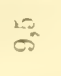 & $\stackrel{63}{7}$ & $\begin{array}{l}61 \\
150\end{array}$ & 15 \\
\hline • น & $\hat{B}$ & $\begin{array}{l}\infty \\
\infty\end{array}$ & c & es & 25 & 5 \\
\hline • uәр!qI $\&$ 'ct8z & $\stackrel{\infty}{\varrho}$ & $\stackrel{\dot{U}}{\tilde{U}}$ & $\ddot{\infty}$ & $H$ & $\begin{array}{l}\mathrm{ON}_{\mathrm{f}} \\
25^{\circ}\end{array}$ & $\sqrt{10}$ \\
\hline 'uәp!̣I $\bullet$ & $\varrho$ & $\infty_{\infty}^{\infty}$ & $\infty$ & $\rightarrow$ & $\ddot{\sigma}$ & $\stackrel{0}{10}$ \\
\hline 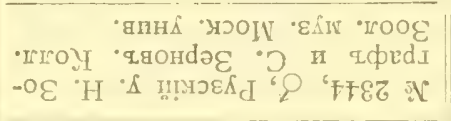 & $\overbrace{0=1}^{c 2}$ & $\infty^{\infty}$ & $\tilde{\infty}^{\infty}$ & $=$ & $\stackrel{\infty}{\forall-i}$ & 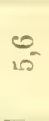 \\
\hline 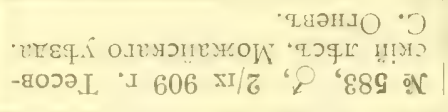 & 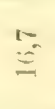 & 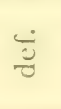 & $\Xi$ & - & is. & 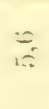 \\
\hline 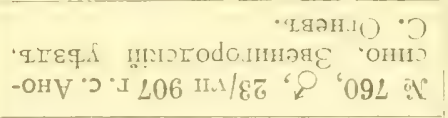 & $\overrightarrow{0}$ & $\bar{a}$ & $\because$ & 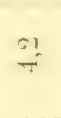 & $\dddot{-}$ & 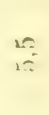 \\
\hline 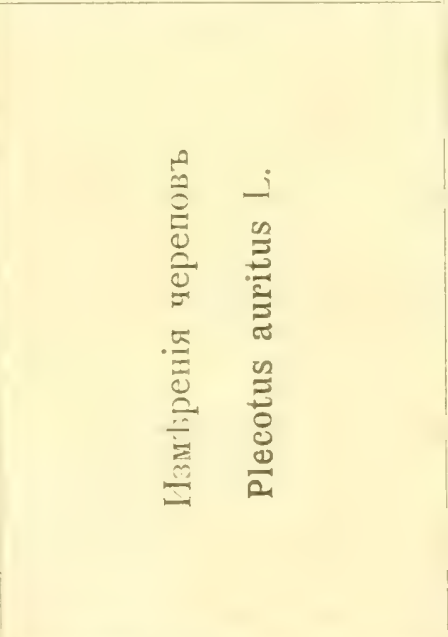 & 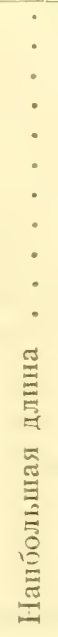 & 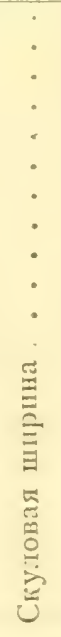 & 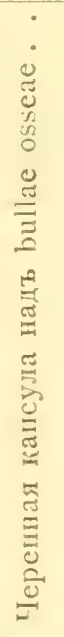 & 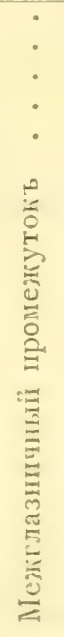 & 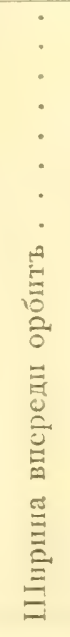 & 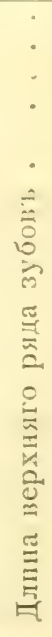 \\
\hline
\end{tabular}


интересна первая, лежашая между клыками. Эта складка, совершенно прямая спереди, съ очень замьтнымъ языюовиднымъ вы-

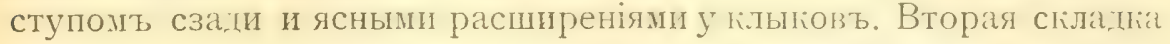
глубоко вогнута спереди и очень слабо сзади. Далье идутъ 4 разобщенныя складии, изъ поихъ каждая имьетъ форму полудуги, а самая посльдняя, седьмая, - форму тупого угла, своей вершиної направленнаго назатъ.

Уии и козелоко подробно описывались прежними авторами, но я считаю здьсь необходимымъ подробнье остановиться на разсмотрбніи ихъ строенія. Дьло въ томъ, что нысіольо авторовъ пытались по строенію ушей и козелка устанавливать новые виды. Такъ, напримьрь, L e on a rd J enyns въ „Trans. of Linn. Soc. of London" описаль новый видъ, давши ему имя Pl. brevimamus ${ }^{1}$ ).

Краткій діагнозъ этого вида по Jenyns таковъ: „P. velleve supra rufo-fusco, subtus albescente, anviculis oblongis, capite haud duplo longioribus; trago ovato-lanceolato; caude antibrachim aequanti, apice acuto $\left.{ }^{2}\right)$.

Какъ мы увидимъ ниже, ограска ушана подвержена грайне сильнымъ варіаціямъ и не можеть служить надежной основой для видовой дифференцировки. Что касается второго признака о со-

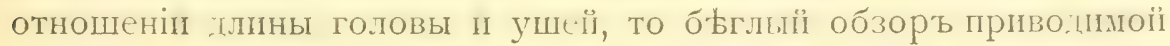
таблицы измьреній ушановъ изъ одной и той же мьстности сразу показываетъ необычайную пластичность этого отличія. Ушаны изъ Московскої губерніи по этому прнзналу : гожны быть отнесены частью къ „brevimanus", частью къ типичному „quitus". Вьроятно, г. Барреть - Гамильтонъ правъ, говоря; что Јеnyns описаль своего „brevmams" по молодому экземпляру обычнаго ушана, въ чемъ особенно убъждаешься при разсматриваніи таблицы, приложенной къ работь посльгняго автора (табл. I, fig. 2).

Значительно позднъе Jenyns, Бона парте въ своей монографіи итальянскихъ млекопитающихъ даль рисуноюь Pl. brevimamı (несомньнно взрослаго экземпляра) и болье подробный діагнозъ ${ }^{3}$ ). Изъ приводимыхъ признаковъ полная несостоятель-

1) L. Jenyn s: The distinctive Characters of the British Species of Plecotus, supposed to have been confounded under Name of Long-eared Bat. Trans. of Linn. Soc. of London, vol. XVI, 1828.

2) 1. c. p. 55 .

3). C a r lo B o n a p a r e: Iconographia della Fauna Italica, Tomo I, Roma, 1832-1841, p. 96, tab. fig. 2. Діагнозъ таковъ: „P. auriculis capite minus duplo ongioribus, trago longiore dimidio auriculae, ejusque latitudinem excedente; 
ность главнаго-соотношеніе длины головы и уха мной уже была разобрана. Что касается до двухъ новыхъ, то одинъ изъ нихъ, по гіоеу предплечье и хвость по длинь превышають ухо, щ’ликомъ подходить къ нашимъ ушанамъ, а второй, что длина liозеліа болlс ширнны уха, не у:лалось қонстатировать ни у оцного экземпляра. Это, въ сущности, единственное отличіе такъ наз. "brevimams" отъ $P$. auritus L., и Кащенко, готорый своихъ алтайскихъ ушановъ отнесъ къ „brevimams“ Вр., говоритъ, что этого признака ему не удалось отмьтить. (8 I, стр. I I.)

Думается, что я врядъ ли ошибусь, считая $P$. Wrevimams Jen. et Bonap. лишь за синонимъ $P$. auritus L.

Oжраска. Проглядывая серіи ушановъ, я могь установить два хорошо дифференцированныхъ типа окраски. Во-первыхъ, мы имъемъ передъ собою Plecotus, вся верхняя часть тьлакоторыхъ покрыта длинными сырыми волосами съ болье или менће выраженнымъ бурымъ и палевымъ оттьнкомъ. Основанія волосъ знаqительно темнъе, интенсивнаго сыраго тона. Эта окраска становится свьтлье на спинної сторонь лишь у основанія ушей и на верхней части междебряной перепонки, основаніе коей покрыто рьдкими волосами. Нижняя сторона много свђтлье: здьсь волосы у ихъ корней съро-буроваты, но окончанія довольно свђтлаго бьлесаго тона. Летательная перепонка темносьро-бураго цвћта, который значительно свьтльеть на нижней части межбетряной области. Уши свътло-сьрыя у концовъ и бьловатыя у основаній, козелокъ и окружность губъ бћловатые, съ болье или менъе выраженнымъ сьроватымъ оттьнкомъ. Ко второму, болье яркому типу окраски, относятся особи, вся верхняя часть тьла которыхъ покрыта свћтлыми ржаво-палевыми волосами, болье темными у основаній и свьтлыми у концовъ. Нижняя часть тьла свьтло-палево-сьрая сь ярко дифференцированными темно сњрыми основаніями волосъ. Летательная перепонка очень свютлая, рыжевато-сьрая, переходящая въ желтоватую снизу межбедряной области. Уши, козелокъ, окружность губъ свьтло-палево-желтые. По словамъ Добсона (47, р. І79), молодые индивпдуумы, а, выроятно, и самки много темнl: старыхъ самцовъ. На это замьчаніе ссылается и Б а р р е т ъГ а м и ь тон ъ въ своей посльдней монографіи ( с 6, p. I96). Тщательный просмотръ : овольно большихь серій ушановъ не только 11з7. Московской губ., но и изъ многихь мьстъ Россійской имперін,

antibrachio et cauda auriculas valde superantibus, quinto digito parum brevioribus; vellere griseo rufescenti; subtus albicante, pilis basi tantum fuscentibus; membranis rufercentibus:. 
показаль мнь, что эта летучая мышь подвержена очень большимъ грасочнымъ варіаціямъ, два главныхъ типа которыхъ были мною сейчасъ описаны. Здћсь же я особенно подчеркваю, что видыль старыхъ очень свьтлыхъ самокъ, еще болье свьтлыхъ, чьмъ самцовъ соотвьтствующаго возраста, а также то обстоятельство, что многіе изъ изсльдованныхъ мною молодыхъ были очень свьтлы и вовсе не „much darker", какъ пишеть Добсон ъ.

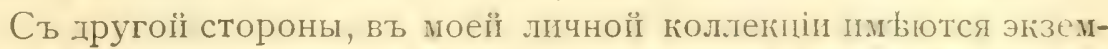
пляры старыхъ самцовъ (추 760) очень сьрої и темної окраски.

Разильрь: ГІз приводимыхъ таблицъ пзм Бреній ясно можно видћть, что самки крупнње самцовъ, при чемъ особенно рьзко отличаются онь оть посльднихь длиною предплечья и размахомь. (См. табл. А. и В.).

\section{Географическое распространеніе.}

Въ предьлахъ Московскої губ. ушанъ всюду очень обыкновененъ,-у меня им вется матеріаль пзъ Звенигородскаго уызда (с. Аносино), Можайскаго у. (бо. с. Тесова), Рузскаго и Подольскаго (с. Валуево). По словамъ К. А. Сатунин а, эта мышь очень обыкновенна во всей губерніи. Ее часто ловили на чердакахъ въ самої Mоскв b, напримьръ, въ зданіи ІІолитехническаго Музея. Въ ІІмайловскомъ Звьринць ушанъ, по Сатунину, водится въ грома:номъ количеств' на пасыћ въ зданіи дворца. Въ центральныхъ губерніяхъ онъ найденъ Эсауловы м ъ 5 8, стр. 223) въ Псковской губ., П. С. Г а ль ц в ы м-въ Дорогобужскомъ у. Смоленской губ., С. Н. Горбачевымъ и мною въ Орловскомъ, Болховскомъ п Малоархангельскомъ уу. Орловской губ. Д.я Харьковскої губ́. его помђчаеть проф. Чернай (2о3, стр. 8) и Н. Н. Сомовъ (І 84, стр. І5I), для Кіевской $\mathrm{Ke} \mathrm{еслеръ} \mathrm{и} \mathrm{Belke.} \mathrm{Въ} \mathrm{Украйны} \mathrm{ушанъ} \mathrm{най-}$ денъ Блаз і у сом ъ; около Аккермана - А. А. Бр ау н ером ъ, близъ Каменецъ-По:ольска-Belke. Далłе на югћ онь добыть

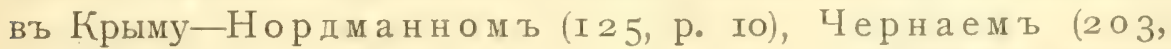
стр. 8), К е с л ером ъ, Браунером ъ (39, стр. 87). Восточнђе этоть видъ встрбчается въ области Поволжья (Богданов ъ), въ губерніяхъ: Саратовской (Иконниковъ), Симбирскоп̆ ( К и тковъ), Казанской, Оренбургскої и предгоріяхъ Урала (Э в ер см аннъ, 49, стр. 5³; 3 ар удны й, 7 7, стр. 364; С абан ьевъ, І 48, стр. 2І6). Сьвернье найденъ: въ Вятскої губ. (Сарапульскій, Малмыжскій, Іржумскій уу. Л. Кру ликовскій 93, стр. г86), въ Петербургской губ. и Финляндіи (Бі ан ки), при чемъ, по Ге ор ги, ушанъ въ своемъ распростра- 


\begin{tabular}{|c|c|c|c|c|c|c|c|c|c|c|}
\hline 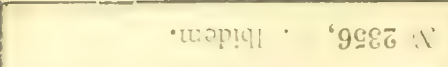 & $\stackrel{0}{0}$ & $\underline{5}$ & ణิ & $\overline{\underline{x}}$ & $\stackrel{\infty}{\sim}$ & $\overline{250}$ & $\cong$ & $\infty^{-1}$ & 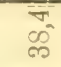 & $\bar{S}$ \\
\hline 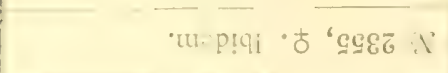 & $\stackrel{a}{\square}$ & $\underline{\infty}$ & $\begin{array}{l}\vec{J} \\
\tilde{\omega}\end{array}$ & $\stackrel{x}{*}$ & $D^{\infty}$ & $\bar{z}$ & $\overline{\tilde{\varepsilon}}$ & $\infty^{\infty}$ & $\underset{\infty}{\infty}$ & เ \\
\hline 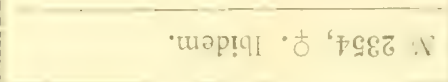 & $\underset{30}{10}$ & $\underset{\vec{\infty}}{\vec{\sigma}}$ & लं & is & $\stackrel{2}{=}$ & $\underset{\vec{J}}{\vec{f}}$ & ลิ & $\bar{\theta}$ & $\stackrel{0}{\infty}$ & 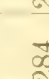 \\
\hline 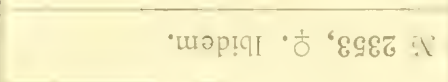 & $=$ & $\stackrel{5}{E}$ & 5 & $\underline{\tilde{g}}$ & $\stackrel{\infty}{\infty}$ & $\frac{6}{7}$ & $\stackrel{20}{i}$ & $\ddot{0}$ & $\underset{\sigma_{0}^{2}}{\tilde{c}_{0}}$ & iे \\
\hline 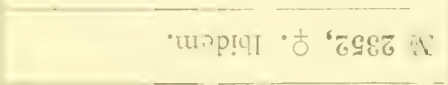 & $\overrightarrow{75}$ & $\stackrel{a_{1}^{1}}{\infty}$ & $\begin{array}{l}\infty \\
1 \\
6 \\
6\end{array}$ & $=$ & $\overline{0}$ & $\stackrel{\vec{\rho}}{\tilde{\sigma}}$ & $\begin{array}{l}0 \\
0 \\
0 \\
\text { in }\end{array}$ & $\begin{array}{l}\infty \\
\infty^{-}\end{array}$ & $\stackrel{\infty}{\infty}$ & 난 \\
\hline 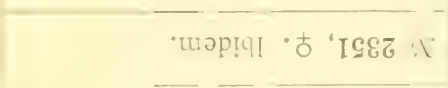 & $\frac{15}{12}$ & $\infty_{-\infty}^{\infty}$ & $\begin{array}{l}\bar{N} \\
\tilde{\infty}\end{array}$ & 5 & $\stackrel{50}{5}$ & 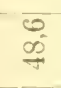 & $\overline{\bar{j}}$ & $\stackrel{50}{=}$ & $=$ & $\frac{a}{2}$ \\
\hline 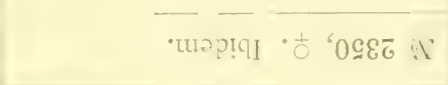 & $\underline{\pi}$ & $\overline{D^{-}}$ & $\frac{62}{60}$ & $\stackrel{x}{=-1}$ & $\infty_{-\infty}^{\infty}$ & $\begin{array}{l}\infty \\
\delta_{1}^{\infty}\end{array}$ & $\overline{0}$ & $\overline{-}$ & $\begin{array}{l}-15 \\
5\end{array}$ & हू \\
\hline 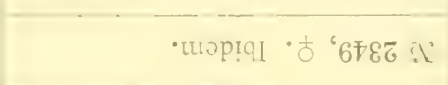 & $\underset{\infty}{\infty}$ & $\cong$ & $\vec{E}$ & 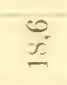 & $\stackrel{62}{=}$ & $\frac{15}{15}$ & 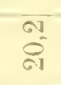 & $\bar{\sigma}$ & $\overbrace{0}^{\infty}$ & हू \\
\hline 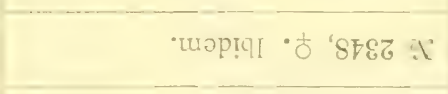 & $\frac{\pi}{\pi}$ & $\stackrel{\infty}{\infty}$ & कs & $\overline{\tilde{a}_{1}}$ & 음 & $\frac{\sqrt{20}}{50}$ & $\stackrel{a}{a}$ & 0 & 악 & a \\
\hline 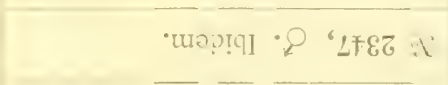 & क् & $\stackrel{5}{\Xi}$ & $\stackrel{20}{90}$ & $t=$ & $\underbrace{20}_{-6}$ & $\stackrel{\square}{\rightrightarrows}$ & $\stackrel{\text { बू }}{\varrho}$ & $\bar{\sigma}$ & $=$ & $c$ \\
\hline -unp!q1 'P ' $9+86: 1$ & $F$ & $\stackrel{\infty}{2}$ & $\overline{\mathbb{D}^{-}}$ & $\stackrel{?}{\infty}$ & 201 & $\stackrel{\bar{c}}{a}$ & $\infty$ & $\bar{\infty}$ & Sి & ic \\
\hline 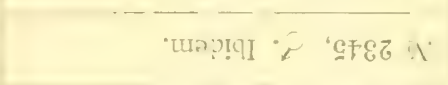 & $\stackrel{i}{-}$ & $\stackrel{G !}{=}$ & 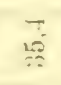 & 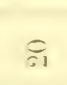 & $\overline{\dot{y}}$ & $\stackrel{\curvearrowright}{\leftrightarrow}$ & $\hat{\ddot{E}}$ & se & $\because$ & 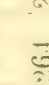 \\
\hline 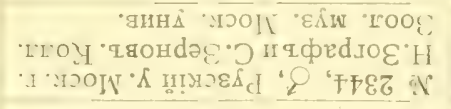 & $\stackrel{5}{\rightarrow}$ & $\underline{x}$ & $\underset{\vdots}{\vdots}$ & 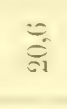 & 15 & $\cong$ & $\stackrel{1}{x}$ & $\begin{array}{l}31 \\
x \\
x\end{array}$ & 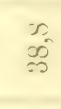 & $\frac{x}{19}$ \\
\hline 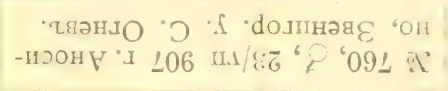 & $\ddot{=}$ & $\vec{y}$ & $\stackrel{2}{\because}$ & $\bar{E}$ & $\underline{\Xi}$ & $=$ & 15 & 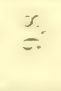 & 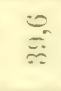 & 5 \\
\hline 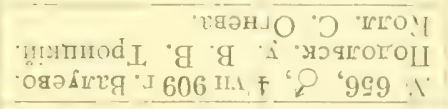 & $\stackrel{5}{-i}$ & ! & $\begin{array}{l}\because 1 \\
\therefore \\
\therefore 0\end{array}$ & $\cong$ & 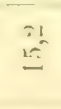 & $\cong$ & $\tilde{\tilde{s}}$ & $\begin{array}{l}3 ! \\
x\end{array}$ & 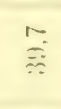 & 3 \\
\hline 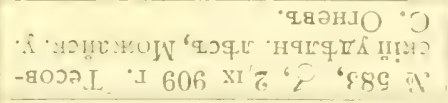 & 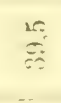 & & $\ddot{n i}$ & $\stackrel{1}{1}$ & $=$ & $\begin{array}{l}\because ! \\
\ddot{x}\end{array}$ & $\stackrel{s}{\Xi}$ & $\begin{array}{l}15 \\
y\end{array}$ & $\stackrel{\ominus !}{\ddot{*}}$ & $\Xi$ \\
\hline 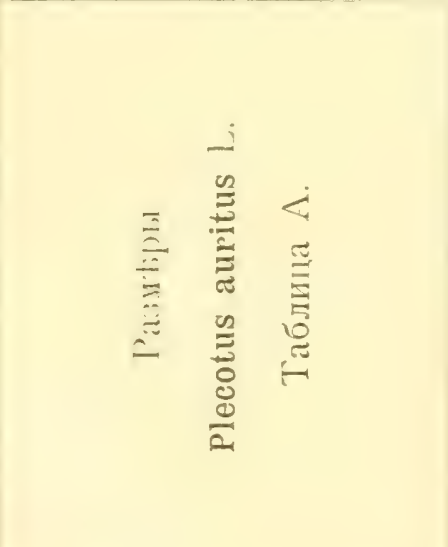 & 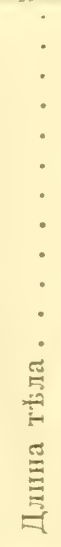 & 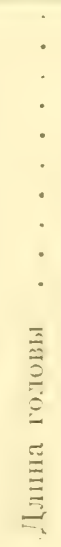 & 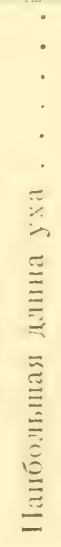 & 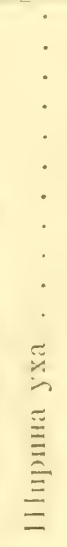 & 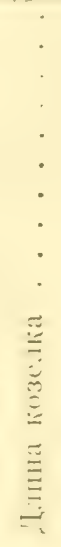 & 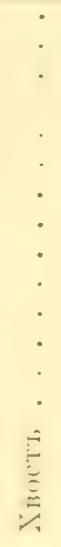 & 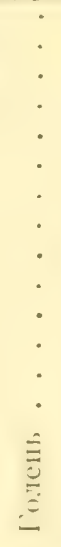 & 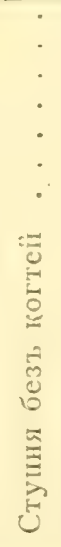 & 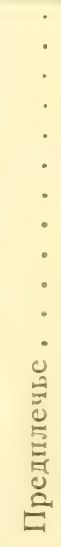 & $=$ \\
\hline
\end{tabular}




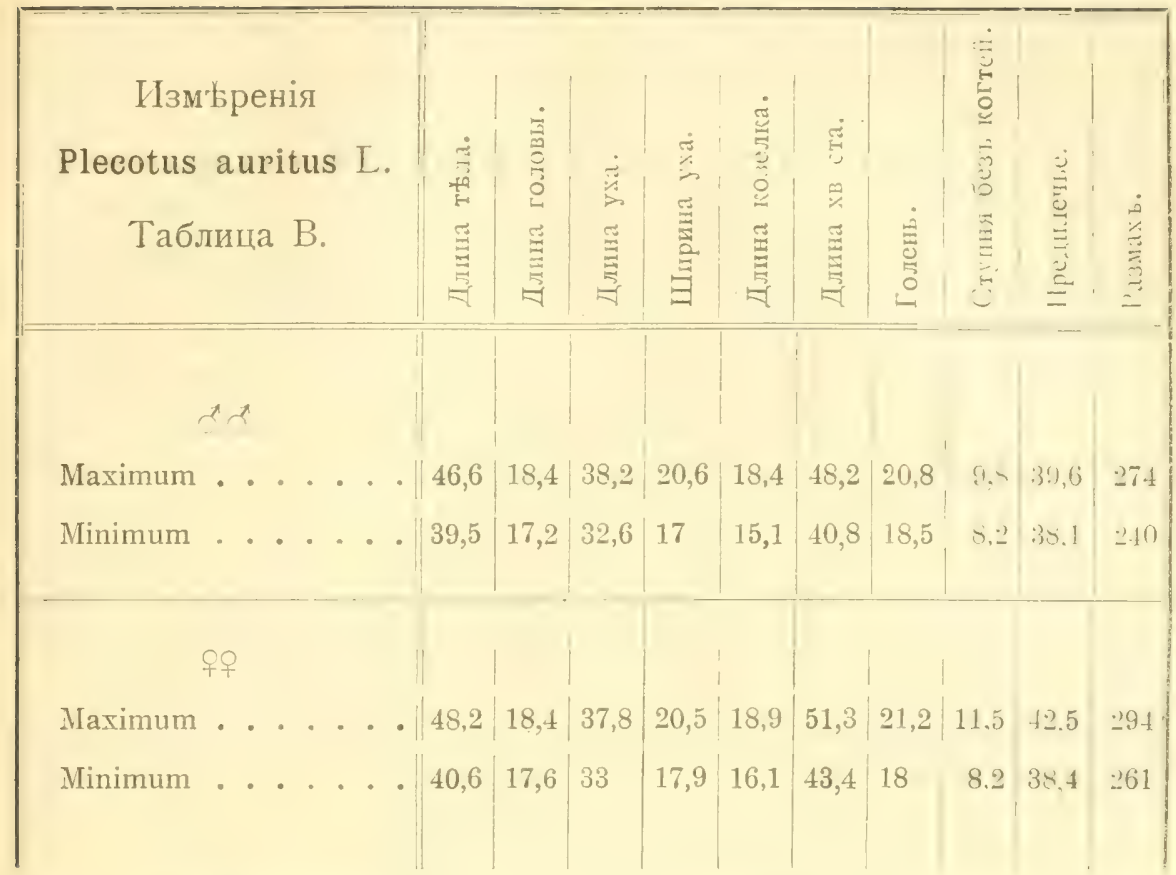

неніи доходить до $62^{0}$ c. ш. Въ остзейскихъ провинціяхъ найденъ въ Лифляндіи и Эстляндіи Ассмусом (см. Brandt, 33, р. 40), въ Курляндіи Лихтештейномъ. На Кавказь ушанъ добытъ С атунинымъ въ центральномъ и западномъ Закавказьь (Горіӥск. у., Боржомъ, Бакуріаны, Караклисъ, Сухумь).

Свьдьнія о распространеніи Plecotus auritus L. въ Сибири не очень многочисленны. По словамь П лласа (І 30, р. I24), ушанъ встрьчается въ южной Сибири (безъ точныхъ указаній мбстности). Словцов и имлљ экземпляры изъ Тюменскаго округа Тобольской губ. По словамъ Бр ан д та (33, p. 40), встрычается въ Алтайскихъ горахъ до китайскої границы (См. Э в е р сманнъ, Геблеръ). Проф. Н. Ө. Кащенко добыль одинъ экземпляръ около Уймона въ центральномъ Алтађ. Этотъ же авторь упоминаетъ объ Plecotus auritus L. съ р. Чуи на Алтаь и изъ Тарбагатая, прибавляя, что ему былъ присланъ ушанъ изъ Красноярска. Н. А. С Б в е р цо в ъ нашелъ этотъ видъ близъ г. Вьрнаго и Ходжента. Посльдній экземплярь быль описанъ какъ новый видъ „P. leucopleaens Sev.", впосльдствіи причисленный въ спнонимы обычнаго ушана. Наконецъ, проф. К а щенко упоминаетъ объ экземплярь отъ г. Недзв пцаго изъ гор. Вьрнаго. Восточнье ушанъ най:енъ близъ Верхнеудинска, олочо Селенги (Поповым ), въ Аянь (Вознесенскимъ), на 
Kanчаткы (Стелле ромъ), на Яблоновомъ хребтћ (Р адде). III ренгъ добыль эту мышь близъ Бай-Хаджи (въ Татарскомъ пролив' $49^{\circ}$ ), М а ак ъ-въ Нерчинск на южномъ Сахалинь. Южнъе Гр м ъ-Гр жимайло наблюдаль $P$. auritus L. на хребть Богдо-Ола между Урумчи и Гученомъ), Scully-въ Гильгить', B lan for d-въ Ладаг't. На Европеїскомъ матерпић онъ встрђчается, начиная отъ Великобрлтаніи и Скандинавіи, по всей Германіи, Франціи, Нталіи, Далмаціи, Венгріи до Сициліи и Испаніи, а, еще далье на югъ,

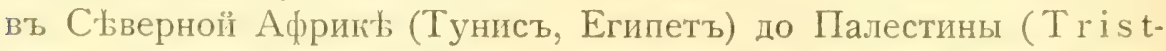
ram). Кромь того, ушанъ распространенъ отъ Гималаевъ (Dobson) на востокъ до Хоккаидо (Old. Thomas) и на югъ до Остъ-Индіи. За посльднее время было описано ньсіолько географическихъ формъ.-Такъ, въ Ладакь и Кашмирь былъ найденъ особый видъ Plecotus wardi Thom.; въ Гималаяхъ-Plecotus homochrous Hodgs., который уже давно установиль Hodgson, но который лишь не:авно выведенъ изъ синонимовъ; въ сыверной Индіи-Pl. pucl Barr.-Нам.; въ Таціенлу и Се-Чуань- $P$. ariel. Thom.; въ Японіи-слабо дифференцированный-P. anvitus sacrimontis Allen; въ Египть-P. clivistiei Gray.

\section{Образъ жизни.}

Наши свьдынія о біологическихъ особенностяхъ этого вида, къ сожальнію, до сихъ поръ еще очень скудны. Онъ придерживается почти исключительно старыхъ построекъ, собираясь на чердакахъ, часто очень большими обществами. На добычу ушань вылетаеть очень поздно-обычно при наступленіи полної темноты. Полеть его быстрый, но неровный, онъ то кружится довольно высоко, то спускается почти къ самой земль. По Сатунину, Plecotus mitus L. летаеть до самаго разсвьта. Весною его можно видьть со второй половины апрьля, осенью посльднія особи исчезають въ серединь сентября, скрываясь въ своихъ зинихъ уб́ьжишахъ. К. А. Сатунинъ наблюдалъ одного ушана I9. IX. I892 г. Мнь не приходилось держать этоть видъ въ неволь, но, по словамъ большинства изсльдователей, онъ отличается характернымп свойствами,: крайне подвиженъ и прожорливъ. Нивwie у К. А. Сатунина экземпляры ловко ловили мухъ, бабочекь и другихъ наськомыхъ, которыхъ имъ бросали въ кльтіу.

Экзелиляри коллекии перечислены вь таблиць измьреній. 
Оканчивая отрядъ летучихъ мышей, я считаю нужнымъ дать таблицу для опредьленія московскихъ (lirpteя, составленную на основаніи изсльдованнаго матеріала. Это тьмъ болье важно, что діагнозы въ такихъ работахъ, какъ классическая монографія Бла з і у са. или "Catalogue of Chiroptera" Д о б со на составлены по западно-европейскимъ экземплярамъ и потому не вполнь подходять къ нашимъ средне-русскимъ.

То же надо сказать и о работь проф. Н. Ө. Кащенко, им твшаго подъ руками главнымъ образомъ сибирскій матеріаль ${ }^{1}$ ).

А. Ушигораздокорочепредплечьяи несрошены на л л бу.

I. (II.) Уши короткія, широкія, будучи прижаты къ голов' обыкновенно не доходяпғ до кония иоса. Внутренній қонтуръ уха выдается впередъ глубоко выюллою дугю, полукруглый, загнутый внутрь край которой оканчивается приблизительно на середип длииь козелка. Внутренній контуръ посльдняго волнутый, вершина его отклонена виутрь (впередъ). Шпорный лоскутъ фб́ичио ясио развито.

Pm. $\frac{2-2}{2-2}$ или $\frac{I-I}{2-2}$.

Роды: Nyctalus, Vespertilio, Pipistrellus.

I. (2.) Козелокъ булавовидной формы и достигаетъ наибольшей ширины выше своей середины. Крыло длинное, узкое; основной членикъ 3-го пальца гораздо длиннье, чьмь 5-го. Летательная перепонка прикрьпляется съ вньшней стороны къ серединь ступни. Шпорный лоскутъ развитъ очень сильно. Размьры крупные: предплечье не менье

$43 \mathrm{~m} / \mathrm{m}$., обычно же много длинные. Pm. $\frac{2-2}{2-2}$.

\section{Родъ Nyctalus.}

Виды, относяшіесякъ роду Nyetalus:

а. (ь.) Мьхъ короткій и ровный. Длина предплечья $50-56 \mathrm{~m} / \mathrm{m}$. Наибольшая длина черепа: І9-20,2 m/m. Выступающая наружу часть внњшняго рбзца верхней челюсти равна 1/2

1) Въ таблицу включенъ отићченный $(+)$ пा не найденный въ Московской губ. Vespertilio borealis Nilss, который, весьма возможно, будетъ добытъ въ ея предьлахъ. 
внутренняго, но въ поперечномъ сђиеніи много толще посльдняго.

N. noctula $L$.

b. (а.) Мћхъ длинный, волнистый. Длина предплечья: 43$46,8 \mathrm{~m} / \mathrm{m}$. Наибольшая длина черепа: I5-I6,2 m/m. Выступающая наружу часть вньшняго рьзца верхней челюсти равна $2 / 3$ внутренняго, но въ поперечномъ сыченіи почти равна посльднему. N. leisleri Kuhl.

2. (г.) Козелокъ достигаетъ своей наибольшей ширины выше середины и едва замьтно суженъ къ вершинь, не имья формы булавы. Крыло длинное, узкое. Основной членикъ 3-го пальца только едва длиннье такового 5-го. Летательная перепонка прикрђпляется къ основанію вньшняго края ступни. 凹порный лоскутъ развитъ довольно хорошо. Размьры средніе: предплечье не превышаеть 47 m/m., обычно же короче. $\mathrm{Pm} \cdot \frac{1-1}{2-2}$. Poль Vespertilio.

Виды, относящ іеся къ роду Vespertilio:

c. (d.) Внутренній двувершинный рђзецъ верхнеї челюсти болье чьмъ вдвое выше наружнаго и въ поперечник много шире посльдняго. Вньшняя вершина перваго (внутренняго) ръзца только немного ниже внутренней и обычно болье чьмь вдвое выше второго (наружнаго) рђзца. Передній край уха далеко выдается впередъ и оканчивается глубокимъ загибомъ на половинь высоты короткаго, широкаго козелка. Длина тьла 55,4-62,3 m/m.

v. murinus $\mathfrak{L}^{\circ}$.

d. (с.) Внутренній двувершинный pћзецъ верхней челюсти только немного выше и въ поперечник' незначительно толще внышняго. Наружная вершина перваго рызца только на $1 / 3$ выше внбшняго рђзца, а иногда почти равна посль̌ынему. Передній край уха не такой выпуклый, внутренній загибъ его къ козелку идетъ много ниже. Длина тьла около $54 \mathrm{~m} / \mathrm{m}$. V. borealis Nilss. ( 1 ).

3. (2.) Козелокъ достигаетъ своеї наибольшеї ширины ниюе середины и къ вершинь суженъ, никогда не имья формы булавы. Крыло короткое, широкое; основной членикъ 3-го пальца почти равенъ таковому 5-го. Летательная перепонка прикрьпляется съ внбшней стороны къ основанію 
пальцевъ. Џпорный лоскуть развитъ слабъе. Размьры мелкіе: предплечье обыкновенно не превышаетъ 36 m/m., обычно еше короче. Pm. ${ }_{2-2}^{2-2}$. Родъ P i p istrellus.

Виды, относящіесякъ роду Pipistrellus:

е. (f.) Внутренній двувершинный рђзецъ верхней челюсти менье чьыъ вдвое выше одновершиннаго наружнаго. Посльдніiі обычно выше наружної вершины внутренняго рьзца или, рьже, равенъ посльдней. Клыки сравнительно велики. Вторая нёбная складка или прямая, или съ незначительної вогнутостью на переднемъ крањ. Предплечье 32,4-36 m/m., длина тьла: 44-50 m/m.

\section{P. nathusii Keys. et Blas.}

f. (е.) Внутреннії двувершинный рђзецъ верхней челюсти вдвое выше наружнаго, который обычно ниже вньшнеї вершины перваго (внутр. рьзца). Клыки сравнительно коротки. Вторая нёбная складка глубоко вдавлена спереди, имья видъ двойної дуги. Предплечье: $29-3 \mathrm{x}, 5 \mathrm{~m} / \mathrm{m}$. длина тьла: $35-40 \mathrm{~m} / \mathrm{m}$. P. pipistrellus Schreb.

II. (I.) \ши болье удлиненныя, будучи прижаты къ головь, обычно доходято или заходяпг за конещо носа. Внутренній контурь уха, болье прямо срьзанный и выпуклый, оканчивается почти у основанія козелка. Внутреннії контурь посльдняго замьтно вылуклииi, рьзко суженная вершина обычно отклонена назадъ. Шпорныї лоскутъ

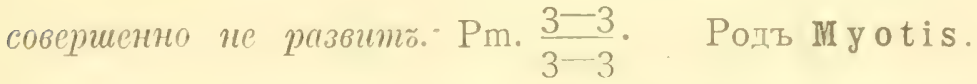

4. (5.) Ступня короткая (7-8,9 m/m.). Крыловая перепонка доходить до основанія пальца; межбедренная перепонка образуетъ сзади у конца хвоста тупої уголъ.

Подр. M y o t is.

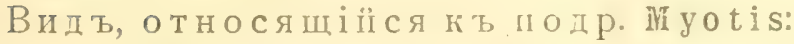

Јхо, булучи прижато къ головь, заходитъ за конецъ носа и очень рызко вырьзано по линіи внышняго края. Козелокъ выдается ньсколько надъ серединою уха, суженная вершина его занћтно отлонена назадъ. Верхняя губа и область между глазъ покрыта очень длинными волосами. Длина тььла: 40-47 m/m., предплечье: $34-36,8 \mathrm{~m} / \mathrm{m}$. 
5. (4.) Ступня длинная (9-I2,7 m/m.); трыловая перепонка доходитъ до основанія ступни, межбедренная перепонка образуетъ сзали у конца хвоста острыї уголъ.

Подр. L e u e o n oё.

Виды, относящіеся къ подр. Lе иеопё:

g. (h.) Ухо, будучи прижато къ головь, почти доходитъ до конца носа. Вершина козелка слабо отклонена назадъ. Длина черепа: I4,8- г5,9; длина тьла: 4I-50 m/m.; предплечье: 35,6-39,6; ступня 9-Iо,7 m/m, L. daubentonii Kuhl.

h. (g.) Ухо, будучи прижато къ головь, далеко не доходитъ до конца носа. Вершина козелка слабо отклонена впередъ (внутрь). Длина черепа: І7,9-I8,г; длина тьла: $55-58,2$; предплечье: 46-47,6; ступня: II,7- $12,7 \mathrm{~m} / \mathrm{m}$.

L. dasycneme Boie.

В. Уши по длиньпочти равны предплечьюи срощнына лбу.

Козелогъ очень длинный и широкій, снаружи, у основанія снабженный зубовиднымъ отросткомъ. Крылья очень широкія, крыловая перепонка доходить до основанія пальцевъ. Шпорный лоскутъ не развитъ.

Родъ Plecotus, Къ которому относится одинъ видъ.

P. auritus $L$. 


\section{II Отрядт, Insectivora. I Iackigmos, пи,}

\section{Краткія характеристики семействъ.}

\section{I. Семейство Soricidae.}

Мелкія мышевидныя млекопитающія, тьло которыхъ покрыто короткимъ бархатистымъ мьхомъ. Конечности приспособлены лля бъганія и плаванія, при чемъ по размьрамъ заднія сравнительно немного превышають переднія. Os tympanicum имьеть форму узкаго кольца; скуловыхъ дугъ ньтъ. Зубовъ 30 (Neо-

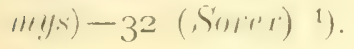

\section{2. Семейство Talpidae.}

Размьры болье кругные. Тьло покрыто или короткимъ бархатистымъ мьхомъ (р. Talpa), или болье длиннымъ (р. Myogale). Конечности рьзко отличаются по размћрамъ: или заднія больше переднихъ и характернзуются очень широкой плавательной пере-

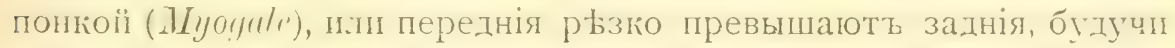
весьма широки, плоски и вооружены длинными когтями (p. Talpa). Os tympanicum образуеть плоскую bulla; скуловыя дуги вполнь развиты и тонки. Зубовъ 44.

\section{3. Семейство Erinaceidae.}

Вся спинная область покрыта длинными и жесткими иглами; волосы нижней стороны грубые и длинные. Заднія конеqности лишь слабо превышають переднія и объ пары ихъ приспособлены для хожденія. Os tympanicum имьетъ форму широкаго кольца; скуловыя дуги сильно развиты. Зубовъ 36.

1) Только у рода Crocidura IVagler, не встрьчающагося въ Московскої губ́, нхъ-28. 


\section{Семейство Soricidae.}

\section{Родъь S о гх. 3 емл е рой й.}

1758. Sorex, Carolus Linnaeus (98), p. 53.

Къ этому роду принадлежитъ рядъ мелкихъ мышеподобныхъ формъ, характеризующцхся настолько удлинениої носовой областью, что разстояніе отъ конца носа до глаза значительно превышаеть таковое отъ посльдняго до слухового отверстія. Глаза крайне малы и сильно скрыты сравнительно густымъ мыхомъ. Vши довольно малы, частью прикрыты мьхожъ и слабо одыты волосами. Конечности сравнительно короткія, прпспособленныя для бьганія, съ 5 пальцами, изъ коихъ два среднихъ длиннье другихъ. Хвостъ длинный и болье или менье равномьрно покрытый волосами. Сосковъ три пары.

Что касается до строенія черепа, то онъ отличается своей вытянутой формой, отсутствіемъ скуловыхъ дугъ и заглазничныхъ отростковъ, а также тымъ, что тимпанальныя кости имьють форму плоскаго кольца безь образованія bullae osseae.

Относительно зубної формулы необходимо сказать ньсколько словъ, чтобы избьжать неясности при детальномъ описаніи. По II о б сону (46, р. 49-5I), номенклатуры котораго мы и будем'ь придерживаться, вверху съ каждой стороны, за очень большимъ, иногда раздвоеннымъ переднимъ рьзцомъ сльдуетъ нысколько меньшихъ боковыхъ рызцовъ (у Sorex aranens L. всьхъ рыз. цовъ 4). Еще далье расположенъ очень небольшой клыкъ, за коимъ идутъ два ложнокоренныхъ, отличающихся очень малыми размьрами передняго изъ нихъ, и, наконецъ, три коренныхъ ${ }^{1}$ ). Въ нижней челюсти за первымъ очень длиннымъ рьзцомь сльдуетъ конусовидный второй, клыка нытъ совершенно, далье расположенъ ложнокоренной зубъ, за которымь сльдуют"ь 3 коренныхъ.

Такимъ образомъ, зубная формула имьћетъ сльдующій видъ:

$$
\text { i. } \frac{4-4}{2-2} \text {, c. } \frac{I-I}{O-O}, p m \cdot \frac{2-2}{I-I}, m \cdot \frac{3-3}{3-3}=3^{2} \text { ). }
$$

1) Всльдствіе країняго сходства въ размьрахъ боковыхъ рызцовъ, клыка и ложнкоренного зуба-въ ц пхъ не столь важно, что дало поводъ нбқоторымъ авторамъ дать пмъ общее названіе иромемумочиых зуо̆овъ.

2) По Эдуарду Бр анлту (32, р. 76) зубиая формула представляется ньсколько иною: i, $\frac{4-4}{1-1}$ с. $\frac{1-1}{1-1}, \mathrm{pm}, \frac{1-1}{1-1}, \mathrm{~m} \cdot \frac{4-4}{3-3}=£ 2$. 


\section{Sorex araneus L.}

\section{Обыкновенная землеройка.}

Sorex araneus, Carolus Linna us (98), p. 53. Sorex vulgaris, C a r o1 us Linnaeus, Museum Regis Adolphi, 1704. Sorex araneus L. Trouessart (200), p. 51. Barret-Hamilton (16), p. 82. Millais (110). Sorex vulgaris L. Blasius (27), p. 129. К. А. С а тун ин в (165), стр. 5 й ( 166$)$, p. 3 .

\section{Систематическія особенности.}

पерепг (см. табл. I, рис. I3, I4) характеризуется, какъ уже было сказано выше, своей удлиненної формої, въ особенности въ носовой области, полнымъ отсутствіемъ скуловыхъ дугъ; bullae tympani не развиты, вмысто нихъ имьются тимпанальныя кости въ видь кольца. Несмотря на значительныя личныя уклоненія въ строеніи черепа Sorex araneus L., можно установить съ несомньнностью ньсколько довольно рђзкихъ возрастныхъ измьненій. Прежде всего, однако, надо отмьтить тотъ крайне важный фактъ, что черепъ молодой особи уже очень скоро достигаеть длины такового у старой, даже если самъ молодой экземплярь значительно мельче стараго. Для того, чтобы убъдиться въ справедливости этой законности, стоитъ только взглянуть на нашу таблицу измьреній, гдь, напримьрь, черепь еще совершенно молодой самки (.ํ 247), тьло которой достигло 51,9 m/m., равенъ І9,3 m/m., т.-е. больше, чьмъ у очень старой особи (№ 246), которая длиною въ $73,2 \mathrm{~m} / \mathrm{m}$., а черепъ равенъ только $\mathrm{r} 8,9 \mathrm{~m} / \mathrm{m}$.

Эта совершенно неожиданная особенность меня крайне удивила, тьмъ болье, что у другихъ отрядовъ млекопитающихъ мы встрьчаемъ рьзко выраженную возрастную измьнчивость. Такъ, напримьръ, у грызуновь черепь молодой полевки очень рьзко отличается по своей конфигураціи и размьрамъ оть такового у старыхъ особей (кромы только межглазничнй ширины, о чемь рђчь будетъ ниже). Тоть факть, что черепа еще очень молодыхъ землероекь столь рано достигають своихъ предьльныхъ размьровъ, влечетъ за собою крайнее сходство въ общей конфигураціи ихъ у взрослыхъ и молодыхъ Sorex araneus L. Только прайне тщательное слисніе позволило иньь установить несомнынныя и все же довольно рьзкія возрастныя отличія. Прежде всего могу указать на сльдуюшее: черепная капсула молодыхь землероекъ уже, чьыъ у старыхъ, но особенно рьзка разница въ строеніп этой капсулы, если смотрьть на черепъ сбоку. Здысь мы ясно можемь видьть, что у молодої Sorcx черепь болье 


\begin{tabular}{|c|c|c|c|c|c|c|c|c|c|c|}
\hline 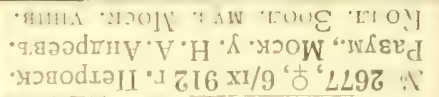 & & & & & & & $\stackrel{\infty}{\stackrel{\infty}{\Sigma}}$ & $\stackrel{\vec{\theta}}{=}$ & $\therefore$ & $\bar{\sigma}$ \\
\hline 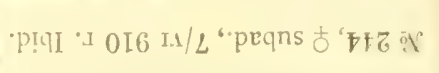 & $\because$ & $\begin{array}{l}1 ! 1 \\
\ddot{\infty} \\
\infty\end{array}$ & $\stackrel{\theta}{=}$ & in & & & $\Xi$ & $\equiv$ & $\longrightarrow$ & $\Leftrightarrow$ \\
\hline 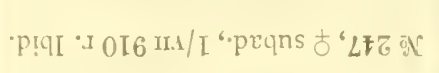 & $\frac{5}{10}$ & છ & $\overline{\underline{N}}$ & $r$ & & & $\because$ & 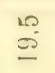 & $\stackrel{\bullet}{\rightarrow}$ & $=$ \\
\hline 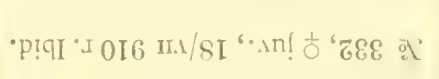 & $\ddot{\leftrightarrow}$ & $\begin{array}{c}1 \\
10 \\
10\end{array}$ & $\triangleq$ & $\stackrel{\varphi}{i}$ & & & $\therefore$ & $\begin{array}{l}\ddot{1} ! \\
\ddot{0}\end{array}$ & $\ddot{?}$ & $i_{i}$ \\
\hline 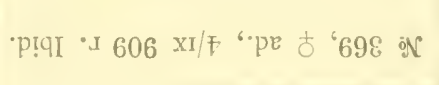 & 10 & 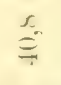 & ii & $\stackrel{\sim}{\infty}$ & & & $\underline{1 z}$ & $\underline{x}$ & $\dddot{?}$ & $\Leftrightarrow$ \\
\hline 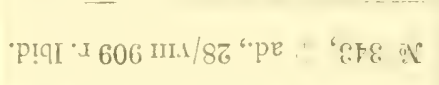 & 0 & $\stackrel{0}{\stackrel{+}{+}}$ & ii & $\frac{1}{x}$ & & & $\underline{x}$ & $=$ & $\stackrel{10}{-}$ & $\equiv$ \\
\hline 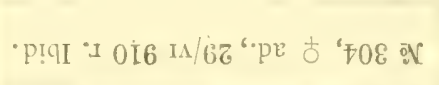 & $\ddot{B}$ & 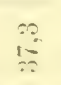 & $\stackrel{\hat{\imath} \dot{I}}{-1}$ & $x_{=}^{x}$ & & & $\Xi$ & $\begin{array}{l}\underline{0} \\
\underline{x}\end{array}$ & $\stackrel{10}{i}$ & $\ddot{\ddot{E}}$ \\
\hline 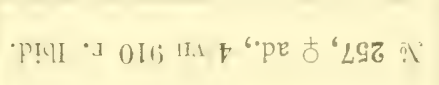 & $\begin{array}{l}0^{2} \\
\text { go }\end{array}$ & 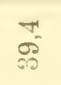 & $\stackrel{\leftrightarrow}{\stackrel{1}{I}}$ & $1-$ & & & $=1$ & 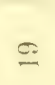 & - & $\stackrel{x}{=}$ \\
\hline 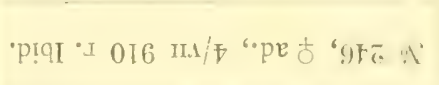 & $P_{i}^{\infty}$ & 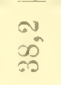 & $\begin{array}{ll}o+1 \\
\dot{y}\end{array}$ & t- & & & $\bar{x}_{i}$ & $\stackrel{x}{x}$ & $\because \bar{r}$ & $\bar{\Xi}$ \\
\hline 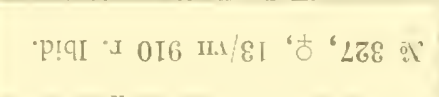 & $\bar{E}$ & $\bar{B}$ & $\because$ & $\stackrel{\leftrightarrow}{\sim}$ & & & 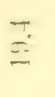 & $\equiv$ & ल & 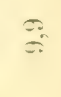 \\
\hline 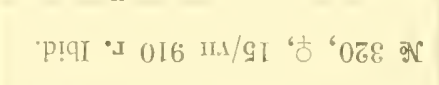 & 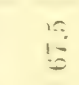 & $\Rightarrow$ & $\stackrel{i}{i}$ & $\underline{x}$ & & & 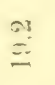 & $\equiv$ & $\underset{T}{\pi}$ & $\dddot{\fallingdotseq}$ \\
\hline •P!qI 'I LI6 II.I/EI '十 'LIL ò & $\stackrel{\infty}{g}$ & $\bar{\nabla}$ & $\stackrel{\leftrightarrow}{a}$ & 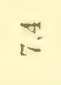 & & & $\bar{\Xi}$ & $\Xi$ & $\rightarrow$ & $=$ \\
\hline 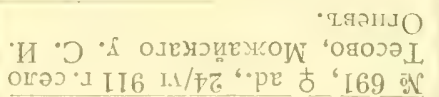 & $\bar{E}$ & $\stackrel{\infty}{\infty}$ & $\stackrel{0}{i \underline{i}}$ & $\bar{\infty}$ & & & $\equiv$ & $\equiv$ & $\cong$ & $\frac{1}{2}$ \\
\hline 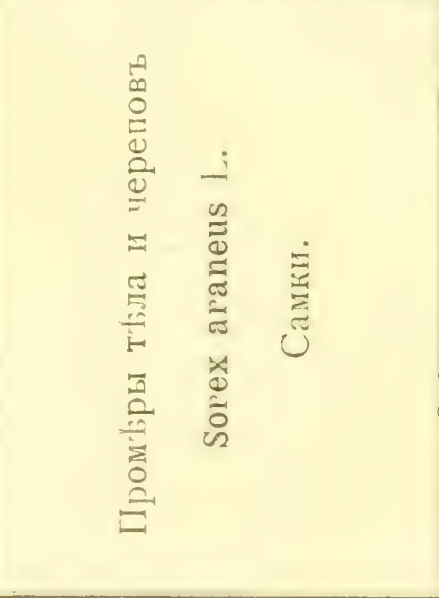 & 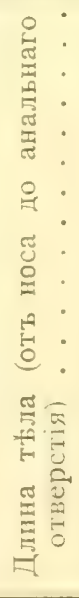 & 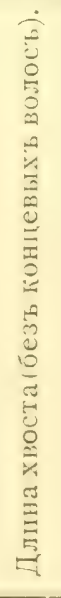 & 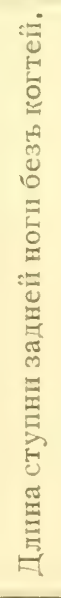 & 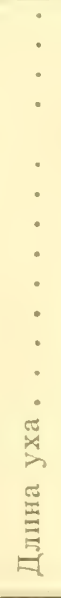 & 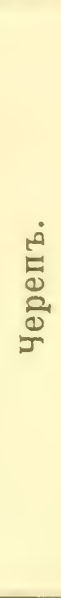 & 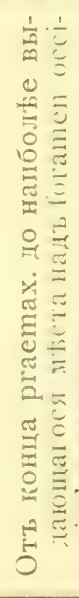 & 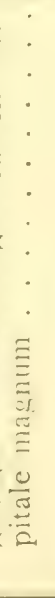 & 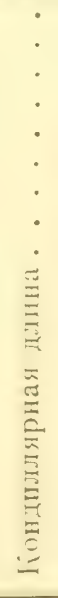 & 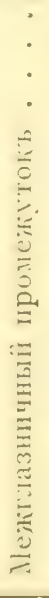 & 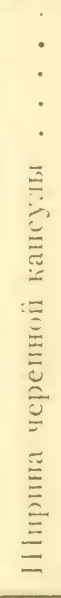 \\
\hline
\end{tabular}




\begin{tabular}{|c|c|c|c|c|c|c|c|c|c|c|}
\hline 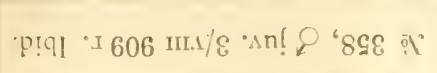 & $\frac{0}{20}$ & $\stackrel{\infty}{\because}$ & $\begin{array}{l}\bar{\vdots} \\
\bar{z}\end{array}$ & 10 & & & 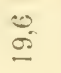 & $\stackrel{\infty}{\Xi}$ & $\stackrel{21}{\pi}$ & $\dddot{2}$ \\
\hline 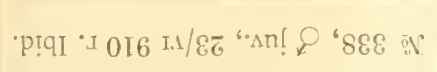 & $\ddot{0}$ & $\stackrel{10}{20}$ & $\stackrel{\Xi}{=}$ & $\because=$ & & & 20 & $\cong$ & $\overbrace{10}^{10}$ & $\tilde{\omega}$ \\
\hline 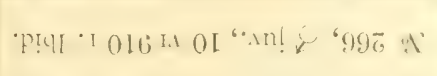 & $\ddot{\text { in }}$ & $\begin{array}{l}y_{1} \\
\infty \\
\infty\end{array}$ & $=$ & $0_{1}^{0}$ & & & $\stackrel{\infty}{\mathscr{D}}$ & 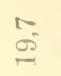 & $\vec{T}$ & $\overline{\sigma o s}^{-}$ \\
\hline 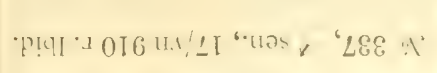 & 3 & $\stackrel{20}{F}$ & $\ddot{-}$ & $\stackrel{0}{=}$ & & & $\ddot{g}$ & $\bar{\theta}$ & $\stackrel{3}{\div}$ & $\ddot{\varrho}$ \\
\hline 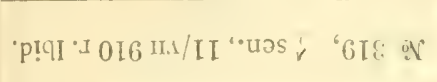 & 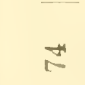 & $\begin{array}{l}\infty \\
\infty \\
\infty\end{array}$ & $\begin{array}{l}20 \\
\pm i\end{array}$ & $\stackrel{\infty}{=}$ & & & $\underset{\infty}{\infty}$ & $\begin{array}{l}\overline{10} \\
\infty \\
\infty\end{array}$ & - & 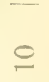 \\
\hline •p!ЧI & is & $\stackrel{\infty}{\infty}$ & ấ & $\stackrel{0}{\infty}$ & & & $\stackrel{\infty}{\infty}$ & $\stackrel{\infty}{\infty}$ & $\stackrel{\infty}{+\infty}$ & 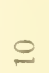 \\
\hline 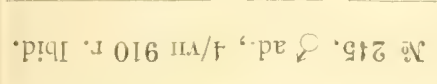 & $\stackrel{20}{=}$ & लै & $\stackrel{10}{10}$ & 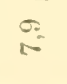 & & & $\stackrel{2}{=}$ & $\begin{array}{l}\infty \\
\stackrel{\infty}{-}\end{array}$ & $\frac{10}{79}$ & $\sigma_{0}$ \\
\hline 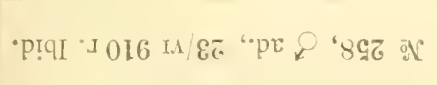 & 18 & के & $\Rightarrow$ & $E$ & & & 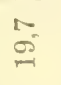 & $\bar{g}$ & $\mathbb{N O}^{\circ}$ & 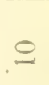 \\
\hline 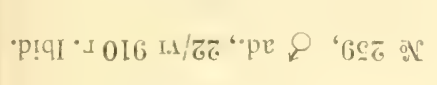 & $\approx$ & $\stackrel{+}{\circ}$ & $\begin{array}{l}\infty \\
\text { N }\end{array}$ & $\stackrel{0}{\circ}$ & & & $\begin{array}{l}\infty \\
\stackrel{\infty}{=}\end{array}$ & $\stackrel{\infty}{g}$ & $\underset{*}{+}$ & $\stackrel{90}{\circ}$ \\
\hline 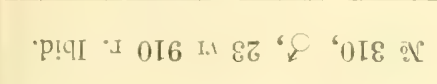 & कै & $\stackrel{\circ}{\circ}$ & $\stackrel{\forall}{\simeq}$ & $\vec{\infty}$ & & & $\stackrel{\oplus}{\Phi}$ & 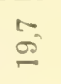 & $\stackrel{N}{*}$ & $\stackrel{\ominus}{\varrho}$ \\
\hline 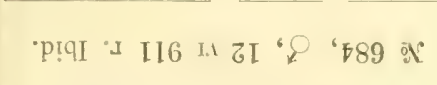 & 8 & $\vec{k}$ & $\stackrel{\forall}{\stackrel{H}{2}}$ & $\bar{\infty}$ & & & 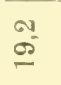 & $\stackrel{\theta}{-}$ & $\overline{F i}$ & $\stackrel{\infty}{\infty}$ \\
\hline 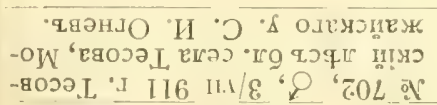 & ๑ & $\tilde{c}$ & $\stackrel{\infty}{\infty}$ & $\bar{\infty}$ & & & $\stackrel{\infty}{\infty}$ & $\stackrel{\sim}{\mathscr{\sigma}}$ & $\bar{F}$ & $\ddot{g}$ \\
\hline 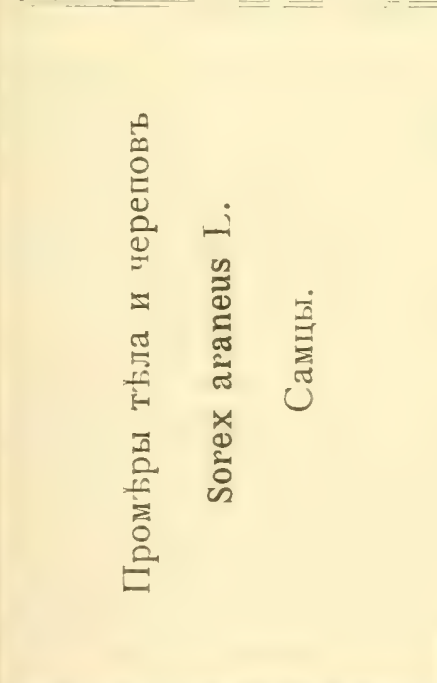 & 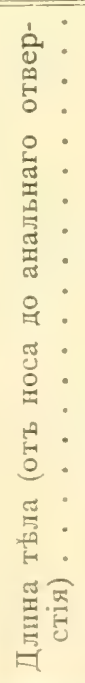 & 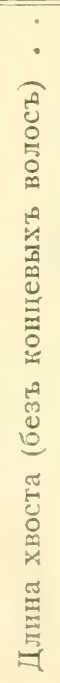 & 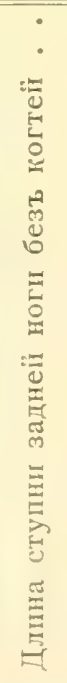 & 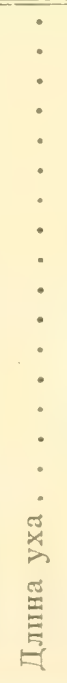 & 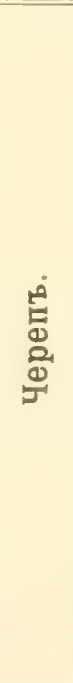 & 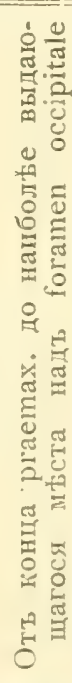 & 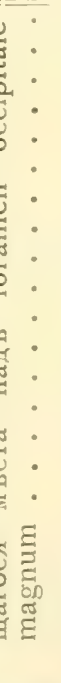 & 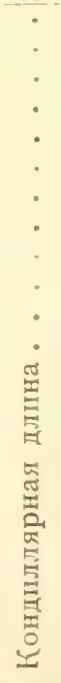 & 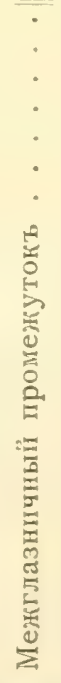 & 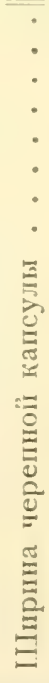 \\
\hline
\end{tabular}


вздуть въ вертикальномъ направленіи, шовъ между parietalia имьеть выпуклую форму дуги, у старыхъ особей этотъ шовъ въ виды прямой линіи.

Граница между os occipitale и parietalia у молодыхъ, если смотрыть на нее сбоку, болье откинута иазадг, чьмъ у старыхъ, rды она наклонена влередб. Вообще можно сказать, что конфигурація затылочной области черепа старыхъ Sorex araneus L. болье уплощенная и вытянутая въ бока, что, въ свог очередь, обусловливаеть большую ширину черепної капсулы.

Что касается до строенія нижнеї челюсти, то форма отростка, отходящаго оть ея угла, довольно характерна: онъ обычно полукруглый, при чемъ длина его значительно варіируетъ. Сравненіе его съ таковымъ у Sorex minutus L. показало, что у этого посльдняго вида отростокъ болье прямої и, въ соотвьтствіи съ общей величиной нижней челюсти землеройкикрошки, длиннье, чьмъ у Sorex araneus L. На эту особенность организаціи указываль еще проф. Н. Ө. К а щ е н к (8о, стр. 9I), затрудняясь, однако, считать ее характернымь признакомъ отличія двухъ близкихъ формъ: Sorex araneus L. и minutus L. Просмотрь моего матеріала убьбдилъ меня, что эти отличія несомньнно существують, они особенно рьзки, если смотрьть не столько на относительную длину отростка и всей челюсти, сколько на самую форму посльдняго. При сравненіи нижнихъ челюстей описываемыхъ Sorex обнаружилось также, что уголь между processus condyloideus и coronoideus у S. mimutus L. больше, чьмь y Sorex araneus L.; это отличіе особенно рельефно выступаетъ только на большихъ серіяхъ.

ІІереходя теперь къ описанію зубово обыкновенної земтеройки, я долженъ замьтить, что относительные размьры ихъ довольно постоянны, если, конечно, зубы не стерты. Большинство авторовъ, начиная съ Бл аз іуса, отмьчаютъ, какъ признакъ видовой дифференцировки для Sorex araneus L., строеніе ея верхнихь рьзповъ, размыры лоихь płзко уменьшаются по направленію назадь, тогда какъ у S. mimutus L., по этимъ описаніям, боковые рьзцы всь равны мекду собою. (См., напр., К а щ е н к о, Обзоръ, стр. 85.) Этотъ признакъ, однако, далеко не точенъ: и у посльдняго вида рђзцы уменышаются по направленію къ затылочной области, но только не столь рҺзко, какъ у Sorex araneus L. Дыйствительно постояннымъ и точнымъ отличіемъ является строеніе второго рђзца нижней челюсти: у $S$. araneus L. высота этого зуба приблизительно равна длинь его основанія, тогда как'ь у малой зеллеройки посльдній промьр вовос превышаеть первый. 
Orраска типичнаго экземпляра въ льтнемь мғху такова. - Вся спина до горня хвоста покрыта густыми буроватосьрыми, иногда съ палевымъ оттынкомъ, волосами, основанія коихъ свьтло-сьраго цвыта. Мьхъ головы, передней части носа свћтлье: здьсь примышивается болће палевыхъ тоновъ. Цвьть боковъ отличается отъ спины своимъ ржаво-палевым оттынкомъ. Вся нижняя сторона покрыта волосаии, очень свљтло-сьраго тона у ихъ основанія, съ широкими быловато-желтыми окончаніями. Хвость слабо двуцвътный-сверху с’ьровато-бурый, снизу болье желтовато-сырый. Возрастиая излиичивость сказывается въ болье св'ьломъ, ржавомь мьғы старыхъ особей, въ отличіе оть болье темнаго молодыхъ. Хвость (см. табл. II рис. 39-40) посльднихъ, по сравненію съ общей длиной тьла, кажіется больше, чьмъ у старыхъ, всльдствіе того, что онъ очень рано достигаеть своей полной длины. Важно также отмьтить, что у молодыхъ экземпляровъ онъ покрытъ довольно густыми волосами, въ отличіе отъ старыхъ, у коихъ онъ почти голый. Всегда постояннымъ и рызкимъ возрастнымъ отличіемъ является ивитъ

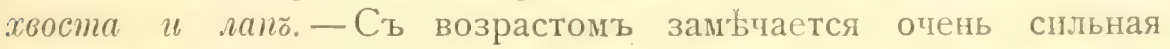
депигментація этихъ частей. Лапы становятся желтовато-бђлыми, хвость рыжевато-палевым, волосы на немь дылаются рь;е и короче, длинныхъ волосъ на его конць совершенно не замьтно.

Сезомиыя излюиенія довольно постоянны.-Зимній мғхъ рłзко отличается отъ описаннаго льтняго. Прежде всего надо отмњтить, что волосы дњлаются әораздо длиннће, цвћт”ь ихъ на спинћ глубоко коричневый, съ черно-сырыми основаніями, что сообщаеть мхху еще болье темныї видъ. Спинная тасть головы и носа свђтлье спины и болье коричневато-ржаваго оттьнка, хотя гораздо болье темнаго, чьим у льтнихъ экземпляровъ. Цвътъ спины болье рђзко переходить въ съровато-б́ллую окраску нижней стороны тьла, горла и подбородка. Волосы брюшной стороны тоже значительно длиннье, чћиь у льтнихъ особей, съ ярко замұтными, довольно темными сьрыми основаніями и бьловатыми окончаніями, при чемь и здысь замьчается желтоватый оттьнокь, однако, болье слабый, чћиъ у льтнихъ землероекъ. Хвость рьзко двуцвњтный: сверху темно-бурый, снизу желтовато.бьловатый.

Въ заключеніе остановлюсь на такъ называемыхъ „промежуточныхъ формахъ" между Sorex araneus L. и Sorex minutus L. При тщательномъ просмотр ихъ съ несомнынностью въ моей большой голлекціи. Думается, 
џто большинство авторовъ ${ }^{1}$ ), писавшихъ объ этихъ „formae intermediae", имъли подъ руками просто молодыхъ Sorex araneus L. Это тымъ въроятнъе, что такой хорошій признакъ какъ относительная длина хвоста и тьлла, у молодыхъ сходить на нытъ, и хвостъ достигаетъ у нихъ $2 / 3$ общей длины тнैла, что обычно считаютъ видовымъ отличіемъ $S$. mimutus L.

Въ такомъ случаћ діагнозъ все же крайне легокь, если обратиться къ длинћ черепа, который, какь мы уже видьли, весьма рано достигаетъ своихъ полныхъ размћровъ, и этоть признакъ такъ р£зокъ, что распознаніе нашихъ землероекъ крайне легко и не для спеціалиста.

Въ заключеніе остановлюсь на размьрахъ нашихъ экземпляровъ, указавъ колебанія ихъ, полученныя при измьреніи большинства имьющихся у меня серіiі Sorex aramens L. ${ }^{2}$ ) изъ Moсковской губ.

Заканчивая очеркъ систематическиъ особенностей Sorex ara-

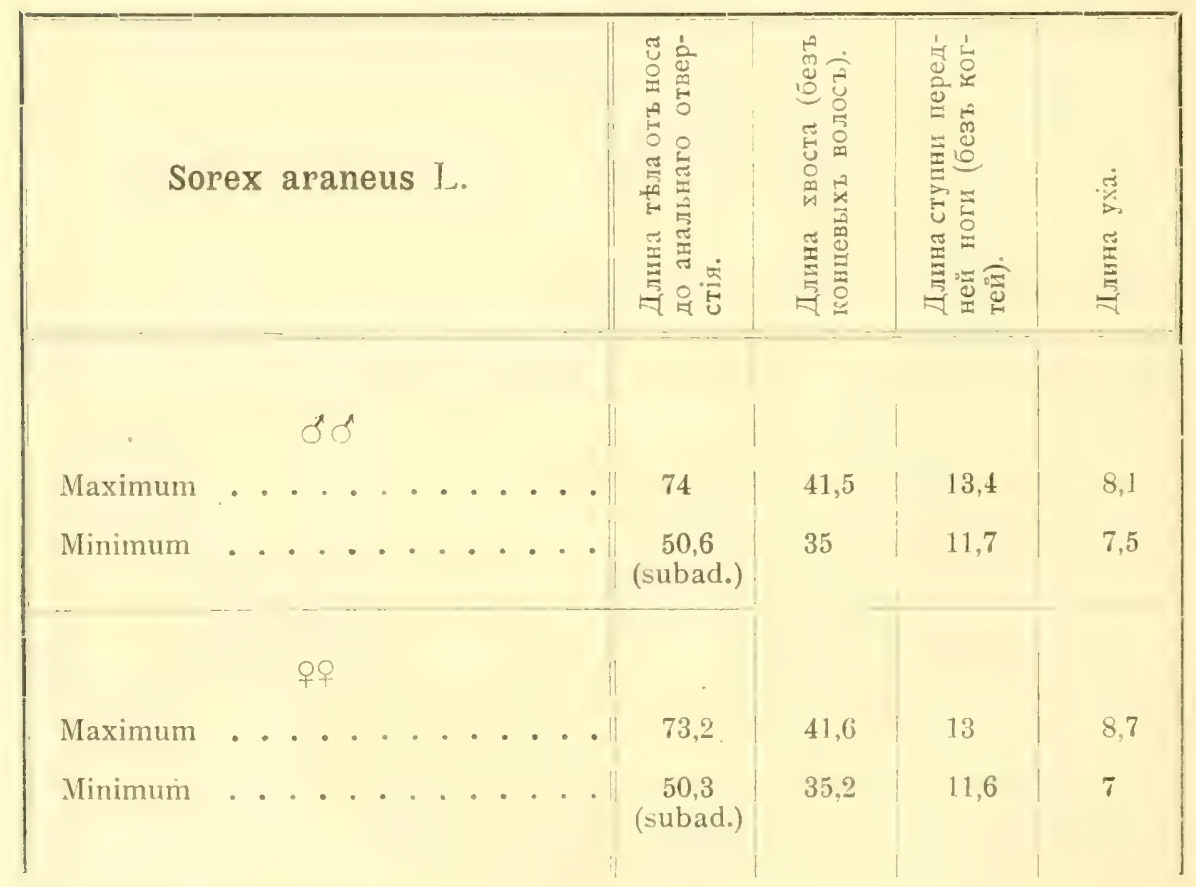

1) Си. Тихоиировъ (197), стр. 27.

2) Отмьчу, что въ моей коллекцін не было такихъ прупныхъ Sorex ara-

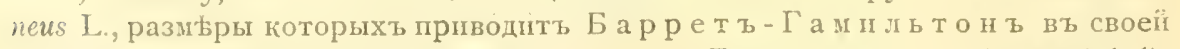
„History of British Mammals“, part. VIII, p. 92. (Длина головы съ тьлозъ (Ъ๙ $82 \mathrm{~m} / \mathrm{m}$. (†o): $83 \mathrm{~m} / \mathrm{m}$.) 
neus L., мнђ хотьлось остановиться на разсмотрћніи взаимоот-

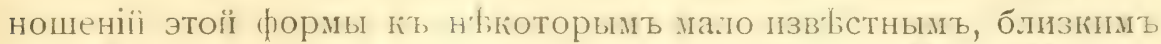
кь ней видамь. Прослатривая въ коллекціи Зоолог. Mузея Москов. унив. небольшую серію Sorex, собранную Ю. Н. Вагнером ъ въ Горномь Заренту и I экземпляръ, добытый В ад. С. Му рале в и че м в на р. Амазарt (Забайкальск. обл.), я могь уб̆tдиться, что забайкальская землеройка рłзко огличается отъ Sorex aranens L.

По строенію черепа эта интересная форма несомнћнно стоптъ близко къ обычному виду, рбзко отличаясь отъ $S$. mimutus L., но черепа забайкальскихь особей мельче, чьмъ у $S$. arancus L., а межглазничная ширина и ширина черепної капсулы значительно у́же. Изъ краніологическихъ прлзнаковъ рђзко бросается въ глаза еще одна особенность: разстояніе оть foramen infraorbitale до конца praemaxillaе забайкальскихъ землероекь меньше, чћиъ у типичныхъ.

По строенію зубовъ описываемая форма стоптъ ближе всего къ S. mmutus L.: такъ, вышина второго рłзца нижнеї челюсти вдвое меньше длины его основанія. Форма отростка нижней челюсти совершенно такова, какъ у S. mimutus L. Bc 古 4 имьющіяся у меня землеройки, какъ показываетъ изученіе ихъ зубовъ, еще довольно молоды, всльдствіе чего я не могу съ увьренностью говорить о тьхъ наибольшихъ размћрахъ, коихъ эта фориа достигаетъ. Однако, нъкоторые признаки можно считать все же довольно характерными. Мы видьли уже, что хвость даже у очень молодыхъ землероекъ быстро вырастаетъ до своихъ нормальныхъ размьровъ, болье не удлинняясь по мьрђ роста животнаго. Это, въ свою очередь, вызываетъ несоотвђтствіе длины его съ общей длиною тьла у молодыхъ и старыхъ особей. При первомъ взглядt; на забайкальскихъ землероекъ бросается въ глаза удивительио малая длина хвоста, значительно меньшая, чьмъ у европеїскихъ $S$. araneus и mimitus L.

Окраска трехъ собранныхъ Ю. Н. В агнером ъ экземпляровъ отличается очень св ьтлымъ тономъ.-Верхняя часть головы, спина и бока тьла лркаго палево-рыжеватаго цвњта, болье свьтлаго на верхнеї части спины и переходящаго въ интенсивно рыжіиі на бокахъ и задней части туловища. Верхняя часть носа и окружность глазь очень свђтлаго желтовато-палеваго оттьнка. Нижняя сторона бьловато-сьрая, основанія волосъ, ее покрывающихъ, болье темнаго сыраго тона, тогда какъ концыóli.ловаты. Хвость свют.ло-рыжеватыї, покрытый длиными палевозолотистыми волосами, ланы окрашены такь же, какъ и хвостъ. 
Oкраска четвертаго экземпляра, гобытаго Вад. С. Муралевичемъ 3о. IX. о9 г., болье темна, такь какъ землеройка частью получила уже свой зимній м⿻х㇒ъ. Посльдній очень длинпыі и болье свњтлый, юћмъ зимняя шерсть обычнаго вида. Обпій тонъ спины и головы описываемаго экземпляра буроватосђрый, съ очень замұтным палевым оттьнкомь на концахь волосъ, основанія коихъ болће темнаго сыраго тона. Вся нижняя сторона покрыта волосами съ довольно темными сьрыми основаніями и широкими бъловато-сћрыми вершинами. Лапы и хвость сьровато-желтые, посльдній покрыть длинными св бтлобуроватыми волосами и замғтно двуцвћтный: сверху буроватый, снизу желтоватыї. Волосы на хвость неравномұрной длины: по бокамт короче, а на концћ гораздо длиннће. Размыры нашихь әкземпляровъ приведены на стр. 107.

Итакъ, резюмируя все сказанное, мы можемъ видьть, что забаїкальская землеройка отличается оть обычной сльдующими признаками. Oкраска ея значительио свит.лье, ит.ио у S. araneus L.;

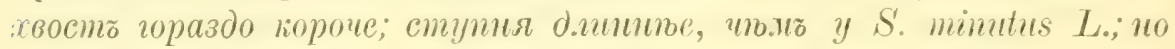

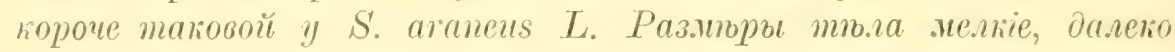

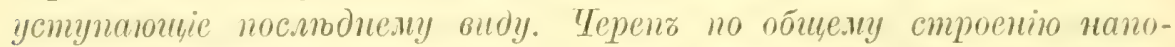
минаетг maновой $S$. araneus $L$., но длина ецо менвие и носовия область короче. Зубо и отростоко иияней челюсти, какй у $S$. mimutus L. Въ виду этихъ особенностей я считаю необходимымъ выдћлить описываемыхъ землероекъ въ особый видъ Sorex baikalensis sp. nova.

Очень давно Laxmann (95, p. 285-286) описаль байкальскихъ землероекъ, какъ отдельный видъ, но это описаніе было составлено въ такихъ общихъ чертахъ, что уже P a llas ( I 3 о, p. I35-І 36) затруднялся сказать, что представляеть „Sorex caeculiens Laxm., относя это названіе въ синонимы $S$. minutus L. Въ нов ьйшее время это дьлаеть, правда, съ знакомь вопроса, Бар-

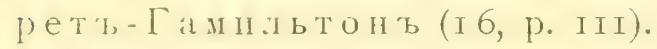

Мнь думается, что проф). Н. Ө. К ащенко (8о, стр. 93) вполн' правь, причисляя эту землероїку кь групп' Sorex araneus L. или даже Crocidura (?), въ виду отношенія ея длиннаго түла $(79 \mathrm{~m} / \mathrm{m}$.) къ очень короткому хвосту $(28 \mathrm{~m} / \mathrm{m}$.). Тщательно сравнивая свонхъ землероекь сь описаніемь Л а сі ман, я не могъ наїти сколько-нибудь совпадающихъ признаковъ, за исклюэеніемъ только малой длины хвоста. Но это измьреніе зависитъ оть суммы различныхъ условіп: оть крайнихъ точекъ промьра, принятія въ счеть длины хвоста его конечныхъ волосъ и т. ..

Съ цругої стороны, рtзкая разница въ тьль животнаго и 


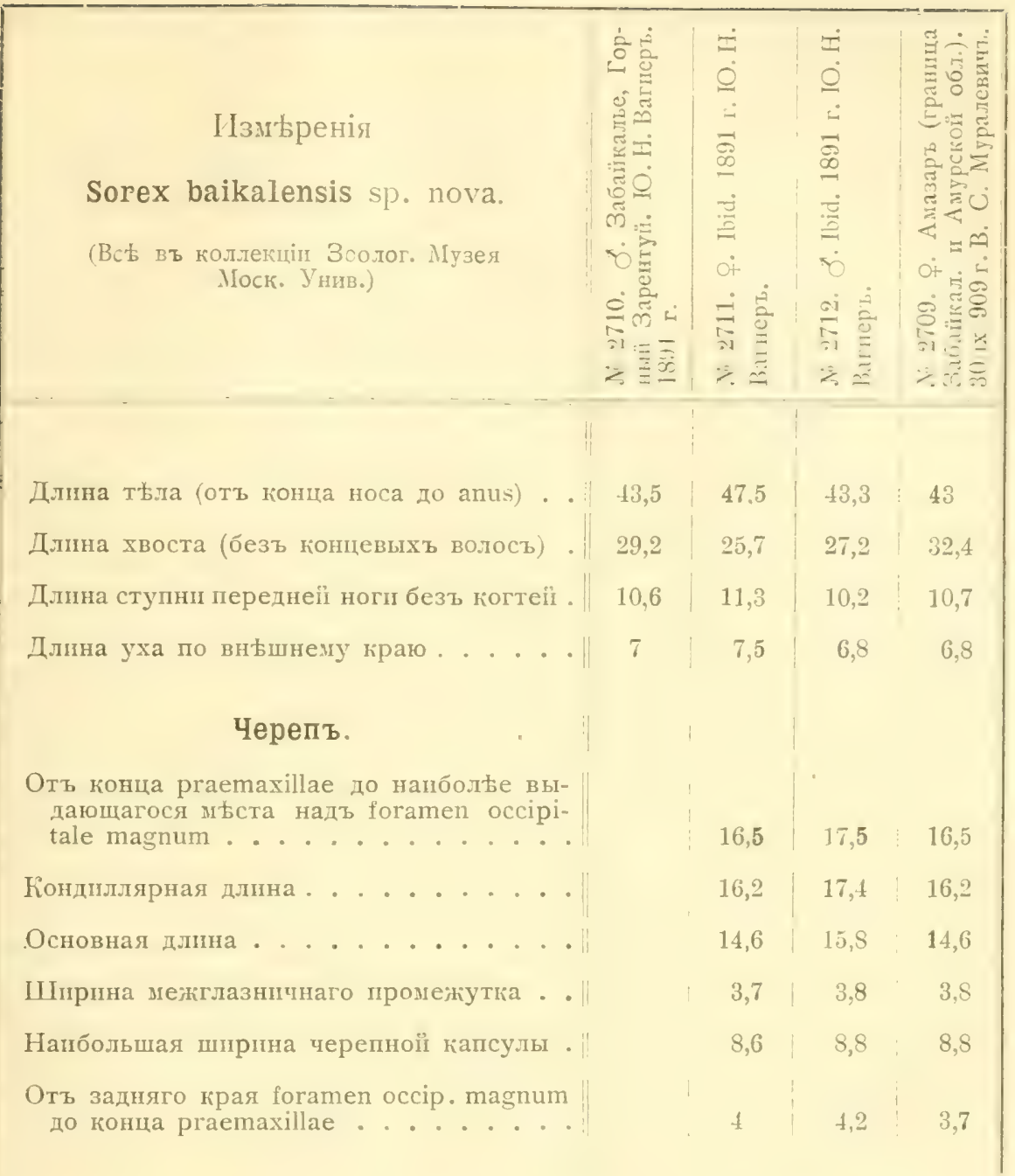

несоотвђтствіе прочихъ признаковъ сильно поколебали во мнь рьшеніе причислить свонхь зеллероекъ кь весьма сомнительному дiarнозу S. caecutiens Laxm. и заставили дать ему новое названіе. Недавно Old. Thom as (i 95, p. 758) описаль изъ Саянскихъ горъ, въ тоо миляхъ къ W. отъ Баїкальскаго озера, новыї видъ землероїки Sorex centralis Thom. Сугя по описанію, эта форна очень легко отличается отъ $S$. bailialensis sp. nov. свонии значительно большими размьрами. (Длина тьла и головы: 63 m/m., длина черепа: 19,3.)

Важно разсмотрбть отношеніе нашей Sorex bailialensis sp. nov. къ восточно-сибирской Sorex Uuxtomi Allen. Несмотря на то, что 
Алленъ (т, p. І8г) имьль подъ руками очень большую серію землероегъ посльдняго вида (40 экз.) изъ Охотска, Гижигинска, Анадырскаго округа, его описаніе страдаетъ игнорированіемъ ндкоторыхъ интересныхъ и бросающихся въ глаза особенностей Sorex buxtoni Allen. Эта неясность описанія автора повлекла за собою скептическое отношеніе нькоторыхъ зоологовъ къ его новой землерой ’' $^{1}$ ). Благодаря любезности Б. М. Ж и ткова, я имьль возможность просмотрыть серію Sorex buxtoni Allen., собранную С. А. Бутурлиным въ Верхоянскь, около Охотскъ-Ола и на Колымъ, и находящуюся въ обработк' Б. М. Ж и тков в. Землеройки этой интересной коллекціи крайне рьзко отличаются какъ отъ $S$. araneus L., такъ и отъ S. baikalensis sp. nov. Во-первыхъ, какъ указываеть Алл ен ъ, размьры его землероекъ нысколько уступають обычной формь, во-вторыхъ, на что авторъ почему-то не обратилъ достаточнаго вниманія, хотя и привель измьренія, длина стопы и ширина ея гораздо больше, чъмъ у $S$. araneus L., не говоря уже объ $S$. balialensis, у коей стопа много короче, чьъъъ у первой. У S. buxtoni Allen длина стопы (безъ когтей) обычно равна 14 m/m. (minimum: I2 $\mathrm{m} / \mathrm{m}$., maximum: ${ }_{5} \mathrm{~m} / \mathrm{m}$.). Но особенно характеренъ хвостъ: онъ гораздо полие, чъмъ у всьхъ видынныхъ мною землероекъ. Длина его уступаетъ такової S. araneus L., по этому признаку онъ приближается къ S. baikalensis sp. nov., но структура, толщина и характеръ волосъ-совершенно иные. Именно, онъ покрытъ очень длинными волосами, равнольриыли по своей длииь и крайне густо сидяшими по его поверхности. Характеръ мъха S. buxtoni Allen также своеобразенъ: онъ очень длинный и густой. Къ большому сожальнію, на этикеткахъ С. А. Бутурлин а ньтъ обозначеній, когда добыты землеройки ${ }^{2}$ ), но цвьтъ nłха Sorex buxtoni Allen, хотя и рђзко отличается отъ такового у S. araneus L., не можетъ, однако, быть названъ „болье св'ьтлымъ“. Въ немъ преобладаетъ очень красивый каштановый тонъ, при чемъ основанія волосъ темнаго сьраго оттьнка. Лапы и хвостъ у всьхъ, безъ исключенія, желтые, а волосы хвоста двуцвђтны: сверху свђтло-о́рые, снизу желтовато-сьраго цвђта. По характеру зубовъ эта форма стоитъ ближе гіъ $S$. mimutus L. Такъ, высота второго рызца нижней челюсти вдвое уступаетъ длины его основанія.

Отъ Sorex amnexus Thom. ${ }^{3}$ ), описанной изъ окр. Сеула (Корея),

1) Сı. профь. Н. Ө. К ащ ен ко (80), р. 88.

2) Я почти не сомићваюсь, что это-экземпляры въ зимнемъ иьху.

3) Proceed. Zool. Soc. London, 1906, p. 859. 
Sorex bailalensis sp. nov. легко отличается своей болье свظтлой окраской, короткимъ хвостомъ и ныкоторыми деталями строенія черепа.

\section{Географическое распространеніе.}

Въ предълахъ Московской губ. землеройка всюду представляетъ одинъ изъ самыхъ обыкновенныхъ видовъ мелкихъ млекопитающихъ. Mнъ изв'ьстны экземпляры Sorex araneıs L., найденные въ Московскомъ у. (Косино, Измайловскій Зв'ринецъ), въ Звенигородскомъ у. (село Аносино), Можайскомъ у. (Тесовскій льсъ бл. села Тесова, дер. Митьково), Рузскомъ у. (коллекція Зоол. Муз. Моск. Унив. отъ Н. Ю. 3 огр а ф), Клинскомъ у. (село Демьяново), Дмитровскомъ (Пушкино, колл. Зоол. Муз. Моск. Унив.), Богородскомъ (село Саввино), Серпуховскомъ (р. Березня бл. гор. Серпухова, отъ $Ө$. С. Щ е р бакова). Въ центральныхъ губерніяхъ Европейской Россіи обыкновенная землероі̆ка найдена Эсау ло вым ъ въ Псковской губ́. (58, стр. 223), въ Судогодскомъ у. Владимирской губ. (Е. В. Пы ль н вы м ъ), въ Ярославской губ. (Л. П. С аб а н ье вым ъ). Мною она добыта въ Малоярославецкомъ у. Калужской губ., Гжатскомъ и Сычевскомъ уу. Смоленской губ., а Н. М. Кулагинымъ въ Духовщинскомъ у. той же губерніи (экземпл. въ колл. Зоол. Муз. Моск. Унив.). Южнбе Sorex uranens L. очень обыкновенна въ Орловскомъ и Малоархангельскомъ уу. Орловской губ., гды найдена С. Н. Г ор б́ аче вым ъ и мною. Для Харьковской губ. указана проф. Чернаемъ (2о3, стр. 9) и Н. Н. Сомовым ъ (т 84 , стр. І5г). Далье, встрбчается въ окрестностяхъ Кіева, въ Бессарабіи и Херсонской губ. (Черн ай, 2о3, р. 9). Для Крыма этотъ видъ не указанъ въ работь А. М. Н и ко о ьскаго ( ( 22 ). Bосточнде S. arancus L. встрбчается по всему Поволжью въ Казанск., Симбирск., Саратовск. губ. См.: М. Н. Богдан о в ъ (3о, стр. І6I), а также: Б. М. Ж и тков в (7 г, стр. 5) и А. А. Силантьев ъ (І 8 I, стр. 305). Въ Оренбургской губ́., по Эв ерсманну, она распространена по всему граю за исключеніемъ безводныхъ степей. По словамъ Н. А. 3 арудн аго, не рьдка въ окрестн. Оренбурга, по Сакмар', Нлеку и по среднему теченію р. Урала. Тихоми ров ъ и Корчагинъ упоминаютъ объ одномъ экземплярь изъ Оренбургскаго края.

По С аб ан в е ву-это одинъ изъ самыхъ обықновенныхъ видовъ въ Пермской губ́, гдњ $S$. anuеиs L. найдена также Те пл оуховым ъ. Брандт и и Сабан ъев ъ говорятъ о нахожденіи этой землеройки на Јраль. Далье на сћверъ она найдена въ Вятской губ. (Л. Круликовскій), въ Петербургской губ. 
(Бі ан кі) и в' Лапландіи (Pleske). Западнtе она встрычается въ Курляндіп и Јифляндіи (см. Grevé 6 7, p. 42, 43).

На Кавказь, по Сатунину, встрьчается и на сђверь этого края, въ Ставрополь, и въ Закавказьи (Бакуріаны, Зангезурск. у., Гельтская готловина, Эриванск. губ., Лагодехи).

Что касается до распространенія обычной землеройки въ Сибири, то въ западной ея части этоть видъ найденъ Словцовы м ъ въ Кокчетавскомъ, Тюменскомъ и Туринскомь уу. По Рузскому (см. Н. Ө. Кащенко 8 о, стр. 86) она встрьчается въ южной части Тобольской губ., Аникинъ добылъ ее въ Нарымскомь кра'). По $\mathrm{K}$ а щен ко $S$. araneus L. обыкновенна въ Томской губ.

Переходя къ деталямъ распространенія описываемой землеройки въ предьлахъ восточной Сибири, я затрудняюсь указать точныя границы захватываемой этимъ видомъ области. Дьло въ томъ, что за посльднее время было описано нысколько новыхъ географическихь формъ, и только большої матеріалъ поможеть разобраться въ ихъ подробної географическої дифф)еренцировкь. Такъ, по словамъ проф. Н. Ө. К а щ е н о, землеройки, водящіяся на крайнемъ сьверь Сибири ${ }^{1}$ ) и на горныхъ хребтахъ, начиная съ Алтая и далье на востокъ, принадлежать къ болье темной форм-Sorex araneus borealis Kastsch. Eще восточнбе (Охотскь, Гижигинскъ, Анадырскій округъ, Верхоянскъ, Охотскъ-Ола, устье р. Колымы) встрьчается Sorex buxtoni Allen.

Наконецъ, въ Забаіікаль в распространена Sorex bailialmsis Ogn. Быть можетъ, къ Sorex centralis Thom. относятся землеройки, собранныя Р адде въ восточныхъ Саянахъ (?), Забайкальи и на среднемъ Амурь. Труднье рьшить, что представляеть изъ себя „Sorex vulgaris L.", найденная Ш рен ко м ъ въ низовьяхъ Амура и на Сахалинь ${ }^{2}$ ), а Возн есенским ъ-на Камчатк' ${ }^{3}$ ).

Вь Западной Европь землеройка распространена, начиная съ Швеціи, Великобританіи, Даніи, по всей Германіи, Франціи, въ А.льпйской областп, IIталіп, Венгріи и I Іспаніи. Весьма возможно, что тшательное сличеніе средне-русскихъ Sorex заставитъ выдьлить ихъ въ особую географическую форму. Дьло въ томъ, что за посльднее время цьлый рядъ подвидовъ описанъ изъ Запад-

1) До $72^{0}$ сьв. шир. Си, M id dend orf $(107)$, p. 77

2) Сахалинскія землеройи принадлежать къ описанному Д о б со н о т т виду-S. unguiculatus Dobs. На этомь острову встрџтается также относящаяся нт типу "araneus"-S. daphacnodon Thom. (Cxi. 193 , p. 407.)

3) Btppositio, S. macropygmeus Miller. 


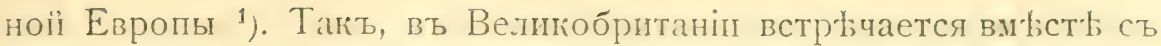
Sorex araneus. L. описанная Jenyns $S$. a. castaneus Jen., въ Альпахь распространена $S$. a. tetragonm неяхъ-S. a. pyrenaicus Miller. Об́上 эти формы характеризуются длиннымъ хвостомъ, превышающимъ обычно $45 \mathrm{~m} / \mathrm{m}$. Далье, въ юго-зап. Франціи распространена S. a. auronotus Miller, на западь Франціи (Charante) водится землеройка, относимая къ особому виду-S. santonus Mottaz. Наконецъ, $S$. $\boldsymbol{a}$. fretalis Miller встрьчается на островь Джерсеь, S. a. granarius Miller-въ Нспаніи, S. a. bergensis Miller-въ западной Норвегіи.

\section{Образъ жизни.}

Быть можеть, широкое распространеніе обыкновенной землероїки обусловливается отчасти той сравнительной неразиорчи востью въ выборђ станцій, которая такъ ясно сказывается у этого вида. Землеройка изб́ьгаетъ лишь совершенно открытыхь мьстъ, но льсъ, состоящій безразлично изъ какихъ деревьевъ, служить ея хараґтернымъ мћстопребываніемъ. Мнђ приходилось встрђчать этихъ мелкихъ млекопитающихъ и въ сухихъ, высокоствольныхъ сосновыхъ льсахъ, вдали оть воды, и въ мелкомъ смьшанномъ льсу, около рьчекъ, среди болотистой почвы. Пожалуй, особенно часто можно ловить Sorex araneus L. въ сырыхъ льсныхъ канавахъ, гдь имьются старые полусгнившіе пни деревьевъ, гдь почва поросла папоротниками, вблизи отъ воды. Осенью землеройки попадаются часто въ домахъ, но льтомъ ихъ видно таль гораздо płже. Sorex aranens L. нельзя назвать исключительно ночнымъ животнымъ, ее часто видно среди дня въ то время, какь она бьгаетъ въ поискахь за добычей. Несмотря на своп незначительные размьры, это-крайне хицное млекопитающее, почти всю жизнь свою проводящее въ поискахъ добычи и въ ьды. Какъ и всь наськомоядныя, обыкновенная землеройка отличается исключительной прожорливостью: она не можетъ оставаться 2-3 часа безъ пищи. Добычеї этого звьрка являются наськомыя и ихъ личинки, которыхъ онъ отыскиваетъ между листьями и травой; далье, землеройка питается мелкими

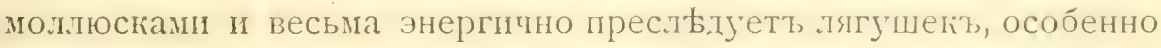
молодыхъ, которымъ трудные убћжать оть своего врага. Нађвшись, землеройка ложится на бокъ и начинаеть облизываться;

1) Mliller (113), p. 415. Cir. тakie: Ann. and Mag. of Nat. History, ser. 8, 1910, p. 458.

2) Miller соединяетъ S. a. curpaticus Barr.-Ham. пзъ Транспльванін съ S. a. tetragonurus Herm. 
подгибая заднюю часть своего туловиша и прижимая голову, она довольно ловко обчищаетъ свой мьхъ. Полежавъ ныскольіо мгновеніиі, она снова вскапиваетъ и начинаетъ свою суетливую, хищную дьятельность.

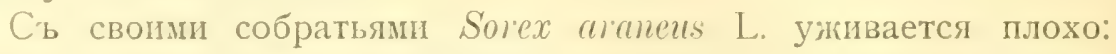
обычно болье сильныя пођдають слабыхъ, что бываеть тогда, погда ньсколько землероекъ попадаются въ одну ловушку: въ живыхъ остаются толыю наиболье сильныя, да и ть кіусаютя каждый разъ, какъ наталииваются другъ на друга. Soiex ai anens L. размножаются начиная съ весны до средины льта: беременныхъ самокь я встрьчаль въ іюнь и іюль. Въ коллекціи кружка любителей Естеств. при Моск. Сельск.-Хоз. Ннст. имьется самка этого вида, добытая 28. IV. 9I2 г. съ 9 зародышами. Количество молодыхъ колеблется обычно отъ 4 до 9.

Къ сожальнію, мны не приходилось находить гньздъ, но K. А. С атун и н думаетъ, тто этому виду принадлежатъ овальныя, довольно большія гнб̆зда, сплетенныя изъ травы и помьщаемыя на земль, среди густої травы и кустарниковъ. Подобныя гньзда случалось находить и мнь, но уже безъ ихъ обитателеї. Осенью, въ ґонць сентября или въ началь октября, землероїћи

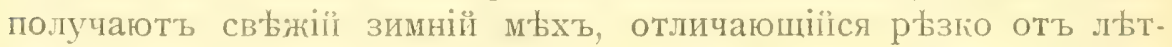
няго. Зимняя жизнь складывается довольно своеобразно: эти звђрки не впадаютъ въ спячку, но дьлаютъ норы подъ сньгомъ и въ сньжномъ погровь, находя довольно обильную добычу, состояшую главнылъ образомъ изъ зимующихъ насыпомыхъ. I’ всьхъ поиманныхъ мною Sorex araneus L. среди зимы вскрытіе желудковь обнаружило остатки хитиноваго слелета разныхъ Coleoptera. Часто можно видьть, какъ землеройка выб Бгаетъ на поверхность снбга и скрывается затьмь въ одной изъ ближайшихъ норъ. Трудно сказать, что заставляетъ звьрковъ показываться на поверхность снғга, вьроятно только не поиски добычи, такь какъ посльднюю они находять во иху и среди листьевъ подъ сньгощъ. Весенняя линька начинается въ апрtль, и еще въ лонцы мая II началь іюня попадаются экземпляры, не вполны замьнившіе свої зимній мьхъ болье свьтлымъ льтнимъ.

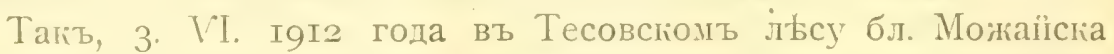
мной былъ поїманъ старый экземплярь, еще не перелинявшії въ льтніï мьхъ. Интересно отмьтить, что зимняя шерсть осталась у него по всеї поверхности спины, вдоль верхней части головы, носа и на бедрахъ.

Въ неволь зеилероїка не представляеть большого интереса. Здыс особенно яріо сіазываются основныя черты ея хараютера: 
большая необщительность и вьчная злобная жадность. Она пресльдуетъ и съ'даеть все, что въ состояніи съьсть, издавая при этомь почти неумолкаемыї цыкающій пискь. Только временами жившія у меня зеллероїни успокаивались и прятались въ мохъ, положенный въ терраріумь, чтобы черезъ короткій срокъ начать вновь свою безпокойную дћятельность.

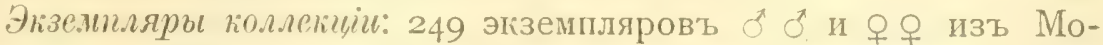
жаліскаго у. Московсіої губ., добытыхъ въ Тесовскомъ удыльномь льсу, въ 5 верстахъ отъ города (льто, осень, зима Igо8I9г2 гг.); 5 экземпляровъ (л'ьто 1907 года) село Аносино Звенигородскаго у.; 2 экземпляра (우) VII: 906 г. дер. Сысоево Звенигор. у.; of и 우 2I. VII. І896 г. Куусково Moсковск. у.; \& Subad. 29. VI. о9 г. с. Валуево, Подольск. у.

Экзелилары коллекии Зоолоииескало Музел Моск. Уливерс.

г) (24г4) Нзмайловскій Звъринець, г89г г. К. А. С атунин и. 2) -3) (24г2-24г3) Ibidem 1889 г. Г. А. Ко ж е в н и ко в ъ. 4) (24І5) окр. Обираловки (Московск. у.) Г. А. Ко же в ни ко в ъ. 5) (24г6) 8. VI. о9 г. Косино (Московск. у.) П. С. Гальцов ъ. 6) (24г7) Люберцы (Московск. у.) І897 г. Г. А. Кожевников ъ. 7) -8) (2446-2447) ст. Мухино бл. Москвы, проф. Го рожан кинъ.

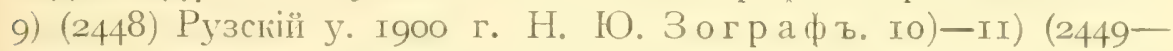
2450) Пушкино (Дмитр. у.) Н. В. Н а с онов ъ.

\section{Sorex minutus L.}

\section{Землеройка крошка.}

Sorex minutus, Carolus Linna e us (98), p. 73. Sorex pygmaeus Erich L axm a n n, Sibirische Briefe, 1769 , p. 72. Sorex minutus L, B a r r t-H a milton (16), 1911, p. 109. Trouessart $(200)$, p. 55. Sorex pygmaers Pall. Bl a sius (2 7), p. 133. Sorex minulus (Linn.) K. А. Са т унин в (165), стр. 5.

\section{Систематическія особенности.}

Черепо (см. табл. I, рис. I5, І6) отличается своими мелкими размьрами. Эта малая величина черепа дьлаетъ діагнозъ крайне легкимъ по первому взгляду и безъ помощи сравнительнаго матеріала. Кромь того, существуеть еще цылый рядъ пластическихъ признаковъ, на которые, страннымъ образомъ, мало указываютъ.При первомъ взглядь на черепа этихъ землероекъ бросается въ глаза болье узиал иосовал часmь иереnа Sorex minutus L. сравнительно съ вздутой и широіої затылочной областью. Далье можно отмьтить, что ossa squamosa S. mimutus L. никогда не образують такихъ рьзкихъ, угловатыхъ контуровъ, каль у $S$. araneus $L$. 
Относптельно разницы вт строеніи нижнеї гелюсти и размьровъ зубовъ я писаль уже выше.

Тпательное сличеніе череповъ разныхъ возрастовъ $S$. mimins L. показало, что обшая схема возрастної измьнчивости совершенно аналогична таковой у S. araneus L., т.-е. и здысь мы имыемь передь собою болье вздутую заднюю часть черепа у молодыхъ, болье выпуклый шовь между parietalia, что легко отличаетъ эти экземпляры оть болье плоскихъ по строенію черепа старыхъ землероекъ. Далье, и здысь мы можемъ констатировать тотъ, видимо общій для рода Sorex факть - крайне скорое развитіе черепа у молодыхъ особей, у ћоихъ онъ рано достигаетъ свопхъ напбольшихъ размьровъ. Въ справедиивости этої законності можно убьдиться при взгляды на таблицу. Что касается до полового диморфизма, то сколько-нибудь надежныхъ краніологическихъ признаковъ мнь установить рьшительно не удалось. То же можно сказать и относительно размьровъ череповъ разныхъ половъ у этого вида.

Oкраска. Въ различныхъ оттьнкахъ мьха сказывается такая же широкая измьнчивость, какъ у Sorex araneus L. Большинство экземпляровъ моей коллекціи по своей окрасќ⿱⺊口灬 совершенно аналогичны посльднимъ. Однако, большая часть $S$. mimutus L. изъ Московскої губ., хранящихся въ коллекціи Зоологическ. Муз. Имп. Моск. Университета отличаются своимь сравнительно свьтлымъ мұхомъ. Особенно свьтель экземпляръ, добытый К. А. С aтуни ны м б бл. ст. Голицыно въ І89о году. Мьхъ этой землеройки бльдно-палево-рыжеватый, съ свђтлыми, сьроватыми основаніями волосъ. Особенно свьтла верхняя часть носовой области и головы, въ окраск' которой примьшиваются желтовато-палевые тона. Вся нижняя часть бұлесая, съ замьтными болье темными сбрыми основаніями волосъ. Хвость и лапы бльдно-желтоватые.

Въ заключеніе укажу на одинъ очень интересный экземпляръ моей коллекціи (으 4II). Эта землеройка () ръзко отличается отъ всьхъ прочихъ S. mimutus L. уже по первому взгляду. Прежде всего мы должны отмбтить крайне короткій хвостъ этого экземпляра. Конечно, трудно сказать навђрно, но очень возможно, что здьсь передъ нами искусственное поврежденіе, но вотъ что пнтересно: волосы на хвость расположены весьма pьдко, напоминая распредьленіе ихь у землероекь рода Crocidur Затьиъ можно отмьтить сравнительную короткость ея морды. Краніологическія отличія также рызки. Помимо общихъ болье мелкихъ размьровъ, черепъ этой Sorex характеризуется отно- 


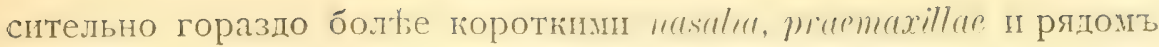
промежуточныхъ зубовъ. Затьиъ бросается въ глаза очень уплощенная форма всего черепа и, наконецъ, посльдней его особенностью является строеніе шва между os occipitale и parietalia, который вдается значительно болье впередъ, чьыъ у всьхъ изученныхъ S. minutus L., у коихъ онъ къ тому же имьетъ форму неправильнаго ирямоугольника, а у нашего экземпляра-далеко выдающагося угла. (См. табл. I, рис. г7.)

\section{Географическое распространеніе.}

Малая землеройка встрьяается въ Московской губерніи гораздо рьже обыкновенной, но большія серіи этого вида, собранныя мною, доказывають, что этоть видъ не можеть быть отнесень къ особенно рьдкимъ представителямъ московской маммологической фауны. Sorex mimutus L. найдена: въ Московскомъ у. (Косино, Измайловскій Звьринецъ-экземпляры въ коллекщіи Зоол. Музея Моск. Унив.; б.т. Петровскаго-Разумовскаго добыта В. К а п о вым ъ), въ Звенигородскомъ у. (бл. ст. Голицыно 4 экземпляра добыты К. А. С а ту н и ны мъ), въ Можайскомъ у. (Тесовскій удьٔльн. льсъ,-экземпляры въ моей коллекціи). Наконецъ, Ассмусъ нашель малую землеройку бл. г. Подольска въ парк' гр. 3 акревскаго. Џзъ центральныхъ губерній Европейской Россіи малая землеройка найдена мною и С. Н.Г о р бач е в м ъ въ Орловскої губ. Для Харьковской губ. ее указываютъ H. Н. Сомов ( о 84 , стр. І5I) и Ч ернай (2о3, стр. ІІ ), который говоритъ также о нахожденіи малой землеройки въ Кіевской губ. Еще далье на югъ, по словамь Нордманна, она часто встрьчается въ сьверной Бессарабіи. К. Ө. Кесслеръ и проф. Чернай отмьчають $S$. mimutus L. для Крыма, однако, изъ словъ ихъ нельзя видьть, гдь они заимствовали этоть факть (см. Н и кольскі й т 22, стр. 45). Далье на востокъ малая землеройка довольно рыдка въ области Говолжья (М. Н. Богдановъ), въ губерніи Симбирской (Б. М. Жи тковъ). С ъвернье найдена въ Пермской губ. Ө. А. Т е п оуховы м въ Вологодскоі губ. (Великій Устюгъ) Блаз іусомъ, а для Оренбургской губ., въ качеств' рьдкаго звьрка, ее указываютъ

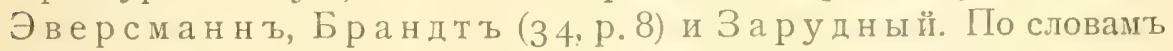
проф. Н. Ө. Кашен ко (8о, стр. 9I), одинъ экземплярь $S . m$. быль привезенъ Р. Г. Щмидтом ъ и Г. Г. Якоб соном ъ съ р. Бьлої (Ураль). Наконецъ, по свидьтельству Брандта (34, p. 8) она добыта въ сьверномъ У ройка-крошка обыкновенна, по словамъ Греве́, въ Рижскомъ, 


\begin{tabular}{|c|c|c|c|c|c|c|c|c|c|c|}
\hline 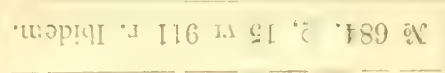 & 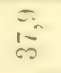 & 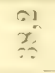 & $\equiv$ & $\infty_{10}^{\infty}$ & & & & & & \\
\hline 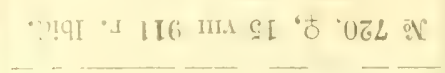 & $\stackrel{s}{-i}$ & $\stackrel{1}{\ddots 1}$ & $\stackrel{n}{0}$ & is & & & & & & \\
\hline 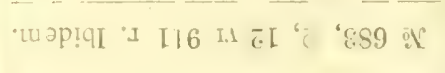 & $\Leftrightarrow$ & $\stackrel{0}{\because}$ & $\stackrel{3}{3}$ & 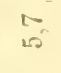 & & & & & & \\
\hline 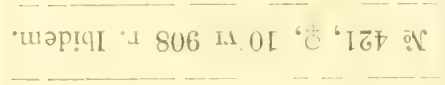 & 管 & \begin{tabular}{ll}
2 \\
\hdashline \\
\hdashline
\end{tabular} & 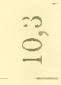 & $0^{\circ}$ & & & & & & \\
\hline - 016 I. $/ 0$ e "pviqus t "Lof & $\div$ & 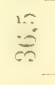 & $\ddot{3}$ & $\dot{0}^{\circ}$ & & & & & & \\
\hline 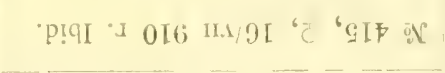 & Iิ & $\frac{6}{30}$ & $\cdot \stackrel{\infty}{\infty}$ & $0^{10}$ & & & & & & \\
\hline 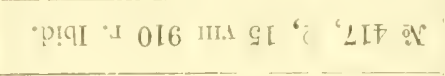 & $\frac{10}{x}$ & 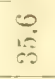 & $\supseteq$ & $\omega^{\infty}$ & & & & & & \\
\hline 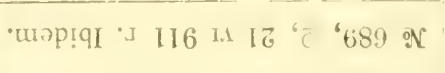 & $\stackrel{0}{2}$ & $\ddot{0}$ & $\stackrel{6}{\varrho}$ & 0 & & 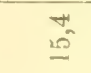 & 0 & $\stackrel{0}{2}$ & $=$ & $\because$ \\
\hline 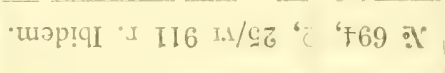 & $\sum_{1.0}^{3}$ & $\stackrel{\oiiint}{\cong}$ & $\stackrel{N}{=}$ & $\stackrel{0}{0}$ & & $\frac{-1}{20}$ & $=$ & 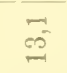 & ๓ू & $\because$ \\
\hline 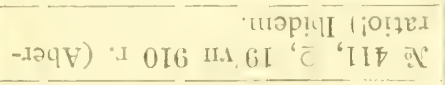 & 3 & $\approx \bar{i}$ & $i=$ & $\hat{\theta}_{0}^{-1}$ & & 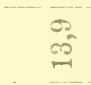 & $\stackrel{\infty}{\infty}$ & $\begin{array}{l}\mathfrak{a} \\
\mathfrak{a}\end{array}$ & $\overrightarrow{\omega^{\prime}}$ & $=$ \\
\hline 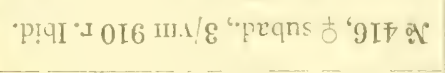 & $\frac{1}{4}$ & $\stackrel{\infty}{3}$ & $\therefore$ & is & & $\begin{array}{ll}10 \\
15\end{array}$ & 20 & $\overrightarrow{\ddot{2}}$ & $\infty$ & $x$ \\
\hline 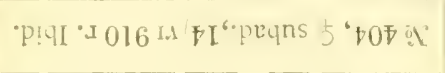 & $=$ & $=$ & $\stackrel{x}{\approx}$ & $\ddot{0}$ & & $\stackrel{9}{ \pm}$ & 20 & 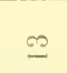 & के & $\therefore=$ \\
\hline 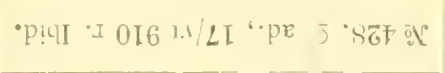 & $\stackrel{P}{\rightarrow}$ & 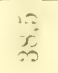 & $=$ & 10 & & 20 & 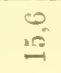 & 9 & $\overrightarrow{\sigma 0}$ & $\hat{i}$ \\
\hline 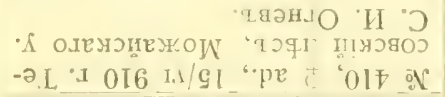 & in & $\vec{x}$ & $\ddot{\Leftrightarrow}$ & 30 & & $\frac{21}{2}$ & 25 & $\stackrel{\square}{2}$ & $\infty^{\infty}$ & 1 \\
\hline 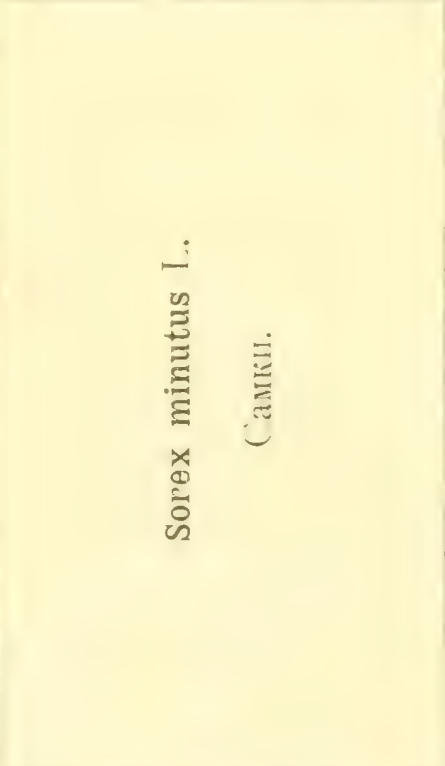 & 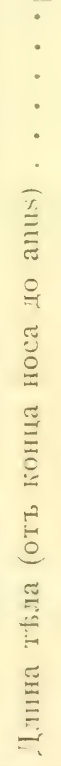 & 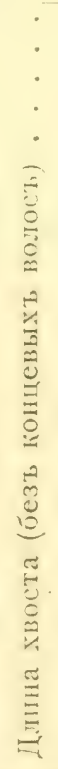 & 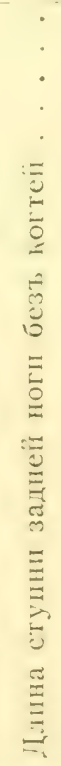 & 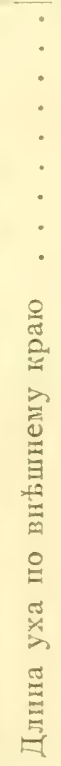 & 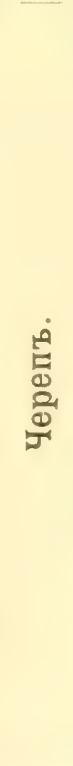 & 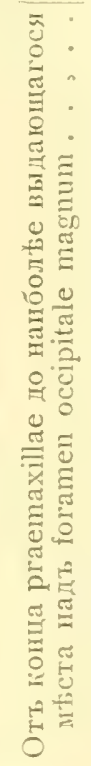 & 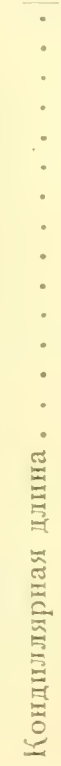 & 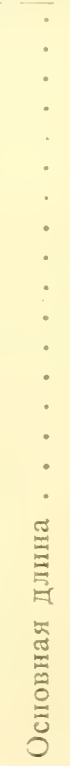 & 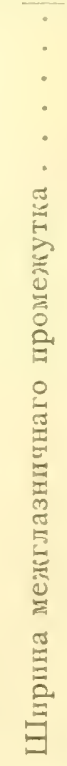 & 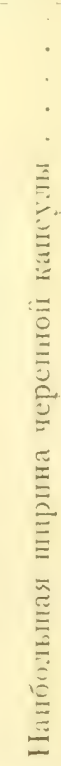 \\
\hline
\end{tabular}




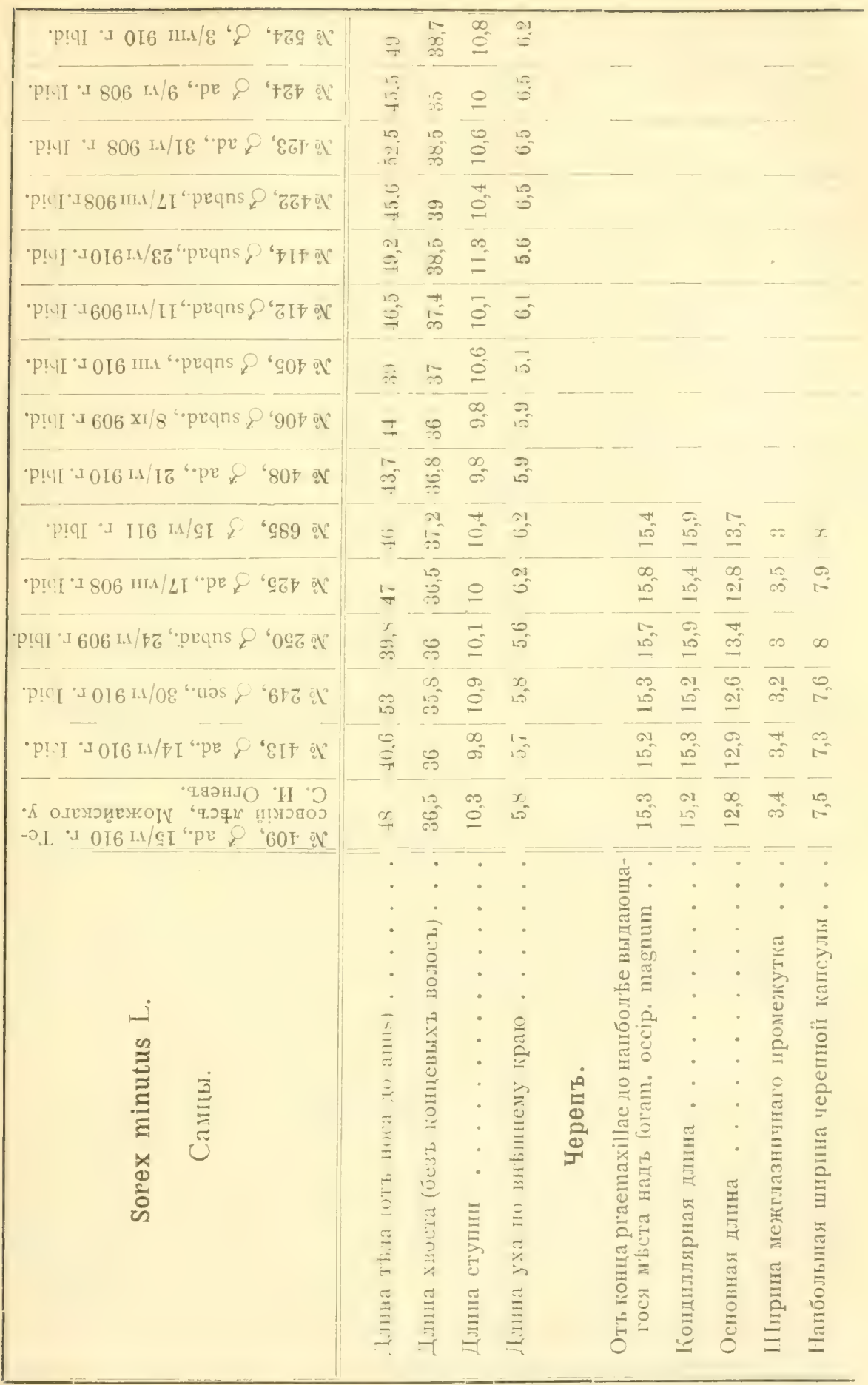


Валкскомъ у., близъ Вольмара и Лисдена. По свидьтельству [I леске, она видимо рьдка въ окрестностяхъ Колы (Соловаракъ) II распространена на съверъ до Варангеръ-фіорда (І 33 , p. 28). На Кавказђ найдена бл. Бакуріанъ К. А. С а т ун и н ы м ъ.

Въ Сибири малая землеройка найдена Словцовым в въ Кокчетавскомъ и Ялуторовскомъ уу. Фалькъ (59, р. 285) добыль ее на р. Ишимђ и Оби, близъ Барнаула. Тамъ же ее наблюдалъ Лакссманнъ. Между Обью и Енисеемъ отмьчена Палласомъ (г зо, р. г 34 ). Геблер ъ очень часто видиль ее въ Катунскихъ горахъ (62, р. 8г). По словамъ проф. К. Ө. К ащенко, два экземпляра S. minutus L. добыты экспедиціеї П. Г. Игнатова на Телецкомъ озерђ (Алтай). Въ Томскомъ крађ, по тому же автору, встрьчается рьдко, добыта только близъ ст. Татарской и въ самомъ гор. Томскь.

На запады малая землеройка распространена оть Ирландіи и Великобританіи по всеіі Западной Европь, а въ Италіи ее замьняетъ описанная Миллеромъ (I 33, p. 4I7) S. minutus luctnius Mill.

\section{Образъ жизни.}

По своимъ станціямъ малая землероїка, повидимому, не отличается отъ обыкновенной, такъ какъ попадается въ ловушки въ однихъ и тьхъ же мьстахъ съ посльдней. Жизнь S. minutus L. тьсно связана съ льсомъ, особенно часто можно ловить этихъ млекопитающихъ въ льсныхъ канавахъ, невдалек古 отъ воды. Этотъ видъ, подобно S. araneus L., обнаруживаетъ свою хлопотливую дьятельность, состояшую въ исканіи добычи не только ночью, но и днемъ. Тогда можно видыть, какъ $S$. munutus L. съ большимъ проворствомъ бьгаетъ между густой травої, исчезая подъ сухими листьями и вновь появляясь на ихъ поверхности, съ большой ловкостью находя мелкихъ наськомыхъ, земляныхъ червеї и пр. Несмотря на свои очень мелкіе размыры $S$. mimия.s L.большой хищникъ. Этотъ звђрекъ нападаетъ иногда на добычу далеко превосходящую его по своимь размьрамъ. Это можно легко наблюдать, когда малая землероїка поймана въ ловушку, куда попали вмьсть съ нею лягушки. Она пресльдуетъ ихъ съ большой энергіей и большинство гибнетъ отъ ея укусовъ. Относительно времени размноженія этого вида мои свьдынія, къ сожальнію, еще довольно отрывочны.-Беременныхъ самокъ я встрьчалъ въ началь льта (VI. I908 г.), количество молодыхъ не превышаетъ девяти.

9кзелиляры коллекиіи: кромь перечисленныхъ въ таблицахъ измьреній, имьются еще 24 экземпляра, добытые льтомъ г9г2 г. въ Тесовскомъ льсу, Можайскаго у. 


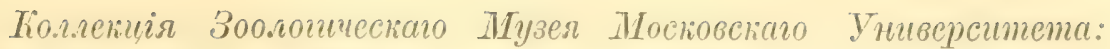

г) (І34I) Косино, Моск. у. 2) (2464) Голицыно, Звенигор. у. ı8go г. К. А. С ат унин ъ. 3) (2465) Измайлово, Моск. у. І893 г.

\section{Родъ N e o m y s Kaup.}

1829. Neomys. Jakob Ka u p, System der Europäischen Thierwelt, I, p. 117 .

По общему виду кутора очень напоминаеть землеройку изъ рода Sorex, но отличается оть посльднеї замьтными и хорошо дифференцированныц признаками. ІІмимо знаиительно большихъ размьровъ, можно отмьтить замьтно болье вздутую по бокамъ и широкую носовую область. Далье, родъ Neomys характеризуется болье длинной и широкої ступней, края которой окаймляютъ длинные и жесткіе волосы. Taкiе же волосы ясно развиты въ видь гребня на конць нижней поверхности хвоста. Сосковъ пять паръ.

Что касается до строенія черепа, то по своимъ общимъ признакамъ онъ очень напоминаетъ таковой.у рода Sorex, отличаясь нькоторыми особенностями, на разсмотрыніи которыхъ я остановлюсь при описаніи вида.

Зубная формула такова:

$$
\text { i. } \frac{3-3}{2-2} \text { c. } \frac{I-I}{O-O} \text { pm. } \frac{2-2}{I-I} \mathrm{~m} \cdot \frac{3-3}{3-3}=30 \text {. }
$$

\section{Neomys fodiens (Schreb.).}

\section{Водяная кутора.}

Sorex foctiens Schreber (172), p. 571, p. 161, 1777. Neomys fodiens (Pall.) Trouessart (200), p. 56, 1910. Neomys fodiens Schreb. B arret-H a milton (16), p. 128. Crossopus fodiens Pall. B l a s i s (27), p. 120. K. A. C a т yн ин н $(165)$, стр. 5 .

\section{Сиетематическія особенности.}

Черепг куторы (См. табл. I, рис. II, I2.) ньъсколько отличается по своему строенію отъ того, что мы видимъ у Sorex araneus L. Прежде всего я могу отмытить очень большую ширину черепної капсулы, бока которої выдаются замћтными углами, также сильнье выдаются боковыя части челюстныхъ костеї. Всльдствіе такого строенія межглазничный промежутокъ, если смотрьть на него сверху, представляется болье рђзко очерченнымъ спереди и сзади, чьмъ въ черепь обычної землеройки. 


\begin{tabular}{|c|c|c|c|c|c|c|c|c|c|c|c|}
\hline ptyl 'I 0L6 II. \&I ' & & ลิ & $\bar{\sigma}$ & $\begin{array}{l}\text { ai } \\
\text { ai }\end{array}$ & $\cong$ & \&! & & $\bar{\infty}$ & $\begin{array}{ll}\because \\
\frac{1}{6}\end{array}$ & $\stackrel{\theta y}{\sigma}$ & $\bar{g}$ \\
\hline 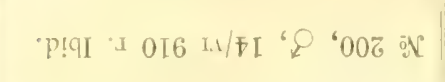 & & बें & $\stackrel{9}{9}$ & $\begin{array}{l}\text { a } \\
\text { gi }\end{array}$ & $\begin{array}{l}\because \\
=\end{array}$ & $\because$ & & ? & $\stackrel{\ominus}{0}$ & $\underset{\infty}{\tilde{O}}$ & $\stackrel{\circ 1}{g}$ \\
\hline 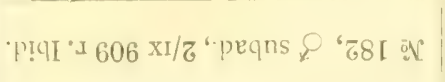 & & and & $\ddot{\sigma}$ & ๙ิ & $\stackrel{5}{=}$ & เo & & $\frac{\infty}{6}$ & $\frac{a 1}{6}$ & $\stackrel{\theta}{\Xi}$ & $\Phi_{\infty}^{+}$ \\
\hline 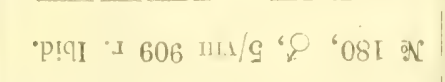 & & ๓ి & $\because$ & สิ & $\stackrel{\oplus}{=}$ & 10 & & $\infty_{\infty}^{\infty}$ & $\frac{\sigma}{6}$ & $\vec{\sigma}$ & $c_{0}^{10}$ \\
\hline ' I 606 is/I " & & న & $\cong$ & สิ & 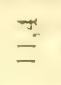 & 210 & & $\infty$ & $\ddot{g}$ & $\stackrel{\circ}{\mathscr{\rho}}$ & $\bar{s}$ \\
\hline 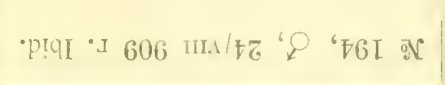 & & बू๊ & 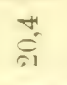 & कू & $\stackrel{1}{=}$ & 10 & & $\stackrel{\infty}{\infty}$ & to & 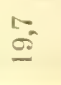 & so \\
\hline " & & $\frac{5}{a 1}$ & $\stackrel{\infty}{=}$ & $\frac{x}{i 1}$ & $\dddot{\square}$ & 2.0 & & $\underset{\substack{n \\
x}}{i}$ & 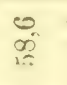 & $\stackrel{\Omega}{\Xi !}$ & $\ddot{3}$ \\
\hline 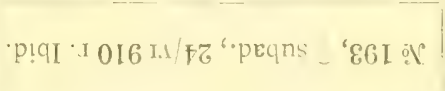 & & $\bar{\infty}$ & $\stackrel{\infty}{\infty}$ & $\frac{\infty}{a}$ & $\Xi$ & + & & $\infty^{\infty}$ & $\dot{8}$ & $\underline{\theta}$ & $\sigma_{\infty}^{\infty}$ \\
\hline 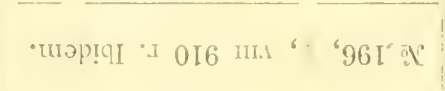 & & $\frac{0}{a}$ & $\dot{\theta}_{\dot{0}}$ & $\bar{a}$ & $\bar{E}$ & $\because 2$ & & $\stackrel{0}{N}$ & 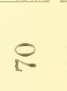 & สิ & $\stackrel{\leftrightarrow}{\infty}$ \\
\hline 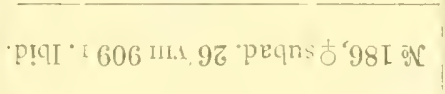 & & ลี & की & $\bar{a}$ & $\overline{0}$ & al & & $\stackrel{\infty}{i}$ & 3 & के & $=$ \\
\hline pṭI I 016 11H.1/g"pe 5'/8I of & & ฟิ & $\overline{2}$ & $\overrightarrow{\text { ai }}$ & $\stackrel{\infty}{=}$ & 15 & & $\begin{array}{l}\infty \\
\infty \\
\infty\end{array}$ & $\stackrel{0}{j}$ & $\stackrel{\infty}{\mathscr{D}}$ & $\tilde{s}$ \\
\hline 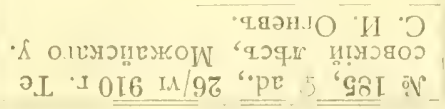 & & कू & $\mathscr{S}_{-1}^{\infty}$ & สิ & $\stackrel{\bar{m}}{=}$ & $\stackrel{\infty}{+}$ & & $\stackrel{n}{N}$ & $\stackrel{\text { जी }}{0}$ & $\underline{\Xi}$ & $\infty$ \\
\hline 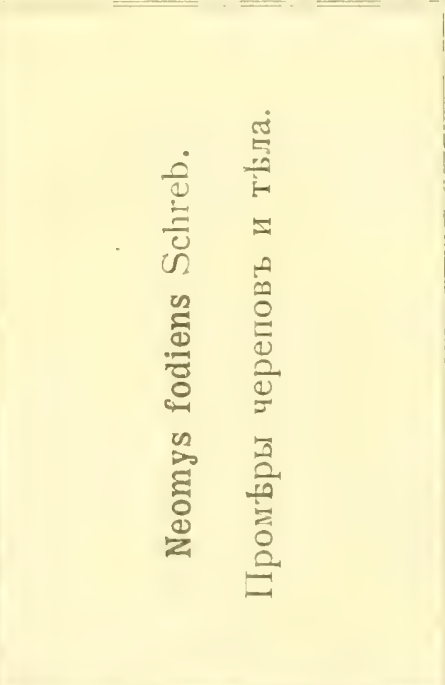 & 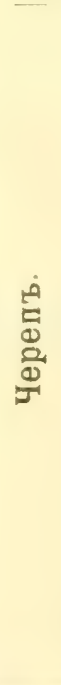 & 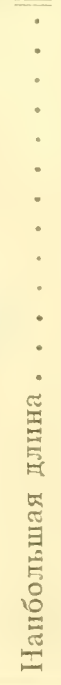 & 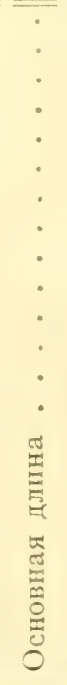 & 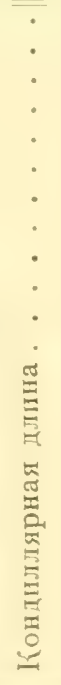 & 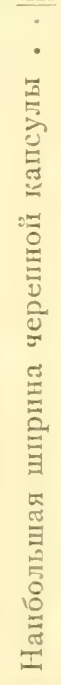 & 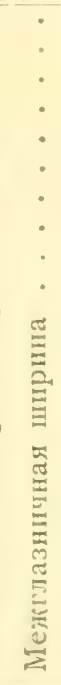 & 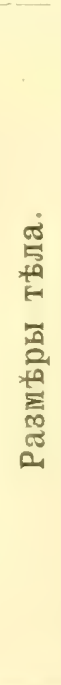 & 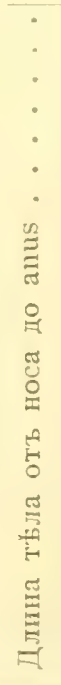 & 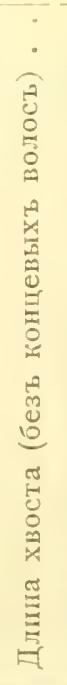 & 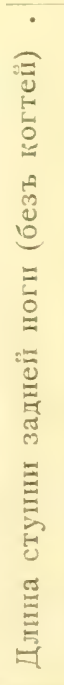 & 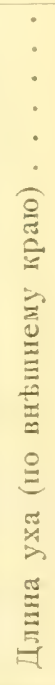 \\
\hline
\end{tabular}


Далぬе могу отмьтить еще одну особенность: ossa praemaxillaria болье круто поднимаются, при взгляды на нихъ въ профиль, чьмъ у Sorex, а также характерно строеніе foramen infraorbitale. у Neomys fodiens Schreb. оно болье широко, основаніе вн'6шняго края этого отверстія выдается зам'ътымъ угломъ. У рода Sorex мы видимъ иное: здьсь foramen infraorbitale много уже, вньшнії контуръ его болье закругленъ и нытъ тої угловатости, которая столь характерна для Neomys. Кромь этихъ отличій строенія, черепъ куторы много крупнье.

Просматривая серію череповъ Neomys fodiens Schreb., я пришелъ къ тому результату, что черепа самцовъ въ общемъ н'bсколько длиннђе, чьмъ у самокъ, хотя эта разница очень мала. (см. таблицу.) Что касается до ионфигураціи костей, то какойлио́о половоїі дифференцировки найти положительно не уда:тось. Къ сожальнію, у меня нътъ очень молодыхъ куторъ, но, сравнивая черепа весьма старыхъ съ черепами еще довольно молодыхъ особей, красные концы зубовъ у коихъ развиты еще очень сильно, я могъ замьтить, что боковой профиль ossa parietatia у экземпляровъ различнаго возраста несомнънно разнится.-У молодыхъ особеї шовъ между parietalia развитъ очень слабо, но зато самыя кости болье вздуты; у старыхъ мы видимъ обратное: здьсь появляется небольшой гребень по шву теменныхъ костей, но, если смотрьть на нихъ сверху, сразу бросается въ глаза ихъ болье уплощенная форма.

Конфигурація зубовб куторы сравнительно очень постоянна. Главныя отличія ихъ структурныхъ особенностеї, помимо общаго меньшаго числа, состоятъ въ сльдующемъ. Передній зубецъ двувершиннаго перваго рьзца верхней челюсти выдается впередъ дугообразно загнутымъ отросткомъ, по країнеиі мьрђ въ четыре раза (если мьрить отъ мыста разрґза) превышающимъ второї, сльдуюшій за нимъ, зубецъ. Посльдній обычно нияе расположеннаго за нимъ второго рьзца. Эти соотношенія у Sorex coвершенно иныя: здысь разница высоты и строенія двухъ зубцовъ передняго рђзца верхней челюсти крайне мала, а второї зубецъ выше сльдуюшаго за нимъ рђзца. ІІоверхность нижняго, очень удлиненнаго ръзца гладкая и вогнутая; только у основанія этого зуба замьчается небольшой округлый выростъ. У рода Sor’ на верхнемъ крађ этого зуба ясно очерчены четыре острыхъ выступа.

Что касается до окраски, то здысь замьчаются значительныя варіаціи. Наиболье обычными являются ть куторы, мьхъ спинної поверхности коихъ болье или менъе интенсивнаго чернаго, 
бархатистаго цвьта, а нижняя сторона бьлая, различної интенспвности. Отъ этого основного типа имьются многочисленныя отілоненія, состоящія въ болье или менье яркої примьси коричневаго оттьнка къ черному мьху спины. Гораздо рыже попадаются куторы, мъхъ спины которыхъ яркаго каштановаго цвъта. Такіе экземпляры (два) были добыты $\mathrm{Ha}$ а ар о вы м ъ въ Южномъ Ураль и хранятся въ коллекціи Зоологическаго Музея Моск. Vнив, а третій, болье темный, быль привезенъ изъ Симбирской губ. Б. М. Жи тковымъ. Въ литературь имьются указанія на существованіе подобної цвытової аберраціи куторы, не пріуроченної, однако, къ опредьленной мьстности. Такіе экземпляры описываеть, напримьръ, Ma ts chie (г 3, p. 227) изъ Румыніи, а проф. Н. Ө. Кащенко $(8$ о, стр. 84) имьль схожую Neomys изъ Красноярскаго музея. Въ моей коллекціи московскихъ куторъ особенно интересны №№ 2 I7 и I94 (ð ఫ), добытые въ Тесовскомъ льсу Можайскаго у. У нихъ на брюшной сторонь замычается крестообразное черное пятно (см. табл. II рис. 43), а у № 217 круглое пятно имьется и на шеђ. Окраска самокъ и самцовъ почти совершенно одинакова. Однако, просматривая свои большія серіи, я могъ замьтить, что самки въ общемъ отличаются болье тусклымъ цвьтомь мұха, особенно на брюшной сторонь ихъ тьла, гдь къ бьлому цвьту примьшиваются сьроватые тона. Цвьть лапъ у самокъ также темнье и сьрье. Повторяю, что эти различія сказываются только на серіяхъ. Kромы того, они еще слаб ье, такъ какъ молодые самцы тусклье старыхъ и болье напоминають по мыху самокь. Замьчу въ заключеніе, что въ большинствђ случаевъ только у самцовъ часто въ области горла и груди замычается красновато-ржавый оттьнокъ мьха.

Въ заключеніе привожу паблиу излюреній, составленную на основаніи изученія 62 экземпляровъ Neomys fodiens Schreb.

Географическое распространеніе.

Кутора принадлежитъ къ довольно обыкновеннымъ млекопитаюпцм Московской губ. Она найдена въ Московскомъ у. (ближ. окр. г. Москвы, экз. въ коллекціи Зоол. Муз. Моск. Унив.), Звенигородскомъ у. (окрестности села Аносина), Можайскомъ (окр. г. Можайска и села Тесова), Дмитровскомъ у. (Пушкино, экземпляры коллекц. Зоол. Муз. Моск. Унив.), Богородскомъ у. (окр. с. Саввина, гды добыта Г. И. Поляковымъ). К. А. Сатун и н наблюдаль кутору въ Измайловскомь Звьринць, близъ Москвы по р. Серебрянкь и добылъ близъ ст. Голицыно, Звени- 


\begin{tabular}{|c|c|c|c|c|}
\hline $\begin{array}{c}\text { Измьренія } \\
\text { Neomys fodiens Schreb. } \\
62 \text { экземпляр, добытые въ Тесовскомъ } \\
\text { льсу Можайскаго вь въ 1908, 1909, } 1910 \\
\text { и } 1911 \text { гг. }\end{array}$ & 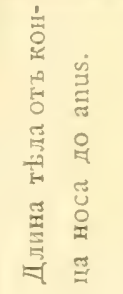 & 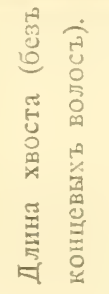 & 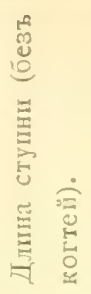 & 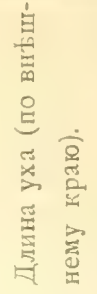 \\
\hline$\pi$ & & & & \\
\hline Maximum .... & 85,3 & 73,2 & 20,3 & 9.8 \\
\hline Minimum $\therefore .$. & $\begin{array}{c}61,2 \\
\text { (subad.) }\end{array}$ & 59 & 18 & 7,8 \\
\hline 우우 & & & & \\
\hline Maximum .... & 88,3 & 71 & 20 & 9,7 \\
\hline Minimum . . . & $\begin{array}{c}66 \\
\text { (subad.) }\end{array}$ & $\begin{array}{c}51 \\
\text { (senex) }\end{array}$ & 18,7 & 7,6 \\
\hline
\end{tabular}

городскаго у. Въ центральныхъ губерніяхъ Yeomys fodien.s Schreb. добыта Эс ауловым ъ въ Псковской губ. (58, стр. 223), М. И. По г один ым ъ въ Ельницкомъ у., бл. с. Гнъздилова (экземпляры въ моей коллекціи). Южнъе встрьчается въ ю.-в. части Орловскіої губ., гды отмычена Даниловымъ (4 I, стр. 28), но въ этой мџстности она позднђе ни мной, ни С. Н. Горбачев ы ъ найдена не была, что несомньнно указываетъ на рьдкость водяной землеройки. Въ губерніи Харьковской ее отмбтилъ Чернай (203, стр. 9) и Н. Сомовъ (I 84 , стр. І5I). По Н ордманну встрђчается въ Малороссіи. Belke найдена въ Кіевской губ. и около Каменецъ-Подольска. Въ Крыму добыта К. Ө. Кесслеромъ бл. Суинаджи (см. Никольскій г 22, стр. 45.) Далье на востокъ Neomys fodiens Schreb., по М. Бо гданову, встрђчается въ большеї части долинъ Поволжья, но всюду рыдка. Въ Симбирской губ. въ долин'ь рьки Алатыря добыта Б. М. Житковымъ, въ Пермскої губ. Л. П. Сабан ъевымъ. Эверсманъ, Леманъ и 3 арудный находили ее въ Оренбургскомъ крағ, при чемъ послудній авторъ точно указываетъ мьста ея нахожденія, именно: г. Оренбургъ, р. Сагмару, Башкиріг и нижн. теченіе IІтека. Въ Оренбургскомъ крау; ее нашель также Крашенинниковъ (экземпляры въ колл. Зоол. Муз. Моск. Унив.), и въ южной части Зауралья Наза- 
ров (2 экземпляра въ коллекц. Зоол. Муз. Моск. Унив.). На. гонецъ, Л. П. Сабан вольно обыкновенної по всему Зауралью. Далье на съверозападъ встрфчается въ Вятской губ. (Малмыжскій и Уржумскій уу. Л. Круликовскіi), въ Петербургской губ., гды найдена Брандтом ъ $(33$, р. 8) и въ недавнее время В. Л. Біанки на берегу бухты у дер. Черная Лахта Петергофскаго у. Еще сьвернье, по словам Брандта, цобыта Рупрехтомь близъ УстьЦыльмы. По свидытельству П л еске, кутора очень обыкновенна въ Лапландіи ( 133, стр. 28). Въ Западномь крађ встрьчается в’ Эстляндіи и Лифляндіи (Grevé, 67, p. 40-4I).

На Кавказ найдена $К$. А. С а туни ны м ъ. [Ахалкалаки, p. Тандурекъ-чаії (Сурмалинск. у.), Гелтская котловина]. Въ Малой Азіи, по К. А. Сатунину (І 57 , стр. 224), встрьчается въ ея съверо-восточной области.

О распространеніи водяной землеройки въ Сибири мы знаемъ еще въ довольно общихъ чертахъ. I. Ф. Брандт в высказываетъ предположеніе, что этоть видъ распространенъ, подобно Sovеx araneus L., до арктическихъ областей Европейской и азіатской Россіи (35, р. 595). До настоящаго времени ее, однако, не находили такъ далеко на сьверъ, какъ обычную землеройку. К а щ е н к о, основываясь на указаніи П алл а с а (г 3 о, р. Ізо), предполагаетъ, что съверная граница распространенія этої формы проходить приблизительно подъ $62^{0}$ с. ш. Самыми южными пунптами мьстонахожденія водяной землеройки въ Сибири являются Тарбагатайскій хребетъ, гды она добыта Финшем ъ (около Бургузутая, на высоть' 500 ф.) и г. Пржевальскъ, гды она найдена проф. Сапо жниковы м ъ. Между этими крайними пунктами распространенія Neomys въ Сибири эта землеройка найдена С ловцовы м бл. г. Тюмени, на p. Ишимы и Иртышь, какъ въ предьлахъ Тобольской губ., такъ и еще южнће (отъ ст.

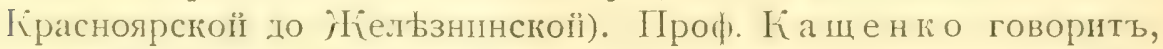
что изсльдоваль одинъ экземпляръ изъ села Убинскаго (на Иртышь, между Семипалатинскомъ и Усть-Каменогорскомъ). Далье онъ видьль 4 экземпляра изъ русскаго Алтая и 3 экземпляра изъ окр. Красноярска. Проф. Сапожниковъ добылъ одну кутору бл. с. Успенскаго (верхн. теч. Енисея). Наконецъ, изъ окр. Томска въ коллекціи проф. К а щенко имьются только 2 экземпляра.

Въ восточной Сибири $N$. fodiens была найдена $Г$. И. Р ад де на p. Кркуть (льв. притокъ Ангары, Иркутской губ.) ( с 43, p. I 24), a Милдендорфомъ на р. Бирюсь (тамъ же) и по берегамъ 
Охотскаго моря ( $о$ о 7, р. 76). Проф. Н. Ө. К ащ е н к упомина. етъ объ одномъ экземплярь изъ окр. гор. Иркутска.

Въ Европь водяная кутора распространена отъ Финмаркена $\left(70^{\circ} 45^{\prime}\right.$ с. ш.) и Великобрптаніи по всей средней и южной области, достигая въ горныхъ мыстностяхъ (Альпы и Карпаты) 6000 ф. въ своемъ вертикальномъ распространеніи

За посльднее время было описано довольно много географическихъ формъ куторы, изъ коихъ право на существованіе имьютъ только немногія. Такъ, въ Великобританіи распространена $N$. fodiens bicolor (Shaw.), въ Нспаніи - N. f. anomalus Cabrera, въ ШШвейцаріи-N.t. millen Mottaz. Что касается до $N$. f. ciliatus Barr.-Ham., N. t. naias Barr.-Ham. и N. f. minor Miller, то описанія ихъ внушають большія сомньнія, и въ новыйшей работь Баррета-Гамильтона ( 6 б, р. гзо) эти расы сведены въ синонимы обычной куторы.

\section{Образъ жизни.}

Кутора принадлежить къ тьмъ животнымъ, которыя съ большою легкостью могутъ приспособляться къ разнымъ жизненнымъ условіямъ. Вьроятно, это одинъ изъ факторовъ широкаго распространенія даннаго вида. Однако, особенно излюбленными станціями Neomys fodiens являются льсныя торфяныя болота, поросшія травой и кустарниками, въ особенности, если поблизости протекаеть неб́оьшая рђчка съ топким берегами. 3дысь можно впдыть выходы норь этого звьрька, отличанціяся ньсколько б́ольшимъ діаметромъ, чьмъ норы Sorex aranens L.

Свои гньзда кутора дылаеть или подъ землею, или наземныя.

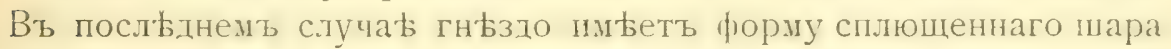
изъ сухой травы и листьевъ и помыщается обычно около самой воды, будучи хорошо спрятано въ густомъ дернь. Къ сожальнію, у меня ньтъ личныхъ наблюденій надъ спариваніемъ этого, столь интереснаго съ біологической стороны млекопитаюшаго, но сроки беременности его весьма различны. Такъ, мн's приходилось находить беременныхъ самокъ въ срединь іюня (го. VI. 908 г.) и половинь іюля (г5. VII. 908 г.), а въ коллекціи студенческаго кружка Любителей Естествознанія при Сельскохозяйственномъ І Інституть въ Петровско-Разумвскомъ имьется зкземпляръ ㅇ куторы, добытой 7. V. rgII г. съ 6 зародышми (близъ ст. Любллнно Казанской ж. дор.).

Количество молодыхъ колебалось отъ шести до семи. Уже выведшіяся молодыя были найдены въ гньзды слыпыми въ срединь іюля г909 года. 
Этоть видъ, подобно другимь нашимъ землеройкамъ, не засыпаеть на зиму, а прокладываетъ себы ходы подъ сньгомъ, иногда появляясь надъ поверхностью посльдняго. Зимою куторы держатся также около незамерзающихъ быстрыхъ ручейковъ.

Mнћ много разъ приходилось наблюдать Neomys foctiens Schrb. въ неволь. Трудно представить себь болье цьльное воплощеніе жадности и злобы, которыя являются основными свойствами характера этого млекопитающаго.

Когда я посадиль къ находящейся въ терраріум куторь ньсколькихь Rana temporana L., она тотчась начала за ними охоту. Бьгъ куторы быстрый, при чемъ она движется, вытянувшись и характерно загибая кверху свою длинную морду, которой водитъ изъ стороны въ сторону, Съ большой быстротой бросилась кутора на одну лягушку, прыгавшую отъ нея изо всьхъ силъ. Поймавъ лягушку, хишникъ прежде всего начинаеть кусать ее за голову. Если лягушка велика и сильна, то часто старается спастись оть своего мучителя и, тогда можно видыть, какь кутора буквально ьдеть верхомъ на своей жертвђ, ухвативъ ее за голову. НҺкоторыя лягушки въ то время, когда за ними гоняется кутора, издаютъ жалкіе громкіе писки и стоны, жъ которымъ примышивается особый цыкаюшій пискъ, который все время слышится отъ ихъ пресльдователя; другія пытаются спастись оть куторы молча. Весьма интересно отмњтить, что въ большинств'b случаевъ, какъ только $N$. fodiens настигаетъ лягугку и слегка кь ней прикасается, съ посльдней дьлается настоящій столбнякъ: лягушка мгновенно вытягивается, какъ мертвая, характерно закрывая передними лапами голову. Кутора, какъ было сказано, начинаеть свои укусы съ затылочной части основанія черепа. Интересно, что въ это время лягушка даже не пытается защищаться и лежитъ, какъ мертвая. Если въ этоть моменть другая Rana temporaria неосторожно подвернется куторь, посльдняя бросаеть свою жертву и начинаеть пресльдовать новую. Въ это время первая лягушка продолжаетъ лежать неподвижно нысколько мгновеній, затьмъ вскакиваетъ и прыгаеть, словно здоровая, что съ несомньнностью указываеть на сравнительную легкость первыхъ укусовъ.

Мы видимъ здьсь явную аналогію съ тьмъ явленіемъ, котоpoe такь легко наблюдать при ловльь ястребомъ или соколомъсапсаномъ своей доб̆ычи. Когда Astur palumbarins L. хватаетъ грача или голубя, съ этими птицами дьлается характерный столбнякъ оть паническаго страха, парализующій всь ихъ движенія. Птица, часто еще совершенно не раненая или получившая сла- 
быя царапины, безпомощно виситъ въ лапахъ хищника, въ то время какъ ньсколько энергичныхъ движеній разомъ освободили бы ее, т. к. ястребъ съ большимъ трудомъ тащитъ грача даже при условіи его полної неподвижности.

Если выстрблить въ этотъ моментъ въ ястреба, или испугать его, чтобы онъ бросиль свою добычу, грачъ, или какая-нибудь другая пойманная птица, падаетъ на землю и лежитъ ньсколько секундъ какъ мертвая, но затьмъ вскакиваеть и спокойно улетаетъ. То же видимъ мы отчасти и въ нашемъ случағ: на лягушекъ находить этоть паническій страхъ, который мћшаеть самозащить и ведетъ ихъ къ в'ьрной гибели. Прожорливость куторы прямо поразительна: одна жившая у меня старая Neomys fodiens Schreb. съ ьла въ одну ночь тушу снигиря (Pyrrtula pyrrhula L.) и 7 Rana temporaria L., которыхъ наполовину обглодала. Интересно отмғтить, что этоть звьрекъ очень легко загрызаеть разныхъ мелкихь млекопитающихъ, если попадаеть съ ними в одну ловушку. Даже съ крысоголовой полевкой онъ справляется очень легко и обычно съ вляя нетронутыми только конечности и тщательно очищенную шкурку. Всь мои наблюденія говорять за то, что кутора не можеть даже короткій срокъ оставаться безъ пищи. Всльдствіе этого только очень немногія, попавшись въ ловушку и посидьвъ тамъ ньсколько часовъ безъ пищи, остаются живыми. Ньть сомньнія, что смерть нькоторыхъ изъ нихъ ускоряется страхомъ и ужасомъ, когда животное не можетъ выбраться изъ западни. Вьдь анологичные случаи можно наблюдать и у птиць, гибнущихъ въ западнђ иногда всльдствіе психическаго потрясенія, безъ сльдовъ всякихъ вньшнихъ поврежденій. Если учесть этотъ чисто-психическій факторъ и для куторы, то все же большую роль играеть самая организація этого своеобразнаго животнаго, весьма пнтенсивно страдаюшаго, если даже ћороткій срокъ оно останется безъ пищи. Я пробоваль иногда брать изъ терраріума, въ которомь уже обжилась кутора, положенную ей пищу. При этомъ опыть животное очень скоро (обычно черезъ ньсколько часовъ) погибало отъ голода. Одной изъ немногихъ привлекательныхъ чертъ куторы является ея поразительная способность плаванія; интересно бываеть наблюдать, съ какой поразительной быстротой она передвигается, если пустить ее въ акваріумъ и сколь быстро бьгаетъ по дну его, то появляясь на поверхность воды, то снова ныряя въ глубину. Я пробовалъ держать по ньскольку куторь, но сварливый и злобный нравъ ихъ, сказывающійся при этихъ условіяхъ наиболье ярко, не пред- 
ставляль большого интереса. јКивотныя дрались все время, какъ только случайно встрьчались другъ съ чругомъ, издавая громкій пыкающій пискъ.

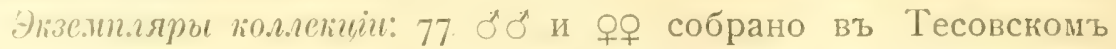
удыльномъ лћсу, въ Можайскомъ убзды льтомъ I908, І909, igio, I9Iі и тgі2 г.г. o. 70 \& ad. 18. VII. 907 г. с. Аносино Звенигор. у. № 7 I sen. 4. VIII. 907 г. Екатериновка Звенигородскаго у.

Гіолиекія Зоолопиеспано Музея Моск. Уиив.: І) (№ 2487) Іо/Х 905 г. окр. гор. Москвы. 2) (을 2488) Голицыно, Звенигор. уьзда г89o г. К. А. С а тун ин ъ. 3) (№ 2489) Нзмайлово І89г г. (бл. Москвы) К. А. С атунин ъ. 4) ф Измайлово, Г. А. К о жев ников ъ. 5) (№ г з33) Пушкино, Дмитровскаго уђзда, Н. В. H а соновъ.

Въ заключеніе, даю синоптическую таблищу водящихся въ Московской губ. Soricidae.

I. По вн

I. Окраска верхней части тьла варіируетъ оть довольно свьтлой до темно-коричневой. Ступня задней ноги, не превышаюцая (безъ когтей) I3,4-I4 m/m., покрыта короткими волосами. Хвость длинный, одътый равномьрными волосами. Сосковъ три пары.

Родъ Sorex.

а. (b.) Размьры сравнительно крупные.-Длина тьла и головы: отъ $50,3 \mathrm{~m} / \mathrm{m}$. (subad.) - $74 \mathrm{~m} / \mathrm{m}$. (ad.); длина ступни: $\mathbf{~} \mathbf{}, 6$. $\mathrm{m} / \mathrm{m}$ - $33.4 \mathrm{~m} / \mathrm{m}$; длина уха: $7 \mathrm{~m} / \mathrm{m} .-8,7$. Хвостъ, длиною. отъ $35 \mathrm{~m} / \mathrm{m}$.-4I,6 m/m., покрытъ довольно короткими волосами у молодыхъ экземпляровъ и почти лишенъ ихъ у старыхъ. Основаніе его слабо сужено. Sorex araneus I.

b. (a) Размьры значительно мельче.-Длина тьла и головы: оть $37,9 \mathrm{~m} / \mathrm{m}$.-57,2 m/m.; длина ступни: $8,7 \mathrm{~m} / \mathrm{m}$. - тा,3, длина уха: $5, \mathrm{r} \mathrm{m} / \mathrm{m}$. $-6,8 \mathrm{~m} / \mathrm{m}$. Хвость длиною отъ $35 \mathrm{~m} / \mathrm{m}$.-39, покрытъ длинными волосами, которые обнашиваются у старыхъ. Основаніе его рьзко сужено. Sorex minutus L.

2. Окраска верхнеї стороны въ большинств аспидно-черная (лишь очень рђдко коричневатая). Ступня задней ноги не менће т8 $\mathrm{m} / \mathrm{m}$. Края ея окаймляють длинные и жесткіе волосы. Такіе же волосы, въ виды гребня, ясно развиты въ понць нижней поверхности хвоста. Сосковъ пять парь.

Родъ N e o m y s. 
a'. Размьры крупные.-Длина тьла и головы: $6 \mathrm{r} \mathrm{m} / \mathrm{m} .-88,3$; хвоста: $5^{\text {I }}-73,2 \mathrm{~m} / \mathrm{m}$; ступни: $18-20,3$; уха: $7,6-9,8 \mathrm{~m} / \mathrm{m}$.

Neomys fodiens Schreb.

II. ПI о строенію черепа и зубовъ:

I. Всьхъ зубовъ 32 . На конц' длинныхъ переднихъ рьзцовъ имьется на каждомъ изъ нихъ по два зубца, изъ коихъ передній только немного длиннЊе задняго, а этотъ посльдній выше сльдующаго за нимь рьзца. На поверхности перваго удлиненнаго нижняго рьзца ясно очерчены четыре острыхъ выступа. Родъ Sorex.

a. (b.) Длина черепа отъ $17,8 \mathrm{~m} / \mathrm{m}$. - $19,9 \mathrm{~m} / \mathrm{m}$.

Sürex araneus $L$.

b. (а.) Длина черепа отъ $13,9-15,8 \mathrm{~m} / \mathrm{m}$.

Sorex minutus $\mathrm{L}$.

2. Всъхъ зубовъ 3о. Передній зубецъ двувершиннаго, перваго рЊзца верхнеї челюсти выдается впередъ дугообразно загнутымъ отросткомъ, по крайней мьрђ въ четыре раза (если мьрить оть мьста разрьза) превышающимь второї зубецъ. Посльдній ниже сльдующаго за нимъ второго płзца. Поверхность нижняго, перваго удлиненнаго рызца, гладкая и вогнутая, только у основанія этого зуба замьчается небольшой, округлый выростъ. Родъ $\mathrm{N}$ е о m у s.

а. Дтина черепа оть 2I,8-23,5 m/m. Neomys fodiens. Schreb.

\section{Семейство Talpidae.}

\section{Родъ таlра. кроты.}

1757. Carolus Linnaeus (98), p. 52.

Характерной особенностью этой своеобразной группы млекопитающихъ является болье сильное развптіе всей переднеї области ихъ удлиненнаго, мъшковиднаго тьла. Особенно массивны переднія конечности грота, имьющія широкую пластинообразную фориу и вооруженныя пятью пальцами, при чемъ еще большіе размыры придаетъ имъ развитіе сесаловидной кости os falciforme, лежащеіі у внутренняго края ступни. Носъ очень удлиненный, далеко выдающіїся за линію переднихъ рьзцовъ, 
ноздри расположены на нижней гасти его передняго края. Глаза крайне малы, ухо совершенно закрыто мбхомъ и состоить только изъ ушного отверстія, безъ развитія внышней ушной раІіовнил.

Зубоная формула такова:

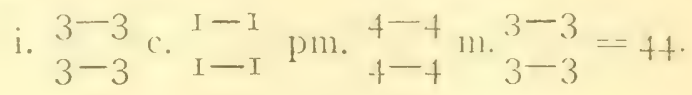

\section{Talpa europaea L.}

\section{Кроть.}

Talpa europace Linna eus (98), 1857, p. 52. Dobson (48), p. 137, p. $\mathrm{XX}$, fig. $8,8 \mathrm{~d}$. Trouessart (200), p. 61. Barret-Hamilton (16), p. К. А. С а ту нии и $(165)$, стр. 6.

\section{Систематическія особенности.}

Черепо сильно удлиненный, съ тонхими замкнутыми скуловыми дугами. Тимпанальныя кости образуютъ плоскія bullae. Просмотръ моей серіи череповъ Talpa еитораеа L. показалъ мнь, что структурныя особенности ихъ относительно постоянны. Черепъ молодого довольно легко узнать, во-первыхъ, по большему вздутію лобныхъ костей, которыя у старыхъ дьлаются площе въ связи съ удлиненіемъ всей передней области и, во-вторыхъ, по меньшей ширинь черепной капсулы. Въ моей коллекціи ньтъ большого матеріала изъ южної части Европеїской Россін, но два хранящіеся въ Зоолог. Музеь Моск. Унив. прота, одинъ изъ Кіевской губерніи (оть г. Н енюкова), другой изъ окрестностей Таганрога (оть Л. П. С абан ьева), при сравненіи съ моими мосіовскпми кротами от.пчались свопми ойции большими разпьрами. (См. табл. А). Къ сожальнію, черепъ кіевскаго крота совершенно испорченъ, а зубы очень сильно стерты, что же касается до экземпляра изъ Гаганрога, то по свонмъ особенностямъ (кромь размьровъ) и по структурь черепа онъ не подходить къ описанію Talpa enropaea tranneri Sat. Такъ, средніе p tзлы верхней челюсти устроены совершенно по типу T. eигораеа L., т.-е. „не вдвое болье боковыхъ“, какъ считаеть это характернымъ для ' $T$. e. Urameri K. А. С а ту ни нъ. Foramen infraorbitale дыйствительно показалось мнь ньсколько болье вытянутымь и

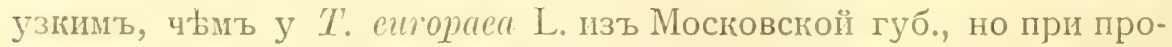
смотрь серій одинъ изъ моихъ экземпляровъ (№569) отличался еце болье длиннымъ нижнеглазничнымъ отверстіемъ. Все это внушаеть ныкоторыя сомнынія относительно реальности отличій въ 
форм⿱⺊口灬 foramen infraorlitale у обычнаго и южнаго кротовъ. Что касается до прочихъ признаковъ отличія, которые приводитъ для своего T. enropaea brameri K. А. С а ту н и ъ, каковы-конфигурація зубоовъ, строеніе одновершпнныхъ рп. верхней челюсти, то всь эти особенности нельзя считать исключительно характерными для крота Браунера, т. к. онь цбликомъ подходятъ къ моимъ московскимь экземплярамъ.

Итакъ, я не могу съ увьренностью отнести упомянутыхъ кротовъ къ южно-русскому $T$. enropaea brameri Sat. всльдствіе несовпаденія особенностей зуб́овь и черепа, но об́піе болыпіс размьры какъ бы говорятъ, что этихъ кротовъ должно считать при-

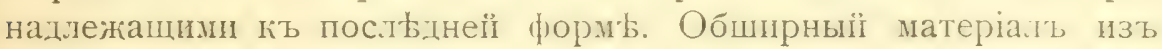
южной части Европейской Россіи, понечно, поможетъ разобраться, что представляеть изъ себя эта форма. При сравненіи промьровъ $T$. ciropaea brameri Sat., данныхъ въ работь K. A. С а т у н на ( I 53), съ моими московскими экземплярами дьйствительно бросается въ глаза рьзкая разница в о обще ї длин b т знакомъ отличія этихъ формъ. Весьма жаль, что въ работь К. А. С ат у н и а вкрались нькоторыя неточности, которыя сразу о́росаются въ глаза. Такъ, напримьръ, этотъ авторъ говоритъ, что весь черепь $T$. e. Zranneri Sat. шире такового алтайскаго крота. Это не совсьмъ вырно: въ стать С С тун и а ширина черепа южнаго крота указана равной $18 \mathrm{~m} / \mathrm{m}$., тогда какъ, по словамъ проф. Н. Ө. К ащ ен ко, соотвьтственные размьры черепа $T$. altaica Nik. достигаютъ I9,5 m/m.

Весьма интересенъ по своимь замьчательно крупнымъ размьрамъ кроть, добытый въ Пермскомъ у. Ө. А. Теплоуховымъ (으 2429 коллекц. Зоол. Муз. Моск. Ун.). Въ таблицахъ (А и В) я привожу сравнительные промьры черепа и тьла этого экземпляра и Talpa altaica Nik., присланнаго мнь проф. Н. Ө. Каще н о. Однако, этоть экземплярь по краніологическимъ особенностямъ и строенію зубовь рьзко отличается отъ алтайскаго крота и долженъ быть признанъ очень крупнымъ $T$. ситораса L. ${ }^{1}$ ).

1) Въ таб́лицу изыненіiі череповъ я включилъ проиьры черепа Talpa coeca Sav. (cancasica Sat.) пзъ Закавказья. Мны хотблось указать на одну оссбенность строенія черепа сльпого крота, қоторая сразу бросается въ глаза при прослотры таблицы. Именно, у Talpa coeca Sav. ппрнна черепа по бокамь foramen infraorbitale значительно больше, чьмь у остальныхъ формъ, а область носовая нђсколько уже, что еще болье подчеркпваеть рызкій контрастъ въ структурь передней части черепа этихъ видовъ. Было бы пнтересіо пров屯рить этоть признакъ на о́ольщемъ матеріаль. 
Почти всћ, добытые мною въ Московской губ. гроты были совершенно нормальной окраск. Только одинъ экземпляръ отличался примьсью свьтло-рыжеватаго оттьніа въ цвьты мыха на нижней сторонь тьла, въ грудной области.

Вь коллекціи Зоологическаго Музея Моск. Унив. имыется очень интересный экземплярь Talpa cигорие L. изъ южнаго Урала оть г. Назарова (№ 2490), отличающійся свьтло-пале. во-сърой окраской всей верхней стороны тьла и еще болье яркой, желтоватой-въ грудной и брюшной области.

Въ заключеніе привожу измьренія моихъ экземпляровъ (см. таú... B II $\mathrm{B}^{\prime}$ ).

\section{Географическое распространеніе.}

Кроть принадлежить іъ очень обыкновеннымъ млекопитающимъ Московсіой губ. Онъ найденъ въ сльдующихъ у бздахъ: въ Mосl一вскомь (Ізмайлово, Косино, Іетровсіое-Разумовсіое), Звенигородсіомъ (село Аносино, Спасское, окр. Новаго Іерусалима), Можнайсколь у. (дер. Дурнево, Митьково, Тесовскіï јдыльный льсъ, окр. гор. Можайска), Рузскомь у. (Борки, дер. Устье, Халдеево), Клинскомъ у. (с. Демьяново, окр. гор. Клина), Богородсіомъ у. (окр. села Саввина, гор. Богородска), Серпуховскомь у. (окр. гор. Серпухова), Нътъ сомньнія, что кротъ представляеть тахое же обычное явленіе и въ другихъ смежныхъ yłздахъ губерніи.

Въ центральной части Европейской Россіи Talpa europaca L. обыкновененъ въ Ярославской губ. (Л. П. Сабан ьев ъ, І 5 о, р. 25I) и въ разныхъ уьздахъ Псковской губ. (Эс а у л о в ъ, 58 , стр. 223). По моимъ наблюденіям онъ часто встрбчается въ разныхъ ућздахъ Сиоленскоїі, губ. (Гжатсіії, Сычевскій, Вяземchiй, Ельнициій, Бьıьскій и др.), въ Малоярославеціомъ у. Калужсіой губ., въ сьверныхъ уьздахъ Тульской губ. Но въ восточной части Орловской губ., какъ показали наблюденія С. Н. Г о рбачева и мон, въ распространеніи крота сказывается извыстная спорадичность: только въ нблоторыхъ мьстахъ онъ попадается еще въ довольно большомъ числь. Повидимому, не часть гротъ и въ Харыковской губ., для поторой указанъ Черн аемъ (2 о 3 , p. 9) и Н. Н. С омовымъ ( 84 , р. І5I).

Далье на югъ обычнаго прота замьняегъ болье крупная форма: Talpa emopaca brameri Sat., которая встрьчается начиная съ Кіевской губ. (экземплярь отъ г. Неню юо ва въ коллекціи Зоол. Муз. Моск. Унив.), по всей Бессарабіи и Херсонсков губ. Крупный экземпляръ крота, добытый Л. П. С абан невым бл. Таганрога, я склоненъ отнести именно къ этой 


\begin{tabular}{|c|c|c|c|c|c|c|c|c|c|c|c|}
\hline 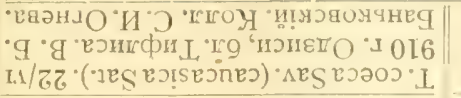 & $\mathfrak{m}^{\infty}$ & ล & oi & & $\infty$ & & $\infty$ & & कृ & $\underset{n}{+1}$ & $\stackrel{N}{O}$ \\
\hline 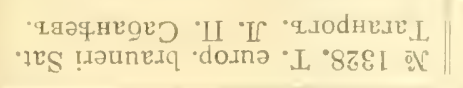 & $\stackrel{\leftrightarrow}{\infty}$ & 50 & $\stackrel{\text { Iิ }}{-1}$ & & $\because$ & & $x$ & & $=$ & $\stackrel{0}{0}$ & 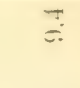 \\
\hline 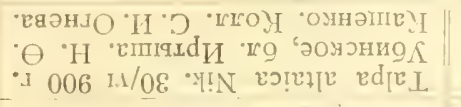 & $\underset{\infty}{\infty}$ & $\mathrm{m}^{25}$ & $\stackrel{90}{-}$ & & $\infty$ & & $\infty^{\infty}$ & & $\log ^{10}$ & $\stackrel{+}{=}$ & $\bar{\sigma}$ \\
\hline 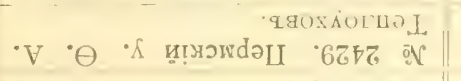 & $\underset{5}{\top}$ & ai & ai & & $\underset{m}{E}$ & & $\infty$ & & $\because$ & $\because$ & $\stackrel{x}{\infty}$ \\
\hline 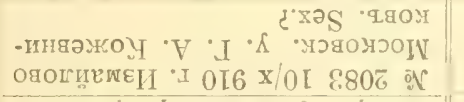 & $\begin{array}{l}\infty \\
10 \\
\infty\end{array}$ & $\overline{60}$ & $\stackrel{g}{=}$ & & $\underline{0}$ & & $\infty$ & & s. & $\stackrel{20}{0}$ & 20 \\
\hline 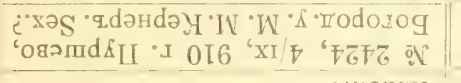 & $\begin{array}{c}30 \\
10 \\
10\end{array}$ & $\stackrel{1}{0}$ & $\stackrel{\infty}{=}$ & & 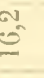 & & 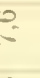 & & $N$ & $\sqsubseteq$ & 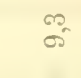 \\
\hline 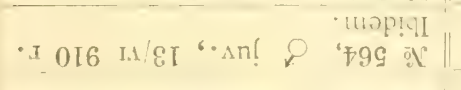 & $\frac{1}{12}$ & $\stackrel{\substack{n \\
\infty}}{\pi}$ & $\overline{a i}$ & & -0 & & 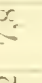 & & $\sigma$ & $\overrightarrow{0}$ & $\stackrel{6}{c}$ \\
\hline 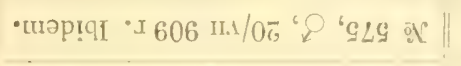 & का & क्षे & $\stackrel{-1}{-}$ & & 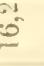 & & - & & $r$ & 인 & कू \\
\hline 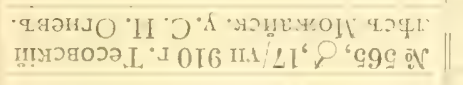 & $\sum_{\infty}^{\infty}$ & $\stackrel{5}{s}$ & 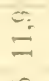 & & E & & 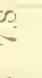 & & $\kappa$ & $\stackrel{\infty}{\infty}$ & $\ddot{\rho}$ \\
\hline 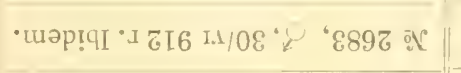 & $\frac{5}{5}$ & $\ddot{8}$ & 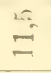 & & 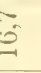 & & 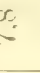 & & $\because$ & $\underline{0}$ & $\stackrel{6 !}{6 !}$ \\
\hline 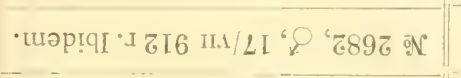 & m & $\begin{array}{l}\vec{n} \\
\text { a }\end{array}$ & $\stackrel{\infty}{0}$ & & $D_{1}^{2}$ & & $\theta_{2}$ & & O] & $\underbrace{\infty}$ & $\sigma_{0}$ \\
\hline 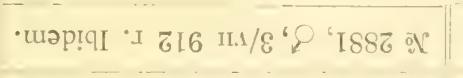 & $\vec{E}$ & $\hat{i}^{\infty}$ & 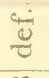 & & $\sigma^{\circ}$ & & $+\infty$ & & 政 & $\Xi$ & $\infty$ \\
\hline 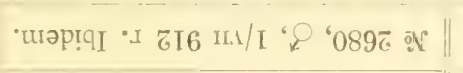 & ॠ & คి & $=$ & & ! & & $=$ & & In & $\stackrel{\infty}{\infty}$ & $\sigma$. \\
\hline 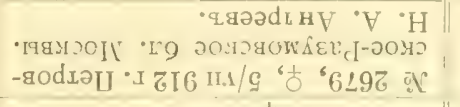 & की & is & $=$ & & $=$ & & $\stackrel{0}{0}$ & & $1-$ & $\underline{\underline{1}}$ & $\begin{array}{l}\infty \\
\infty \\
i j\end{array}$ \\
\hline 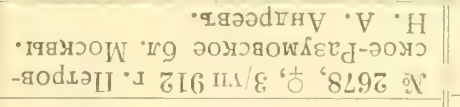 & $\stackrel{\infty}{\infty}$ & ஜே & $\frac{1}{2}$ & & $=$ & & D & & $\stackrel{2}{a}$ & $\stackrel{1}{0}$ & $\sigma$ \\
\hline 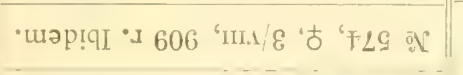 & ले & $\hat{\Omega ̆}^{\pi}$ & $\overline{\text { â }}$ & & 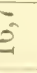 & & 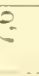 & & $\overrightarrow{0}^{-}$ & $=$ & $\stackrel{\infty}{\infty}$ \\
\hline 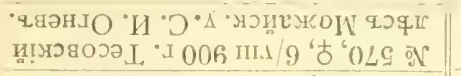 & $\frac{G N}{C D}$ & $\begin{array}{l}1=- \\
\infty \\
\infty\end{array}$ & $\stackrel{0}{\sim}$ & & 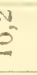 & & $=$ & & No & $\underline{6}$ & $\stackrel{\sim}{\sigma}$ \\
\hline 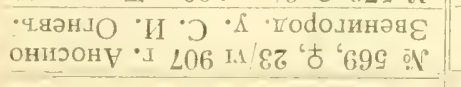 & 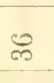 & 点 & of & N & 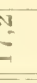 & & $\infty$ & & ng & $=$ & $\underbrace{\infty}$ \\
\hline 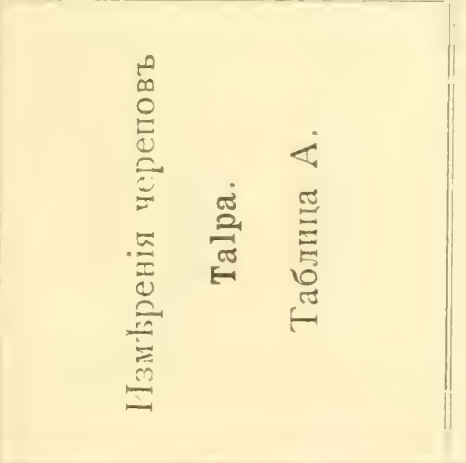 & 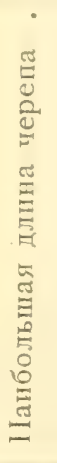 & 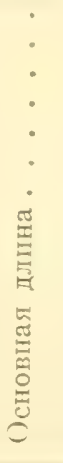 & 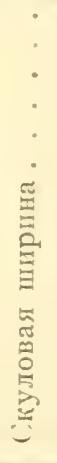 & 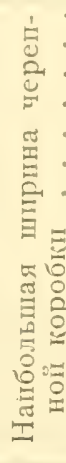 & $\begin{array}{l}\dot{0} \\
\dot{0} \\
\dot{0} \\
\vdots \\
\frac{0}{0} \\
\frac{0}{0} \\
\frac{2}{2}\end{array}$ & 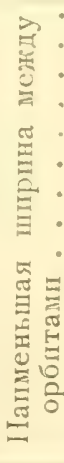 & 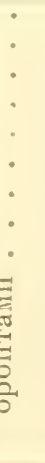 & 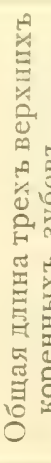 & 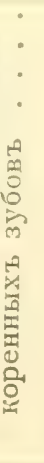 & 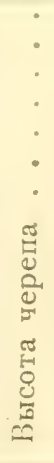 & 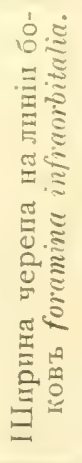 \\
\hline
\end{tabular}


$-134-$

\begin{tabular}{|c|c|c|c|c|c|}
\hline 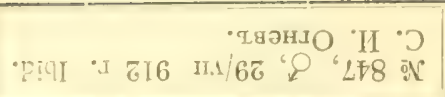 & 요 & $\stackrel{\infty}{\infty}$ & 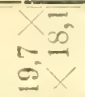 & $\stackrel{\infty}{\varrho}$ & क. \\
\hline 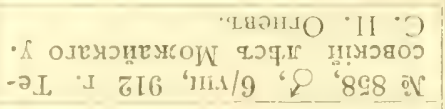 & $\stackrel{\circ}{=}$ & $\stackrel{0}{\infty}$ & $\underbrace{20}$ & $\stackrel{1}{9}$ & $\tilde{\mathrm{g}}$ \\
\hline 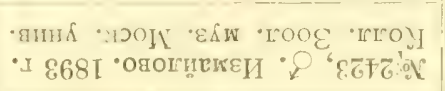 & $\overrightarrow{0}$ & $\overrightarrow{i \vec{i}}$ & 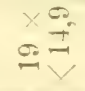 & 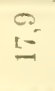 & 15 \\
\hline 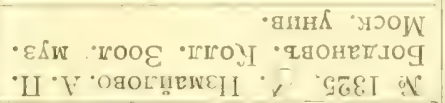 & $\stackrel{\circ}{=}$ & $\frac{a b}{a d}$ & $\frac{\infty}{\underline{X}}$ & $\stackrel{\oplus}{\varrho}$ & $\varrho$ \\
\hline 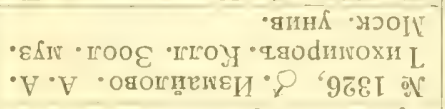 & 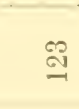 & $\overrightarrow{c s}$ & 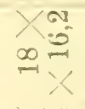 & $\stackrel{\infty}{\infty}$ & $\vec{\infty}$ \\
\hline 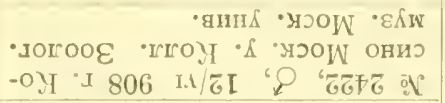 & $\stackrel{g}{g}$ & $\overrightarrow{\mathfrak{C}_{0}^{-}}$ & 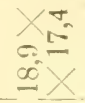 & $\stackrel{9}{-}$ & 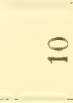 \\
\hline 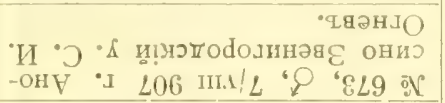 & $\stackrel{5}{\circ}$ & ลे & $\underbrace{\infty}_{0}$ & $\stackrel{\infty}{\infty}$ & $\infty$ \\
\hline 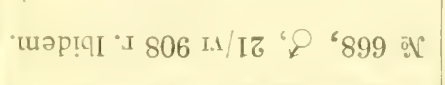 & $\stackrel{10}{=}$ & â & $\underline{0}$ & 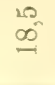 & $\sigma$ \\
\hline 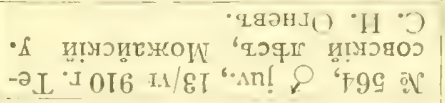 & $\infty$ & $\begin{array}{l}2 \\
25 \\
2\end{array}$ & $=\overline{20}$ & $\stackrel{n}{=}$ & $\overrightarrow{15}$ \\
\hline 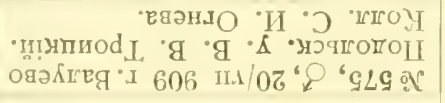 & $\stackrel{10}{=}$ & लै & $\begin{array}{l}x=0 \\
0 \\
0 \\
\infty \\
0 \\
0\end{array}$ & $\stackrel{n}{\infty}$ & $\infty$ \\
\hline 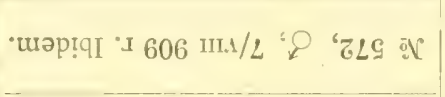 & 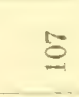 & $\stackrel{1}{0}$ & $\begin{array}{l}x=0 \\
\infty \\
0=0 \\
0\end{array}$ & $\stackrel{10}{\infty}$ & $\stackrel{0}{\circ}$ \\
\hline 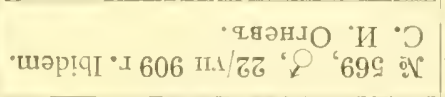 & $\Xi$ & $\approx$ & $\hat{c}=$ & $\begin{array}{l}\hat{\infty} \\
\infty \\
\infty\end{array}$ & $\tilde{g}$ \\
\hline 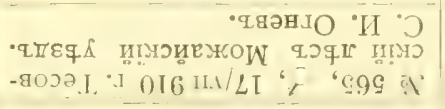 & $\stackrel{\mathscr{g}}{\varrho}$ & $\frac{\infty}{\infty}$ & $\begin{array}{l}x=0 \\
x=0 \\
0=0\end{array}$ & $\stackrel{-}{\infty}$ & $\infty$ \\
\hline 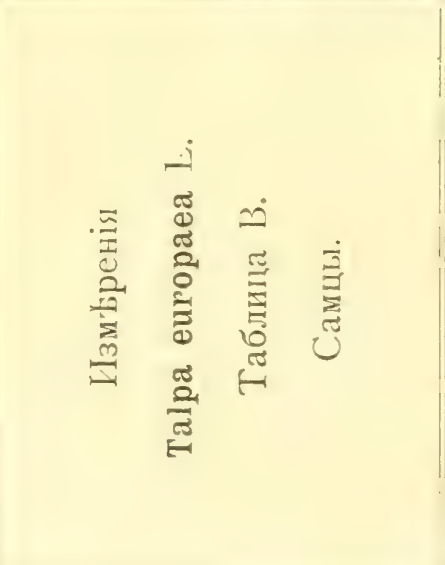 & 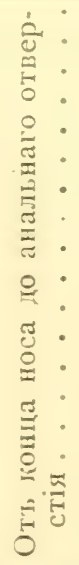 & 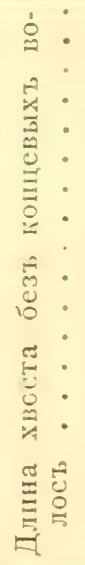 & 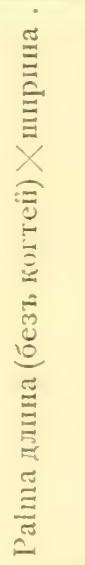 & 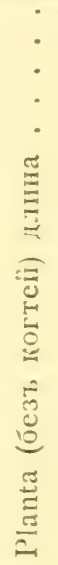 & 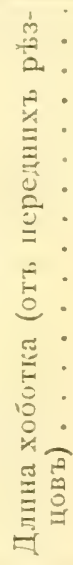 \\
\hline
\end{tabular}




\begin{tabular}{|c|c|c|c|c|c|}
\hline 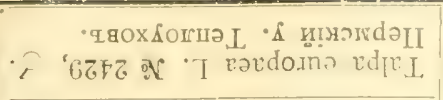 & 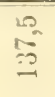 & 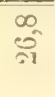 & 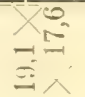 & $\overrightarrow{31}$ & 19 \\
\hline 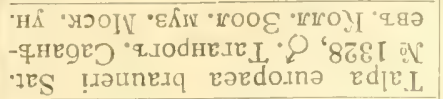 & $\stackrel{9}{\sim}$ & $\begin{array}{l}\infty \\
\mathcal{E}_{1}\end{array}$ & $\begin{array}{l}x=0 \\
0=x \\
5=\end{array}$ & $\underset{\infty}{\infty}$ & $\vec{c}$ \\
\hline 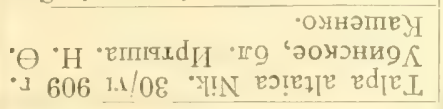 & 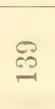 & 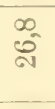 & $\frac{a}{a 1}$ & ai & $\overrightarrow{8}$ \\
\hline 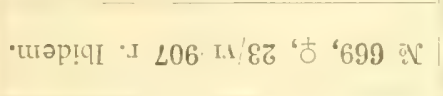 & $\underset{\exists}{\exists}$ & : & $\begin{array}{l}x^{2} \\
\infty \\
\infty \\
\infty\end{array}$ & $\stackrel{\infty}{=}$ & $\stackrel{\infty}{\infty}$ \\
\hline 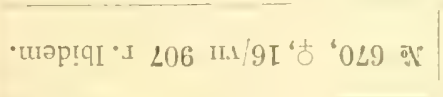 & $\stackrel{+}{\stackrel{1}{-1}}$ & $\tilde{a}$ & $\begin{array}{l}x^{\infty} \\
0=1 \\
0 \\
\infty\end{array}$ & $\stackrel{\infty}{\stackrel{2}{L}}$ & $\ddot{c}$ \\
\hline 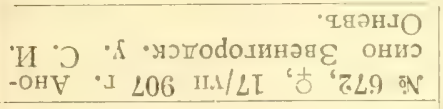 & $\stackrel{20}{=10}$ & $\frac{\overrightarrow{C D}}{\pi}$ & $\begin{array}{l}X^{\infty} \\
0 \\
0 \\
=-1 \\
=\end{array}$ & $\beth$ & $\varrho$ \\
\hline 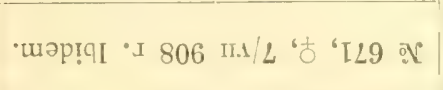 & $\stackrel{\infty}{\stackrel{2}{=}}$ & 5 & 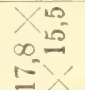 & $\stackrel{20}{=}$ & $\stackrel{\infty}{\infty}$ \\
\hline 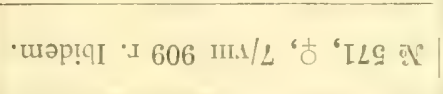 & 후 & act & $\stackrel{\substack{2 \\
-\infty}}{\infty}$ & $\hat{-1}$ & $\ddot{\ddot{\theta}}$ \\
\hline 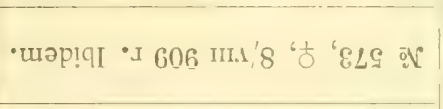 & $\stackrel{8}{8}$ & $\begin{array}{l}20 \\
\text { ली } \\
\text { ही }\end{array}$ & $\begin{array}{l}x=0 \\
x=0 \\
0=0\end{array}$ & $\stackrel{\infty}{=}$ & $\vec{\infty}$ \\
\hline 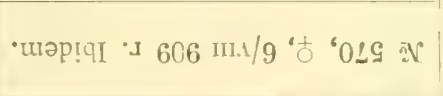 & $\stackrel{\infty}{=}$ & $\mathrm{cos}^{\circ}$ & $\begin{array}{ll}X \\
\infty\end{array}$ & $\stackrel{2}{=}$ & 2 \\
\hline 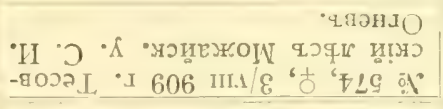 & $\begin{array}{l}\stackrel{2}{2} \\
\stackrel{0}{0}\end{array}$ & $\begin{array}{l}61 \\
\text { sí } \\
\text { co }\end{array}$ & $\begin{array}{l}c^{2} \\
00 \\
2 x\end{array}$ & $\varkappa_{\infty}^{\infty}$ & $\underline{\theta}$ \\
\hline 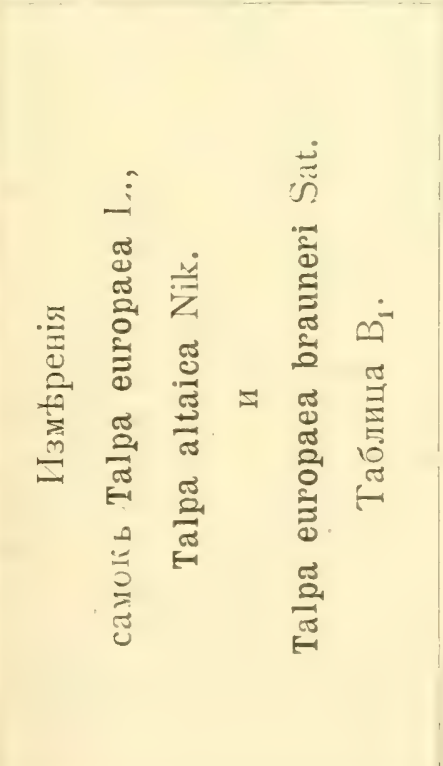 & 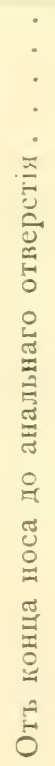 & 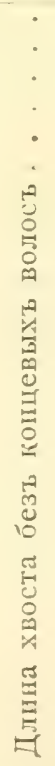 & 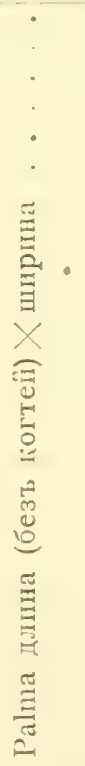 & 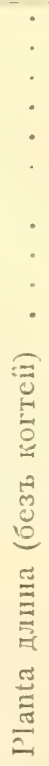 & 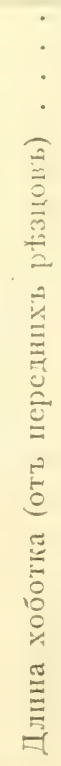 \\
\hline
\end{tabular}




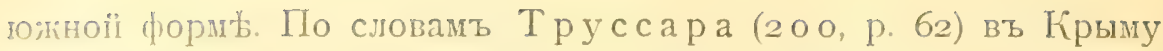
встрфчается T. е. Uraneri Sat. Проф. Кесслеръ и проф. A. M. Нигольслі їі совершенно не нашли крота въ этой мустности. (І 22 , стр. 44-45).

Далье на востокъ обыкновенный кроть встрьчается въ долины Волги, гдњ, по словамь прод). М. Н. Богданова, очень обыгновененъ въ Казанской, Саратовской и Симбирскої губерніяхъ. Въ посльднеї найденъ таюже Б. М. ЖК и т о вы м въ Курмышскомь у. По Эверсманну кроть рьдокъ иіь востоку отъ ১рала и южной части его предгорій. Л. П. Сабан вевы м кротъ найденъ въ среднемъ У раль и встрычается, по словамь этого автора, въ Екатеринбургскомъ и Щадринскомъ уу. Въ коллекціи Зоологическаго Музея Шмп. Моск. Унив. имьется экземпляръ изъ окр. Екатеринбурга отъ г. К ле ра. 1Іо свидытельству Н. А. 3 аруднаго $T$. еитораеа L. очень рддоѓ въ Оренбургскомъ краь: ему удалось добыть только одно животное этого вида въ бассейнь Сакмары, около деревни Ямангуловой. Въ коллекціи Зоол. Музея Моск. Јнив. имьется экземплярь грота оть г. Назарова съ помыткої „Южный Уралъ“. Въ спискћ животныхъ Оренбургскаго грая $T$. eиropaca L. упоминается Леманом ъ.

Подвигаясь далье на сьверъ, мы встрь̆чаемъ грота въ Вятской губ. (Круликовскій) и въ Пермскомь у,, гды онъ добытъ $\Theta$. А. Т епл о х о вы ъ (экз. въ колл. Зоол. Музея Моск.

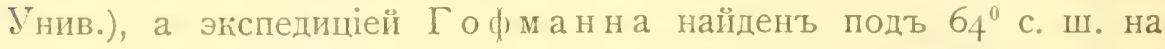
Ураль. По словамь Брандта $(35$, р. 569) экземплярь грота быль присланъ изь Усть-Цыльмы въ Зоол. Музей Имп. Акад. Наукъ. Далье кротъ найденъ въ районь средняго теченія С верной Двины Блазіусомь и въ Петербургской губ. бл. дер. Лебяжьё' В. Л. Біа нки, по словамъ потораго онъ здьсь очень рьдокь. По свидьтельству Кесслера, гроть встрьчается на западн.' сторонь Онежскаго озера (87, стр. 2I). Въ западной части Европейской Россіи кротъ встрбчается въ Минской губерніи (А. А. Браунеръ), бл. Варшавы, Юрьева. Въ прибалтійскихъ провинціяхъ онъ, по словань Gl’evé, найденъ въ Лифляндіи и Эстляндіи.

Что касается до распространенія T. сщюраса L. въ Западної Сибири, то съ несомньнностью онъ констатированъ только Сл о в о вымъ въ Тюменскомъ олругь и въ окр. Ишима. Въ салыхъ южныхъ частяхъ Тобольской губ. кротъ не найденъ, то же надо сказать и относительно области между Петропавловскомь, Омскомъ, Атбасаромъ, Акмолинскомъ и Баянъ-Ауломъ. По Финшу гротъ найденъ въ городь Березов'b - это самый 
cьверный пунктъ нахожденія его въ Западной Сибири. Далье на востокъ обычнаго $T$. eиropaea L. замыняетъ болье групный T. altaica Nikolsky.

Въ Западной Европь обыкновенный кротъ распространенъ отъ Скандинавіи и Великобританіи до Италіи. Въ Средиземноморской области, южной Франціи, Далмаціи, Греціи его смьняеть Talpa coeca Sav, а въ центральной Испаніи $T$. coeca occidentals Cabrera. Въ окрестностяхъ Рима встрьчается своеобразная dopra-Talpa romana Thomas.

Наконецъ, для Кавказскаго прая К. А. С атун ины м ъ описанъ, правда, еще сомнительный подвидъ-Ialpa сосса сапсаsicol Sat.

\section{Образъ жизни.}

По разнообразію занимаемыхъ станцій кроть можетъ быть названъ весьма неприхотливымъ животнымъ. Я находилъ его въ самой чащ' разнообразныхъ льсовъ, гды ходы, имъ сдыланные, служатъ какъ бы обшими коридорами для самыхъ разнообразныхъ мелкихъ млекіпитающихъ. Достаточно сказать, что въ ведро, вырытое поперегъ кротовины, попались, кром' кротовъ, разные виды Microtus, Sorex, Ncomys foctiens, Schreb. и Sicista subtilis Pall. Особенно часто встрђчается Talpa eиropaea L. на открытыхъ мыстахъ, особенно на лугахъ по рьчнымъ долинамъ. По словамъ К. А. Сатунина, кротъ избьгаетъ сырыхъ луговъ, заливаемыхъ полой водою, а держится, напротивъ, на суходолахъ, въ садахъ и льсахъ. Тщательно изучая распространоніе крота въ предьлахъ Московской губерніи, я пришель ґъ тому заключенію, что это животное особенно охотно придерживается прирьчныхъ луговъ, часто встрбчаясь около самой воды. Въ этомъ отношеніи мои наблюденія скорье сходятся съ таковыми А с с у с а,

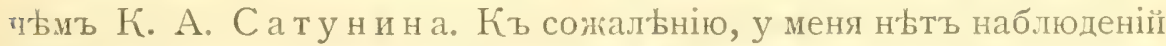
надъ періодическими явленіями жизни этого скірытнаго животнаго.

Зимою кроты не впадаютъ въ спячку, но дьлаютъ свои галлереи подъ снъжнымъ покровомъ. Эти ходы особенно хорошо видны, когда сньгъ только что стаялъ и молодая трава еще не успьла ихъ закрыть. Первыя кучки кротовъ часто видны уже тогда, когда онь поднимаются надъ псчезающимъ тонкимь слоемь сньга.

По С абан ве ву, въ 1873 году T'alpa eиropaca L. начали копаться І6 марта.

Ннтересно отмьтить, что самки попадаются значительно рьже самцовъ.

Экзелияяри коллекий перечислены въ таблиць измьреній. 


\section{Родъ Myogale Cuvier (г8oo). Выхухоли.}

Все тьло покрыто густымъ длиннымъ мьхомъ, блестяще бурымъ сверху и серебристо-желтовато-сьрымъ снизу. Носъ вытянутъ въ четыреугольный, слегка сплющенный въ горизонтальномъ направленіи хоботъ. Верхняя сторона хобота покрыта только при основаніи густыми и очень короткими волосамп, тогда кагъ средняя и переднія части его совершенно голы. Передняя область хобота раздьлена неглубокой, лучше замьтной снизу, продольной бороздою; на каждой половинь его конечної части располагается по одному продолговато-овальному носовому отверстію, открываюшемуся по внбшнему краю. Вибриссы густыя и длинныя. Глаза очень малы и окружены кольцомъ бъловатыхъ волосъ, которые въ видь двухъ замұтныхъ пятенъ расположены среди общаго темнаго тона м'вха. Наружное ухо чрезвычайно укорочено и почти не выступаетъ изъ кожи. Хвостъ продолговато-ланцетовидный, сильно сжатый съ боковъ, всльдствіе чего высота сильно превышаеть ширину. Онъ почти лишенъ волосъ и покрытъ чешуями; толыю волосы верхней стороны хвоста много гуще, чъмъ на бокахъ, образуя, какъ бы слабо диффиренцированный гребень; длина хвоста только немного меньше длины тьла. Заднія конечности значительно превосходятъ по размьрамъ переднія. Обђ пары ногъ снабжены плавательными перепонками, которыя въ внц' лопастевидныхъ складокъ особенно развиты на заднихъ конечностяхъ; по внбшнимъ сторонамъ посльднихъ тянутся гребневидныя отторочки желтоватыхъ волосъ (какъ у куторы).

Зубная формула:

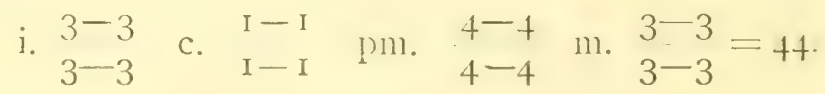

\section{Myogale moschata Pall.}

\section{Выхухоль .}

Sorex moschatus Palla s, Nova Acta Acad. Petrop., 178l, II, p. 315. Mryogale moschata Pall. D o b s o n (48), 129-130. T rou e s a r t $(200)$, p. 59. C iм а шко (181), стр. 101-132 (Статья акад. Брандта). С а тун и н (165), стр. 5 и (1 66$)$, стр. 3 .

Несмотря на выдаюпійся интересъ въ смысль⿱⺊口灬 біологіи и распространенія, выхухоль можеть считаться еще очень мало изученнымъ животнымъ. 
Изъ предћловъ Московской губ. въ коллекціи Зоологическаго Музея Мосовск. Унив. имьются только два экземпляра оть $\Theta$. К. Л о р енца, изъ Дмитровсіагог у. Нзъ литературныхъ данныхъ о распространсніи выхухоли въ нашей мұстности извlістно сльдуюшее.-Въ 1839 году въ университетскомъ отчет

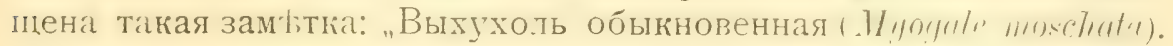
Поймана во время рыбной товли въ $3 о$ верстахъ отъ Москвы и въ 4 отъ Бермоковской пустыни, въ пруду имұнья пом'щика Св ьи ина“: По Сатунину встрђчается, но довольно рждко, въ Бого одскомъ, Дмитровскомъ и Звенигородскомъ уу. „По Окъ, - пишетъ С атунин ъ,-она многочисленна, и въ Нижегородской губ. весною на нее существуетъ особый промысель". Интересно отмьтить, что на Окћ, близъ Серпухова она очевидно очень рћдка, такъ какъ промышленники ее почти не знаютъ и требовали очень большую сумму денегъ за доставку одного экземпляра.

Распространеніе выхухоли отличается большою узостью, будучи пріурочено къ бассейнамъ Волги, Дона и Урала. По Эв е рсманну выхухоль не встрђчается въ систем' Урала и не должна бы водиться въ низовьяхъ р. Волги. Южной границей распространенія ./yogal' этоть авторь считапь невысокії хребетъ Общаго Сырта. Однако М. Н. Богдановъ ( 3 о, стр. I62), а за нимъ С атунин и ( 67 , стр. 7) приводятъ въ качеств'b ptsдкаго вида это млекопитающее для Волжскої дельты. Далье, въ противоположность Э в е р с м ан ну, Н. А. 3 арудный $(77$, стр. 365$)$ даеть очень точныя и подробныя свьдьнія о распространеніи выхухоли по р. Уралу до г. Уральска въ качеств' обыкновеннаго животнаго, но вверхъ по теченію оть Уральска она дьлается значительно рьже. По Л. П. С абан в е ву ( I 49, стр. II) выхухоль найдена въ юго-зап. части Екатеринобргскаго уъзда, дłлаясь болье ptдкой въ его юго-восточн. половинь (Метлинская дача).

Врядъ ли можно сомнъваться, что это интересное млекопитающее дылается все рьже и рьже. Такъ, по свиджтельству Б. М. Ж итков а (7 1, стр. 5-6), выхухоль встрфчалась въ большомъ количеств' въ долин' р. Суры, въ особенности по среднему ея теченію; теперь, какъ говориль мнђ Б. М., она стала тамъ много рьже.

Что касается до литературныхъ указаній (Dobson, Trouessart) на распространеніе выхухоли въ Туркестань и Бухарt, то они совершенно не подтверждаютя новыми изсиьдованіями Н. Ө. Кашенко (8о, стр. $77-78)$. 


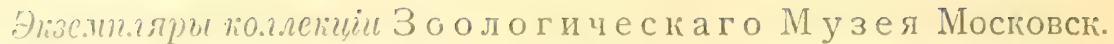
Унив. I) \е 2673, Дмитровскій уьздъ. Ө. К. Л оренцъ. 2) І332, Пмитровскіиі уьздъ оть г. А льб рехта черезъ $\Theta$. К. Лоренца.

\section{Erinaceidae. Ежи.}

\section{Родъ Erinaceus.}

1758. Erinacens, C a rolus Lin na e us (9 8), p. 52 (Основанъ на Erinacens europaeus L.)

Ежи по внҺшнему виду отличаются свонмъ толстымъ, неуклюжимъ тыломъ и короткимъ хвостоль, позвонки котораго рудиментарны. Вся спинная часть тьла ежа покрыта длинными иглами съ гладкими продольными ребрышками и съ очень слабо выраженної поперечной штриховкой (посльдняя рtьдко бросается въ глаза у рода Hemicelimus). Волосы нижней стороны жесткіе и длинные. Уши очень коротки, въ большинствЫ случаевъ короче половины длины головы. На особенностяхъ черепа я остановлюсь при описаніи видовъ.

Зубная формула такова:

$$
\text { i. } \frac{3-3}{2-2} \text { C. } \frac{I-I}{I-I} \text { pm. } \frac{3-3}{2-2} m \cdot \frac{3-3}{3-3}=30 \text {. }
$$

\section{Erinaceus europaeus L.}

\section{Ежъ обыкновенный.}

Erinaceus europaens $\mathrm{C}$ a rolus $\mathrm{L}$ in na eus (98), p. 52. B a r r e t-Hamil-

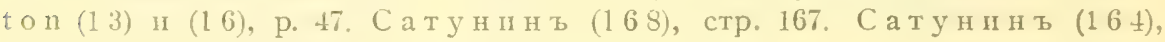
стр. 7. Сатунин в (16 5), стр. 4 иі (166), стр. 2.

\section{Erinaceus europaeus danubicus Matschie.}

\section{Ежъ южный.}

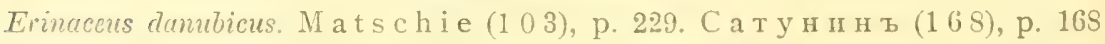
Огиев и Горбачевъ (129), стр. 10-12.

\section{Систематическія особенности.}

Въ своигъ общихъ чертахь строеніе черела названныхъ видовъ хараптеризуется цьлым рядомь признаковъ, свойственныхъ всей группь ежей рода Erinaceus-Fossae pterygoideae развиты хорошо, ихъ выдающіеся по бокамъ отростки не полы внутри и не принимають участія въ построеніи bullae osseae. Pirocessus postgle- 
noidalis много меньше processus mastoidens пи внутрп не полый. Вь частности Erinaceus envopacus tambicus отличается сльдующимъ граніологическимъ признакомъ: длина sutu'a maxillo-intermaxillavis короче разстоянія оть начала sutu $а$ около os nasale до того мьста, гдt os maxillare наиболье глубоко вдается въ os frontale. У Eirnaceus curopaeus L. первая длина болье второй, какъ и у Ei inacens enropaens transcancasicus Sat. Это является въ дыйтвительности единственнымъ надежнымъ отличіемъ описываемыхъ ежей,

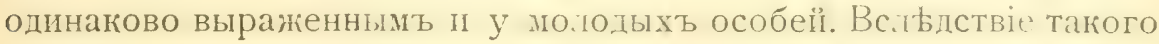
соотношенія названныхъ костей въ черепь Evinaceus enropaeus dambicus Matschie замьчается ньсколько иная ихъ относительная конфигурація. Если смотрьть на черепъ обычнаго ежа сверху, то можно видьть, что задніе контуры межчелюстныхъ қостей выдаются назадъ довольно острыми отростками, которые почти сходятся съ таковыми оть лобныхъ костей, лежащими между носовыми и челюстными костями. У Emacens europacus dambicus Matschie задніе контуры межчелюстныхъ костей срђзаны болье прямо и разстояніе оть нихъ до отростковъ лобныхъ костей довольно велико. Ннтересно отмьтить, что даже этотъ признакъ подверженъ значительному колебанію, и встрбчаются экзеипляры съ ясно выраженнымъ промежуточнымъ характеромъ. Въ моей коллекщіи имьется черепъ „не типичнаго“ Erinaceus europaeus dambicus Matschie, у коего задніе контуры межчелюстныхъ костей имьють форму удлиненныхь выступовъ, а общая длина sutura maxillo-intermaxillaris сь львой стороны уступаеть длинь указаннаго выше измьренія, а съ правой стороны превышаеть его. Всльдствіе существованія такихь промежуточныкь формъ, а также того факта, что оба описываемыхъ ежа въ нбкоторыхъ мьстностяхь встрьчаются вмьсть, я могу придавать южному ежу, до окончательнаго выясненія его таксономическаго значенія, лишь характеръ подвида. Въ заключеніе разсмотрим еще нысколько краніологическихъ признаковъ, считаемыхъ характерными д.іs Erinacens curopacus dambicus Matschie ${ }^{1}$ ).

I) Отъ foramen lacrymale до crista лобныхъ гостей ньть сплошного гребня, а существуетъ только выступь у задняго края toramen lacrymale. Тщательный просмотрь серіи имьющихся у меня череповъ показаль мнь большія колебанія этого отличія даже у типичныхъ Einacens curopacus L. Тогда какъ у нькоторыхъ особей названный гребень достигаеть довольно высокой степени дифференцировки,-у цругихъ его почти ньть налицо. У Eina.

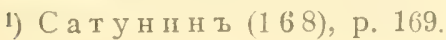


cens curopaens dambicus Matschie въ большинствь случаевъ онъ дtíiствительно не развитъ.

2) Јобныя кости сильно вздуты. Этотъ признакъ едва можетъ блть отмьчень даже на серіи, не говоря уже о многочисленныхъ переходахь къ нему въ черепахъ типичныхъ ежей.

3) Въ строеніи поперечнаго гребня, идущаго по заднему краю твердаго нёба, у этихь ежей рьшительно ньть отличій.

Переходимъ къ строенію зубовъ Einacens. К. А. С атунин ъ считаетъ характернымъ для всего рода присутствіе только одного корня у клыка. „Эта особенность“, говоритъ С атунинъ, (I 64, стр. 8) „отличаетъ обыкновеннаго ежа отъ всьхъ другихъ видовъ, у которыхъ клыкъ (c) имъетъ два короткихъ корня." Просмотръ моей серіи череповъ Erinacens ясно показаль мн'b совершеннное непостоянство этого признака.-Мы имћемъ передъ собою экземпляры, у которыхъ ґорни клыковъ дьйствительно слились, но существують и такіе, гды оть этихъ зубовъ отходять два рьзко гифмеренцированныхъ корня. Въ строеніп зубовъ южнаго п об̆лновеннаго ежей мн’s не удалось Констатировать какихь-либо отличій ${ }^{1}$ ).

Для полноты этого очерка считаю нужнымъ привести таблицу пзмьреній череповь описываемыхь ежеї пзъ разныхь мьстностей (см. стр. I44).

Къ сожальнію, въ моемь распоряженіи ньтьь большого набора шкурокъ Evinaceıs. Всльдствіе этого я не могу сь опредыленностью говорить о различіяхъ во окраски обычнаго и южнаго ежей. Просматривая матеріаль по Erinacens e. damulicus Matschie изъ Орловской губ., С. Н. Горбачевъ и я отмьтили въ свое время, что мьхъ южной формы сьрье, а окраска передней части морды и вокругь глазъ чернье, чьмъ у Ei. europaens L. ( 29 , стр. II). Теперь, когда я располагаю ньсколько бо̀льшимь матеріаломъ, я склоняюсь къ тому заключенію, что окраска обычнаго ежа подвержена очень большимъ варіаціям. Такъ, напримьръ, у 스 727 моей коллекціи область между глазъ еще темнье, чьмъ у большинства Er.e. dambicus Matschie. Съ другой стороны, Н. Ф. Иконников ъ передаль мнь двухъ типичныхъ Er.e. dambicus Matschie, которые отличались своей очень свђтлой окраской и полнымъ отсутствіемъ сколько-нибудь замьтнаго чернаго пятна въ межгтазничной области. Все это заставляетъ притти къ заключенію, что красочныя отличія описываемыхъ

1) Тотъ признакъ, что пятыї зуб́ъ верхнеї челюсти $\left(\right.$ mm $\left.^{1}\right)$ у Erinaceus $e$.

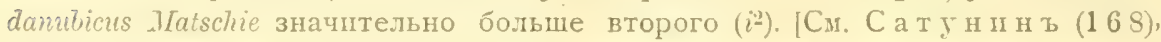
p. 170.] цьлпкомъ подходитъ іп ко всьмъ типичнымъ Erinacens europaeus L. жоеюї коллекцін. 
ежей еще весьма проблематичны и не такъ постоянны, какъ можетъ казаться по первому взгляду.

\section{Географическое распространеніе.}

Въ распространеніи ежа въ предьлахъ Московской губ. сказывается извьстная спорадичность: мьстами онъ совсымъ не встрђчается, мыстами водится въ довольно значительномт, числь, хотя очень обыкновенным нигдь не можетъ быть названъ. Мною ежъ найдень въ ућздахь: Московскомь (Петровское-Разумовское), Звенигородскомъ (село Аносино), Можайскомъ (окр. гор. Можайска, села Тесова, дер. Дурнева), Рузскомъ (окр. дер. Устье, при сліяніи Рузы и Москвы), Богородскомь (село Саввікно, [по словамъ Г. И. Полякова]). К. А. С атунин ъ отмбчаетъ обыкновеннаго ежа для Московскаго, Звенигородскаго, Богородскаго, Подольскаго ућздовъ. По словамъ В. Г. Дурова одинъ экземплярь ежа быль пойманъ имъ два года тому назадъ въ большомъ саду богодьльни Гееръ на Красносельской улиць въ г. Москвь. Экземпляры моей личной коллекціи всь, кром одного, принадлежать къ типичнымъ Erinacens eniopacus L. Этоть уюлоняюшійся отъ типа эюземплярь добытъ В. Г. Ду р в ы м ъ Іо/ 912 г. въ „Лосиномъ островь“ бл. Москвы (№ 899 우). По строенію своего черепа онъ представляеть очень большой интересъ, таюь каюъ организація костей занимаеть ћаюъ разъ промежуточную ступень между двумя близиими подвидами, съ бо́льшимъ отклоненіемъ въ сторону $E r$. enrop. danthicus Matschie. Но въ коллекции Зоологическаго Музея Император. Аладеміи Наукь имбется чучело и черепь типичнаго Er. enrop. dambicus Matschie изъ Коломенскаго уњзда Московской губ., отъ г. К и с еле в а ( $九$ за № г 84і) г 883 г. Кромь упомянутаго, это-единственный случай нахожденія такъ далеко ћъ сђверу южнаго ежа. Было бы крайне интересно на большемь матеріаль просльдить точныя взаимоотношенія этихъ формъ и детали ихъ географпческаго распространенія. Въ настоянее время әто еще очень трудно, такъ какъ по большинству работъ совершенно невозможно рьшить, о какомъ видь ежа идетъ рьчь. Всльдствіе этого я въ своемъ очеркб укажу въ самыхъ общихъ чертахъ географическое распространеніе ежа, поскольу оно выясняется изъ литературныхъ данныхъ, не задаваясь цылью рьшать въ кандомъ отдыльномь случаь, о какомь виды идеть рьчь (такъ как это возможно только при непосредственномъ прослотры матеріала), а въ понць перечислю точныя мьста нахожденій Eimaceus enropacus dambicus Matschie. 


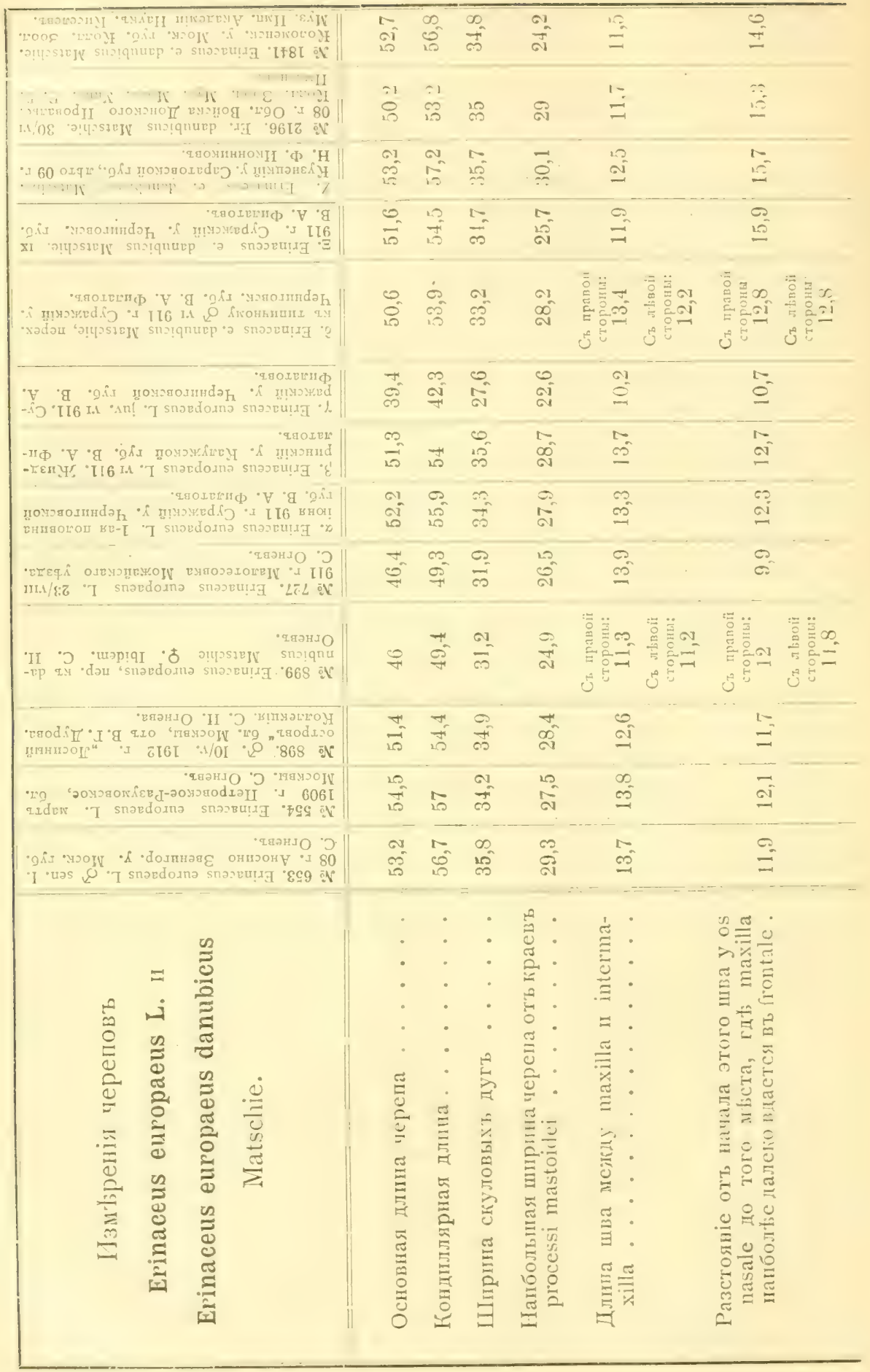


Итакъ, ежъ распространенъ отъ $62^{0}$ с. ш. по всей сьверной части Европейской Россіи. Нахожденіе Einacens enropaens L. гонстатировано для сльдующихъ губерній: онъ найденъ въ Олонецкой губ. на Онежскомь озерь, въ окр. Шокши Кесслеромъ (87, стр. 2г), въ Петербургскіої гуо́. (см. B randt, 34 , p. 596; Сатунинъ, г 68, стр. г67; Бі анки, 23, стр. Іо9); въ Вятской губ.- Л. Крули ков скимъ. Въ Прибалтійскихъ губерніяхъ его отмьчаетъ Греве́ для Лифляндіи, Эстляндіи и Курляндіи, а для Ржевскаго у. Тверской губ.,-К. А. С а т у н и н ъ. По свидътельству Эсаулова $(58$, р. 223) ежъ очень рьдогъь въ Холмскомъ у. Псковской губ., и, по Л. П. Сабанъеву (г 5 о, p. 25I) встрбчается въ Ярославской губ. По моимъ наблюденіямъ онъ не рбдогъ въ восточныхъ у'зддахъ Смоленской губ. и Малоярославецкомъ у. Калужской губ. В. А. Филатов ъ любезно доставиль мнь ньсколько череповъ типичнаго Elin. europaeus L. изъ Жиздринскаго у. Калужской губ., и Суражскаго у. Черниговской губ. Къ сожальнію, у меня ньть матеріала изъ Тульской губ., гды ежъ довольно обыкновененъ, чтобы судить, какой видъ тамъ встрбчается. Далье на востокъ ежъ встрьчается въ долин'ь Волги, но и здьсь точная дифференцировка районовъ, занимаемыхъ описываемыми впдами, еще невозможна всльдствіе недостатка указаній.

Однако уже въ Казанской губ. встрьчается Einucens europaens damubicus Matschie. На основаніи однихъ литературныхъ данныхъ невозможно рьшить, какої видъ ежа встрђчается въ Оренбургской губ., гды, по словамъ проф. Эв ер сманна, этотъ зв брь распространенъ и не рбдокъ въ юго-западныхъ предгоріяхъ Урала, по рькь Сакмарь, Ику и др. По Л. П. Сабан ъеву онъ найденъ въ Верхотурьљ, у Княспинскаго озера (Богословскій Уралъ) и въ Павдинской дачь'. На восточномъ склон' средняго Урала ежъ гораздо рыже.-Н. А. З а рудн ы й нашель его по среднему теченію р. Урала и далье къ сьверу, на Общемъ Сырть и въ Челябинскомъ у. Еще далье на востогъ обыкновенный ежъ указанъ Сло вцо в м ъ для Тюменскаго и Тарскаго уу., встрьчается изрьдка и въ. Ялуторовскомъ у. (І 83 , стр. 26). Проф. Н. Ө. К а щ е к о на основаніи этихъ свьдыній, а также прежнихъ указаній $Г$ е о р г п, полагаетъ, что об́ласть распространенія Erinacens curopaens L., вдаваясь на востокъ отъ Урала языковиднымъ выростомъ, не простирается дал'ье города Тары.

Всю южную часть Европейской Россіи вплоть до Крымскаго полуострова и Кавказскихъ предгорій занимаетъ Erinacens eиropaeus dambicus Matschie. Провести точно сь̌верную границу 
распространенія южнаго ежа довольно трудно. Самымъ сывернымъ мыстомъ его нахолденія является Коломенскій у. Mосковcrolı губ. ${ }^{1}$ ). Сльдовательно, Ока не служить сьверной границей распространенія Evinacers e. danubicus Matschie, какъ предполагаль я въ одной изъ своихъ прежнихъ работь (г 29 , стр. 12). Въ центральныхъ губерніяхъ южный видъ найденъ С. Н. Г орбачевым и мною въ восточныхъ убздахъ Орловской губ. B. А. Филатов в передаль мны нысколько череповъ изъ Суражскаго у. Черниговской губ. Вьроятно, къ этому виду относятся погазанія Черная и С омо ва о нахожденіи ежа въ Харьґовской губ. и проф. Кесслера и Веlke-въ Кіевской, а также указанія разныхъ авторовъ (Pallas, Kaleniczenko, Си маш о, Чернай, Никольскі й ир.) о распространеніи этого животнаго въ степной и горной части Крыма. Далье Einaceus e. damulcus встрьчается, по С атунин у ( 57 , стр. 247), въ Волжско-Цонскої степи. Одинъ экземплярь быль доставленъ изъ окрестн. Провальскаго завода (Обл. Войска Донского) Е. В. П ы ль о вы м ъ и хранится въ коллекціи Зоол. Муз. Моск. Унив. (ㅊ 2196). Восточнђе этотъ видъ. встрђчается, по Сатунин у, въ пескахъ Волжско-У ральской степи (I57, р. 247) и цобытъ около Сарепты, Астрахани и Ставрополя (см. С а тунин ъ, г 68 , стр. І68). Что касается до распространенія этого ежа въ нижнемъ и среднемъ Поволжьь, то наши свьдынія еще далеко не могуть быть названы достаточно полными.-Онъ найденъ М. Н. Б о гдан о вы м ъ въ Казанской, Симбирской и Саратовской губ. По словамъ Б. М. Ж и т к в а, ежъ обынновененъ въ Симбирской губ., а Силантьевъ отмьчаеть его чрезвычайно обыкновеннымъ въ окр. Падовъ Балашевскаго у. Сарат. губ. (г8г, стр. Зо5). Однако изъ этихъ указаній нельзя съ точностью рђшить, какія относятся къ обычному, какія къ южному виду. Ньсколью ежей, доставленныхъ изъ Кузнецкаго уьзда Н. Ф. И ко нни и о в ы м ъ, принадлежатъ къ типичному $E$ r. e. dambicus Matschie. Ньть сомньнія, что этотъ видъ поднимается въ Волжской долиньь довольно далеко къ сьверу, такъ какъ въ Зоологическомъ Музеь

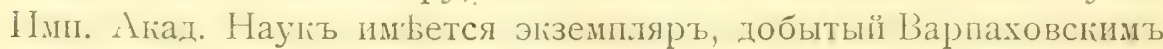
бл. Казани. Въ Закавказьь встрьчается своеобразный подвидъ ежа Er. c. transcancasicus Sat. (І7о и г57, стр. Іо6) котораго въ Mалої Азіи замьняетъ Eivinaceus e. concolor Martin ").

1) Не типиный экземпярь, кақъ мы видыли, быль добыть В. Г. Дуровымъ бл. Москвы въ „Лоспномь Островь“.

2) Приводимй въ раоботь Д энфорда и Эльст о и а Erinaceus europaeus L. несомнднно относптся нъ этому подвиду. (Си. D a n ford and A is ton, 2.) 
Ежъ распространенъ по всей западной Европь отъ Скандинавіи, гды онъ доходитъ до $63^{\circ}$ с. ш., вплоть до Средиземноморской области, включая Сицилію, Сардинію и Критъ. За посльднее время описано довольно много мьстныхъ подвидовъ, отличающихся сравнительно мелкими признагами. Такъ, въ южной Испаніи (окр. Севильи) встрьчается Er. e. hispanus Barret.Ham., на Балеарскихъ островахъ (Маньорка, Менорка)-Evinacens algimus vagans Thom. (Proceed. Zool. Sor. of London, I9or, I, p. 38), въ Италіи-Erinaceus e. italicus Barret-Ham., въ Сициліи - Er. e. consolei Barret-Ham., на Крить - Er. e. nesiotes Bate (Proc. Zool. Soc. Lond., 1905, II, p. 316). Нқкоторые изъ описанныхъ B arretHamilto n'омъ подвидов' сведены въ синонимы обычнаго ежа. Такъ, ero Er. e. occidentalis Barr.-Наm., какъ показаль проф. Lönnberg (го, p. 542), ничьмъ не отличается отъ типичнаго, a Ei. c. roumanicus Bar-Ham., вьроятно, идентиченъ съ E. e. damulicus Matschie (см. также: С а тунин ъ, г 68, стр. 168).

\section{Образъ жизни.}

Излюбленными станціями ежа являются суходолы, опушки лиственныхъ льсовъ, поросшія кое-гдњ гіустарниками, особенно если вблизи находится ржаное поле. „Странно“, пишетъ Сатунинъ, „что онъ (ежъ) ни разу не попадался мнь въ Измайловскомъ Звьринць, гды я весьма энергично экскурсироваль почти полгода въ I89I г. и льто 1892 г. Замьчательно, что здьсь ньтъ любимой пищи ежеї-змьй. Изъ этого можно вывести, пожалуй, что ежъ не любить большихъ высокоствольныхъ льсовъ" (165, стр. 4-5). Совершенно аналогичное наблюденіе пришлось сдылать и мнь въ Тесовсіомъ удьльномъ льсу Можайскаго у. Здьсь также почти совершенно ныть ежей.-Думается, что это стоитъ въ связи съ характеромъ высокоствольнаго льса, а также съ полнымъ отсутствіемъ рептилій. Ежъ съ полнымъ правомъ можетъ считаться ночнымъ животнымъ, такъ какъ день проводитъ гды-нибудь спрятавшись. По вечерамъ, посль захода солнца, когда сгущаются сумерки, онъ начинаетъ свою хлопотливую дыятельность. - Въ это время можно видҺть, какъ онъ неуклюжей походкой довольно быстро переб́бгаетъ открытое мьсто и скрывается въ поросляхъ травы и кустарниіовъ. Пища описываемаго жұивотнаго кіраїне разноои́разна: онъ охотно Һсть насыкомыхъ, дождевыхъ червей, мелкихъ млекопитающихъ до крота включительно, ловитъ и молоденькихъ птичекъ. Весьма энергично пресльдуетъ лягушекъ и, по словамъ большинства авторовъ, пстреб.ляеть змьй. Мнь много разъ 
приходилось видыть, главнымъ образомъ въ неволь, гакъ ежъ ловитъ свою добычу. - Увидавъ лягушку, онъ дьлаетъ обычно по направленію иі ней ньсколько тихихъ шаговъ, а потомъ

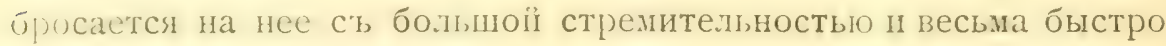
схватываетъ свою жертву. Если бросить въ кльтіу ежа какуюнибудь, довольно крупную застрћленную птицу, напримьръ, соїly, онъ съ осторожностью градется къ пей, затьмъ энергично гидается и начинаетъ грызть, при чемь первые укусы приходятъ обычно въ область головы и шеи. Интересно отньтить, что въ эти моменты, совериенно такъ же, какъ и въ минуты раздраженія и злоб́л, ент издаетъ особый фыркающій звукъ, въ родь глухого постукиванія, причемь тьло его весьна хараптерно подергивается. По словамъ К. А. Сатунина, гнбздомъ ежа является ямка между корнями густого кустарника, выложенная разными мягкими травами. Мнt не удалось ионстатировать время рожіденія молодыхъ, но пришлось видьть самку ежа въ конць іюня 1908 года въ Рузскомъ у. съ 8 только что выведшимися молодыми. Поздней осенью, обыкновенно въ конць сентября или въ началь октября, ежи закапываются въ листья и дернъ, который сносятъ въ кучу. По Л. П. Сабан веву, въ 1874 году они залегли такимъ образомъ тольћо 30 октября. Весенняя дьятельность этихъ животныхъ начинается тогда, когда стаять сньга, т.-е. обычно въ началь апрьля.

Экзелиларь коллекии перечислены въ таблиць измьреній. 


\section{Oтря.цт, Rodentia. Грызуны.}

\section{Краткія характеристики подотрядовъ семействъ и подсемействъ.}

\section{I подотрядъ. SIMPLICIDENTATA.}

Въ теченіе всей жизни, какъ въ верхней, такъ и въ нижней челюстяхъ находится только по одной парђ рьзцовъ.

I. Семейство Muridae. Мыши.

Ложножоренныхъ зубовъ ньтъ. Коренные зубы или съ плоскими жевательными поверхностями и призматическими складками, дьћлающими боковые контуры зуо̆а угловато-пзрфзанными, или съ ясными бугорками на жевательной поверхности и безъ изрьзанныхъ контуровъ.

a) Подсемейство Microtinae. Полевки.

jћевательная поверхность поренныхъ зубовъ поская; боковые контуры пхъ очерчены угловатыми вдав.леніями эмалевыхъ скіадокъ, дылающими очертанія зуба изръзанными. Морда тупая, короткая. Чешуйчатый, довольно густо покрытый волосами хвостъ значительно короче тьла.

b) Подсемейство Murinae. Мыши (собственно).

Жевательныя поверхности коренныхъ зубовъ съ параллельными рядами бугорковъ, по при въ каждомъ ряды. Морда острая, длинная. 'Гешуйчатый, слабо покрытый волосами хвостъ почти равенъ длинь тьла, а иногда се превышаеть. Верхиял губа съ разрызомъ посрединь。

с) Подсемейство Cricetinae. Хомяки.

Жевательныя поверхности коренныхъ зубовъ съ параллельными рядами бугорковъ ил дыс бугорка въ каждомъ ряды. Морда 
очень широкая, тупая. По бокамъ ротовой полости располагаются два зашечныхъ мьшка. Хвостъ безъ чешуї и менье $8 / 4$ длины ть́ла.

\section{2. Семейство Jaculidae. Тушканчики.}

Подсемейство Sicistinae. Мышевки.

ЦЦилиндрическій, чешуйчатый хвость слабо покрыть волосами и превышаетъ обычно длину тьла и головы. Ложнокоренныхъ зубовъ $1 / 0$. Коренные зубы съ тупыми бугорками на жевательныхъ ıоверхностлхъ. Морда острая, короткая. Верхняя губ́ б́ез’ь разрьвза посрединь.

\section{3. Семейство Gliridae. Сони.}

Нечешуйчатый хвость равномьрно покрытъ довольно длинными (ок. $6 \mathrm{~mm}$ и болье) волосами. Јожнокоренныхъ зубовъ $1 / 1$. Первыї ложнокоренной зубъ малъ, но хорошо замьтенъ снаружи. Коренные зубы съ параллельными складками эмали на жевательныхъ поверхностяхъ.

\section{4. Семейство Sciupidae. Бъили.}

Пушистый, нечешуйчатый хвость, равный приблизительно $2 / 3$ длины (тьла и болье) густо, по всему протяненію, покрыть очень длинными волосами, вьерообразно расходящимися на дв стороны. Ложнокоренныхъ зубовъ $2 / 1$. Коренные зубы съ поперечными складками эмалли на жевательныхъ поверхностягъ.

\section{а) Подсемейство Sciurinae. Бちлки.}

Признаки подсемейства общи с'ь харақтерными особенностями семейства. Летательной перепонки между передними и задними ногами-ньтьь.

b) Подсемейство Pteromyinae. Летяги.

Между передними и задними ногами находится широкая, покрытая волосами кожная складка (летательная перепонка).

\section{II. Подотрядъ DUPLICIDENTATA.}

двь пары верхнихъ рьзцовъ; вторая болье мелкая, располагается позади передней, крупной.

\section{5. Семейство Lерoridae. Зайцы.}

$\checkmark$ ши очень длинныя; задняя ступня массивна и удлиннена; хвостъ весьма короткій пушистый. Коренные зубы съ поперечными складками эмали на жевательныхъ поверхностяхъ. 


\section{I. Подотрядъ SIMPLICIDENTATA. Семейство Muridae. Мыши. Подсемейство Microtinae. Полевки.}

Родъ Evotomys. Coues (1874).

\section{Рыжія полевки.}

Наиболье рьзкими и дыйствительными признаками этого рода являются несомньнно краніологическія особенности и строеніе зубовъ его представителей. Но и по вньшнему виду эти полевки могуть быть легко отличены отъ близкихъ къ нимъ формъ. Bct представители рода Evotomys характеризуются болье или менье выраженнымъ красновато-бурымъ мбхомъ дорзальной стороны тьла. Уши замьтно выступають изъ мьха и въ большинств случаевъ равняются половинғ длины головы. Только одна Evo. tomys myava Bailey представляетъ исключеніе изъ этого общаго правила. На нижней сторонь ступни задней ноги находятся пиесть бородавокъ. Болье или менье ярко двуцв屯тный хвость достигаетъ приблизительно половины длины тьла. Зимній мьхъ очень длинный и мягкій, льтомъ онъ болье грубъ и коротокъ. На бокахъ тьла самцовъ, на каждой сторонь находится по одной железь, каждая изъ нихъ достигаеть $10 \mathrm{~mm}$. въ діаметрђ и скрыта волосами. У самокъ имьются 8 паръ сосковъ, при чемъ четыре пары лежать въ паховой области, четыре въ грудной.

Черепь (таб. I, рис. 22, 23) характеризуется болышой округ.лостью своихъ ионтуровъ; гребни на его верхней сторонғ обычно совершенно не развиты. Скуловыя дуги сравнительно тониі, тогда какъ межглазничное пространство отличается своей шириною. Foramina incisiva въ своей передней части только немного превышаютъ ширину ихъ задней области и оба отверстія на всемъ своемъ протяженіи болье или менье параллельны цругъ другу.

Зубы отличаются отъ таковыхъ рода Microtus болье мелкими разиьрами и короткиь рядомъ верхнихъ инжжнхь поренныхь, а также тьмъ, что коренные зубы имьють два ясно дифференцированныхъ корня (во взросломъ возрастьे). Въ свою очередь родъ Microtus характеризуется отсутствіемъ обособленныхъ корней въ теченіе всей жизни животнаго. О деталяхъ строенія эмалевыхъ петель будетъ сказано при описаніи видовъ. Общая зубная формула такова: $\mathrm{i} \frac{\mathrm{I}-\mathrm{I}}{\mathrm{I}-\mathrm{I}} \mathrm{c} \cdot \frac{\mathrm{o}}{\mathrm{o}} \mathrm{pm} \cdot \frac{\mathrm{o}-\mathrm{o}}{\mathrm{o}-\mathrm{o}} \mathrm{m} \cdot \frac{3-3}{3-3}=\mathrm{I} 6$ зубовъ. 


\section{Evotomys glareolus Schreb.}

\section{Рыжая полевка.}

IIus glareolus Schreber (172), p. 680. Hypudaeus hercynicus M e hl is, Isis, Jahrg 1831, p. 876. Evotomys hercynicus (Mehlis) Miller (115), p. 97. Troues. s art, Supplementum, 1904, p. 445. Arvicola glareolus Schreb. B l as i us (27), p. 337. Evolomys glareolus Schreb. Mille r, An. Nat. Hist., III, p. 419 Microlus glareolus (Schreb.) K. А. С а т у н пи ъ (165), стр. II. и (166), р. 2.

\section{Систематическія особенности.}

Общая характеристика строенія черепа была уже дана при описаніи рода, всльдствіе этого я на ней болье останавливаться не буду и перейду къ очерку возрастной измьнчивости. Сравнивая черепь молодого экземпляра рыжей полевки съ болье старымъ, можно замьтить сльдующія отличія.-Въ строеніи черепа молодої Er. ylıюolı. Schreb. бросается въ глаза спльное развитіе задней его половины по сравненію съ переднеї, носовоій областью, которая значительно уступаетъ въ длины таковой у старої полевй. Далье можно отмьтить обшую черту, какъ для полевокъ, такъ и для рода Mus, въ измьненіи, которое претерпьваетъ высома задиси иясти иерела, кажущаяся у молодого экземпляра гораздо большей всльдствіе значительно меньшаго подъема носовой области. Слћ̆довательно, уголь, образованный сходящимися спереди линіями, проведенными по сснованіг и дорзальной части черепа, у молодого экземпляра зиалительио больие, чьмъ у старыхъ полевокъ. Кромь этпхъ, такъ сказать, специфическихъ чертъ п особенностей эволюціи молодого черепа Evotomys glaveolus Schreb., какъ мы увидимъ, общихъ съ таковыми у другихъ видовъ полевокъ, т.-е.: удлиненіе ossa nasalia относительно прочихъ костей, уплощеніе черепа, расширеніе скуловыхъ дугъ и пр., мы имьемь еще одну черту, свойственную, кажется, только описываемому виду.-Именно у посльдняго съ возрастомъ появляется вогнутость въ области ossa fiontalia, края коихъ, напротивъ, приподняты, а упомянутая вогнутость занимаетъ центральную часть этихъ костеіі, захюатывая собою и выдаюцуюся неравнопьрнымъ полукруглымъ контуромъ часть firontalia въ область теменныхъ костей. Замьчу въ заключеніе, что межглазничная ширина уже на очень раннемъ возрасть встрьчается развитой такъ же, какъ и у старыхъ особей. Напримьръ, у № I $5^{8}$ (d), не достигшаго 1/2 роста старыхъ, межглазничная ширина $=4,2 \mathrm{~mm}$.

Тщательное сравненіе серій череповъ самцовъ и самокъ Evotomus glarcolus Schreb. не дало мнь какихъ-либо стойкихъ призна- 
ковъ для ихъ несомньннаго различія. Что касается до общихъ размьровъ, то, хотя это и странно, черепа самокъ ньсколько крупнье таковыхъ у самцовъ. Въ нашей серіи имБются черепа очень старыхъ особей, гдь эти различія сқазываются особенно

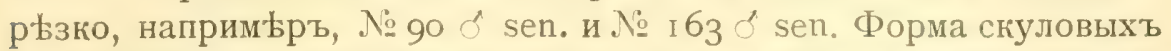
дугъ этого вида країне варыиуетъ: помимо рызкихъ возрастныхъ измьненій, которыя были мной уже описаны, мы встрьчаемъ весьма разнообразную конфигурацію этихь костеї у особей приблизительно одного и того же возраста.

Все сказанное можетъ быть хорошо иллюстрировано на прилагаемыхь таблицахъ измьреній. (См. таблицы А, B, С и D.)

По характеру и строенію эмалевыхь петель зубово рыжая полевка принадлежить, внь всякаго сомньнія, къ наименье стоикимъ формамь по крайней мърђ изъ числа средне-русскпхь представителей этого рода. И, дьйствительно, я рђдко встрбчалъ столь рђзкія и сильныя измьненія въ общей конфигураціи зубовъ, какъ у этого вида. Какъ и у всьхъ представителей полевокъ особенно измьнчивы: посльдній коренной зубъ верхнеї челюсти и первый-нижней. Что касается до двухъ первыхъ (molares) верхней челюсти ${ }^{\mathbf{1}}$ ) и двухъ посльднихъ нижней, то они наиболье консервативны и имьють для всьхъ Microtinae одинаковое строеніе. Однако, какъ мы увидимъ далье у описываемаго вида, и эти зубы подвержены, правда болье рьдкимъ, варіаціямъ. Переходя теперь къ обзору конфигураціи $m^{3}$, мы встрьчаемъ нысколько главныхъ типовт его измьнчивости. Наиболье примитивно его строеніе у тьхъ формъ, у коихъ какъ на его внутреннеї, такъ и наружной сторонь имьется лишь по три эмалевыхь зубца 2 ). Эта довольно частая варіація строенія описываемаго зуба напоминаетъ его структуру у Craseomys rufocams Sundev. Однако, посльдніӥ видъ полевки легко отличается свонми гораздо болье крупными зубами и черепомъ, иной формой интерпаріетальной кости и пр. Отъ упомянутыхъ особей, примитивныхъ по строенію зубовъ, имьются всь переходы къ слћдующему типу, гды какъ на внбшней, такъ и на внутренней стороны посльдняго коренного зуба верхнеї челюсти мы имьемъ ясно

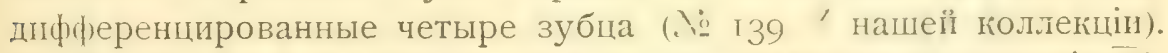
Особенно рьзкія измьненія могуть быть отмьчены въ строеніи $\bar{m}^{1}$. Нормальное строеніе зуба таково: на его поверхности лежать

1) Только второіи зуб́ъ верхнеї челюстпи въ одномъ случађ имьетъ уклоняющееся строеніе (Microtus agrestis L. et sbsp.).

2) Подобное строеніе наблюдали Rörig и Börner (146), Tafel IV, fig. 33. 


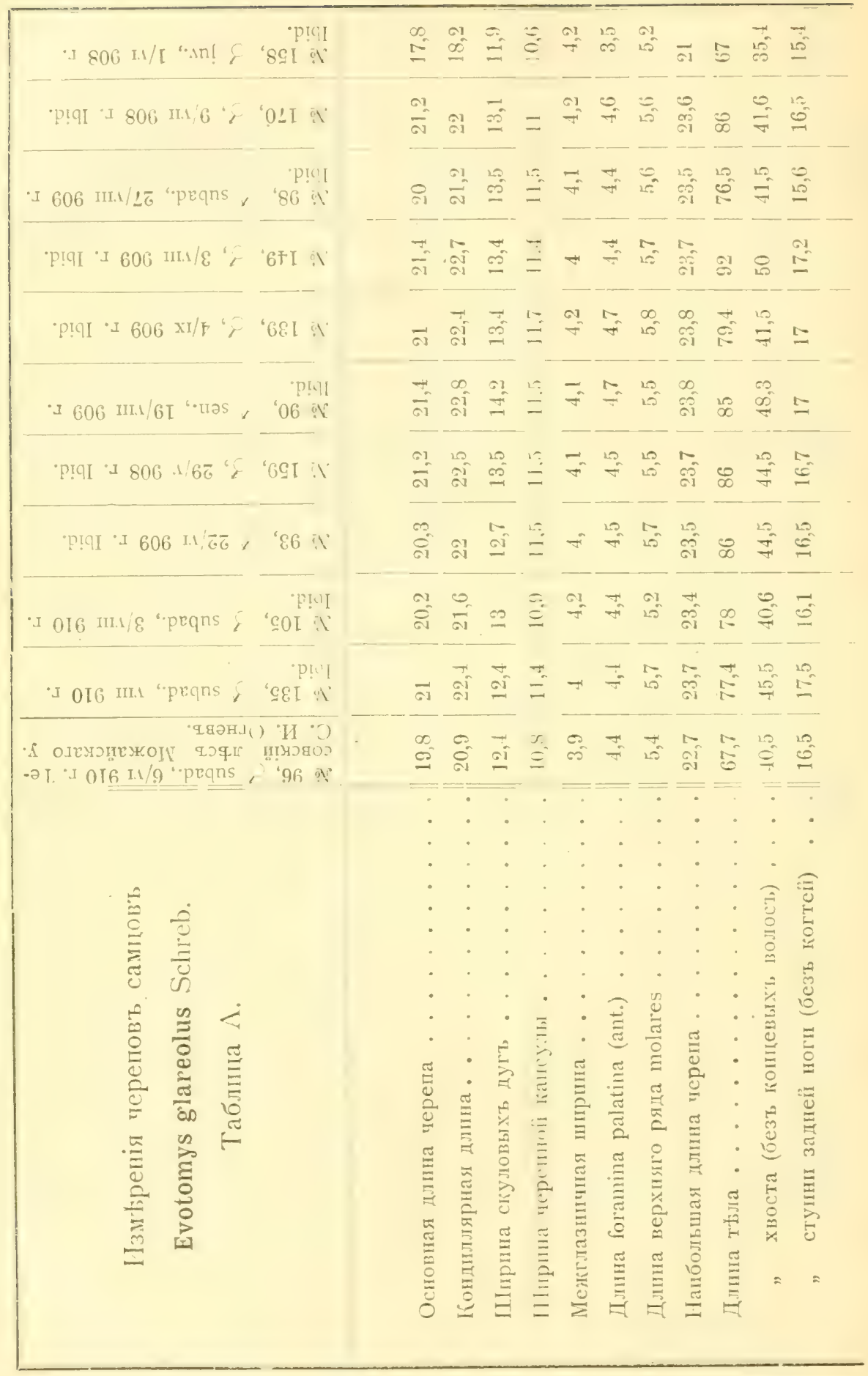




\begin{tabular}{|c|c|c|c|c|c|c|c|c|c|c|}
\hline 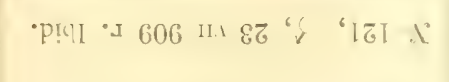 & $\begin{array}{ll}\infty & \infty \\
0 & \text { â }\end{array}$ & 1 & 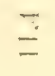 & $\longrightarrow$ & $\stackrel{15}{\pi}$ & 10 & $\widehat{\mathrm{si}}$ & $\begin{array}{l}\text { N } \\
\text { aí }\end{array}$ & $\stackrel{-1}{\varrho}$ & 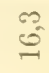 \\
\hline 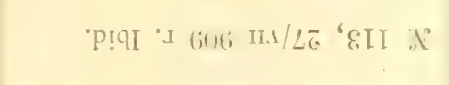 & 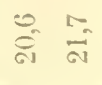 & 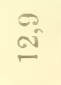 & $\ddot{\Xi}$ & $m_{i}$ & $\vec{\rightarrow}$ & 20 & ๙ิ के & $\stackrel{\infty}{\infty}$ & 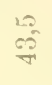 & $\underline{-}$ \\
\hline 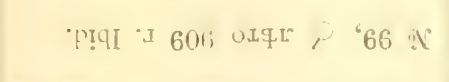 & $\frac{m}{n}$ a & $\stackrel{\oplus}{-i}$ & 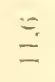 & $\nabla$ & $\stackrel{?}{\sim}$ & 10 & $\frac{a 1}{a 1}$ & $\infty_{\infty}^{\infty}$ & $\stackrel{1=}{10}$ & $=$ \\
\hline 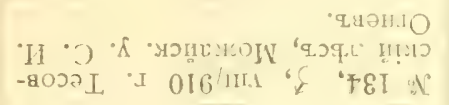 & जा बी & $\stackrel{\overrightarrow{5 S}}{5}$ & $=$ & $\rightleftarrows$ & 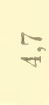 & $1: 2$ & $\stackrel{\infty}{2}$ & $\stackrel{\infty}{\infty}$ & $\stackrel{12}{\stackrel{1}{6}}$ & $\stackrel{a !}{5}$ \\
\hline 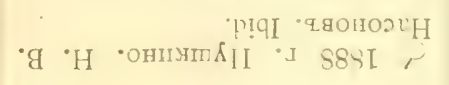 & $\frac{a}{a}$ बे & $\stackrel{\mathrm{I}}{\sim}$ & 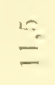 & $\vec{F}$ & $\stackrel{c o}{T}$ & $\begin{array}{l}63 \\
1.5\end{array}$ & $\hat{\tilde{\sigma}}$ & $\approx$ & $\stackrel{10}{7}$ & 5 \\
\hline 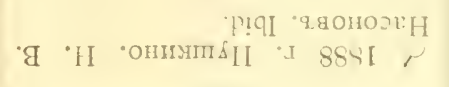 & $\stackrel{\infty}{\mathscr{\Omega}} \stackrel{-}{=}$ & $\stackrel{\infty}{=}$ & $\underline{-}$ & $=$ & $\underset{\text { co }}{\infty}$ & $\overrightarrow{50}$ & $\begin{array}{l}\infty \\
\text { si }\end{array}$ & $\overrightarrow{\hat{Q}^{2}}$ & 우 & $\underbrace{19}$ \\
\hline 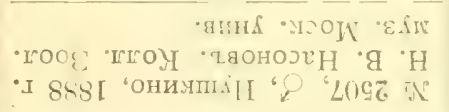 & ही ब1 & oi & $\cong$ & $\Rightarrow$ & 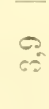 & 150 & $\stackrel{9}{6}$ & t & $\exists$ & of \\
\hline 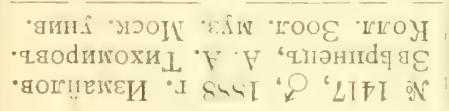 & $\begin{array}{l}20 \\
\Leftrightarrow\end{array}$ & $\stackrel{\infty}{\infty}$ & $\stackrel{s}{\Xi}$ & $\stackrel{\infty}{\rightarrow}$ & $\stackrel{2}{\sigma}$ & I5 & $\frac{a}{a}$ & $\infty$ & $\begin{array}{l}\sigma_{1}^{1} \\
\sigma_{0} \\
c 0\end{array}$ & 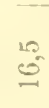 \\
\hline 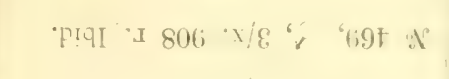 & $\frac{G 1}{\mathrm{~N}}$ ล & $\stackrel{61}{9}$ & $=$ & $\stackrel{\infty}{\leftarrow}$ & $\vec{\sigma}$ & $\overrightarrow{15}$ & ลิ & 8 & $\overrightarrow{25}$ & 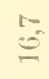 \\
\hline 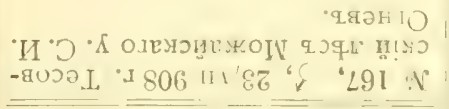 & की & 1 & $\stackrel{\varrho}{=}$ & $\stackrel{\text { s? }}{\leftarrow}$ & $\stackrel{\infty}{-\infty}$ & 두음 & 65 & के & $\begin{array}{l}10 \\
65 \\
70\end{array}$ & $21=$ \\
\hline 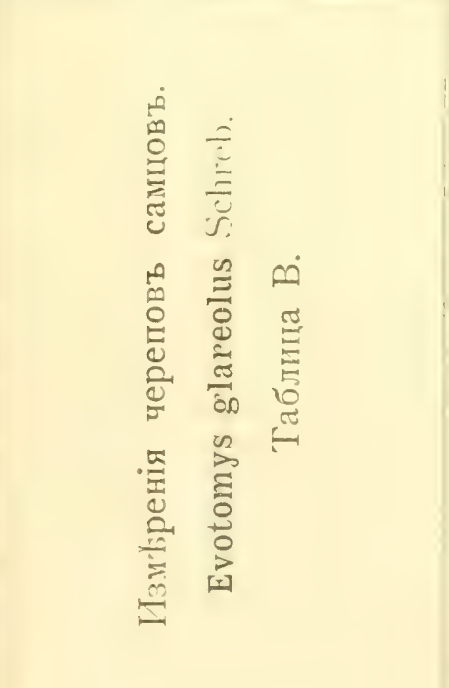 & 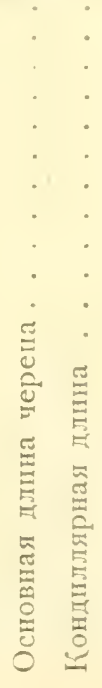 & 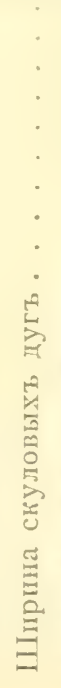 & 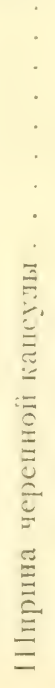 & 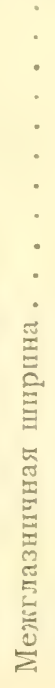 & 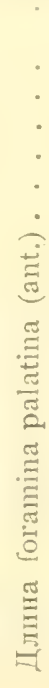 & 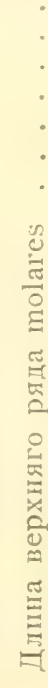 & 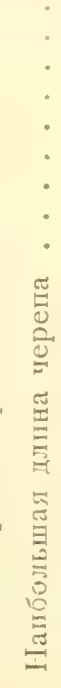 & 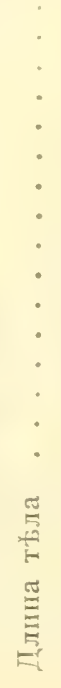 & 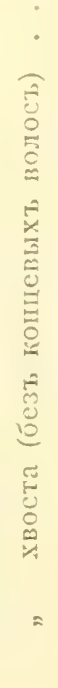 & 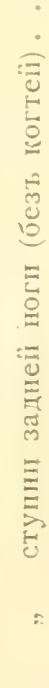 \\
\hline
\end{tabular}




\begin{tabular}{|c|c|c|c|c|c|c|c|c|c|c|c|}
\hline 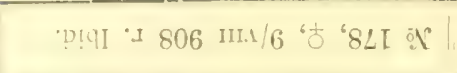 & $\frac{5}{51}$ & ${ }_{i}$ & 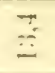 & $\stackrel{1}{=}$ & $T$ & $\stackrel{x}{\longrightarrow}$ & 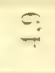 & $\frac{15}{3 i}$ & s: & $i \equiv$ & $\because$ \\
\hline 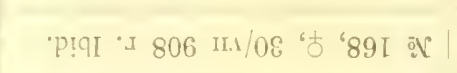 & $\frac{s}{31}$ & $\frac{15}{a i}$ & $\stackrel{c i}{s i}$ & $\approx$ & - & $\stackrel{9}{\rightarrow}$ & $\because !$ & $\stackrel{5}{\circ}$ & 13 & $=$ & $\bar{\Leftrightarrow}$ \\
\hline 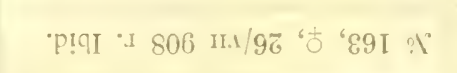 & $\oiiint i$ & $\stackrel{3:}{3 i}$ & $=$ & $=$ & is & $\bar{E}$ & $\overline{:}$ & 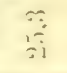 & $\dddot{\Xi}$ & $\equiv$ & 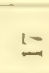 \\
\hline I 606 111. $/ 8$ "prqns " "usprqI & $\bar{\Xi}$ & 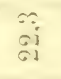 & 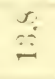 & $=$ & $\bar{i}$ & $\dddot{20}$ & 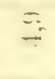 & $\stackrel{31}{13}$ & $\stackrel{5}{\Xi}$ & $\bar{E}$ & $\stackrel{\because}{\because}$ \\
\hline 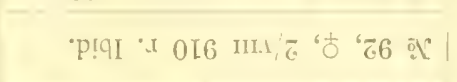 & ili & $\stackrel{-1}{3 i}$ & $\bar{I}$ & $=$ & $\mp$ & 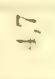 & $i 5$ & $\stackrel{\bar{c}}{\overline{s i}}$ & 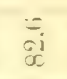 & $\stackrel{\because !}{\longrightarrow}$ & $\because$ \\
\hline •uวp? & $\overline{31}$ & 究 & $\ddot{\dot{m}}$ & $\stackrel{6 !}{=}$ & $\overline{-}$ & $\therefore$ & 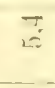 & 1= & $\vec{E}$ & 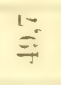 & 1- \\
\hline 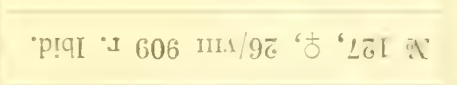 & 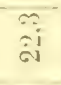 & 20 & 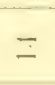 & $\stackrel{x}{=}$ & 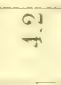 & $\rightarrow$ & $\overline{15}$ & $\frac{\pi}{4}$ & 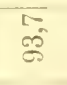 & $\stackrel{+2}{=}$ & $=$ \\
\hline 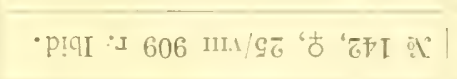 & $\stackrel{\leftrightarrow}{\check{c}}$ & $\frac{x}{51}$ & $\because$ & $\cong$ & $=$ & $T$ & 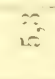 & $\hat{\mathrm{i}}$ & i: & $\stackrel{s i}{i}$ & 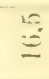 \\
\hline 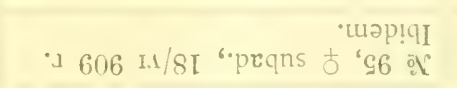 & $\bar{E}$ & $\stackrel{x}{3}$ & $\bar{i}$ & $=$ & 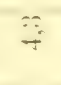 & $\because$ & $\overline{5}$ & $\stackrel{\infty}{\rightarrow 1}$ & $\hat{\imath} \hat{\imath}$ & $=$ & $\ddot{\Xi}$ \\
\hline 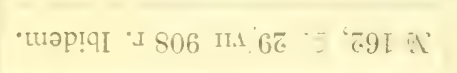 & $\stackrel{\Xi}{\Xi}$ & 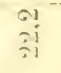 & si & $\Xi$ & $\stackrel{6 !}{\div}$ & 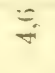 & $\dddot{2}$ & $\frac{1}{6 i}$ & $\bar{s}$ & $\bar{g}$ & $\stackrel{\because}{\because}$ \\
\hline 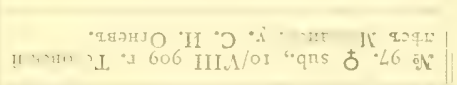 & $\stackrel{1=}{\overline{1}}$ & $\hat{\sigma}$ & $\bar{m}$ & $\bar{Z}$ & $\stackrel{2 !}{-}$ & 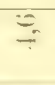 & $=$ & $\frac{91}{31}$ & ळ & 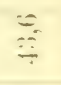 & 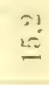 \\
\hline 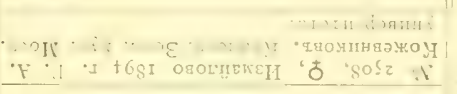 & 20 & $\stackrel{10}{i=0}$ & $\underline{\underline{m}}$ & in & $\stackrel{01}{-}$ & $\Sigma_{i}$ & 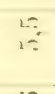 & $2 \frac{2}{61}$ & $\stackrel{i}{i=i}$ & 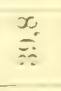 & $\bar{E}$ \\
\hline 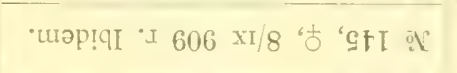 & $\stackrel{\text { s }}{1}$ & $\frac{1}{61}$ & $\underline{2 i}$ & $=$ & $\because$ & $\div$ & $=$ & ấ & $\ddot{\infty}$ & 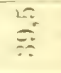 & 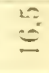 \\
\hline 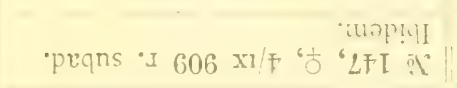 & 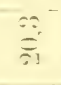 & $\frac{10}{31}$ & $\because$ & $=$ & $=$ & $\stackrel{6 !}{-}$ & $1=$ & $\frac{5}{31}$ & $\sum_{1:}^{2}$ & $\stackrel{\infty}{\stackrel{s}{\rightarrow}}$ & $\stackrel{n}{-\infty}$ \\
\hline 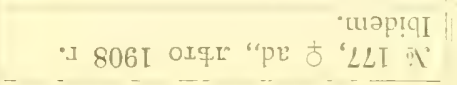 & $\overrightarrow{\mathrm{Bi}}$ & $\overrightarrow{6}$ & $\stackrel{\circ}{\stackrel{0}{-}}$ & $=$ & $\stackrel{9}{-}$ & $\equiv$ & 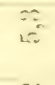 & $\frac{t=}{a i}$ & 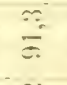 & 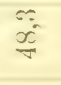 & $\bar{E}$ \\
\hline 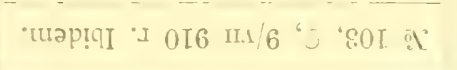 & $\frac{3 !}{31}$ & $\overline{\hat{i}}$ & $\because$ & $=$ & $\rightarrow$ & $\because$ & $2 !$ & $=$ & $\frac{3}{15}$ & 1 & 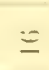 \\
\hline 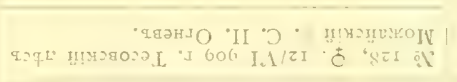 & $\frac{2=-7}{91}$ & $\overrightarrow{i \hat{i}}$ & 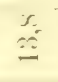 & 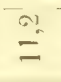 & $\bar{z}$ & $\because$ & $\because$ & $\stackrel{\circ}{\infty}$ & $\therefore$ & $\stackrel{\ddots}{\Leftrightarrow}$ & $\doteq$ \\
\hline 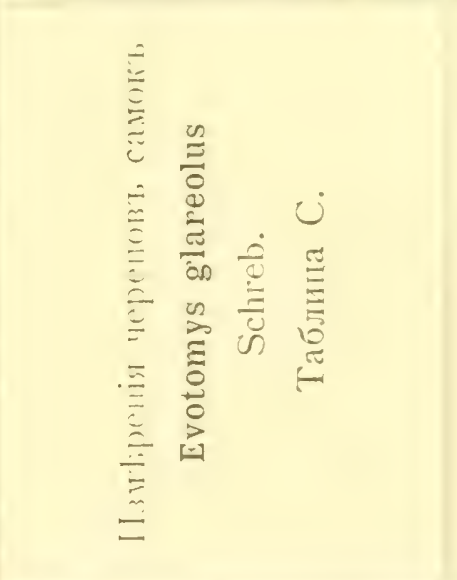 & 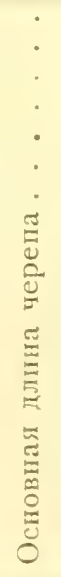 & 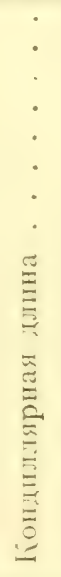 & 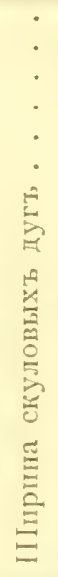 & 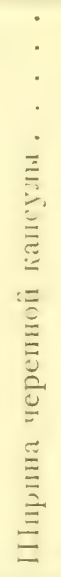 & 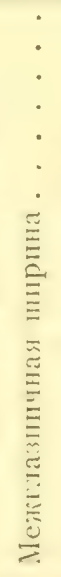 & 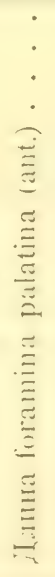 & 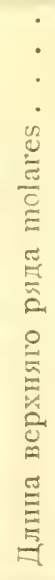 & 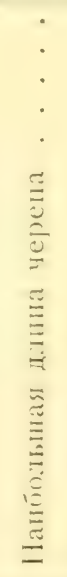 & 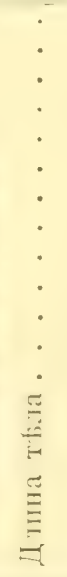 & 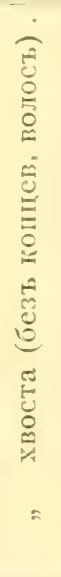 & 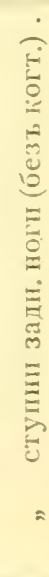 \\
\hline
\end{tabular}


Сравнительныя измьре-

нія череповь самцовь

и саноюь

Evotomys glareolus

Schreb.

Таблица D.

\begin{tabular}{|c|c|c|c|c|c|c|}
\hline 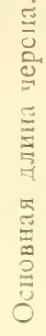 & 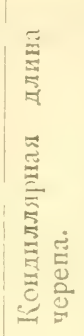 & 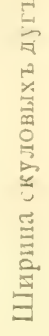 & 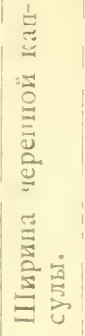 & 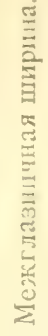 & 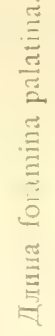 & 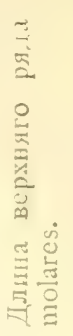 \\
\hline
\end{tabular}

С а м ц ы.

Maximum

Minimum

$21,4 \quad 22,8$

।

\begin{tabular}{r|r|r|r|r|r|} 
& & & & \\
& & & & \\
14,2 & 11,7 & 4,4 & 4,7 & 5,8 & 24,2 \\
11,8 & 10,8 & 3,9 & 3,6 & 5,2 & 21,9 \\
\hline
\end{tabular}

\begin{tabular}{l|l|l|l|}
19,3 & 20,5 & 11,8 & 10,8
\end{tabular}

3,6

C a $\pi$ ir.

Maximum ....

\begin{tabular}{l|ll|}
24,3 & $14,4 \quad 12,3$ & 4,3
\end{tabular}

$4,3 \div 5,4$

\begin{tabular}{l|l}
5,7 & 25.3
\end{tabular}

Minimum

19,4

\begin{tabular}{l|l|l|}
$20,8^{\circ}$ & 12,5 & 11
\end{tabular}

$3,9 ! \quad 4$

\begin{tabular}{l|l}
4,9 & 22,5
\end{tabular}

семь эмалевыхъ петель, при чемъ съ вньшней и внутренней сторонъ расположены по четыре зубца. Наиболье характерно строеніе передняго зуо́ца, который петлеобразно загнуть наружу II довольно длиннен. Отъ этой нормальной струкгуры уклоненія идутъ, во-первыхъ, въ ту сторону, что этотъ первый зубецъ бываеть почти не развить и зубъ иньеть тогда въ своеї передней части нькоторое сходство съ таковымъ у Microtus arvalis 1 .

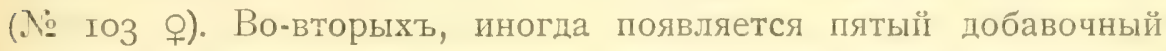
зубецъ съ внутренней стороны совершенно такъ же, какъ у Evotomys rutilus Pall. Посльдній видъ полевки все же легко отличается болье длинными и тонкими эмалевыми петлями, промежутки между коими много уже, а также по строенію посльдняго коренного зуба верхней челюсти, который имьеть весьма вытянутую, подковообразную петлю, чего я никогда не запьчаль у

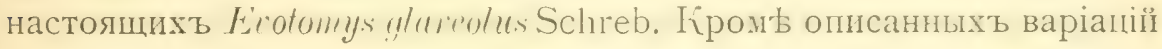
строенія зубовъ, у рыней полевкп мы встрьчаемся съ цылымъ рядомъ случайныхь отк.тоненій отъ ихь нормальної структуры, которыя не погуть о́ыть сведены въь какую-лиобо дифференцірованную группу. Къ такимъ уклонившимся отъ нормы индиви-

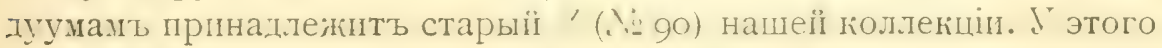
экземпляра совершенно необычный видъ пмьеть второй зубъ 
верхнеї челюсти, который, какь я уже говориль, въ большинтв'ь случаевъ наименъе способень къ варіаціям. Этотъ зубъ съ правой стороны у нашеці Lvotomys glarcolus Schreb. dooünoü, т.-е. заднія эмалевыя петли совершенно отграничены отъ переднихъ; съ львой стороны этотъ зубъ, хотя и сильно отличается отъ типичнаго, но не разтьленъ на два. Также крайне интересно строеніе посльдняго $m^{3}$ : здђсь съ внутренней стороны зам бтны три зубца, а съ внбшней-два слабо развитыхь и зачатокъ третьяго. Наконецъ, стоить упомянуть о структурь $m^{3}$ у № 163 q ad. Тогда какь всћ зубы этой полевки болье или менье нормальны, этоть зубъ представляеть удлиненную эмалевую складку въ видь цифры 8. Необходимо отмьтить при этомъ, что зубы еще не стерты и всь совершенно развились.

Oкраска типичнаго экземпляра въ льтнемъ мбху такова: вся верхняя qасть головы и спины покрыта рыжевато-бурыми волосами, съ темно-сырыми основаніям. Межту подобыни во.тосами замьтно большее или меньшее количество совершенно черныхъ волосъ, придающихъ общему тону мьха довольно темный видъ. На бокахь тьла рыжіевато-бурлй оттьнокь мьха дьлается болье желтоватымъ и сьрымъ, а вся нижняя часть тьла покрыта бьлесоватымъ мыхомь съ довольно темными, сьрыми окончаніями волосъ. Хвость сверху сьро-черный, снизу бьловатый. Сезонныя измьненія этого вида очень рьзки. Именно, цвьтъ мьха зимнихъ әкземпляровъ болье желтоватаго и свьтлаго оттьнка, но не "краснье", какъ писалъ въ своей работь К. А. Сатунин ъ ( I 65 , стр. II). Особенно бросается въ глаза окраска верхней части головы, гды примьшиваются желтовато-сырые тона взамьнъ довольно темныхъ и рыжеватыхъ у льтнихъ особей. Далье могу отмьтить, что мьхъ зимнихъ Evotomys glaveolus Schreb. ды. гается иного длиннье, а нижняя сторона болье пнтенсивно б́ьлой, иногда, впрочемъ, съ замьтнымъ желтоватымъ оттьнкомъ. Хвость покрытъ густыми, болье длинными, чьмъ льтомь, волосами и р Бзко двуцв бтенъ: верхъ его съровато-черный, нижняя сторонажелтовато-бьлая, чьмъ онъ замьтно отличается оть такового льтнихъ представителей Evotomys.

Зимній мьхъ вполнь развивается только въ половинь октября, въ это время я находиль экземпляры уже совершенно перелинявшіе. Весною этотъ мьхъ замьняется болье короткимъ льтнимъ, который вполнь развитъ у майскихъ особей, но въ первой половинь апрьля (I2. IV. I909 г,) я находиль экземпляры, еще сохранившіе длинный зимній мьхъ, правда уже довольно изношенный. 
Далье привожу таблицу измьреній моихъ экземпляовъ. (Эта таблица составлена на основаніи промьра I39 особей, собранныхъ въ Московск. губ.)

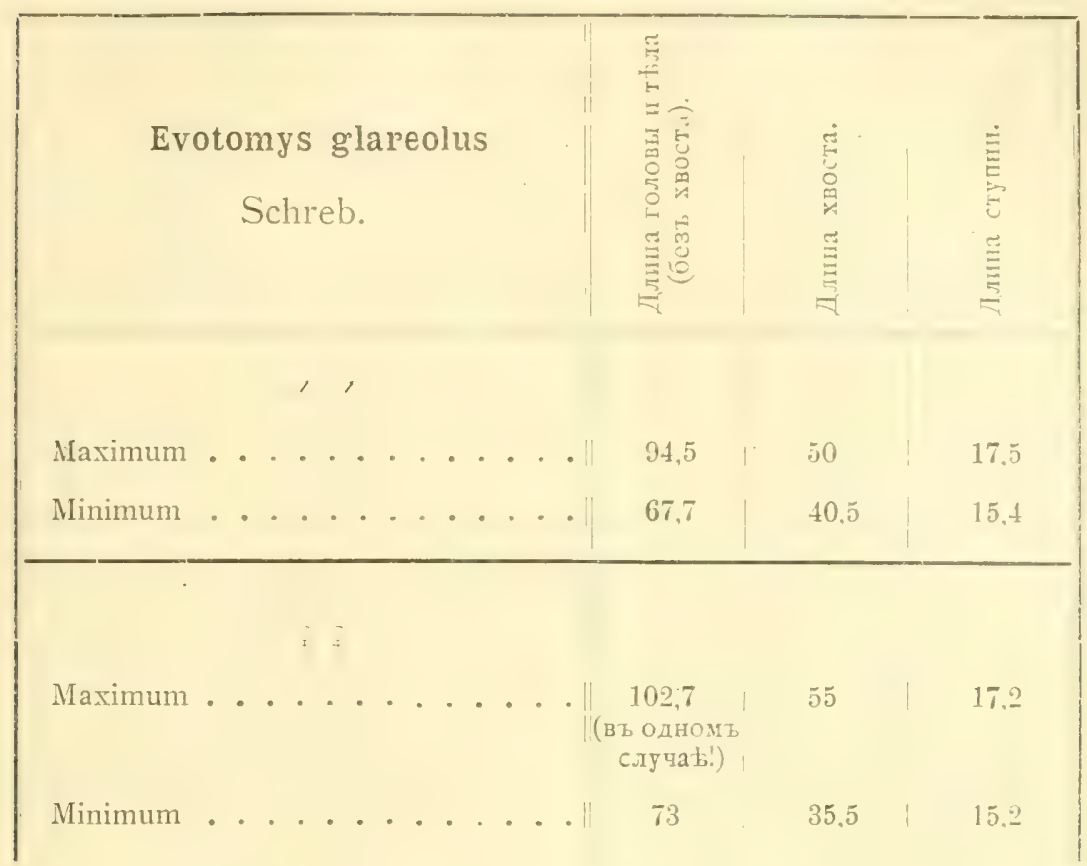

Въ заключеніе я считаю необходимымъ ньсколько разобраться въ томъ вопрось, къ какому изъ описанныхъ до настояшаго времени подвидовъ стоять ближе всего средне-русскія Evotomys? Въ настояшее вреия полное рышеніе поставленної задачи является, по моему убьжденію, еще не выполнимым. Только при непосредственнощъ об́зорt очень обшпрнаго матеріала б́ыло бы возможно высказать какіе-нибудь положительные выводы, такъ какъ одни литературныя данныя-весьма шаткая база для подобныхъ заключеній. Къ тому же эти данныя страдаютъ, съ одной стороны извьстної отрывочностью и незаконченностью, съ другої-неточностями и невырными свыдыніям. Выпе питированная мною работа М илле ра, какъ признаетъ и самъ авторъ, носитъ только предварительный характеръ (Preliminary Revision). He смотря на точность и достаточность діагнозовъ совершенно непонятно, почему авторъ въ концы своеиі статьи въ нькоторыхъ случаяхъ не указываетъ такихъ важныхъ промьровъ, какъ длина головы и тьла (напримьръ, для Eiotomys hereyniens britamicus Miller, Evotomys noricegicus Miller). Посльдняя работа Т ру с са ра 
(Conspectus mammalium Europae, I9го) страдаетъ гораздо большими недостатками, являясь во многихъ отношеніяхъ довольно неудачной компиляціей. Такъ, напримъръ, Т русс ар ъ указываетъ длину тьла и головы („Long. tête et corps“) Evotomys glareolus succicus Miller, равную I39 m/m., что является совершенно несоотвытственнымъ съ крайне малыми размьрами хвоста и ступни (40 m/m., г7,8 m/m.). Ошибка объясняется просто: Т р усса р ъ "total length" М ил л ра приравниваеть своей "Long. tête et corps", упуская изъ виду стоящія рядомъ съ этимъ измьреніемъ промьры „Head and body“ въ работь Миллера. Та же ошибка повторяется у Т ру с с ар а и относительно Evotomys glareolus Schreb., Evotomys glareolus britanicus Miller ${ }^{1}$ ).

Переходя теперь къ самому существу разбираемаго вопроса и тщательно просматривая діагнозы въ работь г. Миллера, я прихожу къ заключенію, что московскія и вообще средне-русскія полевки рода Evotomys, в'Һроятно, принадлежатъ къ Evotomys glareolus istericus Miller. [E Evotomys hercynicus hercynicus apud. Miller (non Mehlis!)]. Эта форма, распространенная, по МилI е р у, въ Румыніп, Венгріи, Австріп, восточной Германіп и западной Россіи, встрђчается, вђроятно, по всей средней Россіи до Ј ральскаго хребта Iі характеризуется сл-дующими признаками-- Іорзальная часть тыла этой полевки, по М и л е р у, довольно яркаго ржаво-желтовато-бураго цвьта, съ примьсью черныхъ волосъ, при чемъ бока и задняя часть тьла животнаго слоямб во довольно ризиолг контрастп со ивитолй спины. Зимнія особи характери-

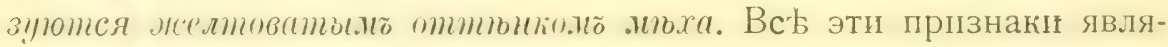
ются характерными для средне-русскихъ Evotomys, чьмъ они отличаются отъ болье темныхъ Lv. glareolus suecicus Miller и Ev. Zritamicus Miller, а также болье сьрой E. g. helveticus Miller. Что касается до строенія черепа, то общіе промьры его болье или менье совпадають сь тьми, которые даеть Мил лер ъ для Ev. g. istericus Miller. Замьчу только, что среди московскихъ экземпляровъ изрњдка попадаются такіе, длина черепа коихъ $(25,3)$ превышаетъ приводимую въ работь г. Миллера $(24 \mathrm{~m} / \mathrm{m}$.). НҺтъ сомньнія, что для точнаго сужденія о ко:'ебаніяхъ єъ размьрахъ черепа нужень громадный матеріаль.-Странно поэтому видьть въ цитированной работь Миллера заявленіе, что черепъ $E v$. \% helveticus Mill. „is slightly larger than that of the other races", тогда какь вс" приводимые размыры

1) Длина головы и тьла указывается для этого вида въ раб́оты Milla is (110), p. 77. 
черепа упомянутій формы совпадають съ таковыми Ex. Teюеу nicus hereynicus Miller! Высказанныя здћсь предположенія объ отнесеніи средне-русскихъ Eintrmy.s ґъ вплу E. \% istericus Miller, по моему мнђнію, могуть считаться довольно обоснованными, но я не могу придавать имъ сколько нибудь категорическјю форму, только сравненіе большого матеріала позволило бы сдылать это съ полной увыренностью. Думается все же, что сдыланный здысь критическій обзоръ признаковъ вићсть съ указаніеш колебаній въ размғрахъ нашей рыжеї полевки можіеть помочь булущимь изсльдователямъ этого вопроса.

\section{Географическое распространеніе.}

Рыжая полевка принадлежитъ къ однимъ изъ самыхъ обыкновенныхъ млекопитающих Московской губ́. Я видł: эъ экзепляры этого вида изъ Московскаго у. (Петровское-Разумовское, I Ізайловскій Звтринецъ), Звенигородскаго у. (село Аносино, Екатериновка), Можайскаго у. (Тесовскій .łсъ б́.т. гор. Можайска), изъ разныхь мұсть Рузскаго у., Диитровскаго (Пушкино), Серпуховского у. (р. Березня, окр. гор. Серпухова). Въ нћкоторыхъ изъ этихъ мҺстностей рыжая полевка встрбчается въ громадномъ количеств है и доминируеть надъ всћми прочими видами.

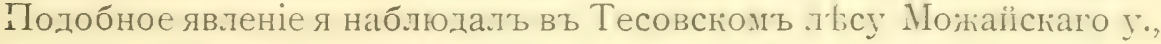
а К. А. Сатунинъ-въ Измайловскомъ Звьринци. Въ центральныхъ губ́ерніяхь Европеїскої Россіи рыжая полевка найдена Эсауловымъ въ Торопещкомъ у. Псковской губ. Въ коллекцін Зоологическаго Музея Пмп. Московск. Унив. пмџется энземпляръ изъ Дорогобуясккаго у. Смоленской губ. оть П. С. Гальцов а, въ той же губерніи этотъ видъ найденъ мною въ Гжатскомъ у. Для Ярославской губ. его помьчаетъ Л. П. С а бан в ев ъ ( 5 о, p. 250-252), правда со знакомь вопроса, хотя по своему общему

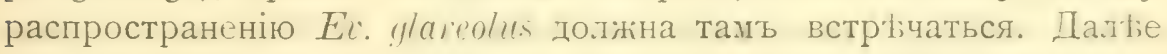
на югъ эта полевка найдена С. Н. Г орбачевым ъ и мною въ Орловскомъ у., а проф.Г. А. К о же в н и к в ы ъ около Батурина Черниговской губ. Н. Н. С омовъ отмћчаеть ее для Харьковской губ. По словамь проф. Черн ая, она встрђчается къ сłверу отъ Воронежа, а проф. Кесслеръ добылъ въ Кіевской губ. только два экземпляра: одинъ въ окрестностяхъ города, въ хвойномъ льсу, другой-въ самомъ городь, въ ботаническомъ саду. Далье на востокъ этотъ видъ найденъ Пал ласом ъ по среднеї Волгћ, особенно около деревень,-въ губерніяхъ Казанской и Симбирской. M. Н. Богданов д добыль Evotomys glareolus въ л‡сахъ (дубовой полосы) Казанской губ. (зо, стр. І73). По 
Ә версманну она встричается въ предгоріяхъ Урала и въ Сим-

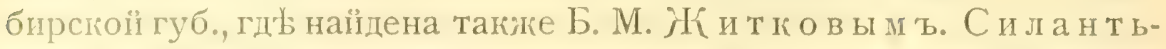
евъ ( 8 I, стр. 298) отмџчаетъ ее для Балашевскаго у. Саратовсіой губ. По Н. А. 3 арудн о му (77, стр. 345) встрғчается въ разныхъ мъстахъ долины средняго теченія У рала и р. Сакмары. Сабан бевъ ( 148, стр. 2І2) нашель ее только въ Тагильской дач $b$, а Наз ар о в доставилъ въ коллекцію Зоолог. Музея Моск. Университета одинь экземплярь съ южнаго Урала. На съверђ этоть видъ найдень въ Лапландіи Плеске ( 133 ), а на западђ ее отмђчаеть Греве́ $(67$, р. II9) для Курляндіи и Лифляндіи.

Начиная съ Зауралья и по всей Сибири Evotomys glaveolus Schreb. замғняеть близкая къ ней форма-Evotomys rutilus Pall. ${ }^{1}$ ).

\section{Образъ жизни.}

Жизнь рыжей полевки тьсно связана съ льсомъ, который является преобладающей и наиболье характерной станціей этого животнаго. Evotomys glareolus Schreb. особенно охотно селится въ высокоствольныхъ, старыхъ участкахъ сосноваго бора съ подсьдомъ изъ лиственныхъ деревьевъ. Въ такихъ мьстахъ [ныкоторые участки Тесовскаго льса близь Можайска, Измайловскій Зв ьринець (по Сатунину)] вся почва бываеть изрыта галлереями изъ норъ этого звьрька, безусловно доминирующаго надъ всьми мелкими млекопитающими даннаго района. Но и въ лиственныхъ молодыхъ льсахъ особенно около сырыхъ канавъ, съ порослями папоротника, можно наблюдать довольно много этихъ полевокъ. Свои гньзда онь дьлають подъ землею между корнями деревьевъ, въ самомь близкомь сосьдствь съ лћсными мышами. Обычно въ гнбздо ведетъ нысколько норъ, изъ коихъ выходы бокавыхъ отстоятъ иногда довольно далеко отъ самаго гньзда. Кромь подобныхъ подземныхъ норъ, мны только въ одномъ случа' пришлось наблюдать наземную постройку. По своему общему виду

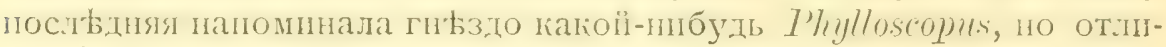
чалась отъ него отсутствіемъ яснаго входнаго отверстія, представ.яя сплошную шарообразную куниу сухой травы п пистьевъ. Отъ гнћзда начиналась нора, уходившая подъ стоящій тутъ же маленькій кустикъ. Въ гнызды было 6 молодыхъ. Беременныхъ самокъ мны приходилось встрьчать въ теченіе всего льта, начиная съ гонца мая (28. V. 908 г.) до конца іюля (26. VII. 908 г.). Количество зародышей колеблется оть 4 до 6-ти. Осенью рыжія

1) За посльдне время Томасомъ была описана съ Саянскпх горъ Evotomys glareolus saianicus Thom. Отношеніе этой формы къ E. rutilus Pall. требуеть еще выясненія (Ann. and Mag. Nat. Hist., 1911, p. 759). 
полевки начинають придерживаться жилыхъ построекъ и погребовъ, гды встрьчаются иногда и льтомъ. Вь началь зимы, когда сньгъ еще не очень глубокъ, онъ бываетъ въ тьхъ мьстахъ, гдн держится много Ev.glareolus Schreb., довольно сильно изрытъ ихъ норами. Съ увеличеніемъ толщины сньлнаго покрова полевки начинаютъ все рыже появляться на его поверхности, и въ многосньжныя зимы видно довольно мало ходовъ этихъ млекопитающихъ. Насколько позволяютъ судить мои наблюденія надъ этимъ звьрькомъ въ неволь, характеръ его довольно робкій іп пугливыи, онъ только въ рыдкихь случаяхъ защищается, стараясь укусить схватившаго его человыка. I2 іюля Igog года мны пришлось поймать живую $\mathbb{E}$. glareolus Schreb. Полевка очень фслабла оть долгаго голода, который она претерпћла, сідя въ цилиндрь, куда попалась. Когда я даль ей моркови, она набросилась на нее п стала ьсть съ большою жадностью. Поћвъ вдоволь, она стала чиститься, вытягивая и приподнимая заднія лапы, она облизывала ихъ, а также энергичными движеніями переднихъ лапъ поправляла мьхъ головы, посль чего облизывала свои конечности. Большую часть дня рыжіая полевка проводи.а, забишиись подъ мохъ и не обнаруживая никакой дыятельности. Насколько я могъ замьтить, любимымъ қормомь ея служать корни деревьевъ и травы, морковь и картофель; довольно охотно эта полевка ьсть и мясо, которое, повидимому, предпочитаетъ позднею осенью и зимою, что отмьтиль въ свое время и К. А. С атунин ъ.

Әкзелиляри коллекии: І48 экземпляровъ совскаго льса Можайскаго у. собраны въ теченіе льта и осени 1908, І909, І9го, І9гі, І9г2 гг. Кіромь нихъ, въ коллекцій имьются: № 253 ㅇ ad. I9. IV. I909 г., р. Березинка бл. Серпухова. (Оть Ө. С. Ш ер бакова). № 254 × ad. 20. IV. о9 г. Ibidem. № 255 우 I9. VI. rgog r. Ibidem. № 485 우 24. VII. I907 г., с. Аноснно Звени-

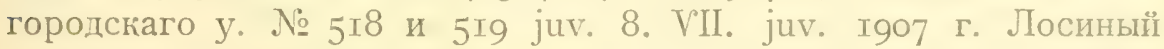
Островъ, Черкизово. (Оть Д. І ㅇ I7. VII. Igo7 г., Аносино Звенигор. У.

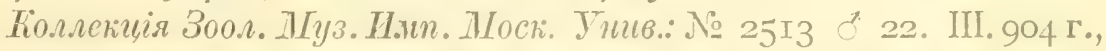

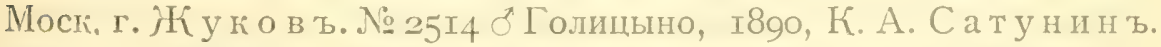

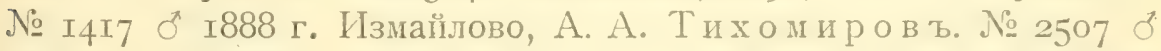

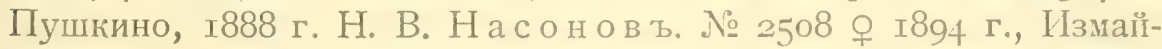
лово, Г. А. Кожевников ъ. Насонов ь (дублеты), № 250 I 12. IV. I909 г. 우 Березинка бл. Серпухова, Ө. С. Ш е р б а о в ъ. ⿺ 2502 우 I3. IV. Igo9 г. Ibidem. № 2503 오 II. IV. Ig09 г. Ibidem. № 2504 O I4. V. Ig09 г. Ibidem. № 2505 I I. IV I909 г. Ibidem. № 2506 đ I5. IV. Ig09 г. Ibidem. 


\section{Родъ мicrotus Schrank: (1798).}

\section{Сьрыя полевки.}

Schrank, Fauna Boica, I, 1798, p. 66 (основанъ на IVicrotus arvalis Pall.). Elliot Daniel, A synopsis of the Mammals of North Amerika, 1901, vol. II, p. $178-179$.

По внбшнему виду принадлежащія къ этому роду полевки отличаются отсутствіемь сколько-нибудь дифференцированной рыжей окраски спины. Цвытъ ихъ мьха измьнчивъ отъ довольно свђтлаго желтовато-сђраго до темнаго буро-сьраго тона. Уши слабо выступають изъ мьха и въ большинствь случаевъ равняются одной трети длины головы. На нижней сторонь ступни находится чаще шесть бородавокъ. Въ большинствь случаевъ слабо двуцв бтный хвость достигаетъ только $1 / 3$ длины тьла. (За исключеніемъ Microtus ratticeps Keys. et Blas., у коей онъ равенъ около 1/2 тьла). Зимній мьхъ длиннье и мягче льтняго. У самоюъ имьется 8 паръ сосковъ, при чемъ четыре лежатъ въ паховой области, четыре-въ грудной.

Черепъ характеризуется угловатостью своихъ очертаній, гребни на его вершинной сторонь у нькоторыхъ видовъ раз. виты довольно сильно. Скуловыя дуги сравнительно толще, чьмь у представителей рода Exotomys, тогда какъ межглазничное пространство относительно уже. Formmina incisiva въ своей передней області значительно расширены, тотда какь сзади сулены и лежатъ параллельно другъ возл'ь друга. Зубы отличаются отъ таковыхъ рода Erotomys свопми большими размьрами и болье длиннымъ рядомъ верхнихъ и нижнихъ коренныхъ, а также отсутствіемъ дифференцированныхъ корней въ теченіе всеї жизни животнаго. О деталяхъ строенія эмалевыхъ петель я буду говорить подробно при описаніи видовь. Общая зубная формула какъ у предыдущаго рода.

\section{Microtus ratticeps Keys, et Blas.}

\section{Полевка крысоголовая.}

Arvicola ratticeps $\mathrm{Keyserling}$ und $\mathrm{Bl}$ asius, Mém. Acad. St.Petersb., 1841, p. 333. Blasius (2 7), p. 365. Rörig (145), p. 430, 471. Trouessart $(200)$, p. 179. К. А. С атунин в $(165)$, стр. 12 ии $(166)$, р. 2.

\section{Систематическія особенности.}

Обшая характеристика черепа была дана при описаніи рода, поэтолу перехожу къ подробностямъ. Черепь молодого экземпляра 
Microtus ratticeps Kejs. et Blas., достигшаго 1/2 размьра стараго, отличается сльдующими особенностями: задняя часть его, по сравненію съ переднеі́, поднимается країне круто вверхъ. С.ть довательно, уголь, образованиый линіей, проведенной по контуру основанія и по спинной его поверхности, будетъ много болье такового у взрослої особи. Сь другої стороны, высота черепа въ передней его части, взятая отъ поверхности твердаго нёба до ossa nasalia, будетъ соотвьтственно, гораздо меньше, чьмъ у взрослаго экземпляра. Скуловыя дуги в ихъ переднеї части у молодой особи ограничены ровными закругленіями, тогпа какъ у старыхъ ясно виденъ уголъ, выступающій на фонь foramen infraorbitale (если смотрьть на черепъ сверху). Наконецъ, у старыхъ $\boldsymbol{M}$. ratticeps межгтазничное пространство дылается, уне и ярко выступаютъ гребни, ограничивающіе теменныя кости. Также крайне характернымъ для старыхъ особеї яв.яется развитіе замьтныхъ выступовъ височныхъ костей, что придаетъ очертанію задней области черепа характеръ неровнаго контура. Въ заключеніе отмьчу ръзкое развитіе гребня мемду побным костями, которое встрьчено только у старыхь Microlus ratticeps Keys. et Blas. Проф. Rörig въ своей посльдней работњ (I45), считаетъ признакомъ отличія половъ развитіе угла въ наружномъ контурђ передней части скуловыхъ дугъ, при чемь этотъ уголь по его мнђнію, замьтенъ только у самцовъ, у самокъ, подобно молодымъ индивидуумамъ, онъ совершенно не развитъ. Дыиствительно, у самокъ средняго и молодого возраста этого угла незамьтно, но у одного экземпляра старой самки (ঐ. І7) я могъ его легко констатировать. Мны думается, что хорошимъ признакомъ полового диморфизма въ строеніи череповъ этихъ полевокъ. можетъ служить развитіе "crista" между ossa frontatia. Я находиль этоть гребень ясно дифференцированнымъ пгкиючительно у самцовъ, но не у одной самки. (Табл. I, рис. І8, І9).

Въ заключеніе привожу (стр. І66) таблицу пзмұреній череповъ моихъ экземпляровъ.

Въ строеніи зубной сислешъ мы встрђчаемся съ очень большими отклоненіями, главньйшіе типы коихь такъ хорошо разобраны въ работахъ Rörig и Börner (I 4 6, pl. V, fig. 45-5I, 52-6o), а затьмъ болье подробно въ посльднеї статьђ R ( 45 , р. 448). Наибольшей изиьнчивости подвержень посльдній зубъ верхней челюсти. Здћсь мы встрьчаемъ всь переходы оть наиболье примитивнаго строенія этого зуба, когда на внутренней сторонь его имьется 4 зубца, а на вньшней - три (№ 24),

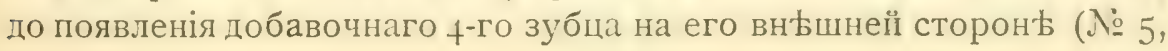




\begin{tabular}{|c|c|c|c|c|c|c|c|c|c|c|c|c|}
\hline 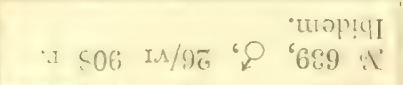 & 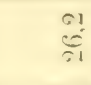 & 1 & $\begin{array}{l}21 \\
10 \\
01\end{array}$ & 1 & 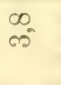 & $\stackrel{10}{=}$ & $\because$ & $\stackrel{20}{\forall}$ & & & & \\
\hline 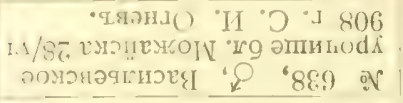 & ध1 & $\frac{0}{4}$ & $\vec{E}$ & $\stackrel{\infty}{\Rightarrow}$ & का & $\underline{z}$ & ?! & $\stackrel{9}{\pi}$ & & & & \\
\hline 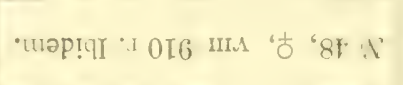 & í & แิ & 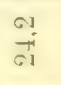 & $\cong$ & $\stackrel{\circ}{\infty}$ & $\stackrel{1}{\mathfrak{m}}$ & $\vec{s}$ & 4 & & $\frac{0}{6}$ & 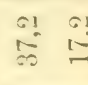 & 皇 \\
\hline 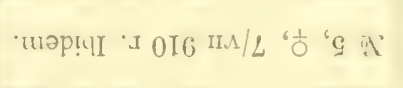 & के & बה. & 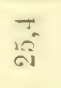 & $\stackrel{\infty}{\sim}$ & 5 & $\stackrel{\text { ol }}{ \pm}$ & $\stackrel{0}{0}$ & $\stackrel{\infty}{\rightarrow}$ & & $\begin{array}{l}\mathscr{N} \\
\stackrel{\infty}{\infty}\end{array}$ & $=\infty$ & 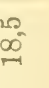 \\
\hline 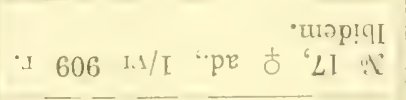 & $\infty_{1}^{\infty}$ & 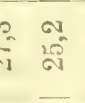 & $\begin{array}{l}0 \\
10 \\
\text { in }\end{array}$ & $\vec{a}$ & $\hat{\omega}$ & $\underbrace{10}_{10}$ & $\cong$ & $\stackrel{\infty}{\rightarrow}$ & & $\stackrel{5}{\circ}$ & $\underset{F}{\infty} \infty$ & \\
\hline 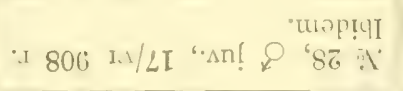 & $\frac{1}{a 1}$ & $\therefore \stackrel{\sigma}{\sigma}$ & $\overrightarrow{\mathrm{ON}}$ & 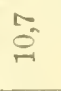 & के & $\stackrel{10}{=}$ & $0_{20}^{0}$ & कs & & $\begin{array}{l}20 \\
0\end{array}$ & $\begin{array}{ll}3 & \infty \\
0 & 1\end{array}$ & \\
\hline 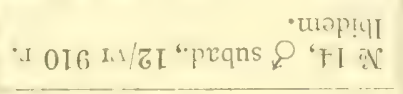 & $\frac{c_{2}}{a+1}$ & 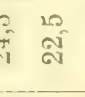 & $\overbrace{0}^{10}$ & $\stackrel{\infty}{=}$ & $\mathrm{cos}$ & $\stackrel{\infty}{=}$ & $\approx$ & $\stackrel{N}{\forall}$ & & $\infty_{1}^{\infty}$ & $\stackrel{0}{\Rightarrow} \stackrel{0}{a}$ & \\
\hline 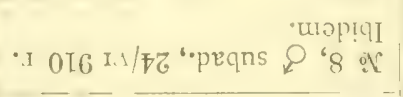 & $\vec{N}$ & $+\frac{5}{10}$ & $\mathfrak{a}$ & $\stackrel{\infty}{=}$ & क्रे & si & @1 & $\stackrel{\infty}{*}$ & & $\begin{array}{l}\infty \\
\infty \\
\infty\end{array}$ & $\stackrel{91}{\rightarrow}$ & \\
\hline . I 016 II.1/g "peqns p "EI & 요 & คิ ลี & â & $\stackrel{10}{=}$ & si & $\stackrel{t a}{a}$ & $\sigma^{6}$ & tis & & $\mathbb{E}$ & $=$ & \\
\hline 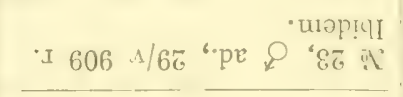 & $\begin{array}{l}0 \\
\therefore-1\end{array}$ & 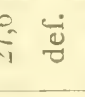 & $\dot{\tilde{g}}$ & $\begin{array}{l}100 \\
10 \\
-1\end{array}$ & $\infty$ & $\stackrel{0}{\circ}$ & ?1: & 20 & & $\begin{array}{l}\infty \\
\infty \\
=\end{array}$ & $\rightarrow$ & \\
\hline 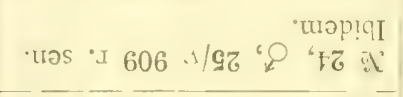 & $\overrightarrow{\text { ai }}$ & $\stackrel{\infty}{\infty}$ & Sิ & $\begin{array}{l}0 \\
\text { Ni } \\
\stackrel{N}{-}\end{array}$ & is & ت્ & $\stackrel{\infty}{N}$ & ton & & $\stackrel{109}{\exists}$ & $0^{13} 9$ & \\
\hline 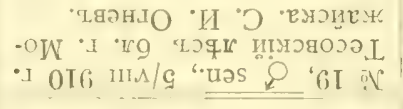 & : & 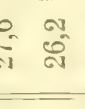 & $\frac{0}{61}$ & $\stackrel{\text { a }}{\stackrel{\sim}{\sim}}$ & + & 5 & 10 & Ho & & $\stackrel{\Re}{\sim}$ & हैं है & \&ิ \\
\hline 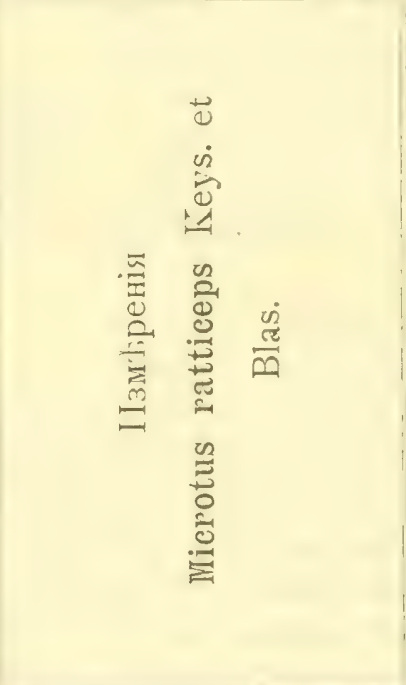 & 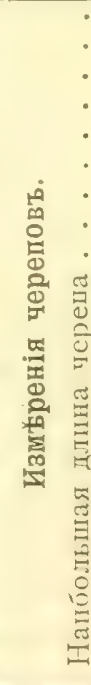 & 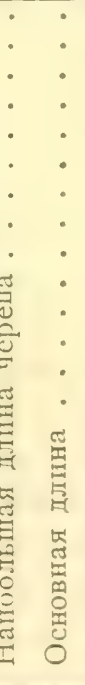 & 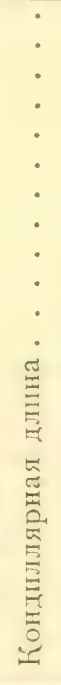 & 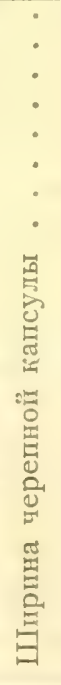 & 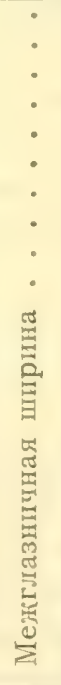 & 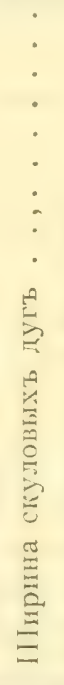 & 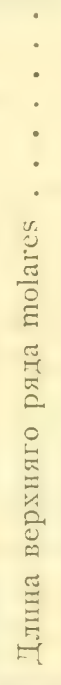 & 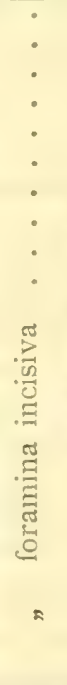 & 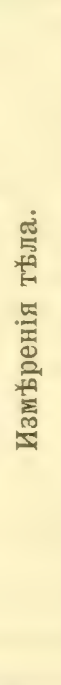 & 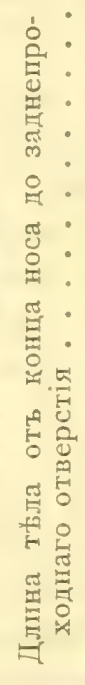 & 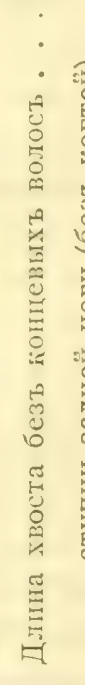 & 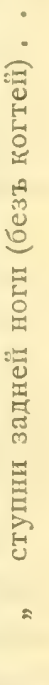 \\
\hline
\end{tabular}


12 т3) и, натонецъ, до ясної дифференцировки пятаго зубца на внутреннеї стороны описываемаго зуба (.요 8). Весьма измьнчпвъ, также передній коренной зуб́ь нижней челюстп. Въ нашихъ серіяхъ имьются всь переходы отъ 7 къ 8 зубцамъ на его поверхности.

Что касается до цвбтовыхъ варіацій этого вида, то оны крайне разнообразны. Мћхъ спины типнинаго экземпляра состопть изъ смьшенія разнообразно окрашенныхъ волосъ. Часть постьлнихъ свБтло палево-желтоватая съ очень слабо развитыми черными окончаніями и широкии сыро-черными основаніям. Среди такихъ волосъ встрьчается довольно значительный процентъ совершенно черныхъ. Отъ общаго смьшенія получается характеръ довольно темнаго буро-сьраго мьха съ болье или менье ярко выраженной примьсью палеваго тона. Этоть тонъ болье рьзокъ на бокахъ, гды свьтло-окрашенные волосы преобладаютъ надъ темными. Вся нижняя сторона быловатая съ довольно темными сьрыми окончаніями волосъ. Хвостъ довольно рьзко двуцвьтный: сверху покрытый черными волосами, сиизудовольно свђтлыми, бћловатыми. Лапы характеризуются сћроб бловатымъ мьхомъ, болье свьтлымъ на верхней сторонь ступни и темнымъ на ея нижней поверхности. Цвьть мыха молодого экземпляра болье тусклый и сырый, что происходитъ отъ большаго развитія сьрыхъ основаній волосъ и гораздо болье узкихъ палево-рыжихъ окончаній, а также отъ примьси совершенно черныхъ волосъ. Нижняя сторона значительно темнье и сьрье, всльдствіе большаго развитія тьхъ же сьрыхъ основаній мtха. Отъ описаннаго характернаго типа окраски мнt встрђчались разнообразныя уклоненія. Мнь попалались, напримьръ, особи съ замғтнымъ коричневатымъ тономъ спины, нь-

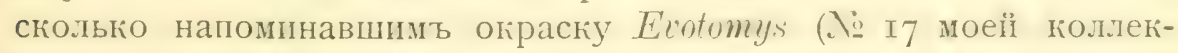
ціи). Съ другой стороны, встрьчались крайне темныя особи, очень походившія на темно-окрашенныхъ Microtus agrestis neglectus Jen. (№ 5 ㅇ). Интересно отмћтить, что цв’ьть ногъ посльдняго экземпляра быль крайне теменъ; что заставило меня первоначально отнести его къ упомянутому виду, только длина хвоста, характеръ мыха его покрывающаго, и, далье, краніологическія особенности ясно показали мнь, что я имью дьло съ $\boldsymbol{M}$. ratticeps Keys, et Blas. Еще болће рьдкой является сльдующая красочная аберрація: цвьтъ спины сравнительно очень темный, но бросается въ глаза очень св Бтлая окраска нижней стороны, тонъ которой цовольно интенсивно-бьлый, что придаетъ

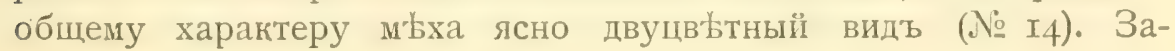


мьчу въ заклоченіе, что цвытъ хвоста подверженъ большимъ колебаніямъ: у наиболье типичныхъ крысоголовыхъ полевокъ

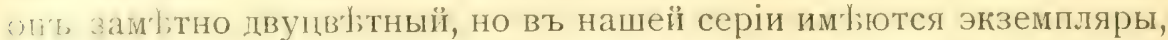
у жоихъ эта двуцв'тность выражена жрайне слабо, что опять является признакомъ общимъ съ $M$. agrestis neglectus Jen. Въ закіпюеніе, привожу таблицу измьрсній моихъ экземпляровъ ${ }^{1}$ ).

\begin{tabular}{|c|c|c|c|c|c|}
\hline $\begin{array}{c}\text { Пзиьренія } \\
\text { Microtus ratticeps } \\
\text { Keys. et Blas. }\end{array}$ & 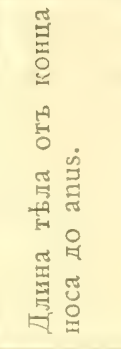 & 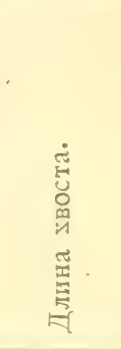 & 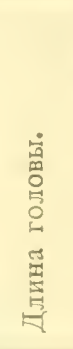 & 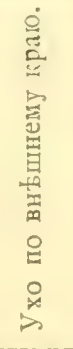 & 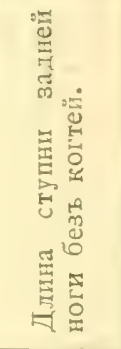 \\
\hline Самцы. & & & & & \\
\hline 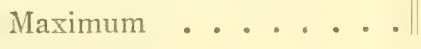 & 128 & 56,5 & 34 & $14, \pm$ & 20,5 \\
\hline Minimum . . . . . . & 112,4 & 45 & 31,5 & 12 & 17,6 \\
\hline Самки .... & $\begin{array}{c}145 \\
\text { (по Сaтy- } \\
\text { ниву). }\end{array}$ & $\begin{array}{c}60 \\
\text { (но Сату- } \\
\text { нury). }\end{array}$ & - & - & $\underset{\substack{\text { (по Caтy } \\
\text { muny). }}}{20}$ \\
\hline Maximum ..... J & 112,4 & 58 & 34 & 14 & 19 \\
\hline Minimum . . . . . & 96,5 & 36,5 & 27,6 & 13 & 16,9 \\
\hline
\end{tabular}

Географическое распространеніе.

Крысоголовая полевка, в屯роятно, довольно обыкновенна въ предђлахъ Московскіої губ́., но теперь, всл'дствіе отрывочности имыющагося въ мопхъ рукахъ матеріала, нахожденія этого вида носятъ спорадическій характеръ. Въ моей коллекціи имъется большая серія (29 экз.), собранныхъ въ Тесовскомъ льсу, въ 5 верстахъ отъ г. Можайска. К. А. Сатунин ъ нашелъ Microtus ratticeps Keys. et Blas. около ст. Голицыно, по берегамъ маленькой рбчки въ І890 году. Въ І89г году онъ добылъ въ Измайповскомъ Звъринци, по берегамъ р. Серебрянки, около ұо экземпл. Наконецъ, С. А. З е рн о в ы ъ одинъ экземпляръ былъ пойманъ на топкомъ берегу Тростенскаго озера (Звенигородск. у.).

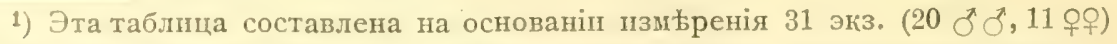
пзъ Московскої губ. Молодыя особи не включены въ число промћровъ. 
Крысоголовая полевка можетъ, по справедливости, считаться типичной cыверной формой, распространенной въ Европейской Россіи только въ ея таёжной области. Впервые этотъ видъ былъ присланъ проф. Блазіусу изъ Устюга-Великаго (на Съверной Двинњ). Литературныя свыдынія о распространеніп Microtus ratticeps Keys. et Blas. въ разныхъ губерніяхъ Европейской Россіи могуть быть названы країне скудными. Она найдена въ Ардатовскомъ у. Симбирской губ. Б. М. Ж и тковым ъ ( 7 г, стр. І5). По свидьтельству Л. П. С а б а н है в а, встрғчиется въ среднемъ Заураль', еще обыкновеннъе M. arvalis L. (въ Богословскомъ округъ и Екатеринбургскомъ убздъ). Н. А. З арудный нысколько разъ ловилъ (M. oeconomus uralensis Poljak.) въ лугахъ и степяхъ по нижней Сакмару и въ степи за Ураломъ (77, стр. 347). По Блазіусу этоть видъ встрбчается на Урал'。. На западж описываемая полевка найдена въ Прпбалтіиіскихъ провинціяхъ: въ Лифляндіи (Ассмусомъ), въ Валкскомъ у бздь (Г реве́, 67, р. І22). На съверђ встрђчается, по словамъ А. Ј. Mela. (Vertebrata fennica etc., Helsingfors, І882), въ сьвверной Финляндіи и Русской Лапландіи до Ледовитаго океана. Б. М. Жи тковъ добылъ одинъ экземпляръ въ устьђ р. Чижи (I9/ wI I902 г.), на запад. сторонь Канинскаго полуострова $\left.{ }^{1}\right)$. Collet нашелъ ее близъ Финмаркена, Бэр ъ въ Лапландіи ${ }^{2}$ ), Нильссонъ-въ Скандинавіи, Lill jeborg-въ съверной Норвегіи.

\section{Образъ жизни.}

Крысоголовая полевка особенно часто встрђчается въ льсныхъ торфяныхъ болотахъ, поросшихъ высокої травої пі кустарниками, по берегамъ мелкихъ рђчекъ, если окружаюшая ихъ урема образуетъ значительную поросль. Тамъ, часто около самаго берега, гдњ обнажается отъ пригрывающеї ее травы черная торфяная почва, въ тьни густо растущаго кустарника, можно видъть норы этой полевки, по своему діаметру превышающія таковыя Microtus arralis L. Къ сожальнію, мои наблюденія надъ этимъ видомъ на свободы сводятся къ немногому. Беременныя

1) Размъры этой особи таковы: длина головы пі тьла: 109; хвостъ: 42,5; голова: 29; ухо по внбшнему краю: 12 ; ступня: 19,6 .

2) R ör ig (145, (p. 464) опредныляетъ крысоголовую полевку изъ Лапландіи за Microtus oеconomus Рall. Въ настоящее время, когда вопросъ о видовой дпфференцировкь этої посльдней II M.ratticeps Keys. et Blas. не можетъ счи-

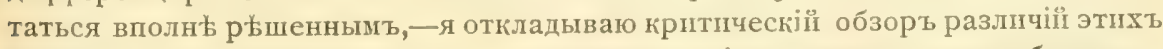
формъ, на которыя указалъ R ӧ r i g, до накопленія въ мопхъ рукахъ большаго количества $M$. oеconomus Pall. изъ Сибири. 
самхи попадались мнь, начиная съ первыхъ чисель іюня (г. VI. 908 г.). Количество зародышей обычно колеблется отъ трехъ до семи. По словамъ К. А. Са тунина, молодыя ранняго помета вырастаютъ къ осени приблизительно въ половину взрослой особи. Ннтересно отмћтить, что самки встрьчались мны значительно рғже самцовъ.--Въ неволt Microtus ratticeps Keys. et Blas. пріятнђе и интереснђе близкихъ къ ней видовъ, Она много подвижнье, чьмь $M$. arvatis $\mathrm{L}$., и не такъ жадна и зла, какъ $M$. amphibins L. Крысоголовая полевка очень любопытна, она внимательно сльдить за движеніями пинцета, съ помощью котораго производится чистка кльтки. Очевидно, блескъ пинцета такъ заинтересовываеть полевку, что она дњлаеть нћсколько шаговъ ближе къ нему и внимательно на него смотритъ. Вњроятно, она умна, такъ какъ стоить приподнять стекло, закрывающее сверху терраріумъ, какъ $M$. ratticeps дьлаеть попытки выпрыгнуть на свободу. Бъгъ ея довольно тихій, какъ и у всъхъ полевокъ, хотя прыгаеть она хорошо, въ ведрь она свободно дылаетъ скачокъ въ 20 сантиметровъ, пытаясь выбраться изъ своей ловушки. Если схватить старую крысоголовую полевку, она издаетъ громкій, цикающій пискъ, внимательно смотритъ за движеніями грозящей ей руки и, при первой возможности, кусается довольно сильно и больно. Въ этомъ лежить одно изъ главньйшихъ біологическихь различіï этої формы оть Erotomys ylareolus Schreb., лоторая сравнительно очень кротка, труслива и смирна. Замбчу также, что рыжія полевки, готорыхъ я держалъ въ неволь, большую часть времени проводили, забившись подъ мохъ, тогда каюъ $\boldsymbol{M}$. ratticeps сдьлала себћ гнъздо на поверхности дерна, положеннаго въ терраріумъ, и обложила грая его мохомъ. Любимой пищей описываемої полевки являются корни растеній, свґжая трава и листья, весьма охотно фсть она также землянику, хватая при этомъ отдьльную ягоду передними лапами и сидя во время ьды на заднихъ. Въ большинств Б случаевъ она отгрызаеть куски отъ корней растенії и ьстъ ихъ такию же образомъ, какъ ягоду земляники, только изрьдка она гложеть цьлый корень, не откусивъ передъ этимъ отдыльнаго небольшого куска. Поьвъ, Мicro tus ratticeps начинаетъ чиститься, при чемъ она поднимаетъ переднія лапки, заводя ихъ за уши, и ньсколькими быстрыми движеніями противъ шерсти приводитъ въ порядокъ мьхх головы. Затьмь она очищаеть лапами переднюю часть морды, облизываетъ бока и снова начинаетъ бьготню по терраріуму.

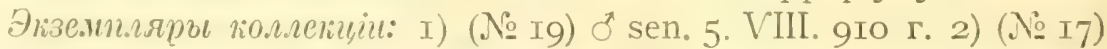
qad.I. VI. 909 r. 3) (№ I4) ơ subad. 2I. VI. 9Io (aberratio). 4) (№ 5) 
우 7. VII. 9Iо г. 5) (№ 25) 오 29. VI 908 г. 6) (№ 22) 5. VII. 9Io r. 8’.

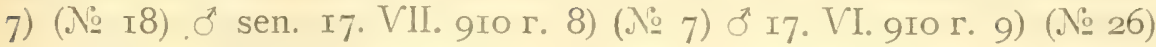

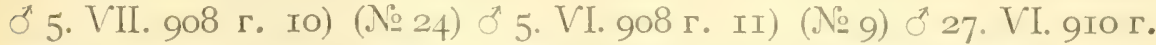

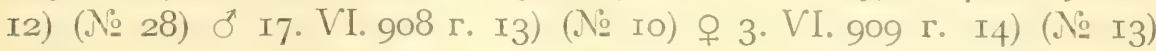

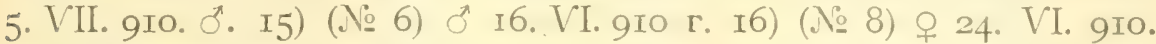
I7) (№ 27) o juv. 2. VI. 908. I8) (№ 29) \& 27. V. 909. I9) (스 30) o sen. 29. V.909 г. 20) (No 3I) o sen. 25. V.909 г. 2I) (No 32) \& 28. V.909 г. 22) (o 33) o 6. VI. 909 г. 23) (№ 34) ठ 26. V. 909 г. 24) (№ 48) VIII. 9то г. 25) (№ 638) 28. VI. 908 sen. 26) (으 639)

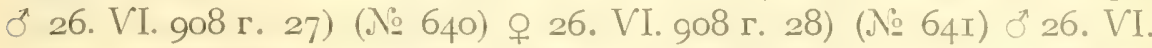
908 г. 29) (№ 864) ㅇ II. VIII. 9т2 г. Bсt собраны въ Тесовскомъ удыльномъ льсу бл. г. Можайска.

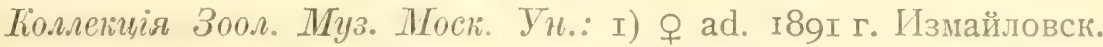
Звьринецъ, К. А. Сатунинъ. 2) q Ibidem. 3) 오 Ibidem (K. A С а.тунин ъ).

\section{Microtus agrestis neglectus Jenyns.}

\section{Полевка темная.}

Arvicola neglecta Thomson, Jen yns, Ann. Nat. Hist., Vol. VM, p. 270274, 1841. Microtus agrestis neglectus Jen. Barret-Hamilton (8), p. 599 Trouessart (200), p. 176. Arvicola agrestis Blasius (27), p. 369. Microtus gregarius Linn. К. А. Сату нин в (165), стр. 12 й (166), р. 2.

\section{Сиетематическія особенности.}

Черепъ (табл. I, рис. 20, 2I) этой полевки характеризуется нысколькии особенностями, изъ коихъ наиболье р Бзими являются сльдующія.-У Micr. agrestis neylectus Jen. шовъ меж.ду frontuha in parietalia имьетъ форму ясно очерченнаго тупого угла. Совсымъ

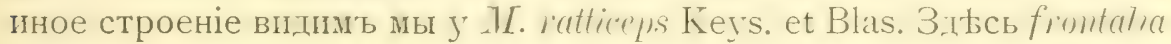
отграничиваются отъ теменныхъ костей по линіи, имьющей видъ части прямоугольника, иногда съ неправильно-закругленными углами, но въ большинствь случаевъ эти углы рьзіо обозначены и каждый изъ нихъ приближается по величинь къ прямому. Этоть признакъ мнђ пришлось провьрить на большой серіи, и всегда онъ былъ весьма постояненъ. Далье въ череп古 і. agrestis neglectus Jen. очень хараптерно строеніе залнеглазничиых выступовъ. Если смотрьть на нихъ сверху, то они замьтно выдаются въ бока и образуютъ рłзко діфференцированные углы по сравненію съ болье срьзанными частями тьхъ же костей у $M i$ crotus ratticeps Keys. et Blas.

Bullae tympani темной полевки болье вздуты и округлы, чьмъ замьтно сжатыя съ боковъ соотвьтствующія окостеньнія въ че- 


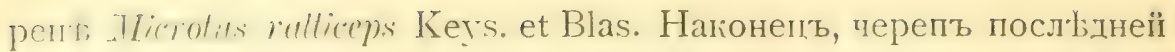
длинные и скуловыя дуги разставлены гораздо шире, ч九мъ у описываемой формы. Что гасается до формы межтеменной иости, строеніе которой у этого вида Блазіусъ считаеть особенно характернымъ, то я долженъ отмғтить здћсь довольно большія голебанія въ ея очертаніяхъ. Однако, у большинства пзслтілованыхь мною череповъ бока этої кости были срьзаны довольно прямыми линіями, образуюпими съ каж,цї стороны os intepuretule по два угла, замtтно приближаюшихся къ прямымъ.

Возрастныя различія въ строеніи черепа сказываются въ сльдуюицхь чертахъ.-Вся носовая область молодого экземпляра, а также его лобныя кости, относительно значительно короче, чłњь у старыхъ. Всльдствіе этого вся задняя часть черепа кажется гораздо болье массивной и удлиненной. Посльднее отличіе выступаеть съ особенной рьзкостью еше потому, что вышина задней части черепа значительно превосходитъ его переднюю область. Наконецъ, скуловыя пуги молодого индивидуума много у́же и тоньше, чьмъ у старыхъ. Что касается до посльднихъ, то вся передняя часть черепа ихъ со временемъ удлинняется. Это влечеть за собою меньшій контрасть въ развитіи передней и задней области черепа. Наконецъ, самъ онъ становится болье плоскимъ. Словомъ, въ общей схемь мы видимъ повтореніе тьхъ же возрастныхь измтненій, которыя мы уже просльдили у крысоголовой полевки. Ниже я даю промьры имұющихся въ моей коллекціи череповъ. (См. табл. А на стр. г73).

Что касается до строенія зубовъ, то общая конфигурація ихъ является болье или менье постоянной. Ннтересно отмытить тоть факть, что строеніе нижнихъ коренныхъ гораздо менье варіируеть, чьмт верхнихъ, и что посльдніе склонны къ отклоненіям всю, а не только третій задній зубъ, какъ у большинства полевокъ. Измьнчивость задняго коренного сводится къ тому, что на его внбшней поверхности число зубцовъ колеблется оть 3 до 4, при чемь наиболье постоянна первая цифра; на внутренней сторонћ этого зуба имьются четыре рьзко дифференцированныхъ зубца. Hanóontse характерно у Microtus ayrestis neglectus Jen. строеніе второго коренного зуба верхней челюсти. Этоть зубъ имћеть на внутреннеї своей сторонь добавочную пятую петлю, выраженную съ большей или меньшей рłзкостью. Barret-Hamilto n описалт, вт, свое время (7, p. 598) варіацію, у коеї первый зубо верхнеї челюсти имьль на внутреннеї сторонь 6-ой добавочный зубелґъ, по своему виду напоминающій таковой на второмъ коренномт. R ̈̈rig, тщательно изучавшій отклоненія въ строеніи зуб- 
$-17: 3-$

\begin{tabular}{|c|c|c|c|c|c|c|c|}
\hline 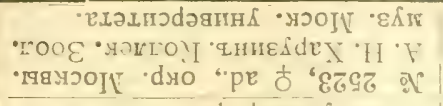 & 20 & $\stackrel{0}{\circ i}$ & $\bar{a}$ & $\underline{\Xi}$ & $\exists$ & $\overrightarrow{a i}$ & $\cong$ \\
\hline 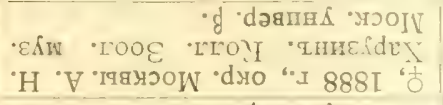 & $\stackrel{0}{0}$ & $\approx \tilde{i}^{20}$ & à & $\stackrel{0}{=}$ & $\rightarrow$ & $\stackrel{5}{i}$ & $\stackrel{9}{0}$ \\
\hline 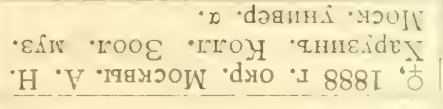 & $\begin{array}{l}3 ! \\
30 \\
\text { ล1 }\end{array}$ & $\hat{i}$ & $=$ & $\stackrel{0}{\because}$ & $\begin{array}{l}\because \\
\therefore\end{array}$ & $\stackrel{x}{=}$ & $\overline{0}$ \\
\hline 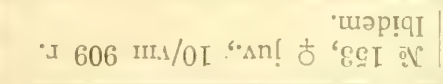 & $\stackrel{n}{a}$ & $\stackrel{\infty}{=}$ & $\stackrel{\infty}{\infty} \underset{\sim}{\infty}$ & $\stackrel{\theta}{=}$ & $\cos ^{20}$ & $\stackrel{0}{0}$ & 25 \\
\hline 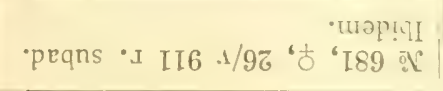 & @i & $\stackrel{\sim}{\stackrel{\leftrightarrow}{0}}$ & $\frac{\infty}{a i}$ & $\ddot{a}$ & $\stackrel{5}{\infty}$ & $\stackrel{-}{=}$ & $\overline{0}$ \\
\hline 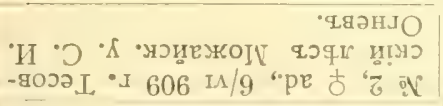 & कू & ๙ิ & $\begin{array}{l}\text { an } \\
\text { ș }\end{array}$ & $\stackrel{20}{2}$ & $\stackrel{5}{s}$ & बे & 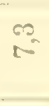 \\
\hline 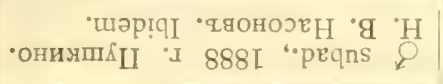 & $\stackrel{20}{\vec{J}}$ & $\stackrel{\text { สิ }}{\sim}$ & ज़ & $\stackrel{m}{m}$ & $\ddot{\nabla}$ & $\stackrel{\sim}{\simeq}$ & $\overbrace{}^{\infty}$ \\
\hline 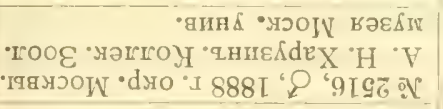 & $\overrightarrow{\mathrm{N}}$ & & 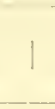 & 1 & $\nabla$ & 1 & 10 \\
\hline I 606 IIs/gI "peqns ק" "76 & $\stackrel{\infty}{\omega}$ & $\vec{c}$ & $\overrightarrow{\text { สิ }}$ & $\overrightarrow{0}$ & $=0$ & $\stackrel{x}{=}$ & $\dddot{\varphi}$ \\
\hline 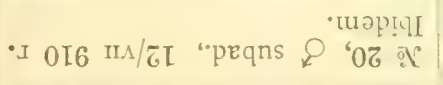 & 동 & ลิ่ & की & 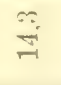 & $\stackrel{\leftarrow}{\infty}$ & $\underset{\sim}{\stackrel{\leftrightarrow}{\sim}}$ & $\stackrel{r}{0}$ \\
\hline 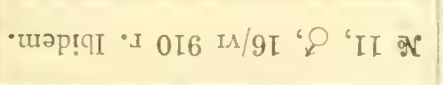 & ลี & $\overrightarrow{\text { ज }}$ & $\stackrel{\text { ai }}{0}$ & $\ddot{z}$ & $\infty$ & $\overrightarrow{\mathrm{g}}$ & $\ddot{1}$ \\
\hline 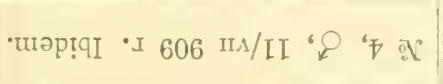 & $\widehat{\widehat{N}}$ & 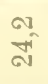 & 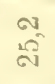 & 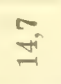 & के & $\stackrel{0}{i}$ & $\mathfrak{\infty}^{-}$ \\
\hline 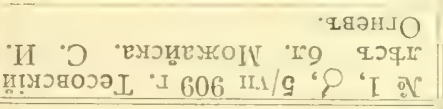 & $\overrightarrow{\text { ज़ }}$ & बू. & $\begin{array}{l}01 \\
28 \\
21\end{array}$ & $\stackrel{\infty}{ \pm}$ & 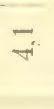 & $\stackrel{\sim}{a}$ & "̇. \\
\hline 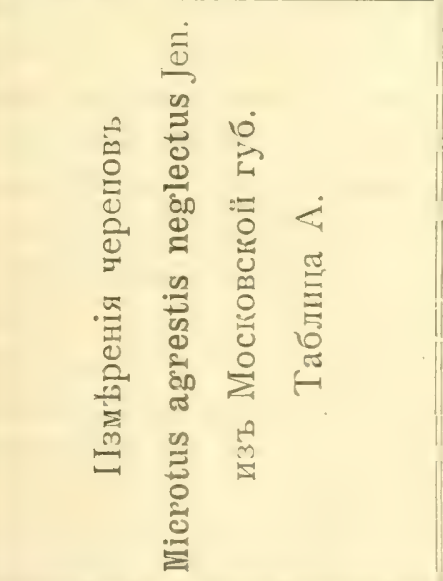 & 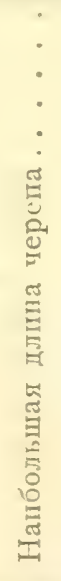 & 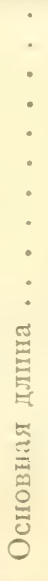 & 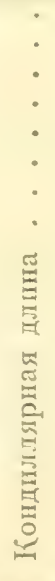 & 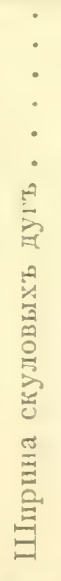 & 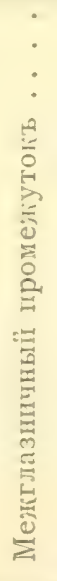 & 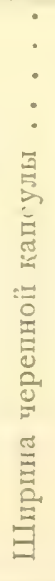 & 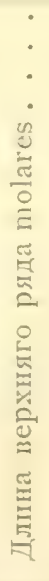 \\
\hline
\end{tabular}


ноli системы этой полевки, не даеть рисунковь подобныхъ варіапіiі. Просмотрь имьющихся у меня серій показаль, что эти отклоненія не представляють рьдкости. Такъ, у № I (ठ) моей поллекціи съ каждой стороны перваго поренного зуба верхней челюсти имьется очень рњзко развитый шестой добавочный зубецъ, совершенно, какъ на рисункахъ В a r ret-Hamilton. У № 2 (우) этоть зубецъ развить только съ правой стороны, тогда какъ съ львой онъ толык намьчается; наконецъ, у 으 20 с съ каждой стороны эти зубцы развиты очень слабо. Нћкоторые экземпляры этой полевки, добытые въ окр. Москвы А. Н. Х а р узи ны м ъ и хранящіеся въ ғоллекціи Зоол. Муз. Моск. Ун., Т и о ми р о в ъ и Корчагинъ были склонны считать особої разновидностью. „По окраск'b,-пишуть эти авторы,-они (экз. полевокъ) отличаются отъ типичныхъ представителей вида ть্ъм, что красный оттђнокъ выраженъ сравнительно слабо; въ зубной формуль также замьчается уклоненіе, именно пятая петля второго зуба верхней челюсти едва выражена; затьмъ, третій отличительный признакъ составляють заднія карпальныя бородавки, которыя здысь приблизительно одинаковы, между тъмъ у типичныхъ представителей наружная бородавка значительно уступаеть по величинь внутренней".

Мнб̆ думается, что указанныя отличія не являются достаточно стойкими для дифференцировки даже особой „varietas". Дћло въ томъ, что слабое развитіе „краснаго оттьнка“ мәха нельзя считать уклоненіемъ отъ типичной формы, такъ какъ у посльднеї онъ въ большинств's случаевъ также почти не замьчается. Въ моеї большой серіи имьется тольћо одинъ экземпляръ, у коего этотъ оттьнокъ выраженъ довольно ясно (№2). Далье, тоть признапь, что заднія карпальныя бородавки у этихъ экземпляровъ приблизительно одинаковы, между тьмъ какъ у типичныхъ представителей наружная значительно уступаеть внутренней-нельзя считать достаточно стойкимъ. Мнь приходилось видыть всь переходы отъ этихъ особей къ такимъ, у коихъ строеніе карпальныхъ бородавокъ уклонялось въ противоположную сторону. Совершенно то же приходится сказать и о строеніи пятой добавочной петли второго зуба верхнеї челюсти.

Окраска Microtus agrestis neglectus Jen. подвержена большимь колебаніямъ.-- Цвьт мьха типичнаго (льтняго) экземпляра тағовъ: верхняя часть головы и вся спина покрыта очень длинными волосами, съ темно-сьрыми основаніями и довольно свьтлыми ржаво-желтоватыми концами; среди подобныхъ волось значитйыниі процентт, составляють совершенно џерные. Цвьть 
боковъ тьла много свьтлье всльдствіе большей примьси желтоватыхь волосъ. Мъхь нижней стороны много короче, отдыльные волосы съраго цвыта у основаній, съ бьловатыми окончаніями, на которыхъ замьтень довольно рызко выраженный желтоватый налеть ${ }^{1}$ ). Хвость слабо двуцв бтный, сверху пожрытый черноватыми короткими волосами, снизу сыровато-былыми. Јапы отличаются своимъ довольно темнымъ цвьтомъ и сьроватым короткимъ мьхомъ, съ большей или меньшей примьсью желтоватаго оттьнка. Отъ этихъ, болье типичныхь особей, мы имьемъ всы переходы къ темно-окрашеннымъ полевкамъ, поторыя попадаются тоже довольно часто. Об̆щiй тонь мьхх ихъ верхнеї стороны однообразно черновато-сырый съ легкия рыжеватым оттынкомъ. Эта темная ограска обусловлена очень широким, почти черными основаніями волосъ, большимъ процентомъ совершенно черной шерсти и бльднымъ тономъ окончаніц нбкоторыхъ изъ волосъ. Вся нижняя сторона тьла тусілаго сьроватаго цвыта съ слабымъ быловатымь налетомь. Хвость подобныхь экземпяровъ покрытъ очень короткими, равномьрными волосами и почти совершенно одноцвьтный. Лапы очень темны и отличаются черноватымь оттьнкомъ шерсті. Наконецъ, въ коллекціи Зоол. Муз.

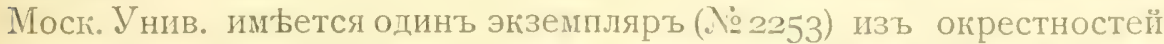
Москвы оть А. Н. Х а рузина, представляющій большой интересъ по своей окраскь. Обшій тонъ окончаній съроватыхь у своихъ основаній волосъ спинной области этой особи-свбтлопалево-сьрый, съ замьтной примьсью желтоватаго оттьнка, особенно на передней части морды. Волосы нижней стороны значптельно сьрые, концы ихъ бьловаты. Окраска ушей и лапь бьлая, съ легкимъ палевымъ оттьнкомъ. Хвость такого же цвњта и покрытъ совершенно былыми волосами, лишь на конщ' его примьшиваются коричневатые волоски. Въ заключеніе привожу размьры моихъ экземпляровъ. (См. табл. В на стр. І75).

Итакъ, темная полевка отличается отъ крысоголовой сльвдующими вньшними признаками:

I) Своими меньшими размьрами.

2) Болье короткимь хвостомь, который у $M$. a. neglectus Jen. равенъ $1 / 3$ (или даже менье) всего тьла. (У $M$. ratticeps Keys. et Blas. хвость $={ }_{i 2}^{1 /}$ (или около этого) длины тьла). Крол'b того, хвость $M$. a. neglectus Jen. обычно довольно одноцвьтный, тогда какъ у $\boldsymbol{M}$. ratticeps онъ ярко двуцвьтенъ. Далье, волосы его по-

1) Этоть признакъ Barret-Hamilton считаеть особенно характернымъ для $\boldsymbol{L}_{\text {. }}$. neglectus Jen. 
$-176 \ldots$

\begin{tabular}{|c|c|c|c|c|c|}
\hline 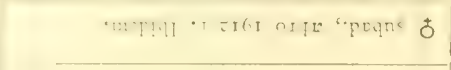 & की & $\stackrel{a}{\pi}$ & $1=$ & $\hat{\sigma i}$ & 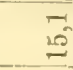 \\
\hline 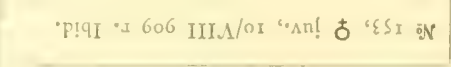 & $\frac{61}{10}$ & $\frac{a}{a-1}$ & $\stackrel{\infty}{\infty}$ & 1 & 12 \\
\hline 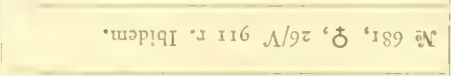 & ag & ติ & $\stackrel{G !}{=}$ & I & $\varrho_{-1}^{-}$ \\
\hline 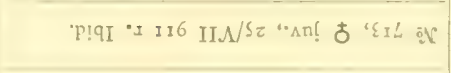 & 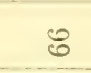 & m & $\stackrel{\circ 1}{=}$ & $\underset{0}{0}$ & $\stackrel{10}{10}$ \\
\hline 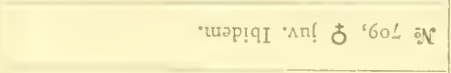 & i & 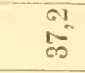 & $\stackrel{\rho}{=}$ & $\overrightarrow{a i}$ & 210 \\
\hline 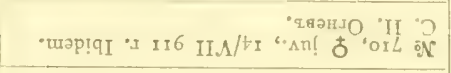 & $\delta_{0}^{10}$ & เ & $\stackrel{\text { a! }}{=}$ & $\sqrt{2}$ & 19.5 \\
\hline 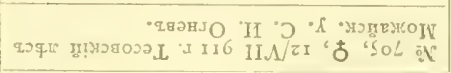 & $\begin{array}{c}\mathscr{8} \\
\infty \\
\infty\end{array}$ & $\underset{\infty}{\pi}$ & $\stackrel{20}{=}$ & $\begin{array}{l}\text { N } \\
\text { ô }\end{array}$ & $\stackrel{0}{=}$ \\
\hline 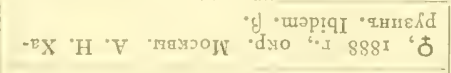 & $\stackrel{5}{\circ}$ & $\mathscr{m}^{\infty}$ & $\stackrel{\sim}{\sim}$ & 1 & $\underline{二}$ \\
\hline 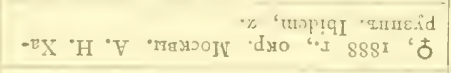 & 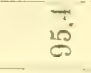 & ஜ & $\stackrel{\infty}{-1}$ & 1 & $\simeq$ \\
\hline 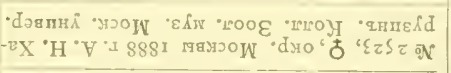 & E & 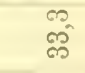 & $\underset{c}{\infty}$ & 1 & 上 \\
\hline 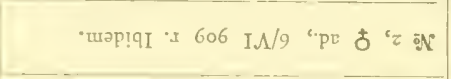 & $\begin{array}{l}10 \\
\mathscr{\rho}^{\circ}\end{array}$ & $\stackrel{\infty}{\infty}$ & $\stackrel{\infty}{a}$ & $\begin{array}{l}0 . \\
\text { oi } \\
\text { co }\end{array}$ & $\stackrel{0}{\stackrel{0}{N}}$ \\
\hline 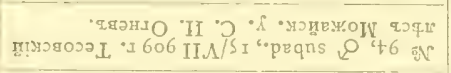 & \& & $\begin{array}{l}25 \\
205 \\
21\end{array}$ & $=$ & 1 & 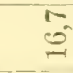 \\
\hline 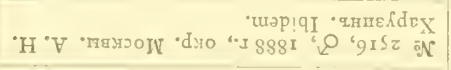 & 8 & $\stackrel{\infty}{\infty}$ & $\stackrel{\mathscr{N}}{\rightarrow}$ & 1 & 9 \\
\hline 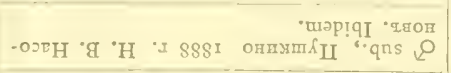 & $\infty$ & $\overrightarrow{\mathscr{R}_{3}}$ & $\stackrel{5}{9}$ & 1 & $\stackrel{10}{2}$ \\
\hline 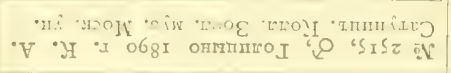 & $\begin{array}{l}0 \\
\stackrel{0}{0}\end{array}$ & ले & $\begin{array}{l}\text { of } \\
\text { si }\end{array}$ & $\begin{array}{l}0.0 \\
20 \\
20\end{array}$ & $\stackrel{\infty}{\sim}$ \\
\hline 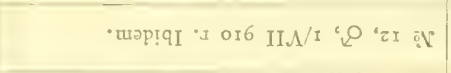 & 5 & बीं & $\stackrel{\because 1}{=}$ & $\begin{array}{l}\text { iे } \\
\text { ô }\end{array}$ & $\stackrel{\infty}{\infty}$ \\
\hline 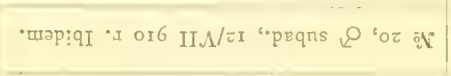 & $\begin{array}{c}\mathfrak{1}_{1} \\
\infty \\
\infty\end{array}$ & बे & $\stackrel{\circ}{2}$ & 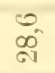 & $\stackrel{\oplus}{\infty}$ \\
\hline 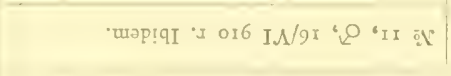 & $\widehat{c}$ & $\overbrace{i}^{\infty}$ & $\begin{array}{l}\text { a } \\
\text { and } \\
\text { a }\end{array}$ & ลิ & $=$ \\
\hline 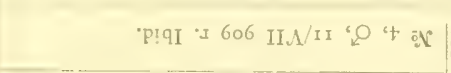 & है & $\overbrace{}^{10}$ & $=$ & $\frac{a}{m}$ & $\stackrel{\sim}{\tilde{\rho}}$ \\
\hline 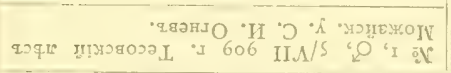 & $\begin{array}{l}\infty \\
\infty\end{array}$ & $\stackrel{a}{\rho}$ & $\stackrel{1}{20}$ & $\begin{array}{l}29 \\
12\end{array}$ & $\begin{array}{l}\sigma_{1}^{\prime} \\
\infty \\
\infty\end{array}$ \\
\hline 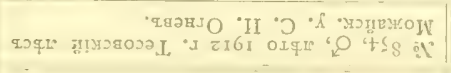 & 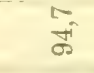 & $\overline{10}$ & $\overrightarrow{\mathrm{I}}$ & $\vec{\infty}$ & $\begin{array}{ll}10 \\
0^{\circ} \\
-1\end{array}$ \\
\hline 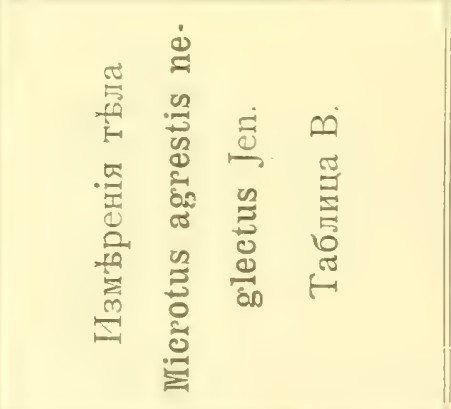 & 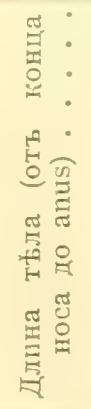 & 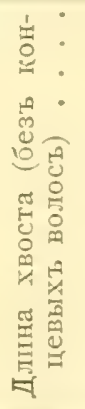 & 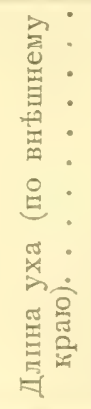 & $\begin{array}{l}\dot{ } \\
\dot{0} \\
\dot{ } \\
\dot{0} \\
:\end{array}$ & 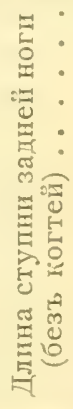 \\
\hline
\end{tabular}


крывающіе, коротки п равнольрны, а у крысоголовой полевки они длинны и неравномьрно расположены на хвость.

3) Окраска лапъ у M. a. neglectus Jen. обычно темнье, чьвм у $\boldsymbol{M}$. ratticeps Keys. et Blas.

4) Морда тупье и короче. Уши также болье коротки и скрыты

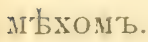

Въ заключеніе остается остановиться на разсмотрыніи таксономическаго значенія болье южнаго подвида темной полевки

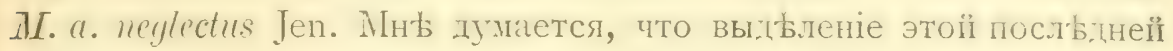
является вполнь раціональнымь и Millais врядъ ли правъ, относя ее въ синонимы $\lambda I$. ayrestis $L$. Просматривая пзмүренія тіпичной сћверної формы, ноторыя приводить въ своеї работь Barret-Hamilton $\left.{ }^{1}\right)$ (8, p. 6оo), можно видьть очень значительную разницу съ тьюи, которыя были получены при промtpt нашихъ экземпляровъ. Болье того, посльдніе даже нысколько менье тьхъ $М$. а. neglectus Jen., измьренія коихъ даетъ Barret-Hamilton въ своей работь ${ }^{2}$ ).

Что касается до геграфическаго распространенія темной полевки въ предылахъ Европеїской Россіи, то наши свыдынія объ этомъ страдаютъ какой-то исключительной скудостью.

Въ предьлахъ Московской губ. мною добыты только I5 экземпляровъ этого вида въ Тесовскомъ льсу близъ Можайска.

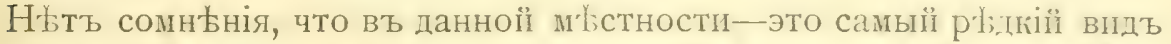
изъ встрџчающихся тамъ полевокъ. Вт коллекціи Зоолог. Муз. Москов. Унив, имьется экземплярь, добытый акад. Н. В. Н а с он о вы м в Ћ Пушиины Дмитровскаго у. К. А. С атунин ъ пишеть объ этомъ видь сльдующее ( 65 , стр. І2): „По моимъ наблюденіямь, это самая płдкая полевка въ губерніп. Я поймаль только нысколько экземпляровъ въ Голицынь, въ льссу, около небольшого, густо обросшаго ивнякомъ прудка. Одна полевка этого вида доставлена Г. А. К ж жевни ко вы м изъ Измайловскаго Звжринца. Въ г892 году я нашель мьсто, гд' эта полевка водится въ значительномъ количеств остатокъ прежней плотины, на лугу въ Изайловсконъ Звћрннцј".

Если свьд屯нія о распространеніи М. а. neglectus Jen. въ Moсковской губ́. страдають извьстної отрывочностыю, то литературныя данныя о нахожденіи этого вида въ другихъ губерніяхъ

1) Длина ть́⿻二丨凵 101-160; хвоста: 25-40; ступни: 17-20.

2) Я не рбшаюсь сколько-ниоудь опредъленно высказаться по этому поводу. Быть-можеть, большій матеріаль заставить выдълить п средне-русскую темную полевку въ отдьльную форму. 
прямо поражають своей исключительной скудостью. Темная полевка была добыта Блазіусомъ на Съв. Двинж. Въ Западномъ кра木 она найдена за посльднее время д-ромъ Миддендорфом и и. Греве́ въ Лифляндіи. По Васмуту она врядъ ли встрђчается въ Эстляндіи.

Что касается до распространенія типичной $M$. agrestis L., то эта форма встрђчается, по Selys Longchamps и BarretHamilton, въ Швеціи, Норвегіи, Финляндіи и Даніи. Вьроятно, къ этої формҰ относятся экземпляры, найденные П ле ске ( 33 , стр. 39) в' южной Финляндіи до Лапландской границы, а также около Варангеръ-Фіорда и въ русской Лапландіи. Съ друтой стороны, M. a. neglectus Jen. встрбчается, по В arret-H amilton, въ Шотландіи и Великобританіи, Бельгіи, во Франціи ${ }^{1}$ ) (къ сьверу отъ Сены) и, в броятно, въ Пиренеяхъ. По Фатіо она водится въ ШІвейцаріи. За посльднее время Т ом асомъ (Ann. Mag. Nat. Hist. Igrı, р. 759) была описана новая форма M. agrestis mongol Thom. изъ Танну-Ола (С'sер.-Западн. Монголія).

Образо жизии. Насколько я могъ рџшить, темная полевка придерживается главнымъ образомъ льса, гды чаще всего встрђчается въ мұстахъ сырыхъ и тьнистыхъ, около поросшихъ канавъ, часто невдалекь отъ воды. Въ большинств такихь мьстахь держатся и Nicrotus ratticeps Keys. et Blas., In Neomys fodiens L., съ которыми описываемый видъ часто попадался мн古 въ одной и той же ловушк. Беременныхъ самокъ я встр⿱⿱亠䒑十чаль въ началf іюня (6. VI. 909 г.). Количество зародышей обычно равно семи. Гнғздъ этого вида мны находить не случалось, но, в Һроятно, они строятся подъ землею, такъ какъ К. А. С атунинъ наблюдалъ темныхъ полевокъ, таскавшихъ въ нору тонкіе листки полевыхъ злаковъ, в ьроятно, для устройства своихъ гнњздъ.

Экземиляри коллекии перечислены въ таблицб измћреній на стр. 176 .

1) По словамъ Трусс ара (200), р. 175, во Франціи, к’ сыверу отъ Сены водится типчная $\boldsymbol{M}$. agrestis L., подобно тому, какъ въ Бельгіп ил Альпахь. Эти свъдънія стоятъ въ полномъ противорьчін съ данными $\mathrm{Sely}$ L ong champs in B a r e t-H a mil t o n пи нуждаются поэтому въ провђркь. 


\section{Microtus arvalis Pall.}

\section{Полевка обыкновенная.}

Mus arvalis Pallas (132), p. 78 Arvicola arvalis Pall. B I a i i s (27), p. 379. Microtus arvalis (Pall.) T r o u essart $(200)$, p. 173. К. A. С а т у н п н т, (165) стр. 12 (1 66 ), р. 2.

\section{Систематическія особенности.}

Въ строеніи черепа обыкновенной полевки не замьчается ка. кихъ-либо отклоненій отъ того общаго описанія его структуры, которое было дано при характеристик' рода Microtus. Что касается до возрастныхъ измьненій черепа $M$. arvalis Pall., то они крайне значптельны (табл. I, рис. 24-29). Черепь молодої полевки, еще не достигшеї половины взрослой особи, характерпзуется весьма высокой затылочной областью. Далье, разстояніе отъ задняго края глазницы до затылочнаго грая черепа у молодого эгземпляра гораздо больие, чьмъ отъ перваго пункта до конца носовыхъ костей. Однако, у полевокъ, уже достигшихъ половины роста старыхъ, эти соотношенія р'ззко мыняются, и начпнается замьтное удлиненіе передней части черепа, т.-е., главнымъ образомъ, челюстныхъ и носовыхъ костей. При этомъ посльднія не только удлиняются, но мъняется также пхъ общая конфигурація: у молодыхъ $M I$. arvalis Pall. оны очень широки, рызкой разницы въ ширинь ихъ задней частп и передней, ограничивающей сверху носовое отверстіе, совершенно не замьчается. Иную картину видимъ мы у старыхъ особей: здьсь появляется очень замытная перетяжка въ задней части mыsali, которыя спереди пріобрбтаютъ лопатообразно расширенную форму. Въ затылочної области черепа рьзко мьняется форма os interparitale. I’ молодыхъ Іliciotus arvalis Pall. описываемая кость значительно вытянута въ бока и ея соотношенія съ прочими костямп черепа совершенно иныя. Съ возрастомъ, всльдствіе развитія теменныхъ костеї, o.s interpariptule кажется меньше, бока этой кости, у молодой полевки идущія параллельно другъ другу, какъ у $\boldsymbol{M}$. agrestrs neglectus Jen., съ возрастомъ начинают” сходиться тупыми углами, а передняя часть болье заостряется. Далье можно отм'тить, что bullae osseae старыхъ полевокъ болье вытянуты и уплощены съ боковъ, форма скуловыхъ гугъ тоже совершенно иная, чьм у молодыхъ. Нтакъ, мы видимъ, что черепъ M. arvalis Pall. претерпьваетъ съ возрастомъ очень большія шзмтненія. Однако, очень характернымъ является тотъ фактъ, что уже у очень молодыхъ полевокъ ширина межглазничнаго пространства мало чъмь отличается отъ 
такової у старыхъ особей. Этоть интересный фактъ еще разъ попчерғизать естественность, остроумнаго раздь.ленія проф. Н. $\Theta$. К а щенко нашихъ Microtus на роды узкочерепныхъ (Stenocranius) и собственно Microtus, съ характерної особенностью: шириної межглазничной области.

Въ заключеніе привожу измьренія череповъ разныхъ возрастовъ M. arvalis Pall. (См. табл. на стр. І8I).

Я не буду здьсь подробно останавливаться на варіаціяхъ въ строеніи эмалевыхъ петель зубовъ, такъ какъ этотъ вопросъ очень основательно разработали Rörig и Börner ( I 46, taf. V). Tt пзмненія въ строеніи зубной системы, которыя были замtчены мною, могуть быть сведены къ немногимъ типамъ. Наименьшей сложности достигаетъ строеніе зубовъ у той формы обычної полевкп, у коеї заньчается полное недоразвптіе четвертаго внутренняго зубца на посльднемъ коренномь зубь верхнеї челюсти. Подоб́ные экземпляры встрћчаются сравнительно ptzко и напоминаютъ по строенію зубовъ Stenocranins raddei Pol. R ӧrig и Börner выдьляютъ ихъ, какъ „forma simplex". Наиболье распространенної можеть быть названа "forma principatis" Rör. et Börn. У этої „формы“ можно видьть на заднемъ коренномъ зубь верхней челюсти ясно дифференцированными четыре внутреннихъ зубца и три внышнихъ. Что касается до длины посль.днеї петли описываемаго зуба, то здысь мы встрьчаемъ различныя колебанія: она варьируетъ отъ короткаго тупого выступа до формы длиннаго подковообразнаго загиба. Въ рtдкихь случаяхь встрtчается такъ наз. "forma duplıcata" Rör. et Börn., у которої наблюдается болье или менье рызко замьтное развитіе четвертаго внышняго зубца на посльднемь зубы верхнеї челюсти, что приближаетъ эту форму къ еше загадочної Microtus compestis Blas. Наконецъ, интересно отмћтить еце одно отклоненіе отъ нормальнаго строенія зубовъ, которое можетъ сиптаться довольно распространеннымъ у обычной полевки, именно: замьчается развитіе пятаго зубца на второмь коренномъ зубы верхней челюсти,-признакъ, гакъ мы уже видыли, характерный для Ilicrotus agrestis neylectus Jen. Однако, мны никогда не случалось наблюдать, чтобы этоть зубецъ достигалъ столь замьтнаго развитія у обычной полевки, какъ это наблюдается у $M$. agrestis neglectus Jen.

Возрастныя измьненія окраски Microtus arvalis Pall. могутъ быть вкратць представлены такимъ образомъ.-Совсьмъ молодыя полевки, не достигшія половины роста старыхъ и не выходяпія еще изъ гнбзда, отличаются очень свьтлымъ палево-сьрымь - мkхомь, рьзко отграниченнымъ отъ бьловатыхъ волосъ нижней 


\begin{tabular}{|c|c|c|c|c|c|c|c|c|}
\hline 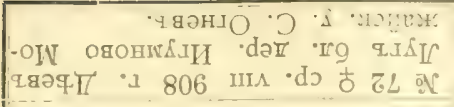 & $\frac{a}{N}$ & $\frac{\pi}{n-1}$ & ח़ी & 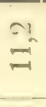 & 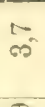 & $\stackrel{\text { at }}{ \pm}$ & in & $\overrightarrow{\forall i}$ \\
\hline 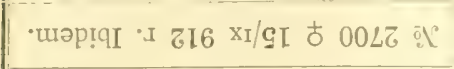 & $\frac{2}{9}$ & $\stackrel{\infty}{\infty}$ & $\overrightarrow{61}$ & $\overline{7}$ & के & ai & 10 & 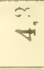 \\
\hline 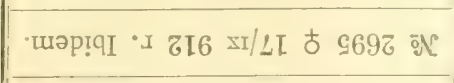 & $\hat{\infty}$ & $\stackrel{01}{2}$ & $\vec{a}$ & $\Rightarrow$ & Es & ㅁำ & $\underbrace{}_{20}$ & $\stackrel{6}{60}$ \\
\hline 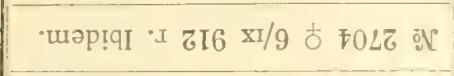 & 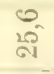 & in & $\frac{\text { â }}{20}$ & $\stackrel{N}{\sim}$ & $\infty$ & च & 10 & 4 \\
\hline -üp!qI I zI6 IIs/97\& 6697 이 & $\frac{\pi}{a-}$ & $\stackrel{3}{2}$ & $\frac{a 1}{61}$ & $\cong$ & $\infty^{x}$ & 1 & 109 & के \\
\hline 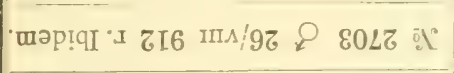 & $\frac{\overline{a r}}{2}$ & 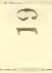 & 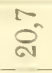 & $\stackrel{5}{5}$ & का & $\bar{a}$ & $=5$ & $\overbrace{}^{\infty}$ \\
\hline 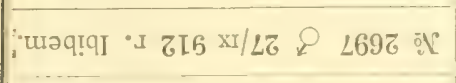 & खิ & $\infty_{-\infty}^{\infty}$ & an & $\stackrel{\infty}{=}$ & $\infty$ & $\stackrel{\infty}{\infty}$ & 125 & 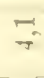 \\
\hline 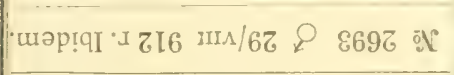 & ผ & กิ & ๙n & $=$ & लs & $\stackrel{2}{-2}$ & 10 & $\overline{7}$ \\
\hline 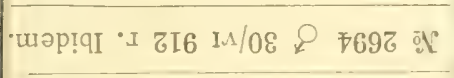 & ๓) & กิ & ลิं & $\Xi$ & $\stackrel{\infty}{\infty}$ & $\stackrel{\infty}{\infty}$ & 25 & es \\
\hline 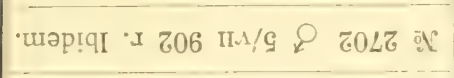 & $\stackrel{\infty}{a}$ & $\stackrel{1}{0}$ & $\frac{2 \pi}{61}$ & $\stackrel{\infty}{\infty}$ & 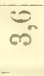 & 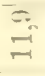 & 25 & 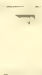 \\
\hline 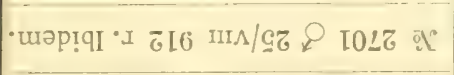 & $\overline{G i}$ & $\stackrel{s}{\infty}$ & की & $\stackrel{20}{=}$ & $\infty$ & 1 & 20 & $T$ \\
\hline 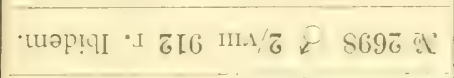 & $\stackrel{0}{\circ}$ & $\stackrel{\infty}{\tilde{N}}$ & $\frac{\infty}{\infty 1}$ & $\stackrel{\Xi}{\varrho}$ & $\underset{-\infty}{\infty}$ & $\begin{array}{l}\infty \\
-1 \\
-1\end{array}$ & $\stackrel{2}{2}$ & $\because$ \\
\hline 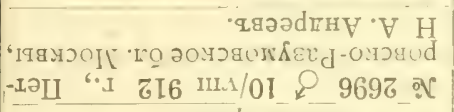 & $\stackrel{\infty}{a j}$ & $\stackrel{\infty}{\infty}$ & $\frac{62}{61}$ & $\stackrel{\varrho}{\varrho}$ & 20 & al & 20 & $\stackrel{\sim}{\rightarrow}$ \\
\hline 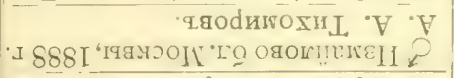 & ลี & ฒิ & $\infty_{\substack{1 \\
\text { की }}}^{\infty}$ & $\underline{z}$ & $\stackrel{\infty}{\infty}$ & $\vec{I}$ & 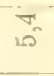 & $\operatorname{lig}$ \\
\hline 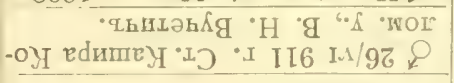 & $\infty_{01}^{0}$ & in & On & $\stackrel{0}{\because}$ & $\forall$ & 10 & $\underset{0}{\sigma-1}$ & 1 \\
\hline 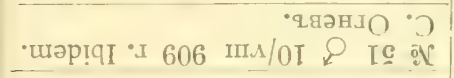 & న్ & की & $\hat{a}$ & $\stackrel{\infty}{=}$ & $\therefore$ & $\stackrel{\infty}{-1}$ & $\infty$ & $\underset{0}{0}$ \\
\hline 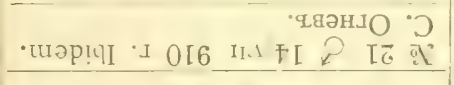 & $\frac{\infty}{\infty 1}$ & $\stackrel{\infty}{\infty}$ & $\stackrel{\infty}{\infty}$ & $\stackrel{\infty}{0}$ & $\infty$ & $\stackrel{\sim}{\sim}$ & $\begin{array}{l}\infty \\
10^{-}\end{array}$ & 1 \\
\hline 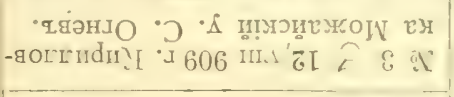 & Hू & $\underset{\mathfrak{s}}{5}$ & $\frac{m_{n}}{a 1}$ & $\stackrel{\infty}{=}$ & $\infty^{\infty}$ & $\stackrel{1.0}{r}$ & అ & $\stackrel{N}{\forall}$ \\
\hline 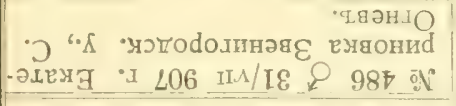 & 气ू. & 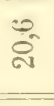 & ๙ิ- & $\stackrel{0}{0}$ & Es: & $\vec{\infty}$ & $=$ & $\stackrel{\infty}{\infty}$ \\
\hline 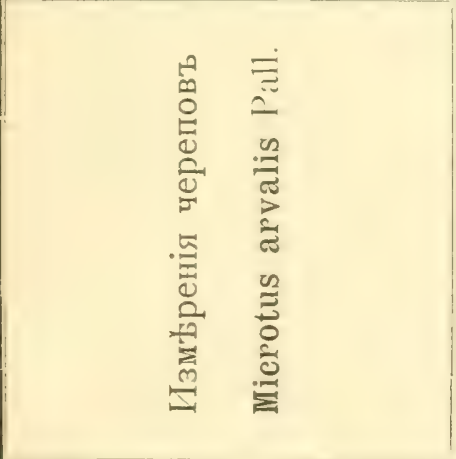 & 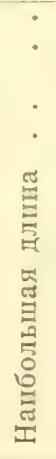 & 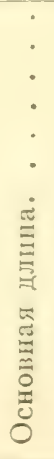 & 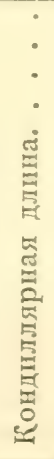 & 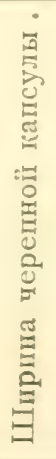 & 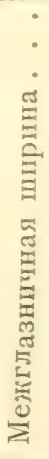 & 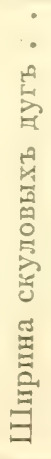 & 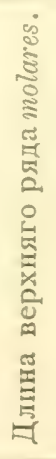 & 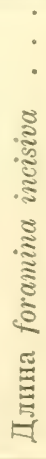 \\
\hline
\end{tabular}


стороны. Въ области между глазъ и въ передней части морды примғшиватся черноватые волосы, готорые также хорошо замытны на верхнеї части хвоста и спинной сторонь лапъ. Нижняя сторона хвоста покрыта короткими бьловатыми волосами; подошвы ногъ съровато-бблыя; концы ушей сьроваты и покрыты короткими черноватыми волосами, основаніе уха-желтовато-бьлое. Словомъ, общій тонъ окраски молодой полевки значительно свытлье, чьмъ у старой. Экземпляры, достигшіе половины взрослой особи, значительно темные. Основанія волосъ спины становятся темно-сђрыми, но окончанія ихъ гораздо свђтлье, съ замытнымь палевымъ оттьинкомъ, который сохраняется и у ныпоторых з старыхь особей ( varietas“ /uté Kastsch.). Лапы полевокъ описываемаго возраста становятся темнье всльдлствіс все б́ольей примьси черноватыхъ волосъ, хвостъ дьлается почти одноцвьтнымъ. Окраска взрослой полевки значительно темнъе и сьрье.Передняя часть носа, верхняя сторона головы и спина буроватоcҺраго цвьта. Основанія волосъ этой области темно-сьры, концы ихъ болье свьтлаго сьраго цвьта, съ очень легкимъ желтоватымъ оттбнкомъ. Около половины всыхъ волосъ спины совершенно чернаго цвьта, что въ комбинаціи съ свђтло-сьро-желтоватыми олончаніями другой части волосъ придаетъ окраскь спины общій буровато-сърый тонъ. Бока значительно свьтлье спины, здћсь количество черныхъ волосъ значительно убываетъ. Вся брюшная сторона тьла, подбородокъ и нижняя часть щекъ, покрыты длинными волосами, у основанія темно-сђрыми, съ свђтлыми бъловатыми окончаніями. Ступни ногъ отличаются сьровато-бьлыми волосами; то болье свьтлыми, то болье темными. Хвость слабо двуцвђтный: сверху сърый, снизу болье бълесаго тона.

Оть этой типичной формы замьчаются значительныя отклоненія. Въ коллекціп Зоологическаго Музея Московскаго университета имыются два экземпляра очень свћтлой окраски. Одинъ добыть А. А. Тихомировым ъ въ Измайловскомъ Звъринць (близъ Москвы), другой-въ Рузскомъ у. Н. Ю. З о графомъ и С. А. 3 ерн о вым ъ. Мъхъ этихъ полевокъ желтовато-палевоcłрый, хвость, уши и лапы ржаво-бю́ловаты. Одинъ экземплярь моей толлекціи (o I5), добытой льтомъ Igog г. на заливномъ лугу Москвы-рћки, близъ Тесовскаго льса Можайскаго у., представляеть несомньнный интересъ по своей окраск先. Основанія волосъ спины этой полевки темно-сьраго цвьта, а концы свђтлопалево-желтые. Среди такихь свђтлыхь волось встрђчаются совершенно черные, придающіе общему цвьту мъха болье сьро- 
ватый тонъ. Окраска особенно свћтла и желтовато-палевый оттьнокъ замьтенъ въ области между глазъ и передней части морды. Интересно отмытить, что на лбу ясно замьтно пятно изъ б́ғлыхъ волосъ. Лапы очень свьтлаго сьраго цвьта съ легкимь буроватымъ оттьнкомъ; уши сьрыя, покрытыя довольно свьтлыми палевыми волосами. По общему виду эта полевка очень напоминаетъ Microtus sociatis Pall., ${ }^{1}$ ) оть коей отличается болье длиннымъ хвостомъ. Однако, хвостъ этого экзелпляра относительно ліроче, чћмь у вполнь типичныхъ M. arvatis Pall.

Въ заключеніе даю сводную таблицу измьреній самцовъ и самокъ обыкновенної полевіи, составленную на основаніи всего имьющагося въ моемъ распоряженіи матеріала ${ }^{2}$ ).

\begin{tabular}{|c|c|c|c|c|c|}
\hline & $\begin{array}{c}\text { Измьренія } \\
\text { Microtus apvalis Pall. }\end{array}$ & 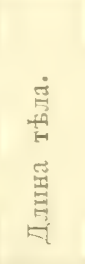 & 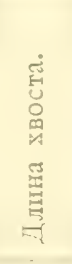 & 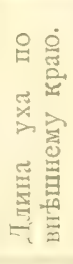 & 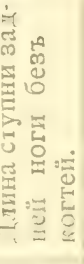 \\
\hline & $\sigma^{\pi}$ & & & & \\
\hline Maximum & $\ldots \ldots \ldots \ldots \ldots$ & 120 & 44,5 & 14 & 17,9 \\
\hline Minimum & $\ldots \ldots \ldots \ldots$ & 75.4 & 30,3 & 11 & 15 \\
\hline & 우우 & & & & \\
\hline Maximum & $\ldots \ldots \ldots \ldots$ & 102,7 & 40,2 & 11 & 16,8 \\
\hline Minimum & $\ldots \ldots \ldots \ldots$ & 80 & 27,2 & 9 & 14,5 \\
\hline
\end{tabular}

Интересно отмғтить, что у описываемой полевки самшы, повидимому, крупнће самокъ, тогда папъ у Erotomys ylacolus Schrcb. мы видыли обратное явленіе.

Оканчивая систематическій очеркъ Microtus arvatis Pall., мнt хотьлось въ заключеніе затронуть вопросъ о систематическомъ положеніи средне-русскихъ обыкновенныхъ полевокъ, и, въ

1) Microtus socialis Pall., помимо своего короткаго хвоста пі цвŁта миха, легко отличается отъ тишчныхъ $M I$. arvalis Pall. присутствіемъ только 5 бородавокъ на ступнъ задних ногъ. Кромь того существуютъ очень постоянныя краніологическія отличія.

2) Въ эту таблицу включены только взрослие экзеиияяри, т. к. введеніе въ нее молодыхъ, еще очень мелких особеіг, дало бы неясную картину. 
частности, водящихся въ Московской туберніи. Уже прежніе пзсльдователи какъ, напримьрь, J. Blasius, отмьтили тоть ()апть, что восточно-европейскіе представители $M$. arvalss $\mathrm{Pall.}$ окрашены темнъе западныхъ. Blasius на 38г стр. своей „Fauna d.r Wirbelthiere Deutschlands“ говорить по этому поводу cirb.дующеe: „Die Feldmäuse im östlichen Europa sind häufig durch etwas dunklere, mehr schwärzlichgraue Oberseite und einen undeutlich zwifarbig(n Schwanz ausgezeichnet". Подобные темноокрашенные экземпляры изъ окрестностей Кёнигсберга De Selys отмьтиль подъ особымъ названіемъ „Arvicola arenicola De Sel. ') Б. М. ЖК и тковъ въ своей работь о симбирскихъ млекопитающихъ (7 I, p. 19), просматривая большія серіи $M$.arvalis Pall., отмьтилъ тотъ факть, что межу ним преобладали болье сьрые и темные представители сравнительно съ рыжеватыми западными полевками этого вида. Далье, по его словамъ, заиьчается постоянное отличіе въ формь и строеніи посльдняго коренного зуба верхней челюсти, посльдняя эмалевая петля котораго у нашихъ полевокъ болье удлиннена по сравненію съ западными. „Среди сотенъ просмотрьнныхъ мною обыкновенныхъ полевокъ такъ окрашенныхъ “, пишетъ Ђ. М. ЖК и т к о в ь, „я нашель лишь два экземпляра, замьтно отличавшихся оть посльднихъ и приближавшихся по цвьту къ описанію, которое даеть Бл а з і с с для западно-европейскихъ формъ “.

За посльднее время въ моихъ рукахъ собрался огромный ма-

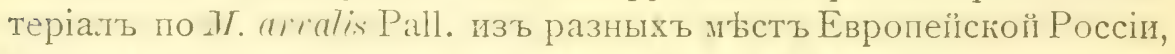
благодаря просмотру котораго я могъ болье пли менће обоснованно и критически отнестись къ различнымъ признакамъ обычной полевки. Ть результаты, къ которымъ я пришелъ, стараясь проc.тьдлть, насколько диференцированы указанныя выше отличія (въ географическомъ смысль), --носять на себь отрицательный характеръ. Дьло въ томъ, что рыжая форма $M$. arvalis Pall. встрьчается въ общемъ много чаще, чьмъ можно было бы судить по работь Б. М. Жі и това, а, главное, въ ея распространеніи не сказывается ґакої-либо пріуроченности къ западному району обитанія темної $M$. arvalis Pall. Такъ, я находиль рыжеокрашенныхъ представителеӥ въ Московскої губ., видњ.ль экземпяры изъ Гверскої губ. (Новотарусскій у.), Пермской (отъ Ө. А. Т е п л о у о в а), изъ окрестностей Екатеринбурга (оть О. Е. К л ёра). Наконецъ, въ окрестностяхъ Симферополя, какъ показаль просиотръ большой серіи этпхъ полевокъ, присланныхъ мнь для опредыленія Симферопольским Музеемь, даже преобладаеть ры-

1) Revue Zool., 1847. 
жій типь окраски. Не лучше обстоить дьло и съ отличіемъ въ строеніи посльдняго ґоренного зуба верхнеї челюсти. Выше я уже указаль, что строеніе и форма его посльдней петли крайне варьируетъ даже у московскихъ экземпляровъ. Резюмируя сказанное, я прихожу къ тому выводу, что въ настояшее время выдьленіе восточной формы $\boldsymbol{M}$. arvatis Pall. врядъ-ли возможно.

Въ заключеніе мн' хотьлось остановиться на разсмотрыніи еще загадочної формы полевки, описанної впервые Блазіуc о ъ-Nicrotus campestris Blas. Эта полевка отличается, по Блазі у су, отъ типичної 1 . arvalis Pall. ясно двуцвђтнымъ мьхомъ, сверху буроватымь, снизу свђтло-сьрымъ и почти былымь на нижней сторонь брюшной поверхности. Кром шняго отличія, Блаз іусъ отмьчаеть еще характерное строеніе посльдняго коренного зуба верхней челюсти, на вньшней сторонь котораго замьчаются четыре зубца. Что представляетъ собою Microtus campestris Blas.-сказать вполнь опредьленно еще трудно. Относительно ея таксономическаго значенія могтть и́ыть дв Б гипотезы. Во-первыхь, ее можно разсматривать, какъ древнюю форму, прежте широко распространенную, но теперь ставшую очень рьдкої. В Бдь, и среди птицъ мы имьемъ примьры подоб̆ныхъ спорадично распространенныхъ видовъ, какъ, напрпuьръ, Poecule atricapillus bianchii Sarudny et Härms, Gecmus squamatus flavirostris Menzb. и др. Однако, этой гипотезь можно сдылать въское возраженіе. Дьло въ томь, что древнія и ставшія p b.дими формы характеризуются об́чно узостью своего современнаго географическаго распространенія, что же жасается $\boldsymbol{I I}$. campestris Blas., то она встрьчается, повидимому, всюду параллельно съ $M$. arvalis Pall., но значительно рьже посльдней.

Мнь предствляется поэтому наиболье вьроятнымъ, что надо прпзнать 1 . camprstis Blas. лишь пндивидуальнымь красочнымъ уклоненіемъ обычногі полевки. Этоть взглядъ обстоятельно развить Б. М. М纤 ко вым ъ $(75$, р. 274-275), проводяшимъ параллель между описываемыми полевками и между Epimys rattus L. и Epimys alexandrims Geoffr. За то, что M. campestris Blas. не представ.леть самостоятельнаго впда, говорить присутствіе многочисленныхъ переходныхъ формъ къ ней отъ обычної полевкі. Въ особ́енности часты эті переходы въ смысль строенія посльдняго коренного зуба верхней челюсти. Подоб́ные экземп.яры пзъ Московской губ́. были ошио́очно причислены къ . pestris Blas. A. А. Тихомировымъ и А. Н. Кор qагиным ъ. Конечно, можно считать M. campestris Blas. за отдьльный видъ, хотя посль сказаннаго выше это представляется довольно сомни- 
тельнымъ, но для меня совершенно непонятны причины, по которымъ Т руссаръ настойчиво относить эту полевку къ подвидамь $\boldsymbol{M}$. agrestis L.; съ посльдней $M$. campestris Blas. не имъетъ рłшительно никакого сходства. Просматривая два экземпляра II. compestiv Blas,, добытые Б. М. ЖК ит ковымъ въ Симбирскої губ. (со сльд. отмьтками: I) апрьль т894 г. Ардатовскій у. (р. Алатырь), 2) ㅇ subad. марть I894 г. Ардат. у., я прихожу къ заключенію, что по строенію черепа $M$. campestris Blas. совершенно не отличается отъ $\boldsymbol{M}$. arvalis Pall., но очень рьзко оть $M$. agrestis neglectus Jen. Такъ, напримьръ, крайне характерный признакъ отличія $M$. agrestis neglectus Jen. отъ близкихъ къ ней формъ-

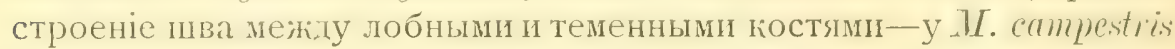
Blas. рьзко отличается отъ такового у темной полевки и совершенно аналогично со строеніемъ его у $\boldsymbol{M}$. arvalis Pall.

\section{Географическое распространеніе.}

Обыкновенная полевка съ полнымъ правомъ можеть считаться однимъ изъ самыхъ распространенныхъ мелкихъ млекопитающихь по всей Московской губ. Я находилъ ее въ очень большомъ количеств' въ Московскомъ у., Звенигородскомъ (село Аносино, д. Спасское, Екатериновка), Можайскомъ (дер. Митыково, Игумново, Дьевъ лугъ въ пойм' р. Москвы, дер. Зачатье, с. Тесово и др.), Рузскомъ у., Клинскомъ (окр. с. Демьянова и г. Клина), Богородскомъ (окр. с. Саввина, оть Г. И. Полякова), Коломенскомъ (бл. Каширы отъ В. Н. Вучетича). Что касается до распространенія этого вида въ центральныхъ губерніяхъ Европейской Россіи, то, по моимъ наблюденіямъ, онъ очень обыкновененъ въ Гжатскомъ и Сычевскомъ уу. Смоленской губ. изъ Ельнинскаго у. которой я имью также экземпляры отъ М. И. Погоди на. Далье, Microtus arvalis Pall. найдена мною въ Малоярославецкомъ у. Калужской губ. и очень обычна въ ю.-в. части Орловской губ. По литературнымъ даннымъ мы знаемъ о ней сльдующее. - По словамъ Э сау лова (58, р. 226) она очень обыкновенна въ Холмскомъ и Торопецкомъ уу. Псковской губ., отмьчена для Ярославской губ. Л. П. Сабан в евым ъ ( 5 о, р. 49I). Въ коллекціи Зоологическаго Музея Моск. у. имьются ньсколько эйземпляровъ отъ А. И. П е трун к е и ч а изъ Новоторжскаго у. Тверской губ. Двигаясь далье на сьверъ, мы встрьчаемъ ее въ Петербургской губ., гдњ она найдена Брандтом ъ (34, р. 37), Порчинским (г 37 , стр. 388), Біанки (23, стр. II4), К ащ енко, (84, стр. І74-I75). Въ Пермской губ. эта полевка добыта $\Theta$. А. Т епл оуховым и Б. М. ЖК и тковы мъ 
(бл. Перми) и около села Ильинскаго Пермск. у. А. А. Тих ом и ро вы м ъ ( 97 , стр. 27). Южные встрьчается въ окрестностяхъ Екатеринбурга (экземпляры въ коллекци Зоол. Муз. Моск. у оть О.Е.Клера); по Сабан веву (г 49, стр. 6 и. г 4 8, р. 2І2) найдена на Ураль въ Богословскомъ округь. По Брандту (34, p. 37) водится въ Оренбургской губ. Во многихъ мъстностяхъ посльдней этотъ видъ полевки очень обыкновененъ, по словамъ H. А. 3 ар удн аго (7 7, стр. 345). Онь нашель ее также на Общемъ Сырть, въ южныхъ предгоріяхъ У рала, въ сњверныхъ Мугоджарахь и на югъ до верхнихъ теченій Уила, Кіила и Темира. По свидьтельству М. Н. Богданова, очень обыкновенна въ Казанской, Симбирской и Саратовской губ. (3о, стр. І73). Для Симбирской губ. въ качествь очень обычнаго вида указана и Б. М. Жи тковымъ (7 I, стр. І9), а для Балашовскаго у. Саратовской губ.-А. А. С и л ан ть е в ы м з ( 8 І, стр. 298). За посльднее время очень много экземпляровъ было доставлено мнб изъ Кузнецкаго у. Саратовской губ. Н. Ф. Иконниковы ъ. Въ Белебеевскомъ у. Уфимской губ. добыта В. К о обовы м ъ (экз. въ колл. Зоол. Муз. Моск. Ун.). Западнье, по словамь К. А. Сатунина, встрьчается въ Волжско-Донской степи (г57, стр. 249). Найдена Н. Н. С о м о в м ъ въ Харьковской губ. и Г.А. К ж жевниковы ъ около Батурина Черниговской губ. (экз. въ колл. Зоол. Муз. Моск. Ун.). По К е с сл е р у $(86$, стр. 7 I) очень обыкновенна въ Кіевской губ., гдь найдена“ также и B elke. Нордманнъ отмьчаетъ ее для Бессарабіи, а особенно для окрестностей г. Одессы. Веlke указываетъ ее для КаменецъПодольска (г 7, р. 4г8). По моимъ изсльддованіямъ, очень обыкновенна въ окр. Симферополя (на основ. коллекци Симф. Музея), то же говорить и А. М. Никольскій. К. Ө. Кесслерь часто наблюдалъ этотъ видъ по Салгиру, а близъ Өеодосіи найдена В. С. Муралевичемъ (экз. въ колл. Зоол. Муз. Моск. Ун.).

Въ Прибалтійскомъ краь $M$. arvalis Pall. довольно обыкновенна, по словамъ Г реве́ (67, р. г23). Наконецъ, проф). К ащ ен о $(84$, стр. I74-г75) упоминаеть объ экземплярахъ отъ г. Бихнера изъ Финляндіи. По Сатунину (т62, стр. 59), встрьчается на возвышенностяхь большого и малаго Кавказа. Что касается до распространенія этого вида за Уральскимъ хребтомъ и въ Сибири, то наши свьдынія сводятся къ сльдующему. - По Сло в о в у ( 183 , стр. 22), одинъ экземпляръ доставленъ изъ Тавдинскаго края; въ южн. частяхъ Тюменскаго окр. онъ не найденъ. Въ сьверной части Тобольской губ., въ 
полось тундрь $M$. arvals Pall. отмичена Финшемъ. По Г ео рги, встрьчается по всей Европ. Россіи, оть Дньпра и Чернаго моря вплоть до Каспійскаго и р. Оби. Палласъ ( $3_{2}$, p. 78) говорить о распространеніи этой полевки по Иртышу и Оби (бл. Березова). По словамъ проф. Каще н ко, встрьчается въ Томскомъ краћ повсемьстно (82, стр. 46), тоть же авторъ нашель $M$. arvalis Pall. на Алтаь (8 I, стр. 50). П. П. С ушкиным ъ было послано мнъ для опредьленія ньсколько экземпляровъ, добытыхъ на южныхъ склонахъ Тарбагатая у перевала Сай-асу въ I904 году. Г. И. По ля ковы м ъ найденъ одинъ экземплярь бл. южн. угла озера Норъ-Зайсанъ, около КараСуата (колл. Зоол. Муз. Моск. Ун.). Р адде и Вальтеромъ добыть одинъ экземплярь въ Закаспійскої области ( 14 , р. тодо). Наконецъ, М ил л е р ъ въ горахъ Тянь-Шаня, Музарта и Капкана встрьтиль $\boldsymbol{M}$. avvalis Pall., или форму къ ней очень близкую ( I I 4, p. 372). O ld f. Th o m a s (Ann. Magaz. Nat. Hist. I9I I, p. 398) прямо относитъ къ этому виду полевокъ, собранныхъ D. C a rruthers въ Тянь-Шань. Т руссаръ отмьчаеть общее распространеніе этого вида, говоря, что онъ встрђчается въ Сибири, до ръки Оби, въ Туркестань, Киргизскихъ степяхъ и далье къ югу-въ Малой Азіи и Палестинь.

Въ Западной Европь обыкновенная полевка распространена оть побережья Атлантическаго океана до равнинъ сьверной Германіи и на югъ черезъ среднюю Францію до Ломбардіи, Далмаціи и Турціи. Въ Ирландіи, Исландіи, на Корсикь, Сардиніи и Сициліи этоть видъ не встрбчается ${ }^{1}$ ).

\section{Образъ жизни.}

Насколько я могъ замьтить, любимыми мьстами пребыванія обычной полевки являются большіе луга, расположенные въ рьчныхъ долинахъ. Въ такихъ мьстахъ, особенно если поблизости находится болото съ рьдкими кустарниками и сырыми кочками, держится очень много Microtus arvalis Pall., образуя часто большія колоніи. Интересно отмьтить, что иногда туть же, y camoï воды, колоніями придерживается и Licrotus ratticeps Keys. et Blas., такъ что эти виды живуть въ самомъ близкомъ сосьдств д другь возль друга. Мны приходилось встрьчать описываемую полевку и на суходолахъ, на льсныхъ полянахъ и опушкахъ, а иногда въ большомъ количествь и среди пахотныхъ полей, но,

1) У подножія Пиренеевъ (Біарритцъ) водится, по М ил л е р у, особая форма: Microtus arvalis meridianus Miller (cм. An. Mag, Nat. Hist., 1908. I, p. 197)• 
повторяю, излюбленной станціей ея являются рьчные луга. Большія колоніи, которыя тамь встрьчаются, не придерживаются съ неизньннымъ постоянствомъ одного и того же мбста, ньтьъ никакого сомньнія въ томъ, что эти полевки совершаютъ иногда довольно значительныя перекочевки. 'Гакь, въ концћ льта часть ихъ регулярно перебирается къ жилымъ постройкамъ-въ усадьбы и деревни. Microtus arvalis Pall. мечеть отъ 3-6 разъ въ годъ и преимущественно оть 4-8 дытенышей. Свои гньзда она устраиваетъ обычно подъ землею, иногда у самой ея поверхности, иногда на глубинь 1/2 аршина. На лугахъ, гды мнь случалось находить особенно много гныздъ, посльднія располагались въ центрь высокихъ мшистыхъ кочекъ. Самая гньздовая постройка представляла изъ себя шаръ, сложенный изъ сухихъ злаковъ. Если аккуратно разрывать кочку, то можно было видьть боковое отверстіе, ведущее въ полость самаго гньзда, но это отверстіе обычно разрушалось, если гнћздо было вынуто изъ окружающей его земли. Въ большинствь случаевъ къ одному гнғзду ведутъ ньсколыко главныхъ норъ, число которыхъ иногда сводится къ одной, двумъ. Кромь этихъ главныхъ норъ, существуютъ еще побочныя, часто соединяющія одно гнњздо съ другимъ и, подобно длиннымъ коридорамъ, раскинутыя по всей колоніи. Наконецъ, существують еще очень короткія, обычно сльпыя развьттленія, которля играють роль запасныхь уб́ьъ;ицъ, куда полевки скрываются при наступающей опасности. „Когда выпадеть сньгъ и покроетъ землю на ньсколько вершковъ“, пишетъ 3 а р удны й (77, стр. 346), „обыкновенныя полевки... устраивають себњ еще одно гнђздо, но уже на поверхности почвы, подъ сньгомъ“. Мнь лично случалось изрьдка находить такія наземныя гньзда и льтомъ. Они лежали обычно въ небольшомъ углубленіи почвы. Отъ гнђзда отходили вглубь нћсколько норъ, при чемъ главная находилась всегда подь самымъ гныздомъ. Постройка посльдняго отличалась оть подземныхъ только большей плотностью и величиной. Какъ я уже говорилъ, съ наступленіемъ зимы, позднею осенью, часть полевокъ покидаётъ свои колоніи и перебирается ближе къ жилищамъ челов'кка, часть остается на своихъ гныздовыхъ мьстахъ. Если сньжный покровъ не очень великъ, то количество выступающихъ на его поверхности норъ можетъ быть очень значительно. Въ это время полевки часто выбираются наружу, и мнь приходилось находить высохшія зонтпчныя растенія, торчащія изъ сньга съ подточенными стеблями и наклоненными вершинами, изъ которыхъ были вытрясены и поьдены находящіяся тамъ сьмена. 


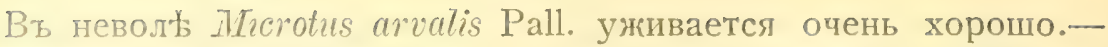
[Інтересно держать ихь въ одномъ терраріумь съ Evotomys glareolus Schreb., такъ какъ при этомъ особенно наглядно сказывается разница біологическихъ свойствъ этихъ видовъ: обыкновенная полевка вскор \$ продылываетъ по всему терраріуму свои галлереи норъ и, въ противоположность рыжей полевкь, почти не появляется на поверхности земли.

Экземляри коллекии: 90 экземпл. изъ огр. Тесова Можайск. у. II, кромь нихъ: № 252 subad, I9/IV 1909 г. Серпуховъ,отъ Ө. С. Щербакова. 스 256 q juv. Ibidem. № $45^{2}$ juv. 2/vir, I904 г. Митьково Можайскаго у. № 486 3І/vil 907 г. Екатериновка Звенигор. у. № 487 우 берем. I7/vi, І907 г. Аносино Звенигор. у. № 488 о льто г9oо г. Демьяново Клинск. у. № 900 subad. Io/vir т9г2 г. Пуршево Богор. у. отъ Г. И. По ля ко ва.

Во̆ коллекии Зоолопиеск. Музея Московск. Уииверс.: № 2524. Ст. Кашира, І3/vi 9II г. В. Н. Вуч ет ич ъ. № 2525, O Ibidem, I4/vi 9 I г г. В. Н. В уч е т и ч ъ. № 2526. 26/vi 9I г г. Ibidem. № 2527. Рузскій у. Московск. губ., проф. Н. Ю. З ографъ и С. А. З ерн о в ъ. № 2528. 6/r ı909 г. Измайловскій Звъринецъ, В. Н. В у ч ети ч ъ す) и 4 молод.). № 2529 о г888 г. Измайл. Звђринецъ, А. А. Тихомировъ. № 2530. II/צ' I908 г. Косино Моск. у., П. С. Гальцовъ. № 253т. 20/rv, т9го г. Арпьево Серпух. у. Ө. С. ШЦ е р баков ъ. 4 әкземпляра отъ К. А. Сатунин а, Воробьевы горы 1889 г.

Родъ A rvicola Lacépède (1799).

\section{Водяныя крысы.}

Формы, относящіяся къ этому роду, отличаются отъ настояпџхъ полевогъ свопми очень значительными размьрами и длиннымъ густымъ мьхомъ, что стоитъ въ связи съ преимущественно воднымъ образомъ жизни этихъ животныхъ. Хвостъ-очень длинныї, достигаюпії $1 / 2$ длины тьла и въ большинствђ случаевъ даже превышаюшій посльднюю длину. На ступны заднихъ ногъ находятся пять бородавокъ. Сосковъ восемь паръ. Особенно характернымъ для этого рода является присутствіе большихъ мускусныхъ железъ по бокамъ брюшной области.

Характеристика черепа и зубовъ дана при описаніи вида. 


\section{Arvicola amphibius L.}

Водяная крыса.

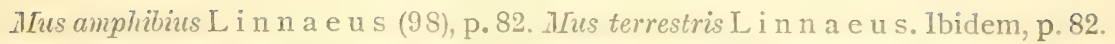
Arvicola amphibius Lin. Mill a is (1 10$)$, vol. II, p. 287. B las ius (2 7), p. 344. Arvicola terrestris L. a. amphibins L. Trou ess a rt (201), Supplem. 1904, p. 460. Arvicola terrestris (L.) T ro u e s s a r t (200), p. 194. Arvicola terrestris amphibine (L.) Trouessart, Ibidem, p. 194. Arvicola amphibius L. In Arvicola terrestris L. Gerrit Miller, p. $19-20$. Microtus amphibius (Linn). K. A. С а т у ни ин в (165), стр. 11-12 II (166), p. 2.

\section{Систематическія особенности.}

पерепг характеризуется рызкой угловатостью своихъ контуровъ. Скуловыя дуги разставлены очень широко; лобныя кости вдаются въ область теменныхъ довольно правильно очерченной дугою. Межтеменная кость измьнчивой формы, но все же характерна: передняя часть ея въ большинствћ случаевъ вытянута въ острый отростокъ, а боковыя стороны сужены и неправильно закруглены. Носовыя кости значительно расширены въ ихъ передней области ${ }^{1}$ ) и сужены въ задней. Foranina incisiva (palatina anterior) рђзко увеличиваются въ ширинњ спереди и суживаются кзади. Воздстиия изивия черепа этого вида весьма замұтны: черепъ молодого экземпляа характеризуется приподнятостью своей затылочной области; гораздо болье узкими скуловыми дугами; очень короткими носовыми костями, ширина которыхъ приблизительно одинакова на всемъ ихъ протяженіи. Bullae tympani гораздо болье коротки и вздуты, чьмь у старыхъ, y коихъ онђ, кромь того, значительно п.лотные. Оканчивая характеристику черепа, мнь хотьлось указать на одну особенность, обшую съ другими видами полевокъ: межглазничный промежутокъ водяныхъ крысъ очень рано достигаетъ своей наибольшей ширины. Болье того, часто можно видьть, что у старыхъ особей онъ даже у́же, чъ̌мъ у молодыхъ (см. табл. А., стр. 194).

Зубы характеризуются присутствіемъ семи эмалевыхъ петель на первомъ коренномъ нижней челюсти. Этотъ зуб́ъ по своей конфигураціи сравнительно постояненъ. Гораздо болЊе измьнчивъ посльдній коренной верхней челюсти. Здъсь мы имњемъ пять эмалевыхъ петель и шесть зубцовъ: по три снаружи иі съ

1) Однако не такъ, кагт у Arv. sapidus Mille r, распространенної въ южної Франціг. У этої формы nasalia въ пхъ передней области достигають ширнны rostrum. 
внутренней стороны. Посльдняя эмалевая петля отличается то белін आытянутої, языковидної формої, то, напротивъ, короткимъ закругленіемь съ замьтнымъ зубцомъ на внутренней сторонғ. Наиболье типичныя измьненія этого зуба очень точно изображены у Блазіуса (27, p. 345).

Orраска весьма измьнчива. Верхная часть головы и вся спина mилииаго экземпляра покрыта очень густыми волосами, двухъ рłзко диференцированныхъ типовъ. Одни изъ нихъ, болье короткіе и тонкіе, у своего основанія желто-сђраго цвђта съ бурожіслтовато-красными предвершинными частями и узіни черноватыми концами,-другіе, болtе :линные и толстые, у основанія сьры, подобно первымъ, но вся остальная часть ихъ темнаго чернаго цвьта. Џосльдніе волосы преоб́лалають на всей верхней стороны тьла и дылаются особенно длинными въ брюшной области. Но уже на бокахъ тьла и на щекахъ начинаютъ преобладать болье свьтлые волосы, что придаетъ этимъ областямъ болье красноватый или желтоватый тонъ. Нижняя часть морды, подбородокъ и грудь покрыты болье короткимъ сьроватымъ иьхомъ, со слабымъ ржавымъ оттьнкомъ, который рьзко отличается отъ совершенно б́ьлаго тона волосъ, окаймляющихъ губы. Нижняя часть груди и вся брюшная область характеризуются густыми волосами, у основанія сьрыми, съ яркими рыже-грасноватыми концами, безь примбси совершенно черныхъ остей. Лапы темныя, буровато-черныя, съ бьлыми когтями. Хвость темно - бурый, большей частью почти одноцвьтный. Молодыя отличаются болье тусклой, желтой и сърой окраской. Отъ этого основного типа окраски мы имьемъ два рода, географически совершенно не .пфференцированныхъ, отклоненій. Къ первому изъ нихъ принадлежатъ формы очень темной ограски, въ волосяномь полровы которыхь преоблацають совершенно черные волосы, что приближаеть этихъ крысъ къ меланистическимъ экземплярамъ. Во-вторыхъ, встрьчаются очень свђтлыя Arv. amphibius L. съ преобладающимъ желтовато-краснымъ тономъ мбха. Посльдняя окраска особенно выступаетъ на всей нижней сторонь и щекахъ.

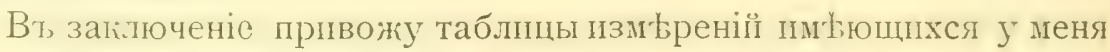
экземпляровъ (см. стр. І94 и г95).

Въ эти таблицы включены промьры экземпляровъ не только изъ Московскої губ., но также изъ разныхъ другихъ мьстъ, такъ какъ въ конц этого систематическаго очерка мны хоть:ось остановиться на разбор талісономическаго значенія Ailicnla amphibius L. и $A$. terrestres L. Эти крысы отличались большин- 
ствомъ прежнихъ изсльдователеіг, при чемъ признаки, характеризующіе этихъ млекопитающихъ, выдвигались не только систематическіе, но и біологическіе. Для $A$. amplibius L. считалось типичнымъ: І) темно-зенлистая окраска верхней стороны, переходящая въ болье ржавую на бокахь и брюх шающій половину длины тьла; 3) болье острая морда; 4) массивный черепъ; 5) образъ жизни вблизи воды. Съ другой стороны, Arv. terrestris L. отличалась: I) болt'е свьтлой окраской верхней стороны, въ которой преобладаютъ ржавые и желтоватые тона, особенно развитые на щекахъ, бокахъ и брюшной сторонь тьлла; 2) хвостомъ, уступающимь половинь длины тьла; 3) тупоп̆ мордой; 4) тонкимъ и узкимъ черепомъ; 5) станціями, расположенными вдали оть воды. Блазіусъ (27, р. 344-358) впервые жритически и подробно разобралъ эти отличія, отмьтивши рядъ переходовъ между ними и невозможность точной дифференцировки. Но за посльднее время, благодаря главнымъ образомъ работамь М и л л е ра, снова болышинство авторовъ стало выдылять эти формы, придавая пмъ то значеніе подвидовъ (Trouessart), то видовое (Miller). Въ моихъ рукахъ скопился довольно значительный матеріаль (27 экз.), но, къ сожальнію, все же недостаточный для какихъ-либо окончательныхъ вывыдовъ. Однако, просмотрь его привель меня къ нбкоторымъ соображеніямъ, думается, не лишеннымь интереса. Просмотръ серій, изъ коихъ особеннаго вниманія заслуживаютъ водяныя крысы, собранныя Б. М. Жі ит ковым ъ въ Симбирской губ. съ почиыли обозиаченіяли сманиіи, привель меня къ тому результату, что $\boldsymbol{M}$. terrestris L. всюду встрьчается параллельно съ водяной формой, но, повидимому, чаще вдали оть воды. Сь другой стороны, Блаз і усъ быль совершенно правъ, говоря о большомъ количеств' переходовъ между этими формами. Болье того, иногда мы имьемъ передъ собою полное смьшеніе ихъ признаковъ. Напримьрь, экземпляъ, добытый въ Донской обл. В. В. Троицицм по соотношенію тьла и хвоста долженъ быть отнесенъ къ $A$. terrestris L. тогда какь окраска его очень темна (признакъ A. amphibius

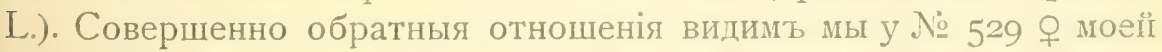
коллекціи: здьсь при равныхъ размрахъ тьла съ предыдущимъ, хвостъ почти вдвое длиннће, и по этому признаку онъ долженъ быть отнесенъ къ $A$. amplitins L., но окраска краіие свпmла. Такое несоотвьтствіе признаковь особенно рьзіо выступаеть у 샤응 2І93, 2532, 2535 и др., но останавливаться на этомъ подробнье не имьеть интереса, такъ какъ приведенная таблица лучше словъ и.люстрируеть сказанное. Быть ложеть, эта спутанность призна- 


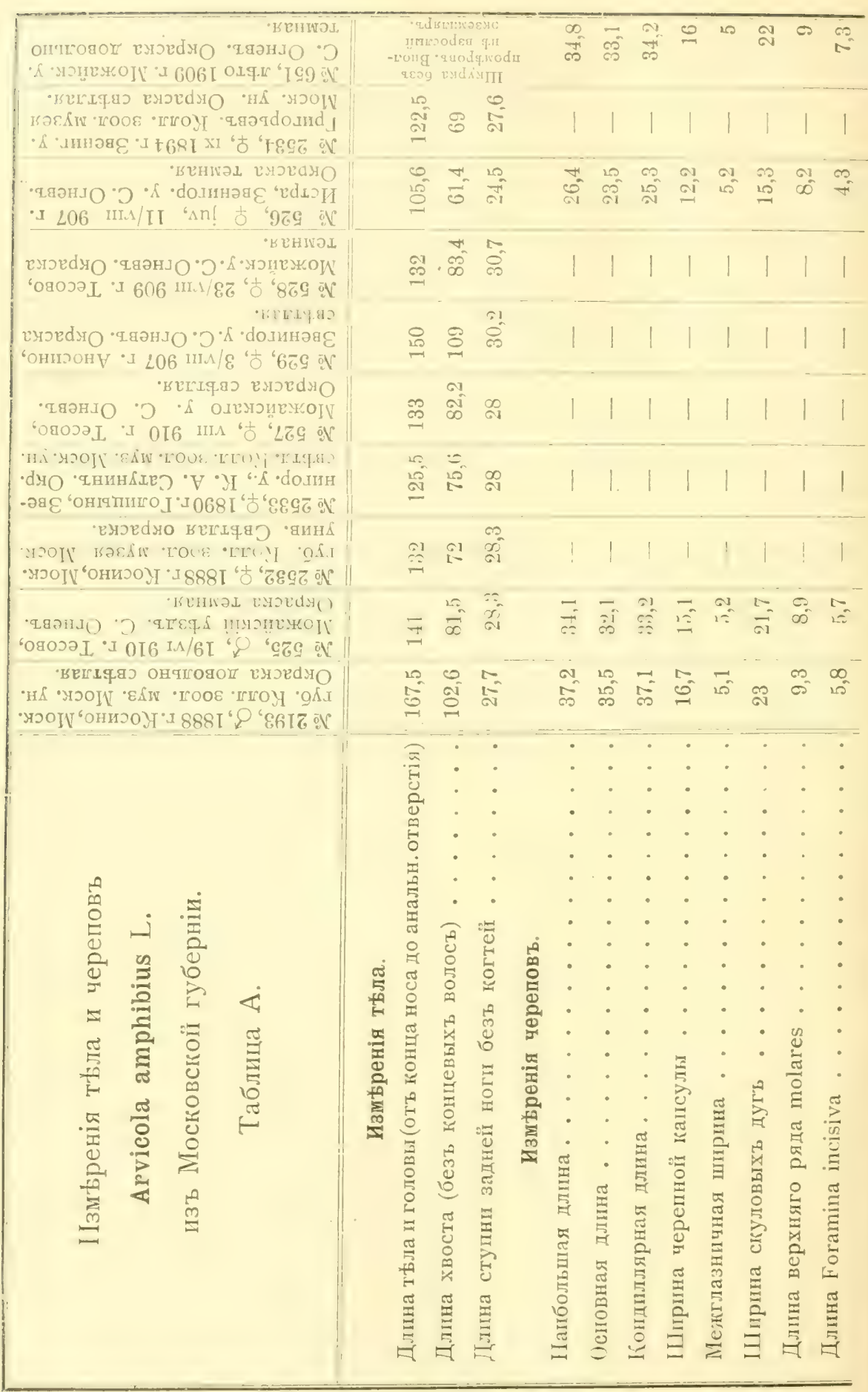




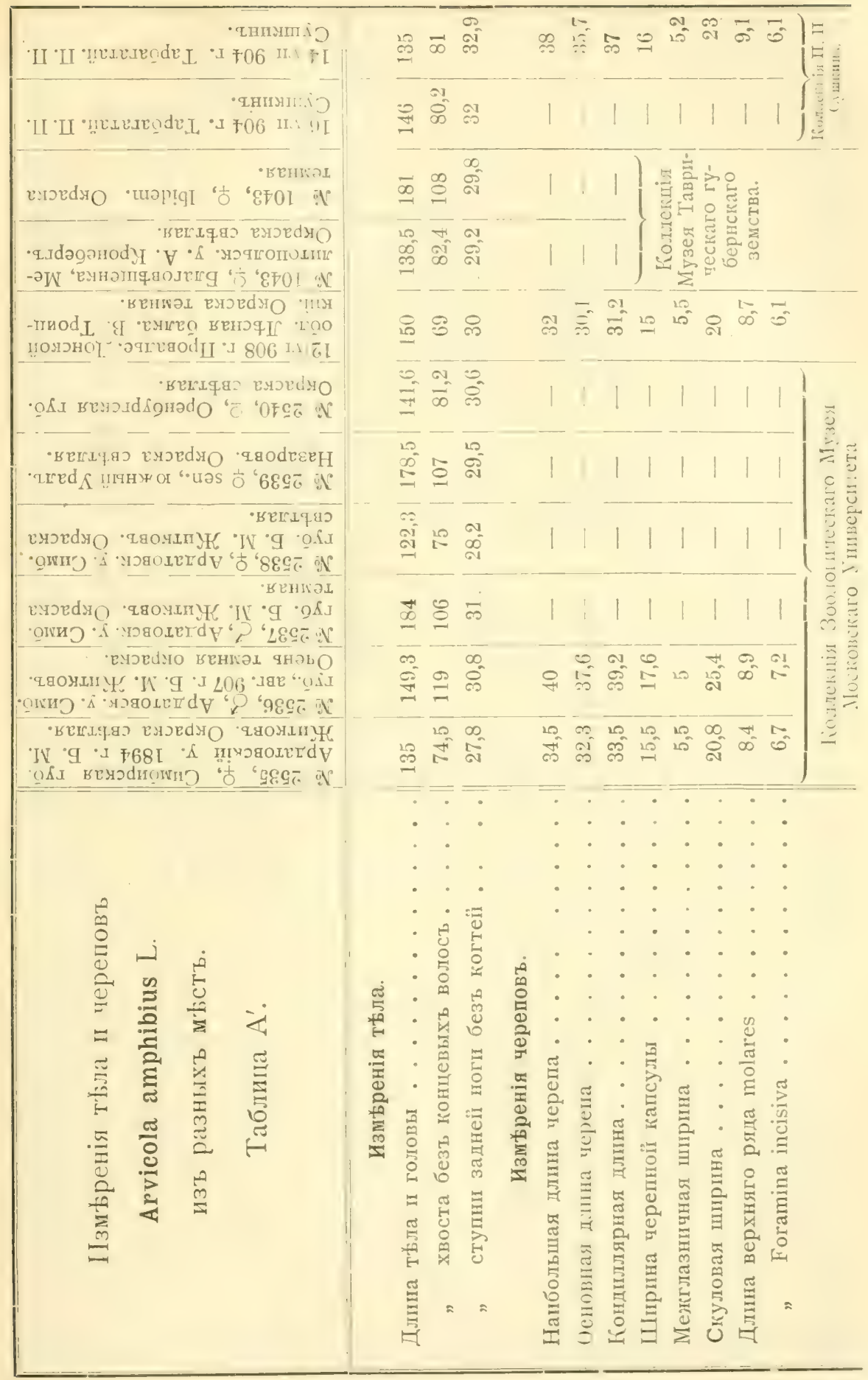


ковт повлекла за собою неясность описанія у разныхъ авторовъ, доведенную иногда до полної противоположности. Такъ, по словамь М ил ле р а, окраска $A$. terestris L. приближается къ типу A. amphitins reta Miller, которая темнђе типичної формы (Miller, I I 2, p. 20), а, сльдовательно, и A. terrestris L., по этому автору, должна быть темнье $A$. amplibins L. Это стоить въ полномъ, не оговоренномь авторомъ, противорьчіи со всъми прежними описаніями. Размьры для A.terrestris L. приведены такіе: длина тьла и головы-ок. I $75 \mathrm{~m} / \mathrm{m}$; хвоста-- $о 0 \mathrm{~m} / \mathrm{m}$; задней ступниor. 28-3 I m/m; кондиллярно-базальная длина черепа-36-39 m/m. A. amphibius L. характеризована сльдующими размғрами: длпна тьла и головы-ок. $200 \mathrm{~m} / \mathrm{m}$; хвоста-ок. І Іо $\mathrm{m} / \mathrm{m}$; задней ступни-ок. 3о-34 m/m.; ґонд. -баз. длина черепа-оть $40-46 \mathrm{~m} / \mathrm{m}$. Выше я указывалъ, и изъ приводимой таблицы было ясно, что ныкоторые экземпляры, которые по длинь хвоста должны быть относимы къ $A$. amphibius L. отличались малыми размьрами тьла и свђтлой окраской-признаками A. terrestris L. Bct эти противорьчія не разъясняются вь новой работь Т руссара, а, напротивъ, въ ней объективный читатель находить только новыя загадки. Такъ, для $A$. amplibius L., которую $\mathrm{Trouessart}$ считаеть болье темнымъ подвидов $A$. terrestiv L., длина хвоста указана равной $85 \mathrm{~m} / \mathrm{m}$, при длинь тьла $194 \mathrm{~m} / \mathrm{m}$. Не говоря уже о томъ, что такое указаніе одиоло промьра (безь оговорки, что это-средняя величина, полученная на большой серіи) надо считать совершенно не научнымъ, строгое сльдованіе описанію этого автора приводитъ къ полному недоумьнію, куда отнести экземпляры, у коихъ хвость достигаетъ Iо7-то9 m/m., между т屯мъ какь прочіе признаки соотвьтствують частью $A$. terrestr is L., частью A. amphibius L.?

Для A. terrestris L. Trouessart указываетъ такіе мелкіе размьры (длина головы и тьла-т4о $\mathrm{m} / \mathrm{m}$; х хвоста-63 m/m.; ступни-22 m/m.; черепа 35 × $20 \mathrm{~mm}$.), которые невольно наводять на мысль, что авторъ имьлъ передъ собою молодые экземпляры. Резюмируя все сказанное, мы приходимъ къ заключенію, что между описанными формами водяныхъ грысъ сушествують многочисленные переходы, затрудняющіе ихъ точную дифференцировку въ систематическомь отношенік, между тьиъ какь біологическія отличія, повидимому, выражены довольно р‡зко. Это существованіе промежуточныхъ формъ не даетъ права выдьлять A. terestris L. какъ особый видъ. Однако еще болье страннымъ является признаніе ее за „subspecies“, какъ дьллаеть это Trouessart. Вьдь, характерной особенностью этой систематической 
единицы является опредыленная область обитанія, которая въ большинств' случаевъ соприкасается съ областью обитанія основной формы. Въ нбкоторыхъ случаяхъ область подвида можеть быть заключена въ области распространенія ближайшей генетической формы, но въ таґомъ случағ она представляетъ сплошную область. Въ нашемь примьрь мы видимъ иное,-здьсь двь формы встрбчаются богъ о бокъ, при чемъ распространеніе одной какъ бы вкраплено въ область другой. Ньскольк поспьшныъ было считать $A$. terrestris L. элементарной формой (Elementarart) въ смысль І оганзена ${ }^{3}$ ), принадлежащей къ одному общему phaenotipus съ A. amplibius L. Этотъ вопросъ могъ бы рұшиться путемъ энсперимента. Однако элементарныя формы I о ганзена, вьроятно, характеризуются географическої дифференцировюї, им Бя въ этомъ отношеніи много общаго съ subspecies новьйшей систематики. Мнь дулается, что напболье раціональнылъ б́ыло о́ы считать $A$. terrestris L. мо р фо й $A$. amplizins L., какъ понимаетъ ее А. П. Семенов ъ-Тянь-Шаньскі й $\left.{ }^{2}\right)$, т.-е. такої систепатическої единицеї, которая характеризуется зависпиостью оть

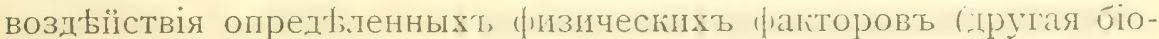
логическая среда) и отсутствіемъ очерченной области обитанія.

\section{Географическое распространеніе.}

Въ предьлахъ Московскої губ́. водяная крыса распространена, повидимому, широко. Она найдена въ Московскомъ у. на болотахъ близъ Косина (по Казанской дорогь, въ I5 в. отъ города), встрбчается въ большомь числь́ въ Шзмайловскомъ Звьринць (по К. А. С атунину). Изъ Звенигородскаго у. я имью экземпляры, добытые около Аносинскаго монастыря, а К. А. Сатун и н ъ отмьчаетъ ее для окрестн. ст. Голицына. Въ Можайскомъ у. она довольно обыкновенна въ поймы Москвы рьки близъ села Тесова и встрьчена мною въ огромномъ количеств' около дер. Храброва (на границь съ Гжатскимъ у. Смоленской губ.), гды водяныя крысы держатся на большихь моховыхъ болотахъ. Въ Рузскомъ у. онь̆ не рьдки на болотахъ бл. дер. Гавшина. Наконецъ, A. amphibins L. не рьдки въ Богородскомъ у. Вь центральныхъ губерніях Европейской Россіи этотъ видъ найденъ мною въ Гжатскомъ и Сычевскомъ уу. Смоленской губ., въ Малояросла-

1) W. Joh a n sen, Ueber Erblichkeit in Populationen und in reinen Linien, Jena, 1903.

2) А. П. С еуг еновъ-Тянь-Ш аньскі ій, Таксономиескія границы вида II его подраздьленії, Спб., 1910, стр. 22. Записки Имп. Ак. Наукъ. т. XXV, № I. 
вецгомь у. Калужской губ., Э с а у л в ы ъ, въ Торопецкомъ и Холмскомъ уу. Псковской губ. (58, стр. 225), Л. П. С абанћевымъ-въ Ярославской губ. ( 5 о, стр. І9, отд. отт.). Далье ґъ югу она встрьчена К. А. Сатуниным в въ Черниговской губ. (г 6 5, стр. І2). С. Н. Г' о р ба ч е вы м ъ и мною найдена въ юго-в. части Орловской губ. К. $Ө$. К К сслеръ отмьчаеть ее для береговъ Дньпра и его притоковъ (86, стр. 70), Belk для Кіевской губ. и окр. Каменець-Подольска, а Н ордм ан н ъдля поймы Дньстра и Буга. Въ' Харьковской губ. она добыта Чернаемъ и Сомовым ъ ( 184 , стр. I49). По Сатунину A. amphibius L. встрьчается въ Волжско-Цонской степи ( т 57 , стр. 249). Одинъ экземпляръ добытъ бл. Провалья Донской обл. В. В. Троицкимъ. Въ Таврической губ. она найдена бл. Мелитополя Кронебергомъ. Далье на востокъ она встрьчается, по K. А. Сатунину, въ Волжско-У ральской степи ( 6 7, р. 8), будучи пріурочена, главнымъ образомъ, къ Волжской долинь. По свидытельству М. Н. Богданова, водяная крыса весьма обыкновенна по рьчнымъ долинамъ Поволжья, особенно часто встрьчаясь въ поймь Камы и Волги. Б. М. Жи т ко в ь нашель ее въ Ардатовскомъ у. Симбирской губ. (7 I, стр. I4-I5), a, по свидьтельству С илан ть в а, она крайне обыкновенна въ Балашовскомъ У. Саратовской губ. ( І 8 I, стр. 296-298). По Я ко вл в у, водяныхъ крысъ очень много въ окрестностяхъ Астрахани, откуда имьль экземплярь и К. А. Сатунин ъ. A. amphibius L. найдена по всему Оренбургскому краю Н. А. 3 арудным и и около Орска (Южный Уралъ) Назаровымъ. Lehman нашель ее оть Уральскаго хребта до Каспійскаго моря. Уральскою экспедиціей $A$. amplibius L. добыта въ тундрь подъ $67^{\circ}$ с. ш. (34, p. 36). По Л. П. С аб ан ье в у она встрьчается во всемъ Богословскомъ Ураль, но здьсь этоть видъ далеко не такь многочисленъ, какъ въ южныхъ частяхъ Пермской губ., гды мьстами водится въ огромномъ количествь, особенно на озерахъ I49, стр. 5). Далье на сьверо-западъ A. amphibius L. найдена близъ Архангельска и въ дельть Сьв. Двины Миддендорфомъ. ІІля Финляндіи указана Брандтомъ. Въ Петербургской губ. она отмычена для Петербургскаго у. (на р. Лебяжьей) В. Л. Біанки, а въ Гдовскомъ у. добыта Порчин ским в ( 137 , р. 388). К. Ө. К е с с е р ъ помьчаетъ ее для Обонежскаго края (по собраннымъ свьдьніямъ, см. 87 , стр. 22). Въ прибалтійскихъ провинціяхъ она добыта Греве́ въ.Курляндіи и Лифляндіи (67, р. х20-І2І). По Т ачан о в скому встрьчается въ Польш ( I 85, р. I3I). 
На Кавказ' водяная крыса водится, по К. А. Сат.унину, повсемьстно въ Закавказьь, по Курь (Тифлись, Елизаветпольская губ.). За посльднее время этоть авторъ описаль изъ горныхъ луговъ Карачая особый подвидъ Micr. amphibius rufescens Sat. (Матер. къ позн. Кавказск. края, I908, стр. 95). Въ Западномъ Закавказььे въ предълахъ Карсской области и Эриванской (а, быть можетъ, въь зап. части Тифлисской губ.), распространена A. amphibius persicus De Filippi-персидская форма.

Что касается до распространенія водяной крысы въ Сибири, то въ западной ея части она встрђчается, по С ло вцову ( с 8 , стр. 22), по всей Тобольской губ. до самыхъ береговъ Ледовитаго океана. Вардр п пе р з замьчаль ее и на Тазовой губь. Въ Тюменскомъ округ' Агальской волости. Въ коллекціи Зоолог. Музея Москов. Унив. имьется экземплярь сь р. Сосьвы ${ }^{1}$ ) (оть Н. Л. Гондатти). Палласомъ найдена въ очень большомъ количеств'ь на Оби, гдь ею питаются собаки (г3І, р. І9). По К а ен ко $(82$, стр. 4I) она обыкновенна по всему Томскому краю. Объ экземплярь изъ Томска упоминаетъ и К. А. С а т ун и н ъ (Матеріалы къ позн. Кавгазск. края, І909, стр. 9о), а по Б р а н д т у (34, стр. 36) одинъ экземпляръ добыть въ Алтайскихъ горахъ. Р а д д е ( 143 , р. г84) нашель ее на Саянскихъ горахъ и на среднемъ Амурь близъ Буреи. Т ом асъ относитъ къ $M$. terrestris L. экземпляры съ Саянскихъ горъ (Ann. Mag. Nat. Hist. I9I I, p. 398). П. П. С уш к н ъ прислалъ мнь для опредьленія два экземпляра изь Тарбагатая. Г. К. По л яко в ъ добылъ одну крысу близъ западнаго берега озера МаркаКуль Семипалатинск. обл. (экземпляръ въ коллекціи Зоол. Муз. Москов. Унив.). Далье на востокъ встрьчается, по Миддендорфу, около Туруханска и Якутска и на нижнемъ Енисеь (до $70^{\circ}$ с. ш.). По М а аку (го2, стр. Іо6) довольно обыкновенна на Ленt, Вилюь и Оленекь. Шре нкомъ найдена .въ Амурскомъ краь ( I 7 4, р. г36-г37), откуда по Брандту (34, р. 36),

1) Этотъ экземпляръ очень пнтересенъ по своей окраскь: мбхъ его сравнительно темныі, ржавые тона на нижнеї стороны совершенно не развиты и замьнены темно-сђрыми и, что особенно пнтересно, на задней сторонъ шеи п на груди расположены цва большихъ свбтлыхъ пятна, образованныхъ совершенно бълыми волосами. Я отмычу здысь, что о такихъ әкземлярахъ съ былыми пятнамп писаль еще Двигубскі ї (44, р. 59), по словамъ котораго они попадаются на Енисеъ, а Р а дде имблъ пхъ съ Саянскихъ горъ. В броятно, эта аберрація встрбчается главнымъ образомъ въ Сибирі (въ долннь Оби, Енисея іп на Саянскихъ горахъ). Въ виду ея постоянства я отмычаю ее особыщ названіемъ-Arvicola amphibius pallasii aberratio nova). 
распространена до Охотскаго моря. По свидттельству Г ео рг и, (64, s. I564) встрьчается по всей Россіи и Сибири вплоть до І́амчатки. Однако, по Палласу, Двигубскому, Брандту I Вознесенскому, на Камчатк' $A$. amplibius L. совершенHO нђтъ.

Водяная крыса распространена по всей средней Европь отъ Британіи и Швеціи до южной Италіи. Въ Пиренеяхь встрђчается очень близкій жь основной формь подвидъ Avvicola amphibins monlicola Selys, въ Испаніи ее замьняеть Arvicola sapidus Miller, въ восточныхъ Пиренеяхъ и юго-зап. Франціи Avv. sapidus tenebricus Miller, въ съверной Италіи - Avv. itaticus Sav. ${ }^{1}$ ), въ центральной Италіи - Avvicola musignanoi Sélys, въ Босніи - A. m. illiricus Barret-Нам. Нагонецъ, въ Бельгіи и южной ГерманіиAvv. scherman scheman Schaw, а въ IІвейцаріи, къ востоку оть Тироля - A. scherman exitus Miller. Такое большое количество формъ водяной крысы стоитъ въ полномь соотвьтствіи съ сильной измьнчивостью, къ коей, повидимому, она такъ склонна. Mнғ думается, что тщательная переработка большого матеріала заставила бы свести въ синонимы часть перечисленныхъ подвидовъ, описанныхъ главнымъ образомъ за посльднее время и къ тому же весьма схематично.

\section{Образь жийни.}

Ізлюбленными мьстами пребыванія водяныхъ крысъ яв.яются берега рыкъ, озеръ и прудовъ, въ особенности если они болотисты и поросли кустарниками. Я находиль этихъ млекопитающихъ въ большомъ количеств' Москвы рбки, въ Можайскомъ у. Особенно много приходилось мнь наблюдать Avv. amphibius L. на большихъ моховыхъ болотахъ около дер. Храброва, на границ скаго уу. Здысь болота идуть однимъ непрерывнымъ рядомъ. Большія моховыя кочки, густой кустарникъ и плёсы рнавой отъ

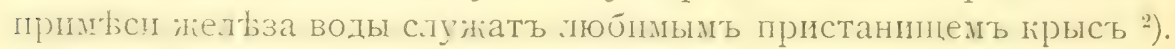
A. amplibins L. нельзя назвать ночнымъ животнымъ: мнћ очень часто приходилось видьть, какь она, часто при блескь яркаго сопнца, бђгаеть между кочками, и, завидьвъ опасность, ныряеть въ воду, быстро проплывая открытый плёсъ, чтобы очень искусно спрятаться въ густомь кустарникь и трав' С Стунин ъ говорить, что молодыя очень ловко бьгають по плавающимъ водя-

1) По Т русс ару она тождественна съ типичной формоํ.

2) Несомнынно, что водяныя крысы держатся пногда и вдали отъ воды оголо пахотныхъ полей (Avv. terrestris L.). 
нымь растеніямъ, при чемь хвость тащится по водь. Гньздо помьщается обычно въ подземной норь, вырытой на берегу рьки. Такія гньзда я находилъ по рык' Истрь въ Звенигородскомъ у. По словаль К. А. С атунина, бывають и наземныя гнызда. Подобное гнъздо, грубо сдьланное изъ крупной осоки, было найдено этимъ авторомъ на болоть' въ Измайловскомъ Звьринць; другое гньздо было интересно тьмъ, что оно помьщалось на высоть 3 футовъ надъ поверхностью воды, на кусть большой осоки, при чемь постройка была сдьлана изь листьевъ этого растенія. Оба гнъзда принадлежали молодымъ и, повидимому, служили только для временнаго убъжища, а не для вывода дђтей. Интересно отмбтить, что въ тьхъ мұстахъ, гдь встрьчается много водяныхъ ирысъ, берега рђчекъ б́ываютъ часто изрыты во всбхъ направленіяхъ ихъ норами. Естественно, что это облегчаетъ размываніе берега и способствуетъ его частичнымъ обваламъ. Иногда, особенно во время паводковъ, затопляются норы водяныхъ крысъ, и посльднія выбираются часто на совершенно открытыя мъста, ища спасенія отъ наступающей воды. Я помню, какъ посль такого наводненія въ серединь іюня 1907 года мнь удалось найти цђлую компанію въ семь еще совсњиъ молодыхъ крысъ, которыя спаслись отъ поднявшейся воды на совершенно открытомъ мысты высокаго берега p. IІтры (Звенигородскаго у.). Взятыя мною и посаженныя въ терраріумъ, онь стали довольно скоро приноравливаться къ новымъ жизненнымъ условіямь. - Но, страннымъ образомъ, чьмъ болье онь росли, тьмъ болье пробуждались ихъ дикія и злыя наклонности. Особенно злились онь, когда я приступаль къ необходимой чисткћ терраріума и трогаль мохъ, изъ котораго онь устроили себъ ньчто въ роды большого шарообразнаго гнызда. Тогда всы крысы становились, какь по командь, на заднія ноги, щелкали зубами и энергично, однимъ движеніемъ, взмахивали своими передними лапами. Насколько я могь замьтить, водяныя крысы особенно охотно ћли морковь, корни водяныхъ лилій, куски яблокь и картофель. Къ сожальнію, у меня ныть наблюденій надъ зимнимъ образомъ жизни этого своеобразнаго животнаго. По словамь К. А. С а тунина, онь на зиму, въроятно, скрываются, такъ какъ уже въ октябрь ихъ нельзя было поймать въ ловушки, и не замьчалось сльдовъ на сньгу.

Экзелиляры коллекии: почти всђ перечислены въ таблиць измьреній. o 646 §. Іо. V1I. I904 г. деревня Храброво, граница

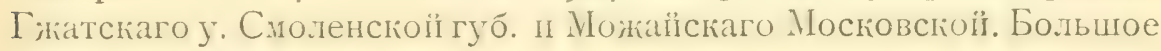
моховое болото. 
Прплатаю опредылительную таблицу полевокъ, водящихся вт Московской губерніи.

А. Длина черепа не превышаетъ $30 \mathrm{~m} / \mathrm{m}$. Хвость не превышаетъ $60 \mathrm{~m} / \mathrm{m}$.

г. Окраска верхней стороны красновато-бурая, съ рыжимъ оттьнкомъ. Уши замбтно выступаютъ изъ мұха и равны $1 / 2$ длины толовы. На заднеї ступн'ь 6 бородавокъ. Сосковъ 8 парь. Коренные зубы имьють во взросломь возрасть по два корня. Длина зубного ряда не болье $5,8 \mathrm{~m} / \mathrm{m}$. Двуцвьтный хвостъ достигаетъ $1 / 2$ длины тьла или немного превышаеть ее.

Родъ Evotom y s.

а. На поверхности перваго коренного зуба нижней челюсти (у типичныхъ экземпляровъ) семь эмалевыхъ петель, при чемъ на внутренней и внышней сторонь по 4 зубца. Передній зубецъ петлеобразно загнутъ наружу и довольно длиненъ.

E. glareolus Schreb.

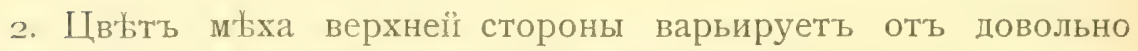
свътлаго желтовато-сьраго до желто-буро-сьраго тона. Уши слабо выступаютъ изъ мьха и равны $1 / 3$ длины головы. На задней ступнь обычно 6 бородавокъ. Сосковъ 8 паръ. Коренные зубы въ теченіе всей жизни животнаго не имьють корней. Длина зубного ряда верхней челюсти не менье $5,4-6,8 \mathrm{~m} / \mathrm{m}$., но часто значительно больше. Двуцвњтный хвость обычно равенъ $1 / 3$ длины тьла. Родъ Microtus.

$\mathrm{a}^{\prime}$ (b) Хвостъ равенъ $1 / 2$ длины тьла (или около этого). Онъ ясно двуцвђтныи; волосы, его покрывающіе, длинны и неравномьрно расположены. На переднемъ коренномъ зуб́ нижнеі челюсти чаще 7 , рьже 8 эмалевыхъ петель, но не болье. Длина ступни-задней ноги (безъ когтей): г6,9$20,5 \mathrm{~m} / \mathrm{m}$., черепъ: $26,2-29,4 \mathrm{~m} / \mathrm{m}$.

M. ratticeps Keys, et Blas:

b (a') Хвость равенъ 1/3 длины тьла (или даже около 1/4). Окраска его одноцвьтная, темная; волосы, его покрывающіе, горотки и равномьрно расположены. На переднемъ коренномъ зубћ нижней челюсти 9 петель; на второмъ коренномъ верхней челюсти пять петель и по три зубца съ внутренней и внбшней стороны. Длина ступни задней ноги (безъ когтей): І7-r9,2 m/m; черепъ: 25,5-27 m/m.

M. agrestis neglectus Jen. 
c. (b.) Хвость, равный приблизительно $1 / 3$ длины тьлла (или около этого), зам'бто двуцвы़тный; волосы, его покрывающіе, неравномЊрной длины. На переднемъ коренномъ зубъ нижней челюсти 9 петель; на второмъ коренномъ зуб́ь верхней челюсти четыре эхалевыхъ петли, при чемъ два зубца расположены съ внутренней стороны и три съ внышнеї. Длина ступни задней ноги (безъ когтей): I4,5-I7,9 m/m; черепъ: 2I,8-26,6 m/m. M. arvalis Pall.

В. Длина черепа взрослыхъ особей не менъе $32 \mathrm{~m} / \mathrm{m}$., часто достигая $40 \mathrm{~m} / \mathrm{m}$. Хвость не менье $69 \mathrm{~m} / \mathrm{m}$., обычно же его длина колеблется въ предьлахъ 80-II9 m/m.

3. Мьхъ очень густой и длинный. Уши очень слабо выступаютъ наружу. На задней ступнь 5 бородавокъ. Сосковъ 8 парь.

Хвостъ обычно превышаеть $1 / 2$ длины тьла. Длина верхняго ряда коренныхъ зубовъ не менье $8,4 \mathrm{~mm}$.

Родъ Arvicola, къ которому относится одинъ видъ.

Arvicola amphibius $L$.

\section{Подсемейство Murinae.}

\section{Родъ мus Linn. (1758.)}

\section{М ы ш и.}

Linna us (9 8), p. 59.

Къ этому роду принадлежатъ млекопитающія, размњры которыхъ колеблятся оть очень мелкихъ (Micromys mimutus L.) до сравнительно крупныхъ (Epimys norvegicus Erxl.). Они характеризуются строїнымъ тыломъ; удлиненной головой, сильно сужіенной въ носовой области; длинными ушами, обычно превышаюшими ${ }^{1}$ д длины головы; задними конечностями, очень удпненными сравнительно съ передними. Хвостъ покрытъ весьма короткими волосами, такъ что кольцеобразная чешуйчатая структура его кожи ясно сквозитъ между посльдними, а длина равна длинь тьла и даже часто ее превосходитъ. Верхняя губа расщеплена или надрьзана посрединђ. Вибриссы очень длинныя.

Черепъ характеризуется своей удлиненной, яіпцевидной формой со сравнительно очень вытянутой носової областью, тонкими, болье узко разставленными и длинными, чъмъ у полевокъ, скуловыми дугами и небольшими, сравнительно съ Мicrotus, bullae osseae. Очень характернымъ признакомъ этого рода является также строеніе нижней челюсти: ея сочленовный отро- 
стогъ (processus condyloideus) коротокь и сильно отклонень назадъ, тогда какь у полевокь онь значительно длинные и отвьсithe посаженъ.

Длина ряда коренныхъ зубовъ верхней и нижней челюстей значительно короче, чьмъ у полевокъ. Сами коренные зубы съ цорнями, безъ pl;зко выступаюпцхъ боковыхъ реберь. Строеніе описываемыхт зубовъ, при взгляды на нихъ сверху, характеризуется тупыми бугорками, расположенными въ нћсколько поперечныхъ рядовъ на каждом' зуб́ь съ тремя бугорками въ каждомъ рядь. Правый и львый ряды верхнечелюстныхъ коренныхъ зубовъ расположены параллельно другъ другу. Все это рғзко отличаеть зубы мышей оть призматическихъ и плоскихъ на ихъ верхней сторонь зубовъ полевокъ.

Детали строенія черепа и зубной системы будуть разсмотрыны при описаніи видовь.

Зубная формула такова:

$$
\text { i. } \frac{I-I}{I-I}, \mathrm{pm} \cdot \frac{\mathrm{o}-\mathrm{o}}{\mathrm{o}-\mathrm{o}}, \mathrm{m} \cdot \frac{3-3}{3-3}=\mathrm{I} 6 .
$$

Подродъ $\mathbf{M u s}$ urop. dict.

Нёбныя складки, кромь одной или двухъ переднихъ, съ разрьзомъ посрединь. Ступни ногъ сравнительно тонки и коротки. На хвость постоянно меньше 200 колецъ. Всь бородавки на ступняхъ заднихъ конечностей круглы. Длина тьла (безъ хвоста) взрослыхъ особей всегда меньше $150 \mathrm{~m} / \mathrm{m}$.

\section{Mus sylvaticus mosquensis sbsp. nov.}

\section{Средне-русская льсная мышь.}

Irus sylvaticus L. (partim!) B la si u s (2 7), p. 322. Mus sylvaticus Linn. K. A. С атунин ъ $(16$ 5), стр. 13 II (166), p. 2. С.И. Огневъ иі С. Н. Горба́ че в в (1 29$)$, стр. 24-25.

Дianıов: Стоитъ ближе всего къ Mus sylvaticus celticus BarretHam., отъ коей отличается меньшей цлиной ступни задней ноги, болће длиннымъ черепомъ и относительно свьтлой окраской.

Tипы: ๆизепляры, перечисленные въ таблицахъ пзмұреній изъ разныхь мұсть Московскої губ́, Малоархангельскаго и Орловскаго

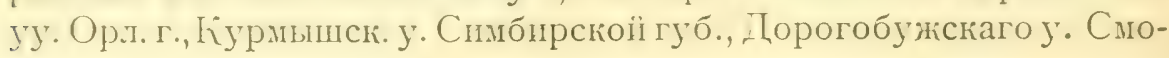
ленской губ.

\section{Систематическія особенности.}

Черепъ (табл. I рис. 32) характеризуется своей удлиненной, яйцевидної формой, съ сравнительно сильно вытянутой носовой 
областью. Лобныя кости вдаются сзади въ область теменныхъ закругленной дугою. Съ другой стороны, теменныя кости, охватывая съ боковъ лобныя, не дають по направленію впередъ замьтныхъ острыхъ отростковъ, но только два небольшихъ, тупыхъ выроста, съ неправильными контурами. Межтеменная кость характеризуется замытными боковыми суженіями и значительнымъ расширеніемъ ея центральної части. Bullae osseae округлы, тонкостћнны и малы. Черепа молодыхъ экземпляровъ отличаются особенно рђзко, если смотрђть на нихъ въ профиль: пменно, задняя часть черепа кажется болье вздутой и уголь, проведенный по линіи основанія и спинной сторонб черепа, болюе, чьиь у старыхъ. Но съ возрастомъ постепенно возстанавливаются нормальныя отношенія всльдствіе замытнаго удлиненія носового отдъла и уплощенія всей черепной коробки.

На характеристикь зубовъ я остановлюсь только въ двухъ словахъ, отмътивши ихъ особенности. Коренные зубы верхней челюсти расположены двумя почти параллельными другъ другу рядами, тогда какъ ряды нижнихъ molares болье сходятся сзади, чьмъ впереди. Особенно типичнымъ для льсной мыши является структура перваго коренного зуба нижнеї челюсти. На его поверхности, если смотрђть на этотъ зубъ сверху, находятся 6 попарно расположенныхъ тупыхъ эмалевыхъ бугорковъ и, кром нихъ, одинъ спереди, образующій съ бугорками первой (передней) пары трехлучевую фасетку. Далье имбется еще два, три дополнительныхь, мелкихъ бугорка, лежащихь на внђшней сторонь описываемаго зуба.

Ниже я привожу измьренія череповъ имьющихся у меня экземпляровъ (см. табл. на стр. 206).

Oкраска варьируетъ сильно, но всь эти колебанія укладываются въ довольно опредьленныя рамки. Мғхъ верхней стороны типичнаго льтняго экземпляра таковъ: вся верхняя часть головы и область затылка покрыта густыми темно-сырыми у ихъ основаній волосами, сь ржаво-желтоватыми вершинами. Между таґип волосами прићшивается довольно значительный пропенть совершенно черныхъ, количество которыхъ замћтно возрастаетъ на спинной области. Здъсь мьхъ носить поэтому болье сырый и темный тонъ. На щекахъ и особенно на бокахъъ тьла начинають снова преобладать ржавые волосы, что придаетъ этимъ частямъ свьтлый и яркій цвьтъ. Вся нижняя сторона покрыта менье густыми волосами, св`тло-сћрыми у основаній и яркобьлыми на концахъ. Такимъ образомъ, нижняя часть туловиша по своеї ожрасќ⿱亠䒑 pliзко отгранпчена оть темнаго верха. Рынаго 


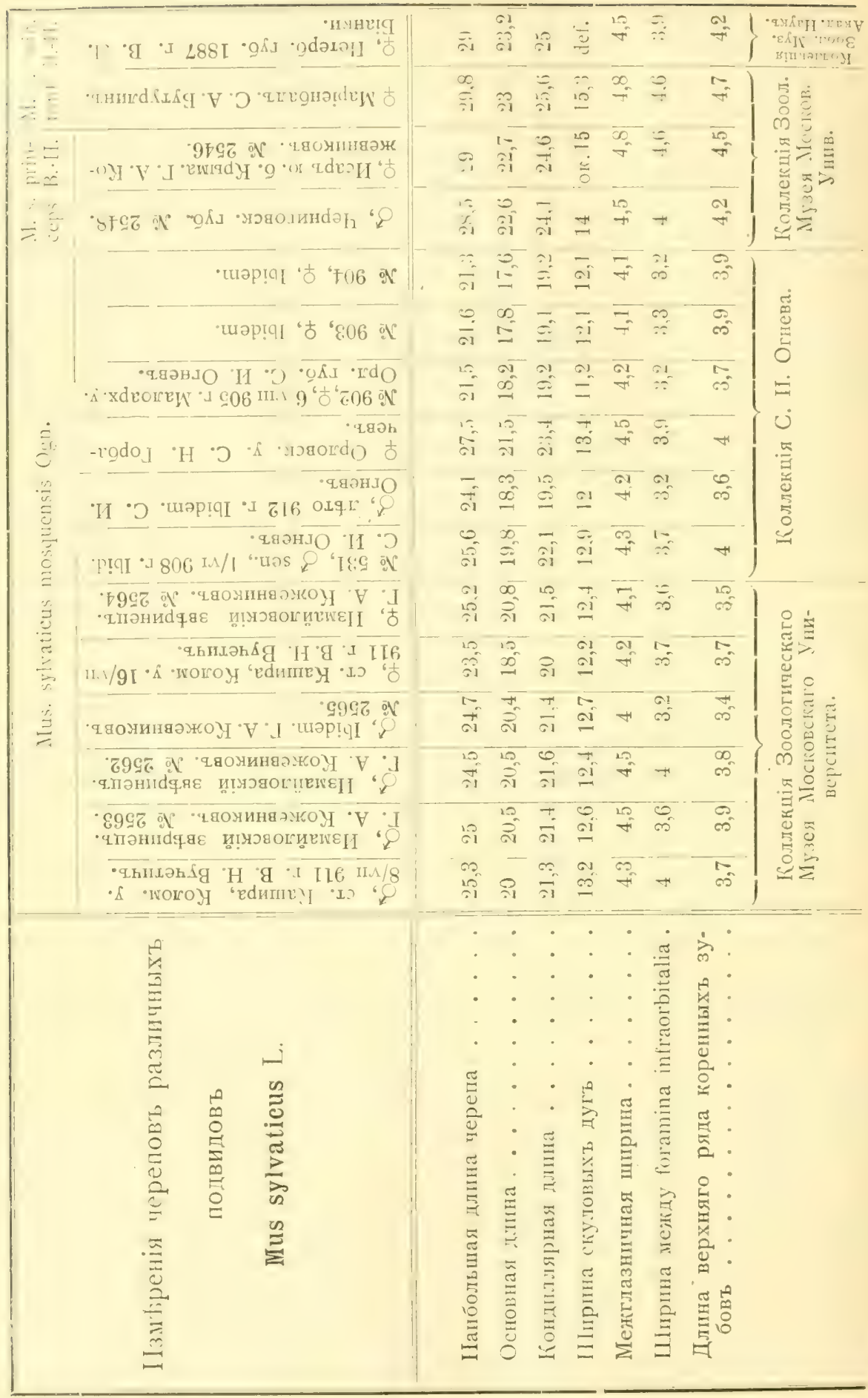


пятна на груди, между передними конечностями, никогда не бываеть. Хвость болье или менбе рłзко двуцвьтный, темно-сьровато-бурый сверху п бълый снизу. Отъ этой наиболье распространенной окраски существуетъ много довольно значительныхъ отклоненій. Именно, мнъь попадались большею частью старые экземпляры, въ мьхь жоторыхъ было много болће свљтлыхъ рыжеватыхъ волосъ, особенно развитыхъ на верхней части головы, въ носовой области, а также на бокахъ тьлла. Но никогда яркость окраски этихь особей не могла достигать приблизительно той степени, какъ у южной формы Mus sylvaticus princeps Barret-Ham. Съ другой стороны, мнь часто попадались льсныя мыши, по окраск'ь удивительно напоминавшія Mus musculus L. Какъ у этої посльдней, вся верхняя сторона тьла этихъ экземпляровъ отличалась своимъ замьтнымъ сыроватымъ тономъ

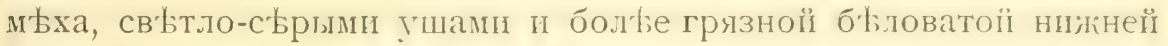
стороної тьла. Отмьчу зднсь, что эта окраска является типичной для молодыхъ особей и служитъ, сльдовательно, возрастнымъ признакомъ отличія. Я считаю, однако, нужнымъ подчеркнуть здъсь, что мнћ попадались и уже взрослыя особи, окрашенныя подобно молодымъ. Мнғ думается, что здъсь мы имьемъ только нъкоторое отклоненіе оть средней нормы, когда тастью остаются признаки болье молодого возраста уже у взрослыхъ особей. Что касается до зимняго мьха Mus sylvaticus mosquensis sbsp. nov., то, благодаря любезности В. В. Кар пова, я имьль возможность просмотрыть довольно большую серію льсныхъ мышей, собранныхъ пмъ в’ь зимніе мьсяцы въ Петровско-Разумовскомъ (бл. Москвы). Мћхъ зимнихъ мышей, кромћ большей длины, отличается замктнымъ ржавымъ оттћнкомъ, ясно выступающимъ особенно на бокахъ; хвость очень р‡зко двуцвђтный; брюшная сторона тьла еще бълье, чьмъ льтомъ.

Наконецъ, чисто-уклоняющійся характеръ носить экземпляръ, добытый К. А. С атунины мъ въ І891 гопу въ Измайловскомъ Звъринцћ (подъ Москвою). Этотъ экземплярь, хранящійся въ коллекціи Зоол. Музея Москов. Унив. (№ 256 г ), отличается необыкновенно свћтлым желтовато-палевымъ тономъ мұха, особенно свьтлымъ на головђ. Вся нижняя сторона тظла бьлая, а лапы, хвость и уши желтовато-бљлы.

Заканчивая на этомъ описаніе систематическихъ особенностей средне-русскихъ льсныхъ мышей, привожу въ таблицахъ ихъ изиьренія. (См. стр. 2т3-2І8.)

До настоящаго времени точный разборъ систематическихъ признаковъ средне-русскихъ льсныхь мышей еще никьмь не 
предпринимался, п большинство старыхъ и новыхъ авторовъ пазывали водящуюся здысь льсную мышь Mus sylvaticus L. Между тьмь, какъ показаль мнь разборъ довольно значительнаго матеріала,-этоть видъ разбивается въ Европейской Россіи

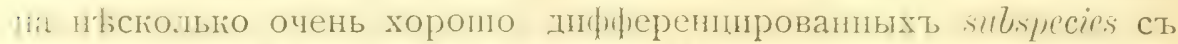
постояниыми ия точными признаками. Прежле чьмь переходить къ

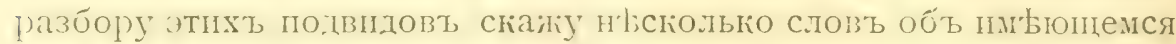
въ моихъ рукахъ матеріаль. Помимо своей коллекціи льсныхъ мышей изъ Орловской и Московєкой губ., я пересмотрьлъ серіи этпхъ, млекопиаюцихь, храняніяся въ Зоол. Музеь Моск. Јнив., въ Моск. Сельско-Хозяйст. Инст., въ Имп. Петерб. Академіи Наукъ. Кромь того, мнь были переданы для опредьленія мыши Естеств.-Истор. Муз. Таврическ. Земства и довольно значительная серія, собранная проф. П. П. С ушки ны и ъ въ Тарбагатаь. Такимь образомъ, весь матеріаль достигаетъ приблизительно 200 экземпл. и состоитъ изъ сльдующихъ подвидовъ: Mus sylvaticus minceps Barret-Ham., Mus sylvaticus wintoni Barret-Ham. (= cellarius Fisch.), Mus s. intermedius Bellamy, Mus. s. mosquensis sbsp. nov., M. s. major Radde, M. s. chewrieri M.-Edv. (=tscherga Kastsch.). Къ сожальнію, я не имьль въ рукахъ $M$. s. celticus Barr.-Ham., къ которой ближе всего стоить описанная мною форма, но точное описаніе, детальные промьры и рисунки этой мыши ${ }^{1}$ ) дали мнь возможность разобрать ея взамоотношенія къ моему подвиду съ достаточной ясностью.

Итакъ, тщательный просмотрь описаній показаль мнь наибольшую близость $M$. s. mosquensis sbsp. nov. именно къ $M$. $s$. çlticı.s Barret-Ham., распространенной въ Нрландіп п на Геб́рпдскихъ островахъ (Јюисъ, Скэй). Эта форма, по БарретъГ ам ильтону, характеризуется своими малыми размьрами и очень темной окраской верхней стороны тьла (a very dark upperside), отъ которой рђзко отдьляется бьлая нижняя часть тьла, лишенная рыжаго пятна между передними конечностями. Какъ можно было видьть изъ предыдущаго описанія, мои льсныя мышц по окраскь сильно варьирують и толык наиболье темныя особи приближаются къ рисунку M. s. celticus Barret-Ham. Размьры тьла M. s. celticus Barr.-Ham. п моего новаго подвида очень близки другъ къ другу (Mus. s. celticus Barr.-Нат.: длина тьла-80-90 m/m., хвоста-75-94, ступни-20-25, уха І3-г5,7). Единственное pызкое отличіе сказывается въ длины ступни, которая у $\boldsymbol{M}$. s. celticus Barret-Ham. очень велика по сравненію съ

1) Bъ работь B arret-H a milton pl. XXV; Milla is (110) vol. II, pl. 186. 
тьломъ животнаго, на что указываеть и Барретъ-Гамильтонъ $(25 \mathrm{~m} / \mathrm{m})$. Какъ можно видьть изъ приводимыхъ таблицъ, у средне-русскихъ экземпляровъ она никогда не превышаеть $2 \mathrm{I}, 5 \mathrm{~m} / \mathrm{m}$., даже у очень старыхъ особей. Наконецъ, посльднимъ отличіемъ является длина черепа, не превыпаюшая у ирландскаго подвида $25 \mathrm{~m} / \mathrm{m}$., тогда какъ у $M$. s. mosquensis sbsp. nov. она доходить до $27,5 \mathrm{~m} / \mathrm{m}$.

Весьма интересенъ тотъ факть, что распространеніе ирландской формы не простирается на Великобританію, прпо́атійскія провинціи и сьверо-запад. губерніи Европ. Россіи, гды еe замtщаетъ другой подвидъ, по всьмъ своимъ признакамъ стоящіи гораздо дальше оть нашей новой формы, чьмь отрызанная отъ посльдней по своему географическому распространенію $M . s$. celticus Barret-Ham. Этоть сьверный подвидъ (M. s, wntoni Barret-Ham.) встрьчается въ западної Англіи (Graftonbury, Herefordshire), въ Германіп, Саксоніи, Богеміи, Сп.тезіи, Венгріи, прио́алтійскихъ провинціяхъ и Петербургской губ. Барретъ-Гам и льтонь полагаетъ, что посльдней мьстности свойственна особая форма. M. s. cellarins Fischer. Объ особенностяхь этой льсной мыши до настояшаго времени въ литературь было изв'ьстно только довольно схематичное описаніе поверхностныхъ признаковъ въ работь' Фишера ${ }^{1}$ ), а самъ Бар реть-Гали ль тон ъ имьль въ рукахъ только одинъ черепъ, наибольшая длина коего была $27 \mathrm{~m} / \mathrm{m}$. На основаніи этого шаткаго матеріала этоть авторь рышился признать M. s. cellarius Fisch. за subspecies.

Вэ моихъ рукахъ быль большой матеріаль льсныхъ мышей изъ Петербургской губ. и прибалтійскихъ провинцій. Тщательное сравненіе показало ихъ полныйее сходствө. Между тьиъ, прибалтійскія льсныя мыши совершенно правильно отнесены $\Gamma$ р еве́ $(66$, p. 34-35) къ $M$. s. wintoni Barret-Ham. Къ этому подвиду относятся, по моеху мнынію, и экземпляры изъ Петербургской губ. И дьйствительно, какъ по окраскь, такъ и по размьрамъ (длина черепа $29 \mathrm{~m} / \mathrm{m}$.) онь цьликонъ подходять къ описанію M. s. wintoni Barret-Ham. ${ }^{2}$ ). Отъ $M$. s. mosquensis sbsp. nov. онь очень легко отличаются значительно большими размьрами (см. таблицы), болье яркой окрасіой пn постояннымь присутствіемь рыжаго пятна между передними юонечностями.

Въ заключеніе остается разсмотрьть взаимоотношеніе $\boldsymbol{M}$. $s$.

1) I. F is c he r, Zoologisch. Garten, VII, p. 1866, p. 153.

2) Есліг пдентичность MI. s. wintoni Barret-Ham. II MI. s. cellarins Fisch. подтвердится дальныишимп пзсльдованіям, то II. s. wintoni B a r r.-H а m. должна будетъ отнесена къ синониманъ $\Phi$ п ш е р о в с к о ї формы по праву пріоритета. 
mosquensis sbsp. nov. къ типичной Mus sylvaticus L., распространенної въ Швеціи, Норвегіи, Даніи. Эта форма отличается отъ средне-русской присутствіемъ ржаваго пятна между передними конечностями, которое не такъ ясно развито, кагъ у $M$. s. vintomi $\mathrm{B}$ a r r.-H a m. и иногда сливается съ желтоватымь тономъ мыха

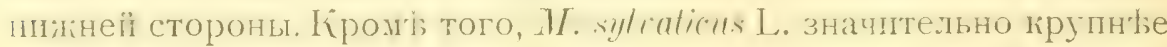
описаннаго мною подвида. (Длина тьла: 93- $104 \mathrm{~m} / \mathrm{m}$; хвостъ: 89-II4; ступня: $20-25 ;$ ухо: $17-17,5 \mathrm{~m} / \mathrm{m}$ ).

\section{Географическое распространеніе.}

Въ предълахъ Московской губ. распространеніе средне-русской льсной мыши носитъ довольно спорадическій характеръ: въ. нькоторыхъ мьстностяхъ она попадается очень часто и почти доминируетъ надъ прочими мелкими грызунами, въ другихъ сравнительно рьдка. Эта мышь найдена въ Московскомъ у. въ большомъ количеств Б въ Измайловскомъ Звьринць и въ Петровскомъ-Разумовскомъ; она попадалась мны ptже въ Звенигородскомъ у., откуда я имью экземпляры изъ окрестн. села Аносина (льсь Екатериновка); въ Можайскомъ у. ее нельзя назвать очень обынновенной и здьсь опять сказывается спорадичность ея голоніи. Такъ, напримьрь, въ огромномъ удьльномъ Тесовскомъ льсу я находиль ее только въ опредыленныхъ мьстахъ, тогда какъ въ массь другихъ, гды попадалось много Evotomys glareolus Schreb., - льсныхъ мышей совершенно не было. itћстами она нерьдка въ Рузскомь и Кілинском уу. (село Демьяново) и нацддена въ Коломенскомъ у. В. Н. Вучети чемъ. По Сатунину, льсная мышь распространена по всей губерніи.

IІерехо.я теперь къ разсмотрьнію географическаго распространенія этого грызуна, я съ самаго начала долженъ отмытить ть трудности, съ которыми неизбжжно связано составленіе подобнаго очерка. Дьло въ томъ, что только за посльднее время обрашено-правда очень немногим-достаточное вниманіе на хоponо диференцированныя георафическія формы лtсної мmm. Между тьыъ, всь старые авторы, естественно, отмьчали только Mus sylvaticus L. и безъ просмотра оригинальныхъ экземпляровъ невозможно судить о томъ подвидь, съ коимъ они имьли дьло.

Въ центральныхъ губерніяхъ Европейской Россіи встрьчается исключительно MIus sylvaticus mosquensis sbsp. nov. Она найдена въ Дорогобужскомъ (П. С. Г а ль ц о в м ъ), Сычевскимъ и Гжатскомъ уу. Смоленской губ., въ ю.-в. части Орловской губ. (мною и С. Н. Горбачевым ъ). Для Псковской губ. (Холмскій и Торопецкій уу.), выроятно, этотъ подвидъ указанъ Эс ау ловы м ъ 
(58, р. 225), а въ фауну Ярославской губ., включенъ Л. П. С абан ье в ы м ( 5 о, І9). Далье на востокъ этоть подвидъ встрьчается въ Казанской, Симбирскої, Саратовской и Оренбург-

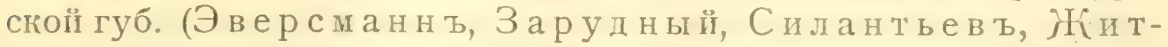
ко въ). Найдена въ Вятской губ. (Эверсман нъ) и въ разныхъ частяхъ Пермской (Л. П. С а б а н в в ъ, І 49, р. 7). Однако, я затрудняюсь даже прио́лизительно указать, какої подепдь льсної мыши встрбчается въ двухъ посльлнихъ губерніяхт. IІ словащь Палласа (г 3 о, р. І68), уральскія особи очень мелки и сьры. Такъ же невозщожно сказать, какой подвидъ встрђченъ въ Мугоджарскихъ горахъ Леманомъ и 3 арудным ъ ${ }^{1}$ ).

Что касается до распространенія льсной мыши въ южныхъ губерніяхъ Европейскої Россіи, то уже экземпляръ изъ Черниговской губ., бывшій у меня въ рукахъ, я отношу къ $M . s . p r i n-$ ceps Barr.-Ham.,-очень свьтлой и крупной формь, съ ярко-ржавой окраской спины и ожрулылғ ржавымъ пятномь на груди, которое рьзко выступаеть на чисто-бьломъ мьх́ нижней стороны тьла. Быть можетъ, къ этому виду относятся и льсныя мыши, найденныя Черн а ем и С о о вы м въ Харыновсіої губ., К е с сл е ом ъ (76, стр. 63)--въ Кіевской и В elk е около Радомысля и Каменець-Юодольска. Нћтъ сомнћнія, что къ этому подвиду принадлежать мыши, добытыя Нордман ном н на побережьғ Чернаго моря, большіе размьры этихъ грызуновъ отиьчаеть и самь авторъ. По крайнеї мьрt; экземпяры окрестностей Симферополя, бывшіе въ моихъ рукахъ, а также съ южнаго берега Крыма представляли типичныхъ II. s. princeps Barret-Ham. Въ западномъ кра'ы къ посльднему подвпду, вьроятно, относятся и льсныя мыши, найденныя Э їх в льдомъ въ Литвь, Волыніи и Подоліи, а въ Польшь-Т ачанов ски м ъ ( 85, р. ІзІ). Но уже въ прпобалтійскихъ провинціяхь, гды льсная мышь много

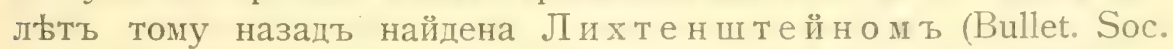
Imp. Nat. de Moscou, І829, р. 290) - въ Курляндіи, Фише ром ъ-въ Лифляндіи, а въ нов́йшее время добыта Греве́ и С. А. Бут у р ли и ы 'ь,-встрьчается особый подвидъ $М$. s. wintoni Barret-Han., распространенный тањће вь Петеро́ургскої губ́., для которой онъ отмьчченъ Брандтомъ (34, р. 33), В. Л. Бі анки (23, р. І3). Весьма вьроятно, что этоть же подвидъ встрьчается и въ Финляндіи (Brandt, 34, p. 33).

1) Тъ „очень свьтлыя особи" льсной мыши, которыя нашель L e h m a n въ долннь Эмбы, на вост. побер. Каспія и въ Бухарь, относятся, вьроятно, къ M. s. arianus Blanf. 


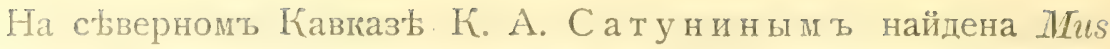
sylvaticus L. (врядъ ли типичная форма). Все Закавказье, кром'b ю.--зап. части, населяетъ M. s. arianus Blanf., а въ Ольшинскомъ округ'ь встрбчается особый, еще не названный подвидъ.

О распространеніи этого грызуна въ Западной Сибири наши свыдднія еще очень кратки. ПІо Словцову, эта мышь встрђчена въ Успенскомъ бору бл. Тюмени и бл. дер. Переваловой. По Двигубскому (44, р. 54), встрьчается въ Сибири до р. Оби. Георги отмычаеть ее для долины Иртыша и Оби. Въ Томскомь крағ, по свидытельству Н. Ө. К аш енко, найдена только одинъ разъ бл. села Локоть (окр. Змьиногорска). Далье на востокъ встрычаются уже хорошо диференцированные подвиды. Такъ, всю область Забайкалья, Ганъ-Су, Ала-шань, Приморскій край населяеть M. s. major Radde.

Въ центральной Азіи (Алтай и прилегающія къ нему рав. нины, Тарбагатай, Тибетъ) встрбчается M. s. chevrieri M. Edw., в Броятно идентичная съ M. tscherga Kastsch. Наконецъ, въ Персіи, Туркестанђ, Кашгарђ, Гильгить, Тянь-Шань и Индіи распространена $M$. s. arianus Blanf.

Въ Западной Европь льсная мышь, распространенная отъ Исландіи, Швеціи, Норвегіи до Испаніи, Италіи и Сициліи, распадается на цълый рядъ хорошо диференцированныхъ географическихъ формъ. На Шетландскихъ о-вахъ (Фэръ Айлъ) встрьчается M. s.fridaricensis Kinnear., въ Англіи, Шотландіи, Бельгіи, Голтандіп, ШІвейцаріп, сьв.-зап. Франціп, Нталіи распространена M. s. intermedius Bellamy. Въ западной Англіи посльдній видъ замғняетъ и встрбчается восточнье колоніями среди него $M . s$. wintoni Barr.-Наm., распространенная далће въ Петерб. губ., въ прибалтійскихъ провинціяхъ, Германіи, Богеміи, Силезіи, ю.-вост. Франціи. Въ Ирландіи и на Гебридахъ (Люисъ, Скэй) встрььчается MI. s. celticus Barr.-Ham., на внћшнихъ Гебридахъ (Борерэй, Люисъ) - M. s. hebridensis Winton, на остр. св. КильдыM. s. hirtensis Barr.-Нат., въ Исландіи-M. s. islandicus Thien., въ Швеціи и Даніи-M. sylvaticus L. typ., въ Румыніи, юж. части Евр. Россіи и Крыму-M. s. princeps Barret-Ham., въ сьв. Испаніи-M. s. callipedis Cabrera, въ Португаліи и южн. ИспаніиM. s. hayi Waterh., въ Сициліи-MI. s. dichrums Rafin.

\section{Образъ жизни.}

Распространеніе этого вида тьсно связано съ льсомъ. Льсная мышь особенно любитъ сырыя тьнистыя мьста, вблизи отъ воды, глубокіе овраги, поросшіе папоротникомь и густой травой, большіе тнилые пни деревьевъ, между покрытыми мхомъ корнями 
которыхъ выступаютъ наружу многочисленныя норы этого грызуна. Какъ я говориль уже выше, даже въ тьхъ мьстахъ, гды этоть грызунъ обыченъ, въ его распространеніи сказывается извьстная спорадичность, стоящая въ связи съ колоніальнымъ образомъ жизни. Насколько я могъ замбтить, льсная мышь проявляеть напбольшую дьятельность ночью,-тогда она часто попадается въ ловушки и, очевидно, выходитъ изъ норъ за кормомъ. Свои гнбзда эти мыши устраиваютъ подъ корнями деревьевъ, часто на довольно значительной глубинь. Зимою Mus sylvaticus mosquensis Ogn. часто появляется на поверхности сньга и попадается въ ловушки. К. А. С атунин и изсльдоваль гньзда въ половинь октября, надыясь найти зимніе запасы, но ихъ не оказалось, несмотря на то, что было пересмотрьно около 20 гныздъ въ то время, какъ выкорчевывали пни. Только въ очень холодные морозные дни льсная мышь, по С атунину, лежить въ оц пеньніи и не выходить наружу.

Поздней осенью, а рьже даже и среди льта, мнь приходилось ловить льсныхъ мышей в домахъ.

Всь⿱㇒ экземляры коллекціи изъ Московской губ. перечислены въ таблицахъ измьреній.

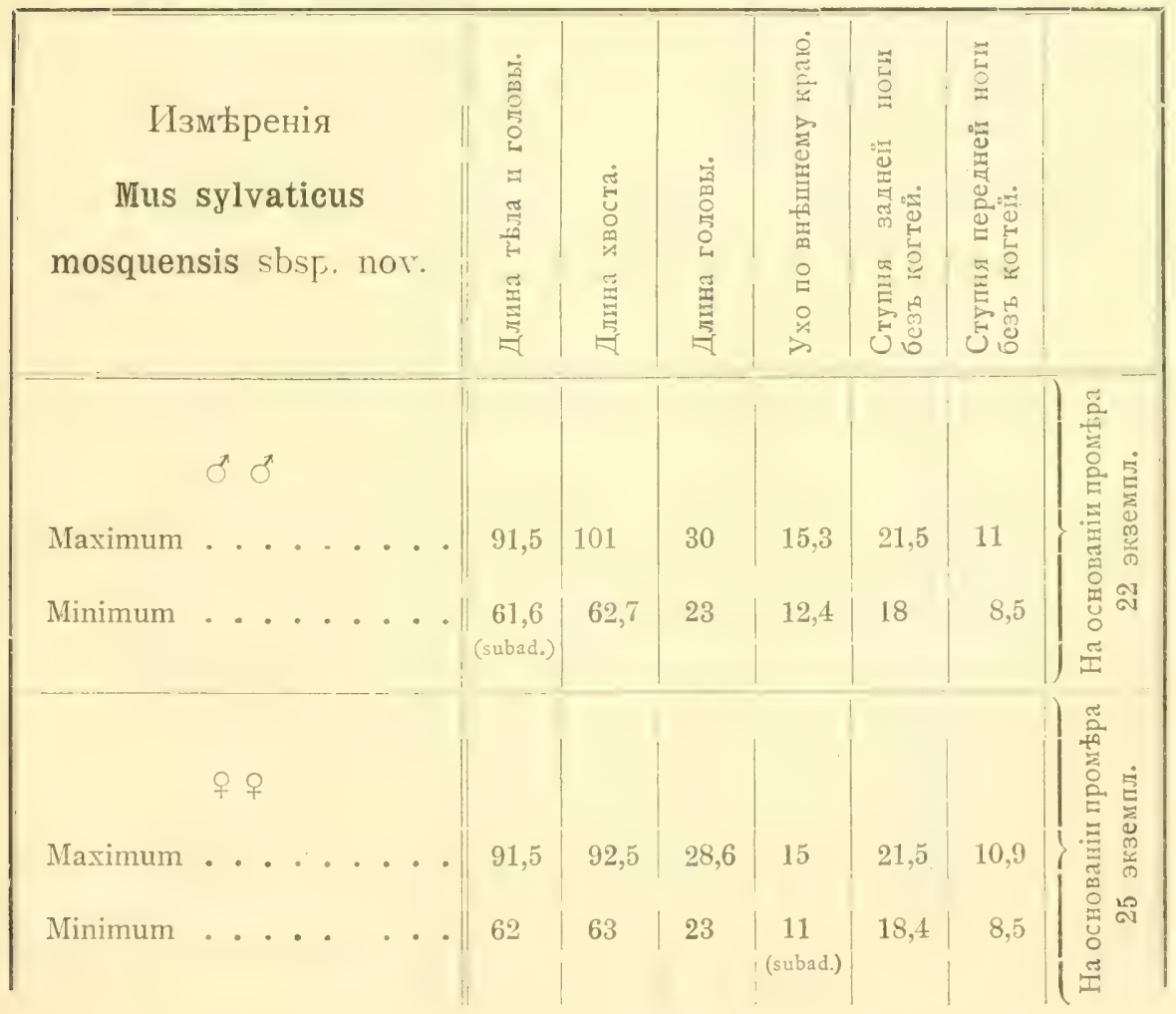




\begin{tabular}{|c|c|c|c|c|c|c|c|c|c|c|}
\hline 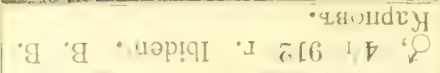 & $\bar{\infty}$ & $\stackrel{\Xi}{\Xi}$ & $\begin{array}{l}69 \\
61\end{array}$ & $\cong$ & $\ddot{0}$ & $\stackrel{\infty}{\infty}$ & $\vec{z}$ & $\vec{\nabla}$ & $=$ & 吾 \\
\hline 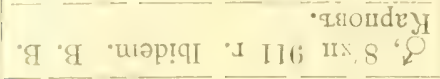 & is & sis & कू & 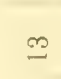 & 1) & $\bar{\infty}$ & $\begin{array}{l}\infty \\
\stackrel{i}{-}\end{array}$ & $\bar{\sigma}$ & $g$ & 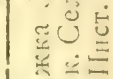 \\
\hline 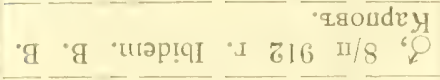 & 80 & $\bar{\infty}$ & ลิ & $\stackrel{1}{2}$ & $\begin{array}{c}\sigma_{0} \\
\infty\end{array}$ & $\infty$ & $\stackrel{20}{-2}$ & $\frac{6 !}{31}$ & $=$ & $\therefore=$ \\
\hline 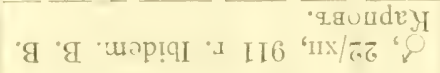 & ${ }_{s}^{s}$ & is & $\overrightarrow{\mathscr{N}_{0}}$ & oi & $\theta$ & $\infty$ & $\rightleftarrows$ & $\frac{61}{31}$ & $\equiv$ & 5 \\
\hline 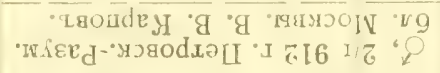 & $\overline{\bar{x}}$ & 秀: & ผึ & 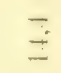 & $\bar{\infty}_{\infty}^{\infty}$ & r & \pm & $\overrightarrow{01}$ & $=$ & 空总 \\
\hline 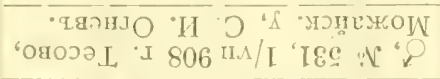 & $\frac{10}{\sigma}$ & $\bar{\Xi}$ & ది & $\overline{\bar{i}}$ & $\stackrel{\circ}{=}$ & $\stackrel{\oplus}{-}$ & 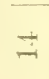 & $\frac{10}{31}$ & $\stackrel{0}{\Xi}$ & \\
\hline 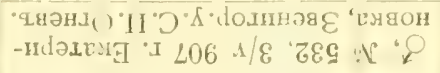 & 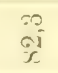 & 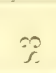 & कू & ai & $\stackrel{\bar{t}}{\infty}$ & $\infty$ & 9 & 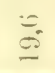 & $\infty$ & \\
\hline 'p!qI "I & 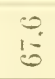 & $\stackrel{0}{i}$ & $\stackrel{\infty}{\vec{N}}$ & $\begin{array}{l}20 \\
\text { si }\end{array}$ & $\overline{\sigma^{\circ}}$ & $\bar{N}$ & $\stackrel{n}{m}$ & 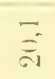 & $\equiv$ & \\
\hline •p!qI " & 影 & $\overline{\bar{\infty}}$ & an & $\overline{a_{i}}$ & $\infty$ & $\infty$ & $\stackrel{0}{ \pm}$ & $\overline{\check{\pi}}$ & $\rightleftarrows$ & \\
\hline 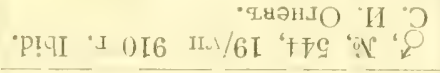 & 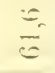 & $i$ & ले & $\underline{=}$ & $\sigma$ & మ & $\stackrel{10}{-10}$ & $\underline{x}$ & t) & \\
\hline 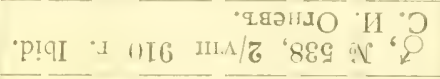 & 8 & $\bar{E}$ & तi & $\underline{z}$ & 0 & $\vec{E}$ & 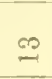 & $\underline{s}$ & 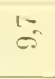 & \\
\hline 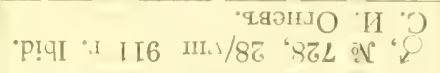 & $1=$ & $\hat{i}$ & ผ & $\stackrel{0}{s i}$ & 10 & $n$ & 92 & 18 & s. & \\
\hline 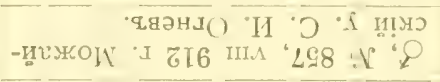 & $=$ & $\overrightarrow{30}$ & ז. & $\stackrel{s}{s i}$ & $\theta$ & $\infty^{\infty}$ & 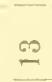 & $\overline{\bar{N}}$ & $\cong$ & \\
\hline 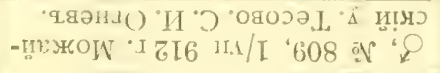 & $\ddot{r}$ & $\stackrel{19}{*}$ & $+\frac{10}{109}$ & ti & $\stackrel{\infty}{\stackrel{\infty}{0}}$ & $\underline{0}$ & si & $\underline{0}$ & $\Leftrightarrow$ & \\
\hline 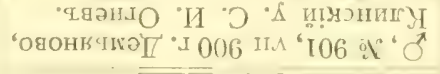 & $\stackrel{10}{=}$ & $\frac{1}{1 !}$ & $\ddot{D}$ & OI & $\tilde{\theta}^{\circ}$ & N & $\stackrel{-1}{4}$ & $\frac{01}{2}$ & $\stackrel{\infty}{\infty}$ & \\
\hline 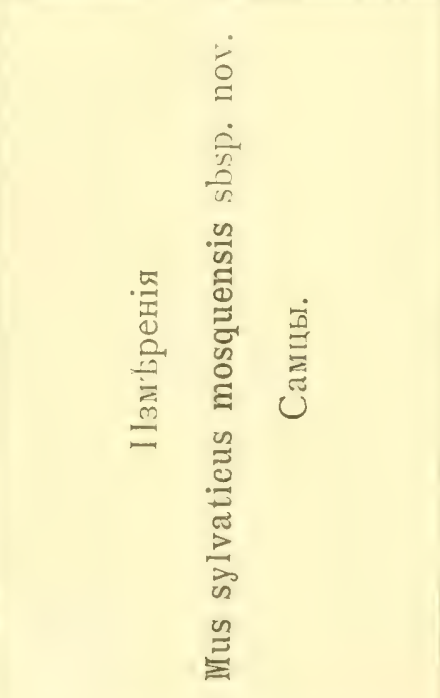 & 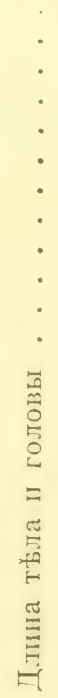 & 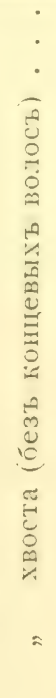 & $\begin{array}{l}\vdots \\
\vdots \\
\vdots \\
: \\
\vdots \\
\vdots \\
\end{array}$ & 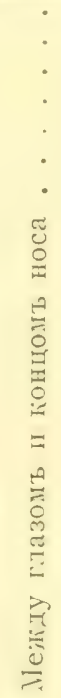 & 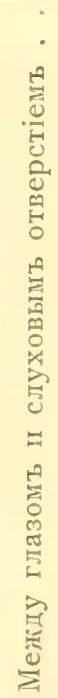 & 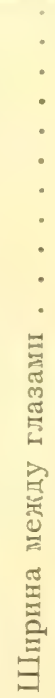 & 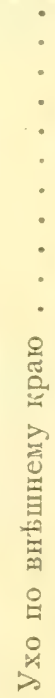 & 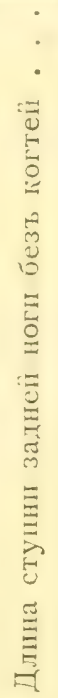 & 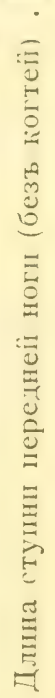 & \\
\hline
\end{tabular}




\begin{tabular}{|c|c|c|c|c|c|c|c|c|c|c|}
\hline 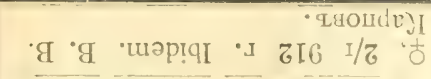 & is & $\tilde{x}$ & ลิ & $=$ & $\dot{\sigma}$ & $\sigma$ & $\stackrel{12}{=}$ & $\frac{\pi}{\tilde{\sigma}}$ & $\equiv$ & \\
\hline 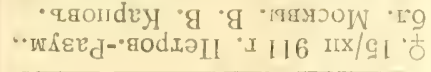 & $\bar{\omega}$ & $\bar{x}$ & 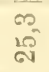 & $\therefore$ & $\bar{\infty}^{2}$ & 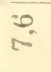 & $\underset{-10}{-10}$ & $\overline{\sigma 1}$ & $\Xi$ & \\
\hline 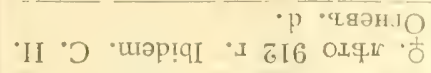 & 15 & $\frac{13}{6}$ & $\begin{array}{l}\overline{0} \\
10^{\circ}\end{array}$ & $\stackrel{c}{a i}$ & 12 & $\infty$ & \pm & 12 & $1=$ & \\
\hline 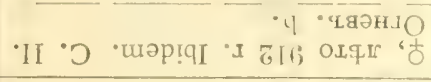 & $\stackrel{5}{a}$ & $\stackrel{\infty}{i-\infty}$ & $\begin{array}{l}\infty \\
\text { న్ } \\
\text { ลิ }\end{array}$ & $\because$ & $\infty$ & $\approx$ & 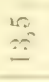 & $\stackrel{0 !}{=}$ & $\equiv$ & \\
\hline 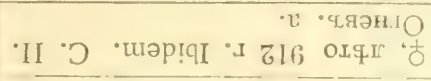 & $\stackrel{10}{E}$ & $\stackrel{3}{=}$ & $\begin{array}{l}\infty \\
\text { an } \\
\text { and }\end{array}$ & $\underline{i}$ & $\infty$ & $\approx$ & $t=$ & $\stackrel{n}{0}$ & $\because$ & \\
\hline 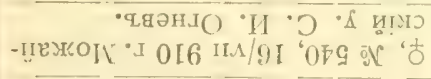 & $\bar{i}$ & $\stackrel{+i}{\frac{3}{3}}$ & $\begin{array}{l}\infty \\
\mathrm{a}\end{array}$ & 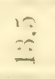 & $\sigma_{0}$ & $\infty$ & 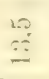 & 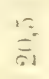 & $\cong$ & \\
\hline •9996 ơ cu & $\hat{s i}_{i-}^{+}$ & $\vec{s}$ & ๙ิ & $\stackrel{20}{2 i}$ & $\vec{\infty}$ & $\infty$ & \pm & $\bar{a}$ & $\equiv$ & . \\
\hline 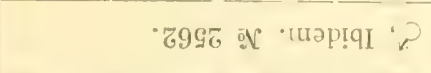 & $\frac{a 1}{\dot{x}}$ & 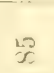 & ลั & $\cong$ & $\infty$ & $\infty$ & ${ }_{2}^{2}$ & $\bar{g}$ & $\equiv$ & $\sum_{\pi}^{0}$ \\
\hline 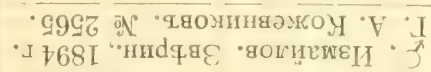 & 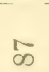 & $\frac{1}{3}$ & $\stackrel{5}{\mathrm{E}}$ & 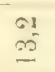 & $\infty$ & $\infty$ & $\overrightarrow{\sigma i}$ & 3 & $\equiv$ & 兽 \\
\hline 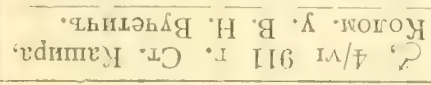 & $?$ & $\overrightarrow{10}$ & 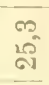 & $\begin{array}{l}6 \\
\text { si }\end{array}$ & $\overline{10}$ & 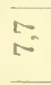 & $\stackrel{0}{-}$ & 气̂́: & $\stackrel{\rho}{\equiv}$ & 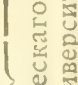 \\
\hline 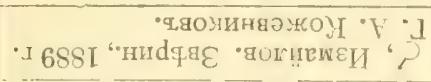 & $\bar{z}$ & i- & S & $\stackrel{25}{2}$ & $\stackrel{F}{\Rightarrow}$ & $\sim$ & $\stackrel{2}{2}$ & $\stackrel{?}{\varrho}$ & $\stackrel{\infty}{\equiv}$ & $\left\{\begin{array}{l}0 \\
0\end{array}\right.$ \\
\hline 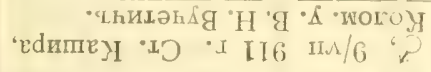 & $\ddot{\infty}_{\infty}^{\infty}$ & $\hat{c}_{i}^{i}$ & ลั & $\stackrel{s}{s i}$ & 8 & $\stackrel{N}{\sim}$ & 19 & $\cong$ & 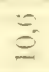 & 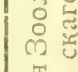 \\
\hline 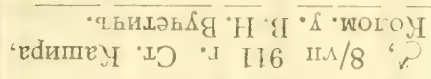 & $\overrightarrow{8}$ & $=$ & a & $\underset{8 !}{9 !}$ & ${ }^{\infty}$ & $\infty$ & $\stackrel{\vec{s}}{i}$ & $\overrightarrow{61}$ & $\underline{3}$ & 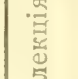 \\
\hline 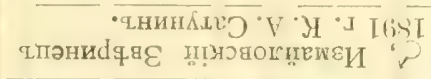 & 芯 & क & $\bar{b}_{\substack{\infty \\
\infty}}$ & $1=$ & $\stackrel{\Xi}{\Xi}$ & ్ㅡㅁ & $\stackrel{\circ !}{ \pm}$ & $\underline{x}$ & $\stackrel{\infty}{\triangleq}$ & ह్ \\
\hline 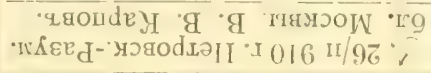 & $\overbrace{i}^{1}$ & $\hat{\vec{r}}$ & เి & $\begin{array}{l}10 \\
\text { ai }\end{array}$ & t & $\infty$ & $\bar{\nexists}$ & $\overline{1}$ & $\equiv$ & \\
\hline 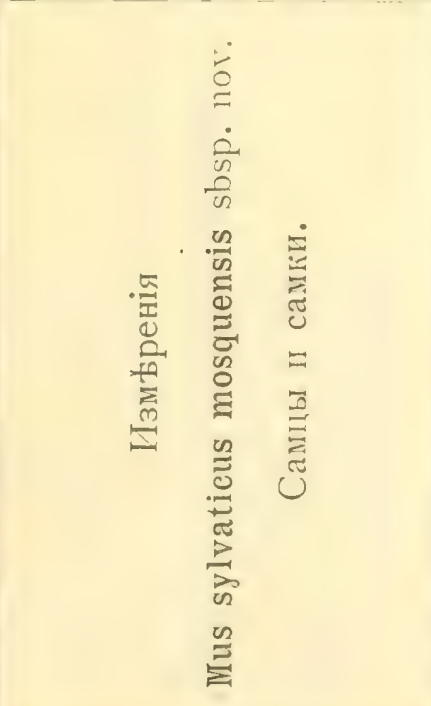 & 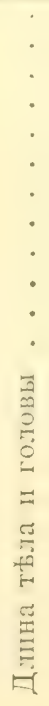 & 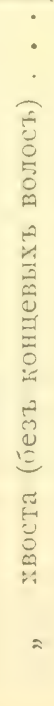 & 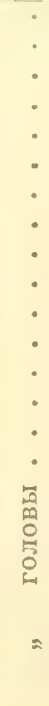 & 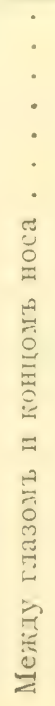 & 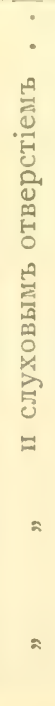 & 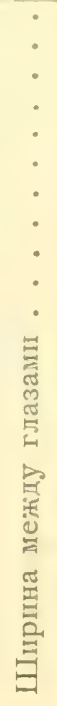 & 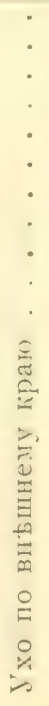 & 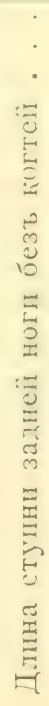 & 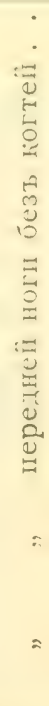 & \\
\hline
\end{tabular}




\begin{tabular}{|c|c|c|c|c|c|c|c|c|c|c|}
\hline 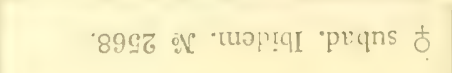 & $\stackrel{ }{\sim}$ & $\frac{10}{12}$ & $\stackrel{\infty}{\text { a }}$ & $\stackrel{\Theta}{\sim}$ & 上 & $\stackrel{10}{1}$ & 30 & $\stackrel{0}{=}$ & $\begin{array}{l}\infty \\
\infty \\
\infty\end{array}$ & $\dot{\Xi}$ \\
\hline 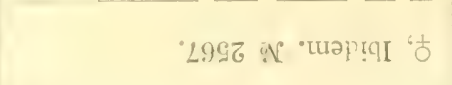 & $\overline{8}$ & \& & $\bar{\infty}$ & $\Xi$ & $\bar{\infty}$ & - & $\underline{Z}$ & ลิ & $\begin{array}{l}10 \\
0 \\
-\end{array}$ & $\underset{\Xi}{\tilde{E}}$ \\
\hline 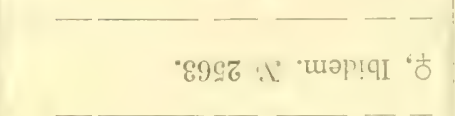 & मू & $\infty$ & ลิ & $\underset{\infty}{\infty}$ & - & $\bar{\sigma}$ & $\underset{\infty}{\infty}$ & $\bar{m}$ & 2 & 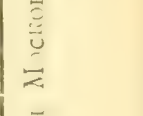 \\
\hline 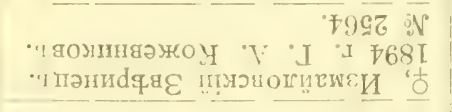 & $\underset{\infty}{\stackrel{5}{\infty}}$ & $\bar{\sigma}$ & $\begin{array}{c}0 \\
\text { à }\end{array}$ & $\stackrel{2}{-1}$ & $\bar{\sigma}$ & $\bar{c}$ & $\Xi$ & $\stackrel{5}{10}$ & 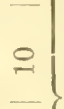 & 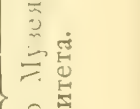 \\
\hline 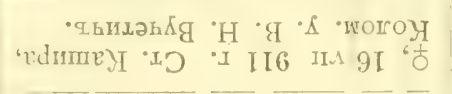 & $\stackrel{0}{\mathfrak{S}^{\circ}}$ & $\underset{\infty}{\infty}$ & â & $\stackrel{\infty}{\stackrel{\infty}{\sim}}$ & $\stackrel{\text { gn }}{=}$ & is & $\underset{\infty}{\infty}$ & ลิ & 을 & 至 \\
\hline 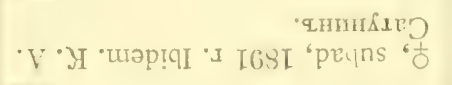 & $\stackrel{80}{0}$ & שి & ลึ & $\stackrel{\text { aI }}{\stackrel{1}{-}}$ & $\stackrel{\infty}{\varrho}$ & 0 & $\exists$ & $\stackrel{+1}{\stackrel{\infty}{\rightarrow}}$ & $\stackrel{0}{\circ}$ & $\begin{array}{l}\overrightarrow{0} \\
0 \\
0 \\
0 \\
0\end{array}$ \\
\hline 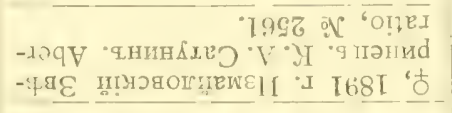 & $\frac{10}{12}$ & $\bar{\infty}$ & $\begin{array}{l}10 \\
\text { ลิ }\end{array}$ & $\underset{10}{10}$ & $\stackrel{\vartheta}{O}_{-1}^{-1}$ & $\tilde{\sigma}$ & 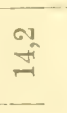 & की & $\stackrel{E}{\underline{\theta}}$ &. \\
\hline 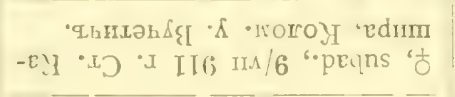 & $\stackrel{20}{8}$ & 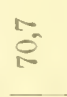 & an & $\stackrel{\infty}{-}$ & $\infty^{20}$ & $\Leftrightarrow$ & $\stackrel{\forall}{\Rightarrow}$ & Еิ & $\begin{array}{l}0 \\
0 \\
0 \\
-1\end{array}$ & $\stackrel{0}{:}$ \\
\hline 'g 'g 'uәpI!I 's II6 IIx/9 ${ }^{\circ}$ & 2 & $\stackrel{\infty}{\infty}$ & $\sqrt[10]{a 1}$ & $\stackrel{\infty}{\infty_{-}^{-}}$ & $\stackrel{ }{\sim}$ & $\stackrel{10}{5}$ & $\underset{F}{\stackrel{N}{Z}}$ & $\stackrel{\infty}{\infty}$ & $\stackrel{-}{\underline{\theta}}$ & 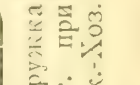 \\
\hline 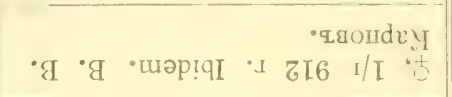 & 8 & $\stackrel{2}{1}$ & 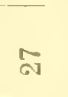 & $\begin{array}{l}20 \\
\stackrel{20}{9} \\
\stackrel{9}{-1}\end{array}$ & $\infty$ & $\stackrel{\sim}{\sim}$ & $\overrightarrow{-}$ & $\vec{a}$ & $\begin{array}{l}10 \\
0 \\
-1\end{array}$ & 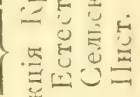 \\
\hline 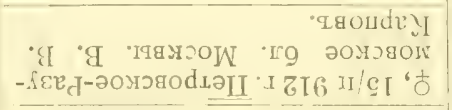 & $\stackrel{\infty}{\infty}$ & 19 & : & $\stackrel{20}{\stackrel{20}{\sim}}$ & 욱 & N & $\begin{array}{l}10 \\
\stackrel{10}{0}\end{array}$ & $\overrightarrow{\mathrm{N}}$ & 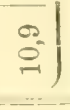 & 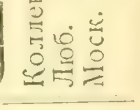 \\
\hline 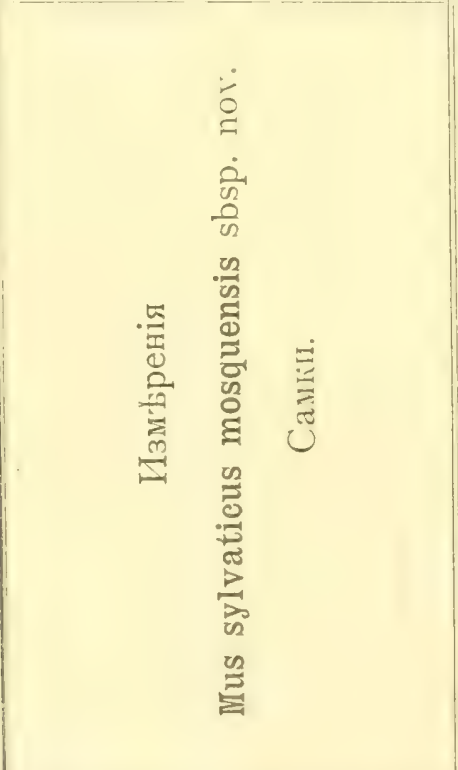 & 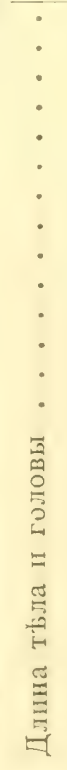 & 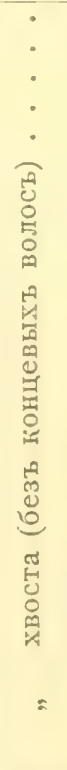 & 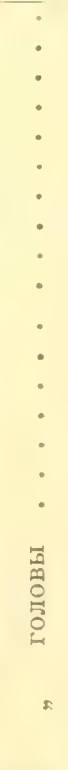 & 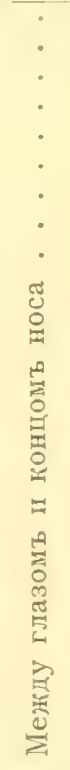 & 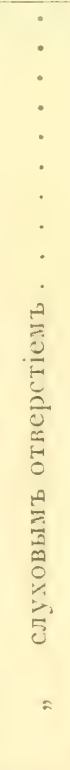 & 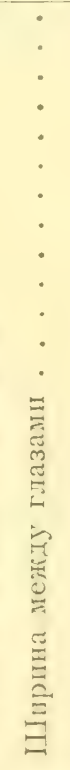 & 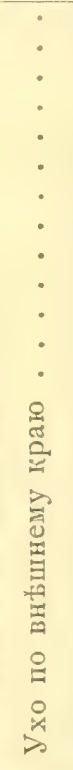 & 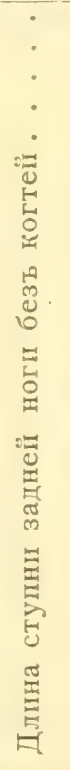 & 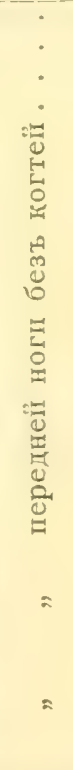 & \\
\hline
\end{tabular}




\begin{tabular}{|c|c|c|c|c|c|c|c|c|c|}
\hline \multirow{3}{*}{ 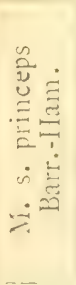 } & 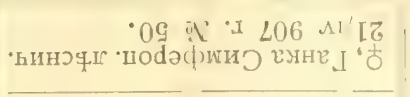 & $\stackrel{\infty}{\infty} \underset{-1}{-1}$ & $\overrightarrow{3}$ & 은 & $\stackrel{10}{=}$ & & Is & $\overrightarrow{\text { से }}$ & 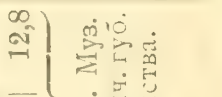 \\
\hline & 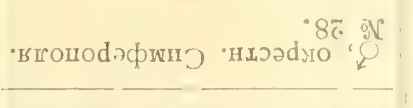 & సิ 1 & बी & $\stackrel{10}{10}$ & $\stackrel{\circ}{\circ}$ & & $e_{0=1}^{\infty}$ & 29 & m \\
\hline & 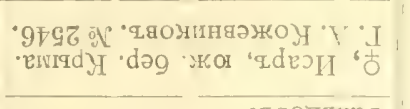 & $\stackrel{8}{9}$ & लै & $\stackrel{20}{-1}$ & $\exists$ & sis & $e_{0}^{\infty}$ & 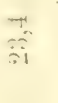 & 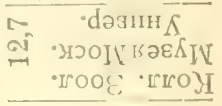 \\
\hline \multirow{8}{*}{ 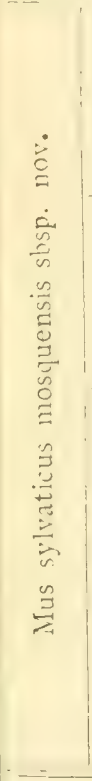 } & 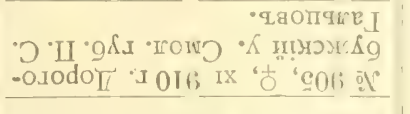 & 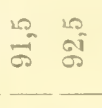 & ลั & $\stackrel{L}{ \pm}$ & $\infty$ & कै & $\stackrel{10}{10}$ & is & 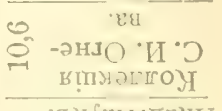 \\
\hline & 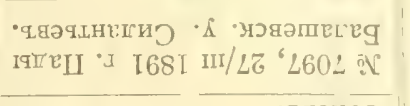 & $\infty$ & बी & $\begin{array}{l}\text { g } \\
\stackrel{-1}{\sim}\end{array}$ & as & 落 & $\stackrel{10}{50^{-1}}$ & $\stackrel{\infty}{2}$ & 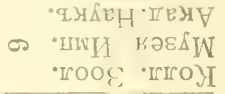 \\
\hline & 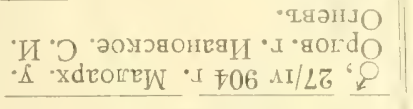 & $\infty$ & $\Xi$ & जิ & 20 & $\stackrel{\infty}{\infty}$ & $\underset{t}{\pi}$ & $\underline{2}$ & $\begin{array}{ll}10 \\
\infty \\
\infty\end{array}$ \\
\hline & 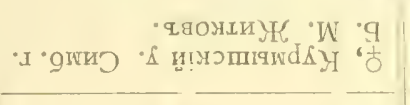 & $\begin{array}{cc}-\infty \\
10 \\
\infty\end{array}$ & कू & $\ddot{H}$ & $\stackrel{10}{0}$ & $\stackrel{0}{\infty}$ & ov & $\vec{\Phi}$ & 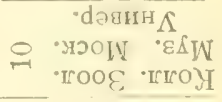 \\
\hline & 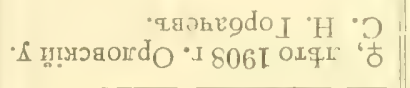 & న & న్ & $\stackrel{109}{\rightarrow-5}$ & os & co 2 & 20 & $\overline{\because 1}$ & $\infty$ \\
\hline & 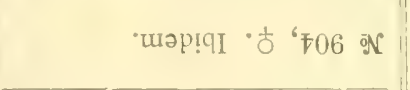 & $\stackrel{\infty}{\mathscr{E}}$ & $\stackrel{\mathrm{c}}{\mathrm{a}}$ & $\stackrel{\Im}{\sim}$ & $\exists$ & $\infty$ & $\stackrel{N}{\sim}$ & $\stackrel{\infty}{\infty}$ & $\stackrel{ }{-}$ \\
\hline & 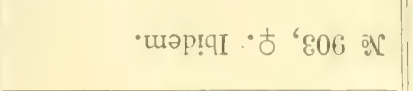 & $\underset{0}{\infty} \approx$ & is & $\stackrel{\infty}{0}$ & 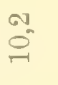 & $\sim$ & $\begin{array}{l}10 \\
\text { Iิ }\end{array}$ & $\Rightarrow$ & 20 \\
\hline & 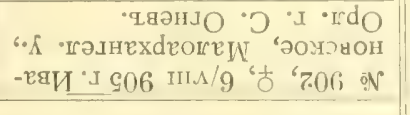 & రิ & बू & $\stackrel{10}{\approx}$ & $\stackrel{ }{-1}$ & - & $\stackrel{2}{a}$ & $\begin{array}{l}\infty \\
\infty \\
\infty\end{array}$ & $\overrightarrow{0}$ \\
\hline & 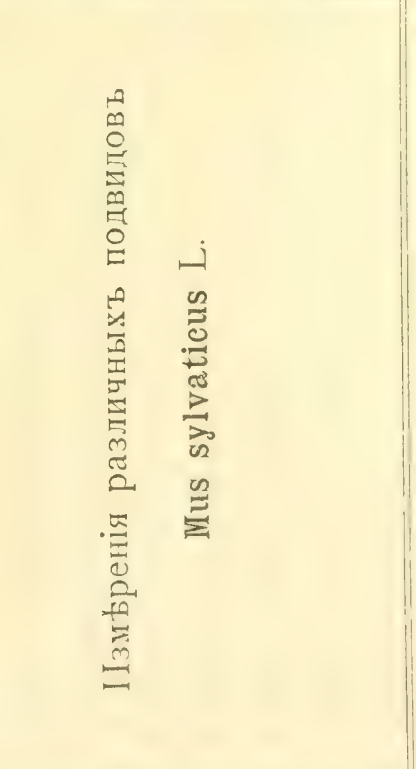 & 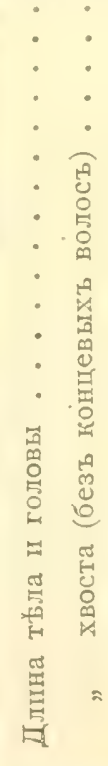 & 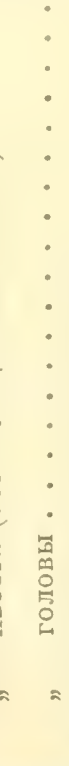 & 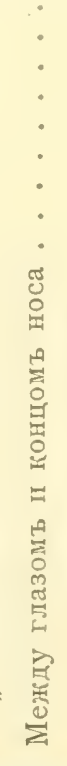 & 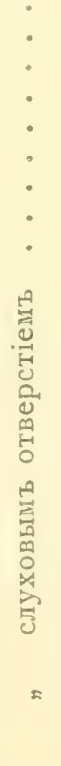 & 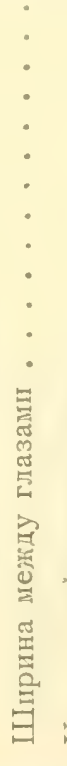 & 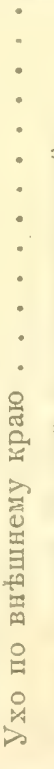 & 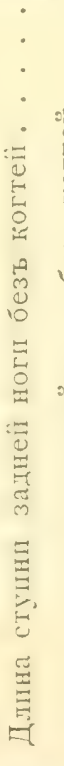 & 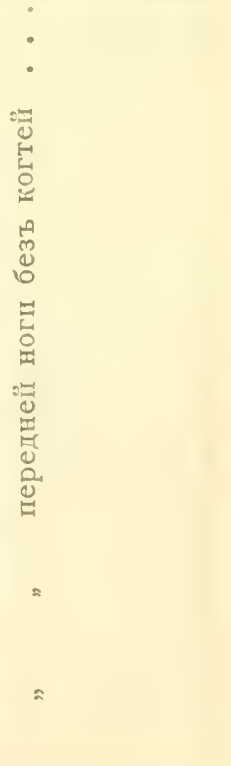 \\
\hline
\end{tabular}




\begin{tabular}{|c|c|c|c|c|c|c|c|c|c|c|}
\hline 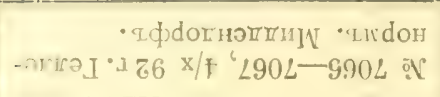 & 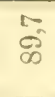 & 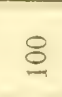 & 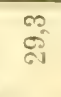 & $\begin{array}{c}20 \\
0 \\
0\end{array}$ & $\cong$ & 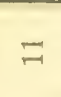 & $\stackrel{\infty}{0}$ & की & $\stackrel{\oplus}{=}$ & | \\
\hline 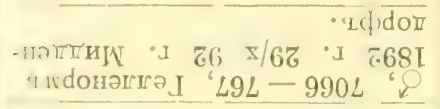 & $\begin{array}{l}6 \\
\infty \\
\infty\end{array}$ & गु & $\overrightarrow{0}$ & $e_{0}^{\infty}$ & $\therefore$ & $\vec{\sigma}$ & $\hat{\imath}$ & â. & $\frac{a b}{c c^{\infty}}$ & I \\
\hline 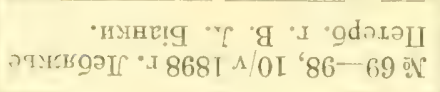 & $\begin{array}{l}10 \\
\infty \\
\infty\end{array}$ & $\because$ & ঙ્స & $\underset{\nabla}{\sigma}$ & 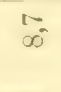 & $\sigma_{5}$ & $\stackrel{10}{ \pm}$ & $\vec{i}$ & $\stackrel{91}{-1}$ & $\underset{\square}{\vdots}$ \\
\hline 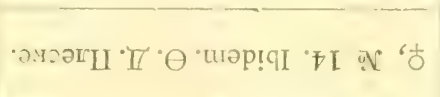 & ळొ & $\bar{\Xi}$ & $\overline{20}$ & $\overline{a y}$ & $\hat{\varepsilon}$ & $\circ$ & $\ddot{\Xi}$ & $\stackrel{01}{a-1}$ & $\stackrel{\square}{=}$ & 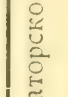 \\
\hline 'Iquд & ळે & $\cong$ & $\overline{\sigma_{3}}$ & กิ & $\cong$ & $\infty$ & $\stackrel{1}{\infty}$ & $\stackrel{\varphi}{+}$ & @1 & 产 \\
\hline 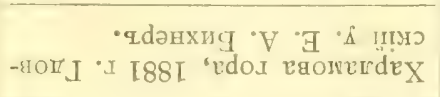 & \& & $\bar{\sigma}$ & $\sqrt{10}$ & $0_{-1}^{20}$ & $\stackrel{10}{\equiv}$ & $\sqrt{10}$ & 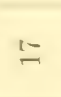 & $i_{10}^{6}$ & $\stackrel{0}{=}$ & $\mid \begin{array}{l}\bar{y} \\
\bar{c} \\
\vec{z}\end{array}$ \\
\hline 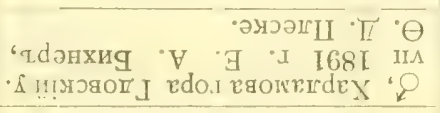 & $\begin{array}{l}10 \\
\stackrel{10}{\mathrm{~N}}\end{array}$ & $\begin{array}{l}10 \\
2 \\
\vdots \\
=1\end{array}$ & 108 & $\underset{10}{10}$ & 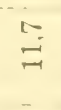 & $\stackrel{\infty}{=}$ & $\ddot{0}$ & $\begin{array}{l}10 \\
15 \\
61\end{array}$ & $\begin{array}{c}\infty \\
\text { si } \\
-\end{array}$ & 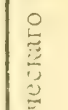 \\
\hline 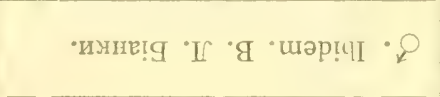 & 总 & $\stackrel{15}{\stackrel{10}{2}}$ & $\ddot{\infty}$ & 20 & $=$ & $\infty$ & $\stackrel{c}{E}$ & $\begin{array}{l}\infty \\
12 \\
\text { si }\end{array}$ & $\stackrel{\Xi}{=}$ & $\begin{array}{l}5 \\
5 \\
0 \\
0 \\
0 \\
0\end{array}$ \\
\hline 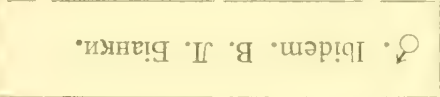 & $\begin{array}{l}21 \\
12\end{array}$ & $\stackrel{5}{\circ}$ & vi & $\stackrel{10}{10}$ & $e^{10}$ & $\tilde{\sigma}^{y}$ & in & in & $\begin{array}{l}20 \\
-1\end{array}$ & 更 \\
\hline 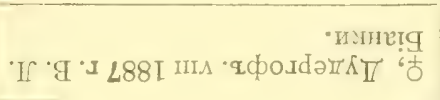 & ธิ & $\stackrel{8}{2}$ & $\stackrel{\infty}{\infty}^{\infty}$ & ${ }_{12}^{10}$ & $\begin{array}{l}12 \\
\infty\end{array}$ & $I_{n}^{2}$ & $\stackrel{\infty}{=}$ & की & $\cong$ & $\begin{array}{l}0 \\
0 \\
5 \\
5 \\
0\end{array}$ \\
\hline 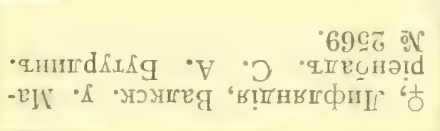 & 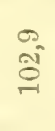 & $\stackrel{?}{\Xi}$ & $\begin{array}{l}\infty \\
\mathfrak{m}^{-}\end{array}$ & $\stackrel{\mathscr{v}}{\mathscr{E}}$ & $\stackrel{\varphi}{0}$ & $\stackrel{\sigma}{\sigma}$ & $\stackrel{0}{\sim}$ & $\hat{s}_{i}^{\infty}$ & + & \\
\hline 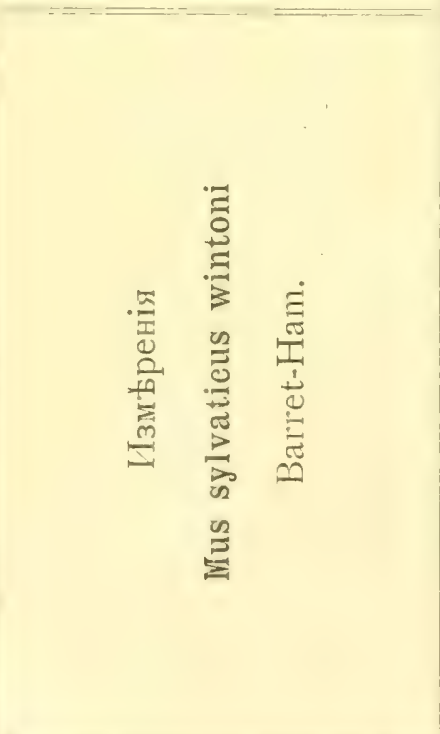 & 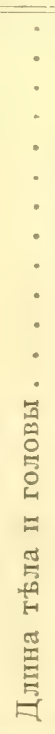 & 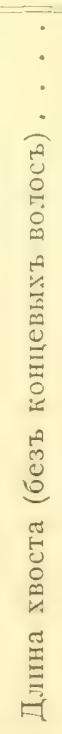 & 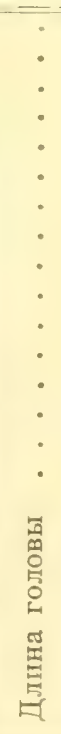 & 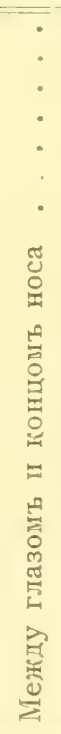 & 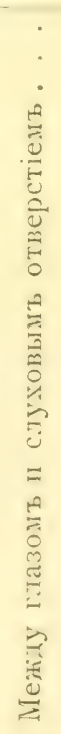 & 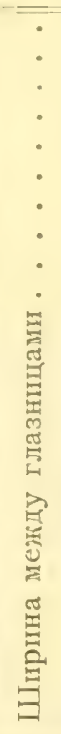 & 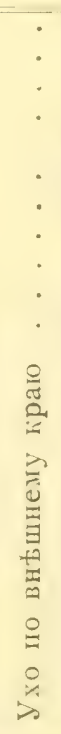 & 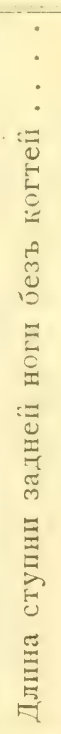 & 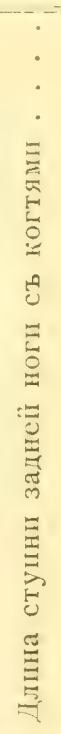 & \\
\hline
\end{tabular}




\section{Mus musculus L.}

\section{Мышь домашняя.}

Mius musculus Linnaeus (98), p. 83, B la s i us (27), p. 320, Milla is (1 10$)$, II, p. 198 p l. 41. Trouessart $(200)$, p. 145. С атунй н $(165)$, стр. 13 II (1 6 6) p. 2.

\section{Систематическія особенности.}

По общему виду, черепь (табл. I рис. 34) отличается тьми характерными особенностяли, которыя своїственны всему роду Миь.

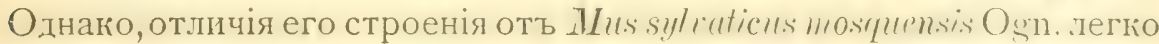
могутъ быть констатированы. Прежде всего, носовая область черепа домашнеї мыни замьтно уступаеть таковой у льсної. Далte;, вь самої формt nasalia сказываются, хотя и не очень рњзкія, но все же постоянныя особенности.-У льсной мыши для структуры носовыхъ костей характерно ръзкое расширеніе ихъ передняго отдыла сравнительно съ заднимь, прп чешъ передъ наступаюшиь расширеніемь заньчается какъ бы слабая перетянка. Nћsиlı домашнеї мыши расширяются ппереди равномырно и описанной перетяжки совершенно не замьтно. Весь характерь контура соприкосновенія лобныхъ и теменныхъ костеї $\mathrm{y}$ домашнеї мыши крайне рђзко отличается отъ того, что мы видьли у M. s. mosquensis Ogn. У Mus musculus L. лоб́ныя кости вдаются въ область теменныхъ обычно довольно рьзко дпференцированным угломъ, который лишь рьдко ииьеть болье округлую форму; но самымь характернымъ и постояннымъ признакомъ домашней мыши являются два длинныхъ острыхъ боковыхъ отростка pпriptiı, которые съ обьихъ сторонъ вдаются глубоко въ область frontalia, очерчивая угловатыї, языкообразный вырость, которымь онђ граничатъ съ теменными костями. Весьма характерна также форма os interparietale: при всеї ея измынчпвости, структура этой кости всегда рьзко отличается отъ таковой, у льсной мыши. У посльдняго вида эта кость, какъ было сказано уже выше, широка въ центральной часті и рђзко суживается къ бокамъ.У IIs musculus L. межтеменная кость гораздо шире, больше и почти совершенно не сужена къ бокамъ, внъшній контуръ которыхъ прямоугольный и не имьеть вида остраго выроста, какъ у льсной мыши. Наконецъ, при взгляды на черепъ домашней мыши сверху, бросается въ глаза контуръ межглазничнаго промежутка, который очерченъ двумя прямыи линіями, тогда какъ у средне-русской льсной мыши линіи, его окаймляющія, полулунно вдавлены съ боковъ. Bullae ossen домашней мыши болье толстостьнны и 
птоски, а condyll occipitales разставлены шире. Постоянная разнциа замьчается также въ развитіп отростковъ нижней челюсти: mocessus condylordeus у домашней мыши значительно короче, чьмъ у лtзсної, а $p r$. coronoideus болье приподнятъ ${ }^{1}$ ).

Что касается до строенія зубовъ, то они очень напоминаютъ таковое у льсной мыши. Главное различіе въ структуры перваго коренного нижней челюсти: на этомь зубь зальтно только 6 тупыхъ парныхъ бугорковъ, безъ развитія добавочныхъ.

Orраска варьируеть очень' значительно. Кромь типичныхъ

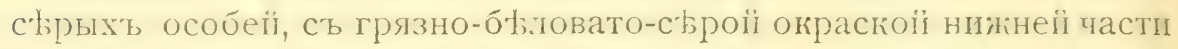
тьла, которыя безусловно преобладають, мы имьемъ цћлый рядъ отклоненій болће ржавой и о́уроватої окраски, окраска ниней стороны которыхъ желтье, особенно на брюхь. По свидьтельству К. А. Сатунина, такіе экземпляры чаще встрбчаются въ поль и льсу, вдали оть жилья. Наконецъ, еще рьже встрьчаются домашнія мыши сь довольно рђзкой двуцвђтной окраской.

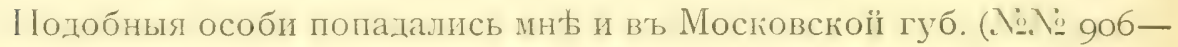
907). Спинная сторона ихъ тьла была не столь сьра, какъ у типичныхъ, но съ довольно рьзкой буроватой примьсью, вся нижняя сторона была бьловатая, съ свьтло-сьрыми основаніями волосъ. Наиболье рұзко отклоняющійся оть нормы экземпляръ добытъ К. А. С а тунинымъ въ І892 г. въ Измайловскомъ Звьрпнць ( 르 2550). Окраска спинной стороны этой мыши рыжеватопалевая, съ буровато-сћрыми окончаніями волосъ, вся нижняя сторона бьлая, съ примьсью палевого тона, особенно у основаванія волосъ. Уши, лапы и хвость-желтовато-бьлые. Этотъ экземпляръ, по особенностямъ окраски, очень близокъ къ Mus musculus bicolor Tich. et Kortsch. Присутствіе въ Московской губ. домашнихъ мышей, близкихъ къ этому подвиду киргизскихъ степей, каковымъ его считаеть большинство новњйшихь зоологовъ (Trou essart, K. А. С атунин ъ), заставляетъ меня остановиться въ Іраткихъ словахъ на выясненіи таксономическаго значенія двуцвћтной домашней мыши. Типичые элземпляры этой мыши отличаются чисто-былымъ (безъ сьрыхъ основаніи) мьхомъ нижней стороны тьла и свьтлымъ тономъ спины. Помимо этихь признаковъ, характернымъ является (см. таб́л. нзм., стр. 223) очень малая относительная длина хвоста и н'которыя структурныя особенности черепа (см. табл. I рис. 33), сближающія M. m. bicolor Tich. et. Kortsch съ M. m. hortulanus Nordm. Про-

1) Измьренія череповъ я даю въ общеї таблиц промьровъ экземпяровъ .II. musculus L. изъ Моск. губ́. см. стр. 222-223. 
сматривая большія серіи посльднихъ, я пришель къ положительному выводу относительно ихъ полнаго тожества съ подвидомъ киргизскихъ степей. Такимь образомъ, на югы Европейской Россіи обычную M. musculus L. заньняеть особая географическая форма M. m. hortulams Nordm. (= M. m. bicolor Tich. et Kortsch. ${ }^{1}$ ). Что касается до бьлобрюхихь домашнихь мышей, изрғдка попадающихся въ среднихъ губерніяхь (и даже на западь,-окр. Виллафранки), то, по комбинаціи отличительныхъ признаковъ, онъ все же довольно легко отличаются отъ южнаго подвида и представляють красочную аберрацію, напоминающую sulspeciès. 3.дtсь мы имґемъ случай какъ бы конвергенціи признаковъ. Особеннаго интереса заслуживаеть также какое-то постоянство отклоненій (свьтлая окраска нижней стороны) у далеко стояшихъ другъ отъ друга родовъ мелкихъ грызуновъ: достаточно вспомнить уже описанную выше Mrerotis campestris Blas. Въ заключеніе даю промьры московскихъ экземпляровъ, а также и астраханскихъ $M . m$. bicolor Tich. et Kortsch.

\section{Географическое растространеніе.}

Домашняя мышь распространена по всей Московскої губ., будучи пріурочена главнымъ образомъ къ человьческимъ жилишамъ.

Въ Западной Европь Mus musculus L. встрьчается повсемъстно; переходя въ Европейскую Россію, мы находимъ этого грызуна отъ Кольскаго полуострова и Јапландіи до побережій Чернаго и Каспійскаго мореї. Однако, на всемъ этомъ обширномь пространств встрьчается нысколько географическихь формъ. Такъ, въ Швеціи встрьчается $M$. m. poschiavinus Fatio, на островь св. Кильды11. m. faeroensis Clarke, въ прпкаспійсгихь степяхъ въ южной части

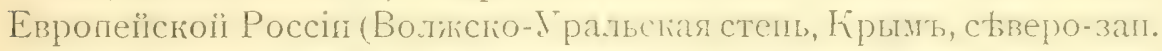
предгорія Кавказа)- M. m. hortulanus Nordmann (= M. m. bicolor Tich. et Kortsch.) қоторую въ восточномъ Закавказь ь зальняетъ M. m. tataricus Sat., а въ Египтьь, Нубіи и Малой Азіи-M. m. gentilis

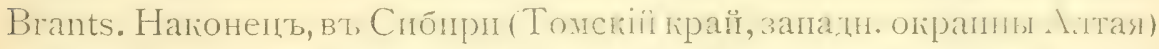
встрьчается $M$. m. tomensis Kastsch., а въ Забайкаль Kastsch.

\section{Образь жизни.}

Әтоть мелкіи грызунъ съ полнымъ правомъ можеть считаться настояцимь паразитомь человька, такъ какь распространеніе

1) Подробная аргументація этого взгляда будетъ дана въ моей, уже под-

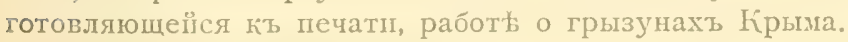




\begin{tabular}{|c|c|c|c|c|c|c|c|c|c|}
\hline 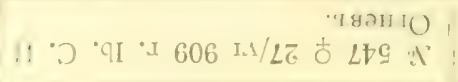 & & 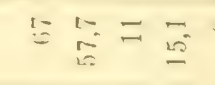 & $s$ & & & & & & \\
\hline H 3 * & & 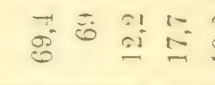 & $\stackrel{\because 1}{\cong}$ & & 1 & 1 & 1 & 1 & $i$ \\
\hline 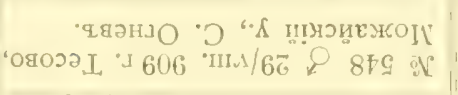 & & 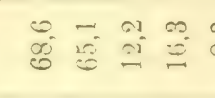 & $\infty$ & & 111 & 11 & & & \\
\hline 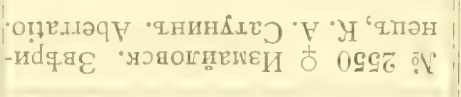 & & 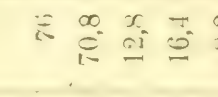 & $\begin{array}{l}01 \\
x \\
x\end{array}$ & & $\frac{61}{6} \pm$ & $\cong$ & $\rightarrow$ & $\Leftrightarrow$ & $\overline{5}$ \\
\hline 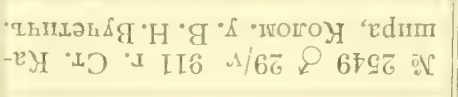 & & $3010 \%$ & 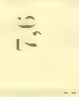 & & $\because \because 1=$ & 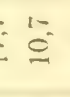 & & $\ddot{0}$ & $\ddot{\infty}$ \\
\hline 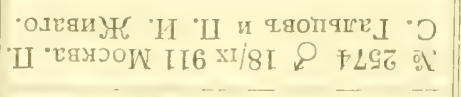 & & $\pm \pi$ & 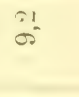 & & ai & 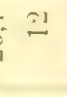 & & $\vec{\infty}$ & $\stackrel{6}{\Leftrightarrow}$ \\
\hline 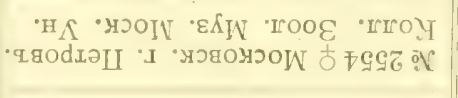 & & 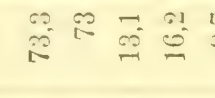 & $\cong$ & & $\begin{array}{ll}0 \\
\text { si } \\
\text { si }\end{array}$ & $=$ & & $\stackrel{\infty}{\infty}$ & $\infty$ \\
\hline 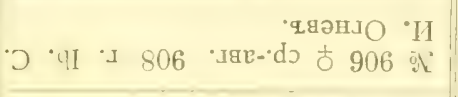 & & 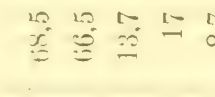 & tó & & 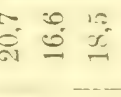 & 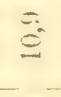 & & 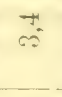 & 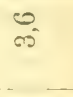 \\
\hline 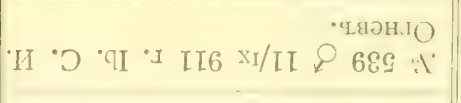 & & 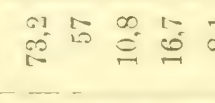 & $\bar{\infty}$ & & 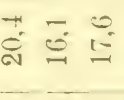 & $\bar{Z}$ & & $\ddot{\therefore}$ & $\overrightarrow{\text { ले }}$ \\
\hline 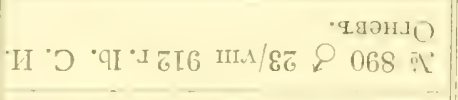 & & $\begin{array}{l}x=1 \\
\dot{g}=0\end{array}$ & & & 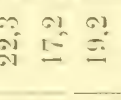 & $\cong$ & co & $\stackrel{1}{\infty}$ & 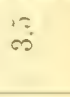 \\
\hline 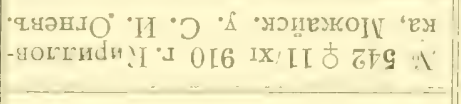 & & 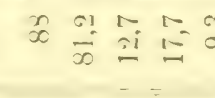 & $\cong$ & & 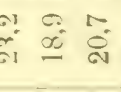 & $\vec{a}$ & $\stackrel{+}{\rightarrow}$ & 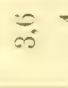 & 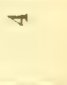 \\
\hline 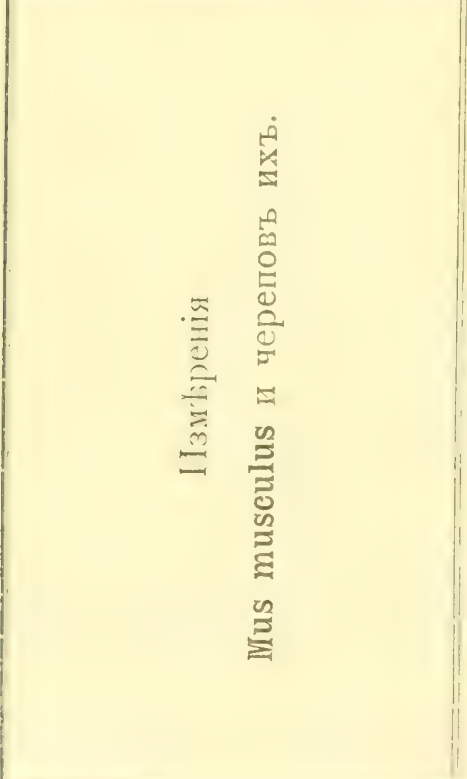 & 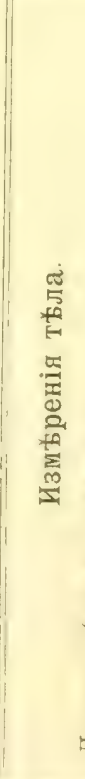 & 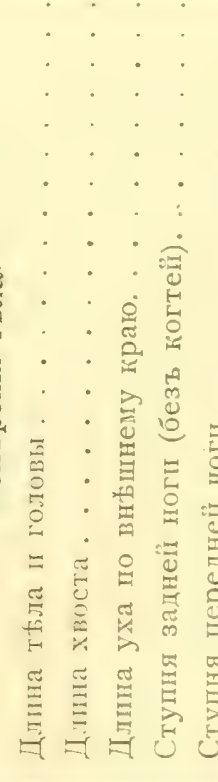 & 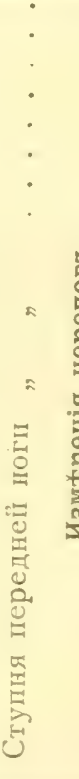 & : & 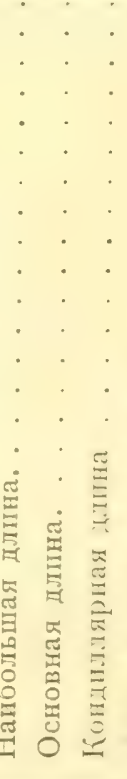 & & 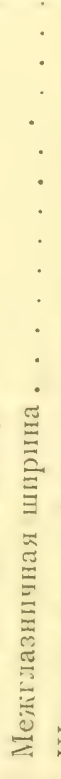 & 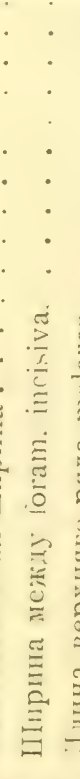 & 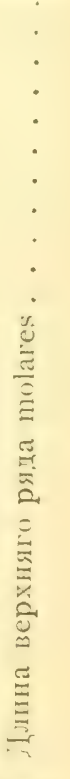 \\
\hline
\end{tabular}




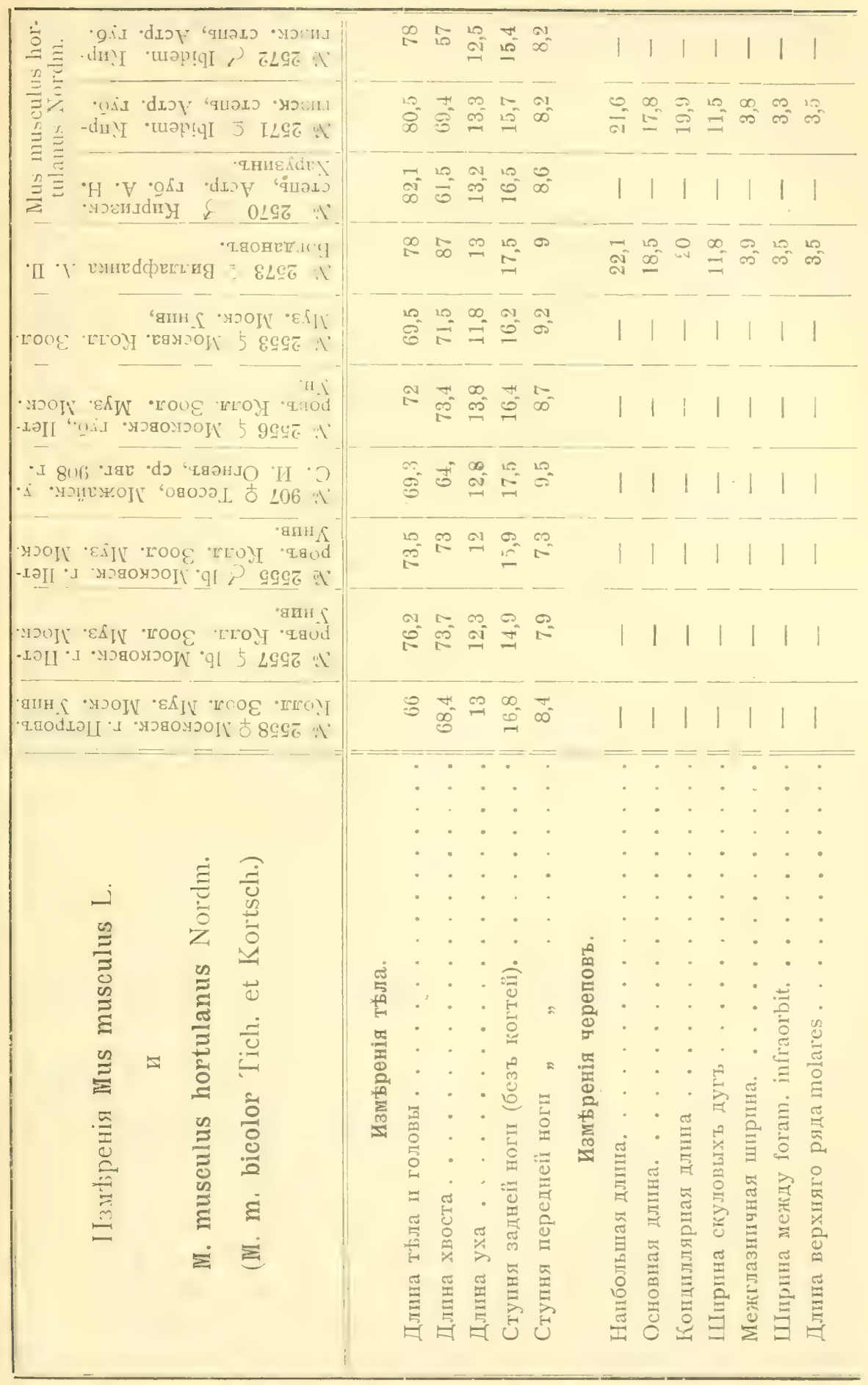


его, а въ значительной степени и біологическія особенности, стоятъ въ тьсной связи съ житьемъ въ жилыхъ домахъ, въ тАсномъ сосьдствы съ человькомъ. Толыко въ довольно рбдкихъ случаяхъ домашняя мышь встрьчается вдали оть жилья, въ поль и льсу. Было бы интересно просльдить, какимъ образомъ отзывается на организаціи животнаго перемьна обычної среды на пругую, природную обстановку.

Размножаются домашнія мыши въ разные сроки, по ньскольку разъ въ годъ.

Әкземлярь коллекиіи перечислены въ таблицахъ измћреній.

\section{Mus (Apodemus) agrarius Pall.}

\section{Полевая мышь.}

ITus agrarins $\mathrm{P}$ all as (1 32$)$, p. 341. B las i us (2 7), p. 324. T r o u es s a r t $(200)$, р.155. К. А. С а тунин и (165), стр. 13. (166), р. 2.

\section{Систематическія особенности.}

Черепь по своему строенію рызко отличается оть такового льсної и домашней мыши. Носовая область его значительно короче, чьыъ у представителей группы Mus sylvaticus et sbsp. По краямъ лобныхъ костей тамъ, гды онь сверху очерчивають глазницы, тянутся, съ каждой стороны, по замьтному прямолинейному гребню. Сзаци лобныя кости вдаются въ область теменныхъ очень тупымъ угломъ, переходящимъ иногда почти въ прямую линію. Теменныя кости не дають по бокамъ лобныхъ длинныхъ, острыхъ выступовъ, какъ у Mus musculus L. Особенно характерна межтеменная кость: она спереди и сзади вытянута въ два острыхъ выроста, а съ боковъ широка и косо срђзана. Bullae osseae значительно болье вздуты, чћмъ у близкихъ къ этому виду формъ. Промьры череповь даны въ таблиць на стр. 225. Зубы по своему строенію напоминаютъ таковые у Mus sylvaticus mosquensis Ogn. Такъ, на первомь коренномъ зубы нижней челюсти, кромы 6 тупыхъ парныхъ бугорковъ, имьется еще нысколько добавочныхъ.

Okраска типичнаго стараго экземпляра въ льмиело мьху такова: передняя часть носа, вся верхняя половина головы ишеи покрыты длинными волосами съ темно-сђрыми основаніями и ржаво-палевыми вершинами; между подобными волосами примћшивается довольно значительныи процентъ совершенно черныхъ, придающій верхней части головы, шеђ и передней части спины общій cłровато-ржавый тонъ. Въ нижней и задней части спинной области количество ржавыхъ волосъ дылается замьтно бо̀льшимъ, а оттьь- 


\begin{tabular}{|c|c|c|c|c|c|c|}
\hline 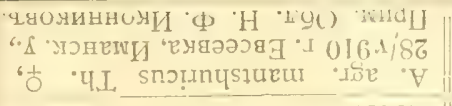 & $\frac{\pi}{5}$ & $\underset{\text { ar }}{\text { ar }}$ & $\mathbb{R}_{10}^{+1}$ & ầ & is & \multirow{8}{*}{ 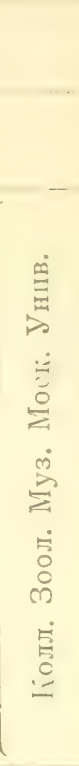 } \\
\hline 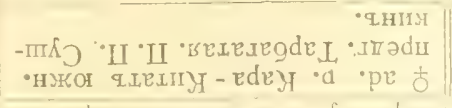 & बू & ลี & m & $\stackrel{-1}{\infty}$ & $\underset{\sigma}{\infty}$ & \\
\hline 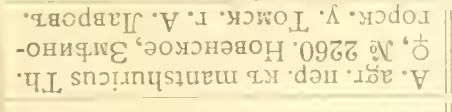 & กิ & $\stackrel{\overbrace{}}{\rightarrow}$ & $\vec{a}$ & I & $\stackrel{0}{T^{-}}$ & \\
\hline 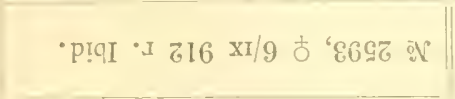 & $\stackrel{n}{a}$ & 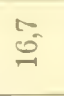 & $\stackrel{\infty}{=}$ & $\exists$ & $\underset{+i}{+\infty}$ & \\
\hline 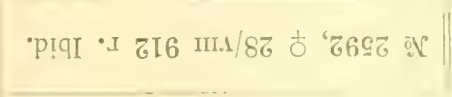 & $\frac{\infty}{\pi}$ & 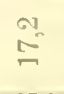 & $\stackrel{\infty}{\infty}$ & 1 & $\approx$ & \\
\hline 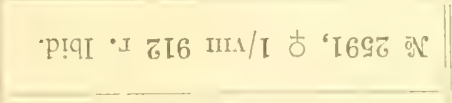 & जे & $\stackrel{\infty}{\infty}$ & 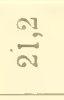 & $\equiv$ & $\stackrel{10}{\rightarrow-1}$ & \\
\hline 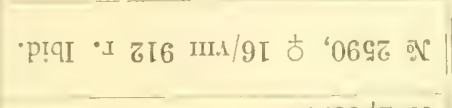 & जे & $\stackrel{10}{\infty}$ & 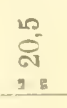 & 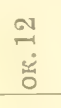 & $\stackrel{5}{\rightarrow-1}$ & \\
\hline 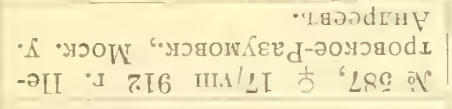 & $\overline{20}$ & $\ddot{\infty}$ & $\frac{a 1}{4}$ & $\vec{a}$ & $\stackrel{25}{\pi}$ & \\
\hline 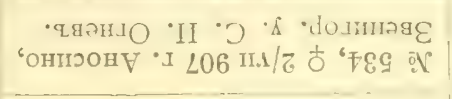 & ตे & ลิ & $\frac{a}{a-1}$ & $\stackrel{10}{\mathrm{~N}}$ & $\stackrel{0}{-}$ & \\
\hline 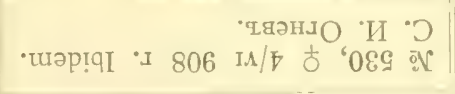 & a & ลิ & $\frac{\cos }{-10}$ & $\vec{a}$ & $\stackrel{20}{7}$ & \\
\hline 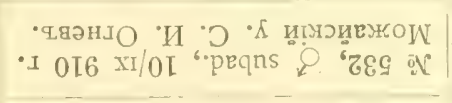 & $\overrightarrow{\text { ลิ }}$ & $\underset{\infty}{\stackrel{5}{-}}$ & 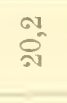 & $=$ & $\stackrel{0}{+}$ & \\
\hline 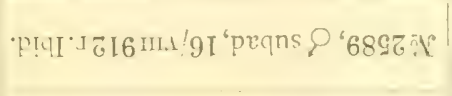 & त̂ & $\simeq$ & $\stackrel{\infty}{\infty}$ & $\stackrel{5}{0}$ & $\stackrel{+}{+}$ & 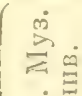 \\
\hline 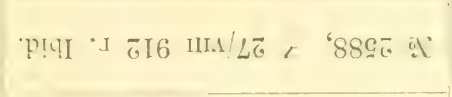 & $\stackrel{0}{1}$ & $\bar{\Xi}$ & $\frac{a 1}{a 1}$ & $\cong$ & $\stackrel{?}{-}$ & $\left\{\begin{array}{l}5=0 \\
0 \\
0\end{array}\right.$ \\
\hline 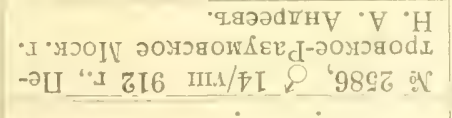 & $\bar{a}$ & $\stackrel{H}{\sigma}$ & $\frac{a}{4}$ & $\stackrel{\infty}{=}$ & $\stackrel{0}{+}$ & 空是 \\
\hline 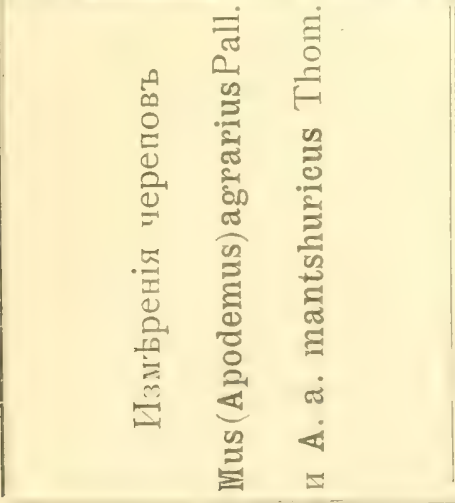 & 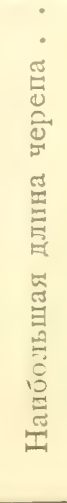 & 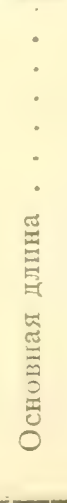 & 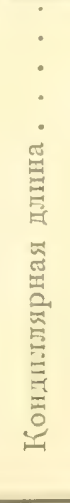 & 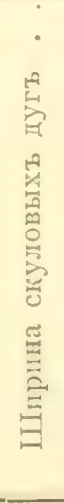 & : & \\
\hline
\end{tabular}




\begin{tabular}{|c|c|c|c|c|c|c|}
\hline 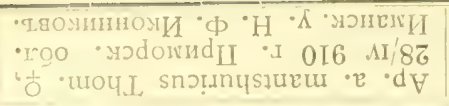 & ஜू & $\sum^{\infty}$ & in & $\stackrel{H}{\sigma}$ & $\stackrel{10}{0}$ & \\
\hline 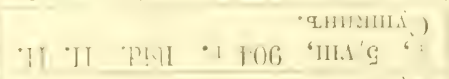 & $\stackrel{-}{3}$ & ઝ & 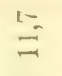 & $\stackrel{10}{2}$ & $\stackrel{6 !}{\sigma}$ & \\
\hline 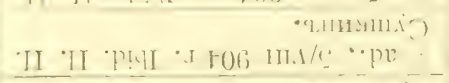 & בְ. & $\vec{x}$ & $\stackrel{1=}{=}$ & $\stackrel{1}{a}$ & an & \\
\hline 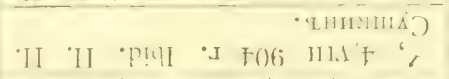 & $\oint$ & $\dot{\Xi}$ & $\stackrel{93}{-}$ & $\underline{5}$ & $\stackrel{0}{0}$ & \\
\hline 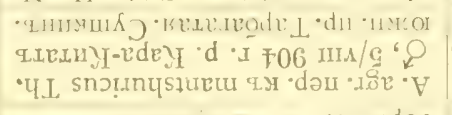 & 동 & $\stackrel{1-\infty}{\infty}$ & $\stackrel{\infty}{=}$ & $\stackrel{+}{\infty}$ & $\Leftrightarrow$ & \\
\hline 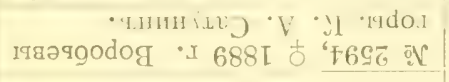 & $\stackrel{9}{1}$ & $\overrightarrow{\mathbb{N}}$ & $\approx$ & $\stackrel{a}{a-1}+$ & $\bar{\infty}$ & 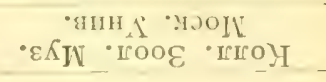 \\
\hline 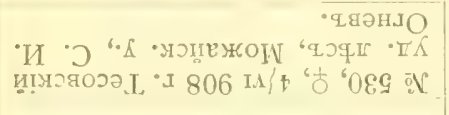 & $\stackrel{N}{\stackrel{N}{N}}$ & is & $\stackrel{r}{\circ}$ & $\mathscr{C}_{-\infty}^{\infty}$ & $\stackrel{0}{\infty}$ & \\
\hline 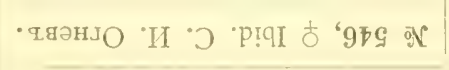 & 8 & 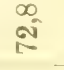 & $\stackrel{N}{=}$ & $=$ & $\infty$ & \\
\hline 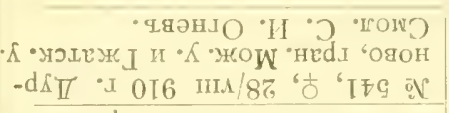 & की & $\dot{\varepsilon}$ & $\stackrel{\infty}{\varrho}$ & 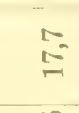 & $\infty_{\infty}^{\infty}$ & \\
\hline 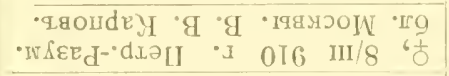 & $\infty$ & $\stackrel{\infty}{2}$ & $=$ & $\stackrel{102}{2}$ & की & 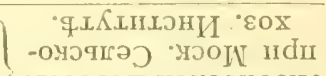 \\
\hline 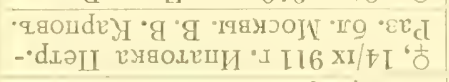 & $I_{\infty}^{+}$ & $\stackrel{2}{i s}$ & $\stackrel{0}{0}$ & $\underline{5}$ & $\vec{\sigma}$ & 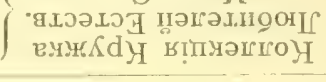 \\
\hline 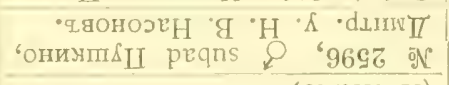 & 19 & $\widetilde{0}$ & $\stackrel{\infty}{0}_{-\infty}^{\infty}$ & $\stackrel{N}{N}$ & न- & ${ }^{\circ} \operatorname{GIH} \propto{ }^{\circ}$ अวоN \\
\hline 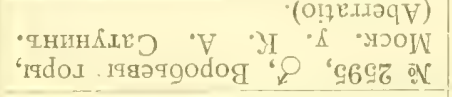 & $\ln$ & 18 & $\stackrel{\infty}{\infty}$ & $\stackrel{\infty}{=}$ & $\vec{\sigma}$ & 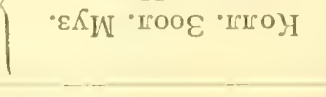 \\
\hline 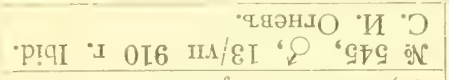 & $\stackrel{2}{2}$ & $\frac{i g}{6}$ & $\stackrel{0}{=}$ & $\stackrel{\stackrel{s}{\sim}}{=}$ & $\vec{a}$ & \\
\hline 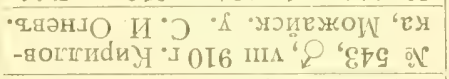 & is & $\overrightarrow{0}$ & $\underset{0}{0}$ & $\stackrel{N}{=}$ & $\stackrel{5}{5}$ & \\
\hline 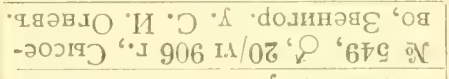 & 10 & $\begin{array}{l}\infty \\
10 \\
10\end{array}$ & $=1$ & $\stackrel{\infty}{\infty}$ & $\infty$ & \\
\hline 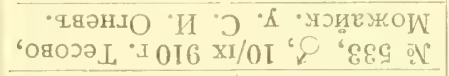 & 6 & 8 & $\stackrel{102}{=}$ & $\stackrel{0}{2}$ & 10 & \\
\hline 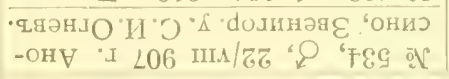 & 焉 & 10 & 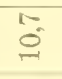 & $\stackrel{\bullet}{\varphi^{-}}$ & $\begin{array}{l}\infty \\
\infty\end{array}$ & \\
\hline 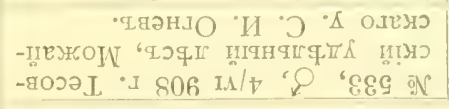 & 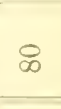 & 苋 & $e_{0}^{0}$. & 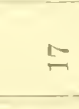 & 100 & \\
\hline 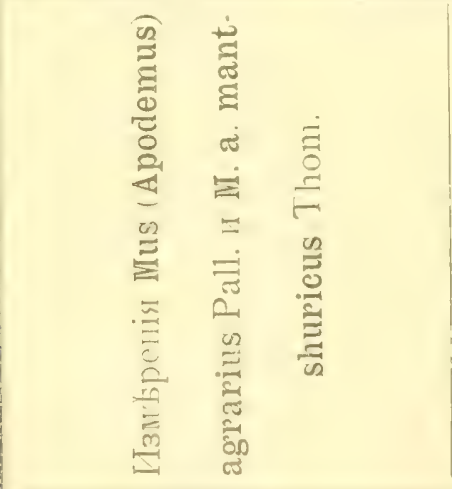 & 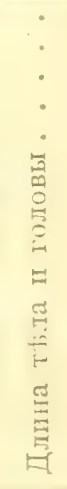 & 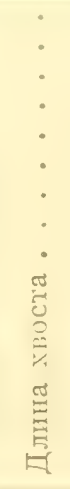 & 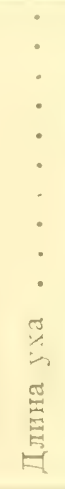 & 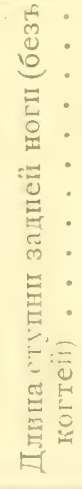 & 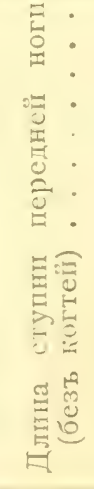 & \\
\hline
\end{tabular}


нокъ ихъ болье яркимъ, красноватымъ; на бокахъ, на бедрахъ черныхъ волосъ почти нбть, и ржавый цвђтъ граничить съ бьлой окраской нижней стороны. Начиная оть межглазничної области и почти до основанія хвоста тянется довольно широкая черная полоса по средней линіи спины, состояшая изъ длинныхъ, совершенно черныхъ волосъ. Нижняя сторона ть́ла, какъ было уже сказано, бълая, при чемъ основанія волосъ-довольно темно-сырыя. Iии попрыты сыровато-палевыми волосами, лапы-сьровато-былыми. Хвость сьрый, слабо двуцвьтный.

Зимніи мьхъ отличается большей длиною и яркимъ ржавымъ оттьнкомъ. Окраска молодыхъ значительно сьрье и тусклье, ржавыхъ тоновъ совершенно не замьтно.

Красочныя варіаціи у этого вида относительно рыдки. - Въ моихъ рукахъ быль только одинъ экземпляръ (№ 2595 đ゙), добытый К. А. С атуниным в въ г889 году на Воробьевыхъ горахъ (бл. Москвы). Этотъ экземплярь отличается необыкновенно свђтлой желто-палевой окрасіой верхней стороны тьлла, съ очень слабо эиференцированной черной полосої вдоль спины, выступающей только въ средней и нижней спинной области. Хвость, уши и лапы-палево-бьлые.

Интересно отмбтить, что сибирсқіе экземпляры, кақъ видно изъ таблицъ изиьреній, отличаютя отъ европейскихъ большимп размьрами тьла и длиною черепа. Но и съ вньшней стороны они легко характеризуются болье яркой каштановой окраской и значительно болье широкої черной полосой вдоль спины. Изъ Сибири я имьль небольшую серію Ap. agrarius Pall. изъ Змьиногорскаго у. Томскої губ. (оть А. Лав рова, въ коллекціи Зоол. Муз. Моск. Ун.), а также оть проф. П. П. Сушкина съ р. Кара-Китать (южн. предгор. Тарбагатая). Всь эти полевыя мыши характеризовались указанными выше признаками и по нимъ приближались къ $A$. a. mantshuricus Thom.-формь, pacпространенной, по Ольдфильду Т омасу, въ Манчнуріи и найденной Н. Ф. И к н н и к в ы м въ Приморскої обл. Въ моей коллекціи имьются экземпляры оть этого зоолога, но количество ихъ мало (2), и, несмотря на большое внышнее сходство, я не рђшаюсь окончательно отнести западно-сибирскихъ представителей именно къ этому подвиду. Быть можеть, большій матеріаль позволитъ выдылить средне-азіатскую форму въ особый подвидъ.

\section{Географическое распространеніе.}

Въ предьлахъ Московскої губ. эта мышь распространена, повидпмому, широко.-Въ моеї коллекціи и въ колл. Зоол. Муз. 
Mock. Ун. имьются эгземпляры изъ Московскаго у. (Воробьевы горы, Петровское-Разумовское), Звенигородскаго (с-цо Сысоево, с. Аносино), Можайскаго (Тесовскій льсъ, с-цо Дурново), Дмитровскаго (Пушкино). По К. А. Сатунину полевая мышь водится повсюду по обработаннымъ полямъ.

Въ центральныхъ губерніяхъ Европейской Россіи Ap. agrarius

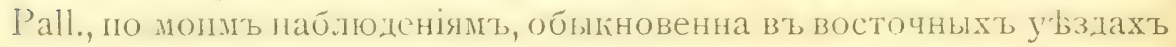
Смоленской губ., въ сьверныхъ Калужской, въ Тульской губ. и юго-вост. части Орловской губ. Эсауловы м (58, p. 225) найдена въ Холмскомъ и Торопецкомъ уу. Псковской губ. Для Ярославской губ. указана Л. П. Сабан ьевым. Далье на югъ встрьчается въ Харьковской губ. (С омовъ, Чернай), Черниговской губ. (колл. З. М. Моск. Ун.), Кіевскої (К е с сл е р.ъ, 86, стр. 65; В е $1 \mathrm{k} \mathrm{e,} \mathrm{I} \mathrm{8,} \mathrm{p.} \mathrm{492),} \mathrm{Екатеринославской} \mathrm{(Ч} \mathrm{е} \mathrm{р} \mathrm{н} \mathrm{а} \mathrm{й)}$ и близъ Одессы (Нордманнъ). Георги помьчаетъ ее для береговъ Днбпра и Волги. Восточнье обыкновенна въ Казанской, Симбирской и Саратовской губ. (М. Н. Богдановъ, Б. М. Жи тковъ, А. Силантьевъ). По 3 арудному (7 7, стр. 342) очень обыкновенна въ Оренбургской губ., въ долинь Урала и степяхъ по Илеку. Въ Периской губ. найдена Л. П. С а бан ( т 49, стр. 8). Въ этой же губ. добыта $\Theta$. А. Т еп л о у х о в м ъ (Тихомировъ, I97, р. 27). На сыверо-западь встрьчается въ Петербургской губ. (Брандтъ, Біанки) и въ Тверской (Ге о р и). Въ прибалтійскихъ провинціяхъ встрьчается въ Лифляндіи и Курляндіи (Lichtenstein, Grevé). По Тачановск о у обыкновенна въ Польшь, по Эйх вальду - въ Литвь, Подоліи и Волыни. На Кавказ' (Псебай, Майкопъ) добыта K. А. С а ту н и ны м ъ. Въ Зап. Сибири, по С ло вц о ву, распространена въ Тюменскомъ и Ялуторовскомъ округахъ. Изъ Зап. Сибири Брандтъ имьль экземпляры оть Карелина. По Георги встрьчается до Енисея. Кашенко отмьчаеть этоть видъ для всего Томскаго края (кром⿰ внутренняго Алтая). Въ коллекціи Зоол. Муз. Моск. Ун. имьются экземпляры изъ Омской губ. и Змьиногорскаго у. Томской (село Новенское). П. П. Сушкиин ъ передалъ мнб для опредьленія экземпляы съ р. Кара-Китатъ, южн. предг. Тарбагатая. Въ восточной Сибири нап̆дена И. С. По ляко в м ъ бл. оз. Шакши, въ бассейнь Лены (г 36, стр. 48) и Р адде около Буреи (г 43, р. г82) ${ }^{1}$ ).

1) $\mathrm{P}$ адде отмбчаеть темную окраску и ширину чернаго ремня этихъ экземпляровъ. Указанные признаки, какъ мы видыли, характерны для всьхъ 


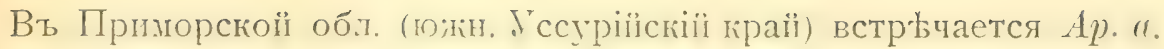
mantshuricus Thom., найденная около Евсеевки Иманскаго у. H. Ф. Нконниковы мъ. Эту манчжурскую форму въ Kоре замьняеть $A$. a. coreae Thom., на полуостр. Шантунг' $-A$. a. pallidor Thom., въ Нанкинь и Фокинь А. a. ningpoensis Swinch.

Распространеніе полевої мыши въ Зап. Европь значительно уже, чьмъ у ея сородичей: она встрьчается оть Даніи до сьверной Италіи, въ области центральныхъ Альпь ее положительно ньтьъ.

\section{Образъ жизни.}

Въ большинств' сп спеціальныхъ работь, а также и въ сводочныхъ сочиненіяхъ характерной станціей полевой мыши считаются хльбныя поля. Хотя посльднія и наиболье излюблены этимъ видомъ грызуна, но я находиль Ap. agrarins Pall. и въ поймь большихъ луговъ Москвы рьки вмьсть съ Microtus arvalis Pall. Болье того, цьлая серія полевыхъ мышей была поймана мною на поросшемъ ольшнякомъ болотистомъ торфяномъ островь, со всьхъ сторонъ окруженномъ ручьемъ, около впаденія его въ Москву рьку. Здысь же, на однихъ и тьхъ же мьстахъ попадались: Ap. agravins Pall., Microtus ratticeps Keys. et Blas. и куторы. Мы имьемъ ясный примьръ, доказывающій невозможность точнаго разграниченія по обособленнымъ станціямь мелкихъ млекопитающихъ. Много фактовъ доказывають намъ, что грызуны легко и хорошо уживаются на, казалось бы, несоотвьтствующихъ имъ мьстахъ. Полевая мышь менье подвижна и флегматичнье льсноц; подобно посльдней, она охотнье выходить наружу ночью. Но и днемъ представители этого вида проявляютъ довольно живую дьятельность.-Въ нькоторыхъ мъстахъ они живуть щьлыми сообществами, при чещъ часть пашни, населенная колоніей, бываетъ въ разныхъ направленіяхъ изрьзана ихъ многочисленными норами и ходами, идущими отъ одного гнызда къ другому. По этимъ ходамъ передвигаются полевыя мыши, избьгая такимъ образомъ пресльдованія со стороны луней и канюковъ. Самое гньздо лежить очень неглубоко отъ поверхности земли, будучи сдьлано изъ травы и злаковъ, выстилающихъ круглую подземную гньздовую камеру. "Отъ посльдней, кромь главнаго хода, отходить еще цьлая система болье длинныхъ побочныхъ. Осенью бо́льшая часть полевыхъ мышей, вмь́сть́ со

сибирсқихъ полевыхъ мышей, что сближаетъ посльдднихъ съ манчжурской формой Томаса, къ которой онб быть можеть, и принадлежатъ, если только большій матеріалъ не заставптъ выдылить особую центрально-азіатскую полевую мышь. 
снопами, перевозится съ полей на гумна, гды иногда масса ихъ собирается подъ скирдами, а при разрываніи посльднихъ видно много норъ и надземныхъ ходовъ. Въ конц падались Ap. agrarius Pall. даже въ домахъ. Ннтересно отмьтить, что по временамь полевыя мыши появляются въ громадномъ количествь. Такъ, по словамъ К. А. С атунина, подобное массовое размноженіе этого грызуна было въ 1890 году, когда осенью онь появились въ Тульской губ. и южныхь уьздахъ Московской г. совмыстно съ $M$. arvalis Pall.

Экземп.ляри коллекии перечислены въ таблицахь измьреній.

Во̆ ґолиекии Зоол. Муз. Моск. Уи., крон古 перечисленныхъ въ таблицахъ, имьются еще шкурки съ черепами: I) (№ 2586) ð, I4/vil 9 г2 г. Петровское-Разум. Н. А. А н п ре в в ъ; 2) (№ 2588) ơ", 27/vin 912 г. Ib.; 3) (№ 2589) ơ subad. I6/vil 912. Ib.; 4) (№ 2587) ㅇ, I7/viII 9I2 г. Ib.; 5) (№ 2590) 오, I6/viII 9I2 г. Ib.; 6) (№ 259I) o, I/VIII 9I2 г. Ib.; 7) (№ 2592) q, 28/viII 9 I2 г. Ib.; 8) (№ 2593) ㅇ, 6/ıх 6І2 г. Ib.; 9) јuv. Московск. у. П етровъ.

\section{Mus (Micromys) minutus Pall.}

\section{Мышь малютка.}

Mrus minutus Pallas (132), p. 96 et 315 . Mus (Apodemus) mimutus Pall. Troues$\mathrm{s}$ art (200), p. 155. B arret-Hamilto n, Note on the Harvest-Mice of the Palaearct. Region, Ann. and Magaz. Natur. Hist. vol. III, 1899, p. 341 II (1 5), р. 527. К. А. С а тунин ъ (16 5), стр. 13 иі $(166)$, р. 2.

\section{Систематическія особенности.}

पерепг, помимо своихъ очень мелкихъ размьровъ, характеризуется цьлымъ рядомъ постоянныхъ пластическихъ признаковъ.При сравненіи съ черепами близкихъ къ $M$. minutus Pall. видовъ бросается въ глаза крайняя укороченность носовыхъ костеї мыши малютки, которыя кпереди расширяются сравнительно очень слабо. Лобныя кости граничать съ теменными слабо выпуклою дугою, не образующей въ своеї серединь сколько-нибудь намьченнаго тупого угла. Съ боковъ теменныхъ костеї не замьтно острыхъ отростковъ, охватывающихъ лобныя кости, какь у $\boldsymbol{M}$. musculus L. Межтеменная кость сравнительно широка, вытянута въ центрь спереди и сзади въ два довольно тупыхъ отростка и ограничена съ боковъ полукруглыми гонтурами, безъ замытнаго суженія по сравненію съ центральної частью.

Въ зубної систем' особенно характерно строеніе перваго

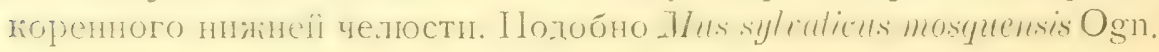


и Apodemus agrarins Pall. на его поверхности, кром' шести бугорковъ, находятся еще нћсколько добавочныхъ. Однако, наиболье характернымъ является расположеніе первыхъ четырехъ бугорковъ, ясно образующихъ фигуру косого креста, спереди отъ котораго лежитъ одинъ добавочный бугорокъ.

Oкраска стараго, августовскаго, экземпляра такова.-Область между глазъ, ушеї и спины покрыта густыми волосами, темносьрыми у ихъ основаній, съ широкими каштаново-рыжими вершинами; среди подобныхь волось примьшивается небольшої проценть одноцвытныхъ, буро-черныхъ. Рыжеватыї оттьнокъ дылается болье яркимъ, красноватымъ на нижнеї части спины и между задними ґонечностями. На щекахъ и бокахъ тьла окраска свьтльеть и желтћеть, рьзко переходя въ совершенно бьлый м⿻хь нижней стороны. Одноцвьтный хвостъ и лапы палево-сърые. Окраска молодыхъ рłзко отличается оть описанной. - Вся спинная область ихъ тьла значительно сырtе всльдствіе большеї примси совершенно черныхъ волосъ и полнаго отсутствія яркихъ каштаново-бурыхъ окончанії отдьльныхъ волось, которыя замьнены здьсь сьровато-палевыми. Нижняя сторона, какъ у старыхъ, ярко бьлая.

Всльдствіе недостатка матеріала я не могу здысь разбирать еще спорный и неясный вопросъ, къ какому подвиду относятся московскія и вообце средне-русскія мышп малюткп и откладываю его на будущее время.

\section{Географическое распространеніе.}

Всльдствіе трудностей, съ которыми связано добываніе этого звьрка, коллекція Micromys minutus Pall. изъ Московской губ., бывшая въ моихъ рукахъ, очень мала. Я видьль экземпляры изъ Московскаго у. (Петровское-Разумовское, отъ Н. А. А н д р е ева и В. В. Карпова) и Можайскаго у. (Тесовскій удыльный льсъ). По словамъ К. А. Сатунина, встрбчается по всеї Московской губ., но значительно рьже предыдущихъ. О присутствіи мыши малютки можно судить по старымъ гнђздамъ этого звБрка. Я находиль ихъ въ Можайскомъ у. близъ села Александрова и на границь Можайскаго и Гжатскаго уу. около дер. Митькова. Въ коллекціи Зоол. Муз. Моск. Ун. имьется одно гньздо, найденное подъ Москвою Ө. С. М о чалки и м ъ.

Что касается до распространенія мыши малютки въ Европейской Россіи, то наши свьдынія объ этомъ таковы.-По Ге о рг и и Двигубскому $(44$, р. 55), она встрьчается въ южной и средней частяхь Европ. Россіи, на берегахъ Дона, Оки и Волги. 


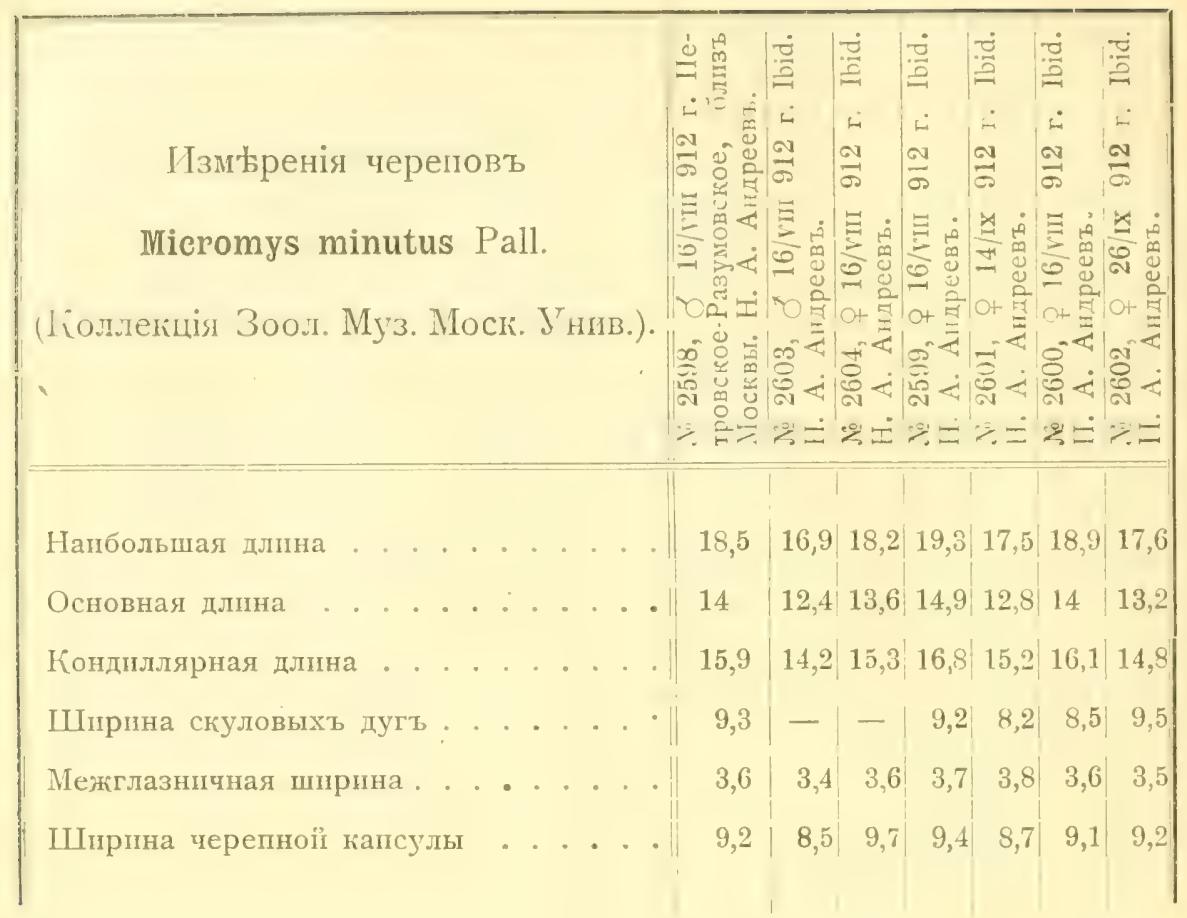

Найдена въ центральныхъ губерніяхъ, въ Дорогобужскомъ у. Смоленской губ. Н. М. К у лаг и ны м ъ, въ Торопецкомъ и Холмскомъ у. Псковской губ. Эсауловы м (58 р. 225), въ Новотарусскомъ у. Тверской губ. А. И. П е т р н ке в и чем ъ, въ Ярославской губ. Л. П. С абан ве в м ъ (пойма р. Которости), въ юго-вост, части Орловской губ.-мною и С. Н. Г ор бачев м ъ. Далье на югъ встрьчена въ Харьковской губ. Сомовым ъ ( 84 стр. І47), въ Кіевской губ. - К е с с л е р м ъ (86, стр. 63), въ Екатеринославской губ.-Чернаем ъ, близъ Одессы-Нордм ан ном ъ. Восточнбе мышь малютка добыта въ Казанской губ. (Э версманномъ, Богдановымъ), распространена въ Симбирской, Самарской, Саратовскої, Оренб́ргскої гг. и на Об́цень

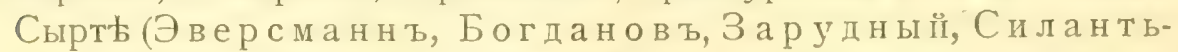
евъ, Ж ит ковъ). Въ Пермской губ. добыта $Ө$. А. Т.еплоу хо в ы м (экз. въ колл. Зоол. Муз. Моск. Ун.). Западные встрьчается въ Петергофскомь у. Петербургской губ. (В. Л. Біан ки) и въ Финляндіи (Brandt, 34, р. 34). Въ прибалтійскихъ пропинціяъ распространена въ Курляндіи, Тифляндіи и Эстляндіи

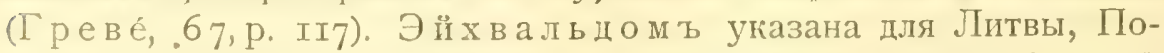
доліи и Волыни, по Тачановскому встрычается въ Польшы ( 85 . p. I3 I). К. А. С атунинъ помғчаеть эту мышь для Съ- 
вернаго Кавказа, Кубанской обл., окр. Сухума, но встрђчаюпійся тамъ подвиц еще не установленъ.

О расиространеніи этого грызуна въ Сибири наши свьдънія являются еще болье отрывочными.-Мышь малютха найдена Словцовымъ въ Тюменьскомъ округь, проф.Н.Ө. Кащенко бл. Барнаула и въ Барабь, А. Л а в ровым ъ-бл. села Новенскаго Змьиногорск. у. Томск. губ. Встрьчается въ бассейн' нижней Оби и по Енисею (см. Георги, Двигубскіиї). Добыта И. С. Поляковым ъ въ бассейн Һ Лены, гды описываемая мышь весьма обыкновенна въ окр. озеръ Шакши и Арахлея (I 3 6, стр. 48). М а акъ (го 2, стр. го6) поймалъ одинъ экземпляръ въ окр. Иркутска. По словамъ проф. Н. Ө. Кащенко, мышь малютка изъ окр. Иркутска, хранящаяся въ мъстномъ музе сится къ особому подвиду Mus mimutus batarovi Kastcsh. (79, стр. 284). Страннымъ является, однако, тотъ фактъ, что экземпляръ изъ Верхнеу.,инска (Забайкальск. обл.), сльдовательно восточнђе Иркутска, по свидьтельству проф. Кащенко не отличается отъ томскихъ. Наконецъ, мышь изъ Енисейскаго музея этотъ авторъ считаеть „особой разновидностью" $M$. mimutus var. liytmanovi Kastsch. Р адде нашель малютку въ долинь р. Онона (южн. часть Забайкальск. обл., притокъ Амура). Вь Приморской обл. и Уссурійскомъ краб распространенъ MI. minutus ussuricus BarretНаm. За посльднее время мышей малютокъ, встрьчающихся въ Западної Европь, раздыляють на ньсколько подвидовъ. Таґъ, въ Англіи водится MI. mimutus minimus White ${ }^{1}$ ), въ Венгріи и Румыніи-M. m. pratensis Ockskay, въ сьв. Франціи, Бельгіи, среднихъ и западныхъ частяхъ Европы-M. m. campestris Desmarest, въ сьверной части (типъ изъ Брауншвейга) - M. m. agilis Dehne.

\section{Образъ жизни.}

М屯ста обитанія этой мыши весьма разнообразны: она встрђчается какъ въ хльбныхъ поляхъ, такъ и въ рғъчной пойм'ь, на заливныхъ лугахъ. Я находилъ ея гнђзда также въ густой заросли травы и кустарниковъ, среди болотъ и около самой воды. Одинъ экземпляръ былъ пойманъ мною въ самой чащ'ь льса, далеко отъ опушки, въ сырой канав'b. Гньздо Micromys minutus Pall. представляетъ собою одну изъ наиболье изящныхъ и красивыхъ построекъ млекопитающихъ. Оно помьщается обыкновенно на вершинахъ высогой травы, при чемь верхушкі отды.льныхъ травъ сплетаются между собою ньжной и тонкой осокой

1) Milla is (1 10$)$, vol. II, p. 174 . 
или злаками, придавая гньзду особую эластичность и прочность. По словамь К. А. С а тун ин а, замьтнаго отверстія наружу никогда не бываетъ; на музейскихъ экземплярахъ, прибавляеть этоть авторъ, эти отверстія сдђланы всегда пальцемъ какогонибудь любознательнаго изсльдователя. Мнђ ньскольно разъ приходилось находить гньзда малютокъ, и на одномъ изъ нихъ, постройка котораго отличалась особою св'жестью, можно было ясно ґонстатировать округлое боковое отверстіе. Весьма часто гньзда дьлаются среди ржи, въ такомь случағ гныздо построено всегда изъ сухого матеріала. Подобно предыдущему виду, мыши малютки на зиму переселяются въ скирды и амбары. K. А. С а тунинъ говорилъ мнь, что ему приходилось много ловить этихъ мышекъ въ то время, когда крестьяне поднимали слежавшіеся скирды. Въ неволь, по словамь К. А. Сатунин и, M. mimutus Pall. очень скоро приручается и охотно ловитъ крупныхъ мухъ, которыхъ пускаютъ въ ея помьщеніе.

Экземиляри коллекии: кромь одного (№ 629, Тесовскій льсъ Можайск. у. 22/үюп 909 г.,) перечислены въ таблицахъ измьреній (черепа и шкурки).

\section{Родъ Ep im ys Trouessart (1881).}

\section{Крысы.}

Нёбныя складки, кромь почти прямыхъ и цыльныхъ двухъ переднихъ, съ остроутольными прогибами назадъ, но безъ разрыза посрединь. Ступни ногъ массивны и толсты. На хвость находится обыкновенно больше I75 чешуйчатыхъ колецъ (обычное число ихъ г8о-26о). Посльдняя бородавка на ступняхъ заднихъ ногъ вытянута и искривлена.

\section{Epimys norvegicus Erxl.}

\section{Сьрая крыса, пасюкъ.}

IIus norvegicus Erxleben, System. Regn. Anim., I, 1777, p. 381. Mis decumanus $\mathrm{P}$ all as (1 3 2), p.91. B lasius (2 7), p. 313. A. A. Б р а у н е р ъ (3 7), p. 3. M I I a is (1 10$)$, II, p. 219, pl. 44. Fpimys norvegicus Erxleben, T r o u e s s a r t (200), p. 142. Alus decumanus Pall. К. А. С а т унин и (165), стр. 13 (166), p. 2.

\section{Сиетематическія особенности.}

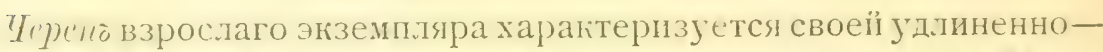
oвiльной 中ормой. Межтеменная п теменная кості, какъ отмытиль

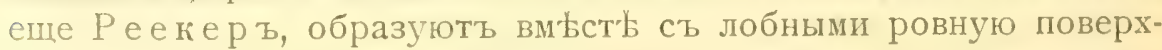
ность, безъ сколько-нибудь замьтноі выпуклости теменныхъ 
костей. Гребни, идущіе по бокамъ лобныхъ костей, переходятъ по заднимъ краямъ посльднихъ въ замьтную оторочку, довольно р*зко суживающуюся у переднихъ краевъ ossa frontalıa. Гребни, служащіе продолженіемъ описанныхъ и идущіе по бокамъ теменныхъ и височныхъ костей, почти прямы и только слабо выпуклы по линіи внбшняго края. Особенно характернымъ въ чеpent пасюка и замьтнымъ у старыхъ экземпляровъ является рћзкая выпуклость въ мбсть соединенія лобныхъ, носовыхъ и межчелюстныхъ костей. Эта выпуклость бросается въ глаза, если смотрьть на черепь сьрой крысы въ профиль, она еще заньтнье всльдствіе наклона носовыхъ костей впередъ, а лобныхъ, теменныхъ и межтеменныхъ-назадъ. Носовыя кости замытно сужены сзади и расширяются спереди не равномьрно: на передней трети ихъ легко видьть перехвать. Foramina infraorbitalia очень вытянуты въ бока, гды они ограничены скуловыми дугами, полукруглыми линіям. Нанболышая ширнна массивныхъ скуловыхъ дугъ, какъ отмбтилъ А. А. Бр а ун еръ, приходится на ихъ середину. На нижней челюсти mcisura semilunaris posterior, какъ вьрно замьчаеть А. А. Б р а у н е р ъ, имьеть почти полукруглую форму и глубоко врьзывается внутрь; processus coronoideus довольно тупой и широкій. Черепъ молодого пасюка, помимо меньшей угловатости своихь очертаній, характеризуется меньшей вздутостью въ мьсть соединенія лобныхъ, носовыхъ и межчелюстныхъ костеї и болье слабымъ расширеніемъ кпереди ossa nasalia.

Окраска спины просмотрьнныхъ мною экземпляровъ колебалась отъ рыжевато-бурой сверху до почти сьрой; нижняя сторона обычно грязно-бълая или пепельно-сьрая..Ухо по длинь составляеть ньсколько болье трети головы, булучи прпгнуто къ глазу, не доходитъ до него. Хвость қороче тьла (только у одного экземпляра онъ почти равнялся длинь тьла и головы). Число колецъ колеблется отъ І75 до 200.

Въ заключеніе привожу размьры имьющихся у меня экземпляровъ.

Географическое распространеніе.

Пасюкъ распространенъ по всей Московской губ., но въ его распредьленіи сказывается изв Бстная спорадичность: мьстами онъ рьдокъ, мьстами встрбчается въ огромномъ количеств Б. Однако, всюду бросается въ глаза тьсная связь распространенія пасюка съ человьческии жилищами, при чемъ въ особенно большихъ количествахъ онъ встрбчается въ городахъ. Такъ, напримъръ, въ Москвђ онъ очень обыкновененъ около боенъ, въ Охотномь рялу, въ раїоны Остоженки и Красносельскої улицт. 


\begin{tabular}{|c|c|c|c|c|c|}
\hline $\begin{array}{l}\text { Epimys } \\
\text { norvegieus Erxl. }\end{array}$ & 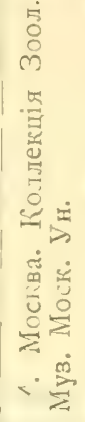 & 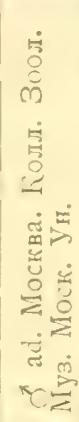 & 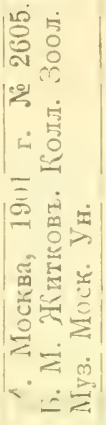 & 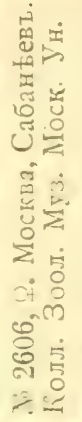 & 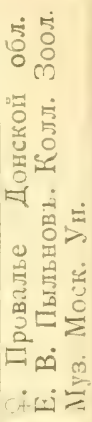 \\
\hline Кзмы̆ренія ть́ла. & & & & & \\
\hline Длина тьла и головы . . . . . . . . & 151,2 & 215 & 196 & 139 & 190 \\
\hline$\ldots \ldots$ & 44,2 & 55,4 & 47 & 41,5 & 55,5 \\
\hline Длпна уха . . . . . . . . . . & 18,2 & 20,7 & 20.8 & 17 & 20) \\
\hline Длина хвоста . . . . . . . . . . & 151 & 194 & 181 & 135,3 & 170 \\
\hline Длина ступни заднеї ноги безъ когтеї . & 38,8 & 39,2 & 39,2 & 35,6 & 39,7 \\
\hline Измьренія черепа. & & & & & \\
\hline Напбольшая длина . . . . . . . . . & & & 47,5 & 37,8 & \\
\hline 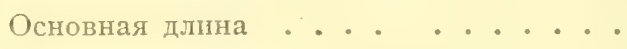 & & & 39 & 31,8 & \\
\hline Кондиллярная длина . . . . . . . & & & 42,1 & 34,7 & \\
\hline Ширнна скуловыхъ дугъ . . . . . . . . & & & 23 & 19,2 & \\
\hline Межглазничная ширина . . . . . . & & & 7,5 & 6 & \\
\hline Длина верхняго ряда molares. . . . . . & & & 7,2 & 7,3 & \\
\hline
\end{tabular}

По своему общему распространенію-это типичный космополитъ. Въ настоящее время онъ найденъ по всей Европейской Россіи и Западной Европь. Интересно отмьтить, что такъ широко онъ распространился только сравнительно недавно. По свидьтельству Ге орги, въ южн. окраинахъ Европ. Россіи пасюкъ встрьчался на Кавказђ, откуда затьмь распространился на сьверъ. Осенью І727 года, по словамъ Палласа (г 3 o, p. I64165), огромныя скопища этихъ крысъ двинулись въ Астраханскія и Куманскія степи, причемъ переплывали Волгу. Въ І73о году они уже показались въ Англіи. Въ 1829 году проф. Двигубскій писалъ: „водится по всей почти Россіи, а особливо въ Астраханской губ. и по Кавказу, въ УкрайнЊ называютъ его пащюкомъ". (42, стр. 40). Въ I856 году академикъ Брандтъ 
отмьтиль, что уже льть двадцать помнить пасюка, какъ одного изъ распространенныхъ паразитовъ въ Петерб. губ. (3 4, р. 35). По свидытельству К. Ө. К е с сл е р а (86, стр. 56), эти крысы появились въ Кіевской губ. только въ І850 году. Съ тьхх поръ Ep. norvegicus Erxl. очень широко распространилась по всымъ южнымъ, среднимъ и сьвернымъ губерніямъ Евр. Россіи.

Что касается до ея распредьленія вь Сибирш, то здьсь замытна несомнынная спорадичность и, новидимому, намњчаются различные центры разселенія. Такъ, по С л о в о в у, сьрая крыса рьдка въ Тюменьскомъ округь. Интересно далье отмьтить, что по категорическому заявленію проф. Н. Ө. К ащенко, въ Томскомъ крағ ньть никакихъ крысъ, въ томъ числь и пасюка. Въ тьхъ случаяхь, говорить Кащенко, когда приходилось слышать жалобы на „крысъ“, посльднія всегда оказывались Cricetus cricetus L. или водяной крысой (Avv. amphibius L.) По свидьтельству Н. А. С в верцо ва встрьчается въ юго-зап. части Туркестана. По Мааку ( о 2, стр. го5) встрьчается около Нркутска лишь изрьдка, тогда какь въ Лауріи, напримьръ, около Нерчинскапасюкъ обыкновененъ. Н. С. П о ля ко в ъ считаетъ Ep. norvegicus Erxl. очень обыкновеннымъ въ окрестностяхъ Иркутска и по теченію Лены, а также на пріпскахь Олекминско-Витилскої горної страны (I 36 , стр. 47). По Щр е н у пасюкъ распространенъ по всему Амурскому краю, куда первоначально проникъ, вьроятно, изъ Китая; на пароходахъ завезенъ и размножился на Сахалинь (O ld. Th om a s, ( 193 ) р. 404) и на Камчатк' (Ш р е н ъ). Р а дде нашель эту крысу по всей вост. Сибири (окр. Иркутска, Тарей-Нора, вост. цьпь Саянъ, Бурея).

\section{Біологическія особенности.}

Какъ было уже сказано выше, сьрая крыса встрьчается главнымъ образомъ въ ближайшемъ сосћдствь съ человькомъ, являясь однимъ изъ самыхъ непріятныхъ и вредныхъ паразитовъ. Большіе размьры и сильные зубы вщьсть⿱⺊口 съ злобной смблостью пасюка дьлаютъ его довольно непріятнымъ даже для человька, защищаясь отъ котораго, эта крыса, если отнять у ней возможность бьгства, можеть броситься и начать кусаться. Забравшись въ птичникъ, пасюкъ наноситъ тамъ очень значительныя опустошенія. Онь душить молодыхъ птиць и пошдаеть запасы корма.

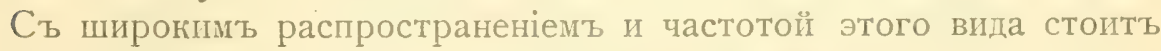
въ связи его большая плодовитость: онъ мечеть въ годъ отъ двухъ до трехъ разъ по 4-8 дьтенышей.

Экзелплары коллекии перечислены въ таблицахъ измьреній. 


\section{Epimys rattus L.}

\section{Черная крыса.}

ITus rattus Linnaeus (98), p. 83. B lasius (27), p. 317. Milla is (110), p. 203 pl. 42. A. А. Бр а уне ръ (3 7), стр. 4. B. M. Shitkov (7 4), p. 171, Mrus (Epimys) rattus L. T rou ess a r t $(200)$, p. 143. K. А С а т у н ин т $(165)$, crp. 13. и (1 6 6), р. 2.

\section{Сиетематическія особенности.}

По словамъ А. А. Браунера, черепъ черної крысы съ ея аберраціями не отличается рћзко оть черепа пасюка, но это наблюденіе справедливо только по отношенію къ молодымъ экземплярамь, тогда какъ черепа старыхъ очень рҺзко разнятся между собою. Въ черепь старой черной крысы теменныя кости значительно вздуты, рłзко выдаваясь надъ линіеї, проведенної отъ задняго края межтеменной кости до средины лобныхъ. Гребни, идущіе по бокамъ лобныхъ костей, образуютъ по заднимъ краямъ посльднихъ зам'九ную оторочку, постепенно суживающуюся у переднихъ краевь омьи fioutalia. Гребни, служашіе продолженіемъ описанныхъ и идущіе по бокамъ теменныхъ и височныхъ костей, образують дугообразную линію, сильно выпуклую по внбшнему краю. Выпуклости на м бсть соединенія лобныхъ, носовыхъ и межтеменныхъ костей-совершенно ныть; болье того, она замънена ясной впадиной. Если смотрыть на черепъ черной крысы въ профиль, то наклонъ носовыхъ костей впередъ, а лобныхъ и теменныхъ назадъ, представляется очень слабымъ. Носовыя кости сужены кзади, но расширяются впередъ равномьрно и довольно слабо. Foramina infraorbitatia вытянуты въ длину, но очень слабо въ бока. Наибольшая ширина тонкихъ скуловыхъ дугъ приходится въ ихъ заднемъ отдыль. На нижней челюсти, какъ вьрно пишеть А. А. Бр ауне рь, incisura semilunaris posterior имъеть характеръ выемки, т.-е. мелка, являясь не въ видь полукруга, а въ видь полуовала; processus coronoideus тонкій и острый.

पерепа молодыхб, какъ было уже сказано, характеризуются не столь рьзқо. Однако, форма скуловыхъ дугъ, foramen infraorbitale и пр. прізнаки дылають діагнозь не очень труднымъ. Черепь Epimys rattus alexandrimus Geoffroy ничьмъ не отличается отъ такового типичной черной крысы.

Вся группа черныхъ крысъ можетъ быть характеризована сльдуюшими пластическими признаками: вышина: уха составляеть половину, или только немного менбе половины длины головы; хвостъ всегда длиннье туловиша съ головою; число колецъ на немъ отъ 2 го ( 
Orраска черной крысы подвержена очень спльнымъ варіаціямъ. Цвъть верхней стороны мұха московскаго экземпляра, добытаго Н. Ю. 3 о г рафо м ъ,-очень св'ьлый, каштаново-бурый; нижняя сторона сђровато-бълая, съ рђзкимъ серебристымъ оттьнкомъ.

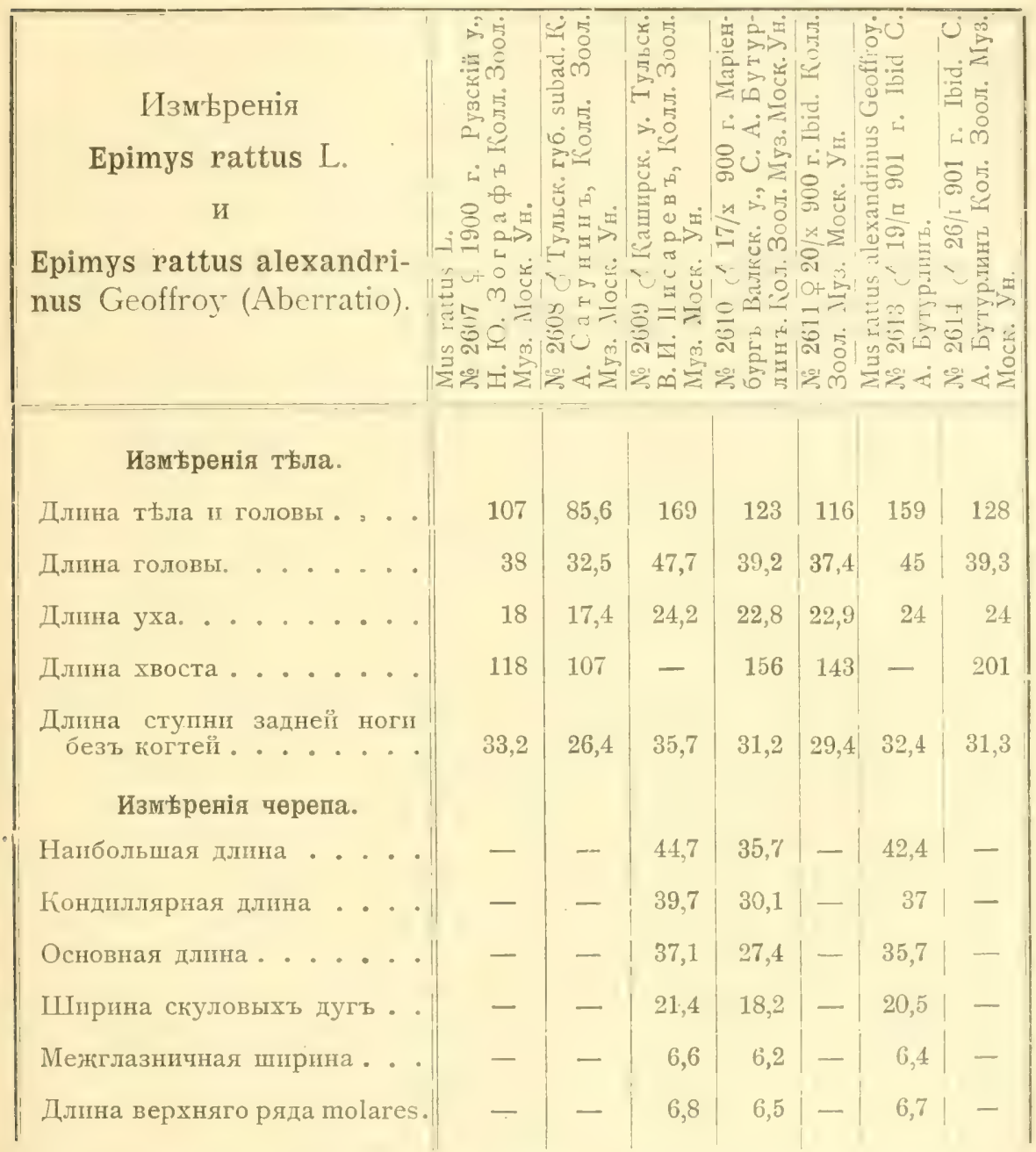

Лапы очень свћтлыя б́ыло-желтоватыя. Два туғпсиия эгземпляра, въ особенности добытый К. А. С атуниным, значительно темнье: у этой крысы мъхъ верхней стороны черно-коричневый, нижняя сторона довольно темнаго сьраго цвђта. Отъ упомянутыхъ типовъ окраски встрђчаются всь переходы къ совершенно черной. Подобныхъ Epinys rattus L. очень красивой, блестяще черной окраски я видьль изъ окрестностей Тифлиса, а Браунеръ находилъ ихъ въ Одессъ. 
Въ заключеніе мнь хотьлось еще разсмотрьть, что представляетъ собою такъ называемая египетская крыса Epimys rattus alexandrims Geoffroy. Эта форма частью изсльдователей (А. А. Бр а уне р ъ) считается „варіаціей“ черной крысы, частью (T ro uessart, Milla is) - подвидомъ. Mны кажется, что одно очень интересное наблюденіе А. А. Бр аунера въ значительной мърь рьшаеть эту задачу. Въ конць февраля, пишетъ Браунеръ, (37, стр. Іо), изг одиоєо ильзда ему были доставлены: взрослая крыса, поцростокь и два дьтеныша. „Взрослая была сверху темнобураго цвьта, снизу бьлаго, т.-е. по окраскь египетская крыса (us alexandimus), подростокъ принадлежаль къ той же разновидности, судя по окраскҢ (сверху рыжевато-сьрый, снизу бьлый), пзъ двухъ дьтенышей: одинъ--почти черный сверху, снизу же пепельный, т.-е., какъ у черной крысы (Mus rattus typ.), между тьмъ, какъ другої дьтенышъ сверху рыжевато-сћраго, а снизу б́ьлаго цв'ьта, т.-е. какъ у египетской крысы (Mus alexandrims).

Этоть интересный факть можетъ, какъ мнь кажется, быть объясненъ по теоріи Менделя. Сравнивая приведенный А. A. Браунеромъ случай съ таковыми при опытахъ скрещиванія разноцв бтныхъ мышеї $\mathrm{C}$ uén o ${ }^{1}$ ), невольно бросается въ глаза извђстная аналогія. Въ этихъ опытахъ гетерозиготное, одноцвьтное потомство оть разно окрашенныхъ родителей давало при дальньйшемъ скрещиваніи июсколько мипово различныхъ окрасокъ мышей. Эти опыты различно толковались разными изсльдователями (B a teson, C a st le, Miss D urham), но сущность дьла въ общемъ оставалась одна: допускалось, что при. скрещиваніи мышей различныхъ типовъ окраски, напримъръ, сьраго и коричневаго, получалось однотипное (сьрое) потомство-

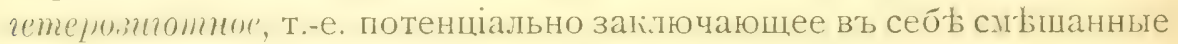
признаки, выступающіе наружу при дальньишемь скрещиваніи. Въ случағ А. А. Браунера многое говорить за то, чтобы считать материнскую форму Ep. vattus alexandrinus Geoffroy за гетерозиготную помьсь типичної rattus и alexandrimus, готорая въ скрещиваніи дала разнотипное потомство. Cuénot имьлъ дьло съ разно ограшенными цвьтными аберраціями домашнихъ мышей,-многое говоритъ за то, чтобы считать. . rattus alexandrimus Geoffroy тағже только аберраціей типичной rattus. Конечно, такої вопрось монетъ ясно разрьшить только опытъ. Мнь думается, что съ прысами такіе опыты жогли бы дать плодотворные результаты.

1) Cr. V a lentin Haecker, Allgemeine Vererbungslehre, 1911, p. 264, pl. III $a$, III $b$. 
Географическое распространеніе.

Хорошо извьстень тоть фагть, что черная грыса, въ прежнее врепя столь распространенная въ предблахъ Европейской Россіи, начиная со второй половины прошлаго стольтія рюькко уменьшается въ числь и совершенно исчезла изъ многихъ мбстъ, гдь была обыкновенна, уступивъ свое м’сто болье прупному и сильному пасюку. Въ частности, въ Московскої губ., по словамъ Ассмуса, писавшаго въ I857 году, черная грыса „пять льтъ тому назадъ была еще очень обыкновенна, а теперь совершенно истреблена“. К. А. С а тунин ъ во время своихъ изсльдованій фауны млекопитающихъ Московской губ. пришелъ относительно черной грысы къ отрицательному результату, считая ее окончательно истребленной въ данной мьстности. Совершенно неожиданно проф. Н. Ю. 3 ог раф 'ь въ І9оо году добыль одинъ экземпляръ черной крысы въ своемъ имъніи „Мытники“, расположенномъ на р. Озерной, притокь р. Рузы, бл. гор. Рузы. Этоть, пока единственный, фактъ все же доказываетъ, что Еріmys rattus L. еще встрьчается въ Московскихъ предълахъ.

Распространеніе черной кррысы въ Европейской Россіи я разсмотрю въ хронологическомъ порядкы постепеннаго убыванія.

По прежнимъ изсльдованіямъ Георг и эта грыса была широко распространена въ Европ. Россіи, встрьчаясь до $62^{0}$ с. ш. Георгі указываетъ ее для Польши, Курляндіи, Лифляндіи, Финляндіи, Вологды, Перми и Астрахани. Въ Финляндіи ее нашель $\mathrm{Sadelin.} \mathrm{Д} \mathrm{в} \mathrm{игубск} \mathrm{і} \mathrm{й}(42$, стр. 40) ограничивается общимъ указаніемъ „водится по всей Россіи“. По свидытельству Палласа встрьчалась въ Симбрскь, воділась въ Царицыны, откуда вытьснена пасюкомь ( 13 o, р. I65). Нордм ан н ъ (1 2 5) считаль ее менье распространениой по Черноморскому побережью, чьмь пасюка, и указываетъ находки ея в’ь Харьковской и Екатеринославской губ. Въ г 853 году Черна ї (2 о 3) совершенно не нашель этой крысы въ Харьковской губ,, а только пасюка. По свидьтельству Ке с л ера, до І850 года въ Кіевской губ. встрђчалась только черная крыса. Однако, въ 1866 году Epimys rattus L. найдена Belke близъ Радомысля Кіевской губ. и указана этимь же авторомь для Каменець-Подольска (І7, Р. 4І8).

Переходя теперь къ болье новымъ указаніямъ, мы встрычаемся со свидьтельствомъ М. Н. Бо гд ан о в а (187 I г.), что черная крыса совершенно истреблена пасюломъ въ области Поволжья, гдь въ свое время ее помдтль очень рьдкой проф. Әे в рсманнъ. Посльдняя находка здысь Epimys vattus L. была сдылана проф. 
Футсом ь (въ началь прошлаго стольтія) въ Казанской губ. Такке очень рыдка она въ Оренбургскомъ крағ: Н. А. 3 а рудны й добыль тамь только два экземпляра $(77$, стр. 340$)$. Въ центральныхъ губерніяхь черную крысу нашель Э саулов ъ въ Холмскомъ и Торопецкомъ уу. Псковскої губ́. (58, р. 225); я наблюдаль ее въ Сычевскомъ у. Смоленской губ. (въ I9о г). В. И. Писаревъ и К. А. Сатунин добыли экземпляры въ Тульской губ. По моимъ наблюденіямъ, она еще всгрьчается въ Малоархангельскомъ у. Орловской губ. (І905 г.). Въ Одессь найдена А. А. Брауне ром ь (37, стр. 4). Въ I Грибалтійскихъ провинціяхь, по Л и т енш т еî́ н у (г829 г.), встрьчалась въ Курляндіи очень часто вмысть съ пасюкомь. Теперь ина стала тамъ весьма рђдка. Изъ новыхъ указаній на ея распространеніе въ этої мьстности мы имьемъ находку двухъ Epimys rattus L. typ. и двухъ Epimys $r$. alexandrinus Geoffroy около Маріенбурга Валкск. у., сдьланную С. А. Бут у р и ны м . Для Лифляндіи и Эстляндіи ее указываетъ и Г ре ве́ (67, p. II2). Въ западнощъ крат Ep. rattus L., по Т ачанов кому, наїдена Валковиче мъ въ Литв' и Минской губ. На Кавказ' встрьчается, по К. А. Сатунину, около Мухрани, Артвина и Тифлиса, въ посльднемь она найдена также $\Theta$. $Ө$. Каврайским и В. Б. Баньковскимъ ${ }^{1}$ ). Въ Западної Европь описано нысколько "Подвидовъ“; таксономическое значеніе одного изъ нихъ (Ep. $*$. alexandrims Geoffroy) мы уже разсмотрьли. Въ Венеціи, Франціи, по Труссару, встрьчается Ep. rattus intermedius Ninni, въ сьверной и южной Африк' распространена Ep. ratt. ater Millais, которую, по Т руссару, на судахъ завозятъ на Черноморское побережье. Наши свьдьнія о распространеніи черной крысы въ Азіи очень скудны. Она найдена около Асхабада В а ренцовымъ и, по Т о асу, встрьчена близъ Самарканда ( 96, p. 262).

\section{Образъ жизни.}

Къ сожальнію, въ Московскої губ. никакихъ біологическихъ св'ддніï собрать не удалось.

Въ ю.-в. части Орловской губ. черная крыса попадалась мнь, въ противоположность пасюку, въ нежилыхъ строеніяхъ и амбарахъ.

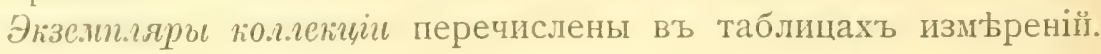

1) Всь⿱ крысы, собранныя послбднимъ, относятся къ Ep. rattus ater Millais, но я склонент счптать эту форму лишь меланистической аберраціеі. 


\section{Опредйлительная таблица М u inae $\mathbf{L}$.}

I. Нёбныя складки, кромь одної или двухъ переднихъ, съ разрьзомъ посрединь. Ступни ногъ тонки и коротки. На хвость постоянно меньше 200 чешуїчатыхъ колецъ. Всь бородавки на ступняхъ заднихъ конечностей округлы. Длина тыла (безъ хвоста) взрослыхъ особей всегда меньше І5о mm.

$$
\text { Родъ M us (pr. dict.). }
$$

А. Теменныя кости, охватывая съ боковъ лобныя, не даютъ по направленію впередъ замћтныхъ острыхъ выступовъ, но толыко два небольшихъ тупыхъ выроста. Лобныя кости вдаются въ область теменныхъ закругленної дугою. Межтеменная кость съ замытными боковыми суженіяи и значительнымь расширеніемъ въ центральной части. На поверхности нижняго передняго коренного зуба находится 6 тупыхъ, попарно расположенныхъ эмалевыхъ бугорковъ и, кромь нихъ-одинъ спереди, образующій съ бугорками передней (первої) пары трехлучевую фасетку. Помимо нихъ, нбсколько дополнительныхъ (2-3) бугорковъ распредьлены на вньшней сторонћ зуба.

\section{Группа Mus sylvaticus L. (et subsp.).}

a (b). Окраска рыжевато сьро-бурая сверху, бьлая-снизу (старыя особи); или: сњрая, съ легкимъ рыжимъ оттьнкомь сверху и грязно былесая-снизу (молодыя). Рыжаго пятна на груди между передними конечностями никогда не бываеть. Длина тьла не болье 9I,5 mm.; хвость не болье Iог mm;; ступня задней ноги: І8-21,5 mm; наибольшая длина черепа: 2I,3-27,5 $\mathrm{mm}$.

Mus sylvaticus mosquensis Ogn.

b (а). Окраска болье яркая, иногда съ каштановымъ оттьнкомъ. Постоянное присутствіе замьтнаго рыжаго пятна на груди между передними юонечностями. Длина тьла (adult.): 93-г2о,5 mm.; хвоста-не менье гоo mm., обычно: Iо5I28 mm.; ступня: 22,4-26,3 mm.; наибольшая длина черепа: ок. $29 \mathrm{~mm}$.

$(\dagger)$ Mus sylvaticus wintoni Barr.-Ham. $\left.{ }^{1}\right)$.

1) Въ Московской губ. не найдена и, в роятно, не встрђчается. Прівожу этотъ подвпдъ въ опредьлительної таблиць, въ виду полной возможности нахожденія его въ Тверской. Псковской пl др. смежныхъ съ Московской губерніяхъ. 
В. Теменныя кости, охватывая съ боковъ лобныя, даютъ по направленію впередъ два зальтныхъ острыхъ выроста. Лобныя гости вдаются въ область теменныхъ языковиднылъ угловатымъ гонтуромъ. Межтеменная гость почти совершенно не сужена по бокамъ, внышніе контуры посльднихъ прямоугольны и не имьютъ формы острыхъ выростовъ, какъ у льсной мыши. На поверхности нікняго передняго коренного зуба только 6 тупыхъ, парныхъ бугорковъ безъ развитія добавочныхъ.

\section{Грруппа Mus musculus L.}

c. (d.) Окраска сверху сьрая, нижняя сторона грязно-бьловатая (рьже: сверху буроватая, снизу желтовато-бьлая). Длина тьла не болье 88 mm.; хвостъ: 57 -8I mm.; ступня задней ноги: I5,I-I7,7 mm; наибольшая длина черепа: $2 \mathrm{O}-23,2 \mathrm{~mm}$.

Mus musculus typ. L.

С. Теменныя кости, охватывая съ боковъ лобныя, не даютъ длинныхъ, острыхъ выступовъ. Јобныя кости вдаются въ область теменныхъ очень тупымъ угломъ, переходящимъ иногда въ прямую линію. Межтеменная кость спереди и сзади вытянута въ два длинныхъ выроста, а съ боковь широга и косо срьзана. На первомь коренномь зубь нижней челюсти, кромь 6 тупыхь парныхъ бугорковъ, имьется еще нұсколько добавочныхъ, какъ у Mus sylvaticus (et subśp.).

Подродъ А podemus.

е. Окраска сверху ржаво-буроватая; оть межглазничної области до основанія хвоста тянется по среднеї линіи спины черная полоса, нижняя сторона бьлая (adult.). Или: сверху тонъ мғха сьрый, съ буроватым оттынконь, चерная полоса хорошо замьтна, нижняя сторона сьробьлая (subad.). Длина тьла (взрослыхъ экземпляровъ): 68-90 mm.; хвоста: 57-78 пm.; ступни заднеї ноги: I6-ı8,6; наибольшая длина черепа: 2I,3-25,3.

\section{A. agrarius Pall.}

D. Теменныя гости, охватывая съ боковъ лобныя, не даютъ по направленію впередъ замьтныхъ острыхъ выступовъ. Лобныя пости граничать съ теменными слабо выпуклою дугою, не образующеї въ своей серединь сколько-нибудь замьтнаго тупого угіа. Межтеленная кость сравнительно широга, вытянута въ пентры спереді п сзади въ два довольно тупыхъ выроста ІІ огранпчена съ боковъ полукруглыми контурами безъ замьтнаго суженія по сравненію съ центральной частью. На поверхности 
перваго нижняго коренного зуба, кромь 6 тупыхъ бугорковъ, находятся еще ньсколько добавочныхъ. Первые четыре бугорка образують фигуру косого креста, спереди оть котораго лежитъ добавочный бугорокъ.

Подродъ Мi i r o m ys.

f. Окраска сверху каштаново-рыжая, снизу чисто-бьлая (adult.) или сверху сьро-буроватая (subad.). Наибольшая длина черепа: I6,3- $19,3 \mathrm{~mm}$. Micromys minutus Pall.

II. Нёбныя складки, кромь почти прямыхъ и цыльныхъ двухъ переднихъ, съ остроугольными прогибами назадъ, но безъ разрьза посрединь. Ступни ногъ длинны и толсты. На хвость обычно болье I75 чешуйчатыхъ колецъ (чаце ихъ: г8о-260). Посльдняя бородавка на ступняхъ заднихъ ногъ вытянута и искривлена.

Родъ E pim y s Trouessart.

g. (h.) Гребни, идущіе по бокамъ лобныхъ костей (если смотрьть на нихъ сверху), образують по заднимъ краямъ посльднихъ замьтную оторочку, довольно рђзко суживающуюся у переднихъ концовъ ossa frontatia. Гребни, служащіе продолженіель указанныхъ и идущіе по бокамъ теменныхъ и височныхъ костей, почти прямы и только слабо выпуклы по линіи вньшняго края. Наибольшая ширина массивныхъ скуловыхъ дугъ приходится на ихъ срединную часть. Ухо по длинь составляеть нысіолько болье $1 / 3$ головы; хвость короче тьла, число чешуйчатыхъ колецъ на немъ колеблется оть 175-20о.

Epimys norvegicus Erxl.

h. (g.) Гребни, идущіе по бокамъ лобныхъ костеї, образуютъ по заднимъ краямъ посльднихъ замьтную оторочиу, постепенно суживаюшуюся у переднихь краевъ ossa fiontalia. Гребни, служащіе продолженіемь указанныхъ и идущіе по бокащъ теменныхъ и височныхъ костеї, образують дугообразную линію, выпуклую по вньшнему краю. Наибольшая ширина тонкихъ скуловыхъ дугъ приходится въ ихъ заднемь отдьль. Длина уха составляеть $1 / 2$ (или только немного менье) длины головы; хвостъ всегда длиннье туловища съ головою, число колецъ на немъ отъ 2 го (рьдко) до 280.

Epimys rattus L. 


\section{Подсемейство Cricetinae.}

\section{Родъ Cricetus Leske (1779).}

\section{Хомяки.}

Млекопитающія этого рода очень легко отличаются отъ описанныхъ цьлымъ рядомъ признаковъ. Размьры ихъ толстаго и неуклюжаго тьла сравнительно крупные, лапы очень короткія. Морда широкая и большая; по бокамъ ротовой полости располагаются два защечныхъ мьшка. Хвостъ менъе $1 / 3$ тьла.

Коренные зубы верхней челюсти съ двумя бугорками въ каждомъ поперечномь ряду ${ }^{1}$ ).

Правый и львый ряды верхнечелюстныхъ зубовъ по направленію кпереди сильно между собою расходятся. О подробностяхъ строенія черепа будеть сказано при описаніи вида.

Зубная формула:

$$
\mathrm{i} \cdot \frac{\mathrm{I}-\mathrm{I}}{\mathrm{I}-\mathrm{I}}, \mathrm{pm} \cdot \frac{\mathrm{O}-\mathrm{O}}{\mathrm{O}-\mathrm{O}}, \quad \mathrm{m} \cdot \frac{3-3}{3-3}=\mathrm{I} 6 .
$$

\section{Cricetus cricetus $L$.}

\section{Хомякъ обыкновенный.}

Mus cricetus $\mathrm{L}$ inn a e us (98), p. 82. Cricetus frumentarius $\mathrm{P}$ a $1 \mathrm{l}$ as (130), p. 161. B lasius (2 7), p. 306. Cricetus cricetus (L.) Trouessart (200), p. 159. Cricetus frumentarius Pall. С атунн н ъ $(165)$, стр. 10. С а т унин в, (1 6 6), p. 2. С. И. Ог н ев в и С. Н. Г ор б а че в т (1 29), стр. 16-22.

\section{Систематическія особенности.}

Крупный, угловатый черепв хомяка отличается въ старомъ возрасты сильнымъ развитіемъ гребней и широко разставленными скуловыми дугами. Носовыя кости крайне рьзко расширены кпереди и сужены сзади. Foramen infraorbitale ограничено по линіи наружнаго края угловатої линіей и сильно суживается книзу. Форма межтеменной кости у хомяковъ крайне измьнчива. У моихъ экземпляровъ изъ Московскої губ. она то крайне мала (은 64) и коротка, то вытянута въ два длинныхъ острыхъ отростка, далеко расходяцихся по бокамъ (스 648). Всльдствіе этого утвержденіе К. А. С а тунина ( 56 , стр. 122), что у мо-

1) Этотъ прпзнақъ легко. отличаетъ зубную систему хомяқовъ отъ $\boldsymbol{M} и$ vinae, у конхь, какт было сказано, въ каждомъ поперечномъ ряду находятся по 3 бугорка. Указанное отличіе хорошо въ прпмненін къ довольно молодым хомякамъ, тогда какъ у старыхъ бугоркі совершенно стіраются иі остается только выпуклая оторочка по внъшнему контуру зуба. 
сковскихъ хомяковъ „задній край межтеменной кости очень коротокь", которое онъ дьлаеть въ категорической фориь, какъ видно изъ его работы, только на основаніи одного экземпляраболье чьиъ поспьшно. Возрастная измнчивость черепа очень велика. Черепъ молодого экземпляра округлой, яйцевидной формы, безъ развитія гребней; скуловыя дуги узкія и тонкія; носовыя кости расширяются кпереди сравнительно слабо, межглазничный промежутокъ относительно гораздо шире.

Ниже, на стр. 248, я даю промбры череповь имћैющихся у меня экземпляровъ.

Oкраска стараго хомяка изъ Московской губ. въ свьжемъ осеннемъ м'bxy такіова.

Вся верхняя часть тьла, начиная съ заглазничной области и продолжаясь отсюда широкой полосої къ ушамъ и далье по всеї верхнеї сторон' спины,-покрыта длинными и густыми волосами съ замьтными черно-сьрыми основаніями и очень широкой желто-палевой вершинной частью. На вершинахъ многихъ изъ такихъ волосъ замьчаются совершенно черныя окончанія. Кромь подобнаго мьха, можно видтть очень значительный процентъ болье длинныхъ, совершенно черныхъ волосъ, придающихъ общему тону спины сьро-палево-желтоватый цвьтъ. Въ области нижнеї спины, около хвоста, а также на бокахъ примьшиваются въ значительномъ количеств вершено вытћсняютъ остальные, придавая этимъ частямъ ровный и чистый ржаво-коричневый тонъ. Весь хвостъ и подхвостье покрыты такимъ же мьхомъ. Область впереди глазъ, кронь конца носа, и далье все окологлазное пространство, щеки, околоушныя части и бока тьла за ушами-отличаются яркимъ, пнтенсивнымъ ржаво-красновато-бурымь мбхомъ, съ очень слабой примбсью черныхъ волост. Подбородокъ, окружность рта и направляюшійся отсюда ярко ограниченныи островъ мыха къ щекамь покрыть совершенно бьлымъ мххомъ сь болье или менье замьтнымъ желтоватымъ оттьнкомъ. Два обозначенныхъ, но обычно менье яркихъ острова ржаво-бьлаго мыха залtтныодинъ впереди передней конечности, другої-на боку тধла, за ней. Вся нижняя сторона тьла покрыта широкимь полемъ интенсивно-чернаго мьха, захватывающаго собою нижнюю часть шеи, переднія конечности, брюхо, заднія конечности. Верхнія части ступни и пальцы-бьлые. На пятк' заднихъ конечностей находится ясное черное пятно. Уши покрыты рыжевато-сбрыми волосами съ бьлой каймої, ширина кооторой крайне измьнчива. Вибриссы черныя и длинныя. 


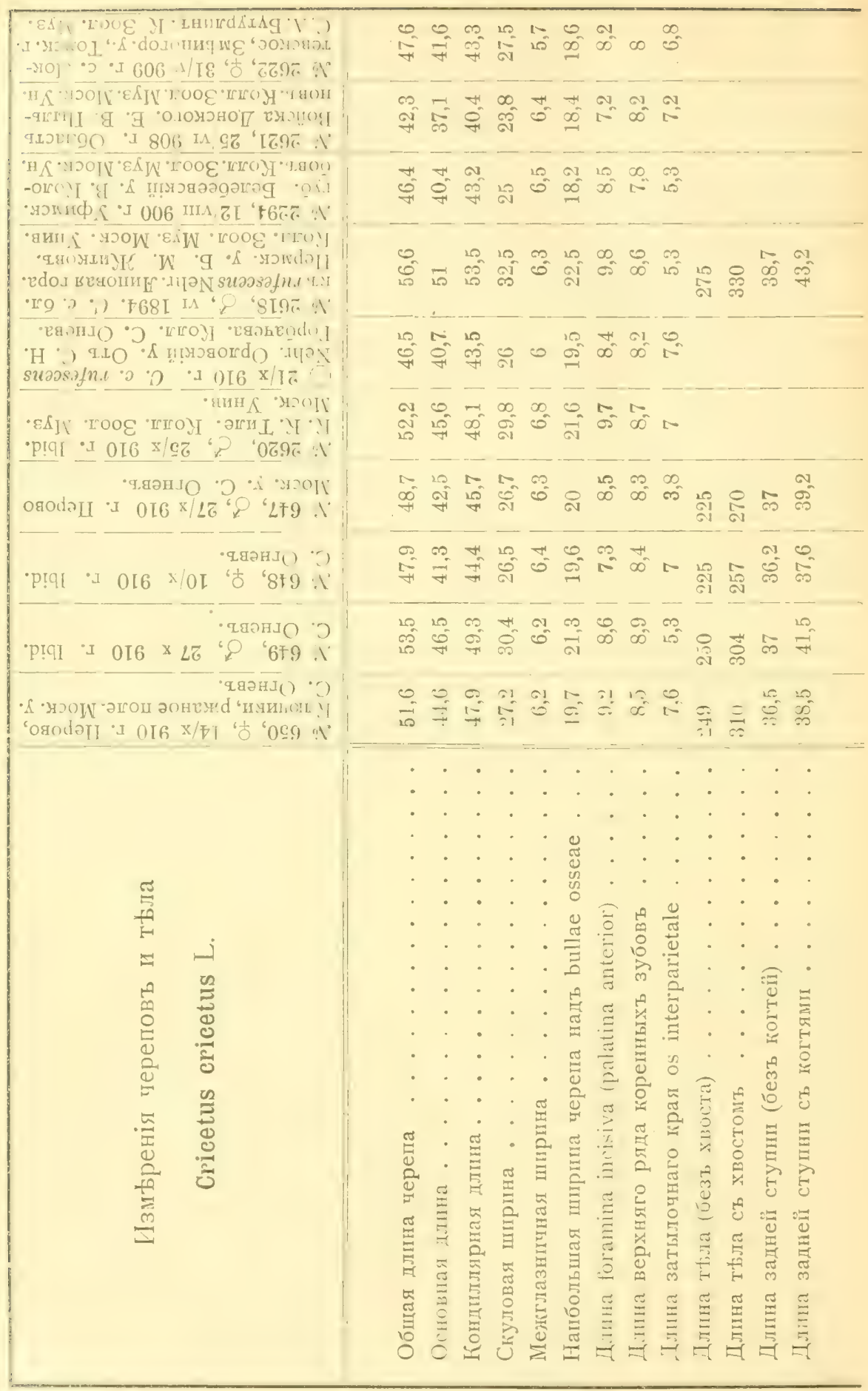


Отъ этого основного типа окраски зимняго мыха имьются довольно значительныя колебанія: мы легко можемь видыть на серіи хомяковъ изъ одной и той же мыстности разные переходы въ интенсивности рыжаго тона спины, который то спабо замћтенъ, то достаточно ярокъ. Оть лю плло зимній мћхъ легко отличается, кромы замьтно большей длины-болье сьрымъ общимь оттьнкомъ, обусловленнымъ широкими черными окончаніями волось и значительной примьсью длинної, совершенно черной шерсти. Льтній мьхъ измьнчивъ въ окраск' еще замьтные зимняго. Мы имъемs здысь передъ собою всь переходы оть яркаго рыжаго оттьнка къ палево-сърому и притомъ у хомяковъ изъ одной и той же мьстности. Въ періоды линьки, т.-е. весною въ апрьль и осенью въ августь, концы волосъ изнашиваются, длинные черные волосы дылаются короче, всльдствіе чего выступаютъ наружу уже выцвьтшія среднія части волосъ.

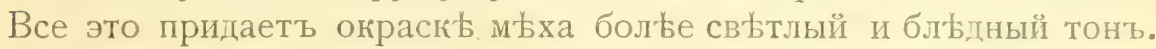
Наконецъ, молодыя особи значительно сырые и тусклье старыхъ. Въ заключеніе этого систематическаго очерка я остановлюсь въ краткихъ словахъ на обзорь таксономическаго значенія разныхь подвидовъ обыкновеннаго хомяка, которые описывались многими авторами. Въ нової сводочной работь Т р у сс ара "Conspectus mammalium Europae" (IgIo) приводится какљ „видъ" Cricetus fuscatus Brdt. Я почти не сомньваюсь, что подъ этимъ названіемъ Брандтом была описана просто рыжая аберрація Cricetus cricetus L. Самъ авторъ въ своихъ поздныишихъ работахъ считаеть его „варіететомъ ", равносильнымъ черному хомяку (34, р. 40). Весьма вьроятно, что къ этой же аберраціг принадлежали т古 желто-бурые хомяки, о которыхъ упоминаеть Н. А. 3 а р удны й въ своей работь (7 7, стр. 338). Къ сожальнію, по словамъ К. А. С атунина, чучело, представляюшее типъ $C$.fuscatus Б р а нд т а, настолько плохо, что діагнозъ его крайне затруднителень. Переходя теперь къ такь наз. черному хомяку, который въ сводочної работь Труссара (2оо, p. 159) названъ Cricetus cricetus niger (Schreb.) и, сльдовательно, выдьленъ каюъ „subspecies",一я могу безъ всякихъ колебаній считать его только цвьтовой аберраціей. Доказательствомъ этому служить вкрапленность распространенія чернаго хомяка въ область обитанія Cricetus cricetus L., а также еце старый факть нахожденія П ал ла с ом ъ (I 3 I, p. І 28) въ одномъ гньздь какъ черныхъ, такъ и рыжихь хомяковъ. Укажу здысь побочно на одну очень интересную особенность распространенія чернаго хомяка. Именно, въ нькоторыхъ мьстностяхъ онъ положительно 
преобладаетъ надъ Cricetus crectus L. Мы имьемъ здысь примьръ

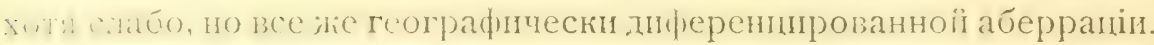

Разборъ систематическаго значенія недавно описанныхъ разнвли авторами подвидовъ хомяковъ я далъ въ своей совмЂстной съь С. Н. Г орбачев м з работы „Млекопитающія ю.-в. Орловской губ.". Теперь я располагаю значительно бо̀льшимъ матеріаломъ ${ }^{1}$ ) и хотьлъ бы пополнить высказанные раньше взгляды и предполотенія.

Какъ мы писали ранte, Cricetus cricetus canescens Nehr. (I 2 I, S. I -3) съ льв. бер. p. Мааса (Бельгія), вћроятно, имћеть право на дальныйее существованіе, а также румынскій C. c. nehringi Matschie, т. к. Длина ступни посльдняго очень мала (max. 29 mm.) и вмьсть съ цвђтовыми признаками, по крайней мырь по описанію, позволяетъ легко отличить эту форму. (Этотъ подвидъ къ тому же быль описанъ Матчи на основаніи серіи въ го экземпляровъ.) Что касается до C. c. rufescens Nehr. изъ Тюбука, хомяка, характеризованнаго Нерингом я ярко-красновато-рыжей окраской спины и особенно боковъ, темно-чернымъ мћхомь нижней стороны, короткими ушами, съ широкими былыми каймами, то эта форма врядъ ли заслуживаетъ выдьленія. Какъ я писаль уже ранбе, нькоторые изъ указанныхъ признаковъ, въ родь бьлой каймы вокругъ уха, крайне измьнчивы. Далье, на ряду съ типичными C. c. vufescens Nehr. въ одной и той же мьстности попадағтся очень свьтлые сђроватые экземпляры. Напримьръ, въ Орловскомъ у. среди серіи бльдныхъ хомяковъ попался одинъ (добытый 2/1х 9тог.) типичный и яркій „rufescens" 2). Совершенно такую же картину м'шанаго распространенія я иогъ констатировать при просмотр ьٔ серій изь восточныхъ частей Европейской Россіи. Такъ, въ коллекціи Зоол. Муз. Моск. Унив. имьется экземпляръ (ㄴo 2294) изъ Уфимск. губ. Белебеевск. У•, отъ В. К о лобов а. Этотъ хомякъ-типичный C. c. vufescens Nehr; съ пругой стороны, въ :еріяхь коллекціи Имп. Акад. Наукъ имьются свђтлые хомяки безъ сколько-нибудь замьтнаго рыжаго тона, сльдовательно, далеко стоящіе оть C. $c$. rufescens Nehr., напримьръ: изъ Кыштымской дачи Уфимск. губ. (№ 46г , оть

1) Я пмйъ возможность пересмотрбть серіп хомяковъ въ коллекціп Зоол. Муз. Акап. Наукъ, что вмысть съ пыющимся у меня матеріаломъ и хранящпмся въ коллекціи Зоол. Муз. Моск. Унив.-составляетъ около 7о экзем«ляровъ.

2) Этоть хомякт еще ярче п рыжъе, чйъ добытый Б. М. Жи тиов лт б бл. JІповой горы Пермской губ., который приближается къ $C$. $c$. rufesere Vehr. 
Г. А. С ерг в е ва), изъ Уральской обл. (№ 46г7), изъ Оренбурга (№ 46гз отъ Н. А. 3 а р удн аго). Хомяки изъ Западной Сибири, насколько я могъ заключить по пересмотрынному матеріалу ${ }^{1}$ ), отличаются своей сравнительно свьтлой желтоватой оқраской со значительной примъсью сьраго тона. Первоначально я считалъ возможнымъ ихъ выдьленіе въ качествђ самостоятельной формы. Однако, просмотрђвъ большія серіи изъ Оренбургской, Уфимской и др. губ., я пришель къ заключенію, что такіе экземпляры встрбчаются и тамъ на ряду съ C. c. rufescens Nehr. и, вҺроятно, представляють красочную аберрапію, не пріуроченную строго географически. Наконецъ, время года, возрастъ-все это имьеть огромное значеніе для окраски хомяковъ, а эти факторы, обусловливающіе тотъ или другой тонъ мњха, совершенно упускались изъ вицу прежними авторами.

Переходя въ заключеніе къ обзору C. c. stavropolıcus Sat. $\left.{ }^{2}\right)$, я.долженъ здьсь высказать большія сомньнія въ раціональности его выдьленія. Дьло въ томъ, что рђшительно ни одинъ изъ указанныхъ С а туниным ъ признаковъ не выдерживаетъ критики.

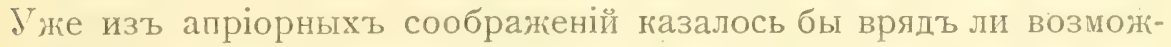
нымъ описывать новый подвидъ только по одному экземпляру въ такой группь, какъ хомяки, столь подверженной широкой изм'ьнивости, личної, сезонной 'и, нагонецъ, возрастной. Въ своей предыдущей работь (г 29) я детально критически разбираль всь признаки C. c. stavropolicus Sat. и пришель къ явно отрицательному результату. Оставляя въ сторон' уже прежде разсмотрынные мною и С. Н. Горбачевым признаки какъ: варіацію окраски спины и бьлой полосы вокругъ уха, ширину скуловыхъ дугъ и межтеменной кости, я остановлюсь еще на одномъ, постоянство котораго я тогда не могъ провьрить,-я говорю о длинь foramina incisiva. Посльднія, по словамъ К. А. С а тунина, у сывверо-кавказскаго хомяка знаиительио короче,

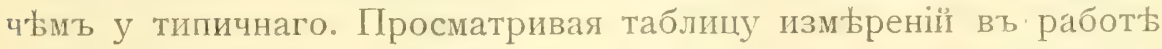
С а тунина, читатель можеть видьть, сколь зиаиителвна эта разница: foram. incisiva у кавказскаго хомяка-8,5 mm., у типичнаго $8,9 \mathrm{~mm}$.

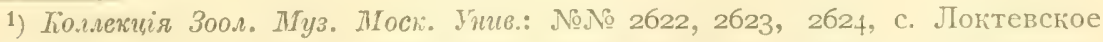

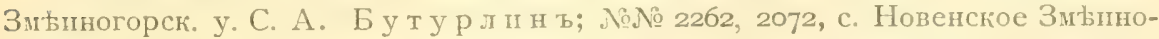

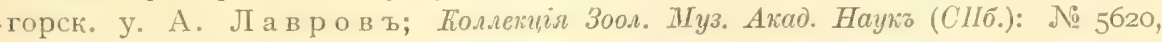
ур. Босъ-Аралъ Семппалат. обл. Плотников ъ; № 5621 (subad.) Ibid.

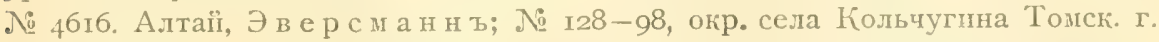
Б. К п сляко в ъ (экземплярт въ спирту и потому об́ъ окраскъ судить довольно трудно, но она представляется довольно свђтлої и бльдної).

2) Извьстія Кавказсқаго Музея, I905 г. стр. II9. 
Я остановился на критик' этого признака потому, что изъ вышеприведенной таблишы промьровъ нашихт экземпляровъ легко можно видьть, что эти отверстія подвержены очень большой измьнчивости даже у хомяюовъ изъ одної и той же мьстности. Часто бываетъ, что у одного и того же экземпляра одно foramen incisivum длиннье другого.

\section{Географическое распространеніе.}

Въ предьлахъ Московской губ. въ распространеніи хомяка сказывается рьзко выраженная спорадичность: въ ныкоторыхъ мьстностяхъ онъ обыкновенень, въ другихъ или очень рьдокъ, или совершенно отсутствуетъ. Благодаря любезности К. К. Т иле, я могъ получить небольшую, но очень хорошую серію хомяковъ изъ окр. ст. Перова Московскаго у. Тамъ эти звьрки держались въ довольно большомь числь' въ мьстечк' „Ключики“ и были хорошо знакомы крестьянамъ. К. А. С атунинъ наблюдаль хомяка на Воробьевыхъ горахъ, бл. Москвы, а Ө. К. Л оренцъ говорить, что хомякь не рћдокъ въ Богородскомъ у Страннымъ образомъ, всђ разспросы крестьянъ объ этомъ млекопитающемь всегда кончались отрицательными отвьтами и большею частью полнымъ недоумьніемъ, о какомъ звьрь идетъ рьчь.

Въ предылахъ средней части Европейской Россіи Cricetus cricetus L. найдень С. Н. Горбачевы мъ и мною въ Малоархангельскомъ, Орловскомъ, Ливенскомъ, Елецкомъ и Болховскомъ уу Орловской губ. Эсауловъ (58, стр. 225) отмьччаетъ его рьдкимъ въ Торопецкомъ и Холмскомъ уу.; по Сабан ье в у, встрђчается въ Ярославской губ. ( 5 o, р. т9). Далье, хомякъ найленъ въ Черниговской губ. К. А. С атунинымъ, въ Кіевской и Полтавской губ. - К. Ө. К есслеромъ (86, р. 67), въ Харьковскої, Екатеринославской - Ч е н а е з (203, р. 275), а въ первой также - С ом в ым ъ ( 84, р. І49). Въ Малороссій онъ добыть. Нордм ан н о ъ ( 125, р. 42), по словамъ котораго, онъ тамъ рьдокъ и обыкновеннье въ Волыни и Подолік. По свид教ельству А. М. Н и ольскаго, хомякъ обыкновененъ около Симферополя, откуда я получиль небольшую серію для опредьленія изь Симферопольскаго Музея. По словамъ К. Ө. К ес слера, этоть звьрь встрьченъ въ долинь р. Салгира, а Г. А. Коже вниковъ добылъ хомяқа на Керченскомъ полуостровь. Zarte на востокъ найденъ Е. В. Пыльновымъ въ области Войска Донского бл. Провальскаго завода (экземпл. въ коллекціи Зоол. Муз. Моск. Унив.), К. А. С атунины мъ-въ Ставропольской губ. (Извьстія Кавк. Муз. І9о5, стр. ІІ9-І23) и въ 
Волжско-Уральской степи (г 67, стр. 8). По Волгь найденъ въ Казанской, Симо́ирской, Саратовской гг. и бл. Сарепты (М. Н. Бо гдановымъ, Б. М. Житков ым Экземпляръ пзъ Новоузенск. у. Самарской губ. хранится въ коллекціи Зоол. Муз. Акад. Наукъ (оть А. Е. Өеоктистов ва). На съверъ отъ Волги и Камы, по М. Н. Богданову, встрычается почти исключительно черная форма, тогда какъ въ Саратовской и Симбирской и въ юго-зап. части Казанской губ. преобладаютъ обычные пестрые хомяки. Однако, черная аберра ція найдена и въ Симо́рской губ. Л епехиным ъ, П алласомъ и Б. М. Житковымъ (экземпляръ въ коллекціи Зоол. Муз. Моск. Унив.). По свидђтельству Д в иг у б скаго (44, р. 72 ; 42, стр. 34), обычный хомякъ встрьчается въ Башкиріи и Уфимской губ. Въ коллекціи Зоол. Муз. Моск. Унив. имбется экземпляръ изъ Белебеевскаго у. (оть К. Колобова). Въ противоположность Эверсманну, по словамъ Н. А. 3 аруднаго, хомякъ обыкновененъ во многихъ частяхъ Оренбургской губ., напримьръ, между Орскомъ и У ральскомъ, на нижней Сакмарь, въ долинъ Нлека, вплоть до Мугоджарскихъ горъ. Далье, онъ найденъ на рькь Бљлой, на верховьяхъ Сакмары, у подножія горы Иремель и у г. Челябинска. По свид'тельству Г. С. К арели н а $(78$, стр. 259), въ Уральскої обл. встрьчается, кромь обыкновеннаго, и черная аберрація хомяка. Очень интересно, что Б. М. Ж и тк о в в нашель Cricelus cricetus 乙. (типа "rufescens" Nehr.) около Перми въ глухой пихтовой тайгб. По Кр ули ковскому (93, стр. II4), въ южныхъ убздахъ Вятской губ. встрђчается довольно часто черная форма, тогда какъ типичный хомякъ вовсе не погадался. По Брандту (34, р. 4ог), сьверная граница распространенія хомяка идеть по $60^{\circ}$. Въ западныхъ ограїнахъ Евр. Россіи Cricetus cricetus L. найденъ Таубе въ Гродненской губ. (экземп. въ коллекціи Зоол. Муз. Акад. Наукъ за № 46o9), Эйх вальдом в въ Литвы и Волыни и, наконець, въ Прибалтійскихъ провинціяхъ онъ, по Греве́ (67, стр. то8-гоg), довольно рыдокъ. Тачановскі ій отмычаеть этого грызуна довольно распространеннымт въ Польш' (І 85 , р. І30).

Въ южныхъ частяхъ Западной Сибири хомякъ найденъ Карелинымъ (см. Brandt, 3 4, p. 4о). По Словцову (г 83 , стр. 209) встрьчается въ Тюменскомь округы, начиная оть Тавдинскаго края и во всъхъ южн. округахъ Тобольской губ. По словамъ Георги, распространенъ вь Сибири близъ Иркутска и въ Бухарб; а по Палласу - въ долинь Обй (г зо, р. т6г). К а щенко (8 2, т. 40) считаетъ хомяка многочисленнымъ во 
всемъ Томскомъ краь. Въ Змынногорскомь у. онъ найденъ бл. села Новенскаго А. Л а в ровы м ъ, а близъ с. Јоктевскаго С. А. Бутур лины м ъ (экземпляры въ коллекціи Зоол. Муз. Моск. Унив.). Въ коллекціи Зоол. Муз. Петерб. Акад. Наукъ я видъль экземпляры изъ урочища Босъ-Араль Семипалатинской обл., отъ г. Плотникова и изъ Алтая отъ проф. Эверсманна. Проф. П. П. С ушкин прислалъ мнь для опредьленія шкурку хомяка изъ Тарбагатая.

Хомякъ распространенъ въ среднихъ частяхъ Западной Европы, образуя, какъ было уже сказано, ньсколько географическихъ формъ: въ Бельгіи - C. c. canescens Nehr., въ Румыніи - C.. melivingi Matsch.

\section{Образъ жизни.}

Выше мной была указана характерная для хомяка спорадичность распространенія, которая является особенно странной потому, что въ Московской губ. имъется много мћсть, пригодныхъ для обитанія этого грызуна. Хомякьь особенно любить яровыя поля, такь какь предпочитаеть овесъ другой пищь. К. А. С атунину удалось сдылать много очень интересныхъ біологическихъ наблюденій надъ этимъ млекопитающимъ. По словамъ этого автора, овальная жилая гньздовая камера хомяка помьшается на глубинь I-2 аршинъ и выстлана кусками рогожи, тряпками, которыя попадають на поля вмьсть съ удобреніемъ. Этотъ выстилающій слой настолько толстъ, что хомякъ, свернувшись клубкомъ, совершенно заполняетъ собою остаюшуюся полость. Далье, пишеть С атунинъ, „изъ жилой камеры идеть короткій ходъ въ другую, гды сохраняются запасы. Такихъ кладовыхъ бываеть иногда нћсколько, расположенныхъ то амфиладой одна за другою, то группой. Запасы состоять главнымъ образомъ изъ овса, котораго иногда бываетъ около мыры, картофеля и разныхъ корешковъ дикихь травъ. Какъ исключеніе, одинъ хомякъ, жившій на опушкь льса, собраль запасъ орьховъ. Подъ Москвой хомякъ затаскиваетъ къ себь также кожи, селедочныя головы и т. п. “... Въ главную камеру идеть съ поверхности земли совершенно правильный вертикальный ходъ, который открывается не посрединь камеры, а ньсколько сбоку. На поверхности, около его отверстія, ньтъ выброшенной земли, что указываеть на то, что хомякъ роетъ его снизу вверхъ, вынося землю черезъ другой ходъ, около котораго всегда набросана порядочная куча земли. Вертикальныц̆ ходъ служитъ для быстраго быгства хомяка въ нору. Такой ходъ бываеть только одинъ, п животное не мьняяетъ его, а потому стьнки его при- 
глаживаются шерстью настолько, что лоснятся. Этоть ходъ слу жить хорошимъ указателемь мьстоположенія гньзда, тогда кақъ другіе бывають разбросаны иногда на пространствы болье квадратной сажени. Спариванье и течку хомяковъ К. А. С атунин ъ въ Московской губ́. не наблюдаль, но, по его словамъ, въ Черниговской губ. она происхоцитъ въ началь сентября. Въ неволь живщіе у меня хомяки были очень злы и не приручались съ теченіемъ времени.

Өкзелляри коллемии перечислены въ таблицахъ измьреній.

Коллекція Зоол. Муз. Моск. Унив.: ad. Московск. у. Ө. К. Лорени ъ (чучело).

\section{Семейство Gliridae.}

\section{С о н и.}

\section{Родъ Muscardinus Kaup (1829).}

Мелкія красивыя млекопитающія съ тупой, короткой мордої, очень длинными вибриссами, мягкой и длинной палево-рыжеватой шерстью. Хвостъ-не чешуйчатый, равный по длинь туловипу, густо покрытый довольно длинными волосами (каждый около $6 \mathrm{~m} / \mathrm{m}$.). Ступни лапь сравнительно очень велики; у окончаній пальцевъ подъ когтями сильно развитыя мозоли.

Зубная формула:

$$
\mathrm{i} \cdot \stackrel{\mathrm{I}-\mathrm{I}}{\mathrm{I}-\mathrm{I}}, \mathrm{PH} \cdot \stackrel{\mathrm{I}-\mathrm{I}}{\mathrm{I}-\mathrm{I}}, \mathrm{I}, \mathrm{H} \cdot \frac{3-3}{3-3}=2 \mathrm{O} .
$$

\section{Muscardinus avellanarius $L$.}

\section{Орьшковая соня.}

Mus avellanarius $\mathrm{L}$ innaeus (98), p. 83. Myoxus muscardinus $\mathrm{Schre}$ ber (1 72 ), p. 835. Myoxus avellanarius B las i us (27), p. 297, fig. 163. Muscardinus avellanarius L. Barret-Hamilton (10), p. 423 II (9), p. 85. Trouessart ( 200$)$, p. 135.

\section{Систематическія особенности.}

Iерепғ. Въ строеніи черепа орђшкової сони сказывается очень много крайне характерныхъ и рђзко выраженныхъ особенностей, позволяющихъ по первому взгляду отличить его отъ черепов Mus и Sicista. Общій видъ характерпзуется большой укороченностью носовыхъ костей, шириной черепной коробки и сильно расширенными, начиная оть foramina infraorbitalia, скуловыми дугами, достигающими наибольшей ширины въ ихъ центральной 
области. Теменныя кости велики и очень замьтно выпуклы; меятеменная пость краине длинна. Простираясь вь бока почти по всему контуру теменныхъ костей, она замытно суживается къ бокащъ и въ центрђ, а спереди вытянута въ тупой отростокъ, тогда какъ сзади ограничена полукруглой линіей. Весьма характерна граница лобныхъ и теменныхъ костей: плоскія, вдавленныя посрединь, лобныя кости выдаются назадъ неправильнымъ полукруглымъ ионтуромъ, дающимъ въ своей центральної части p ъзко диференцированный острый уголь, замьтно выступающій в о оласть теменныхъ гостей. Госльднія охватываютъ съ боковъ лобныя кости и выдаются впередъ притупленными, короткими выростами. Foramina infraorbitalia широко разставлены, округлой формы и сравнительно малы. Bullae osseae крайне вздуты и широки. Въ нижней челюсти характерно строеніе замьтно удлиненнаго и поднимающагося вверхъ processus condyloideus, остраго и прямого processus coronoidteus, тогда какь processi pterygoidei сильно выступаютъ въ бока, а incisura semilumaris posterior мелка и слабо выр взана.

Строеніе зубовъ крайне характерно: premolar'es малы и округлы, настоящіе коренные плоски, прямоугольны, съ параллелъили расположеніемь эмалевыхъ складокъ.

Фориа нёбныхъ складокъ также своеобразна: первая крайне высока и толста, сь двумя боковыми, неправильной формы отростками, направленными назадъ. Сльдующая (вторая) складка дугообразной формы, съ выростомъ въ центрь, выдающимся назадъ. Третья и четвертая складки замьтно расширены по бокамъ и вдаются назадъ глубоко выступающими углами. Далье идуть двь (5 и 6) слабо диференцированныя складки, не сходящіяся посрединь, и, наконець, посльдняя седьмая складка по формь напоминаеть цьльную, слабо выдающуюся впередъ дугообразную линію.

Orраска. Вся верхняя часть тьла покрыта длинными волосами, желто-сьрыми у основаній и съ широкими палево-сьровато желтыми окончаніями. Между такими волосами примьшивается довюльно значительный процентъ болье длинныхъ соверпенно черпыхь. Окраска нижней стороны не рьзко отдылена отъ спинної области: здьсь мьхъ сьрый у основаній съ широкими бьловато-палевымп гонцами. Подбородокъ, область груди и между лапъ полрыта совершенно бьлыми волосами. Јапы густо обросли б́лловато-палевымъ мьхом, пріобрьтащиљ серебристы!̆ оттьнокъ на палыцахъ. Oираска ушеї и боковъ головы ньсколько ярте спины, такъ какъ туть примшивается довольно замьтный ржкавыї оттынокъ. Хвостъ сверху и снизу равномьрно погрытъ 
длинными (въ $6 \mathrm{~m} / \mathrm{m}$.) и густыми палево-сьрыми волосами съ легкой примьсью черноватыхъ на верхней его сторонь и въ конечной части, что дълаетъ окраску слабо двуцвьтной. Вибриссы черныя, очень длинныя.

На основаніи двухъ экземпляровъ орышковой сони, ик⿱⺊口灬ющихся у меня изъ Московской губ., я не могу съ увьренностью говорить объ ихъ точномъ систематическомъ положеніи. Однако, благодаря довольно хорошему матеріалу, бывшему въ моихъ рукахъ изъ. Западной Европы, я могу все же намбтить здьсь главньйшія задачи, которыя надо окончательно рћшить на бо́льшемъ количествь средне-русскихъ экземпляровъ. Для сравненія мнь были любезно присланы всь орышковыя сони Вынскаго Естественно - Нсторическаго Музея (Naturhistor. Hofmuseum für Naturkunde), дирекціи котораго я выражаю здысь свою искреннюю благодарность. Итакъ, изъ окрестностей Вьны я имбль двь шкурки съ черепами и одинъ спиртовый экземпляръ. Завьдую-

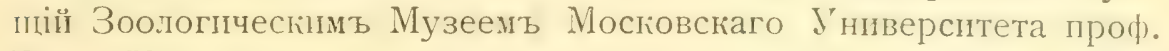
Г. А. Кожевниковъ выписалъ по моей просьбь для Музея оть торговца В. Шлютера въ Галле два спиртовыхъ экземпляра Muscardims, происходящіе изъ Тюрингіи. Кромь того, въ коллекціи Музея имьются еще два чучела изъ Тироля (№ 270727о8). Наконець, я имьль возможность просмотрыть 5 экземпл. Muscartimus, хранящихся въ коллекціи Зоологич. Музея Импер. Академіи Наукь съ помьткої „Западная Европа“ безъ точнаго обозначенія мьста, а также еше два экземпляра моей личной коллекціи (вђроятно, изъ Западной Европы, безъ точнаго обозначенія). На основаніи этого матеріала я прихожу къ заключенію, что московскія орбшковыя сони стоятъ ближе всего къ типичному виду изъ Швеціи, Германіи, Франціи и Англіи ${ }^{1}$ ), отличаясь отъ болье яркаго южно-итальянскаго ․ $a$. speciosus Dehne. Нвкоторые изъ в Ннскихъ экземпляровъ являлись переходными къ этому посльднему подвиду. Отъ нихъ московскія особи отличались: I) своимь болье тусклымъ сьро-желтоватымъ мьхомъ верхней стороны. Эта окраска обусловлена значительной примъсью совершенно черныхъ волосъ, которыхъ почти соверпгенно ньтъ въ мыхь в ьнскихъ Muscavdims. 2) Полнымъ отсутствіемъ палево-красноватаго оттьнка, столь характернаго для вьнскихъ особей. 3) Гораздо болье короткимъ хвостомъ. Орьшковыя сони изъ Тюрингіи (оть Шлютера), хотя тусклье

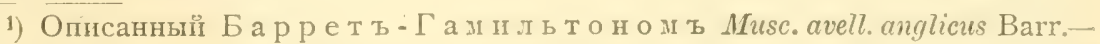
Ham. (изъ Великобританіи) въ посльдней работь этого автора (16, part. ХIIJ p. 354), отнесенъ въ спнонимы тлпичнаго вида. 


\begin{tabular}{|c|c|c|c|c|c|c|c|c|}
\hline $\begin{array}{l}\text { Iзмьренія } \\
\text { Muscardinus } \\
\text { avellanarius L. }\end{array}$ & 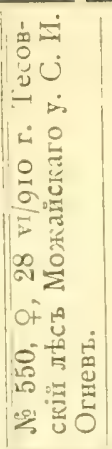 & 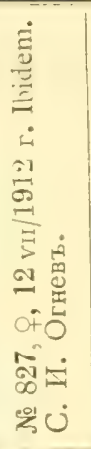 & 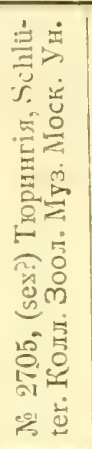 & 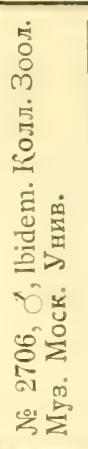 & 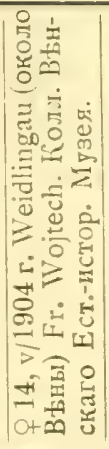 & 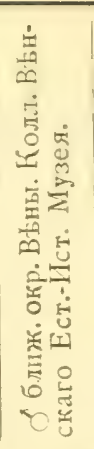 & 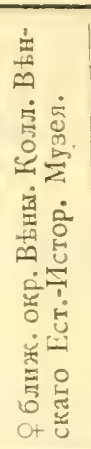 & 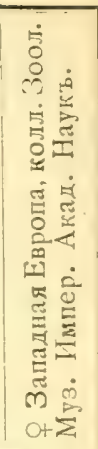 \\
\hline Длина тила іп головы. & 61 & 58,5 & 60,4 & 58,7 & 67,5 & - & - & ок. 69 \\
\hline , головы . . . . | & 23,9 & 24,5 & 22,8 & 23,4 & 25,7 & - & - & - \\
\hline $\begin{array}{l}" \text { хвоста (безъ кон- } \\
\text { цевыхъ волосъ) ... }\end{array}$ & 65 & 61,5 & 62 & 65,3 & 72,1 & - & - & 75,2 \\
\hline $\begin{array}{l}\text { Длина хвоста (съ кон- } \\
\text { цевыми волосами) . }\end{array}$ & 74,5 & 68,2 & 70 & 75 & 80,4 & - & - & 85,7 \\
\hline $\begin{array}{l}\text { Ступни заднеї ноги } \\
\text { (безъ когтей). }\end{array}$ & 15,4 & 16,4 & 15 & 14,8 & 15,7 & - & - & 16,4 \\
\hline $\begin{array}{c}\text { Длина уха по вньш- } \\
\text { нему краю. . . . }\end{array}$ & 10,6 & 11 & 11,4 & 11,4 & 10,2 & - & - & 11,2 \\
\hline Ч е p e п ъ: & & & & & & & & \\
\hline Общая длина ..... & 22,5 & 22 & - & - & - & 22,5 & 23,5 & - \\
\hline Основная длина . . . . & 17,6 & 17,4 & - & - & - & 17,4 & 18 & - \\
\hline Кондиллярная длина . & 19,6 & 18,8 & - & - & - & 19,2 & 19,8 & - \\
\hline $\begin{array}{l}\text { Ширина скуловыхъ } \\
\text { дугъ } . . . . .\end{array}$ & 12,4 & 12,4 & - & - & 一 & 12,4 & 13,3 & - \\
\hline $\begin{array}{l}\text { Межгглазничная ши- } \\
\text { рина ...... }\end{array}$ & 3,7 & 3,8 & - & - & - & 3,7 & 3,7 & - \\
\hline Длина & 6,8 & 7,2 & - & - & - & 8 & 8,6 & - \\
\hline $\begin{array}{l}\text { Длина (въ бока) os inter- } \\
\text { parietale } . . .\end{array}$ & 8,4 & 9,2 & - & - & - & - & - & - \\
\hline $\begin{array}{l}\text { Ширина этой кости въ } \\
\text { ея центральной части. }\end{array}$ & 3,2 & 3,3 & - & - & - & - & - & - \\
\hline
\end{tabular}


в łнскихъ, но легко отличаются отъ московскихъ: І) винно-красноватымъ оттынкомъ мыха и 2) отсутствіемъ черныхъ волосъ. Съ :ругой стороны, тирольскія сони ${ }^{1}$ ) очень близки къ московскимъ. Необходимо просльдить на большощь матеріаль, насколько постоянна желтовато-сььрая окраска среди русскихъ Mиsсы dimus, съ прим ьсью столь характерныхъ черныхъ волосъ, и только тогда можеть возникнуть вопросъ о раціональности выдленія ихъ въ особый подвидъ ${ }^{2}$ ).

\section{Географическое распространеніе.}

Въ Московской губ. два экземпляра этого интереснаго зв †рка были добыты мною въ разное время въ Тесовскомъ ульльномъ льсу, въ 5 верстахъ оть г. Можайска. Относительно распространенія орђшкової сони въ Европейской Россіи наши свьдынія пока крайне отрывочны. По Д в и у бскому (42, стр. 30), она встрьчается въ Малороссіи и по рькамъ Окь, Волгь, I'ралу $(44$, p. 9r). О.днако, эти общія указанія относительно распространенія сони въ пойм поздньїшими изсльлователями. Весьма возможно поэтому, что проф. Двигубскій имьль свьдынія о другомь видь-Myоxиs diyas Schreb., который; по М. Н. Богданову, встрьчается въ лиственныхъ льсахъ Казанской и Симбирской губ; въ посльдней онъ былъ наїденъ также Б. М. Жћ и т ко вым ъ (экз. въ колл. Зоол. Муз. Моск. Унив.). Полчокъ (Myоxus dryas Schreb.) распространяется далье къ югу по Волгы до Астрахани ( $Э$ в е р с а н н ъ).

Возврацаясь къ распространенію сони, мы имћемъ указанія С омо ва о нахожденіи ея въ Харьковской губ. ( І 84 , стр. г49I 5 о), К есслера $\left(86\right.$, стр. $5^{1-52}$-въ Кіевскої и Полтавской, Но рд м нна ( 125, стр. 54) -въ Бессарабіи и Волыніи. По свидьтельству B elke ( I 7, p. 4I8), Musc.avellanarius L. встрьчается бл. Каменецъ-Подольска, по Тач анов скому (І 85 , р. І3о) в’ Польшь, по Эйхвальду-въ Литв'b. Наконецъ, Г реве́ отмьчаетъ ее для Курляндіи и Лифляндіи (67, стр. 104).

Такимъ образомъ, можно видњть, что нахожденіе сони въ Московской губ́. стоптъ пока совершенно особ́някомъ, но ньтъ сомнынія, что дальныйшія изсльдованія покажуть болье широное распространеніе этої интересной юго-западної формы въ предьлахъ центральныхъ частей Европейской Россіи.

1) Вьроятно, это довольно старыя чучела, подвергавшіяся вредному вліянію свђта и сильно потускньвшія,

2) Нпкакихъ стойкпхъ краніологическихъ отличій мнђ найти не удалось. 
Какъ было сказано, въ предылахъ Западной Европы встржчаются двь географическія формы сони, изъ коихъ типичная IInsc. avellanarins L., по Барреть-Гамильтону и Труссару, распространена въ Швеціи, Германіи, Франціи, - а въ южной Италіи найденъ другой подвидъ М. a. speciosus Dehne $(=$ M. a. pulcher Barret-Ham.).

\section{Ооразъ жизни.}

Оба пойманныхъ мною экземпляра добыты въ густомъ старомъ льсу г-го льсного участка Тесовскаго удыльнаго льса, въ 5 верстахъ отъ Можайска. Они были поїманы въ ведра, зарытыя на днь небольшой канавы, густо поросшей орьшникомт и ольхой съ примьсью елей. Къ сожальнію, какихълибо біологическихъ свьдыній собрать не удалось. Проф. Кессл ер ъ наблюдалъ этотъ видъ въ дубовыхъ льсахъ Кіевской губ. и подробно описываетъ гнђзда, сдьланныя изъ сухой травы и напоминавшія птичьи, по своему расположенію на мелкихъ дубовыхъ кустахъ ${ }^{1}$ ).

Әкземиляри коллекии перечислены въ таблиць измьреній на стр. 258.

\section{Семейство Jaculidae. Тушканчиковыя.}

\section{Родъ Sicista Gray (1827).}

(Sminthus Nordmann, 1839).

\section{Мышевки.}

Морда короткая и острая. Длина очень тонкаго хвоста больше, чьмъ длина тьла. Верхняя губа безъ разрћза посрединь.

Зубная формула:

$$
\mathrm{i} \cdot \frac{\mathrm{I}-\mathrm{I}}{\mathrm{I}-\mathrm{I}} \mathrm{pm} \cdot \frac{\mathrm{I}-\mathrm{I}}{\mathrm{O}-\mathrm{o}} \mathrm{m} \cdot \frac{3-3}{3-3}=\mathrm{I} 8 .
$$

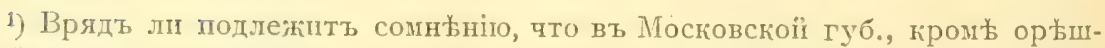
кової сони водится еще другой видъ. Такъ, А. Ө. С луд с кі ї сообщилъ мнь, что наблюдаль однажды въ Дмитровскомь у. бђжавшую по вьткь дерева соню, значительно превосходившую размьрами Muscardinus и характеризующуюся иерной полосой око.и ияаза. По всьмъ прпзнакамъ это была, вьроятно, Elyomys quercinus L. 


\section{Sicista subtilis Pall.}

\section{Мышевка полосатая.}

The subtilis $\mathrm{Pallas}(131)$, p. 705. This vagus $\mathrm{P}$ allas (130), p. 169. Trus betulinus Pallas (130), pl. 22, fig. 1 In 2. Mus lineatus Lichtensch te in (51), p. 123. Sminthus nordmami K e y s e r ling und Blas i us ( 90 ), p. 38. Sminthus vagus Blasius (27), p. 302. Sminthus loriger (N a th us ius) Nordmann (125), p. 49, pl. IV. Siciste subtilis (Pall.) Trou essart (200), p. 205. Sminthus subtilis Pall. К. А. Сатунинъ (165), стр. 13. Б. К. Г пі н дц е, Къ блшжайшему познанію палеарктическаго рода Sminthus, Труды Студ. Кружка для пзсл. Русск. Прпр. I, 1903, стр. 145.

\section{Систематическія особенности.}

Черепг хараютеризуется своей яйцевидної формой и припоонятостью теменныхъ костей. Строеніе носовыхъ костеї очень характерно: наибольшаго расширенія онь достигаютъ во своей среднеї иясти, будучи сужены сзади и спереди. Јобныя кости вдаются въ область теменныхъ неправпльной, угловатої фигурої, а теменныя кости даютъ по бокамъ лобныхъ, охватывая пхъ, два тупыхъ угла. Межтеменная кость сильно сужена по граямъ и выдается въ своей центральної части впередъ и назадъ

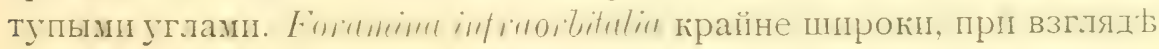
на нихъ спереди напоминають фигуру треугольника, всльдствіе расширенной илюней ихъ части и очень суженної верхнеї. Bullae ossece велики и тонки.

Зубъ, какъ у мышей, покрыты тупыми эмалевыми бугорками. Въ верхней челюсти, съ каждой стороны, имьется по одному небольшому ложнокоренному зуобу округлоп̆ формы.

Нёоия ск.лади. - Передняя очень узка, состоя только изъ ньсколькихъ, тьсно прилегающихъ другъ къ другу бугорковъ. Далье идугъ двь цьльныя, почти прямыя складки, а за ними 3 съ яснымъ разрьзомь посредины. Двь заднія снова цбльныя, пзъ нихъ предпосльдняя выдается впередъ довольно острымъ угломъ, а посльдняя-пологою тугой.

Oкраска моихъ экзелпляровъ совершенно аналогична таковой у мышевокъ, собранныхъ В.А. Филатовыл ъ на Вологодскої Печорь, и рьзко отличается отъ цвьта иtвха Sicista subtilis Pall., добытой $\Gamma$. А. К ж ж в н и к в м ъ въ Жзиайловскомъ Звьрннць.

Вся верхняя сторона тыла нашихъ экземпляровъ покрыта длинными волосами, темно-сьрыми у основаній If съ широкими рыже-палевыми концами. Между подобнымъ мьхомъ примьшивается много совершенно черныхъ волосъ, придающихъ общей

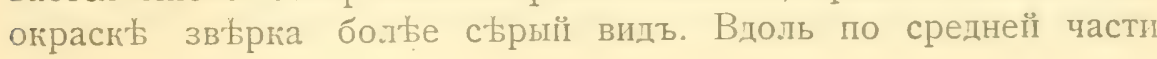


спины тянется совершенно черная полоса, хорошо обозначенная I), нижіе-спинної области и слабо намьченная между ушамп и пт, верхнеї часті спины. Нижняя сторона грязно-желтоватобнлая, покрытая длинными, сђрыми у основаній волосами съ ппрокими палево-бьлыми вершинами. Папы св бтло-желтоватосьрыя; уши покрыты сыровато-палевыми волосами; кольчатыї, длинный, тонкії и коротковолосый хвость-слабо двуцвьтный: сверху сырыї, снизу бьловатыї. Вся верхняя сторона тьла мышевки, добытой Г. А. Кожевниковымъ, отличается длинными волосами, съ довольно свьтлыми сьрыми основаніями и очень широкими желтовато - палевыми вершинами; между подобными волосами примшшивается незначительный процентъ рыже-буроватыхъ волосъ, придающихъ общему тону болье ржавый отт丸нокъ. По центральной части спины тянется ясно диференцированная каштаново-бурая полоса, теряюшаяся въ области между ушей. Бока тьла значительно свытлье и желтье. Нижняя сторона свьтло-б́ьловато-желтая. Уши покрыты желтопалевыми волосами. Хвостъ и лапы одноцвњтные, палевые.

Ниже я даю таблицу измғреній нашихъ экземпляровъ, въ которую включены также мышевки, добытыя В. А. Филатов ы м на Вологодскої Печорt.

\section{Географическое распространеніе.}

Два экземпляра этого интереснаго вида были впервые добыты въ Среднеї Россіи Г. А. К ж же в и к о в ы ъ въ І Ізайловскомъ Звьринц; близъ Москвы. Первая мышевка была наїгена мертвой на дорогь лłтомь г8go г., вторая поїмана на ученической экскурсіи I мая І89I года. Посль этого К. А. Са туни н ъ, собиравшіiі мелкихъ млекопитаюшихъ два гола въ этої же мъстности, не могъ поїмать ни огного экземпляра. Первое время, въ началь монхъ сборовь, полосатая мышевка не попалалась и мнь. Совершенно неожиданно одинъ экземпляръ, перебьгавшій дорогу въ березовомъ участкь Тесовскаго Удъльнаго лыса Можаїскаго у., былъ убитъ и доставленъ мнб моимъ отцомъ И. Ф. Огневы мъ (22 VIII I909 г.). Вскор' посль этого мнь удалось поймать 6 экземпляровъ въ разныхъ частяхь Тесовскаго лыса. Наконецъ, Д. П. Фи латов ъ любезно передаль мнь мышевку, добытую имъ близъ села Горбова Рузскаго у. (V I9Iо г.).

Наши свњдынія о распространеніи полосатоӥ мышевки въ пре.\%:лахъ Европейской Россіи страдають большої отрывочностью, но далеко раскиданныя случайныя находки заставляютъ признать широћое распространеніе этого интереснаго и еше мало 


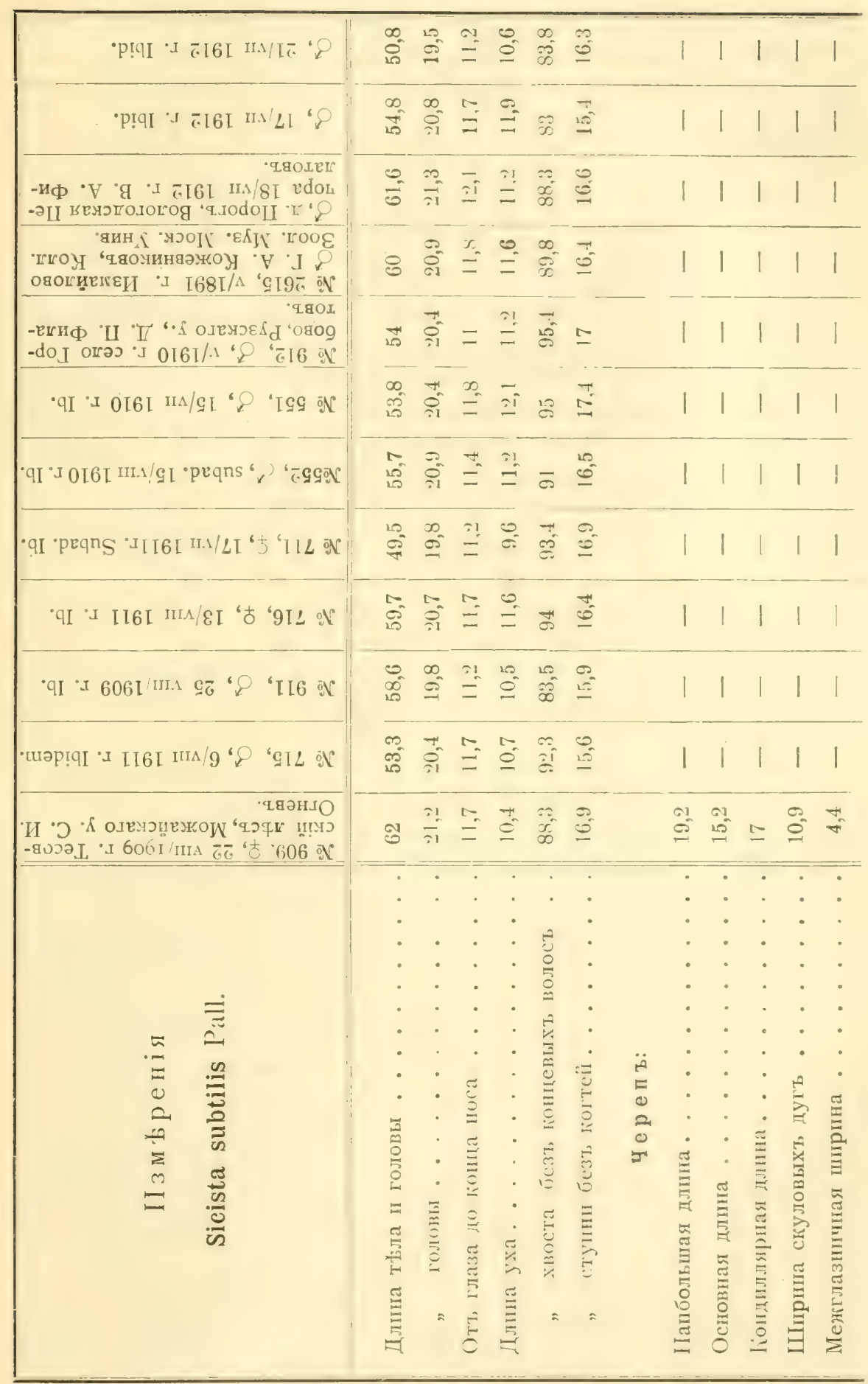


пзутеннаго звьрка. Въ южныхъ частяхъ Евр. Россіи онъ найденъ около Симферополя Никольским ( Одессы-Нордманномъ ( 125 , р. 51), въ Черниговской губ́. (Стародуб́скій у.)-Р огов и чем ъ (см. К е с л е р ъ, 86, стр. 66). Проф. Кесслеръ имылъ около го экземпл. изъ Кіевской губ. ( 85 , p. 57 т-572). По А. Сил ан т в е в, Sictsta subtilis Pall. встр чается въ Балашевскомъ у., Саратовской губ. (Пады, стр. 294). Lehmann нашель мышевку въ березовыхъ лћсахъ южнаго Зауралья, близъ Оренбурга, и въ́ песчаної степи по Иргизу, а Эверсманнъ отм⿰чаетъ ее для южн. предгоріі Уральскаго хребта. Н. А. 3 а р у дн ый добылъ этоть видъ въ самомъ г. Оренбургы и между Нлецкой Защитої и Акъ-Тюбе. За посльднее время были переданы мнға для опредыленія В. А. Ф илатовым ъ, три экземпляра съ Вологодской Печоры (льто I9I2 г., близъ д. Порога). По его словамь, кромь этихъ трехь мышевокъ, онъ наб.іюдаль другихъ въ той же мьстности живьемъ. Далье на западъ Sicista subtilis Pall. становится płже.-- I о Г реве́ (67, p. I 8), одинъ эґземпляръ добытъ въ І858 году въ Јифлянтіи. Тизенгаузъ отмғчаетъ мышевку для Литвы, а Тачанов кі ї упоминаетъ объ экземплярь, добытомъ бл. Млавы (г87о г.) и храняцемся въ Варшавскошь Университеть. Вь сыверо-западной Европ' в втрьчается въ Швеціи, Норвегіи, Даніи, южной Финляндіи, Венгріи. По К. А. Сатунину (8о, стр. 6о), встрбчается на Кавказћ бл. Гуниба. Распространеніе полосатой мышевки въ разныхъ частяхъ Сибири довольно широко. По Георгі, она встрьчается въ Киргизско̆ степи на р. Уп古, Исети, Тоболь, на верховьяхъ Урала, Ишима, на Іртыш', въ Барабинской степи до Оби и Енисея, но не далье $57^{\circ}$. с. ш. П а л л с ъ нашель этоть видъ къ востоку отъ Уральскихъ горъ, особенно въ березовыхъ льсахъ по Ишиму, въ Барабинской и Татарской степяхъ, въ гористыхъ мбстностяхъ по Иртышу, въ долинь Иртыша, бл. Ямышева, по Оби и Енисею и, наконецъ, въ Киргизской степи. Эверсманном быль найденъ на р. Усунбурть одинъ экземпляръ, готорый быль ошибочно описанъ Лпхтенштеїн о м ъ кахъ новый видъ Mus lineatus Licht. (5 I, р. І23). По свидьтельству проф. Н. Ө. К ащ е н ко, встрђчается по всему Томскому краю (82, табл. 37). Ньсколыо элземпляровъ присланы въ Зоол. Муз. Моск. Унив. изъ Зифиногорск. у. Томской губ.. А. Л в р овым ъ. Далье мышевта найдена на Алтађ, около Рыбнуши экспедиціей проф. Н. Ө. К а ш н ко $(8 \mathrm{I}$, стр. 49) и П. Г. Игнатовы м в на берегу Телецкаго озера (83, стр. І2). Бр андт (34, р. 35) упоминаеть объ экземпляр‡ изъ Закаспійской обл. оть Frick. 
Экспедиціеї Н. М. Пржевальскаго мышевка добыта около Зайсанска на р. Кандерлык' (Бихнер ъ, 2 I, стр. 50). За посльднее время найдена около Минусинсга і на Саянскихъ горахъ, въ гоо миляхъ оть Байкала (Thomas, I 94, р. 405). По Труссару (2оo, г9го, р. 206), встрьчается въ Туркестань.

\section{Образъ жизни.}

Наши свђдђнія о біологическихъ особенностяхъ этого звђрка очень отрывочны. Станціи, которыхъ онъ придерживается, весьиа разнообразны. Я находиль мышевокъ въ канавахъ, густо горосшихъ орбшникомъ и мелкимъ подсћдомъизъ ельника и ольшняка, въ крупномъ сосновомъ бору - въ тьххъ самыхъ мьстахъ, гдь попадались Muscardinus avellanarius L. Кром'ь того, л ловиль Sicista въ cырой канав'b, съ густой порослью папоротника и ольхи, гдь встрьчались очень часто Sorex и Neomys. Наконецъ, одинъ экземпляръ добытъ въ березовощъ льсу, расположенномъ на значительномь бугрь.

\section{Семейство Sciuridae. \\ Подсемейство Sciurinae.}

Бьлки.

\section{Родъ Sciurus L. (1758.)}

Јобъ широкій, морда короткая, заостренная. Уши очень сильно выступаютъ изъ мьха и характеризуются длинныли кистями волосъ, особенно развитыми зимою. Пунистый нечепуійчатый хвостъ, равный прпблизительно $2 / 3$ длины тьла, густо по всещу протяженію покрытъ длинными, в Верообразно расходящимися волосами.

Зубная формула:

$$
\text { i. } \frac{I-I}{I-I} \text { pm. } \frac{2-2}{I-I} \mathrm{~m} \cdot \frac{3-3}{3-3}=22 \text {. }
$$

\section{Sciurus vulgaris L. (subsp.?)}

Sciures vulgaris Linn a eus (98) 1776 , I, p. S6. Barret-Hamilton (14), p. 3. Hiller Gerrit (1 11 ), p. 426. Trouessart (202), p. 360 et (200), p. 117. Sciurus vilgaris Linn. K. A. С а тун н н ъ (1 65 ), стр. 10 II (166), p. 2, М ен з бо рі в (106).

\section{Систематическія особ́енности.}

Черепг характеризуется очень выпуклыми и круто опускающимися назадъ теменными костями. По бокамъ лобныхъ костей 


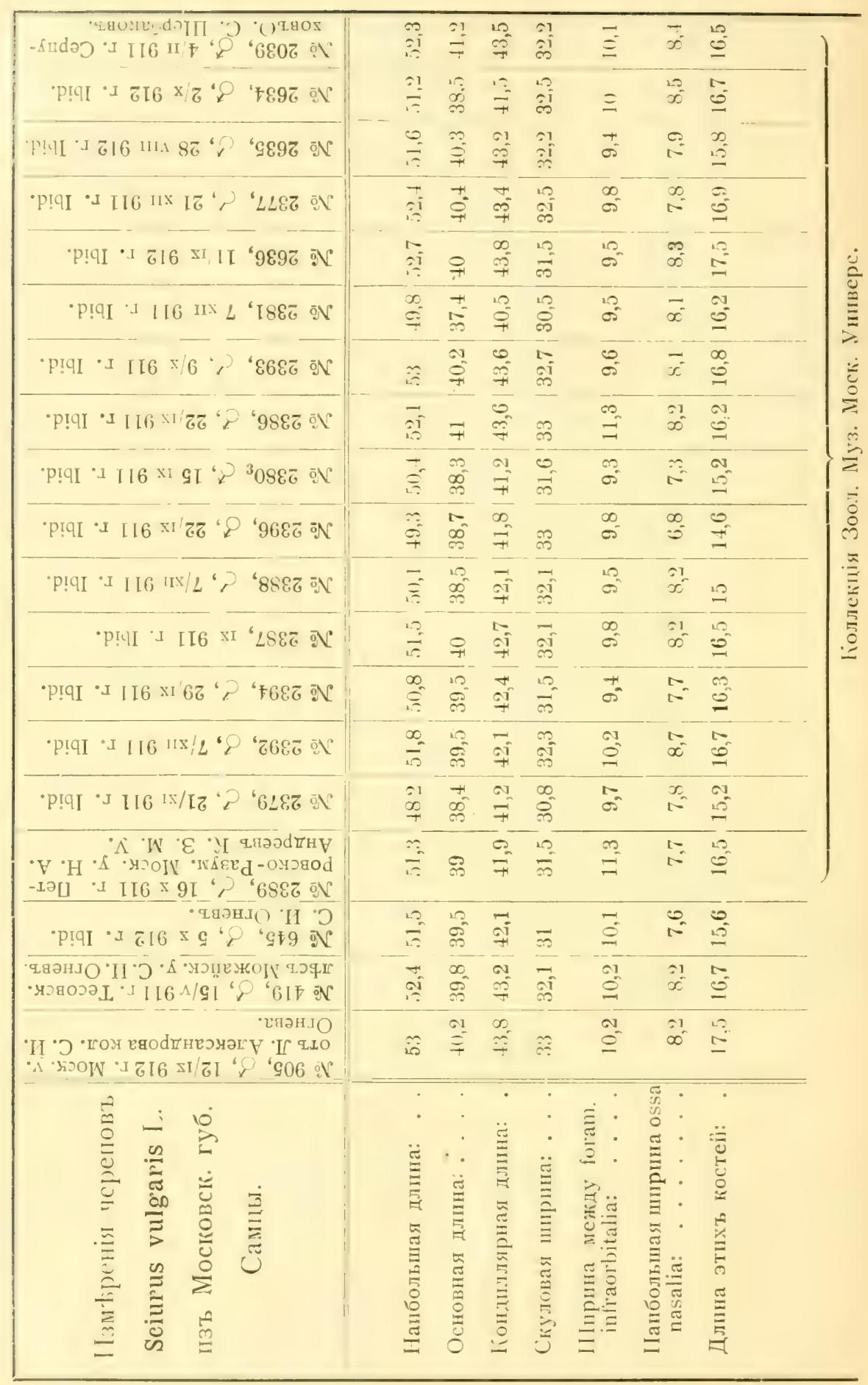




\begin{tabular}{|c|c|c|c|c|c|c|c|c|}
\hline 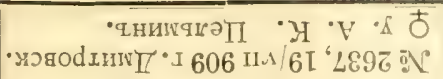 & tó & $\stackrel{r}{\infty}$ & $\stackrel{5}{=}$ & $\stackrel{0}{0}$ & $\begin{array}{l}1.2 \\
02\end{array}$ & $\stackrel{\sim}{2}$ & 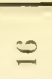 & \\
\hline 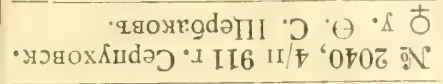 & 01 & $\fallingdotseq$ & $\bar{\psi}$ & $\frac{a !}{\therefore-1}$ & $\stackrel{20}{0}$ & $\stackrel{\infty}{\sim}$ & $\begin{array}{ll}x \\
2 \\
2=\end{array}$ & \\
\hline 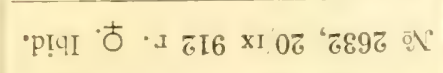 & $\stackrel{\infty}{\frac{\infty}{10}}$ & $\stackrel{\theta+1}{0}$ & 25 & 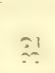 & $\infty$ & 1 & $\underline{13}$ & \\
\hline 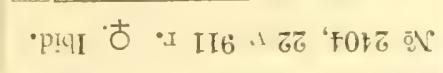 & 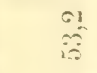 & 1 & $\stackrel{25}{=}$ & $\hat{\vdots}$ & $\stackrel{\infty}{\varrho}$ & $\vec{\omega}$ & \pm & \\
\hline 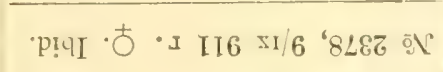 & $\frac{1}{2}$ & $\stackrel{1}{\ddot{\theta}=}$ & $\overline{c i}$ & $\stackrel{1}{20}$ & $\underline{6}$ & 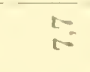 & $\overrightarrow{0}$ & \\
\hline 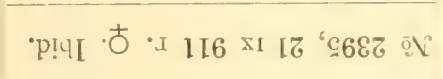 & $\hat{i}$ & $\subsetneq$ & 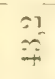 & $\bar{\therefore}$ & $\underline{\underline{g}}$ & 120 & $\underline{2}$ & \\
\hline 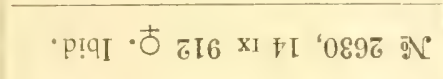 & $\frac{12}{10}$ & $\cong$ & 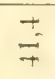 & $\hat{\vdots}$ & $\therefore$ & $\infty$ & 15 & \\
\hline 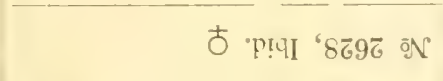 & $\hat{i}$ & $\stackrel{\because 1}{\varrho}$ & $\stackrel{+}{a i}$ & $\overline{Y i}$ & $\stackrel{N}{=}$ & 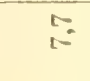 & 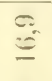 & 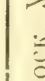 \\
\hline 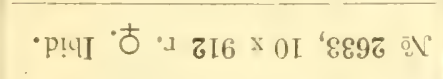 & $\stackrel{x}{\ddot{\partial}}$ & $\stackrel{x}{x}$ & 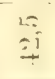 & $\overline{\hat{n}}=$ & 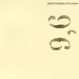 & 1 & $\underline{2}$ & $\tilde{3}$ \\
\hline 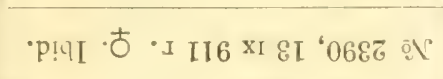 & $\bar{E}$ & $\stackrel{12}{2}$ & $\stackrel{10}{+1}$ & 1 & 20 & $+\vec{\infty}$ & $\stackrel{\infty}{\infty}$ & $=$ \\
\hline 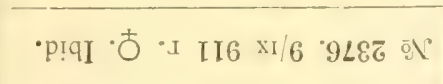 & is & 节 & $\stackrel{2}{2}$ & î̀ & $\begin{array}{ll}\infty \\
\infty \\
\infty\end{array}$ & $\stackrel{\infty}{\infty}$ & $\dot{\ddot{\theta}}$ & $=$ \\
\hline 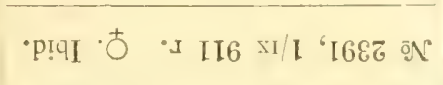 & $\therefore$ & $\bar{\Xi}$ & $\stackrel{5}{9}$ & $\vec{i}$ & $\stackrel{\Omega}{\varrho}$ & $\vec{\infty}$ & $\begin{array}{ll}1 \overline{0} \\
\underline{0}\end{array}$ & 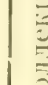 \\
\hline 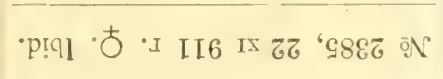 & 趈 & 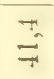 & $\vec{f}$ & $\dddot{\cdots}$ & $\dot{\sigma}$ & $\overrightarrow{+}$ & 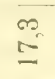 & 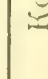 \\
\hline 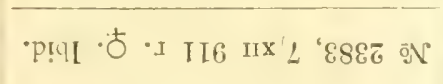 & $\begin{array}{c}\text { mi } \\
\text { ai } \\
\text { bi }\end{array}$ & $\stackrel{\sigma}{\circ}$ & $\begin{array}{l}10 \\
-i f \\
q\end{array}$ & $\stackrel{c}{i}$ & $\stackrel{\infty}{\ominus}$ & $\ddot{\infty}$ & $\underline{10}$ & \\
\hline 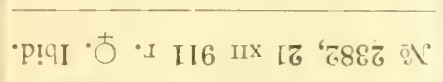 & is & $\stackrel{a !}{9}$ & $\begin{array}{l}\stackrel{2}{\sim} \\
\stackrel{\sim}{\sim}\end{array}$ & $\stackrel{2=}{=}$ & 8 & $\stackrel{\Re}{2}$ & $\stackrel{91}{0}$ & \\
\hline 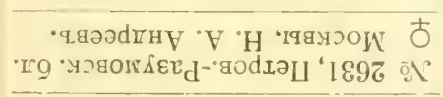 & $\overline{\text { i⿱⺈ }}$ & $\stackrel{\rho}{\varrho}$ & $\stackrel{21}{-1}$ & $\stackrel{n}{\cdots}$ & $\cong$ & $\stackrel{0}{\infty}$ & $\begin{array}{ll}0 ! \\
i=\end{array}$ & \\
\hline 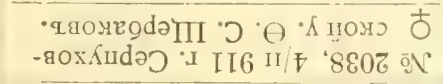 & 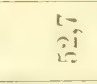 & $\underset{c}{s}$ & $\begin{array}{l}x \\
s i \\
s i\end{array}$ & $\hat{\imath}$ & $\stackrel{20}{\varrho}$ & $\hat{n}+1$ & 0 & \\
\hline 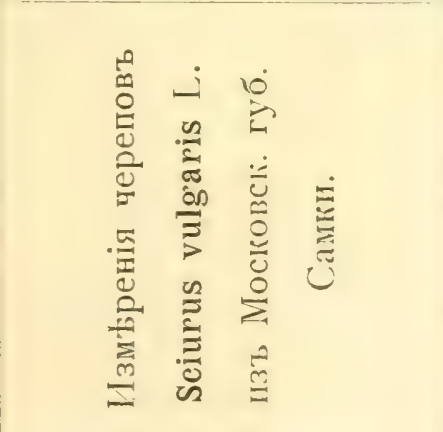 & 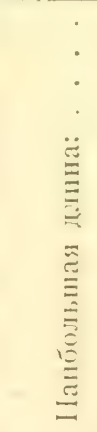 & 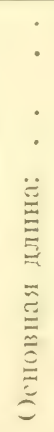 & 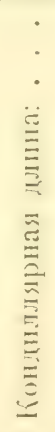 & 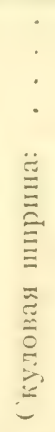 & 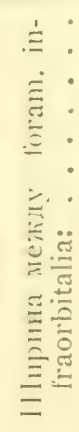 & 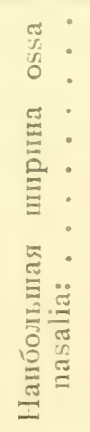 & 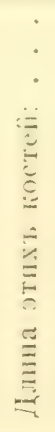 & \\
\hline
\end{tabular}


расположены хорошо развитые processi postortitales. Носовыя жості ръзко расширены вперети. Форна foramina infraorbitalia. очень характерна: эти отверстія весьма малы, узки и низко посажены. Foramina incisiva очень торотки, костное нёбо широко.

Первый ложнокоренной зубь верхней челюсти маль, безъ эмалевыхъ складокъ, и лежитъ такъ глубоко въ зубномъ рядь, что снаружи и сбоку почти не замьтенъ. Коренные зубы съ поперечными складками: эмали (на жевательной поверхности), идущими прямо, безъ неправильныхъ изгибовъ и отдыльно стоящих колецъ.

Едва ли какое-нибудь млекопитающее такъ сильно измьнчиво въ своеі́ окраскт, какъ бълка. Поэтому я считаю нужнымъ описать здћсь наиболье замьтные типы личной измбнчивости московской бьлки, что можетъ дать надежный матеріаль для сужденія о географической фориь, распространенной въ этой мьстности.

Наиболье часто встрђчаемая окраска стараго экземпляра въ льтнемъ мьху такова. - Вся верхняя часть спины и область между ушей покрыта густыми интенсивно каштаново-рыжими волосами, съ узкими темно-сљрыми основаніями, совершенно не вліяюшцми на окраску, зависящую отъ очень широкихъ и яркихь окончаній волосъ. Среди подобныхъ волосъ примьшивается дово.льно значительный процентъ совершенно черныхь, .дылающихъ окраску верхней части спины болье темной, чћмь цвыть боковъ. На бокахъ тьла примьшиваются болье яркіе желтовато-рыжіе тона; здьсь волосы лишены своихъ сьрыхъ основаній и при переход屯 въ бьлую окраску подбородка, груди и брюха становятся все темнье, что дылаетъ самый переходъ въ бьлый цвьть нижней стороны не особенно ръзкимъ, но постепеннымъ. Окраска переднеї части носа въ области вибриссъ сьро-палевая. Вся верхняя часть головы и ушей покрыта короткимъ мьхомъ, состоящимъ изъ сьрыхъ у основанія волосъ съ яркими красно-рыжеватыми вершинами. Среди подобныхъ волосъ примбшивается довольно значительныі процентъ совершенно черныхъ, дьлающихъ общій оттьнокъ этой области болье сђрымъ. Окраска переднихъ и заднихъ конечностей сходна съ таковой б́ковъ: онь покрыты ярко-рыжевато-каштановыми волосами. Нижнія части конечностей въ паховой области окрашены въ únıte желтовато-рыжевато-красный цвьть, диффузно переходяцій въ б блую паховую область. Хвостъ густо покрытъ очень длинными волосами, сьрыми у основаній, съ желтовато-рыжей очень узкой среднеї частью и очень широкими интенсивно-черными верши- 
нами. Отъ описаннаго типа окраски встрычаются самыя разнообразныя колебанія. Такъ, я видаль экзенпляры пзъ Московской гуо́. съ очень темной окраской спины, зависящеї оть значительной примьси совершенно черныхъ волосъ.

Встрђчаются также экземпляры довольно одноцвђтно-рыжіе, что цьликомъ зависить оть отсутствія черной шерсти. Столь же измьнчива и окраска хвоста,-иногда рыжіе тона болье или менье замьтно примьшиваются къ чернымъ окончаніямъ.

Второй болье рьдкій типъ окраски представляютъ экземпляры болье св бтлаго рыжеватаго цвыта, съ приысыю жіелтоватосьрыхъ оттьнковъ. Хвостъ подобныхъ былокъ покрытъ волосами пегельно-сьрыми у основаній, сь широкими свђтло-рыжеватыми вершинами. Иногда встрьчаются особи съ совершенно рыжимъ хвостомъ, безъ сћрыхъ основаній волосъ. Это. типъ окраски такъ называемой Sciurus vulgaris varius Kerr, которую Барретъ-Гамильтонъ и Труссаръ считають распространенной въ Европейской Россіи.

Зимній мъхъ по своей окраскћ очень сильно измьнчивъ. Однако, напоболье распространенной является сльдующая.-Вся спнна, область между ушей отличаются очень густої сњрой шерстью. Окраска отдыльныхъ волосъ такова: за темно-сырымъ основаніемъ идеть болье широкій пепельно-сірый поясъ, смьняюшійся совершенно чернымъ, самый конець волоса опять пепельносьрый. Между подобными волосами примьшиваются также сплошь черные, придающіе общему тону мьха болье темный видъ. На передней части головы, на окончаніяхъ лапъ всегда замғтны острова коричнево-рыжеватаго мұха. На нижней сторонћ заднихъ конечностей, въ паховой области выступаютъ свьтлые желтоватые волосы. На ушахъ развиты длинныя черныя кисти. Окраска хвоста сходна съ такової льтомъ: основанія длинныхъ волось пепельно-сьры, далье идеть слабо замьтный рыжій поясъ и очень широнії совершенно черный, обусловливающій черную съ внбшности окраску хвоста. Отъ подобной, болье частой, окраски замъчаются очень сильныя отклоненія. Мнь встрђчались въ Московской губ. бьлки (ㅊo 5 лекціи) по очень темному цвыту мьха напоминающія Sc. vulgaris calotus Gray. У этихъ экземпляровъ, помимо очень большого развитія совершенно черныхъ волосъ въ области спины, замьчается еще довольно рьзкій коричневатый оттћноъ мыха, особенно ясный на центральной спинной области. Коричневый мьхъ лапъ развить слаб тономъ, а на ступняхъ заднихъ ћонечностей зам'ьаются пятна совершенно черныхъ волось. Сьрыя основанія волось хвоста 
узки, тогда какъ черные концы ихъ очень широки. На ушахъ замьтны длинныя перныя кисти.

Изъ очень большой серіи шкурокъ зимнихь экземпляровъ ๙локь, прослотрбнныхъ мною, только два подходили подъ опиcaнie Sc. vulg. varius Kerr. Они отличались болье свьтлымъ серебристо-сьрымъ оттұнкомь верхней стороны, рыжеватой окраской передней части головы, ярко-рыжеватыми кистями на ушахъ, конечностями и хвостомъ, основанія волосъ котораго были пепельно-съры, а концы свьтло-рыжеватые. Замьчу, что чистоту сњраго тона верхней. стороны нарушаль ржавый тонъ, слабо замьтный по верхней центральной части спины.

Замьчу въ заключеніе, что въ Кол. Зоол. Муз. Моск. Унив. имьются два экземпляра бьлокъ изъ Мазилова (Моск. у.) отъ Ө. К. Лоренца, которые представляютъ очень интересную красочную аб́еррацію.-Общій тонъ мьха ихъ очень свђтлый, түсклыї палево-сырыї. Вдоль верхнеі части головы, спины, на верхней части лапъ, на хвость и концахъ ушей ясно примьшивается бльдно-ржавый цвьтъ, дłлаюпій окраску этихъ интересныхъ бьлокъ пестрої и двуцвьтної. Нижняя сторона бьлая со слабымъ желтоватымъ оттьнкомъ.

Размьры нашихъ экземпляровъ таковы:

\begin{tabular}{|c|c|c|c|}
\hline $\begin{array}{c}\text { Измьренія } \\
\text { Sciurus vulgaris L } \\
\text { изъ Московск. губ. }\end{array}$ & 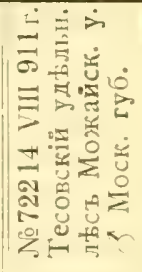 & 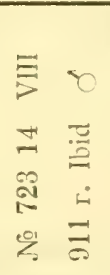 & $\begin{array}{ll}\Xi & 0 \\
\pm & \dot{\Xi} \\
\vec{\Xi} & \vdots \\
\ddots & \vec{\Xi} \\
\%\end{array}$ \\
\hline Длина тьлла и головы: & 192 & 195 & 157 \\
\hline $\begin{array}{r}\text { хвоста (безъ конце- } \\
\text { выхъ волосъ): ... }\end{array}$ & 172 & 173 & 139 \\
\hline $\begin{array}{c}\text { хвоста (съ конце- } \\
\text { выми волосами): }\end{array}$ & 244 & 234 & 192 \\
\hline уха (по внбш. краю): & 34,5 & 30,5 & 30,5 . \\
\hline уха (отъ темени): . & 28 & 23 & 22,8 \\
\hline $\begin{array}{c}\text { " уха съ юистью во. } \\
\text { лосъ:. . . . }\end{array}$ & & & . \\
\hline $\begin{array}{l}\text { Длина ступни задней ноги } \\
\text { (безъ когтей): : . }\end{array}$ & 54,7 & 55,8 & $5 \check{5}, 6$ \\
\hline ” ступни (съ когтями): & 59,2 & 60 & 60 \\
\hline
\end{tabular}


Въ заключеніе считаю нужнымъ разсмотрћть, къ какому изъ описанныхъ недавно подвидовъ приближаются московскіе экземпляры бълокъ. Всльдствіе недостаткіа матеріала для сравненія я не могу высказываться здьсь вполнђ опредfленно. Поэтому я поставилъ себь болье скромную задачу: на большомъ и полномъ матеріаль я, по возможности, точно описаль красочныя колебанія средне-русскихъ былокъ и далье постараюсь провђрить - насколько подходятъ къ нимъ описанія, данныя разными авторами.

По Труссару (200, p. II7-II8), въ Европейскої Россіи (въ сьв. части)встрьчается Sciurus vulgaris varins Kerr. ${ }^{1}$ ) Эта географическая форма, распространенная, по Т руссару, также въ Скандинавіи, Лапландіи, Полышь, Вост. Пруссіи и Венгрін, характеризуется сльдующими признаками. - Льтній м'ьхь ея болье свьтлаго рыжаго цвђта, чьмъ у западно-европейскихъ б̆локъ съ континента. Хвостъ одногвьтный со спиною. Зимній иьхъ характеризуется свђтло-сърымъ серебристымъ тономъ; концы ушей и хвоста остаются красными.

Изъ предыдущаго описанія можно ясно видьть, что въ Московской губ. среди льтнихъ особей преобладаютъ экземпляры довольно темнаго каштаново-рыжаго цв'та съ черноватыми хвостами. Среди зимнихъ особей изъ очень большой серіи я имьлъ лишь два экземпляра, вполнь подходившіе къ описанію Sc. vuly. varius Kerr. Однако, во̆ той же салой пюстиости (Тесовскій льсъ Можайск. у.) я добывалъ зимнихъ бђлокъ темной окраски съ черными хвостами и кистями ушей. Итакъ, точная диференцировка Sc. vulyaris unin. Kerr врядъ ли возможна при сколько-нибудь тщательномъ критическомъ отношеніи.

Просмотрьь хорошей серіи бьллокь пзъ Петербургской гуо́, собранныхъ въ Лужскомъ у. (Княжицкая казенн. дача) препар. А. К. Цель м инымъ, показаль мнь, что и эти экземпляры, по м Бсту нахожденія типичныя Sc. vulg. varus Kerr, не подходять къ описанію Т русс а ра. Они отличаются интенсивнымъ краснокаштановымъ мъхомъ съ яркимъ рыжимъ оттьнкомъ. Основанія волосъ хвоста красно-рыжія, тогда какъ концы интенсивно черные. У нфкоторыхъ изъ этихъ бьлокъ хвосты одноцвђтны съ окраской спины. Особ́енно хараитернымь признакомъ для петербургскихъ бълокъ является окраска боковъ тьла тамъ, гды рыжій цвђтъ переходитъ въ бБлый тонъ нижней стороны. Интересно, что эта пограничная об́ласть отличается иитенсивиы.иб.

1) Kerr, Anim. Kingdoom, 1792, p. 256. 


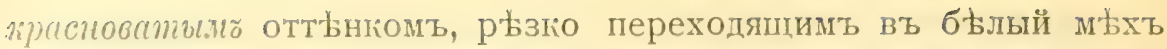
снизу. Далуе подбородокъ и бока горла бльдно-красноваторыжіе. Бжлый цвњтъ горла вдается впередъ острымъ угломъ, не доходящимъ до нижней губы. Посльдняя особенность явшяется очень харантерной. На большой серіи московскихъ экзем. пляровъ мнь не пришлось видђть сходныхъ съ описанными. Однако, необходимо отм'бтить, что между ними встрђчаются всђ перехолы, затрулияюпце точную диференцировпу. Тапия образомъ, вопросъ о взаимоотношеніи петербургскихъ и московскихъ б́ылокъ представляется еще отнрытымь. Считаю важнымъ прпвести здысь промђры череповъ петербургскиъ экземпляровъ.

\begin{tabular}{|c|c|c|c|c|c|c|}
\hline $\begin{array}{c}\text { Измьренія череповъ } \\
\text { б́ьлов изъ Петер- } \\
\text { бургской губ. }\end{array}$ & 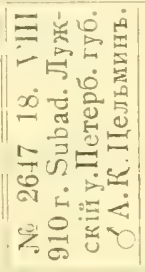 & 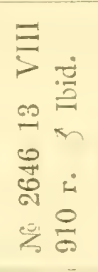 & 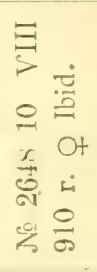 & 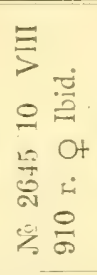 & 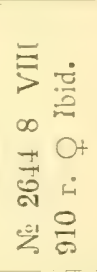 & 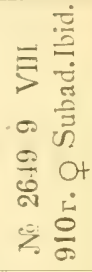 \\
\hline $\begin{array}{l}\text { Напбольшая длина че- } \\
\text { репа: . . . . }\end{array}$ & 48,2 & 50,4 & 51,2 & 49,2 & 49,8 & 47,3 \\
\hline Основная длина: . . & 36,3 & 38,4 & 39 & 37,3 & 38,3 & 35,6 \\
\hline Кондиллярная длина: & 38,6 & 41,7 & 42,3 & 40,5 & 39,8 & 38,4 \\
\hline Скуловая ширина: . . & 29 & 31 & 31,8 & 29,8 & 29,5 & 26,8 \\
\hline $\begin{array}{l}\text { Ширнна между foram. } \\
\text { infraorbitalia: . . }\end{array}$ & 9,3 & 9,9 & 9,8 & 9,7 & 9,5 & 9,8 \\
\hline $\begin{array}{c}\text { Нанбольшая ширнна } \\
\text { nasalia: . . . . }\end{array}$ & 6,8 & 7,5 & 8,9 & 6,8 & 7 & 7,3 \\
\hline $\begin{array}{l}\text { Напбол. длина этихъ } \\
\text { юостей: . . . . }\end{array}$ & 15,4 & 15,3 & 15,1 & 15,5 & 15,8 & 14,4 \\
\hline
\end{tabular}

Колл. Зоол. Муз. Москов. Унив.

Въ одной изъ своихъ прежнихъ работъ Труссаръ предполагаетъ, что въ средней части Европейской Россіи встрьчается Sciuvus vulgavis vufus Kerr $[=$ vussus Miller (nec rufus BarretHam.)]. Эта форма отличается льмолг сравнительно тусклымъ ржаво-бурымъ оттьнкомъ спины и бурымъ хвостомъ. Въ зим-

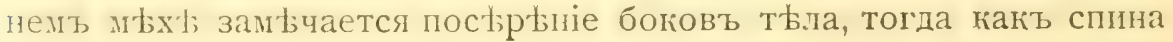
остается бурой. Болье рьдка темная льтняя форма съ черноважим хвостомь. Просматривая предыдущее описаніе, можно видыть, что было бы искусственної натяжкої относить нашихъ москов- 
скихъ бұлокъ и къ этому подвиду. Вьдь наши экземпляры въ льтнемь мьхь отличались, въ большинствы случаевъ, черноватымъ хвостомъ, тогда какъ зимній мьхъ представляль всь переходы отъ чисто-сьраго до болье смбшаннаго тона. Невольно эти отрицательные результаты внушаютъ разныя сомньнія въ своевременности такихъ смьлыхъ географическихь диференцировокъ бьлки, которыя съ легкостью предпринимаются западноевропейскими зоологами. Здьсь, болье чьмъ гдь-либо, приходится считаться съ необыкновенной изньнчивостью животнаго.

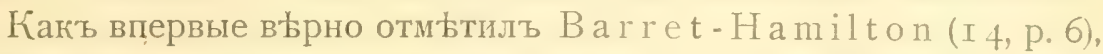
сибирскихъ былокъ необходимо выдьлять въ качествь особаго подвида, всльдъ за Греемъ. Sciurus vulgaris calotus Gray, по Barret-Hamilton, характеризуется своиь болье темнымъ mbxomъ.

Интересно отмьтить, что окраска сибирскихъ б́ллогъ сильно измьнчива въ связи съ тьмъ, гдь̆ добытъ извбстныц̆ экземпляръ. Какъ общее правило, можно опредъленно сказать, что горные экземпляры значительно темные ${ }^{1}$ ), хвостъ и концы ушей у нихъ черные. Это наблюденіе было сдылано уже давно М и ддендор фом п, Ш

Окраска бьлокъ, присланныхъ въ Зоол. Музей Моск. Унив. О. В. М а к г р фом ъ, сильно разнится, спотря по мьсту, гдь онь добыты. Такъ, экземпляры, добытые на правомъ берегу Тены (Алданскій хребетъ), отличаются очень темнымъ сырымъ мьхомъ спины, интенсивно черными ушными пучками и окончаніями волосъ хвоста. Напротивъ, бњлки, обитающія плоскогорья Вилюйскаго и Олекминскаго округа, какъ пишетъ О. В. М а р кграфъ, называемыя тамъ „краснохвосткали", по окраскь спины, хвоста и ушей даже свьтлье пькоторыхъ пзъ московскихъ экземпляровъ (№ 2639 Олекиинск. окр.) Однако, я безъ колебанія отношу и ихъ къ сибирской формь. Дьло въ томъ, что, несмотря на свою довольно свьтлую окраску, онь отличаются гораздо иеныии.и распространеніемъ бђлаго цвьта на нижнеї сторонь. Бока горла ихъ интенсивно сьраго тона (зимою) II коричневаго (льтомъ). Бьлая окраска горла, вдаваясь острым угломь впередъ, на I-2 сант. не доходить до нижней губы. Область паховая и половыхъ органовъ окрашены въ темный цвьтъ, выступомъ выдающійся въ бьлый мьхъ живота. Далье,

1) Это правило простирается на западно-европеїскихъ бълокъ: Sc. vulg. italicus Bonap., распространенная въ Альпахъ, Апеннинахъ, Карпатахъ іп Балканахъ, отличается своей темной терно-бурой окраской въ льтнемъ. мtху й буро-сърої-въ зпмнезъ. 
нижнія части основаній лапь покрыты зимого соверненно черными волосами. У московскихъ экземпляровъ здьсь всегда сохраняются острова рыжихь волосъ.

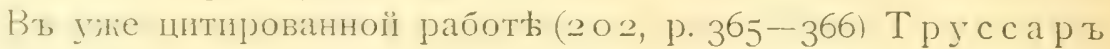
описываетъ съ береговъ Лены ${ }^{1}$ ), живущую тамъ въ области бореальныхъ нхзменностей бьлку за особый подвидъ Sc.vulg. arcticus Tr. Этоть авторъ имьль оттуда три экземпляра, добытые всп во окиябрив.

Первая былка характеризовалась совершенно былымъ мьхомъ, громғ хвоста, который быль желтовато-кремоваго цвьта и напоминаль таковой у Sc. vulg. leucurus Kerr. Второй экземпляръ отличался также бълой окраской, кромь верхней части головы, спины и хвоста, которые были серебристо-сђрые. Третій похо. дилъ на второї, только сьрыя части были замьтно красноваторыжими. Радужиина у всьхъ была корнчневая. Несмотря на то, что всь б́tлки были добыты почти одновременно, Т руссаръ, по совершенно не выясненнымъ соображеніям, считаетъ первый экземплярь пріобрьтшимъ зимній мьхъ, второй - осенній (sic!), наконецъ, третій-находящимся еще въ льтней шерсти. Врядъ-ли можно сомнываться, что это разграниченіе является совершенно произвольнымъ и ничьмъ не доказаннымъ. Я не сомньваюсь, что авторъ имьлъ передъ собою просто частичныхъ альбиносовъ сибирскихь бьлокъ. Еще Р адде въ своей очень интересноі работь о восточно-сибирскихъ животныхъ ( 4 4, p. І 39 ) подробно описываеть подобный же выродокъ изъ Яблоноваго хребта. Среди серіи бълокъ, присланной мнћ Г. Э. Іоганзеномъ, нашелся одинъ экземпляръ (хі, І898 г. Нарымскій край отъ (ухова), по окраскь⿱ крайне близкій къ первой „зимней“ особи Sc.v.arcticus Tr. Весь мьхъ этой бьлки совершенно былый, кромь желтовато-кремовыхъ концовъ ушей, желтовато-палевыхъ ћонцовъ лапъ и бьлесоватаго хвоста, въ которомъ замьчаются, жромы совершенно былыхъ - желто-палевые и черноватые волосы ${ }^{2}$ ). Странным въ высокой степени было бы предположить, что Sc. vulg. arcticus Tr., эта, по Т руссару, арктически-бореальная форна бьлки, встрьчается такъ далеко на югъ, бокъ-о-бокъ съ типичной Sc. vulg. calotus Gray. Тоть факть, что у Sc. vulg.

1) Безъ точнаго указанія широты мъста.

2) Необходимо отмытить, что п среди европейскихъ бблокъ констатнрованы случап альбинизма. Тақъ, F ell m a n, описывая разновидности бђлокъ, говорптъ, что въ окрестностяхъ Энаре встрђчаются бълыя формы, называсмыя тамъ "Lenvje oаrre" на ряду съ типичным особями п другшми красочными отнлоненіями (60 p., 142). 
arcticus $\mathrm{Tr}$. радужная оболочка глаза окрашена въ каштановый цвьтъ, совершенно не мьняетъ дьла и не доказываетъ, какъ думаетъ Труссаръ, что передъ нами не выродокъ. Вьдь новые факты теоріи М енделя указывають, что возможны случаи, когда подъ маской частичнаго альбинизма скрываются въ сушности окрашенныя формы, даже меланисты. У такихъ экземпляровъ альбинизмъ въ большинствь случаевъ не чистый, какъ наприм ьръ, у такь наз. гималайскаго кролика ${ }^{1}$ ), и пигментъ можеть распространяться на разныя части тьла.

\begin{tabular}{|c|c|c|c|c|c|c|c|c|}
\hline \multirow[b]{2}{*}{$\begin{array}{c}\text { Сравнительная таблица } \\
\text { измьреній череповъ } \\
\text { Seiurus vulgaris calotus } \\
\text { Gray ıзъ Якутской обл. } \\
\text { и Sc. vulg. mantshuri- } \\
\text { cus Thom. изъ IIримор- } \\
\text { ской обл. }\end{array}$} & \multicolumn{2}{|c|}{$\begin{array}{l}\text { Sciurus v. } \\
\text { calotus Gr. }\end{array}$} & \multicolumn{6}{|c|}{ Sciurus $\therefore$ mantshuricus Thom. } \\
\hline & 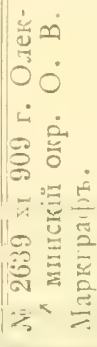 & 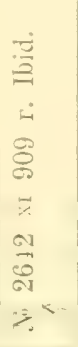 & 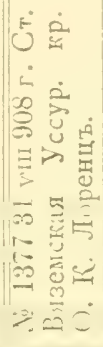 & 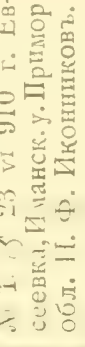 & 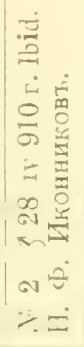 & 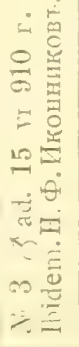 & 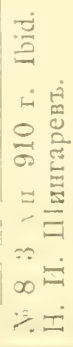 & 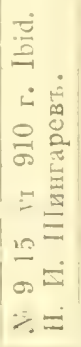 \\
\hline Нанбольшая длина черепа. & 52,5 & 53 & lok. 57 & 56,7 & 54,5 & 53,5 & 52,8 & 56 \\
\hline Основная длина . . . . . & 39,2 & 40,3 & 一 & 44 & 42,5 & - & 41,5 & 45 \\
\hline Кондиллярная длина . . . . & 42,3 & 44,2 & - & 47,2 & 46 & - & 44,6 & 47,9 \\
\hline Скуловая ширина . . . . . & 30,4 & - & 32 & 33,7 & 33 & 32 & - & 34 \\
\hline $\begin{array}{l}\text { Ширнна между foramina in- } \\
\text { fraorbitalia . . . . }\end{array}$ & 11,2 & 9,9 & 11,3 & 11,5 & 10 & 10,9 & 9,7 & 10,6 \\
\hline $\begin{array}{l}\text { Нашбольшая ширина ossa na- } \\
\text { salia . . . . . . }\end{array}$ & 8 & 7,5 & 8,7 & 9,1 & 8,7 & 8,9 & 8,2 & 9,1 \\
\hline Длина ossa nasalia . . . . & 16,4 & 17,3 & 18,2 & 18,9 & 16,8 & - & - & - \\
\hline
\end{tabular}

По словамъ О льдф и льда Т ом а с а (г 8 7, р. 50I), манчжурскія бълки отличаются отъ Sc.vuly. calotus Gray большими размьрами и болье темной ограской сьраго зимняго мыха. Какъ я писаль уже раные ( ( 27 , стр. 500-502), окраска приморскихъ бьлокъ сильно измьнчива. Что касается до сравненія моихъ экземпляровъ изъ Приморской обл., добытыхъ Н. Ф. И к о н н и ко-

1) ГІ ён н е т тъ, Менделизиъ, 1913 г, стр. 62, табл. Г. 
вымъ, то черепа ихъ въ общемъ длиннье, чьмъ у $S c$. vulg. Totus Gray изъ Якутской обл. Долженъ замьтить, что для огончательнаго рьшенія этого вопроса нужень большій матеріаль, чныъ бывшій въ моемъ распоряженіи.

\section{Географическое распространеніе.}

Область распространенія былки въ предылахь Европейской Россіи можетъ быть очерчена такимъ образомъ. Съверная граница ея обитанія начинается отъ, прибалтійскихъ провинцій, rды б́ыла, по Греве $(67,99)$, встрьчается довольно часто. Далье эта граница переходить въ Петербургскую губ́., гдђ Scinı vulgaris, по новынъ даннымъ В. Л. Біанки (2 3, стр. Iт2), встрьчается періодически то въ большемъ, то въ меньшемъ количествь. Въ Финляндіи бьлка найдена еще Валленіу сомъ. Отсюда на сьверъ она добыта близъ Энаре Фелльманомъ (6о, р. 142), для Русской Лапландіи указана Миддендорфом ъ. Однако, этоть авторь сомньвается, чтобъ бьлка встрьчалась сьвернће Иматры. По свидьтельству Ө. Д. П л е к е ( 133, р. 83), этоть грызунъ доходитъ, в рроятно, до Колы. Если принять во вниманіе показаніе N ord vi, что былка найдена около ВарангеръФіорда, т.-е. около $70^{0}$ с. ш., то отсюда, по Ө. Д. П л е с к е, сьверная граница ея распространенія опускается на востокъ до $68^{\circ}$ с. Ш. Далье граница тянется черезъ Олонецкую и Архангельскую губ., всюду совпадая съ сьверными предьлами крупнаго льса, т.-е. около $65^{\circ}$ с. ш. По свидьтельству Б. М. Жи тиова и С. А. Бу ту р лин а (72, стр. 72-73), въ Архангельской губ. особенно много бблокъ добывается промышленниками въ Печорскомъ и Шенкурскомъ уу. Въ предьлахъ Сьвернаго Урала граница распространенія Sciums vulgaris, какъ показали результаты экспедиціи Го фманна, простирается до $62-63^{0}$ с. ш.

Что касается до южной границы распространенія этого грызуна въ Европейской Россіи, то она начинается на западь около $47^{0}$ с. ш. въ съв. части Бессарабіи, гдђ бълка найдена Н о дманном т $\left(125\right.$, р. 54) $\left.{ }^{1}\right)$. Далье граница тянется черезъ губер-

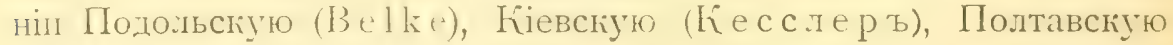
и сьв. часть Харьковской (Ч ернай, С омов ъ), въ предьлы Воронежской губ. Здысь, по Н. А. С 光 в е р ц о в у ( 19 ), граница идетъ черезъ Бобровскій у., переходя затьмъ въ Балашовскій по р. Хопру, въ Петровскій и Сердобскій уу. Саратовской губ. (M. Н. Богданов ъ, А. А. Силантьевъ). Оттуда граница

1) Отмьчу, что въ Крыму бълки нбтъ. 
тянется черезъ уу. Кузнецкім, Хвалынскій, Сызранскій и переходить Волгу выше Самары, направлясь отъ нея по льсамь Общаго Сырта въ южныя предгорія Урала. На Волгы самымъ южнымъ нахожденіемъ бњлки является боръ около Черкасскаго (Вольскій у.). Далье на востогь отъ Общаго Сырта она, по Н. А. З арудному (77, стр. 332), очень обыкновенна въ львсахъ Оренбургской Башкиріи.

Въ Зауральь южная граница распространенія былки опять замьтно отходитъ къ съверу. Такъ, по Сабан ьеву (стр. 9), ея ньть совершенно въ березовыхъ льсахъ Шадринскаго, Камышловскаго уу. и ю.-в. части Екатеринбургскаго. По свидьтельству Бу лы че в а (4 о, стр. 26, 27), она довольно рьдка въ Ирбитскомь уњздь, тогда какъ сьвернье, около Верхотурья, очень обыкновенна.

Въ заключеніе необходимо разсмотрыть, что представляеть изъ себя въ подвидовомъ отношеніи бьлка, встрьчающаяся, по С ло в цо в у, въ Тюменскомъ, Туринскомь, Березовскомь и Тобольскомъ округахъ, т.-е. въ бассейнь р. Оби. Въ 1792 году Kerr описалъ изъ долины Оби былку подъ названіемъ Sc. aюgenteus Kerr. Это названіе Бар реть-Гамильтонь склоненъ относить въ синонимы Sc. vulg. calotus Gray ( 4 , p. 6.) Однако, по С и ашко ( 8 I, стр. 590), зимнія былки въ льсахъ Оби и Чулыма отличаются быловато-сћрымъ мьхомь, а льтомъ бывають свғтло-рыжими. Далье проф. Н. $Ө$. К а ш е н о въ своемь „Опредьٔлитель томскихъ млекопитающихъ“, товоритъ, "что на зиму бьлка „вся бтлюето“. Наконецъ, въ коллекціи Зоолог. Музея Моск. Унив. имьется зимній экземпляръ бьлки съ Нртыша (пзъ Семипалатинска), отличаюцейся необынновенно свьтлым тоноль мьха, рђзко отличаюшимся отъ наиболье свђтлыхъ московскихъ экземпляровъ, и совериенио билили юрлоль. Все это заставило меня сдылать крптичесіую провьрку тапсономическаго положінія б влки долины Оби.

Благодаря любезности Г. Э. Іоганзена, я имњль возможность просмотрьть весь матеріаль по бьлкамъ коллекціи Томскаго Университета. Къ сожальнію, въ хорошей серіи ( I5 экз.), присланной мнь Г. Э., преобладають льтніе экземпляры. Но и они дали мнь возможность притти юь опредћленнымъ результатамъ. Выяснилось, что въ окрестностяхъ г. Нарыма (серія Аникина) преобладаеть бьлка переходнаго характера между нашей средне-русской II Sc.v calotus Gray. Такъ, окраска спины изсльдованныхъ особей совершенно не отличается отъ московскихъ, тогда какъ на подбородкь заньчается ясное развитіе 
темно-бураго цвбтта, очерчиваюшаго узкую клинообразную полосу былаго мьха; въ пахової области темный цвьтъ развить тоже сильно, какъ у сибирской бьлки. На ряду съ подобными пмьются особи, не отличимыя оть московскихь (요. блер. Кальнакъ, бл. Нарыма, I2 г` 900 г. Аникинъ; бл. Нарыма I5 vıг 9оo): Что касается до томскихъ бълокъ, то ныкоторыя особи, напримћръ, линяющій экземплярь, добытый т. Iх I892 г. въ окр. Томска Соколовымъ, отличается своей свьтлой ограской и яркимъ оттьнкомъ пробивающихся сьрыхъ волосъ,-онъ можетъ быть отнесенъ къ свьтлому типу окраски московскихъ бьлокъ. Ннтересно, что изъ окр. Томска (I4 хі I893 г. Н. Ө. Кащенко) имъется темный экземпляръ, почти типичный Sc.v. calotus Gray. Џтакъ можно видьть, что въ долинь Оби встрђчаются вмђсть съ переходными и типично окрашенными бълками, повидимому, болье рьдко, близко стоящія къ Sc. v. calotus Gray. Описанная Kerr Sc. v. argenteus Kerr врядъ ли можетъ быть выдьлена.

Настояшая Sc. $v$. calotus Gray начинаетъ встрьчаться въ Алтайскихъ предгорьяхъ. Такъ, зкземпляръ, добытый К $\mathrm{K}$ ре лин ы м бл. Уймона, несомньнно относится къ этой форны. Отсюда она распространяется по Алтаю, Тарбагатаю и Саянамъ, очевидно, иреобладая на правомь берегу Енисея иі распространяясь затьмъ далеко на востокъ. Какъ было сказано, въ Приморской обл. встрьчается болье крупная форма Sc. vulg. mantshuricus Th., на Сахалинь - Sc. vulg. vupestris Th., въ Хоккайдо - Sc. vulg. orientis Th. ${ }^{1}$ ).

За посльднее время, главнымъ образомъ, западными зоологами бьлка раздылена на цћлый рядъ подвидовъ. Въ Швеціи и Норвегіи встрьчается типичная Sc.vulgaris L., въ Скандинавіи II Лапландіи, по Т руссару, Sc. vulgaris varius Kerr, въ Британіи и Ирландіи - Sc. vulg. leucumus Kerr, въ Германіи и Венгріи-Sc. vulg. fuscoater Alt., во Франціи, Голландіп и Бельгіи-Sc. vulg. vussus Mill., въ Пиренеяхъ - Sc. vulg. alpinus Cuvier, въ Испаніи-S.v. mumantins Miller, въ центр. Нспаніи (горн. обл.)Sc. v. infuscatus Cabr., на Cieppts де-Сегура-S. v. segurae Miller, на Cieppt Mopeнt - S. v. baticus Cabr., въ Альпахъ, Аппенинахъ, Карпатахъ - S. v. italicus Bonap., въ Греціи-Sc. v. lilaeus Miller. На Кавказњ встрғчается особый видъ Sciurus anomalus Gm.

\section{Образъ жизни.}

Жизнь бьлки тьсно связана съ хвойнымъ льсомъ. И дыйствительно, этоть красивый грызунь особенно часто попадался

1) На Камчатк'ь б́ыка не найдена. 
мнђ въ высогоствольныхъ, хвойныхъ или смышанныхъ льсахъ, съ богатой примьсью ели и сосенъ. Благодаря ея необықновенної подвижности и живости, бьлку можно замьтить уже издали. Сидитъ ли она на заднихъ лапкахъ, обхвативъ передними какой-нибудь орьхъ и грызя его, прыгаетъ ли съ вътви на в Ђтвь, широко распушивъ свої длинный хвостъ, или взбирается на верхушку зеленой ели - всегда ея движенія полны қрасоты и граціозности. Завидывъ опасность, бьлка издаетъ глухой цикающй покрикъ, вздрагивая при этомъ всћмъ тьломъ и отрывисто взмахивая хвостомъ. Черезъ минуту она уже б́ыстро взбирается на верхушку дерева, прячась въ его сучьяхъ. Бьлка прекрасно умћетъ пользоваться своей исключительної способностью къ лазанью. Раненая или упорно пресльдуемая, она съ большой быстротой вертится кругомь толстаго дерева, ухватившись за его кору всьми ногами, и достигаетъ того, что все время находится за прикрытіемъ толстаго ствола.-Главной пишей о́ являются сьмена хвойныхъ растеній, которыя она добываетъ, отрывая еловую или сосновую шишку и быстро обгрызая ее. Раннею весною можно видьть въ тьхъ мьстахъ, гды держится много бьлокъ, массу объ бденныхъ шишекъ, лежашихъ подъ деревьми. Кромь того бълка очень любитъ орьхи. Во время ихъ поспьванія иногда цьлыя партіи б́блокь держатся въ орьшникъ; перепрыгивая съ гибкихъ вытокъ и сильно раскачиваясь въ воздухь, обрываютъ онь орьхи. Разгрызая пхъ, онь чрезвычаїно быстро вертятъ ихъ въ разныхъ направленіяхъ передними лапками, прпжимая въ то же время къ зуб̆амъ. Черезь нусколько мгновеній твердая скорлупа бываеть прогрызена въ двухъ, трехъ ићстахъ, I б́ блка, просовывая въ сдьланныя отверстія свол длинные передніе рьзцы, разламываетъ скорлупу по кускамъ. Многими ставится въ вину бьлк' уничтоженіе птенцовъ мелкихъ птичећъ. Охота за ними, которую она иногда предпринимаетъ, носитъ случайный характерь, и поэтому бьлка не можеть считаться вреднымъ животнымъ. Да и самое устройство ея зубовъ съ плоскими поперечными склацками эмали и очень тупыми и малозамьтными бугорками - хорошо указываетъ на неприспособленность этого грызуна къ животной пишь, - Свои гньзда бьлка устраиваеть различнымъ образомъ. Обычно мнь приходилось находить ихъ на половины высоты (2-3 сажени надъ землею) не очень старыхъ елокъ, являющихся подсыдомъ крупнаго льса. Самое гньздо по обшему виду напоминаеть сорочье, т.-е. имьетъ крышу и представляетъ довольно крупную постройку, сдьланную изъ сплетенныхъ сучьевъ и выложенную внутри мохомъ. Кногда гньзда по- 
мьшаются болье низко на кустахъ можжевельника, иногда, даже, въ дуплахъ деревьевъ. По К. А. С атунину, посльднія являются исключительно зимним. Кнтересно отмбтить, что въ очень рыдкихь случаяхъ былка устраиваетъ свои гнызда подъ карнизами домовъ. Подобный случай наблюдаль мой другъ А. $\Theta$. Слудскій въ Дмитровскомъ у. По свидьтельству Л. П. С абаньева, бьлка мечеть два раза въ годъ оть 4-7 молодыхъ. Время перваго помета, по словамъ этого автора, въ конць марта, второго-въ іюнt. Далье онъ говоритъ, что 4 IV I873 года у всьхъ бьлокъ молодыя уже выметаны и едва начинають сьрыть. Къ сожальнію, у меня ньть наблюденій надъ молодыми б́ блками въ тоть періодъ, когда онь находятся еще въ гныздь. Очень мелкихъ молодыхъ, видимо, только что покинувшихъ гньздо и подпускавшихъ къ себь въ упоръ, я встрьчалъ въ первой половинь іюня и началь августа, что подтверждаетъ наблюденія Л. II. С аб ан в ев а.

Осенняя линька бьлки начинается различно у разныхъ экземпляровъ.-Уже I4 VIII 9 II г. мной была добыта бьлка, у которой ясно примышивались въ области затылка сьрые волосы и черные кончики ушей начинали отрастать. Бьлка, добытая H. А. Андреевым 5 IX 9I2 г., находилась въ сильной линьнь. С ьрые волосы появляются прежде всего въ области затылка и верхней шеи, а также по бокамъ спины. Еще болье пестрый линяющій экземплярь быль добыть II IX 9 I2 г. Уже почти закончившая линьку бьлка,, со сльдами рыжихъ волосъ въ области лопатокъ и на бокахъ тьла, была застрьлена Андреевы м ъ I4 IX 9 I2 г. (№ 2630 ㅇ). Бьлки, совершенно перелинявшія, были добыты въ началь октября (을 2634 o 2 X 912 г., № 2633 우 Іо X 912 г.). Весенняя линька (изь зимняго в’ь лььтній мьхъ) происходить въ апрьль. Еще 7 IV 9II г. мной быль

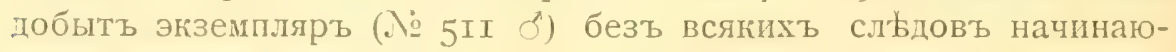
щейся смыны волосъ.

Однако, I5 IV 9I г . я застрьлиль стараго самца (№ 419), находившагося въ очень спльной линькь. Посльдняя вполнь заканчивается, по моимъ наблюденіям, въ первой половинь мая.

Бьлка не подвержена. зимней спячк', и свое существованіе во вреия зимы обезпечиваеть устройствомъ складовъ и запасовъ, собираемыхъ въ теченіе второї половины льта. Для устройства такихъ запасовъ бьлка выбираеть разныя укромныя мьста: дупла деревьевъ, расщелины коры, ямы подъ корнями деревьевъ и пр. Этими запасами былка пользуется и въ дождливые осенніе дни, такъ какъ она очень не любитъ сырости и въ 
такое время избьгаетъ выходить наружу. По словамъ К. А. С атунина, вь очень снльные морозы бьлка скрывается въ дупла и спитъ.

Сколько-нибудь крупныхь переселеній б́ллокъ въ предылахъ Московской губ. мнь наблюдать не приходилось. Могу занътить только, что годами ихъ бываетъ очень много, годами же онь встрьчаются значительно рыже. Въ сыверной Россіи у разных авторовъ попадаются указанія на пропсходящія иногда передвиженія былокъ. Въ ныкоторыхъ случаяхъ они бываютъ вызваны чисто вньшними причинамп. Такъ, Л. К р у лик о в с кій говорить, что льтомь 1897 г., всльдствіе пожаровъ въ льсахъ завятской части Малмыжскаго у., бьлки въ большомъ количеств' переплывали черезъ Вятку близъ гор. Малмыжа и въ теченіе ньсколькихь недьль встрьчались даже въ предьлахъ самаго города (93, с т p. у I 3 ).

Экземиляры коллекии перечислены въ таблицахъ измреній.

\title{
Подсемейство Pteromyinae.
}

Родъ Sciuropterus Fr. Cuvier (1825).

\author{
(Pteromys Geoffroy).
}

Летяги.

Между передними и задними гонечностями тянется широкая, покрытая волосами, кожная складка, такъ наз. лемале.илая пеpenонка. Она поддерживается особої косточкої, прикрьп.яющейся у кисти и длиною равной предплечью.

\section{Sciuropterus russicus Tiedemann.}

\section{Летяга.}

Pteromys russicus T i edem a n n, Zool., I, 180S, p. 151. Sciurns volans Linn a e us (98), p. 88 (nec MIus volans, p. 85). Pteromys volans L. B l as ius 2 7), p. 269. К. А. С а т ун пи ъ (1 65 ), стр 10, пі (1 6 6), р. 2.

Несмотря на всь поиски, летяга мной въ предълахъ Московскої губ. не встрьчена. Я видылъ экземпляръ, добытый въ Покровскомъ у. (Владимирской губ.), граничащемъ съ Богородскимъ у. Московск. губ.. По свидьтельству К. А. Сатунин а, изрьдка встрьчается въ Богородсконъ у. (Московск. г.) и Егорьевскомъ у. (Рязанской губ.). Далье этоть авторъ приводить со знакомъ 
вопроса показаніе препаратора Мясникова, что ему были доставлены летяги изъ Сокольниковъ (окрестн. Москвы). Вђроятно, летяга будеть найдена въ Димитровскомъ у., что днвлается особенно возможнымъ, если ознакомиться съ общимъ распространеніемъ этого вида.

Sciropterus messicus Tied. встрьчается въ Курляндіи, Лифлянпіи и Эстляндіи (Г реве́,-67 стр. гоо-то2), переходя отсюда въ Петербургскую губ. (П о р и н скій, т 37, стр. 388,389 ) и Финляндію. Сьверная граница распространенія этого вида доходить до Куусамо (за $65^{\circ}$ с. ш.) и южныхъ частей Лапландіи (П ле ске, I 33 , стр. 8I). Отсюда граница распространенія летяги спускается ниже и идеть на востокъ, захватывая собою таежные льса Архангельской губ., и простирается до съвернаго Урала, переходя затьмъ въ предылы Западной Сибири. Здьсь, по С ловцо в у ( 83 , стр. 23-24), летяга встрьчается въ Тюменскомъ, Туринскомь, Ялуторовскомъ округахъ, но уже становится очень рьдкої въ окр. Березова. Далье на востокъ она встрьчается въ тайгь по Енисею и Лень (Маакъ, го2, стр. Іоз-Iо4) до побережії Охотскаго моря, захватывая въ своемь распространеніи Приморскую область, Алурскій край, область Забайкалья, 11ркутскую и Томскую губерніи. Южная граница распространенія летяги въ предьлахъ Европ. Россіи начинается въ Литв хватывая, по Т а анов скому ( 8 5, стр. І29), Минскую и Могилевскую губерніи, подымается въ сьверные уьзды Смоленсіой губ., спускается далье на югъ до Брянскаго у. Орловскої губ. и, круто поднимаясь, переходить въ Егорьевскій у. Рязанскої губ., откуда идетъ по Владимирской губ., вћроятно, черезъ сьверныя части Нижегородской въ сьв. зап. часть Казанской губ. (M. Н. Богдановъ, 3о, стр. І68). Доходя до Урала, южная граница распространенія летяги спускается до низовій р. Сакмары, гды одинъ экземпляръ этого млекопитающаго былъ до-

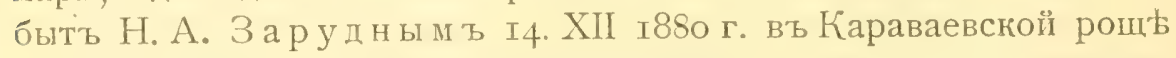
(77, стр. 332). Восточнье граница замьтно повышается, захватывая березовые льса Башкиріи ( $Л$ е м ан ъ, см. Brandt $34, \mathrm{p} .3^{2}$ ) и Екатеринбургской губ. (Сабан в в ъ, I 49, стр. 9).

На Сахалинь, по Т о а су (т 93, р. 409), встрьчается особая форма Sciuropterus russicus athene Thom. 


\title{
II. Подотрядъ DUPLICIDENTATA. \\ Семейство Leporidae.
}

\author{
Родъ Lepus Linnaeus (1758).
}

\section{Зайшы.}

Представители этого рода отличаются своимъ длиннымъ, сжатымъ съ боковъ тьломъ, массивной и большой головой и длинными ушами. Очень пушистая ступня задней ноги весьма длинна по отношенію ко всему тьлу. Хвостъ крайне коротокъ.

Черепъ характеризуется удлиненными носовыми костями, рђшетчатыми, продыравленнымп боковыми частями челюстиыхъ костей, хорошо развитыми залнеглазничными отростками и широко разставленными скуловыми дугами. Твердое нёбо очень узко и образовано главнымъ образомъ нёо̆нымп отростками челюстныхъ костей. Foramina incisiva очень длинны пा широки. Слуховыя отверстія (meatus auditorius externus) ограничены трубкообразными костями, выдающимися вверхъ и по бокамъ черепа. Os interparietale ясно очерчена только у молодыхъ особей, совершенно исчезая у старыхъ.

Зубная формула такова:

$$
\begin{aligned}
& \text { i. } \frac{2-2}{\text { I-I }} \text { c. } \frac{0}{0} \text { pm. } \frac{3-3}{2-2} \text { m. } \frac{3-3}{3-3}=28 . \\
& \text { Группа Eulagos J. E. Gray. } \\
& \text { Зайцы русаки. }
\end{aligned}
$$

Eulagos Gray I. E. Ann. and. Magazine of Natur. Hist. 1867, p. 222. (Основанъ на Lepus mediterraneus IVagner in Eulagos judeae Gray).

\section{Lepus (Euagos) europaeus aquilonius Blas.}

\section{Русакъ средне-русскій.}

Lepus aquitonius $\mathrm{Bl}$ as ius (28), p. 89, in (29), p. 57. Lepres timidus L. B l asius (27), p. 412 (partim!). Lepus m. aquitonius Bl. Hilzh eimer (69), p. 511 Ir (701, p. 388. Trou essart (200) p. 217. Lemus europcteus Pall. H. A. C a т yн ІІ н ъ $(165)$, стр. 14 II $(166)$, p. 2 .

\section{Систематическія особенности.}

耳ерепо (Си. таб. IV, рис. 55 и 58.) зайца русаґа характеризуется довольно легко и отличается оть черепа б́лляка цьлымъ 
рядомъ признаковъ. Однако, въ подробностяхъ эти посльдніе подвержены значительнымь колебаніямъ, но въ совокупности они даютъ возможность безошибочно отличить черепа этихъ видовъ, если даже ньть шкурокъ для подтвержденія діагноза.

Въ обшемъ черепъ русака болье удлиненный и узкій. Скуловыя дуги, сравнительно съ общей длиною черепа э’ж, qьи у б́ляян; носовыя кости длинные, таюже длиннье и os premaxillare, a наклонъ ея впередъ болье nологіiі, чьмъ у Lepus timidus L. Processi postorbitales удлиннены, не подымаются такъ замьтно, какъ у быляка, и болье откинуты назацъ. Межглазничный перехвать въ общемъ уже, чьмь у бьляка. Скуловая дуга въ ея переднемъ отдыль замћтно сужена и ве такљ круто поднимается назадъ, кать у I. timidus L. Bce это дьлаетъ общую форму глазницы рьзко отличающейся у этихъ видовъ. Наконецъ, foramina incisiva русака значительно длиннье, чьмъ у бьляка. Миддендорфь ${ }^{1}$ ) считаль особенно характернымъ для русака шовъ между лобными и носовыми костями, имьющій тупую, изломанную форму, а не характеръ выступающаго впередъ остраго угла, какъ у $L$. timichs L. Далье, у русака, по Миддендорфу, задній кон туръ теменныхъ костей выдается по направленію къ затылочной области замьтнымъ выступомъ. Напротивъ, у бъляка контуръ затылочної части теменныхъ костеї имьетъ неправильную форму: выступа, какъ у русака, нь̆ть, а на мьсть' его зам'ьчается ясно диференцированная вырьзка. На имьющемся у меня болышомь матеріаль я могъ точно провьрить эти признаки и убьдился вт, полноиъ непостоянств ь второго изъ нихъ. Что же касается до перваго, т.-е. формы шва можду лобными и носовыми костями, то этотъ признакъ Hilzhe imer (7 o, p. 407) считаеть очень постояннымъ. Однако, я долженъ констатировать его очень большія ґолебанія: среди русаковъ мнь попадались экземпляры съ описываемымъ швомъ, построеннымъ совершенно по тому же типу, какъ у бьляка, а среди посльднихъ особи (№o 23ог, 2426) съ строеніемъ его какъ у предыдушаго вида.

Довольно надежнымъ признакомъ является указанный Барреть-Гамильтономъ (г 6, p. 249). По этому автору, лобныя кости русака спередиі не вогнуты, какъ у бьляка, и не такъ замьтно поднимаются въ ихъ заднемъ отдьль. Наконецъ, по Schäff, у заїца русака передній отдьлъ твердаго нёб́а доходить до задняго края перваго ґоренного зуба, а у бьляка-до его передней стороны. Я совершенно согласенъ съ Гильц ге й-

1) Mi d d e n d or f, Mélang. Biol., 1851, T. I. livr. 3, p. 244-245. 
м ером ъ въ томъ, что этотъ признакъ совершенно не выдерживаетъ критики при просмотрь большого матеріала.

Гораздо болье постоянныя отличія можно отмьтить въ строеніи нижней челюсти этихъ видовъ. Каюъ совершенно вьрно пишеть Hilzheimer, у русака она значительно тоньше и болье удлиненной формы. Гребень по внбшнему краю processus angularis развить у быляка значительно сильнье, чьмь у русака.

Сколько-нибудь надежныхъ половыхъ отличій въ строеніи черепа мны констатировать не удалось. Могу отмьтить толью, что, по имьющемуся у меня матеріалу, черепа самою представляются болье длинными, чьмъ черепа салцовъ.

Возрастныя измыненія очень рьзки. $Я$ не буду ихь здысь подробно описывать, т. к. главныя отличія видны на прилагаемыхъ фотографіяхъ (табл. III, рис. 5I, 52, 54 и табл. IV, рис. 6r). Въ двухъ словахъ, черепь совсьмъ молодого зайца хараютеризуется: грайней укороченностью носовыхъ костей, очень сильной приподнятостью задняго отдьла лобныхъ, очень широкимь межглазничнымъ промежуткомъ, громадными по отношенію ко всему черепу глазницами. Наконецъ, у молодыхъ экземпляровъ всегда ясно замьтна межтеменная кость, совершенно редуцированная въ зрьломь возрасть. Очень старые экземпляры отличаются: грайне длинными носовыми костями, узкимъ межглазничнымъ промежіт комъ, далеко загнутыми назадъ processi postorbitales и очень длинными переднечелюстными костями.

Строенію зубовъ многіе авторы придавали очень большое значеніе въ смысль надежной основы для систематической диференцировки.

Такъ, напримьръ, Блазіусъ (27, р. 4і2 и сльд.), считаль особенно характернымъ строеніе эмалевыхъ склапок перваго ложно-коренного зуба верхней челюсти. Въ болье новой работt Lönnberg (99, р. 282) этоть признакъ какъ бы подтверждается и приводятся даже рисунки, правда, сильно отличающіеся оть таковыхъ въ книгь Блазіуса. По крайней м⿻丷木 н, на основаніи своего обильнаго матеріала, я положительно могу констатировать очень большую измтнчивость описываемыхь зуб́овъ, не поддающуюся точному введенію отличительныхъ признаковъ въ опредьленныя рамки. Болье того, тотъ рисуною, который изображаетъ въ работь Lönnberg зубы зайца русака, болье напоминаетъ по своему виду строеніе ихъ у нькоторыхъ бьляґовъ моей коллецціи, а отсутствіе третьяго бокового эмалеваго выступа надо считать для перваго вида признакомъ рђдииъ и случайнымъ. Гораздо болье надежнымъ и точнымъ является дру- 
гое отличіе въ строеніи зубної системы, которому, страннымъ образомь, мало удьляли вниманія. Я говорю о строеніи перваго ложногоренного зуба нижней челюсти. Hilz h e im e r (7 o, p. 408) указываеть различія въ длинь этого зуба у описываемыхъ видовъ. Однако, эти различія являются не столь надежными, какъ самое его расположеніе: у Lepus emrop. aquilonius Blas. онъ значительно болье наклолелг назадо, тогда какъ у б́ьляка зубъ сидить болье отвђсно и прямо. Необходимо замьтить, что и это различіе, какъ большинство другихъ краніологическихъ признацовъ зайцевъ, довольно относительное, и замьчаются колебанія то въ одну, то въ другую сторону, но все же постоянство его достаточно велико.

Oкраска стараго русака въ льтнемъ мьху такова.-Передняя часть головы, бока губ́ъ, щеки, кольцо около глазъ покрыты густыми волосами, палевыми у основаній, съ бђловатыми вершинами. Подъ глазомь и за нимь тянется замғтная полоса болье длинныхъ волосъ съ широқими черными окончаніями; подобные волосы примғшиваются также въ заднемь отдыль щекъ. Вся верхняя часть головы покрыта густымъ мьхомъ, съ ясными ржавосђрыми основаніями, широкимъ чернымъ колыцом въ среднеї части, и свытлыми землисто-желтыми вершинами. Јши по центра.льной части ихъ широкаго внутренняго края покрыты короткими, густыми, совершенно черными волосами, между которыми замьчаются также имьюшіе палево-желтоватыя вершины. Съ боковъ широкой, внутренней части уха примьшивается довольно значительный процентъ свьтлыхъ, палево-бьловатыхъ волосъ. По самому вньшнему краю уха тянется полоска короткихь и болье рђдкихъ сыроватыхъ и палевыхъ волосъ, которые смьняются у cinaro края уха ярlіо замћтнымъ бордюромъ совершенно о́tлыхъ. Съ внутренней стороны ухо покрыто рьдкими сьровато-былыми волосами, пріобрбтающими болье рыжій оттьнокъ къ основанію уха. На самомъ концђ посльдняго замьчается широкое черное пятно, особенно большое на внутренней сторонь уха (около $32 \mathrm{~m} / \mathrm{m}$. длины). Вся область за ушами, верхняя часть шеи и бока ея покрыты очень длинными ржаво-красновато-палевыми волосами, съ желтоватыми вершинами. Сейчасъ же за ушами примғшиваются островии совершенно бжлыхъ волосъ. Вся верхняя часть спины почти вплоть до боловъ погрыта длинными, волнистыми волосами съ бьлесыми основаніями, широжими, черными срединными частями и глинисто-желтыми вершинами. Среди подобныхъ волось примьшиваются имғющіе узкіе черные концы, а также небольшое число совершенно черныхъ. Въ задней части 
тьла и въ окружности хвоста черные пояса волосъ совершенно пропадають, глинистый тонъ замъняется болье палевым, тогда какъ былыя основанія сохраняются. Бока тьлл, широкая полоса поперекъ груди, плечи и бедра покрыты однотонными глинистокрасновато-ржавыми волосами. Ступни переднихъ ногъ замьтно желтье, тогда какъ заднія-св́тло палево-желтаго цвьта. Подбородокъ, а частью бола шекъ, область нижней груди, брюха і паха-чисто бжлые. Длинныя виориссы (ололо $105 \mathrm{~m} / \mathrm{m}$.) состоятъ изъ смьси совершенно черныхъ и бълыхъ волосъ. Очень пушистый хвостъ бьловатый съ замћтнымъ чернымъ пятнощъ на его верхней части. Окраска молодыхб много желтье и свьтлtе: глинистыя окончанія волосъ спины замынены здысь пале. выми. Цвћтъ груди и боковъ много тусклье. На средины лба замћчается звьздочка бьлыхъ волосъ.

Зимняя окраска очень рьзко отличается оть льтней. Наиболье рызкое отличіе сводится къ тому, что вся верхняя сторона тьла замътно сьрђетъ. Это обусловливается: появленіемъ б́ьловатьхъ окончаній волосъ на верхней части головы, сильнымъ посвђтльніемъ окончаній волосъ спины, которыя вмьсто глинисто-желтовато-бурыхъ дьлаются палево-бьловато-сьрыли. Вся за:цияя часть спины становится бьловато-сђрой, вся нижняя сторона и бока тьла, кроль центральной спиной области, совершенно б́ Въ области груди и боковъ только самыя основанія волосъ бльдныя, ржаво-красноватыя, но широкіе былые концы ихь дылаютъ общій наружный тонъ мьха совершенно бълымъ. Только передняя часть верхнихъ конечностей сохраняетъ свою обычную окраску; заднія конечности обычно совершенно б́ьльютъ. Спцнная часть хвоста у всьхъ видћнныхъ мною зимнихъ экземпляровъ оставалась черной. Необходимо замьтить, что зимняя шерсть измьнчива сильные льтней. Такъ, попадаются на ряду съ очень свьтлыми поб́лльвшими экземплярами и болье темно окрашенные.

Среди типичныхъ особей встрбчаются довольно многочисленныя аберраціи. Такъ, изрыдіа можно видыть экземпляры съ болье или менье ясно выраженной наклонностью къ меланиз му, переходящей, въ рьдкихь случаяхъ, во вполны выраженный типъ черной окраски.

Но встрьчаются отклоненія и въ другія стороны измьненія организаціи. Въ коллекціи Зоолог. Муз. Моск. Унив. имъется крупный, сильно выб́львшій русагъ, добытый 8/хі 907 г. въ нъсколькихъ верстахъ отъ ст. Царицыно Московск. у. И. Г руше в ским ъ (으 2654). Этоть интересный заяцъ, описанный 
Б. М. Житков и ъ ${ }^{1}$ ), характеризуется ненормально развитымъ хвостомь, который піри изьреніи его уже на готовомъ чучель достигаетъ г20 $\mathrm{m} / \mathrm{m}$. (безъ гонщевыхъ волосъ) и $160 \mathrm{~m} / \mathrm{m}$. (съ золосами). Нзъ прогихь размьровъ ухо равно прибл. г4о $\mathrm{m} / \mathrm{m}$., ступня задней ноги- $166 \mathrm{~m} / \mathrm{m}$.

Ниже я даю промьры имьющихся у меня экземпляровъ. Долженъ, однако, замћтить, что изъ размьровъ тьла я указываю линь длину задней стопы и уха. Такъ какь измьренія дылались хною уже на ширкахъ, то несомнынно точнымъ является лишь первый промьръ; измьреніе уха на шкург'ь должно по результату отличаться оть сдьланнаго на свьжемъ экземплярt, являясь ньсколько меньшимъ настоящей величины. Я ввель этотъ не совсьмъ точный промьръ для сравненія съ таковыми въ работь Hilzheimer, также измбрявшаго своихъ заїцевъ иа

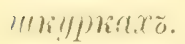

Что касается до въса средне-русскаго русака, то Г. П. Поляко в ъ сообщиль мнь сльдующія, очень интересныя свћдынія. По его словамъ, наиболье тяжелыми экземплярами изъ приблизительно 40 добытыхъ заицевъ оказались:

г) Самка Іо/x I9о2 г. (Богородск. У. Полтево, имьніе кн. Голи. цына), вћсившая I3 ф. 24 зол.

2) 우 I3/xil . 900 г. (им. Саввино Богородск. у.)-I3 ф) 24 зол.

3) 25/Ix I905 г. (Полтево Богородск. у.) - - 3 ф.

Какъ видно изъ этихъ измьреній, наиболье тяжелыми зайцами были самки. Обычный, нормальный вьсъ русака: го- I фунтовь.

Въ заключеніе считаю необходимымъ ньсколько разобрать вопросъ, къ ћакому подвиду относится заяцъ русакъ, встрђчающійся въ средней Россіи. Большинствомъ авторовъ этотъ заяцъ назывался Lepus europaeus Pall., 'г.-е. отождествлялся съ описаннымъ Палласомъ изъ южной Польши ${ }^{2}$ ). Между тьмъ, работы такого тщательнаго изсльдователя, какъ Blasius (28,

1) „Охотничій Вьстникъ“ 1908 г.

2) Необходимо отмбтить, что въ своей „Novae species glirium“ Pallas (р. 5) даетъ довольно сбпвивое описаніе зайца, подъ вопросомъ считаемаго авторомь за польсь между L. variabilis in L. europaeus, коего русскіе зовутъ .Russak“. Въ той же работь, по короткому діагнозу видно, тто $L$. eиropaеи фпгурируетъ пменно какъ русакъ (р. 30). Въ „Zоographia“ (1 4 8) русакъ приводится подъ названіемъ: Lepus timidus со ссылкої на Л н н е я, а помьсь ұазывается-Lepus variabilis var. hybrida (Russak). (р. 147). Такнмъ образомъ ясно, что Палласъ, хотя п отмбчаль пом фатальн путалъ ее съ русакомъ, нпчего об́шаго съ неї не пмъющимъ. 


\begin{tabular}{|c|c|c|c|}
\hline 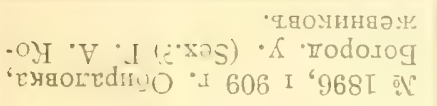 & 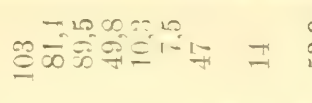 & 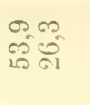 & 祡 \\
\hline 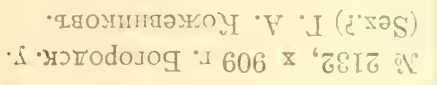 & 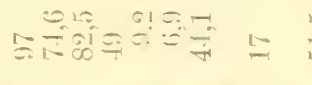 & $\frac{\sin 20}{62}$ & 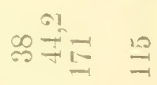 \\
\hline 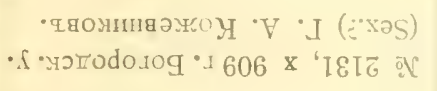 & 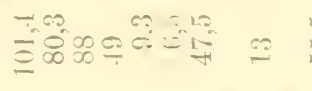 & $\frac{2}{5}$ & $\begin{array}{l}\infty=1 \\
\infty=\infty=0\end{array}$ \\
\hline 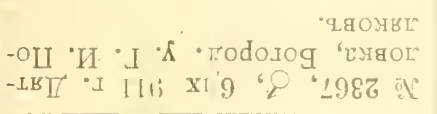 & 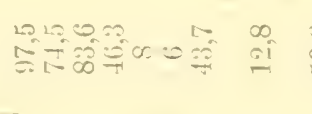 & $\begin{array}{l}01 \\
0300 \\
2060\end{array}$ & 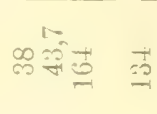 \\
\hline 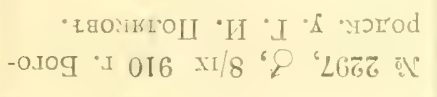 & 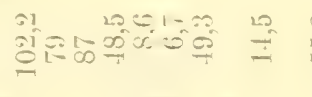 & 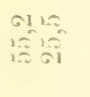 & 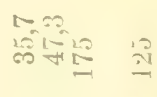 \\
\hline 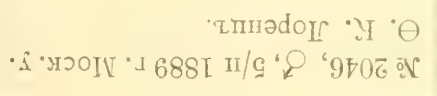 & 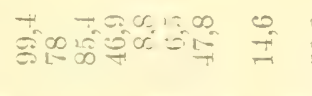 & 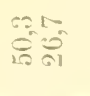 & 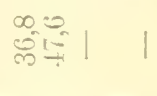 \\
\hline 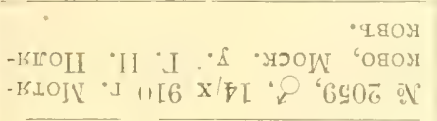 & 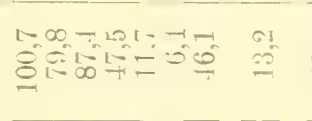 & $\begin{array}{l}0.5 \\
030 \\
010\end{array}$ & $\underset{\circ}{0}$ \\
\hline 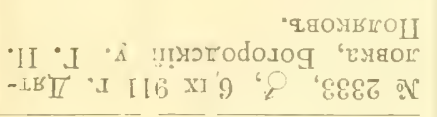 & 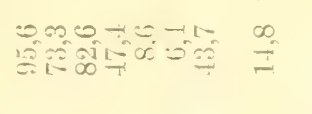 & 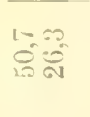 & $\begin{array}{l}0 \\
0=\end{array}$ \\
\hline 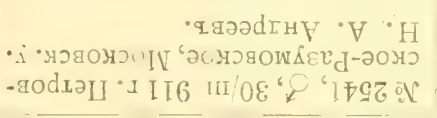 & 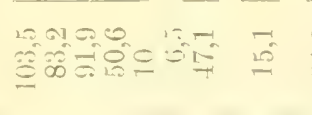 & $\frac{01}{10}$ & $\begin{array}{l}\infty, a ! \\
5=0 \\
50\end{array}$ \\
\hline 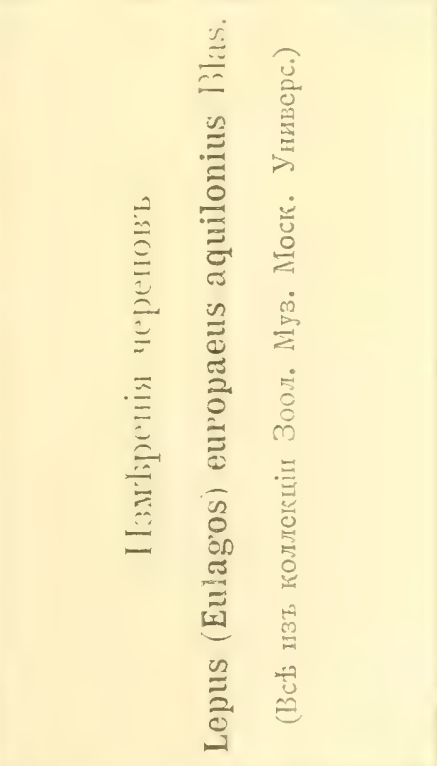 & 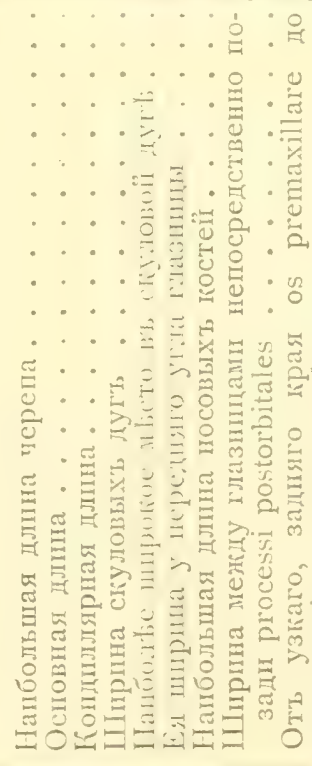 & 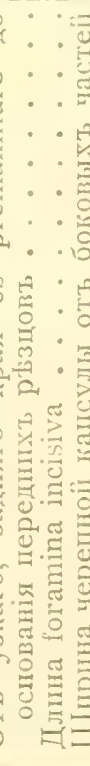 & 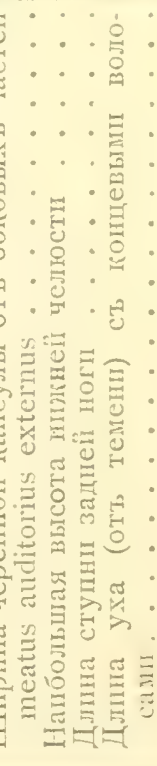 \\
\hline
\end{tabular}




\begin{tabular}{|c|c|}
\hline 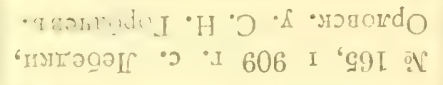 & 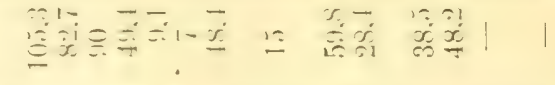 \\
\hline 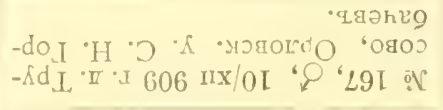 & 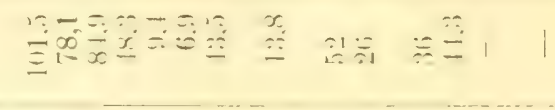 \\
\hline 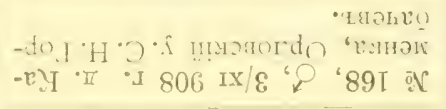 & 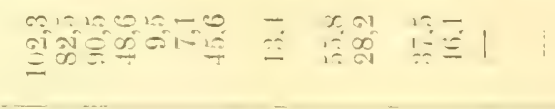 \\
\hline 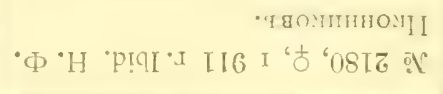 & 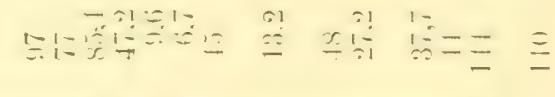 \\
\hline 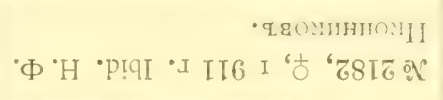 & 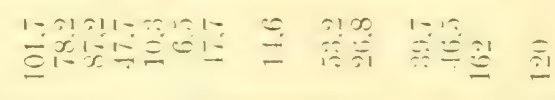 \\
\hline 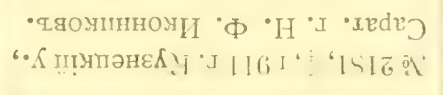 & $0=\overline{1}=1 \div$ \\
\hline 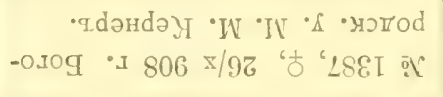 & 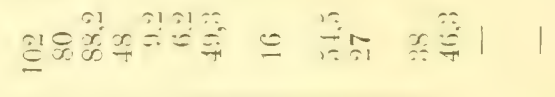 \\
\hline 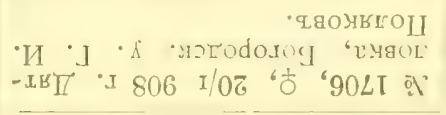 & 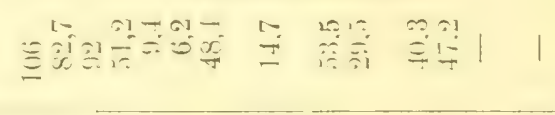 \\
\hline 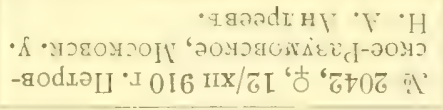 & 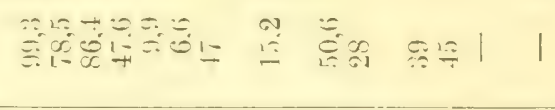 \\
\hline 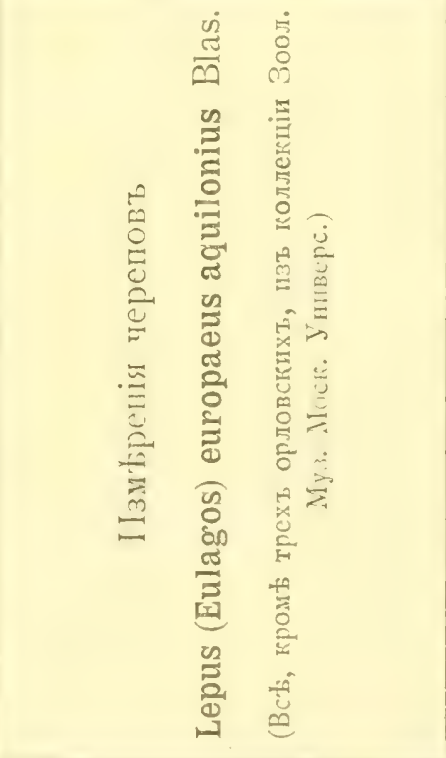 & 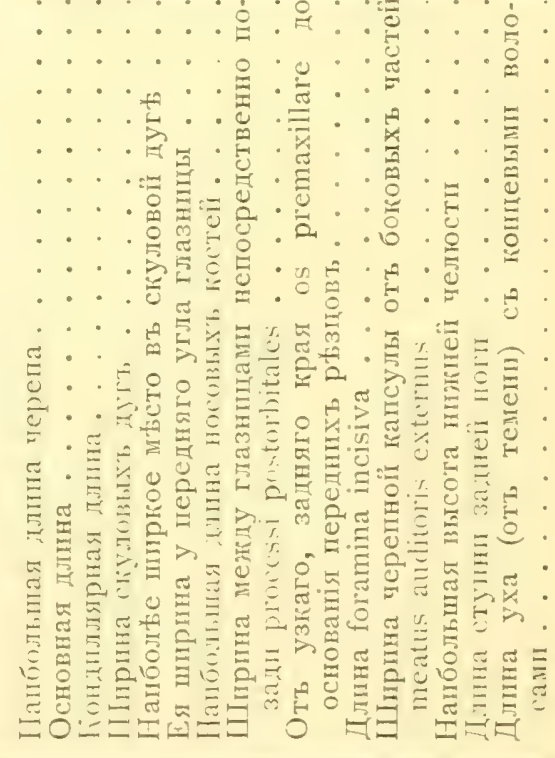 \\
\hline
\end{tabular}




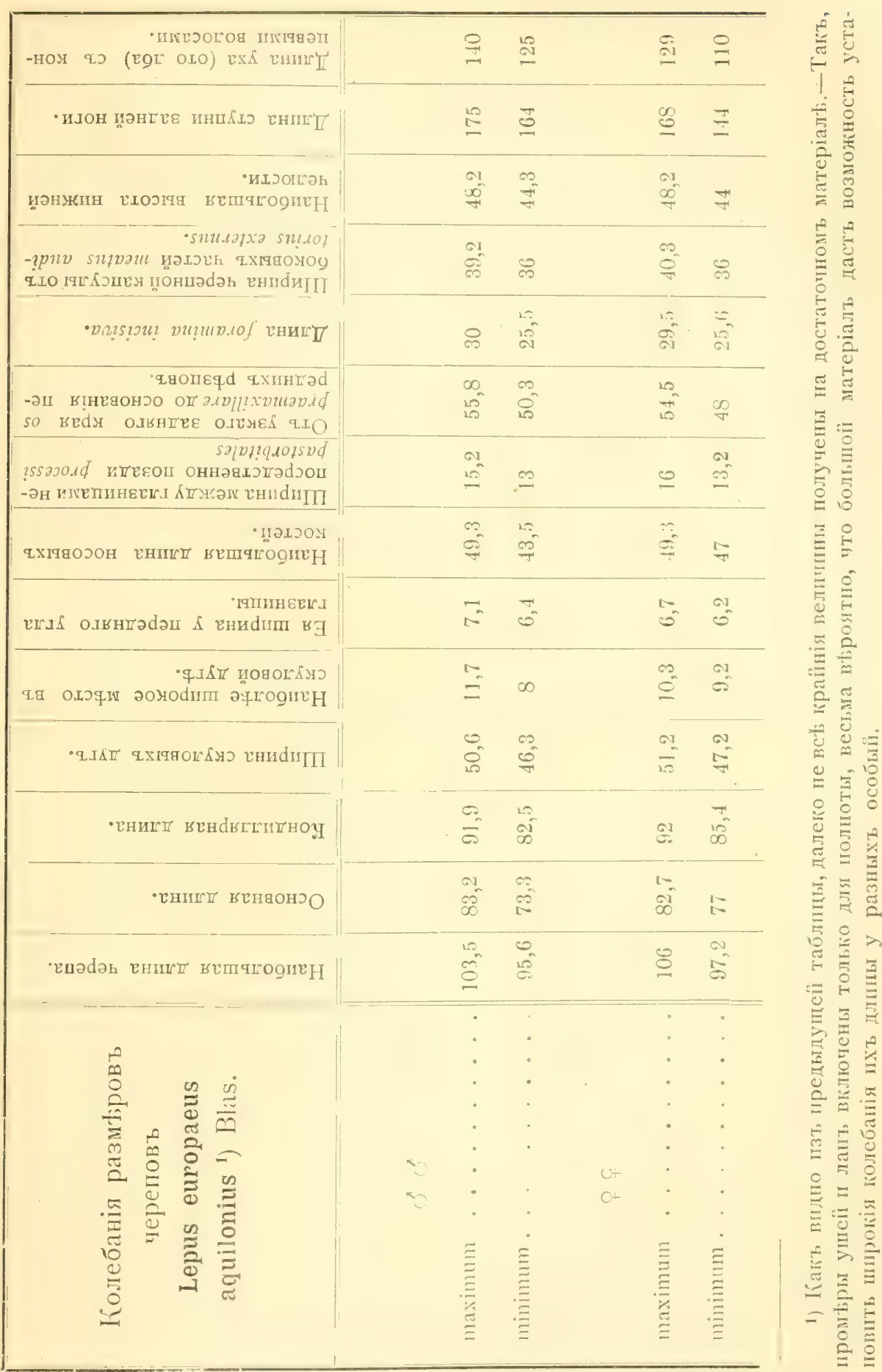


p. 89) показали, что средне-русскій заяцъ отличается оть встрьчающагося въ южной Польшы и Германіи русака. Въ своей по3днtĭmei̊ paботь (Naturgesch. der Wirbelth., I837, p. 4I6) B las i us уже не выдыляеть описаннаго имь раньше Lepus aquilonins и счнтаеть его климатическимь изиненіемь ( Klimatische Abweiclung“) типичнаго русака. Ньсколько ранье посльдней работы Блазіуса къ отрицательному результату относительно самостоятельности средне-русскаго зайца пришель и Мидден-

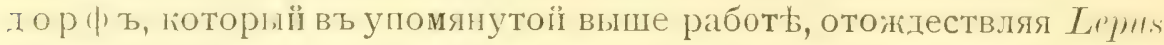
aquilonins Blas. съ Lepus medius Nilss,, считаеть ихъ только варіететами типичнаго Lepus europaeus Pall. (p. 24I).

Только за самое посльднее время $\mathrm{Hilzh}$ imer снова доказываеть самостоятельность какъ Lepus aquilonius Blas., такь и L. medius Nilss, считая перваго nодвидо.ио второго. Такъ какъ у меня ньть пока матеріала изъ Зееландіи (типичнаго мьста нахожденія Lepıs medius Nilss.), то ограничусь толью разборомъ взаимоотношеній Lepus europaeus typ. Pallas и Lepus aquitomins Blas., котораго я считаю nодвидо.ио muличиаго русака, а не L. medius Nilss.

Миддендо рфъ ( с о 9, р. 232) не могъ найти какихъ-либо отличій льтняго мьха типичнаго германскаго русака оть такового у Lepus medins Nilss. (=aquilomins Blas. apud Middendorf), но даль точное параллельное описаніе зимняго мьха этихъ зайцевъ, явно отличающихся въ это время другъ отъ друга. Hilzheimer (7 o, р. 388, 393) однимъ изъ отличій льтней окраски считаеть разницу цвыта спины, которая у средне-русскаго зайца очень св'тлая желтоватая, а у германскаго желтовато-бурая („gelblichbraun"); вторымь отличіемъ, по этому автору, является окраска переднихъ конечностей, которыя у L. europ. aquilonius Blas. спереди кожножелтыя ("ledergell"), а у $L$. europaens typ.--красновато бурыя. Сравнивая шкурки нашихь русаповъ съ чучеломъ L. enropaens tур. изъ Германіи, хранящимся въ коллекц. Зоол. Муз. Моск.

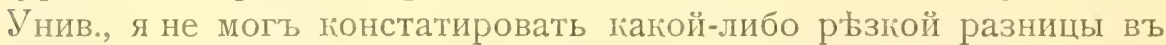
ограскь спины у льтнихъ экземпляровъ. Могу замьтить только, что общії тонъ спины средне-русскихъ зайцевъ быль болье глинистыі, чьмъ у ихъ западнаго сородича. Вообще я долженъ сказать, что окраска спины зайцевъ варьируеть гораздо сильнье, чьмъ думаетъ Hilzheimer, считаюшій ее очень надежнымъ и постояннымъ признагімь.

Значительно болье надежнымъ кажется мнъ различіе въ цвьть переднихъ конечностей. У всьхъ средне-русскихъ зайцевъ переднія части плечевыхъ лістей покрыты довольно свытлыми гли- 
нисто-лрасновато-ржавыми волосами, дьлающимися замьтно желтье на переднец части ступни, у германскаго русака плечевыя области замьтно темные, красновато-бурыя, съ замытнымъ глинистымъ оттьнкомъ, а наружныя части переднихъ конечностеі тусклье, съ большої примьсью буроватаго тона и довольно часто расположенными совещиелио иерныли волосами. У всьхъ просмотрынныхъ мног L. curop. arpilomins Blas. я не нашель примыси этихъ черныхъ волосъ на наружной части переднихъ конечностей, что дьлаетъ ихъ однотонными и гораздо болье свђтлыми. То же надо заиьтить и относительно заднихъ конечностей, которыя положительно желтыя и свђтлыя у русскихъ особей. Что касается до длины уха, то у Hilzheimer мы находимь довольно туманное угізаніе, по которому у $L$. enropuens typ. ухо болие $120 \mathrm{~m} / \mathrm{m}$., а у L.e. aquilomins Blas. болие $115 \mathrm{~mm} /$. Эти промьры повторяеть и Труссаръ (2оо, р. 2І7, 2І9). Какъ видно изъ моихъ измьренії, сдђланныхъ на шкуріахъ, ухо достигаеть у L. europ. aquilonius Blas. 140 m/m. т.-е. того максимума длины, гакой указываеть $\mathrm{S}$ c h äff ( I 7 I, p. I I8) для германскихъ русаковъ. Врядъ ли посль этого можно сколыо-нибудь надежно предполагать, что у L. enropaeus typ. ухо длиннье, чьмъ у L.e. aquilomins Blas. Далье, Hilzheimer говорить, что ступня (задняя) у L. europaeus typ. болmе $1.50 \mathrm{~m} / \mathrm{m}$., а у L. e. aquilomins Blas. превышаеть $165 \mathrm{~m} / \mathrm{m}$. Какъ видно изъ приводимыхъ таблицъ, ступня нашихъ русаковъ достигаеть $175 \mathrm{~m} / \mathrm{m}$. У экземпляра изъ Германіи, который я могь изсльдовать, она равнялась 147 m/m. Нагонець, посльднимъ признаґомъ отличія западнаго и нашего русака является количество позвонковъ хвоста. По Блаз іусу ${ }^{1}$ ), въ хвость L. enrop. aquilonius Blas. содержится I4 позвонковъ, а по Миддендо р фу, г2-г4. У изсльдованнаго мною русака ихъ было І4. Что касается до западнаго русака, то поличество позвонковъ, по разнымъ авторамъ, ²) колеблется оть г4 до г6. Было бы трайне желательнымъ провьрить этоть безъ сомнынія очень важный признакъ.

При обзорь всьхъ указанныхъ отличій становится достаточно яснымъ, что нашъ русаґъ является, повидимому, довольно слабо диференцированнымъ подвидогъ Lepus europaens typ. Pall. Что касается до $L$. metius Nilss, то короткое, мало говоряшее описа-

1) Blasius (29), p. 57. Однақо, въ своеї „Naturgesch. der Wirbelth. Deutschl.“, 1857, p. 416 онъ счптаетъ этотъ признакъ пзмђнчнвымъ.

2) Middendorf 109, p. 238; B u f f o n, Hist. Naturelle, V'I, 1756, p. 291; E y to n, The Transactions of The Royal Jrish Academy, vol XVIII, 2, p. 269 II "Isis" 1848 , I, p. 55. 
нie Nilsson дало возможность Гильцгей м е ру, безъ изсльдованія эгземпляровъ, считать этого зайца опди.ииыл видоиғ. Nнь думается, что такое выдьленіе слишкомъ смьло и поспьшно. Если правъ B arret.Hamilton (г 6, p. 264), эта форма тождественна съ Lepus europaeus Pall. или, въ лучшемь случаь, можеть считаться подвидомъ посльднясо. Повторяю, безъ достаточнаго матеріала, какь дылаеть Hilzheimer, здысь положительныхь рьшеній быть не можетъ и мы находимся лишь въ области болье или менье вьроятныхъ догадокъ.

Въ заключеніе я остановлюсь еше на вопрось, что. представляетъ собою такъ называемый „тумакъ“. Относительно этого зайца, какъ въ научної, такъ и въ охотничьей литературь сушествуеть много разнорьчивыхъ показаній. У меня для изсльдованія было 3 экземпляра: два изъ Московской губ. и одинъ изъ Саратовской. Тщательное изученіе показало, что „тумакъ“несомнынная помьсь между русакомь и бълякомъ, обычно съ преобчладаюшими особенностями пос.тьдяго. Шнтересно отмьтить, что, помимо преобладающихъ признаковъ б лляка, появляются индивитуальныя, свойственныя, только этої помьси отличія, именно ржавый цвђтъ основаній волосъ спины. Въ новьйшее время изсльдованіе Менделевскихъ законовъ насльдственности даетъ много примбровъ возникновенія у помьси новыхъ, не свойственныхъ родителям отличій. Что касается до строенія черепа „тумака", то во многихъ отношеніяхъ оно является промежуточнымъ между двумя скрещивающимися видами. На этотъ фактъ указываетъ въ своей работь Lönnberg (99, p. 282, 283). Черепъ o. 2399 юоллекціи 3. М. Моск. Ун. изъ Саратовской губ. отличается большимъ сходствомъ съ бьлякомъ, но въ строеніи отдьльныхъ деталей: по длинь межчелюстной кости, круто загибающеиуся назадъ первому ложнокоренному зубу нижнеї челюстинапоминаеть русака. (См. табл. V, рис. 56, 59). Черепъ ‘№ 2304 изъ Московскіо̆ губ. по всьмъ признакамь ближе къ русаку, между тьнъ, по вньшнимъ отличіямь шкурки, это - былякъ, съ слабо выраженной особенностью поиьи.

Вотъ промьры череповъ, имьющихся у меня экземпляровъ: Какь было сказано уже выше къ .тумаку“ относится только одно латинское названіе П алласа: Lepus variabilis var. hybrida Pall. $\left.{ }^{1}\right)$

1) Крохт этого, тольқо М. Н. Богданов ( неправильно сипталь т у а ка „степной разностьо“, давая ему особое на-

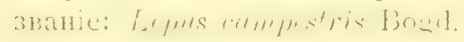




\section{Үзмьренія зайцевъ \\ ,тумаковъ“. Lepus europ. aqui- lonius Blas. X Lepus timidus L. \\ (Всь пзъ коллекцій Зоол. Муз. Моск. Унив.)}

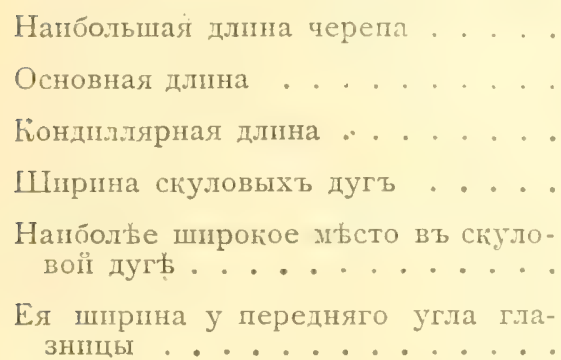

Напоольшая длина ossa nasalia

Ширина между глазницамп непо. средственно позади $\mathrm{processus}$ postorbitalis .......

Отъ узкаго задняго края os praemaxillare до основанія переднихъ рьзцовт . . . . .

Длина foramina incisiva . . . . .

Ширина черепной кости (отъ боковыхъ частеї meatus auditorius| externus) ..........

Наио́льшая высота нпжнеі̆ челюстін . . . . . . . . . .

Длина ступнп заднеї ногп . . . . .

Длина уха отъ лоба (съ ғонцевыми волосамі) ..........

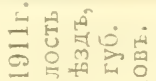 \\ 舟 \\ S :

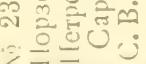

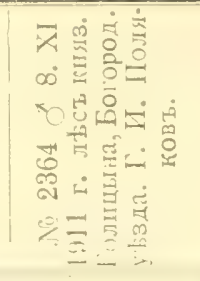

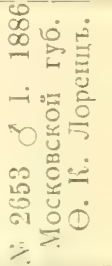

\begin{tabular}{|c|c|c|}
\hline 102,2 & 93 & \\
\hline 78,5 & 69,8 & \\
\hline 88,3 & 78,7 & \\
\hline 51,1 & 46,7 & \\
\hline 11,3 & 92 & ${ }^{\circ}$ \\
\hline 8 & 7,6 & \\
\hline 43,8 & 39,7 & \\
\hline 15,5 & 18,2 & \\
\hline 52,9 & 47,2 & \\
\hline 24,9 & 21 & \\
\hline 38,7 & 36,5 & \\
\hline 51,6 & 45,1 & \\
\hline 171 & 169 & 185. \\
\hline 20 & 110 & ок. 110. \\
\hline
\end{tabular}

Географическое распространеніе.

Заяцъ русакъ широко распространенъ въ предьлахъ Московской губ., всюду придерживаясь такихъ мћстъ, гды льсные острова смьняются пахотными полями.

Я затрудняюсь провести сіолько-нибудь точно границы распространенія настоящаго Lepus europaens aquilonius Blas. всльдствіе крайней запутанности систематики зайцевъ и потнаго отсутствія точныхъ литературныхъ указаній.

Распространеніе зайца русака начинается отъ западнаго угла Курляндіи и тянется по Прибалтіиским провпнціямъ, гдђ этоть видъ встрьчается по свидьтельству Греве́ (67, р. 127-г29). Однако, л не могу пока сказать опредьленно, тождественъ ли 
этоть заяцт съ водяшимся въ центральной Россіи. Просльживая изь Прибалтійскихъ губерній сьверную границу распространенія русага, мы переходимъ въ Петербургскую губ. Зағысь, по свидытельству Біан и, русакъ, хотя рьдко, но встрьчается въ Петербургскомь у., а Порчин скій (г 37, стр. 389) считаеть сђверной границеї распространенія русака р. Сестру (на гра" ниць Петербургской губ. и Финляндіи). Однако, отдыльныя находки этого млекопитающаго извьстны изъ Выборгской губ. Шзвьстно также, что этоть заяцъ попадается въ губерніяхъ Тавастгусской и Сенъ-Михельскої, но очень рьдко. Вьроятно,

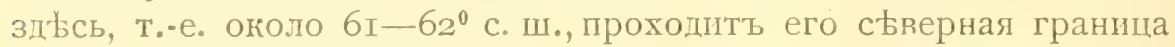
распространенія. Далье на востокъ, по Кесслеру, русакъ почти не заходитъ въ Олонецкую? губернію. Отсюда сьверная граница распространенія русака, в'ьроятно, круто понижается, минуя сплошные таежные льса Вологодской и съверной части Костромской губ., она доходить до южныхь уу. Вятской (г. Малмыжъ), гды русакъ встрьчается, хотя рыдко, по свидытельству Круликовскаго (93, стр. ІІ5). Весьма возможно, что русакь передвигается на съверь вмьсть съ вырубкої льса. По крайней мьрь, подобный факть уже давно быль констатированъ М. Н. Богдановы м (3о, стр. І75) въ сьверныхъ частяхъ Казанской губерніи, гдь въ давніе годы этихъ зайцевь совершенно не было. Восточнье Казани сьверная граница вновь поднимается, и, по свидьтельству Л. П. Саб аньева, рьдкія особи встрьчаются въ Оханскомъ и Осинскомъ уу. Пермской губ., а много льть тому насадъ г. Клинбергъ добыль русака подъ Чердынью $\left(60^{\circ}\right.$ с. ш.) (см. „Жірналь Мин. Государ. Имущ. " т862). Къ сожальнію, въ настоящее время трулно сказать, гдђ идетъ восточная граница распространенія Lepus e. aquilonius Blas. По словамъ Л. П. С а б а н 'ь в в, этотъ заяцъ замьченъ только разъ въ Тибутской дач'ь и около Екатеринбурга; весьна возможно, что онъ встрьчается въ березовыхъ льсахъ Шадринскаго у. H. А. 3 а р у д ны й нашелъ его ( $L$. $c$. (qquilonius Blas.) довольно обыкновеннымъ въ южної части Оренбургской губ., между Орскомъ и Оренбургомъ, на Общемъ Сырть и въ мьстности между Салмышемъ и Чаганомъ. Вьроятно, отсюда по склонамъ Общаго Сырта граница распространенія тянется далье на западъ, минуя южную часть Самарской губ. и пустынную полосу Саратовской губ. (Камышинскій и Царицынскій уьзды), переходить въ степи между Волгою и Дономъ, замьтно опускаясь здысь на югъ. Обширную плошадь Уральскої Области, Астраханскую губернію, южныя части Сапарской и Саратовскої губ., Калмыцкія степи и Ставрополь- 
скую губ. занимаеть, повидимому, другої подвідъ $L$. e. caspius Ehrenb. Къ сожальнію, наши свьдьнія объ этої форны болье чьмъ отрывочны. Кромь прямого указанія Г. С. Карелина (7 8, стр. 263), что въ нпзовьяхь У рала водится L. caspius, форма, отличимая не только по внбшним признакамъ, но и по черепу,

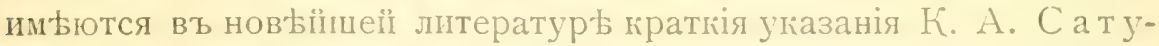
нина ( 56 , стр. I42) на распространеніе этого вида въ степяхъ сьвернаго Предкавказья, но всльдствіе недостатка матеріала этоть авторъ не даеть описанія каспійскаго русака. Я имьль въ рукахъ только одинъ черепь взрослаго русака, добытаго В. Э. Мартино въ Камышинскомъ у. Онъ отличался отъ всьхъ изъ средней Россіи своими замьтно меньиими размырами. Но это отличіе врядь ли обосновано, т. к. черепа русаковъ изъ Сарепты, размьры которыхъ приводить въ своей работь Hilzheimer (7 o, p. 4I6), не отличаются отъ таковыхъ Lepus e. aquilomius Blas. $\left.{ }^{1}\right)$ Итакъ, переходя вновь къ распространенію посльдняго, мы видимъ, что оно захватываеть Волжско-Донскую область, всь среднія и южныя губерніи Европеїской Россіи, вплоть до Кіевской (B elke, Кесслеръ) и Ковенсісї-на запады. Быть можетъ, къ этої формь относятся русаки, встрtчающіеся въ сьверныхъ частяхъ Таврической губ., но какої видъ зайца водится въ Крыму-это вопросъ еще открытый. По тому матеріалу, который имьется у меня изъ Симферопольскаго музея, и посль осмотра чучела, хранящагося въ Зоол. Муз. Моск. Ј нив., доставленнаго Н. М. Ку лагины м изъ Севастополя, я могу вполнь опрегьленно сказать, что это не Lepus mediteraneus Wagner, къ которому относить крымскихь зайцевъ А. М. Н пк о льс к і Il.

\section{Образъ жизни.}

Русакъ встрђчается особенно охотно тамъ, гды острова мелкольсья и кустарниковъ смьняются полями. Сплошныхъ льсовъ онъ положительно избьгаетъ. Течка этого вида начинается въ марть́ и длится бо́льшую часть льта. По свидьтельству К. А. Сатунина, каждая самка мечеть въ льто оть $3-4$ разъ по 3-5 зайчатъ. Молодые зайцы ранняго вывода къ осени почти достигаютъ размьровъ взрослыхъ. Въ противоположность мнынію К. А. С атунина, по слованъ котораго (165, стр. I4) у зайцевъ русаковъ бываеть осенью линька, я посль изученія большого матеріала пришель къ положительнолу результату,

1) Зальчу, что вт коллекціп Зоол. Муз. Моск. Јнив. пиюются два чучела

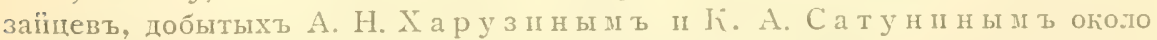
Ханской Ставкп (Астрах. губ.). Это очень зелкіе, быть можетъ, молодые зайпы, точное опредвленіе попхъ безь большого матеріала врядъ .пи возионо. 
что настоящей линьки не бываеть, а происходитъ лишь, какъ у б́ лляка, депигментація волосъ, связанная съ ихъ значительнымъ удлиненіемъ. Молодые зайцы бьльють ньсколько позднье старыхъ, а иногда почти одновременно съ ними. Нормально этотъ процессъ депигментаціи начинается въ первої половинь сентября, при чемъ свњтлые волосы прежде всего появляются въ области нижнеї спины и на бокахъ тьла. Какъ было сказано, зимній мьхъ по степени побыльнія варьируеть очень сильно. Весною начинается настоящая линька, связанная съ интенсивнымъ выпаденіемъ волосъ. Обычно она начинается въ конць марта. Такъ, 3о/иі і9і г. былъ добытъ экземплярь (№ 254I) съ слабыми сльдами начавшеїся линьки. Зимою русаки держатся ближе къ человьческому жилью и забираются въ сады, гдь портятъ фруктовыя деревья, обгрызая кору и молодыя посадки.

Экземлярз коллекиіи перечислены въ таблицахъ измьреній.

\section{Группа Lepus.}

\section{Зайцы бьлякн.}

\section{Lepus timidus L.}

\section{Заяцъ бьлякъ.}

Lepus timidus $\mathrm{L}$ in na e us (9 8), p. 57. Lepus variabilis $\mathrm{Pall}$ as (1 32 ), p. 2. Lepus timidus L. B a r r et-H a milt on (1 1), p. S8. Hil zhe imer $(70)$, p. 386. Trouessart (200) p. 216. К. А. Сатунин ъ (165), стр. 14.

\section{Систематическія особенности.}

При описаніи строенія лерепа русака мною были указаны и критически пересмотрьны признаки отличія его отъ такового у Lepus timidus L. Я не буду поэтому описывать строеніе черепа бьляка,-подчеркну только еще разъ наличность переходовъ, связывающихъ признаки систематической диференцировки этихъ формъ. Однако, по общей совокупности отличій всегда бываетъ легко узнать черепа этихъ зайцевъ. Сколько-нибудь замњтныхъ половыхъ отличій въ строеніи черепа бьляка мнь статировать не удалось. Въ общемъ, черепа самокъ повидимоу, длиннье, чьмъ самцовъ. Возрастныя измьненія очень рьзки и сводятся къ тому, что было описано для русака (см. табл. III рис. 53, табл. IV, рис. 62 и рис. 57 и 6о. Въ строеніи зубовг особенно характерно расположеніе перваго ложнокоренного нижней челюсти, который у этого вида всегда посажень болье круто

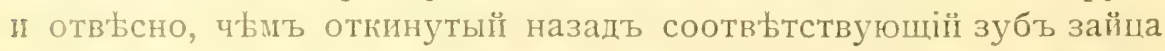
русака. Ниже я даю таб̆лицы измьреній череповъ Lepus timichs L. 


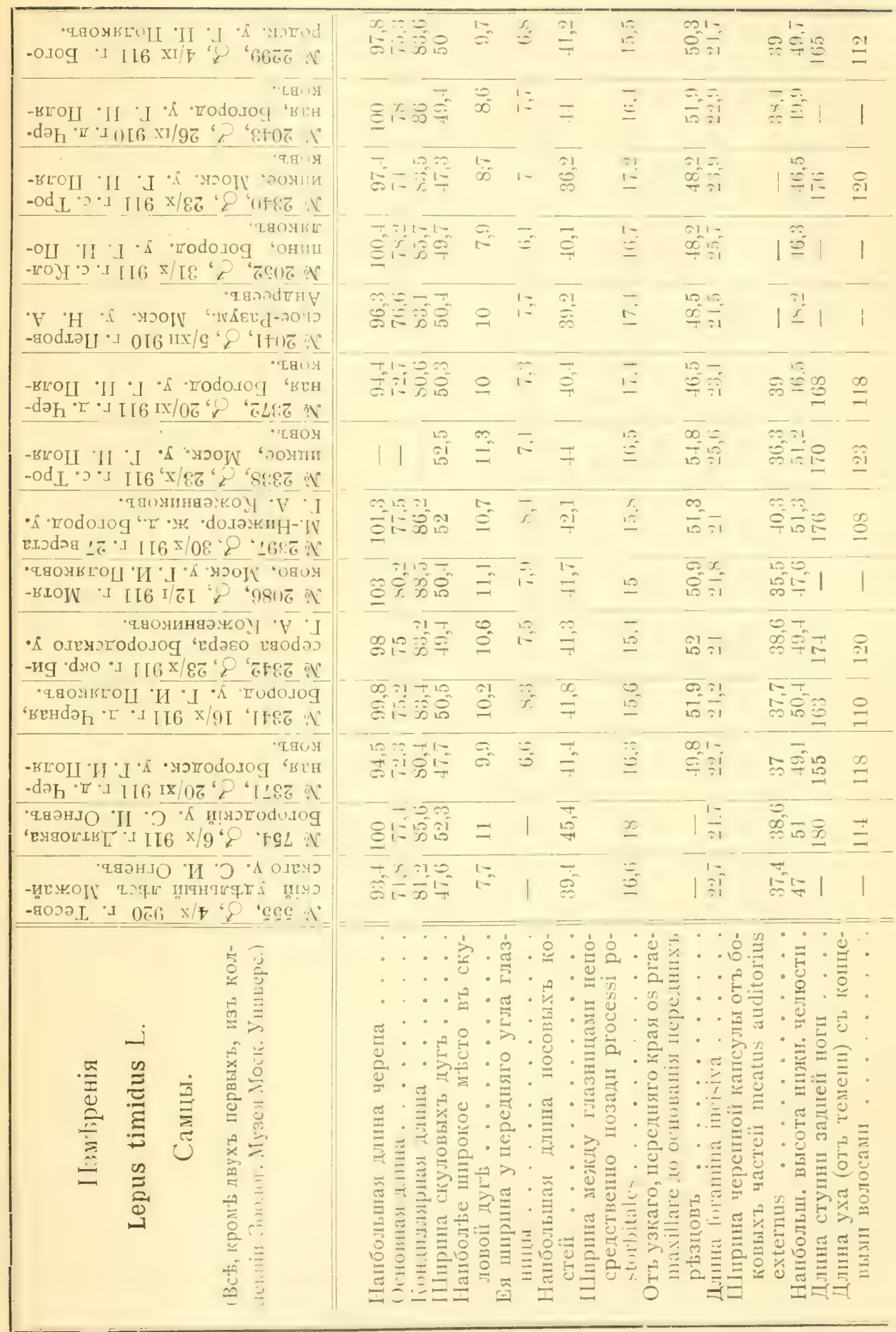




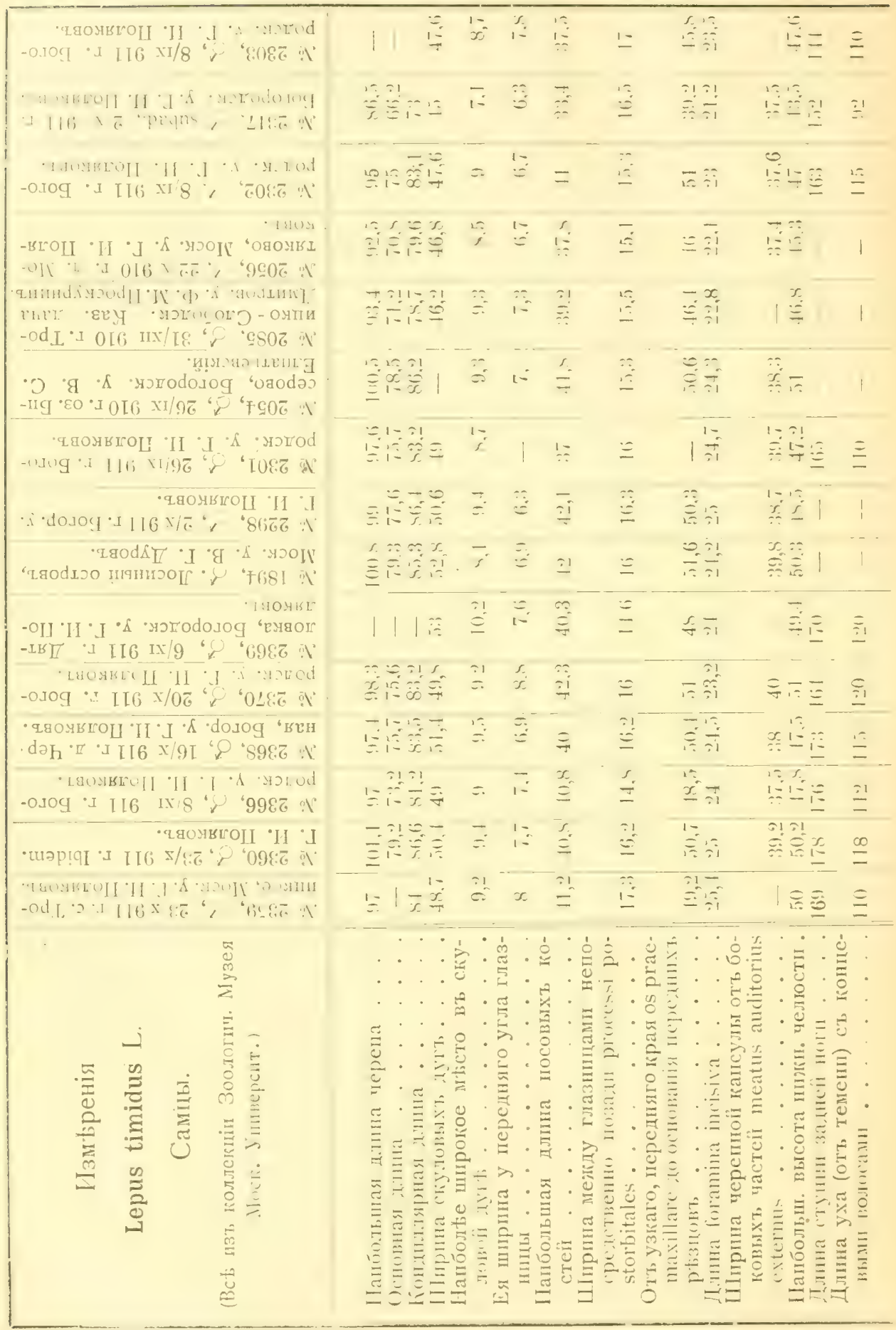




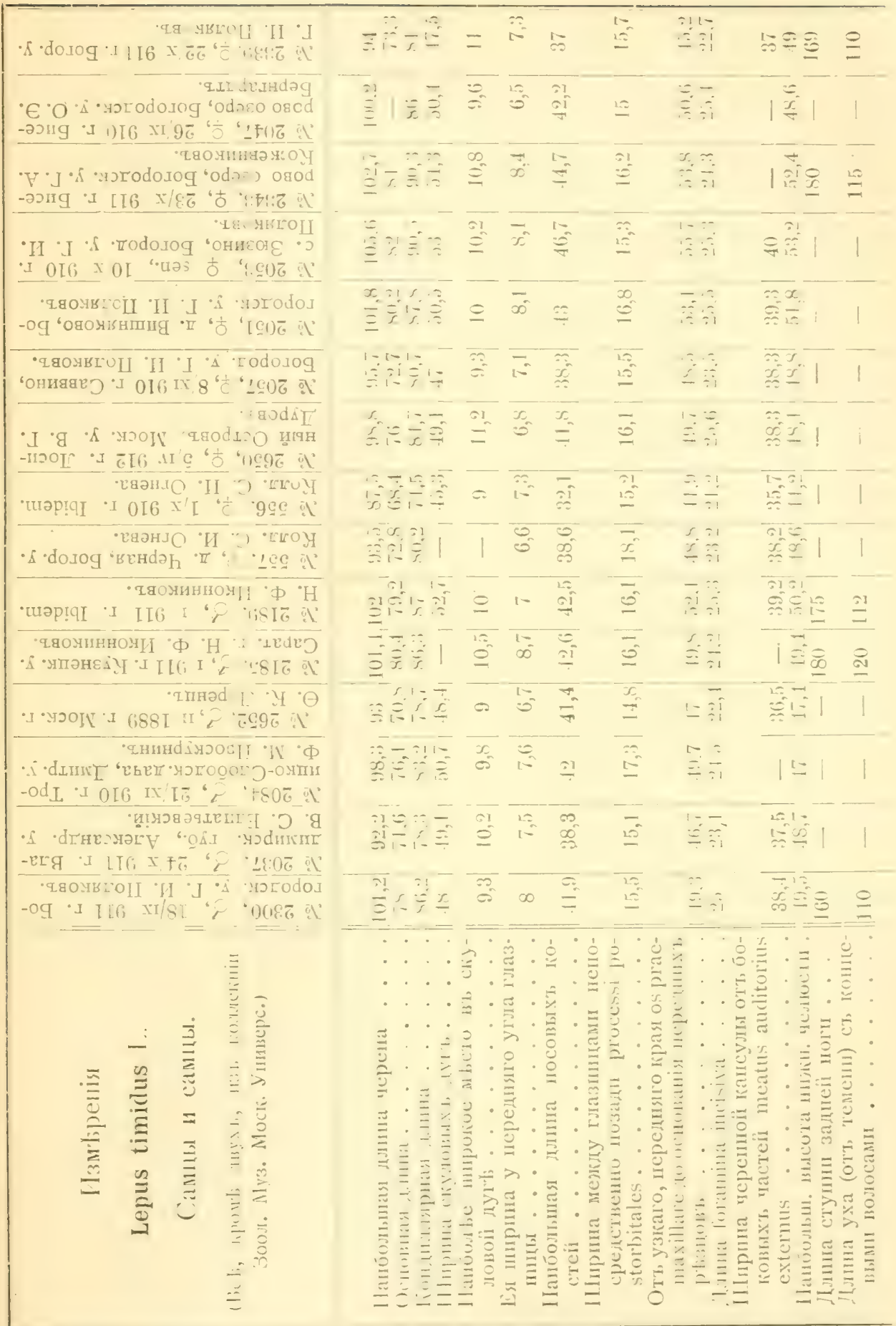




\begin{tabular}{|c|c|}
\hline 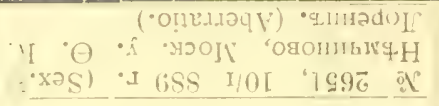 & 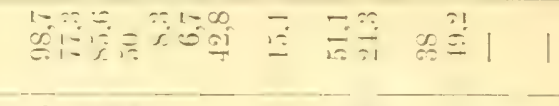 \\
\hline 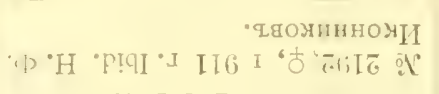 & 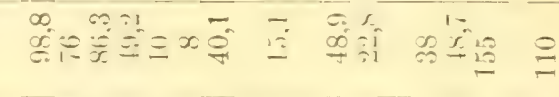 \\
\hline 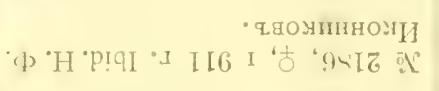 & 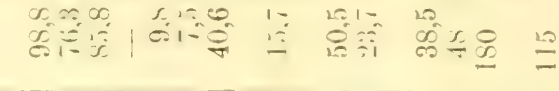 \\
\hline ‘ & 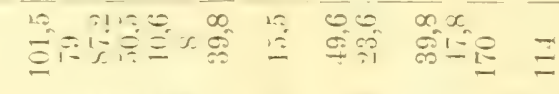 \\
\hline 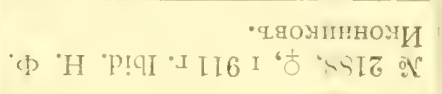 & 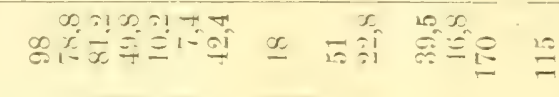 \\
\hline 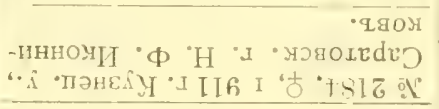 & 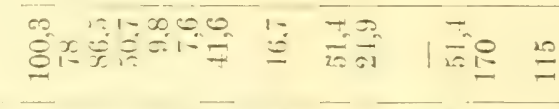 \\
\hline 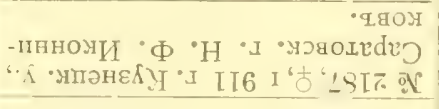 & 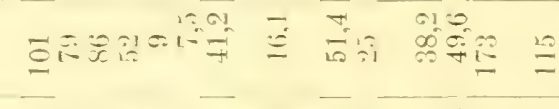 \\
\hline 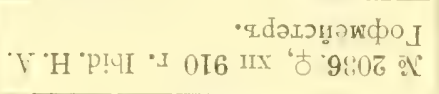 & 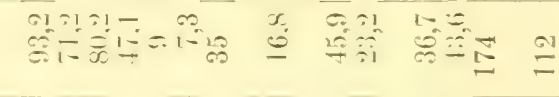 \\
\hline 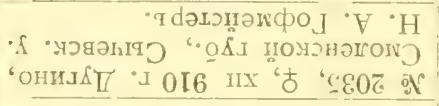 & 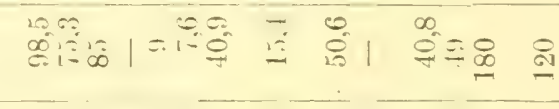 \\
\hline 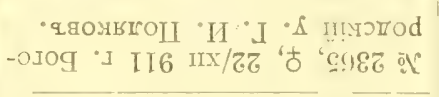 & 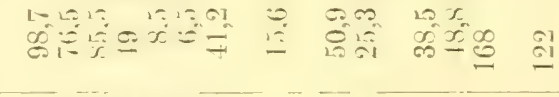 \\
\hline 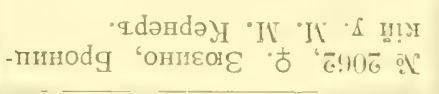 & 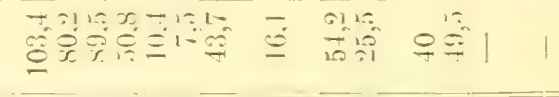 \\
\hline 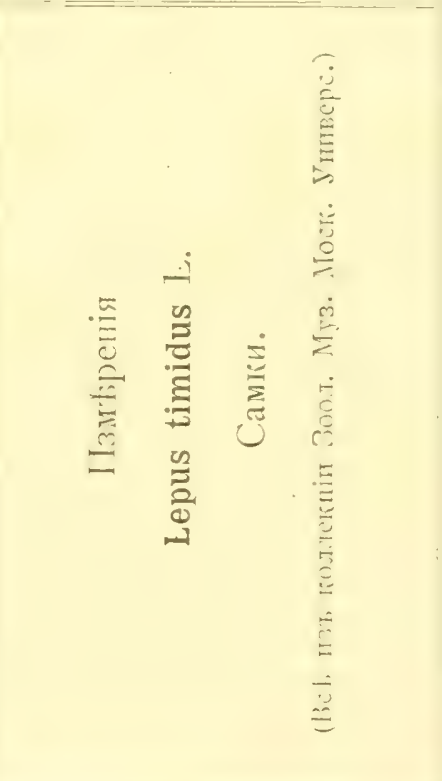 & 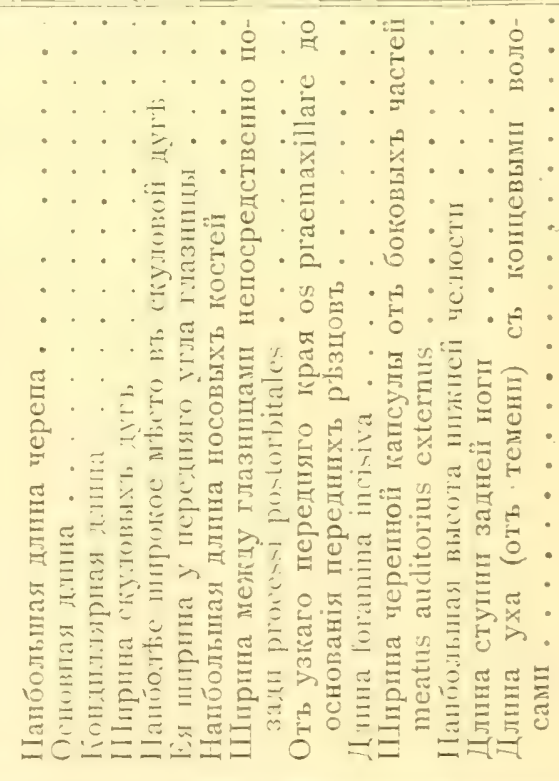 \\
\hline
\end{tabular}




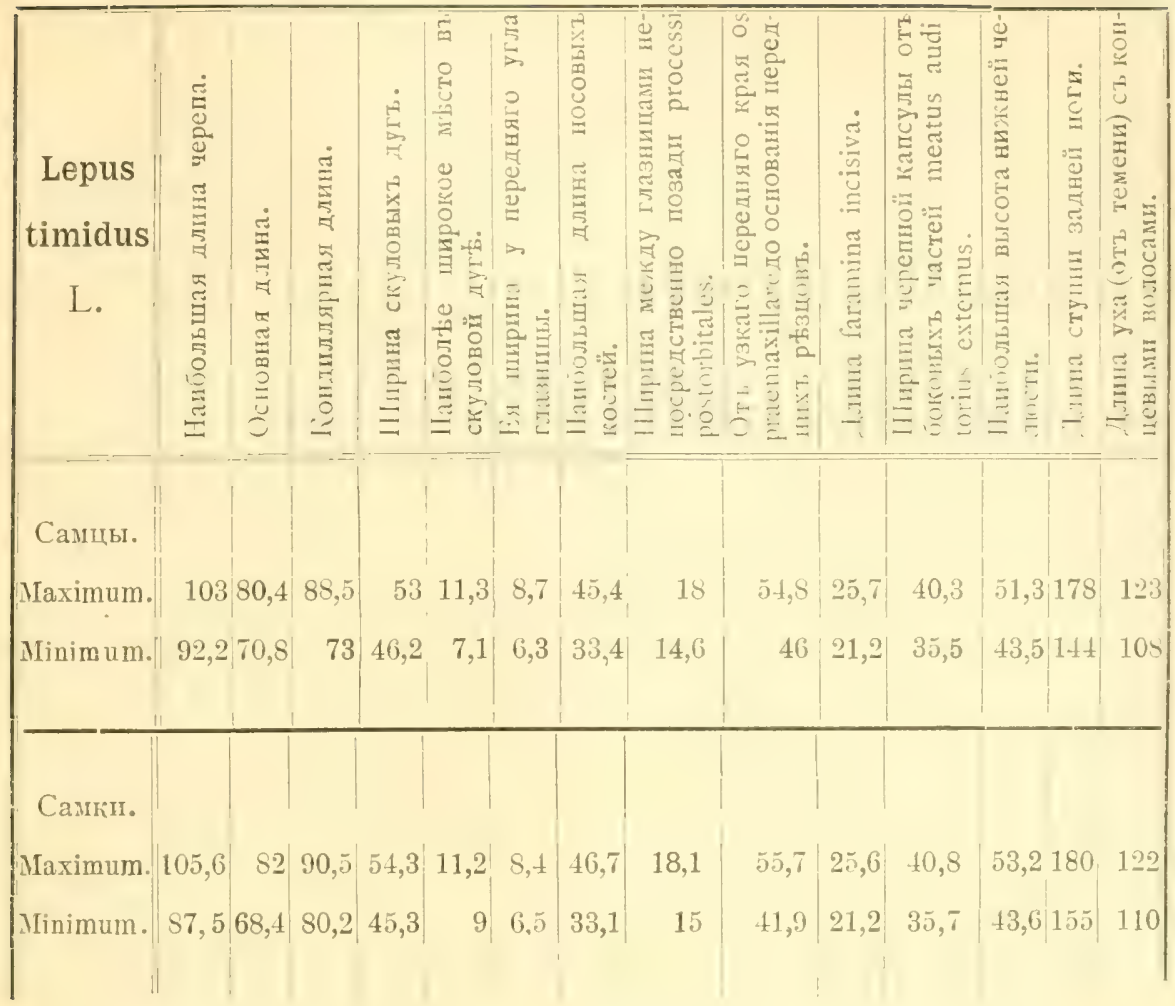

Окраска стараго экземпляра въ льтнемь мбху такова: передняя часть морды, щеки и область около глазъ покрыты ярким ржаво-коричневымъ мьхоль съ замытными сьрымп основаніями волосъ, среди коихъ примғшиваются также совершенно черные. Окраска лба, темени и междоушной области замьтно темнье всльдствіе черныхъ окончаній отдыльныхъ волосъ, боль-

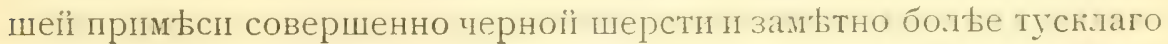
коричневаго оттьнка средней части волосъ. Окраска значительно болье длиннаго мыха спины такова: основанія волосъ сьро-б́ловаты и принимають болье ржавый оттьнокъ передъ широкимъ чернымъ поясомъ; предвершинныя части подобныхъ волосъ имьють ржаво-палевую окраску, а самые концы-черные. Среди такихъ волосъ примьшіваются въ значительномъ числь совершенно черные. Въ общей комбинаціи ограска спинной области сьро - буровато - ржавая, измнчивая по интенсивности тона у разныхь особей. Нижняя часть спины, бока тыла и широкій поясъ, идущій поперекъ шеи и верхнеї части груди-много сырłe, чьмъ описанныя области. Нижняя част груди, брюхо и паховая область покрыты грязно-бьлыми волосами. Переднія и заднія ко- 
нечності спереди покрыты ржаво-буроватыми волосами, съ значптельної примьсью совершенно черныхъ; ступни заднихъ ногъ отличаются длиннымъ, пушистымъ сьрымъ мьхомъ. Хвостъ одноuвłтно-сьрыи; уши по ихъ переднему. краю покрыты густыми, черными у основаній волосами, съ ржавыми околовершинными частями и черными концами; обращенныя внутрь части ушей заwtтно свьтлье, а по вньшнему краю тянется замьтная бьлая полоска, тогда какъ концы ушей совершенно черные. Вибриссы состоять изъ смьси черныхъ и былыхъ волосъ. Окраска молодыхъ, еще не достигшихъ половины роста старыхъ-болће свьтлая и тусклая. Насколько измьнчивъ по интенсивности тона льтніiі мtхъ, настольто однообразна окраска зимняго. Цвђть зимняго иьха у подавляющаго большинства особей чисто бьлый, только на концахъ ушеї сохраняются по пятну черныхъ волосъ. Нарлду съ такими особями, правда, изрьдка, попадаются зайцы, не бьльющіе цьликомъ, общій тонъ мьха которыхъ отличается своей сьрой, дымчатої ограскій. Среди московскихъ эиземпляровъ я видьль только одинъ, отличавшійся подобными особенностями (265I Колл. Зоол. Муз. Моск. Ун.) Кромь того, два болье свьтлыхь были добыты Н. А. Г офмейстеро мъ въ Сычевскомъ у. Смоленской губ. (№o 2035, 2036). По своему общему виду эти зайцы довольно легқо отличаются оть помьси (тумака) и приближаются ґъ еще проблематичному Lepus canescens Nilss., распространеннону, по свидьтельству MидденIо рфа, въ южной Швеціи и Прибалтійскихъ провинціяхъ. Что касается до въса среднеруссіпхъ Lepus timidus L., то Г. И. П ол я к в ъ сообцилъ мнь сльдуюшія интересныя данныя.--По его словамъ, изъ 8о быляковъ самыми тяжелыми оказались: Lepus timidus L. изъ Погровск. У. Владимирской губ. 9 X I903, вьсившій x I фунт. (sex?) и другой, такого же вьса, добытый 3 IX 1906 г. въ Нићоло-Аверкіевской казенной дачь Богородск. у.

Въ настоящее время точное систематическое положеніе бьляка, водящагося въ Московской губ. и прилежащихъ мьстахъне можеть считаться вполнь выясненнымъ. По Hilzheimer, типичный Lepus timidus L. характеризуется длиной уха, превышающей Іо5 m/m и ступней задней ноги- 55 m/m. Какъ легіо видьть изъ приведенныхъ таблицъ измьреній, средне-русскіе б́ плии могуть быть харагтеризованы ухомъ, длина котораго колеб́лется оть $100-\mathrm{I} 25 \mathrm{~m} / \mathrm{m}$ и ступней, часто превышающей I75r80 m/m. Посльлнее отличіе Hilzheimer считаеть свойственнымъ сьверному $L$. timidus collinus Nilss. - формь, сохраняющей свою б́лую окраску въ теченіе всего года. 


\section{Географическое распространеніе.}

Въ предьлахъ Московской губ. бблякъ является широко распространеннымъ видомъ, болье частымъ, чьыъ русагъ. Посльднее обстоятельство стоитъ въ прямой связи съ большимъ поличествомъ льса и кустарныхъ порослей въ изученной губерніи. Что касается до распространенія бьляка в’ь Европейской Россіи, то оно можетъ быть представлено въ сльдующихъ оо́щихъ чертахъ ${ }^{1}$ ). По М идден до рфу (г о 9, стр. 252), сьвверная граница распространенія этого вида простирается за полярный гругъ; именно, онъ наблюдаль Lepus timidus L. близъ Имандры (68 с. ш.). По свидътельству Ө. Д. Плеске (т 33 стр. 85-87), L. $t$. borealis (= collimus Nilss.) встрьчается и значительно сьвернъе озера Имандры, будучи добытъ бл. Энаре, Варангеръ-Фіорда, на полуостровь Рыбачьемъ и далье на востокъ по сьверному побережью Кольскаго полуострова. Восточнье этоть видъ встрьчается, по Шренку, на Пинегь, а Бр андт ъ говоритъ объ экземпля страненіе бъляка достигаеть съвернаго Урала, гдњ его нашла экспедиція Гофманна. По Миддендорфу (г о, стр. 252), южная граница распространенія L. timidus L. начинается на побережьи Балтіїскаго моря близъ Мемеля, откіуда сильно спускается на югъ, доходя до Бьловьжской пущи (около $53^{\circ} \mathrm{c}$. ш.) Далье, по Чернаю, южная граница тянется по сьверной часті Волынской губ. и простирается въ Черниговскую, гдъ заяцъ б́ьлякъ доходить до р. Семи. Просльживая географичесіое распространеніе этого вида восточнье, мы находимъ его въ пойм' Десны (около $5^{\text {I }^{0}}$ с. ш.) и въ южныхъ центральныхъ губерніяхъ, напримърь, въ Харьковской (Чернай, С мов в). Кь востоку южная граница тянется до Борисогльбоска (около $5^{\mathrm{I}^{0}}$ с. ш.), гдњ этотъ заяцъ встрбчается въ большомъ количеств'b по свидьтельству А. А. Силантьева (I 8 I, стр. 303), и продолжается до съверной части Камышинскаго у. (см. Бо г дан о в ъ 3 о, стр. I75). Далье на востокъ бьлякъ, по Н. А. 3 арудному (77, стр. $360-$ 36г), встрьчается на Общемъ Сыртьь, на Илегћ, гдъ водится въ большомъ числь отъ его устья до урочища Бишъ-Томакъ. Кромь того этотъ заяцъ найденъ въ сьверныхъ березовыхъ перельскахъ Мугоджарскихъ горь $\left(50^{\circ}\right.$ с. ш.).

Въ западной Сибири б́блякъ обыкновененъ въ окр. Бере-

1) За недостатком фағтическаго матеріала я не указываю отдьльнаго распространенія L.t. collinus Nilss, формы, своїственної съверу Европ. Россіп. 
зова (Брапдт ъ, 34, стр. 44). По Словцову (т 83 , стр. 2І), зтоть заяцъ распространень по всему Тюменскому охругу, доходя на сыверъ до Обской губы, гдь встрьченъ въ долинь р. Ныды г восточнье, бл. Таза. Каше нко считаетъ бъляка распространенным по всему Томскому граю. За недостаткомъ фактическаго матеріала, я не могу сь полной опредьленностью говорить, тождественъ ли бьлякъ, встрьчаюшійся въ восточной Сибири (см. П. С. Поляловъ, т 6 , стр. 5о, 51; Schrenck, I 7 4, стр. I45- - 47; $\mathrm{R}$ a d d e I 43, стр. 207-2II) и на Сахалинь (Thomas I 93, p. 4I4) съ типичной формой. Необходимы также дальныішія изсльдованія области распространенія L.t.tschulitschorm Nordqu., добытаго около Питлекая (країн. сьв.-вост. Сибириі).

Вь Алтайскихъ горахъ водится своеобразная темноухая форпа - Lepus t. altaicus Eversm. (= Iugubris Kastsch.), а на Kaмчатк - Lepus t. gicliganus Allen.

За посльднее время въ Западной Европь быль описань цълый рядъ географическихъ подвидовъ бьляка и частью воз. становлены старыя, сведенныя въ синонимы названія. Такъ, по Hilzheim er-въ čверной Норвегіи встрьчается: $L$. $t$. collims Nilss., въ Ирландіи: L. 1. hibenicus Bell. ${ }^{1}$ ), въ Шотландіп-L. $t$. scoticus Hilz.; въ Альпахъ-L. t. varronis Miller.

\section{Образъ жизни.}

Бьлякъ, въ противоположность русаку, придерживается исключительно льсныхъ острововъ, гды его можно встрытить и въ крупномъ высокоствольномъ бору, и на льсоськахъ съ кустарными порослями. Періодическія жизненныя явленія-течка и время вывода молодыхъ-совершаются приблизительно въ т占же сроки, какъ у русака. Въ рыдіихъ случаяхъ выводъ молодыхъ можетъ значительно запаздывать. Такъ, Г. Н. Поля ко в ъ сообщиль мнь, что I2 X 1903 года имъ быль добытъ изъ подъ гончихъ въ льсу „Полтево“ Богородскаго у., молодой бьлякъ, вьсившій всего 3 фунта. Это очень пнтересное наблюденіе свидьтельствуетъ о случаь очень поздняго вывода, вьроятно, приходящагося на вторую половину сентября. Какъ показаль впервые Löw is ${ }^{2}$ ), мьхъ бьляка осенью не линяеть, но напротивъ, отдьльные волосы дылаются длинные и депигментируются. Этотъ процессъ побыленія начинается обычно въ началь сентября и заканчивается въ гонць ноября. (См. табл. III, рис. 45-50). Я не буду здьсь по-

1) Lepus timidus lutescens Barr. -Наm. (изъ Дуо̆лина) тождественъ съ этпмь видомъ.

2) Zoologisch. Garten 1877 , s. 16 . 
дробно описывать хараґтеръ этого процесса, таґъ ґаюъ онъ ясно можеть быть просльженъ по рисункамъ таблицы III, изображающей (рис. 46-50) подборъ бьляковъ изъ одной и той же мьстности, убитыхъ въ разныя числа одного и того же года. Въ марть и апрь̈ль совершается интенсивная линька, заканчивающаяся къ маю, когда Lepus timidus L. пріобрьтаетъ свой годичный мъхъ въ его первої, темной стадіи.

Кромь перечисленныхъ въ таблицахъ измьреній әкземиляровь кол.кииіи, у меня были еще сльдующіе: І) (ㅊo 2667) \& Богор. у. зима І9г2 г. Г. И. Поляко в ъ; 2) (№ 2668) sex.? Богор. у. зима г9г2 г. Г. И. Поляковъ (шкурка и черепъ); 3) (№ 2055) sex.? 7 IX 9го г. Никольск.-Аверкіевская газ. дача Богородск. у., Г. И. Поляковъ; 4) з зима І9г2 г. Богородск. у., Г. И. Поляко в ъ (шкурка и черепъ); 5) (№ г7o4) sex.? д. Образцово Моск. у. IX 908 г. Ө. М. Проскурнинъ (черепъ); 6) (№ г7оз) sex.? Ibidem.; 7) sex? (o г705) окт. І908 г. Дятловка Богородск. у., M. М. Кернеръ; 8) (№ І707) sex? 7. XI 908 г. Обираловка Богор. у. Г. И. Поляковъ; 9) (№ 242І) sex? 29 I 912 г. Московско-Ряз.У Ральск. ж. дор. ст. Барыбино И. А. Ал ек с (черепъ), Всь экземпляры изъ коллекц. Зоол. Муз. Моск. Унив.

КОНЕЦЬ ПЕРВОÏ ЧАСТI. 


\title{
Объясненіе рисунковъ.
}

\author{
Таб.лица I.
}

Pric. 1. Черепъ Nyctalus noctula Schreb. of 3/rin 1907 г. (№ 612). Aносино Звенигородскаго у.

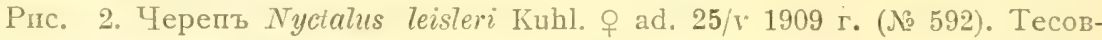
скій удыъльный льсьь Можаїск. у.

Pпс. 3. Черепъ и за-нижняя челюсть Plecotus auritus L. ㅇ Рузскій у. (스 2350). Изъ коллекціп Зоол. Муз. Моск. Унив. Н. Ю. З ог ра фъ пі С. А. 3 е р нов в.

Pис. 4. Черепъ и 4а-нижняя челюсть Plecotus auritus \& 23/ıгі 1907 г. Аносино, Звенигородск. у.

Pпс. 5. Черепъ n 5а-нпжняя челюсть Pipistrellus nathusii Keys. et

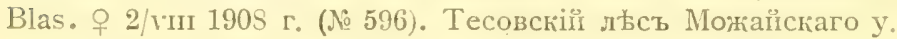

Pıгс. 6. Черепъ Pipistrellus pipistrellus Schreb. львто 1911 г. Тифлисъ B. Б. Бан ь ко в скі ї.

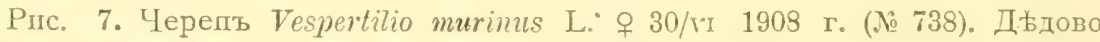
Звенпгородскаго у. Д. Н. С к о ро сп в л ов в.

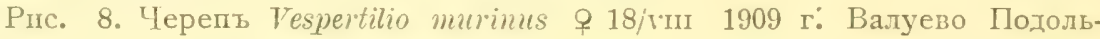
скаго у. В. В. Т р о пц ці і ї. (승 659).

PIıc. 9. Черепъ Tespertilio murinus 우 21/riı 1909 г. Можайскії у.

Pпс. 10. Черепъ Vespertitio murinus o juv. льто 1908 г. Дьдово Звенигородскаго у. Д. И. Скоросп влов ъ. Черепа Tespertitio murinus L. представлены для показанія возрастної пзиннчпости въ ихъ строенін.

Pric. 11. Черепъ Neomys fodiens Schreb. \& ad. 3/г'工i 1910 г. (№ 184).

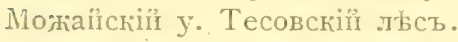

Pric. 12. Черепъ Neomys fodiens \& 2/xi 1909 г. Ibidem. (№ 1S2).

Pirc. 13. Чepenъ Sorex araneus L. 우 ad. 4/ri 1910 г. (№ 246). Ibidem.

Prx. 14. Черепъ Sorex araneus L. ㅇ subad. 1/ri 1910 г. (å 247). Ibid.

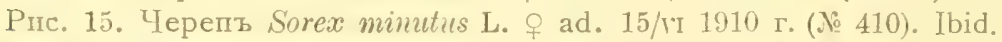

PIrc. 16. Черепъ Sorex minutus L. ㅇ subad. 3/พrI 1910 г. (№ 416). Ibid.

Pric. 17. Черепъ Sorex mimutus L. (aberratio?) ㅇ 19/1п 1910 г. (요 411). Ibid.

Всь⿱㇒㠯 перечпсленные рпсунки (до 츠 17 включительно) въ $1 \frac{1}{2}$ раза превышаютъ натуральную величину.

PIxc. 18. Черепъ Microtus ratticeps Keys. et Blas. 3 25/r 1909 г. Тесовскіî удњиьный льсъ Можайскаго у。

Рпс. 19. Черепъ Microtus ratticeps Keys. et Blas. ㅇ 1/гі 1909 г. (Для показанія половыхъ отлпчіӥ.) Ibidem. 
Puc. 20. Черепъ Mierotus agrestis neglectus Jen. \& 5 тrir 1909 г. Ibidem.

Pис. 21. Черепъ Ificrotus agrestis neglectus Jen. 우 6/үi 1909 r. Ibidem.

PIIc. 22. Черепъ Evotomys glareolus Schreb. O 29/v 1908 r. lbidem.

Pис. 23. Черепъ Evotomys glareolus Schreb. ㅇ 2/vin 1910 г. Jbidem,

Рис. 24. Черепъ Ificrotus arvalis Pall. ad. 12/ril 1909 г。 (스 3). Дъевъ лугъ бл. дер. Игуннова Можайскаго у.

Pric. 25. Черепъ Microtus arvalis Pall. ㅇ advvur 1908 г. Ibidem.

Puc. 26. Черепъ Nicrotus arvalis Pall. of ad. 10/run 1909 г. (№ 51). Ibidem.

PIIc. 27. Черепъ Ificrotus arvalis Pall. of subad. 8/Ix 1909 г. (으 45). Ibidem.

Pric. 28. Чepenъ Microtus arvalis Pall. 0 juv. ri 1909 г. (o 154). lbidem.

Pric. 29. Черепъ Microtus arvalis Pall. ㅇ juv. 29/u 1909 г. (스 52). Ibidem.

Черепа Microtus arvalis Pall. представлены для показанія ихъ возрастної пзмънчпвості, при чемъ черепъ самаго стараго экземпляа помьщенъ крайншмъ сльва, а напболье молодого-справа.

Рис. 30. Черепъ Mus sylvaticus wintoni Barret-Ham. 우 ad. Маріенбадъ. Лпфляндской губ. С. А. Бу ту рл п ъ (коллекц. Зоол. Муз. Моск. Унив.).

Prс. 31. Черепъ Mus sylvaticus princeps Barret-Ham. ㅇ ad. Исаръ, южныі берегъ Крыха. Г. А. Ко же в н пюо в (коллекц. Зоол. Муз. Моск. Унив. № 2546).

Рис. 32. Черепъ Mus sylvaticus mosquensis Ogn. of 8/vir 1911 г. Ст. Кашира Коломенскаго у. В. Н. В у ч е ти ч ъ (колл. Зоол. Муз. Моск. Унив.).

Pис, 33. Черепъ Hhus musculus hortulames Nordm. (= 11. m. bicolor Tich. ef Kortsch.) ㅇ Астраханская губ. А. Н. Х а р узин ъ (스 2571. Коллекц. Зоол. Муз. Моск. Унив.).

Pис. 34. Черепъ Mus musculus L. typ. 우 ad. 23/rin 1912 г. Тесово Можайскаго у. (№ 890).

Всь черепа, начнная съ ํㅜ 18 до ㄲo 34 включительно, въ натуральную величину.

\section{Таблнца II.}

Pпс. 35. Vespertitio murmus L. \& juv. 30/ю 1908 г. Дьдово Звенптородск. у. Д. И. С коросп в лов в.

Рпс. 36. Этоть же экземпяръ снизу. Ibidem.

Pıс. 37. Vespertilio murinus L. \& juv. (моложе предыдущаго) 30/vi 1908 г.

Рис. 38. Этотъ же экземпляъ снизу. На фотографіяхъ ясно видна р屯зкая разница окраскі верхней пи нижнеї стороны тьла еще совсбщъ молодыхъ экземпляровъ.

Prrc. 39. Sorex araneus L. \& subad. vir/1912 г. Тесовскій льсь Можайскаго у.

Pric. 40. Sorex araneus L. $\$$ ad. Ibid.

Prrc. 41. Sorex minutus L. o subad. 12/rir 1912 r. Ibid.

Pric. 42. Sorex minutus L. \& ad. ris 1912 r. Ibid.

Землеройки пзображены для показанія возрастной пзънчивости въ соотношеніяхъ и структур ь тьла и хвоста.

Pric. 43. Neomys fodiens L. 1/rin 1912 г. (ํㅡㅇ S05). Ibidem. Уклоняюшіïся экземпяръ, съ развитіемъ чернаго пятна на груди.

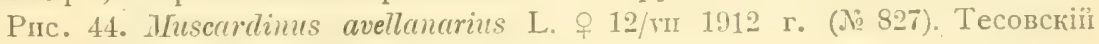
удьльный льсъ Можайскаго у.

Всь рісунки около $3 / 4$ натуральної величнны. 


\section{Таблица III.}

Сезонныя пзминенія ограски м⿻хха зайца бұляка. (Lepus timidus L.).(Изъ полтскцін, составлениої Саввинским кружкомъ охотниковъ для Зоологическаго Музея Московскаго Универсптета).

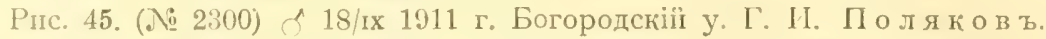

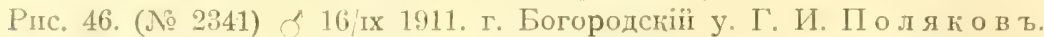

Рис. 47. (№ 2343) ㅇ 23/x 1911 г. Бисерово озеро Богородск. у. Г.А.К ож е в н п о о $\mathbf{~}$.

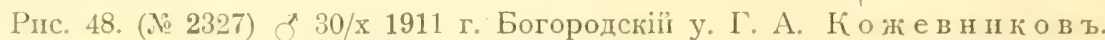

Pис, 49. (o. 2366) of 8/xi 1911 г. Богородскій у. Г. И. П оляко о ъ.

Рıгс. 50. (№ 2370) 20/xi 1911 г. бл. дер. Черної Богородск. у. Г. И. По л я ко в т.

Pис. 51, 52. Черепъ (сбоку II сверху) Lepus europaeus aquilonius Blas. juv. $17 /$ rп 1911 г. Орловскій у. С. Н. Г ор ба ч е в ъ.

Pис. 53. Черепъ (сверху) Lepus timidus L. juv. 16/Ix 1911 г. (№ 733). Boроб́ьевы горы бл. Москвы.

Pнс. 54. Черепъ (сверху) Lepus europaens aquilonius Blas. † juv. 16/xi 1911 г. (№ 734). Никола-Угрьша Московск. у.

Черепа въ размьр $62 / 3$ натуральной величны.

\section{Таблица IV.}

PIIc, 55. Lepus europaeus aquilonius Blas. \& 5/x 1910 r. Богородскій у. Г. И. Поляков в (№ 2297. Коллекц. Зоол. Муз. Моск. Унив.). Черепъ сбоку.

Pис. 56. L. europaeus aquilonius Blas. $X L$. timidus L. XII 1911 г. (Тущакъ) Порзовской вол. ІІетровск. у. Саратовск. губ. (ํㅡ 2399. Зоол. Муз. Моск. Унив. отъ С. В. К и н д я ко в а). Черепъ сбоку.

Pис. 57. Lepus timidus L. 7/xi 1910 г. Никольск. - Аверкіевская каз. дача Богородск. у. Г. И. П о л я о в ъ. (.ํ․ 2055), Черепъ сбоку.

Pric. 58.

Рис. 59. Т古 же черепа въ соотв ьтствующемъ порядкь, снятые сверху.

Pirc. 60.

Фотографін показываютъ отличія въ строеніп череповъ русака, бъляка II ихъ помьси „тумака“.

Рнс. 61. Черепъ Lepıs europaens aquilonius Blas. сбоку. Изображеніе его же сверху дано на табл. III, рис. 54.

Pпс, 62. Черепъ Lepus timidus L. juv. сбоку. Нзображеніе его же сверху дано на табл. III, рис. 53.

Всъ черепа-2/з натур. величины.

\section{Таблица $V$.}

Prс. 63. Норы землероекъ, расположенныя около края льсного болота у основанія куста можжевельника. Тесовсқій удьльн. льсъ Можайск. у. (Къ crp. III).

Prс. 64. Hоры Evotomys glareolus Schreb. въ сосновомь льсу. Тесовскій удыльнй льсъ Можайскаго у。, 1 қварталъ. (Къ стр. 162). 
26360

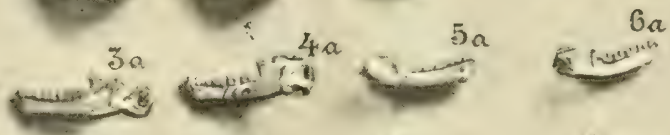

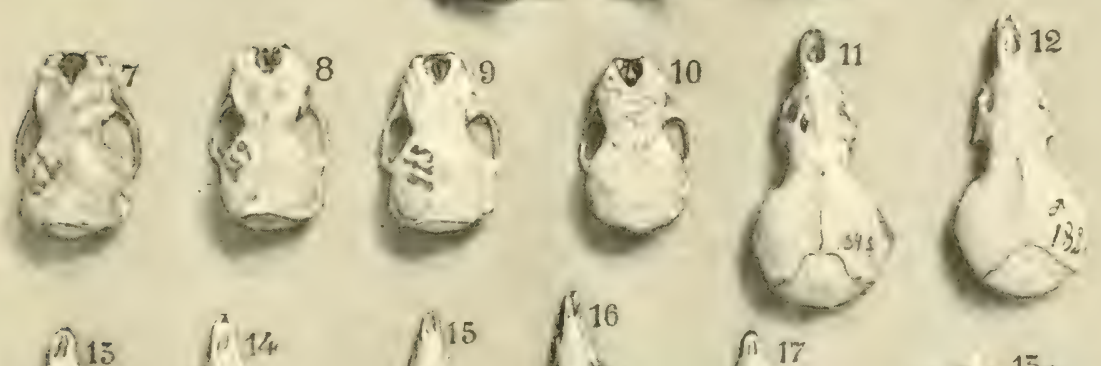

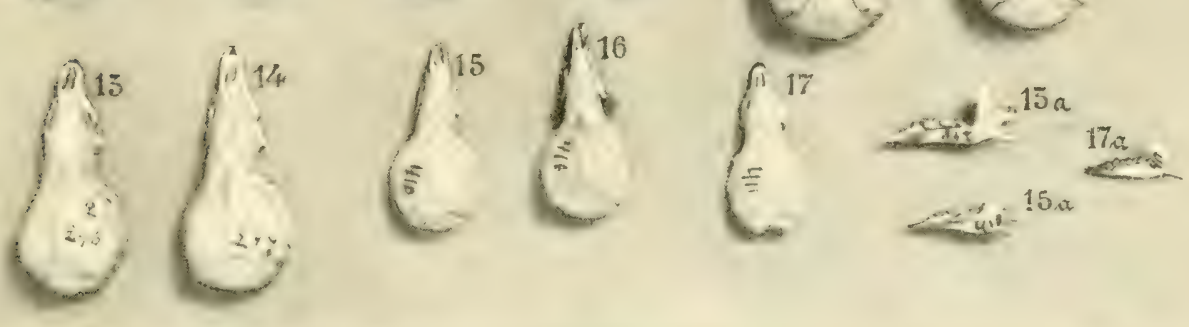
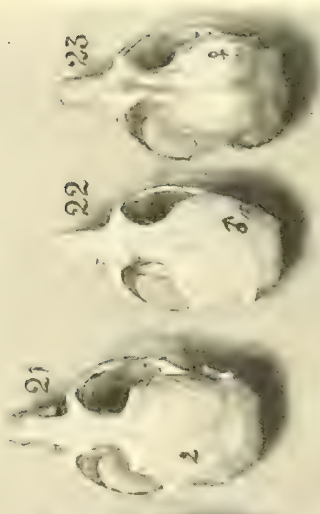

घ)

(

$\sum 0 \times$

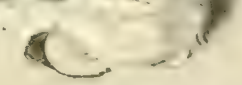

arol
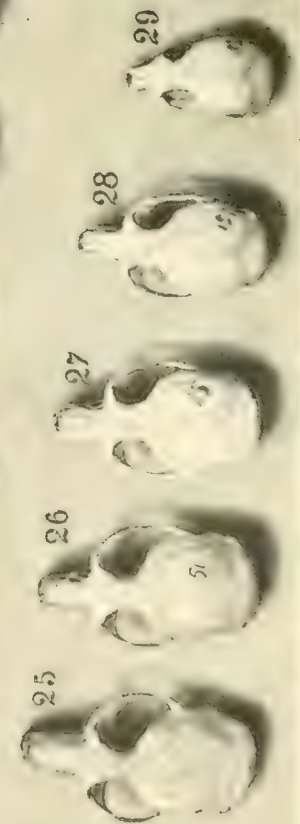

20

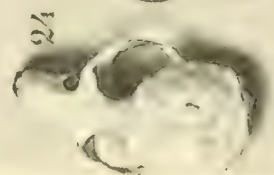

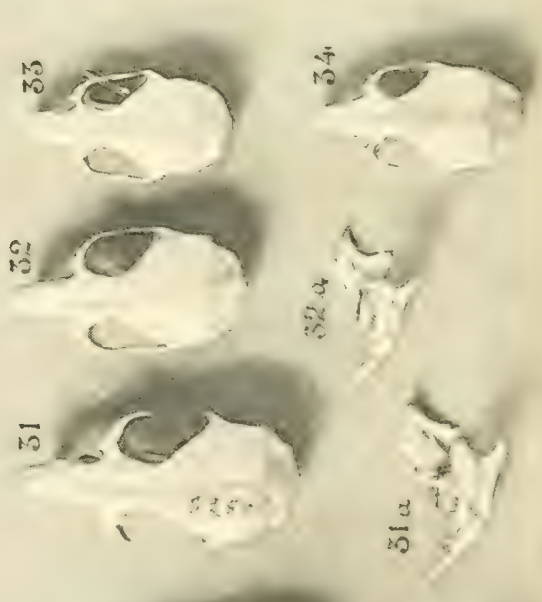

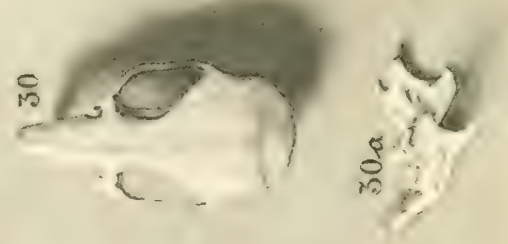





\section{Габ̆лица II.}
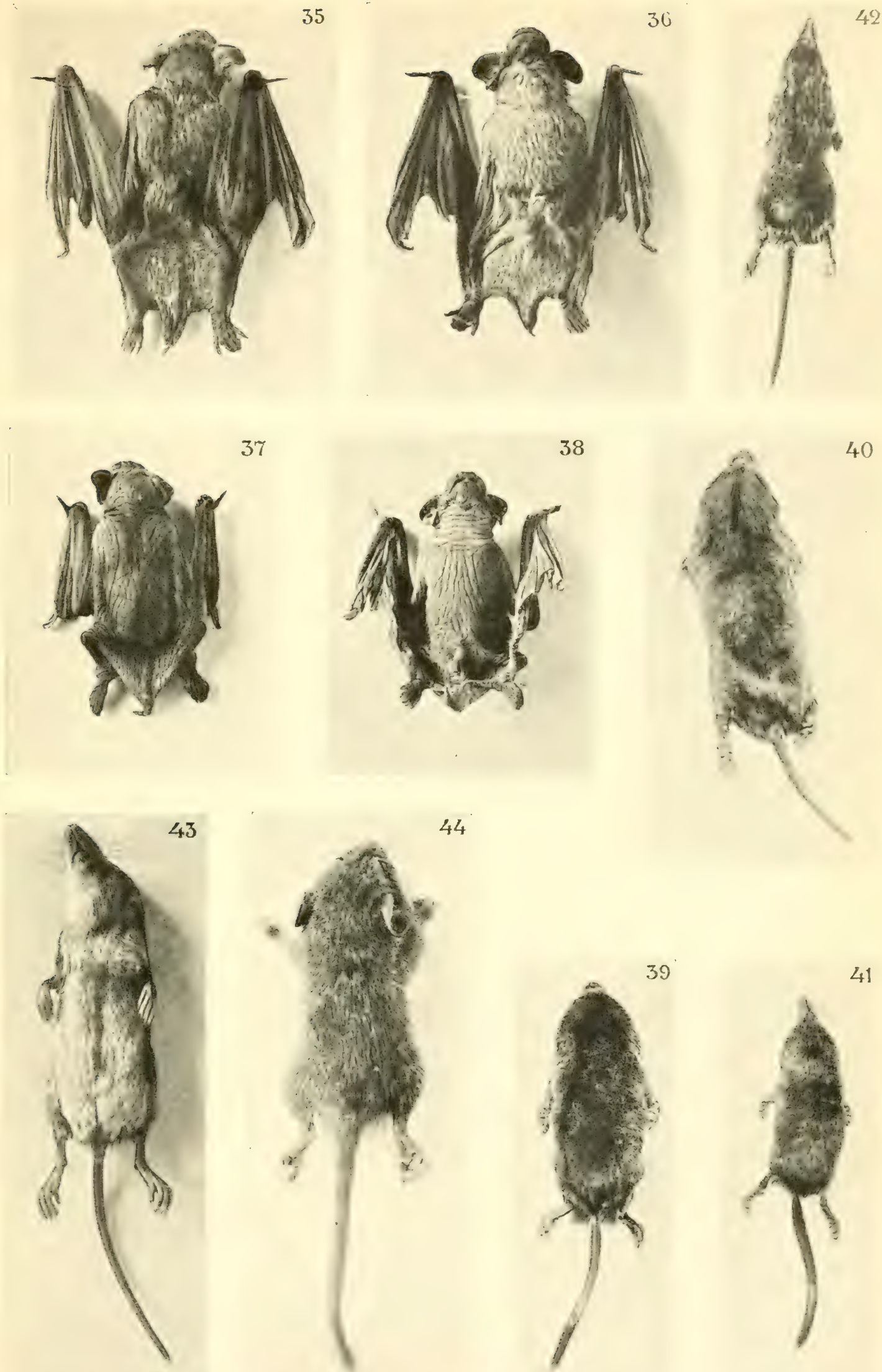

38
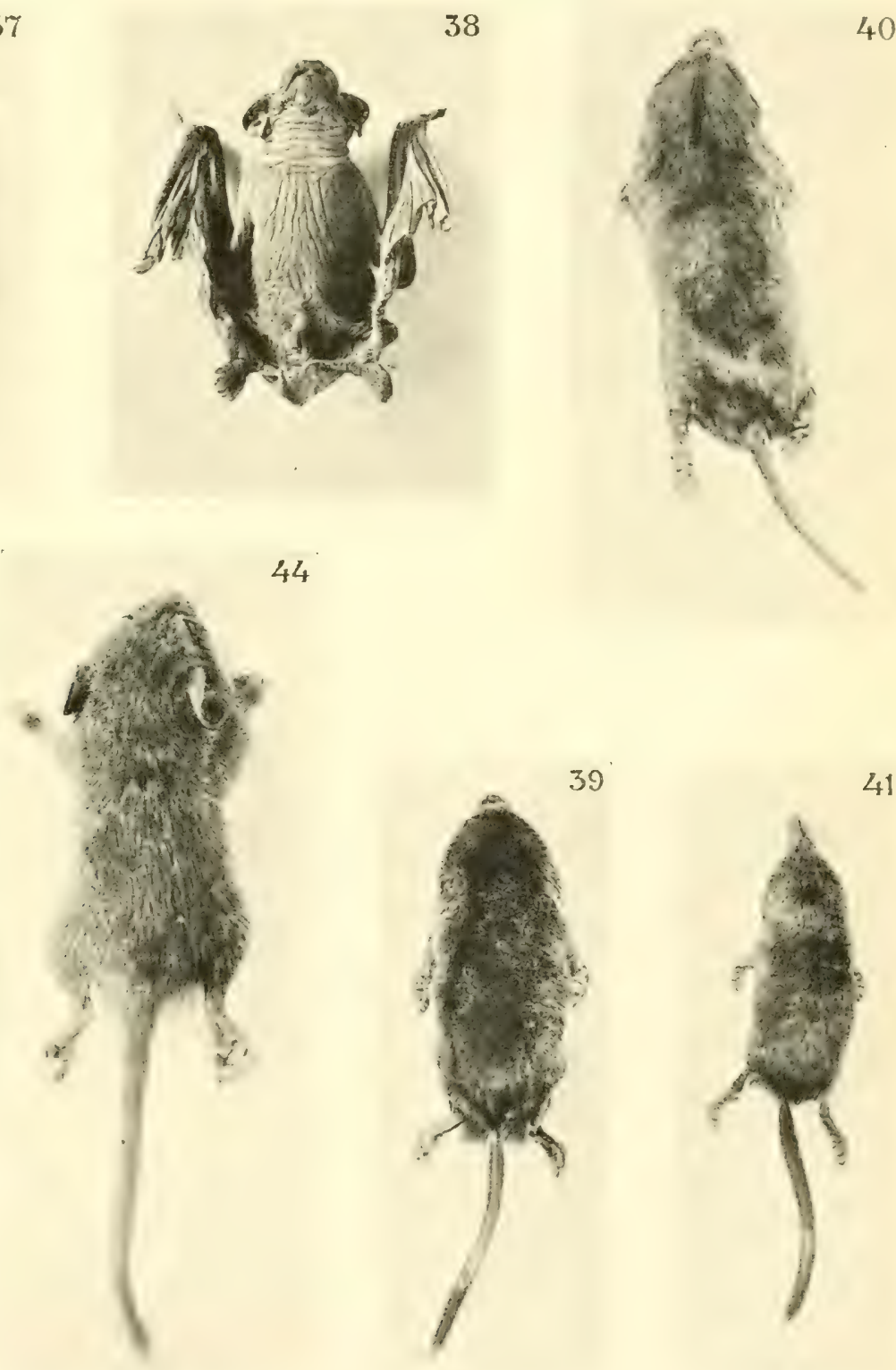

$44^{\circ}$
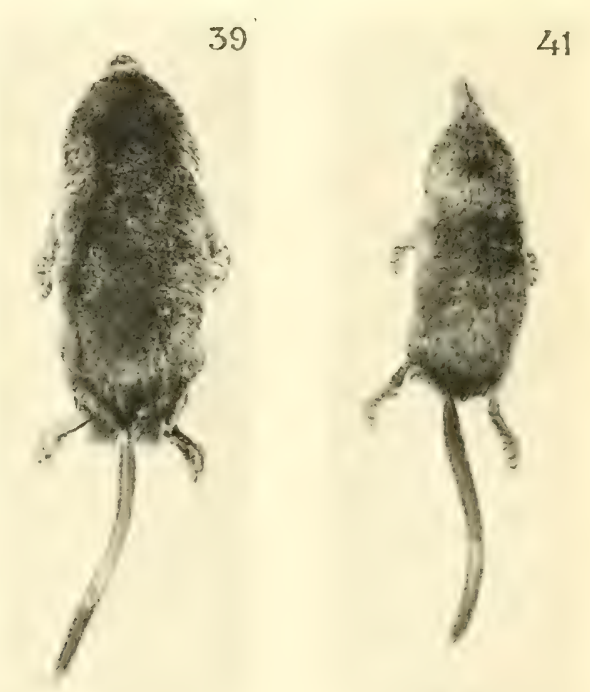

Таб̆лица III.

\section{is}

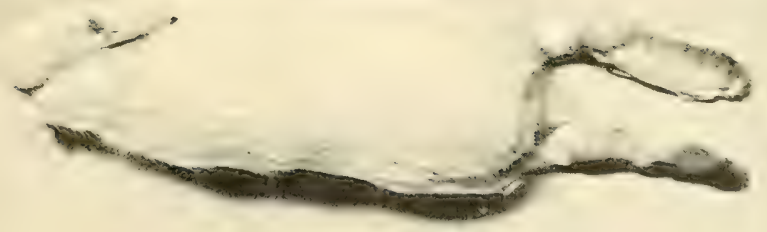

문

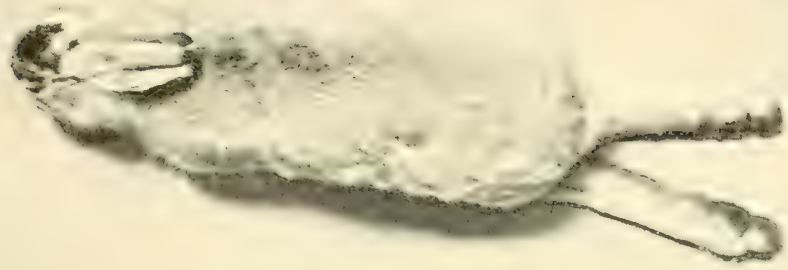

$\stackrel{\infty}{\rightarrow-1}$

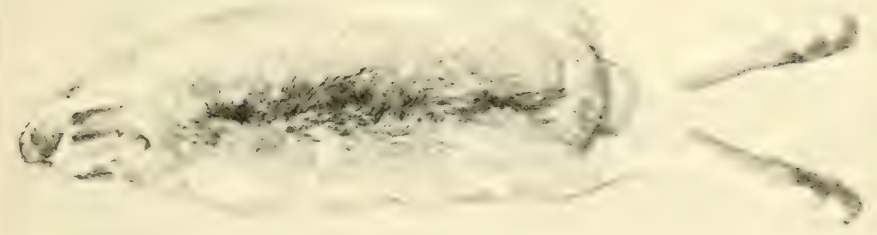

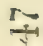

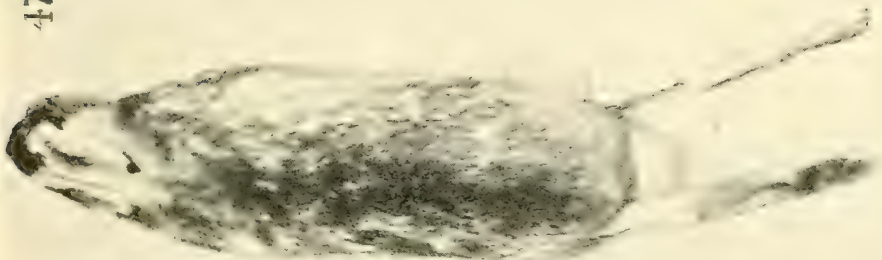

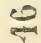

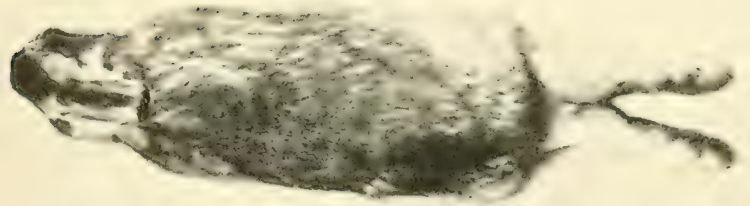

2

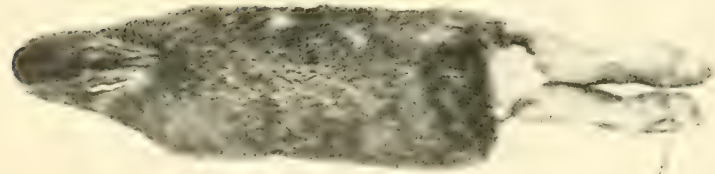

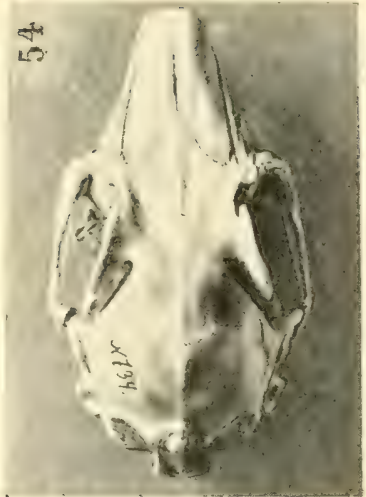

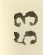
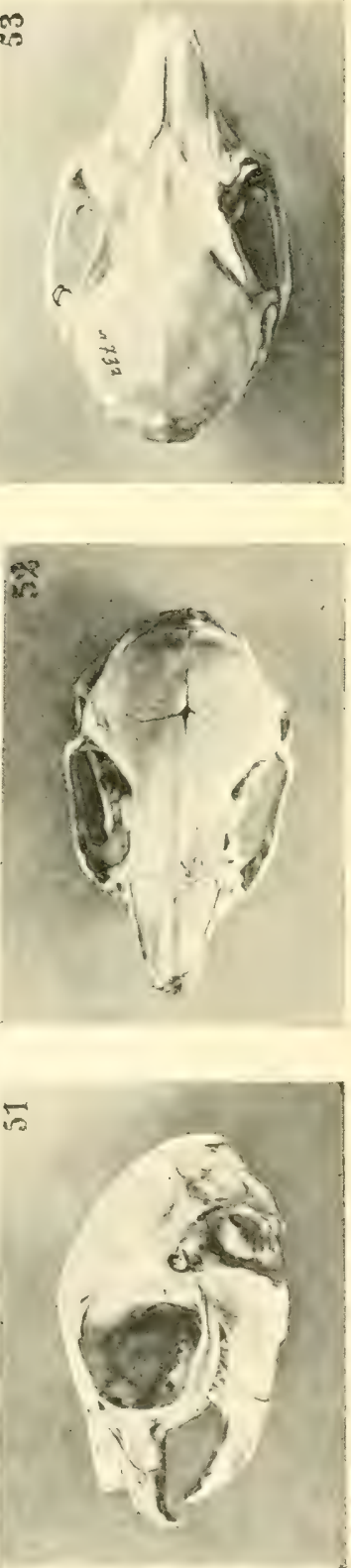

Таб̆лица IV.
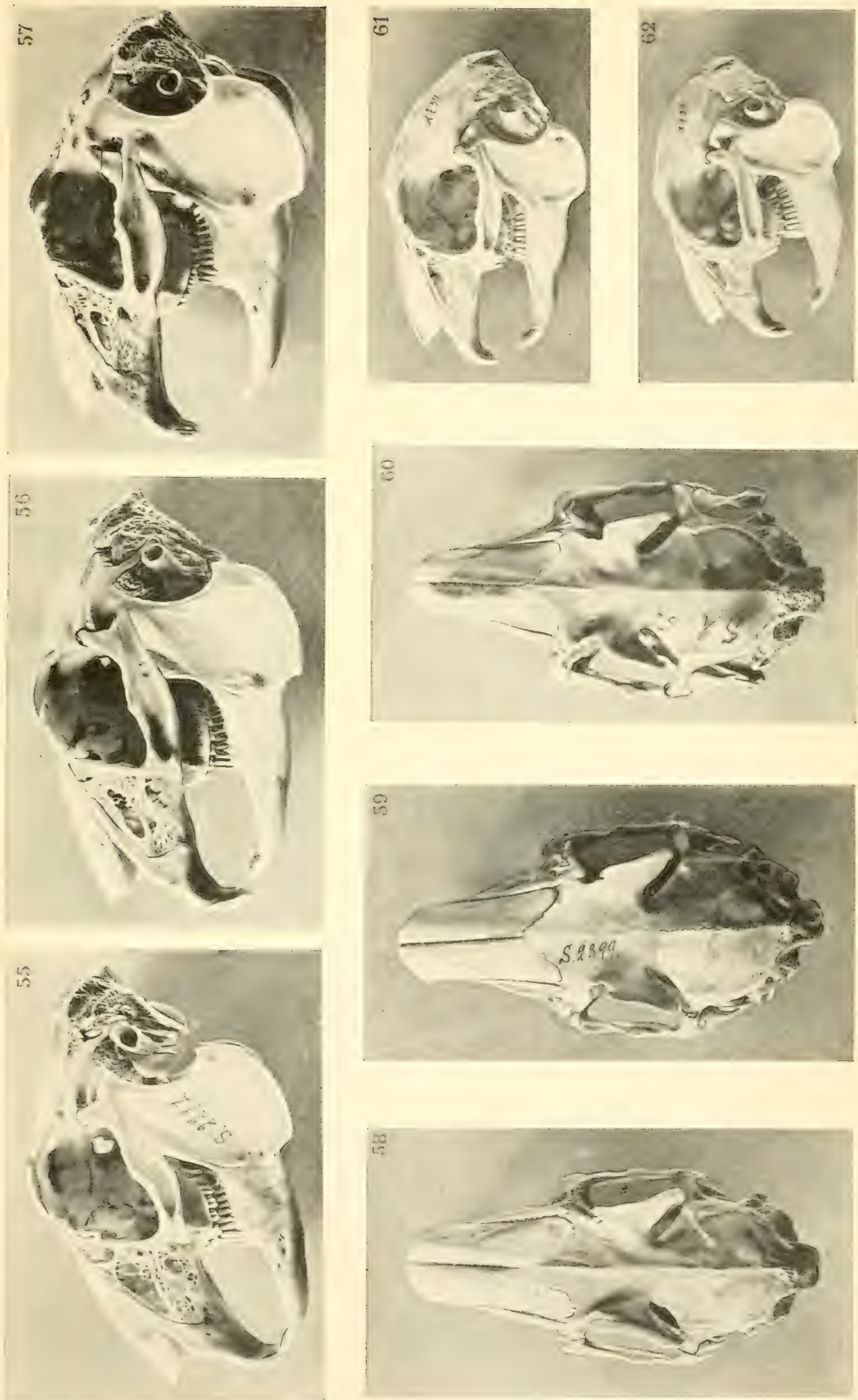



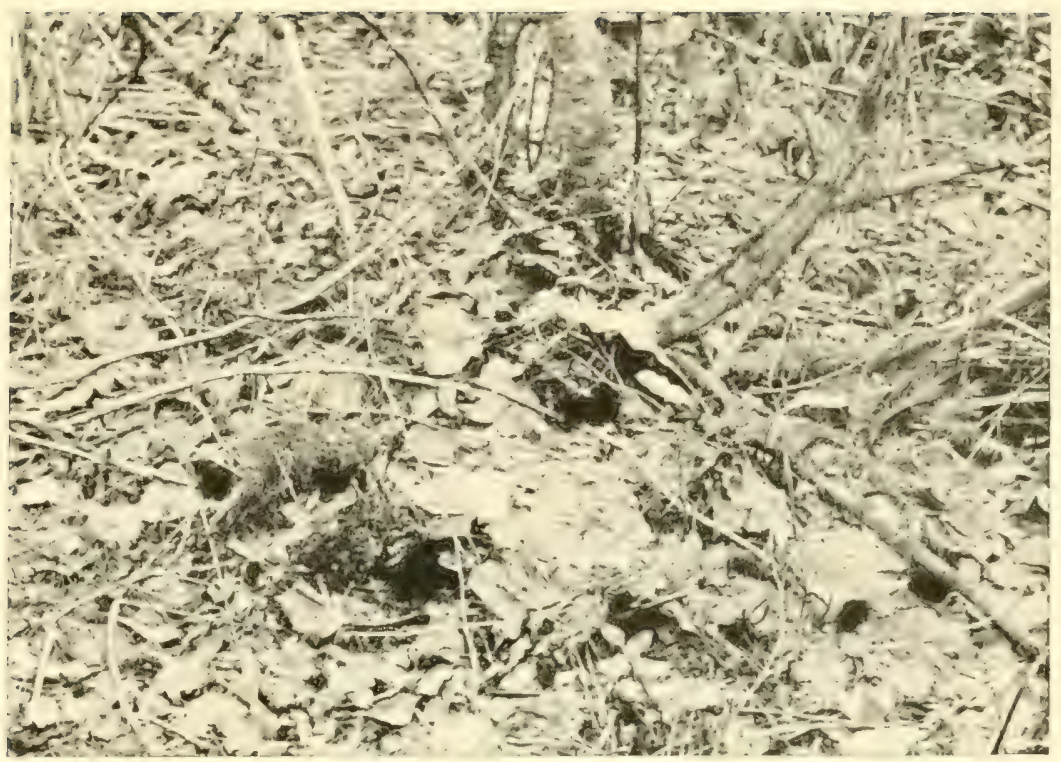

Рис. 63. Норы землероекъ, расположенныя около края льсного болота у основанія куста можжжсвельника. (Тесовскії удьльный льссь, Можайскаго уЊзда).

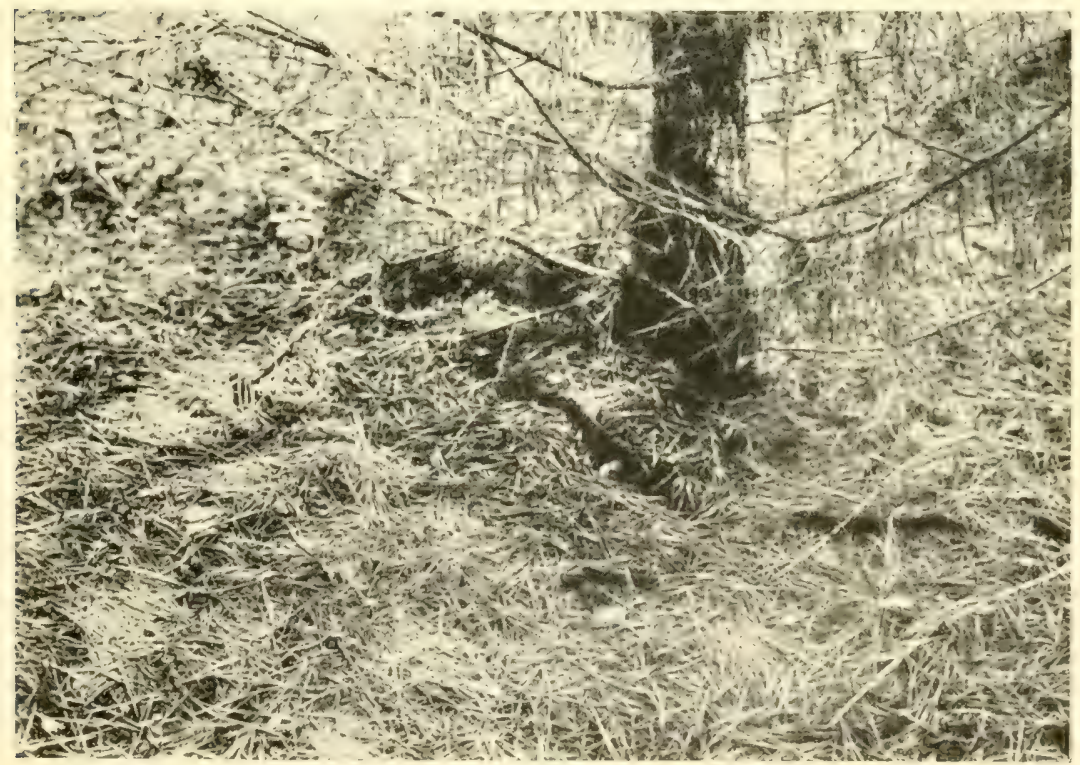

Pис. 64. Норы рыжей полевкг (Evotomys glareolus Schreb.) въ сосновомъ льсу. (Тесовскій удьльный льсъ, Можаискаго убзда, I кварталь). 





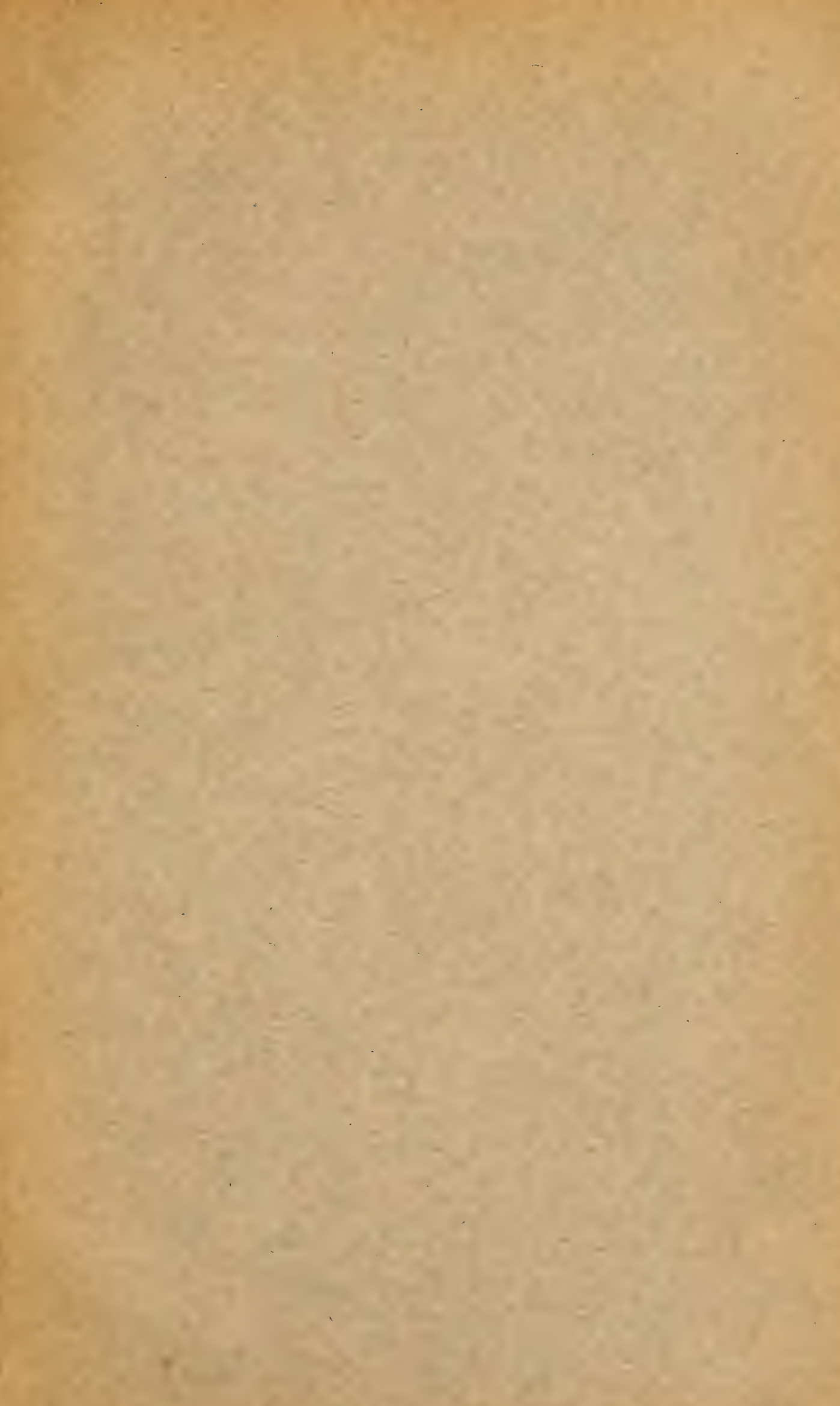




\section{Цьна 2 руб.}

\section{СКЛАДъ ИЗДАНІЯ}

въ Зоологичесномъ Музөt Имперагорскаго Мосновскаго Университета. 






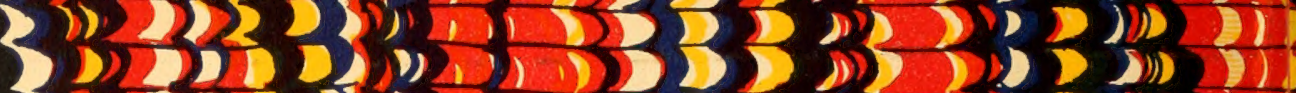

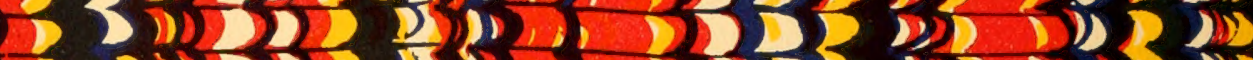

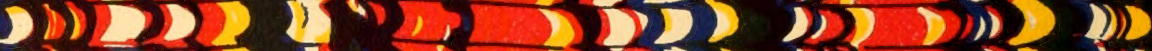

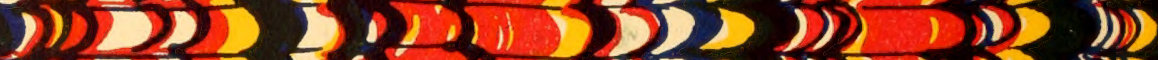

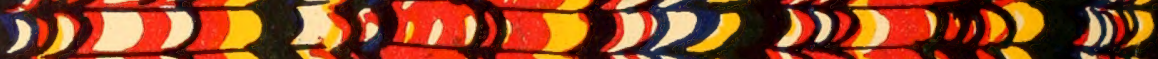

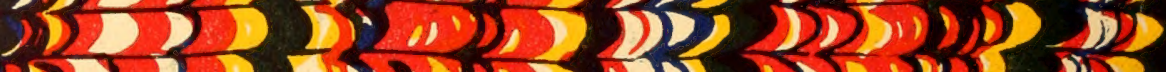

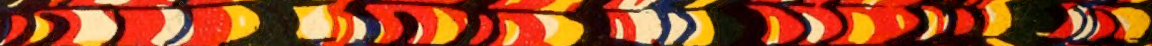
D)
DD DD $452 \div 11$ D) DDDD䏠

02012 $2) 1$

)) 2 102 $4-D, D)$ III DDDDग $202, i)$ 852 D) 2

2,1 2 1) 110 $\frac{12}{12} 212$ )) D D D D D D D I 12012 D) $5>2535$

22 DD 102 DI 2010 D) $5,5,5015,151$,

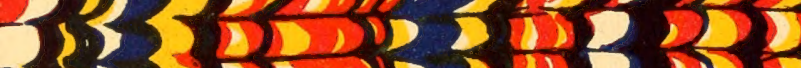

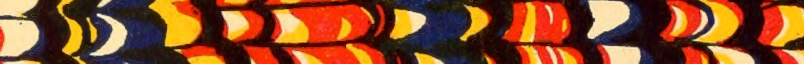
I) DDDDDDD
i) 2 D)

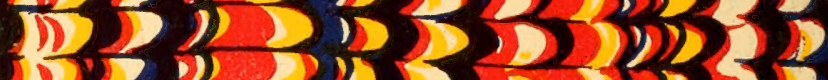

10201212

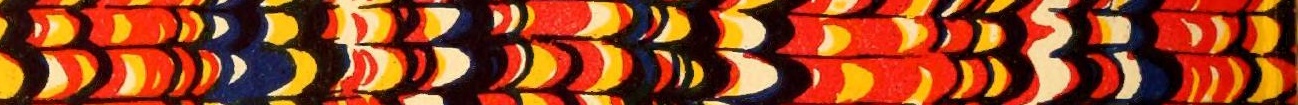

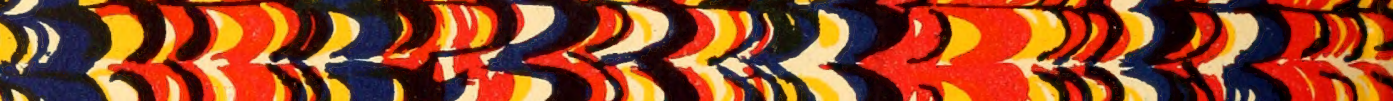
) 1)

$D \rightarrow D D D 0$

DD (D) 100

2010 1211

(1) D) 2 $D(1$, 2DD D) $D D$ a) 22025

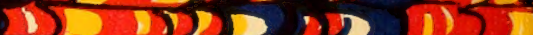
$D, D 120$

$D D D D D$ D) D DD DD 120120
1202 DD

(1) 2 1) 202 $D D D D 2, D$

D)

D) 2) DDD D) 2 i) 12010 1) $D 212$

D) DIS 201 D) 2 $12)$ 120

D) D) $>210$ 2) 2 2020 Di) $D$ DID DD 201010

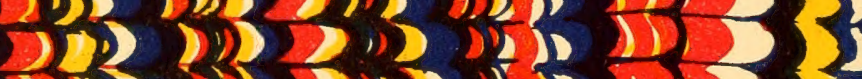
ग) 1202010101010 D) 15

D) 23) $2) 112$ 1)

D) D $D(1)$ ) $\Rightarrow 112$ (3). 22125 (i) D)

21202

D) 202

)) 22

D)

).

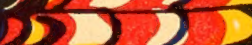

D) $D 2012$ $1 0 \longdiv { 1 0 2 }$ DD 12212 12010 DSO

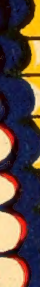
CD $1 2 \longdiv { 1 1 }$ $258(011)$ [1, (11) 1) (1) 1201 425,12 DDDID

\section{$5 D(1) \geqslant 21$}

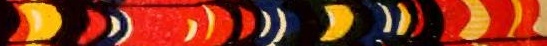
DID DID D II) 320201 (j) $20 D 21101$ $3 D 2 D$

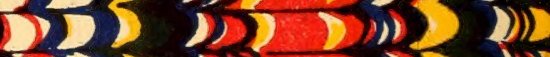

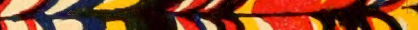
))) DD 2DII) D D2 $2 D 2 D, D 2$ D))

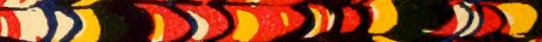

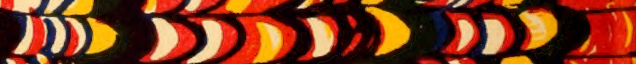

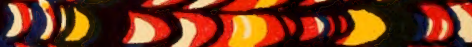
D) DD DD DI (ग) 505135 

SMITHSONIAN INSTITUTION LIBRARIES

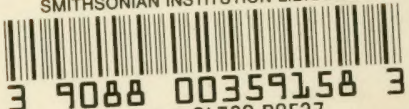
QL728.R8F27

1 pt. I Fauna mosquensis 